DANMARKS GEOLOGISKE UNDERSøGELSE

II. R/EKKE. NR. 79

GEOLOGICAL SURVEY OF DENMARK. II. SERIES. NO. 79

\title{
Molluscan Assemblages from the Marine Middle Miocene of South Jutland and their Environments
}

\author{
By \\ Theodor Sorgenfrei \\ Vol. II \\ Dansk sammendrag: \\ Molluskselskaber fra det marine Mellem Miocæn \\ i Syd- og Sønderjylland og deres miljø
}

I kommission hos

C. A. REITZELS FORLAG (JøRGEN SANDAL)

KØBENHAVN 1958 
With 76 plates

Med 76 tavler 
DANMARKS GEOLOGISKE UNDERSØGELSE

II. RAKKE. NR. 79

Geological Survey of Denmark. II. Series. No. 79

\title{
Molluscan Assemblages from the \\ Marine Middle Miocene \\ of South Jutland \\ and their Environments
}

\author{
By \\ Theodor Sorgenfrei
}

Vol. II

Dansk sammendray:

Molluskselskaber fra det marine Mellem Miocæn

i Syd- og Sønderjylland og deres miljø

I kommission hos

C. A. REITZELS FORLAG (JøRGEN SANDAL)

KØBENHAVN 1958 


\section{GENERAL CONCLUSIONS AND REMARKS ON SHELL MORPHOLOGY}

Although the number of species in which variation of shape has been investigated is relatively small, due to the broken state of the material, it is possible to outline some new fundamental features of shell morphology.

The investigations of Yoldia glaberrima, Leda Westendorpii, Leda pygmaea, and Spisula subtruncata indicate that the length/height ratio of pelecypod valves is very seldom constant throughout the life of the animal. This is important, but some workers are apparently not aware of this principle, to judge by the significance which is often attached to the calculation of means of length/height ratios, or other quantitative expressions of shape. Mean values of this sort have no taxonomic significance unless they are accompanied by information on the size groups of the shells measured.

The determination of Nuculid shells is generally rather difficult, as has also been demonstrated in this treatise. Examination of the hinge dentition in the Nuculid shells from the Arnum formation disclosed that the number of teeth is obviously not constant, and probably not even confined within strict limits, since the number increases with growth. The number of hinge teeth is accordingly not a valid specific character. It should be noted that the numbers of radial elements in the outer shell layer in species of the genus Nucula are apparently normaly distributed around a mean, but future more extensive investigations must decide whether these means are constant specific characters or not.

Particular new observations in pelecypod genera are: the ductus between the inner and outer layers on the posterior end of the right valve in Corbulid species, and the discovery of a previously unknown initial dissoconch stage in the Pectinidae. The biological significance of these features is as yet unknown.

A parallel to the length/height ratio in pelecypods is the height/diameter ratio in gastropods. The variation of this ratio in Nassa Schlotheimi, N. subobesa, N. cimbrica, Ringicula buccinea etc. is clearly correlated with growth. With the exception of Ringicula buccinea, the ratio increases with the size of the shell. Such increase is also evidenced by the height/diameter values hitherto obtained in Bittium spina, B. tenuispina, Nassa Woodwardi, N. cavata, Odostomia mutinensis, and $O$. pallidaeformis. It has therefore to be anticipated that a change of the ratio with growth is the normal in most gastropods.

The observations in gastropods also indicate that means of dimension ratios are insignificant without information on size grouping.

The statistics on collabral sculptural features in Bittium tenuispina, Nassa Schlotheimi, N. subobesa and Terebra Hörnesi and other species illustrate that the number of collabral elements per whorl are often not constant. The number of ribs per whorl generally increases with growth, although a smaller or almost unchanged number of ribs may be found. It seems to be common in ribbed Nassae that the first ribbed whorl has a greater number of ribs than the second, 
but thereafter the number of ribs increases (see e. g. N. Schlotheimi and $N$. subobesa).

The delicate protoconch features of the family Turridae have provided an interesting basis for a morphological subdivision of this very variable family. It is belived that research on this part of the shell, and the corresponding animal stage, in recent representatives of the family should throw light on the problems of taxonomy in both recent and fossil species. 


\section{MARINE PELECYPODA AND GASTROPODA IN RELATION TO THEIR ENVIRONMENT}

Since the earliest paleontological research, students of fossils have endeavoured to apply the principles of the environmental relationships of recent faunas. Numerous far-reaching generalizations have been made in spite of the fact that comparatively little is known about the control which environmental factors exert upon biology even in the living representatives of the most important groups of fossil animals. In this connection the Mollusca are no exception.

Although pertinent data on the environment relations of recent mollusca are still rather scanty, it must be admitted that considerable progress has been made during the last two decades. Some of the results and principles arrived at will be briefly outlined as an introduction to a discussion of the middle Miocene fauna already described. Since this fauna is European, the references to recent marine biology and ecology are mainly concerned with the faunas of European and adjacent waters. The faunas of the North Sea, the Baltic, the North Atlantic and the Arctic seas have particularly been considered. Even in this limited field some essential features may have escaped notice. It is hoped, however, that the following record may encourage further studies of the environmental evidence of recent marine molluscan faunas, since it must never be forgotten that thorough knowledge of recent marine zoology is a fundamental prerequisite for the interpretation af fossil marine faunas, however remote they may be in time.

\section{CONTROLLING FACTORS}

Animal life in the sea is dependant on a number of well known factors of which the following may be mentioned: 1. food, 2. salinity, 3. temperature, 4. depth, 5. enemies and competitors, and, in the case of the bottom fauna, 6 . bottom configuration and deposits. There may be other factors, both known and unknown, but those listed may be regarded as essential. Variation of any of these factors will result in more or less pronounced change in the marine animal communities and the distribution of the individual species.

The importance of knowledge of factors such as salinity, temperature, and depth of water, during the sedimentation of ancient formations is obvious from a geological point of view. It is easy to understand, therefore, why geologists have tried to draw inferences concerning paleo-environments from extinet faunas.

A careful study of fossils, their manner of preservation, their wear, their embedding in the sediment, and also a meticulous study of the sediment itself will often reveal whether the animal was buried where it lived, or not. If one can be sure that the animals found as fossils lived where they were buried, it 
should in many cases be possible to reconstruct the bottom configuration and physical properties of the former sea bottom, on or in which the fossil fauna lived.

The salinity of the water in which a fossil fauna lived may be approximately estimated in most instances. The distribution of recent pelecypods and gastropods shows that it is possible to discriminate between marine genera, and genera which live exclusively in freshwater. Fossil mollusca are often referrable to modern genera, or, if extinct, they may have near allies in the recent fauna. By means of an analysis of the genera, supplemented by thorough lithologic studies, it should be relatively easy to decide whether a fossil fauna lived under marine or non-marine conditions. The degree of certainty regarding the salinity of the water in which a fossil fauna lived may depend only upon the proportion of non-extinet species and genera in the fauna.

Concerning the temperature conditions of paleo-environments, the evidence of fossil marine molluscan faunas may at first be considered less reliable than the evidence they provide for salinity. However, this is due to defects in our information about recent ecology, and not to failure of the paleoecologic method itself. In principle, the degree of certainty arrived at in inferring temperatures from fossil faunas may - as in the case of salinity-be proportional to the modernity of the fauna.

Depth, acting as a controlling factor, was considered more significant in the older literature of marine zoogeography than it is now. Studies of the sea bottom infaunas have clearly shown that depth may be relatively unimportant as a limiting agent, as demonstrated by C. G. Joh. Petersen (1914, p. 34 and 1915, p. 13-14 and see also this paper p. 390).

The regulative effect of enemies and competitors on individual species needs no comments. Being important factors, enemies and competitors should not be neglected when attempting to explain differences in the occurence of particular species in related animal communities, either living or fossil. However, biotic factors are often used to explain away difficulties.

Besides the above named factors, hydrographic phenomena like ocean currents, tide, waves, etc. may exert a great influence on the distribution of species, either directly or indirectly.

Therefore it is obvious that deductions regarding the significance of individual factors on marine animals depend primarily upon a thorough knowledge of the hydrography of the area in which the animals live. A study of zoological literature reveals, however, that this prerequisite is rarely satisfactorily fulfilled. A second point is that environmental conditions vary widely from year to year, and unless data are carefully reported with due attention to the dates of observation, etc., as ORTON (1920) points out, it may be extremely difficult to disentangle the separate effects of the many factors in the environmental complex.

It has been unavoidable that the somewhat fortuitous location of laboratories has had an important effect on the investigational coverage of the different parts of the oceans. Due to the scarcity, and unsystematic distribution of exact data, we are thus confronted with an unknown number of sources of error in trying to determine the principles of ecology of the mollusca. It should be particularly stressed that the study of faunas in hydrographically complex and atypical areas may have been over-emphasized. It is of interest in this connection to point out for instance that the Baltic, in its widest sense, is an extremely complicated brackish-marine region that exhibits pronounced variation and 
even discontinuity of several factors like temperature, salinity, currents, etc. Attention should also be drawn to deep fiords, as found in Scandinavia, Greenland and elsewhere, and to estuaries all over the world. Such areas rank among the best known regarding marine mollusca, but at the same time they display the most extreme hydrographic conditions.

From this it becomes evident how desirable it would be if ecologic research could be concentrated on seas in which only a single environmental factor varies on a major scale. For example the effect of temperature on reproduction and distribution could obviously best be studied in areas where salinity is relatively uniform throughout the year, and where the water is mixed sufficiently to reduce to a minimum the temperature gradient from the surface layer to the bottom. Such an ideal area for the study of the effects of temperature is more nearly approximated by the North Sea than by the hydrographically complex Baltic. In the relatively uniform shelf area of the North Sea, where wave action and tides ensure rapid mixing of water masses, the dominant environmental variable is certainly temperature.

In summary, the following observations seem to be fundamental in any investigation of marine ecology: 1. date, 2. salinity, 3. temperature, 4. depth, 5 . bottom deposit, 6 . bottom temperature, 7. currents, and 8 . tide. The lack of data on several of these subjects renders many otherwise valuable treatises useless for the present analysis of environment relations, and accounts in part for the small number of observations utilized in the following.

\section{FEATURES OF THE LIFE HISTORIES OF SOME MARINE PELECYPODA AND GASTROPODA}

Any species has definite ranges for the possible variation of the environmental factors which control its survival. In the case of marine mollusca we may talk about upper and lower limits in dealing with temperature and salinity. A similar distinction may also be applied in connection with the nature of bottom deposit, exposure to the atmosphere in littoral species, and other factors, although it may be more difficult to define these limits in quantitative terms. A natural consequence of this viewpoint is, that each factor has an optimum value within the range of survival, and that values above and below this optimum are less favourable for the animal, provided all others are equal.

The influence of some factors on the main life periods of marine Pelecypoda and Gastropoda will be illustrated by examples taken from living species.

\section{A. Animal Growth and the Variation of some Shell Properties}

Very interesting investigations on the growth of shell and tissue in molluscan species have at intervals been carried out at the Plymouth Laboratory by Orton (1926, Cardium edule), Stephen (1936, Tellina tenuis, T. fabula, Abra alba, and Cardium edule), and Moone (1936-38, Purpura lapillus, and Littorina littorea). Similar studies have been made by Richards (1946, Mytitus edulis, M. californianus), Thamdrop (1935, Cardium edule, Macoma baltica), and by Sмптt (1951, Cardium edule).

Cardium edule has been studied most intensively, perhaps partly because it offers good possibilities for obtaining material and partly because of 

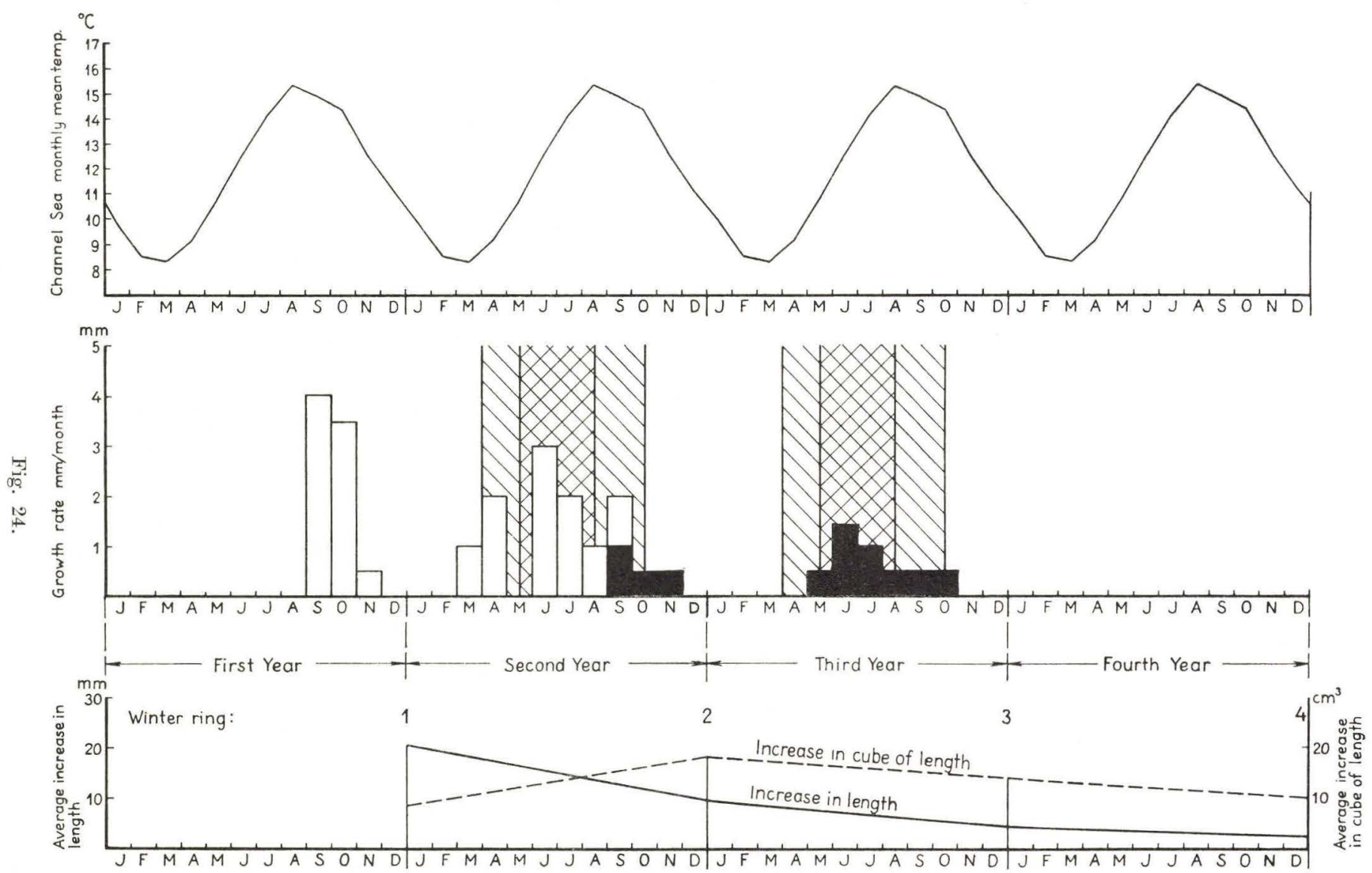

Cardium edule (Yealm) Growth rates (acc.to ORTON 1926) and sea water temperatures off Plymouth (ORTON 1922) 
the clarity of the annual cessations in growth of the shell known as winter rings (ORTon 1926). From study of the winter rings, the authors mentioned above have claimed to be able to follow the growth of various groups of Cardium edule rather closely, although it should be noted that Purchos (1939) found it impossible to use growth as an indication of age in his investigations.

Summarizing the results arrived at by the authors mentioned it may be stated that the growth rate of Cardium edule varies from region to region, and that it also varies from year to year in the same area. The authors quoted have all used shell lenght as an indication of growth. The most detailed results regarding number of specimens, measured groups, and number of measurements per annuum have been presented by ORTON (1926).

ORTON kept a number of individuals of Cardium edule in an experimental box at the River Yealm estuary from August 1919 to October 1920, during which period the length of the individuals was measured monthly, except for January 1920. A final measurement was made Sept. 6, 1921. It was possible to discriminate between two groups, the $A$ group that was the spat of 1919 , and the $B$ group which was mainly the spat of 1918 . When the cockles were first placed in the experimental box they were marked with file marks cutting the growing edge of the shell. ORTon has illustrated the monthly growth by means of graphs showing length, as derived from monthly measurements of marked individuals throughout the experiment, plotted against number of shells in one millimeter size-classes. It is interesting to note from the graphs that the younger group $(A)$ gradually catches up and merges with the older group $(B)$. In 1921 the two-year-old and three-year-old animals were indistinguishable by size. OrTon also gives a table showing the monthly shift of the peaks of the two groups. The growth of the modal individual is not necessarily the same as that of the average individual, but we are forced to assume that it is if we wish to infer growth rates from the data available. The graph, fig. 24, that has been prepared by the present writer on the basis of ORTON's figures show accordingly the monthly shift as an approximate growth rate for the $A$ and $B$ groups. The average increase in lenght is shown for four years on the basis of the $A$ and $B$ groups and for Cardium grown in the box 1921-23. The annual increase in the cube of length (being a measure of volume increment) is calculated on the same material. The Channel monthly mean temperature off Plymouth, and the spawning period of Cardium edule off Plymouth are added to show the possible effect of spawning and temperature on growth.

The graph suggests:

1. Some correlation between variation of temperature and variation of growth.

2. A decrease in the annual increment of shell length with age, as illustrated by the curve showing monthly increase, and by the declining winter ring curve.

3. Maximum growth during the second and third years and thereafter decreasing growth rate as indicated by the curve of the annual increase in the cube of length.

It is impossible to decide with certainty whether any of the minima of the monthly growth rate during the spawning period may be related to spawning activity. This may, however, well be the case, since the species, according to Orton, matures at an early age. The lows on the growth histogram for the 
two-year-old animals may thus indicate retardation of growth due to spawning.

Before leaving ORTON's investigations it should be mentioned that the animals were apparently severely shocked by the process of file marking, since cessation in growth occured immediately afterwards, causing the occurrence of disturbance rings on the shell surface, similar to - though weaker - than the winter rings. Such disturbance rings were also formed by merely taking the shells out of the box for measurement. Rings on the shell surface of Cardium do, therefore, not necessarily mean winter rings.

The influence of salinity on the shell growth of Cardium edule is illustrated by Bateson (1889), Brandt (1897) and Purchon (1939).

Bateson visited the Aral Sea area in 1886. He studied shells of $C$. edule along the shore of the Aral Sea itself, and in some local depressions formerly connected with the Aral Sea, but dry when he visited the area. One of the depressions, the Shumish Kul, was especially interesting because seven very well defined terraces were found on its shore clearly indicating stages in the drying up of the former lake. The highest terrace might have corresponded to water of a salinity comparable with that of the present Aral Sea whereas the lower terraces clearly indicated lake stages of increasing salinity as also evidenced by the salt pan, which covered the lowest part of the lake. On each of the terraces great quantities of Cardium were found. A great number of the shells were paired, and the ligament was preserved in many cases. Further, it turned out that each terrace had its special variety of Cardium which differed from the terraces above and below both in colour and texture of the shell. The general changes which occured in relation to successive stages of evaporation of the lake are, according to BATESON:

1. Diminution in the thickness of the shells (starting on the third terrace from the top) proceeds to such an extent that the shells of the lowest terrace (corresponding to the lake stage with highest salt concentration) are almost horny and semi-transparent.

2. Size of the umbo is greatly reduced. In shells of the lower terraces the umbo hardly forms a projection on the outside of the shell.

3. The shells become highly coloured.

4. The grooves between the ribs appear on the inside of the shell as ridges with rectangular faces. On the lowest terrace all ribs are affected.

5. On the lowest terrace (corresponding to water of high salt concentration) the shells are greatly diminished in size.

6. The length of the shells increases in proportion to their breadth (lenght/ greatest antero-posterior dimension: breadth/dorso-ventral measurement at right angles to the length).

Bateson measured length $(L)$ and breadth $(B)$ of 30 shells and calculated the ratio: $\frac{B}{L}$ for shells from the Aral Sea and the terraces of the Shumish Kul, and got in this way expressions for the relative elongation of the shells (fig. 25). The average ratios and length intervals are given below, for further details reference is made to BATESON.

The water of the Aral Sea has a salt content of about $10 \%$ at the surface.

Due to the special nature of this investigation it is impossible to give any quantitative expression for the change in salinity, or the time which elapsed during evaporation of the lake in the Shumish Kul depression while the 
Cardium edule L. Aral Sea area. Shape and Weight of Shell related to Salinity

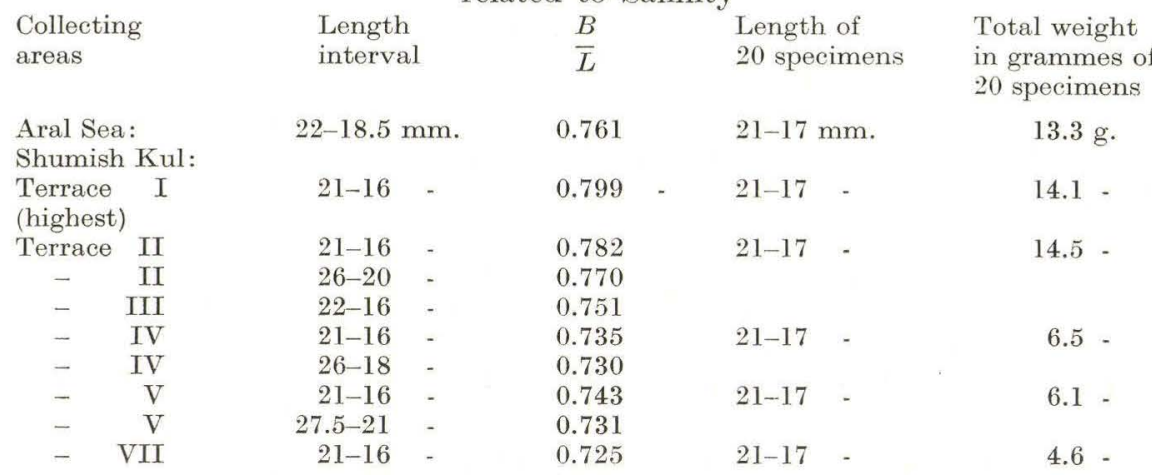

development of the different types of Cardium took place. There is, however, sufficient evidence for the correlation of shell properties with increase in salinity to render this study important in the present connection. BATESon has also studied $C$. edule in two other depressions at the Aral Sea; Jaksi Klich and Jannan Klich, and in the Egyptian lagoon Abu Kir. However, the lack of any
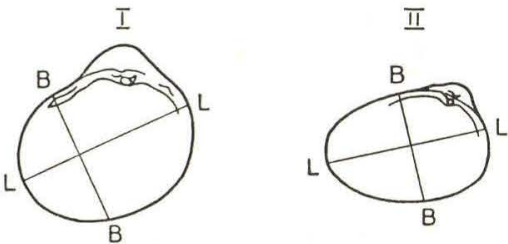

Fig. 25.

Cardium edule L. Aral Sea area.

Diagrams showing the directions in which the length and breadth of the shells were measured. I shell from the shore of the Aral Sea. II shell from the Jaksi Klich. $\mathrm{LL}=$ length, $\mathrm{BB}=$ breadth. (Acc. to BATESON 1889, p. 304). by ORTON off Plymouth, and he stated, moreover, that the animals living on sand attained a larger size than those living on organic detritus. LARSEN (1936, p. 13-14), concluded, therefore: 1. that the small size of $C$. edule in Dybsø Fjord was due to the low salinity of the water, and 2. that the variation in size of Cardium in the bay area could be correlated with variation of the substatum. No serious objections can be raised against this conclusion.

Purchon (1939) collected samples of Cardium edule from the following localities and substrata:

A. Fairlie Sands, Millport. Marine, clean intertidal sand.

B. Pier Cellars Plymouth. Marine, clean sand, rarely above low water mark.

C. St. John's Lake, River Tamar. Estuarine, soft, intertidal mud.

D. Portishead Dock. Estuarine, soft mud, below low water mark.

E. Bawdsey. Brackish (?) mud in shallow lagoon. 
Samples of fifty shells from each locality were investigated regarding the number of ribs, weight and sculpture of the shells, and measure of asymmetry. Investigation of the rib number resulted in the following figures:

Cardium edule L. British waters. Number of Ribs related to Environment. (Loc. A-E see above).

Local- Amount of shells with:

ity

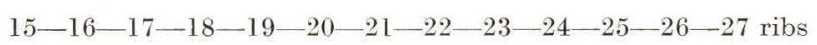

Mean Standard number devia-

$\begin{array}{rrrrrrrrrrrrrr}\mathrm{A} & & & & & & & & & 1 & 11 & 19 & 13 & 6 \\ \mathrm{~B} & & & & & & & 1 & 4 & 9 & 19 & 13 & 4 & \\ \mathrm{C} & & & & 3 & 2 & 9 & 12 & 10 & 11 & 2 & 1 & & \\ \mathrm{D} & 2 & 9 & 12 & 17 & 9 & 1 & & & & & & & \\ \mathrm{E} & & 3 & 4 & 5 & 9 & 14 & 11 & 3 & 1 & & & & \end{array}$
of ribs tion $25.24 \quad 1.13$ $24.01 \quad 1.12$ $21.40 \quad 1.74$ $17.50 \quad 1.03$ $19.54 \quad 1.56$

Purchos does not give any figures for the weight of the shells, but states that shells taken from estuarine mud were lighter than these taken from marine sand. Quoting Loppens, Purchon states further, that the mean numbers of ribs and asymmetry of the shell apparently are related to the same environmental factor, which he thinks is either salinity or texture of the substrate. The

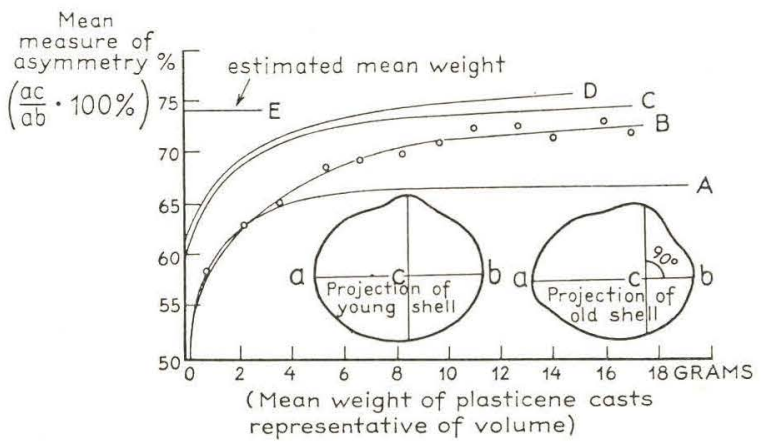

Fig. 26.

Asymmetry of Shells of Cardium edule related to volume.

A. Shells from Fairlie Sands, Millport (marine, clean intertidal sand).

B. Shells from Pier Cellars, Plymouth (marine, clean sand rarely above LWM).

C. Shells from St. Johns Lake, River Tamar (estuarine, soft, intertidal mud).

D. Shells from Portished Dock (estuarine, soft mud below LWM).

E. Shells from Bawdsey (brackish (?) mud, never exposed; fragile shells, no plasticene casts made).

Graph B has been taken as typical, and observations are plotted to indicate the degree of acuracy.

First half of C and D graphs confluent. (Acc. to PuRchon 1939).

asymmetry is illustrated by fig. 26. Purchon made plasticene casts of the shells and weighed the casts, the weights being taken as representative of volume. Also the measure of asymmetry, i.e. $a c$ as a percentage of $a b$ (see, fig. 26) was calculated, $a b$ being the greatest length of the shell, and $c$ the projection of the umbone on $a b$. The measure of asymmetry was plotted against weight classes (0-1.5 g.; $1.5-3.0$ g. etc.) and graphs were drawn as shown in fig. 26.

From his material PURCHON concludes: 1. Shells from sheltered estuarine 
mud are more lightly built and are more asymmetrical than those from marine wave beaten sand. 2 . The measure of asymmetry increases logarithmically with age*), and the greatest rate of increase and highest measure of asymmetry are found in estuarine samples. He finally suggests that the increase of the initial measure of asymmetry from $50 \%$ for "normal" shells, to $60 \%$ for estuarine

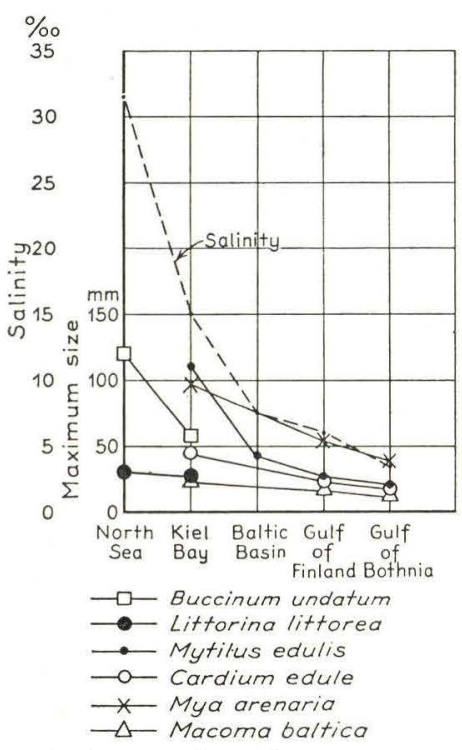

Maximum size of various

Mollusca at different locations in the North Sea and the

Baltic (ACC. to K. BRANDT 1897)

Fig. 27. shells, and above $70 \%$ for shells living in extreme brackish environments may be due to delayed metamorphosis. Subsequent increase in asymmetry may according to Purchon be caused by variation of the environment, or by variation in genetic constitution.

Purchon's investigations suggest that the development of the shell is mainly dependent on salinity and bottom deposit. It may, however, be objected that the number of old shells measured from the Jocalities B, C, D, and E is too low to make the conclusions safe. Quantitative data on salinity for the areas investigated would have been desirable. The assumption that delayed metamorphosis should be responsible for an initial asymmetry appears to be rather speculative. The present writer believes that the measurements of the asymmetry of the smallest sizes are too inexact to provide a basis for discriminating different cathegories of asymmetry. Although Purchon's investigations did not decide whether salinity, bottom deposit or both may be responsible for the observed growth variation, they suggest very strongly the influence of these environmental factors.

In a brief paper on the fauna of the Baltic BRANDT (1897) mentions the maximum size of six molluscs, including Cardium edule, from the North Sea and the following areas of the Baltic region: Bay of Kiel, Baltic Basin, Gulf of Finland and Gulf of Bothnia. His data are shown graphically in fig. 27 together with the salinities of the areas concerned. Unfortunately BRANDT does not give the number of shells investigated, it is accordingly impossible to be sure how much weight should be attached to his statements. Since his data certainly illustrate a significant trend in the response of marine animals to variation of salinity, they have been included here.

The growth of Mytilus californianus was studied by CoE \& Fox during the years 1940-43 at La Jolla, California. On the basis of their data RICHARDS (1946) calculated a growth rate curve which summarizes the seasonal trends for the four year period. This is shown on fig. 28, which has been copied from the Woods Hole report of 1952 , p. 85 . Curves showing the sea water temperature at La Jolla and spawning intensity at the pier colony La Jolla (Young 1946) have been plotted on the same graph.

RICHARDS measured the growth of Mytilus edulis on the Atlantic coast at Woods Hole Massachusetts during the years 1931-34. The calculated

*) "with volume" would be more correct. 
growth rate is shown on fig. 29 together with the surface temperature of the ocean and the breeding season according to FIELD (1911) and FisH (1925) ("Woods Hole" 1952).

It should be emphasized that the studies on $M$. californianus and $M$. edulis were carried out on two different species in very different environments. A detailed record of the discussion of the evidence of the two growth rate curves
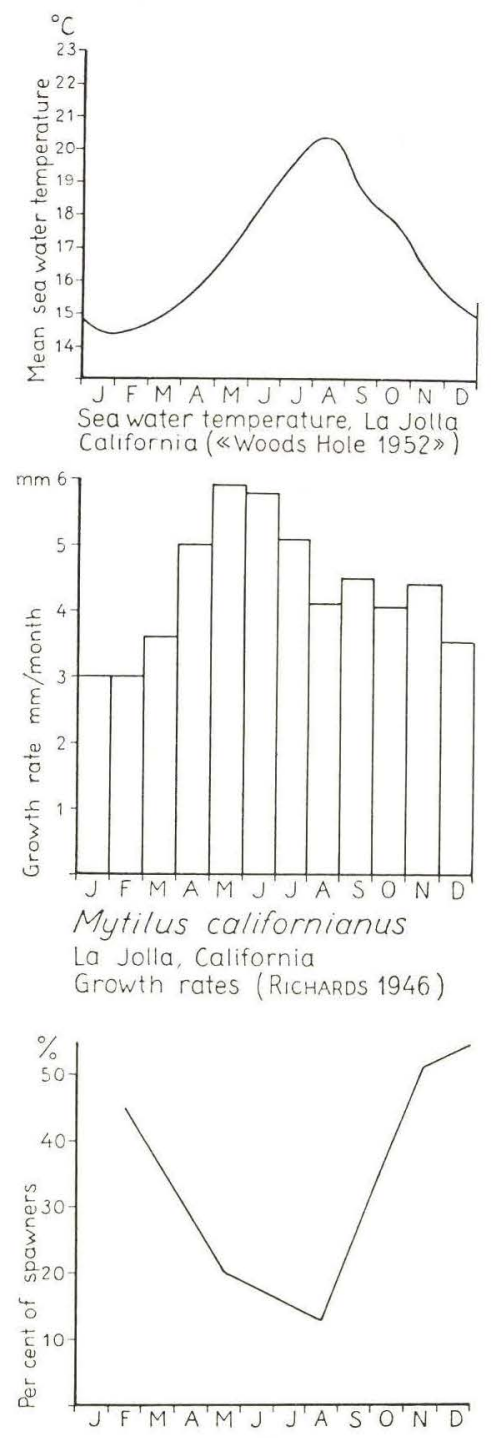

Mytilus californianus

La Jolla, California, Pier colony Averaged percentages of spawners for three month periods (Young 1946)

Fig. 28.

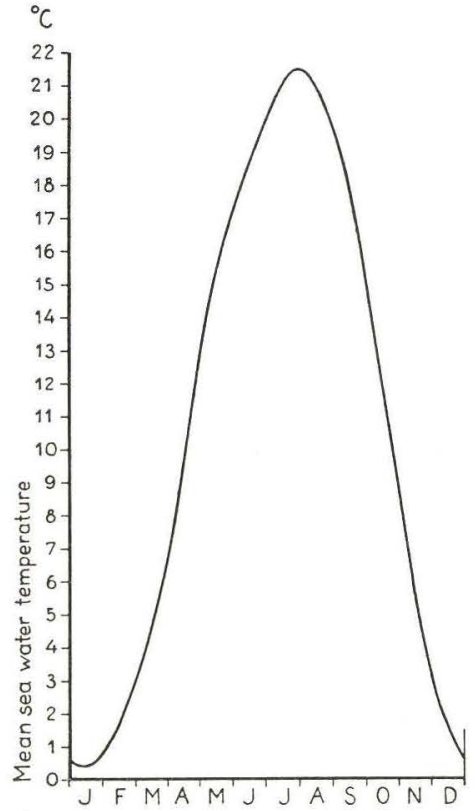

Sea water temperature, Woods Hole

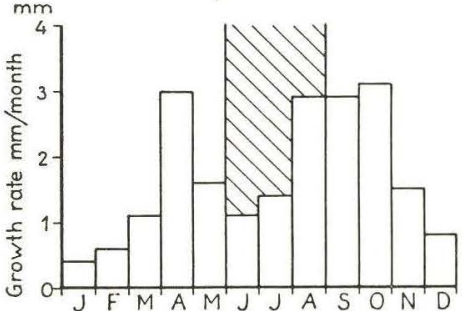

Mytilus edulis L

Woods Hole, Massachusetts Growth rates (RICHARDS 1946) QA Spawning period (FIELD 1911, FISH 1925) \& Sea watertemperatures (SUMNER, OSBURN \& COLE 1911) From » Woods Hole $\ll 1952$.

Fig. 29. 
by RICHARDS (1946) and members of the staff at Woods Hole is published in Woods Hole Contribution No. 580, and will not be given here. Except for CoE \& Fox those concerned obviously agreed that there is some correlation between variation of temperature and growth. In the case of $M$. californianus CoE \& Fox believe that there is an inverse relationship between growth and temperatures above $20^{\circ} \mathrm{C}$. Attempts have further been made by these workers to correlate the growth variations with other factors such as diatom concentration, solar radiation etc. In the case of $M$. californianus CoE \& Fox found the only positive correlation to be with the nutrient supply. RichaRds (1946, p. 370) just touches on the possibility that the reduced growth rate which periodically occurs in both species may result from less energy being available for growth due to sexual activity. From "Woods Hole" (1952) the following is quoted: "The growth curves do not follow the temperature cycle very exactly. This may indicate that some factor other than temperature, such as the nutrient supply, is influencing the growth rate".

The present writer agrees with RICHARDS in his statement that no direct correspondance should be expected for instance between the dinoflagellate abundance and the growth of Mytitus. There is, moreover, very little evidence on lack of nutrient supply being responsible for the depression of growth rates in the two species mentioned, since the depressions occur at a time of the year when sufficient nourishment should be available. It is suggested, therefore, that the apparent coincidence of decline in growth rate and sexual activity is significant and should be correlated. The most simple, and likely explanation is that the energy required for reproduction reduces the growth rate during the breeding period. Sexual activity may thus mainly be responsible for the lowered growth rate in $M$. californianus during the summer. This is in agreement with the statement set forth by CoE \& Fox $(1942$, p. 24) that some of the growth rings on the shell of this mussel, and the corresponding cessation in growth, may indicate spawning periods. It must be admitted that the data on spawning in Mytilus californianus may have been too much generalized. In this connection the curve shown on fig. 28 has only been used to indicate the period in which the main spawning has probably taken place. Since the curve for the "Pier Colony" of Mytilus is very similar to that of the "Rock Colony", but different from the one from "Alligator Head" (Young 1946), the "Pier Colony" spawning has been considered relatively close to the mean spawning period.

The reaction of Mytilus edulis to variation in salinity, as far as growth is concerned, is indicated on the graph fig. 27 . Growth rate in relation to duration of life and environmental factors such as salinity and nutrient supply has been treated by Fischer-Pietre (1941) in Patella and Mytilus.

The growth of Littorina littorea has been thoroughly studied by H. B. Moore (1937) near Plymouth at the following locations:

A. Trevol. Mud flat in the middle of St. John's Lake, opposite Trevol Pier at mid-tide level. On most of the ground there is no macroscopic algal growth.

B. Drake's Island. Stony beach on the north side of the island, medium amount of Fucoid growth, mid-tide level to mean low water of neap tides and spring tides.

C. Yealm Misery Point. About mean low water of spring tides. Very little Fucoid growth. The Littorina cluster in very large numbers on Fucus. A tidal stream of about $2 \frac{1}{2}$ knots maximum flows past the point. 
Moore illustrates the growth of Littorina by means of the cube of the height and by the tissue growth, as for instance shown in fig. 30 (copied from MoorE), which displays the conditions in successive year groups at Trevol. The values are calculated from monthly measurements of representative samples of Littorina that were collected from Aug. 1934 to June 1936. There is good correlation between tissue growth and the cube of shell height. The decrease in tissue weight from February to May in the 3rd and 4th year groups is due to spawning activity as clearly shown by Moore. The dependence of growth on temperature is not so striking in this mode of illustration, and Moore's graphs have therefore been used for the calculation of approximate growth rates. For this purpose height cubed and tissue weight for the middle of each month were read off from the curves, and the height was calculated. On the basis of the figures thus obtained, representing approximate monthly means, growth rates were calculated for shell height and tissue weight, and expressed in $\mathrm{mm} /$ month and $\mathrm{mgm} /$ month respectively. This illustration of growth (fig. 31) is thus comparable with the growth curves shown above for Cardium and Mytilus. It should be noticed, however, that in the present case the measurements are made on different year classes of Littorina during periods of 15,16 and 23 months respectively at Drake's Island, Yealm and Trevol, and not on single year classes that are followed for four years.

The graphs fig. 30 and 31 suggest that the rate both of shell and tissue growth are related to the annual temperature cycle. The main growth apparently takes place during the months of August and September when the sea temperature is at its highest, and growth is at a minimum during the period of minimum.

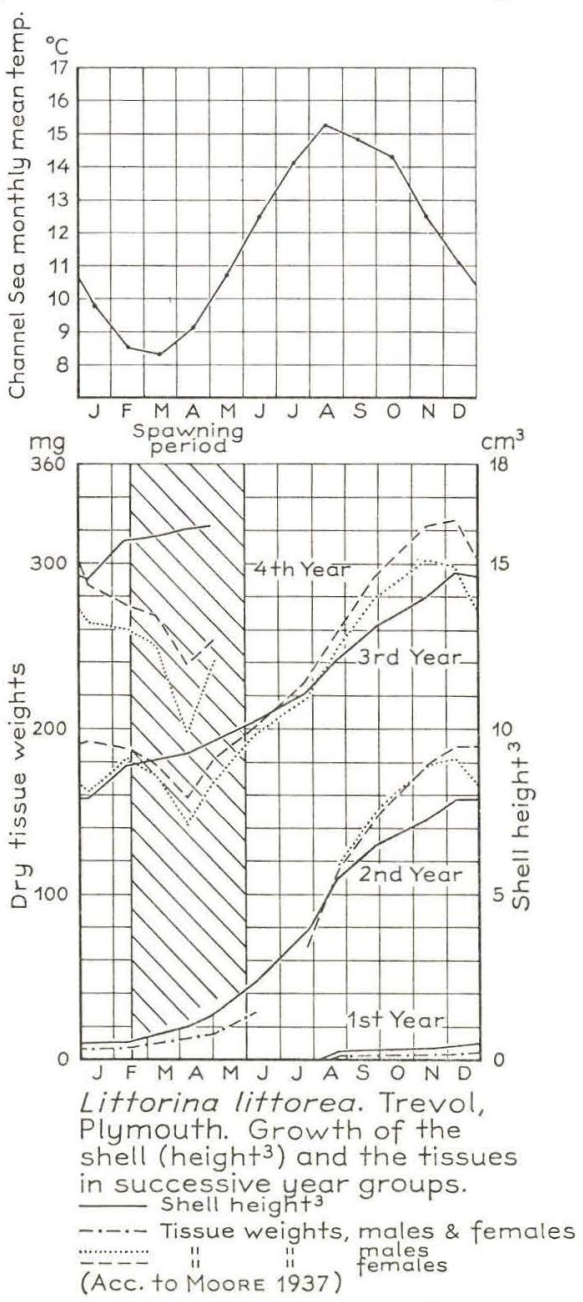

Fig. 30 . temperatures and the breeding season. Growth seems in general to be greatest in the second and third year groups, except that the population at the Yealm exhibits maximum growth in the third and fourth year groups. It might be assumed, therefore, that maximum growth occurs during the second or third year in Littorina, and the conditions at the Yealm may reflect overcrowding and a harder struggle for either room or food than in the two other locations. This would explain why the oldest and most vigorous group grows mostly at the Yealm. Another interpretation is, that the salinity differs in the three 

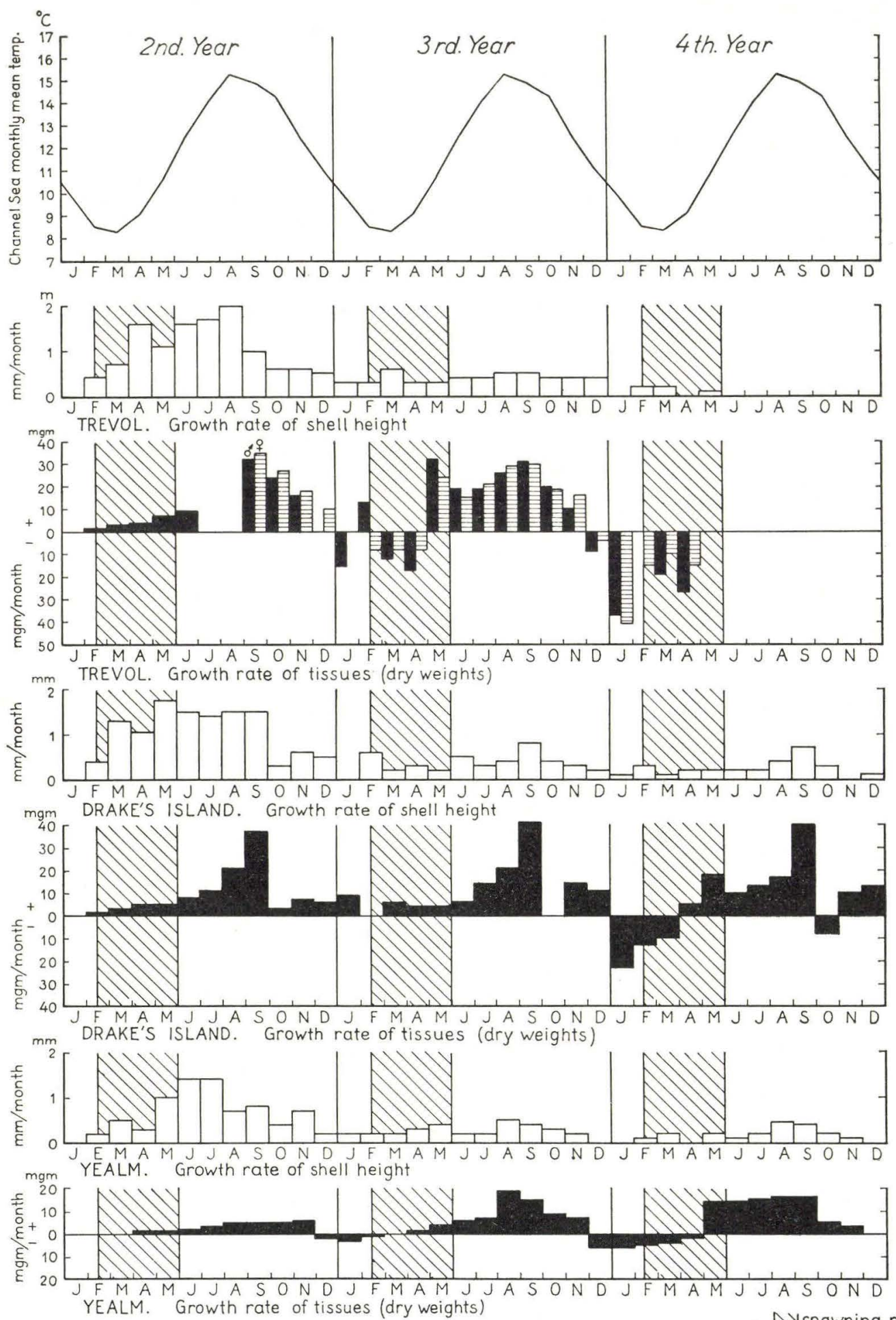

Littorina Littorea. Growth rates (compiled from MOORE 1937) Nspawning period and sea water temperatures off Plymouth (ORTON 1922)

Fig. 31. 
places, and that estuarine conditions prevail in the Yealm area, whereas salinity is more normal at Trevol and Drake's Island.

Moore's measurements also reveal that the females of Littorina littorea attain a greater final size than the males; this is illustrated by graph fig. 32 .

The investigations by Moore are very important. Similar investigations should also be carried out in other areas in order to determine whether the principles suggested by Moone are generally applicable. Research of this kind should be followed by hydrographic studies to secure an adequate interpretation of the results.

An indication of the reaction of Littorina littorea to different salinities regarding growth is shown by fig. 27, p. 366 Maximum size obviously decreases with decreasing salinity.

Purpura lapillus has been the object of very incisive studies by Mooke $(1936,1938)$. This ga-

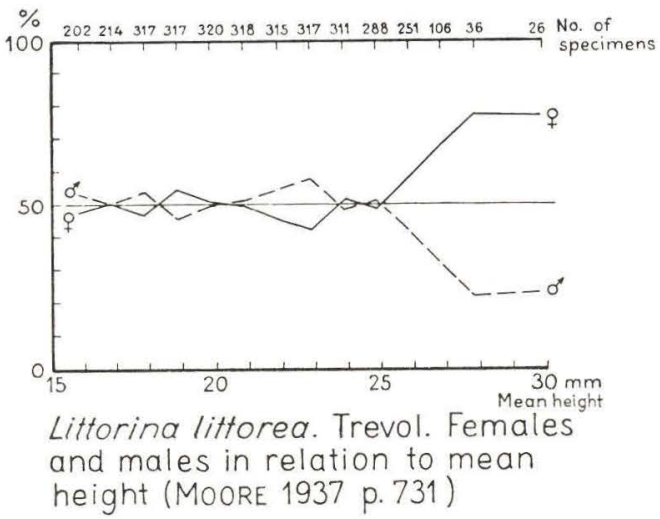

Fig. 32 . stropod differs from Littorina in that as growth ceases at sexual maturity. The growth rate is rather difficult to determine in this species partly due to the fact that it appears impossible to separate individual year groups as in Littorina. Mooke therefore marked individual animals in various ways and measured their increase in shell growth at intervals. The small sizes had to be kept in laboratory tanks whereas the larger ones were living in nature. Observations were made on Drake's Island near Plymouth and on the shores of the Isle of Man. The figure showing the growth of individual Purpura on the shore of the Isle of Man, fig. 3 in Moone's paper from 1938 (a), is reproduced here as fig. 33 . The graphs relate height to the time of observation, and illustrate how growth ceases in various individuals at different shell heights corresponding to the onset of maturity in the individual concerned. The numbers of individuals and measurements is too small to warrant the calculation of growth rates for comparison with temperature variations. In this connection it is noteworthy, however, that the steepest parts of the curves indicating the most rapid growth occurs in spring and summer while the flatter parts of the curves are mainly found opposite cold periods of the year. This might suggest direct or indirect correlation of growth with temperature variations, as in Littorina, Mytilus etc.

Fig. 34 shows the annual variation in tissue weight of mature Purpura and also the spawning period. The weight minimum is doubtless mainly caused by spawning activity. The low temperature and maybe a lack of nutrient supply during winter may, however, be responsible for part of the tissue weight decrease.

Moore's investigation of the influence of the diet of Purpura on the shell colour is now a classical study (1936 a). In a convincing manner Moore succeeded in proving that increase of Mytitus in the diet of Purpura increased the proportion of the two shell colour types: brown-black and mauve-pink, and that specimens of these types, which were put to feeding on Balanus or Chthamalus gradually lost their pigmentation and grew white. The factor responsible 


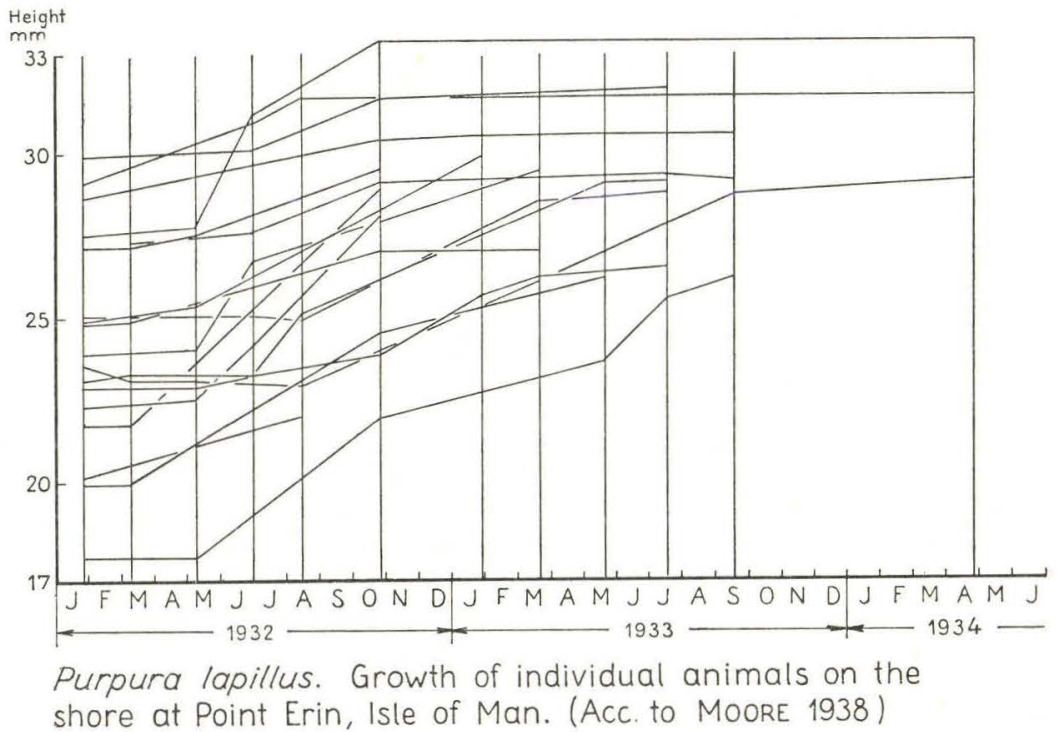

Fig. 33 .

for yellow shells appeared, however, to be very doubtful, although there seemed to be some correlation with exposure to wave action.

The effect of salinity on growth has been treated above in the cases of Cardium edule, Mytitus edulis, and Littorina littorea. The graph fig. 27 on p. 366 shows, moreover, maximum sizes of Buccinum undatum, Mya arenaria, and Tellina baltica at different salinities. All curves agree in showing decrease in size if the salinity falls below the normal values for the marine areas of distribution.

From this review of growth in Pelecypoda and Gastropoda we may conclude the following:

1. Growth is marked by seasonal rythms.

2. Maximum growth rate may be related to the temperature optimum of the individual species.

3. The annual size increment reaches a maximum at a certain intermediate age, after which it declines.

4. The age at which the annual growth increment is at a maximum may be definite, but considerable variation occurs in some species, as shown for instance by Littorina littorea.

5. Spawning periods are generally characterized by decreased tissue and shell growth, in those cases where growth does not cease altogether at sexual maturity.

6. Salinity may affect growth considerably. Salinities above or below the normal range of a species generally result in decreased size and shell thicknesses.

7. Different salinities may result in different shell shapes and colours.

8. Different habitats may give rise to different morphological types of a species.

9. Diet may in some species act upon shape and colour of the shell. 
It is not known whether the variations mentioned under $6-9$ are hereditary. Probably most are not, but knowledge of such variation is nevertheless extremely important for the geologist and paleontologist.

\section{B. Reproduction}

The reproduction of Pelecypoda and Gastropoda has been the subject of studies by N. Odhner (1914), M. V. Lebour (1932 a-c, 1933 b-e, $1937 \mathrm{a}-\mathrm{b}$, 1938 a-b), B. Werner (1939), G. Thorson (1933, 1934, 1935, 1936, 1946), C. Barker Jørgensen (1946), and others. The different phases in reproduction have especially been discussed by Lebour, and Thorson, and particularly THonson's paper of 1946 gives a comprehensive record on this topic. (l.c. p. 417, etc.).

Reproduction may be subdivided into the following phases: a. ripening of sexual products, b. fertilisation, c. spawning, d. hatching, e. larval stage, and $f$. metamorphosis. It is well known, that several prosobranchs for instance hatch in the crawling stage, and that the larval stage is passed in the egg or the egg capsule (see Lebour 1937 b, p. 110, and Thorson 1936, p. 38, and 1946, p. 240). The pelagic larval stage has thus been abandoned in some species, and the subdivision above gives accordingly the aspect of a complete succession of phases that may be modified in various regards in some species.

The influence of environment upon the individual phases of reproduction is still little known, but it is generally realized that salinity and temperature have important effects. The effect of some environmental factors will be illustrated in the following.

Food is an important prerequisite for growth, and consequently for development of the sexual products of the animals. In the case of Littorina littorea off Plymouth it is significant that the first spawning apparently occurs when the animal has attained a certain size regardless of age (viz. when the tissue weight is about 130-180 mg) (see p. 369). In Purpura lapillus we find an
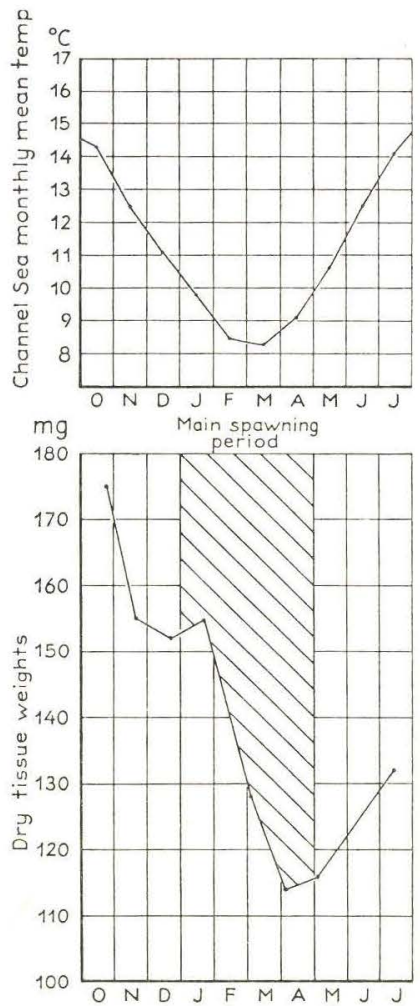

Purpura lapillus. Misery Point, Yealm, Plymouth. Seasonal variation in tissue weight of mature (non-growing) (Acc. to MOORE 1938) high.

Fig. 34 . example of growth ceasing at maturity, with the age of maturity being dependent on diet (see Moore 1936, 1938). No such examples are known in Pelecypoda.

Salinity must undoubtedly be within certain limits to enable the eggs to develop. The salinity range for the development of the eggs is in most cases probably narrower than the range for survival of the adults.

Hayes' (1926) experiments with eggs of Littorina littorea are illustrative of the effect of salinity on development. The eggs were kept in bottles with sea water diluted to salinities of $0,5,10,15,20,25$ and $30 \% 0$, and the bottles were 
hung off the breakwater at the Atlantic Biological Station St. Andrews, New Brunswick, during the summer of 1925 . It appeared that no development took place in the bottles with salinities of 0 and 5 , and no development past early segmentation stages could be found with salinity conditions of 10 . In water with a salinity of 20 and 25 development progressed normally although the lowered salinity retarded the development somewhat. In normal water the veliger hatched on the sixth day.

The lower limit of the salinity range for the larvae of A porrhais pes pelicani, Montacuta bidentata, Eulimella nitidissima, Anomia squamula, and Cultellus pellucidus from the Öresund has been stated to be $20 \%$ by Thorson ( 1946 , p. 382). Späвck (1925) kept larvae of Ostrea edulis alive for 8 days in water of salinities $23 \%$ and $19 \%$, whereas larvae only lived for $3-4$ days in $16 \%$ saltwater, the lower limit of survival is thus apparently about $25 \%$.

Temperature. The significance of temperature as a controlling factor in breeding has been treated by many authors. APELLöF (1912) drew attention to the fact that the eggs of Cucumaria frondosa, an arctic relict Holothurian living on the boreal coasts of Norway, would not develop in water of a higher temperature that $13^{\circ} \mathrm{C}$ and that the main breeding period of this animal on the Norwegian coast is in February and March when the temperature of the sea is at a minimum. He concluded that the vegetative processes of the adult animal are adapted to temperatures higher than those prevailing in the main area of distribution of the animal in the Arctic, while reproduction is restricted to the coldest part of the year at the Norwegian coast and thus indicates less adaptability of reproduction in relation to temperature. ApELLöF discussed also the breeding period of Ostrea edulis and Tapes decussatus in southern Norway and mentioned that these southern forms apparently need a temperature of about $20^{\circ} \mathrm{C}$ for reproduction.

ORTon (1920) attempted to relate breeding to temperature and geographic distribution. Among other facts, he mentioned that Ostrea edulis breeds earlier in southern areas than in northern waters. He stated, moreover, that this species begins to breed at a temperature of about $15^{\circ}-16^{\circ} \mathrm{C}$, and that it continues its activity as long as the temperature is above that figure. Data on the reproduction of Cardium edule, Patella vulgata etc. are given, and ORTon finally concludes that a temperature stimulus may be the normal impulse for in d u cing sexual activity in marine animals assuming normal biological conditions. ORTon clearly regarded particular temperature limits as critical and the significance of temperature is accordingly that of intensity.

SpÄrck (1925) is apparently of a somewhat different opinion. In the case of Ostrea edulis, he thinks that strictly speaking, reproduction is independent of a particular temperature. According to SpÄRCK the critical factor of temperature is one of capacity, not intensity, i.e. the total accumulation of heat.

RUNNSTRÖM's investigations (1928) of the spawning seasons of various marine animals living on the Norwegian coast are of outstanding importance. He arrived at the conclusion that the arctic-boreal species breed during winter, the boreal species during spring, and the Mediterranean species during summer. Twelve species were examined among which Mytilus edulis was the only molluse.

In addition to the observations on breeding RUNNstRöm also made experiments in the laboratory on the development of egg s under various temperature conditions, and thus determined the temperature range for this stage of reproduction. In the case of Mytilus edulis it appeared that at $1^{\circ}-3^{\circ} \mathrm{C}$ the 
development was pathologic, the lower limit for normal development being about $4^{\circ} \mathrm{C}$. The upper limit proved to be about $16^{\circ} \mathrm{C}$, above which temperature the eggs also developed pathologically.

On the basis of his experiments RunNstRöm stated the following temperature ranges for the normal development of eggs:

Three arctic species: $-1^{\circ}-+11^{\circ} \mathrm{C}$.

Four boreal species (including Mytilus edulis): $3^{\circ}-16^{\circ} \mathrm{C}$.

Five mediterranean-boreal species: $7^{\circ}-23^{\circ} \mathrm{C}$.

Runnström thus confirms ApeLLöf's suggestion concerning correlation of spawning season with geographic distribution, and he concludes that in all probability restricted spawning seasons mean that particular ranges of temperature are the main controlling factors. However, RUNNSTRöM also states how important it is to study the reaction of each individual stage of reproduction to temperature. The experiments by PeLseneer (1901) with larvae of marine animals from the English Channel are mentioned. PELSEnEer concluded that the younger the larvae are, the more sensitive they are to temperature. Pelseneer made experiments with 13 species of molluses: 2 cephalopods, 8 gastropods, 1 pelecypod, and 9 nudibranchs. He subjected 3 nudibranchs and the following 2 gastropods to low temperatures: Littorina obtusata (embryo near hatching) and Patella vulgata (three days old larvae). Both gastropod larvae resisted a temperature of $-2.5^{\circ} \mathrm{C}$. The temperature could not be lowered more due to freezing, and an admixture of salt would have killed several of the larvae. Upper death limits were found by experiment in the following 6 gastropods and 1 pelecypod (l.c. p. 282):

$\begin{array}{llll} & \text { Larval stage } & \text { Uper } & \text { Zoogeographic } \\ \text { Species } & \text { Lange acc. to } \\ \text { death } & \text { rangella vulgata } & \text { limit } & \text { BRöGGR (1901) } \\ \text { Patella vulgata } & \text { two days old larvae } & 34^{\circ} \mathrm{C} & \text { boreal } \\ \text { Nassa reticulata } & \text { four days old larvae } & 36^{\circ} & \\ \text { Nassa reticulata } & \text { hatched veliger } & 30^{\circ} & \text { lusitanian } \\ \text { Littorina littorea } & \text { veliger near hatching } & 35^{\circ} & \\ \text { Littorina obtusata } & \text { embryo beginning to rotate } & 37^{\circ} & \text { boreal } \\ \text { Littorina obtusata } & \text { embryo near hatching } & 30^{\circ} & \\ \text { Lacuna pallidula } & \text { veliger near hatching } & 32^{\circ} & \text { boreal } \\ \text { Lamellaria perspicua } & \text { veliger near hatching } & 35^{\circ} & \text { (lusitanian) *) } \\ \text { Pholas candida } & \text { trochosphere } & 32^{\circ} & \text { lusitanian }\end{array}$

Pelseneer mentions the occurrence of heat stupor and cold stupor long before the lethal temperatures were attained (p. 287). He gives, however, no exact figures for these temperature levels.

It should be mentioned that EkMAN (1935, p. 173, and 1953, p. 113) also drew attention to the difference in reaction to temperature in the adult and reproductive stages of marine animals. He distinguished consequently between vegetative and reproductive eurythermy and stenothermy.

Thorson (1946, p. 421) also discussed the effect of temperature upon reproduction. Of particular interest is his statement that breeding in Mya truncata and Saxicava arctica in arctic East Greenland may not be dependant on temperature as a spawning inducer, although spawning is clearly limited to the summer season. This opinion is supported by various arguments based

*) L. perspicua not mentioned by BröGGER. 
on the hydrography of the surveyed fiords. The fact that spawning began in May at temperatures as low as those observed earlier in January, when THoRson started his investigations, is considered to disprove temperature as a (direct) regulator of breeding. Phytoplankton maxima that occurred simultaneously with spawning in Mya and Saxicava led Thorson to the assumption that phytoplankton increase may induce spawning in marine invertebrates.

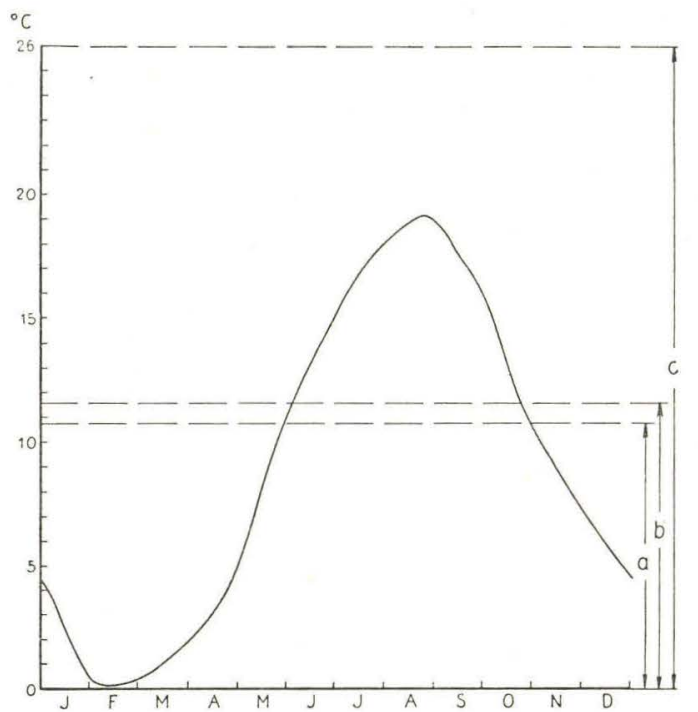

Fig. 35. Thermal intervals of cold water species $\boldsymbol{A}$. Seasonal sea water temperature curve of temperate area, and thermal interval of: period of spaw. ning $(a)$ larval stage $(b)$ adult stage $(c)$.
The mechanism of tem perature control may not be a very simple one. Heat capacity, heat intensity, and temperature changes have been suggested as significant. None of the views hitherto set forth in this connection appear, however, to explain adequately all observations. It may be reasonable to assume heat capacity and intensity as well as temperature changes to be important, and it must furthermore be anticipated that temperature control may work in different ways in different species.

The reaction of aretic species to temperature at their southern limit of distribution indicates that the temperature requirements in such species may not be dominated by heat

capacity demands (see for instance Jensen 1905 b, Yoldia arctica). A general suggestion that heat capacity is the critical factor may thus be wrong. It is also a question whether temperature changes are generally critical, provided that the changes do not exceed certain critical temperatures or rates of change, and it is certainly inadvisable to regard specific temperatures as inducers of the different physiological processes which contribute to reproduction.

From a general viewpoint it seems to be safest at present to accept the fact that the physiological processes of different animals are adjusted to specific temperature ranges by some means or other, and that each individual process may continue as long as the temperature is within its specific range. In the case of reproductive processes it is obvious that temperature limits may be particularly critical, since annual temperature cycles may result in restricted activity, reproduction being confined to short periods of the year. The result of this effect on the geographic distribution of marine life has been treated by Apellöf (1912), ORton (1920), Hutchins (1947) and others, and it is also briefly treated on p. 387 in this paper.

The diagrams fig. 35 and 36 illustrate some of the fundamental relationships connecting the annual temperature cycle, the temperature requirements of the main reproductive stages, the season of reproduction, and the geographic distribution of marine mollusca. Both diagrams refer to the same temperate marine area, the seasonal temperature curves of the water are accordingly 
identical in the two figures. Fig. 35 illustrates the temperature characteristics of a species that lives near its climatic warm limit, and fig. 36 shows the same features in a species that lives near its climatic cold limit.

In accordance with the statements above regarding the salinity requirements of a species, we may accept that each reproductive stage as well as the adult stage is also adapted to a particular temperature range that briefly may be called the thermal interval of the stage. The thermal interval of a stage is signified by various thermal values viz. upper and lower limits of survival, an optimum value lying between, and possibly some other significant temperatures. Our present knowledge regarding thermal intervals is very fragmentary. It must, however, be anticipated that a considerable number of combinations of values and limits will occur, and it is therefore inadequate to characterize a species simply as eurythermal. The definitions of eurythermy and stenothermy are in any case arbitrary, and their application to particular cases may be biased by accidental geogra-

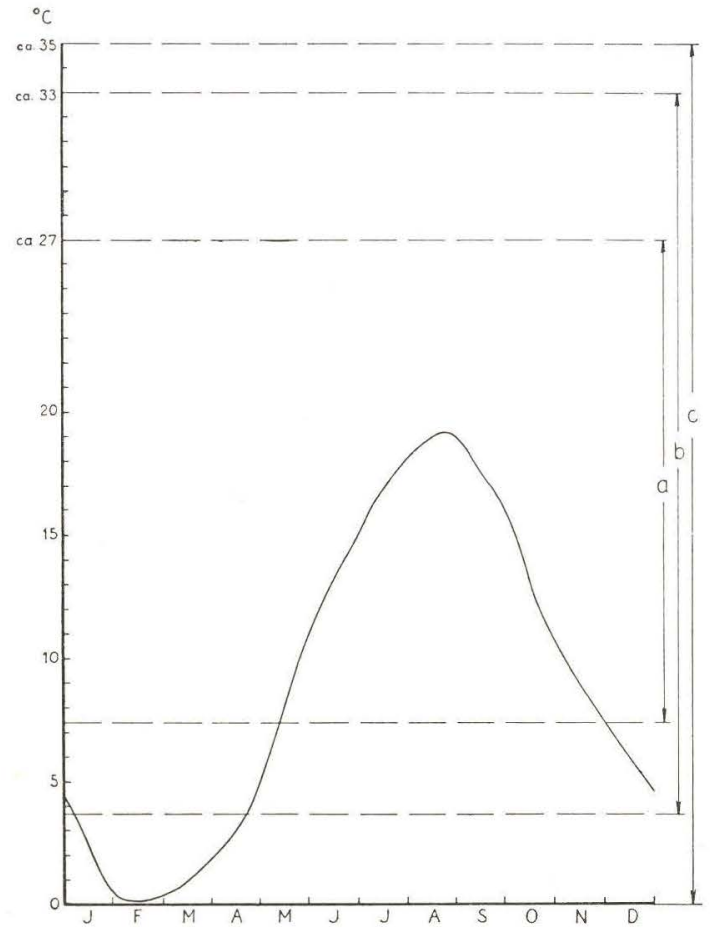

Fig. 36. Thermal intervals of warm water species $\boldsymbol{B}$. Same sea water temperature curve as in fig. 35 and thermal interval of: period of spawning (a) larval stage $(b)$ adult stage $(c)$. phic phenomena. At the limits of its distribution we may be inclined to designate a species as stenothermal, whereas it may be regarded as eurythermal in the center of its geographical range. It would accordingly be more correct to express temperature dependency by means of thermal intervals and corresponding thermal values for each stage of life in the animal concerned. To characterize a species by a complete set of thermal ranges is one goal of ecology, but one that is very far from being realized.

EKMAN's $(1935,1953)$ discrimination between the thermal characteristies of reproductive and vegetative stages is an advance in the right direction. It should, however, be remembered that EkMan's distinctions are based on subjective judgement of where the boundary between stenothermy and eurythermy should be placed, and even PARR's subdivision of stenothermy and eurythermy suffers from being more or less subjective (PARR 1933, p. 80).

A species may be related to the following fundamental thermal intervals:

1. Period of spawning

2. Larval stage

3. Adult stage

4. Period of ripening of sexual products

$$
\begin{aligned}
& \text {-interval } a . \\
& \text {-interval } b . \\
& \text {-interval } c . \\
& \text {-interval } d \text {. }
\end{aligned}
$$


The length of time required for development from one stage to the next should perhaps be added to the above list. The duration of each stage may vary with temperature, provided all other conditions are equal, as is illustrated by the well known case of warm water forms developing more slowly at lower temperatures (see e.g. Spärck 1925, p. 44 etc., and THonson 1946, p. 452). The rate of development may be more or less proportional to the excess of temperature above a certain minimum in possibly most species (see e.g. AlteE etc. 1949 , p. 111 etc.), which is in agreement with the concept that a certain amount of heat is necessary for the completion of a stage (theory of the thermal constant: time $\times$ temperature $=$ constant). For a general outline of the problems involved the reader is referred to textbooks on ecology, e.g. Hesse et al. 1951, Aluee et al. 1949. While it is not intended to enter into a general discussion here, the significance of the duration of the larval stage will be briefly discussed in the following. The length of time required in the larval stage has for practical reasons been indicated as constant, 2 months, regardless of the temperatures at which development takes place.

The conditions shown in fig. 35 reveal that the cold water species $A$ may spawn at any time from about November to about May, and the emerging larvae may survive between about October and June. Only larvae that have emerged before April will complete their development before the temperature of the water rises above the upper death limit of the larval stage due to the two months required in the larval stage.

The first eggs shed, i.e. the ones shed shortly after the temperature has fallen below the upper thermal limit of the spawning stage in November, have the best chance of survival. The resulting individuals consequently form the main stock of the next first year group. Presupposing that this group becomes sexually mature it may spawn and contribute to the brood in the second autumn. As time goes on the population of species $A$ may thus be adjusted to the local thermal conditions, and the main spawning will presumably take place during the time of declining temperature in the autumn and winter. A favourable nourishment supply during the summer months may also encourage tendencies toward spawning in the autumn by providing the physiological basis for such acitivity.

Fig. 36 illustrates the reproductive characteristics of the warm water species $B$ which, as is mentioned, is living near the lower thermal limits of its reproductive stages. The diagram shows that spawning may take place from about May to December. Development of the larvae may proceed until about January, but only the larvae that have emerged before November survive, due to the time required by the larval stage. As in species $A$, it is obvious that species $B$ may gradually become adjusted to summer spawning, since the eggs shed early in summer will have the best chance for further development.

It is of particular interest to note that larvae of species $A$ and $B$ may be present contemporaneously in the plankton, viz. during November and December, in spite of the fact that species $A$ is a cold water form, and species $B$ a warm water form.

The spawning of Mya truncata in Danish waters (Boysen Jensen, 1920, p. 35 etc., Barker Jørgensen, 1946, p. 306) could be explained in accordance with species $A$ above, and that of Pecten opercularis in accordance with species $B$ (BARKER JørGENSEN ibid. p. 306). Larvae of these two species may occur contemporaneously in the Öresund (this was the case in October 1941). Many similar examples may be found in temperate waters where cold and warm species overlap.

It should be realized that the thermal limits discussed above must be 
statistical mean values. The temperature requirements of single individuals differ more or less and therefore may deviate from the mean values for the species, and also the thermal intervals may not be identical in different parts of the geographical range of a species due to the development of local races.

From the above we can conclude that seasonal spawning may be common in areas where there is considerable seasonal variation of temperature. However, seasonal spawning need not be directly governed by thermal regulation. If a species lives all the year round with temperature conditions between the thermal limits of all its stages of development, other potential cyclic factors, like food supply etc., which affect reproduction may cause seasonal spawning. Mya truncata in East Greenland may be mentioned in this connection (THorson 1946, p. 424). It is possible that the seasonal variation of food supply in Greenland waters is responsible for the seasonal spawning of $M y a$, as the animal lives above the lower and below the upper thermal limit for spawning activity throughout the year. This problem has, however, not yet been settled satisfactorily.

In accordance with the statements above, it should be stressed that the writer does not consider specific temperatures to be spawning "inducers", but they are regarded as spawning "requirements". The complete series of thermal intervals covering the developmental stages of a species control reproduction. The thermal intervals act as a set of screens of different meshes which determine the survival, but, contrary to e.g. mechanical sorting, nature initiates sorting with the smallest mesh, i.e. the narrowest thermal interval, when reproduction starts.

\section{The Pelagic Larval Stage}

The pelagic larval stage in some British pelecypods and gastropods has been studied by M. V. Lebour (1932-38), and Thorson (1946) has treated species living in Danish waters in great detail. The effect of environment on this stage has been discussed by Thonson (1946, p. 431-47) and reference is therefore made to his treatise.

The pelagic stage is of considerable interest as it represents that period of development in Mollusca during which the widest dispersal of the species may take place, and its significance with respect to geographic distribution is accordingly obvious.

As mentioned on p. 378 the duration of any developmental stage may depend upon temperature. The relationship between temperature and the duration of the larval stage have not yet been determined. However, Thonson (1946, p. 453) has compiled the data shown in the following table:

Table 4. Duration of Larval Stage (from Thorsox 1946)

\begin{tabular}{|c|c|c|c|c|c|c|}
\hline Gastropoda: & Locality & $\begin{array}{l}\text { In }(\mathrm{E}) \times \mathrm{xpe}- \\
\text { riment or } \\
(\mathrm{N}) \text { ature }\end{array}$ & $\begin{array}{l}\text { (n)ormal } \\
\text { fertili- } \\
\text { zation }\end{array}$ & $\begin{array}{l}\text { Tempe- } \\
\text { rature }\end{array}$ & $\begin{array}{l}\text { Duration } \\
\text { of larval } \\
\text { stage }\end{array}$ & Author \\
\hline $\begin{array}{l}\text { Rissoa mem- } \\
\text { branacea }\end{array}$ & Plymouth & $\mathrm{E}$ & $\mathrm{n}$ & $?$ & $\begin{array}{l}3 \text { weeks } \\
\text { or less }\end{array}$ & Lebour 1934 \\
\hline Nassa & Isefjord & $\mathrm{N}$ & $\mathrm{n}$ & $?$ & $2-3$ weeks & Thorson 1940 \\
\hline reticulata & Plymouth & $\mathrm{E}$ & n & $?$ & $\begin{array}{l}\text { abt. } 2 \\
\text { months }\end{array}$ & LEBOUR 1931 \\
\hline $\begin{array}{l}\text { Nassa } \\
\text { incrassata }\end{array}$ & Plymouth & $\mathrm{E}$ & $\mathrm{n}$ & $?$ & $\begin{array}{l}\text { at least } \\
2 \text { months }\end{array}$ & Lebour $193 \mathrm{I}$ \\
\hline Littorina & Öresund & $\mathrm{N}$ & $\mathrm{n}$ & $?$ & $4-5$ weeks & Thorson 1940 \\
\hline littorea & Isefjord & $\mathrm{N}$ & $\mathrm{n}$ & $?$ & abt.4 - & Thorson 1940 \\
\hline $\begin{array}{l}\text { Bittium } \\
\text { reticulatum }\end{array}$ & Isefjord & $\mathrm{N}$ & $\mathrm{n}$ & $?$ & abt.3 - & Thorson 1940 \\
\hline
\end{tabular}




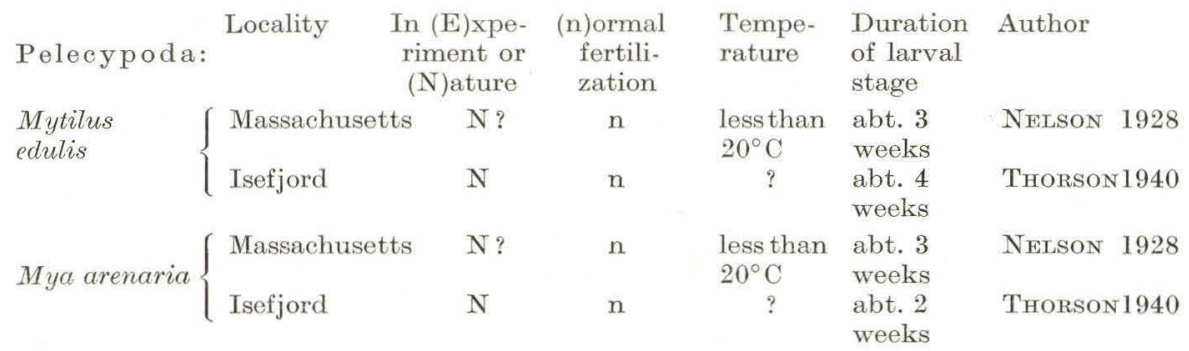

Thorson (1946, p. 415) has made an estimate of the average duration of the pelagic larval stage of invertebrates living in Danish waters. He states that the duration may be about 3 weeks in summer, and 2 to 3 months in winter. This must, however, be regarded as very approximate, and much research must be carried out before more exact data can be furnished.

During the pelagic stage the larvae may be widely dispersed by currents, and the larvae may also themselves contribute to transportation on a minor scale by swimming with their velum. Consequently the greatest potential dispersal will be obtained in species with a lengthy pelagic stage. Very little is apparently known about the distances travelled by pelagic larvae. The only observation in this connection of which the writer is aware, being that by CRAven (1877, p. 124) who observed several "sinusigera"-larvae, the pelagic larvae of prosobranchs probably living in shelf areas of the Indian Ocean, drifting in the sea in a position $11^{\circ} \mathrm{S} 80^{\circ} \mathrm{E}$, more than 1300 kilometres from the nearest land, the coral islands of Pona Molulique. It may be significant that the shells of the pelagic larvae observed by CRAvEN all have relatively many whorls as shown by his illustrations:

\begin{tabular}{lcccc}
\multicolumn{1}{c}{ Species } & Plate & fig. & $\begin{array}{c}\text { Approximate } \\
\text { number of } \\
\text { whorls }\end{array}$ \\
Sinusigera reticulata CrAVEN & III & 3 & 5 \\
Sinusigera perversa & - & III & 4 & $6-7$ \\
Sinusigera minima & - & III & 5 & 4 \\
Sinusigera cancellata & - & III & 2 & 4 \\
Sinusigera Broeckiana & - & IV & 6 & 4 \\
Sinusigera striata & - & IV & 4 & 5 \\
Sinusigera dubia & - & IV & 3 & 6 \\
Sinusigera d'Orbigny & - & II & 3 & 3
\end{tabular}

Lenche (1948, p. 11) has made an observation which is of particular interest, he states that the protoconch of the tectibranch gastropod Diaphana minuta from depths of more than $1000 \mathrm{~m}$ in the North Atlantic near Iceland may have more, or larger whorls than the shells of individuals living in shallow water. LEMche believes this to be due to retardation of metamorphosis on account of the larvae remaining in deep water at the normal time of metamorphosis, when it should settle on the bottom. Lemche's viewpoint is supported by Thorson (1946, p. 466).

Through his studies of Danish pelagic larvae THorson (1946, p. 199) arrived at the conclusion that Pyramidellid larvae with a pelagic stage have a large, sinistral, scalariform shell exposed, whereas the Pyramidellidae with non-pelagic larvae have no such larval shell visible at the apex.

The fact that the larval part of molluscan shells is in many cases easily recognizable in the fossil state renders knowledge of the larval stage highly 
important in the interpretation of this feature. Fossil species which had a long pelagic stage and correspondingly great power of geographic dispersion must be among the most useful paleontologic and stratigraphic index forms.

\section{Substratum Requirements of the Adult Stage}

Marine pelecypods and gastropods may be subdivided into two large groups with regard to the substratum: animals belonging to the infauna that includes species living in the bottom deposits, and the animals of the epifauna living on the bottom, on stones, rocks, seaweeds etc. (C. G. Joh. Petersen 1918). Ostrea edulis, and species of the genera Solen, Patella and Acmaea, as well as several others, are rather fastidious in selecting their substratum, but most molluses will apparently settle in rather different environments, and at a wide range of depths. For example Cardium edule is able to live in mud or detrital mud and sand, and the same is true of Corbula gibba, Cyprina islandica, and numerous other species. Mytilus edulis, a species that prefers attachment to stones, seeweeds etc. may under certain conditions be forced to settle on the level sea bottom. A modern change of biotope has been mentioned by Dexter (1947, p. 273) from the coast at Cape Ann, Massachusetts, where the disappearance of the eel grass Zostera marina in 1932 due to an epidemic, forced Lacuna vincta, which formerly lived on it, to change to the brown alga Laminaria digitata.

These examples are chosen at random to illustrate the general adaptability of the animals concerned. It should be emphasized, however, that each species will probably thrive best with particular combinations of bottom configuration, depth, currents, etc. Also the adaptability of a species concerning substratum in most cases is confined to either the infauna or epifauna environment, although some animals, such as predatory snails, may succeed well in both environments.

\section{E. Adaptation}

The topics treated above are all more or less illustrative of the power of adaptation. One of the main statements of animal ecology is that the ability to adapt is particularly well demonstrated near distributional boundaries where limiting factors attain extreme values. Local races may develop under such conditions, and it is also probable that new species emerge. When dealing with adaptability we are therefore concerned with the inconstancy of species, and adaptation may have an important bearing on the evidence of fossil faunas, particularly when paleobiology is applied as a stratigraphic or paleogeographic tool.

Knowledge regarding the adaptability of marine invertebrates is apparently very scanty, and in the past efforts have been concentrated particularly on the study of acclimatization to temperature and salinity conditions. A general outline of adaptation could be obtained by study of the geographic distribution of a number of species and genera followed by a detailed investigation of the various environments, but the results obtained would have to be verified by experiment. The inductive part of the research on adaptation is, however, very laborious, and this may partly account for the scarcity of exact experimental data.

Adaptation in pelecypods and gastropods will not be treated in detail in the present section, which will be devoted to a brief discussion of relevant physio- 
logical processes, while the geographic aspects of adaptation form the subject of the next section.

Osmotic adaptation. The modifications of osmotic behavior in species that are capable of living under a wide range of salinities has not apparently been studied in detail. Marine molluscs are generally in osmotic equilibrium with the surrounding sea water (KRoGH 1939), and species that are able to migrate into brackish or abnormally concentrated salt water must accordingly develop adaptive features in those physiological processes which are related to osmotic regulation. There is apparently very little information available on this subject. According to Remane (1940, p. 14) dilution of sea water, and corresponding lowering of osmotic pressure, may result in increased oxygen consumption in various animals, among which Hydrobia jenkinsi is mentioned. Whether this is a permanent or temporary change has not been stated.

Metabolic adaptation. It is well known that metabolism in marine animals is related to temperature. (A. KRogh 1914, A. Goldsborough MAYer 1914, H. M. Thamdrup 1935, G. Thorson 1936, R. Spärck 1936). Spärck's investigations on oxygen consumption in marine pelecypoda revealed characteristic metabolic reactions in individuals belonging to the same species, but living under different climatic conditions. He states that the oxygen consumption of Mytilus edulis from Danish waters is higher (related to temperature) than that of $M$. edulis from the warmer Mediterranean. Similarly Astarte borealis, A. elliptica, A. Montagui and Saxicava arctica from Greenland waters have a higher oxygen consumption (related to temperature) than individuals of the same species living in the warmer Danish waters. SPÄRCK relates these differences in metabolism to the development of physiological races. SpärcK's study suggests that the metabolism of the pelecypods mentioned may be adaptable to different temperature conditions. Reversing SPÄRCK's statement, and relating similar values of oxygen consumption to temperature it may be stated that oxygen consumption may attain nearly identical values within different local temperature ranges of the individual species. Spärck's diagrams illustrate these relations. It is of interest to note that the difference between the highest and lowest temperatures to which a species may be able to adjust its oxygen consumption may be regarded as a measure of its thermal adaptability.

Although sufficient research has not yet been carried out in the field of metabolic adaptability in general, studies suggest that physiological processes other than oxygen consumption should, within limits, be adaptible to extreme environmental conditions. This renders deductions concerning paleo-environments based exclusively on fossil species a difficult task.

Discussions of thermal adaptation may be found in papers by VERNON (1899), A. Goldsborough Mayer (1914), Runnström $(1927,1936)$, and Ekman (1935, 1953); for further information reference is made to textbooks on animal ecology and geography. The inheritability of adaptive qualities is considered beyond the scope of this work.

\section{GEOGRAPHIC DISTRIBUTION}

The total geographic distribution of a species may be regarded as representing the sum of its dispersive and adaptive powers. The local variation in distribution within the geographic range of a marine bottom dweller may be mainly related to variation of a few environment factors such as substratum, depth, 
oxygen content of the water, dispersal power, enemies, etc. The location of the regional geographic boundary of a species is determined by the geologic history of the area of dispersal and the species, and by one or more environment factors varying beyond the limits controlling the survival of the species.

Temperature and salinity are undoubtedly the most significant factors controlling geographic distribution in marine biology on a regional scale. Salinity might be considered as a factor of lesser importance because brackish waters should not be included in the marine areas. However, since brackish transition areas attract considerable interest from a geologic point of view, the limiting effect of salinity upon the distribution of marine mollusca should also be treated in this connection.

\section{A. Temperature Conditions of the Oceans}

Uniformity and relatively slight oscillations of temperature are characteristic features of the water masses of the oceans (Sснотт, 1935, 1942). From a physical point of view one may discriminate between the cold Arctic and Antarctic water masses located around the poles, with annual mean temperatures lying between -2 and $+3^{\circ} \mathrm{C}$, and the warm water masses located on both sides of the equator with maximum mean temperatures of about $25-28^{\circ} \mathrm{C}$. These cold and warm water masses are more or less separate due to difference in density, although the salinity deficit of polar waters, ocean currents, wave action, etc. counteract the separation. The annual temperature oscillations of the surface water within the warm and cold water areas are very slight, and amounting to about $1^{\circ}$ to $5^{\circ} \mathrm{C}$.

The most complex temperature conditions in the oceans are found in the transition areas between warm and cold waters, these areas being characterized by greater annual temperature oscillations and by a more or less pronounced stratification. The annual mean temperature of the surface water in the transition zones is between $3^{\circ}$ and $25^{\circ} \mathrm{C}$, and the seasonal temperature oscillations $5^{\circ}$ to $20^{\circ} \mathrm{C}$. The areas of maximum oscillation (from $10^{\circ}-20^{\circ} \mathrm{C}$ ) are found in the northern hemisphere, in the western parts of the oceans and in the marginal seas around Europe. In a generalized way the transition zone in this hemisphere may be defined as the area between the Tropic of Cancer and the Polar Circle. This rough demarcation must be modified considerably in detail, especially in the North Atlantic on account of the effect of the Gulf Stream and the Polar Current.

Knowledge of the thermal gradient of the ocean, and the bottom temperature, is of paramount importance in dealing with the effect of temperature on the distribution of marine faunas. Data on bottom temperatures are very scarce, whereas it is possible to get an outline of water temperatures at depth, on the basis of observations made by deep-sea expeditions. Vertical thermal sections may thus be established for different parts of the oceans, see EkMaN (1953, p. 358). The writer has compiled similar sections for the North Atlantic on fig. 37 with special emphasis on the boundary between the cold and warm water areas around Iceland. It appears from these graphs that the temperature of the transition zone in the North Atlantic generally decreases rather rapidly from surface to a depth of 100 to 200 metres, dependent upon latitude and season. The thermal drop in these sections reaches a maximum (off Cape Finisterre) of about $6^{\circ}$ and $7 \frac{1}{2}{ }^{\circ} \mathrm{C}$ down to 100 and $200 \mathrm{~m}$ respectively. Below $200 \mathrm{~m}$ the temperature of the warm water is between $4^{\circ}$ and $17^{\circ} \mathrm{C}$ whereas the polar water has a temperature less than $2^{\circ} \mathrm{C}$. 


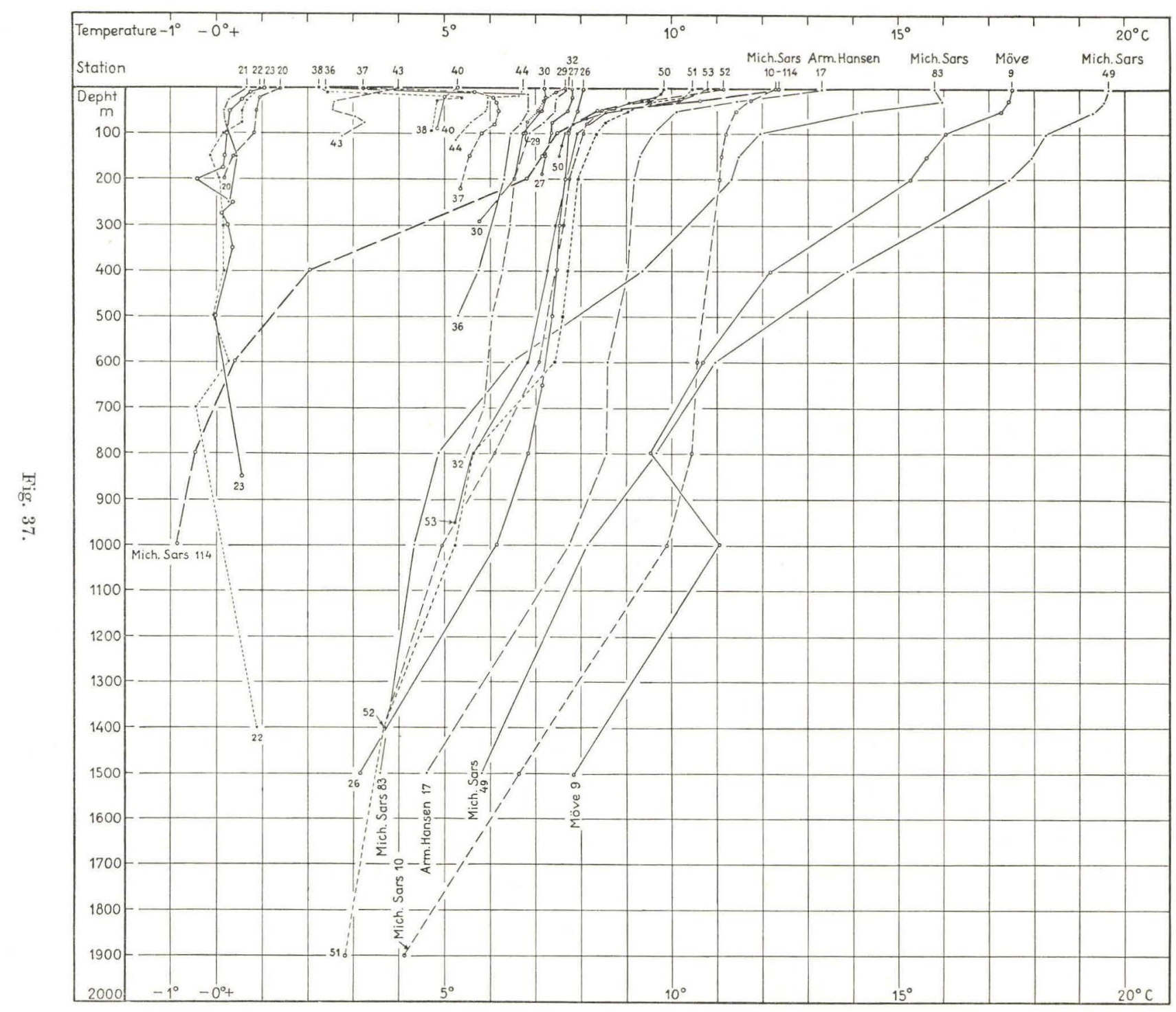


In considering the molluscan fauna we are mainly concerned with the shelf area down to a depth of about $200 \mathrm{~m}$. By means of available surface water temperatures, and using the nearest vertical thermal section as a reference, it should be possible to estimate the mean temperature of the sea bottom within a few degrees. Wave action, currents and tide may cause much intermixture of the water in near-shore areas along open coasts, up to depths of about $100 \mathrm{~m}$. The surface temperatures may consequently represent fair approximations of the bottom temperatures in such areas.

Temperature conditions in the deep sea are relatively homogenous over vast areas. From the graphs fig. 37 it appears that the sections in that part of the eastern North Atlantic which is influenced by the Gulf Stream, viz. the sections off S. Iceland $\left(63^{\circ} 15^{\prime} \mathrm{N}, 14^{\circ} 20^{\prime} \mathrm{W}\right)$, S of Wyville Thomson Ridge $\left(58^{\circ} 0^{\prime} \mathrm{N}, 11^{\circ} 0^{\prime} \mathrm{W}\right)$, and in the Bay of Biscay $\left(45^{\circ} 26^{\prime} \mathrm{N}, 9^{\circ} 20^{\prime} \mathrm{W}\right)$ are practically conformable to a depth of about $1500 \mathrm{~m}$., the difference in temperature being about $1.5^{\circ} \mathrm{C}$ between the first and second section and about $2^{\circ} \mathrm{C}$ between the second and third. This indicates a thermal gradient of about $3.5^{\circ} \mathrm{C}$ from Iceland to the Bay of Biscay, a distance of about 2000 kilometres. The transitional area in the western Atlantic is much narrower than off the European coast due to the North Polar Current. This area displays accordingly sharper thermal brakes at the surface, and the temperature may be somewhat lower at depth

Fig. 37. Temperature curves from the northern part of the Atlantic Ocean $\left({ }^{\circ} \mathrm{C}\right)$.

$\begin{array}{lllll}\text { St. N.Lat. W.Long. Iceland } & \text { Date } \\ 20 & 65^{\circ} 43^{\prime} & 12^{\circ} 30^{\prime} & \mathrm{NE} & 24 / 51903 \\ 21 & 65^{\circ} 57^{\prime} & 11^{\circ} 31^{\prime} & \mathrm{NE} & 24 / 51903 \\ 22 & 65^{\circ} 15^{\prime} & 10^{\circ} 44^{\prime} & \mathrm{NE} & 24 / 51903 \\ 23 & 66^{\circ} 08^{\prime} & 11^{\circ} 13^{\prime} & \mathrm{NE} & 24 / 51903 \\ 26 & 63^{\circ} 15^{\prime} & 14^{\circ} 20^{\prime} & \mathrm{SE} & 31 / 51903 \\ 27 & 63^{\circ} 41^{\prime} & 14^{\circ} 30^{\prime} & \mathrm{SE} & 31 / 51903 \\ 29 & 64^{\circ} 10^{\prime} & 23^{\circ} 22^{\prime} & \mathrm{W}(\mathrm{S}) & 10 / 61903 \\ 30 & 64^{\circ} 10^{\prime} & 24^{\circ} 22^{\prime} & \mathrm{W}(\mathrm{S}) & 11 / 61903 \\ 32 & 64^{\circ} 13^{\prime} 5 & 27^{\circ} 30^{\prime} & \mathrm{W}(\mathrm{S}) & 11 / 61903 \\ 36 & 65^{\circ} 45^{\prime} & 27^{\circ} 03^{\prime} & \mathrm{W}(\mathrm{N}) & 13 / 61903 \\ 37 & 65^{\circ} 38^{\prime} & 25^{\circ} 38^{\prime} & \mathrm{W}(\mathrm{N}) & 13 / 61903 \\ 38 & 66^{\circ} 08^{\prime} & 24^{\circ} 37^{\prime} & \mathrm{W}(\mathrm{N}) & 13 / 61903 \\ 40 & 66^{\circ} 33^{\prime} & 22^{\circ} 27^{\prime} 5 & \mathrm{~N}(\mathrm{~W}) & 16 / 61903 \\ 43 & 66^{\circ} 36^{\prime} 5 & 18^{\circ} 06^{\prime} & \mathrm{N} & 30 / 61903 \\ 44 & 66^{\circ} 19^{\prime} & 23^{\circ} 22^{\prime} & \mathrm{W}(\mathrm{N}) & 2 / 71903 \\ 50 & 63^{\circ} 24^{\prime} & 20^{\circ} 02^{\prime} & \mathrm{S} & 12 / 71903 \\ 51 & 62^{\circ} 11^{\prime} & 19^{\circ} 36^{\prime} & \mathrm{S} & 13 / 71903 \\ 52 & 62^{\circ} 35^{\prime} & 19^{\circ} 48^{\prime} & \mathrm{S} & 14 / 71903 \\ 53 & 62^{\circ} 57^{\prime} & 19^{\circ} 58^{\prime} & \mathrm{S} & 14 / 71903\end{array}$

\begin{tabular}{cccc}
\multicolumn{3}{c}{ Decline } & \\
$100 \mathrm{~m}$. & $200 \mathrm{~m} .100-$ & $\begin{array}{c}\text { Surface } \\
\text { mean }\end{array}$ \\
$0.6^{\circ}$ & $1.2^{\circ}$ & $0.6^{\circ}$ & $6.5^{\circ}$ \\
$0.4^{\circ}$ & & & $6.5^{\circ}$ \\
$0.8^{\circ}$ & $1.0^{\circ}$ & $0.2^{\circ}$ & \\
$0.8^{\circ}$ & $1.4^{\circ}$ & $0.6^{\circ}$ & $6.5^{\circ}$ \\
$0.4^{\circ}$ & $0.5^{\circ}$ & $0.1^{\circ}$ & \\
$0.45^{\circ}$ & $0.65^{\circ}$ & $0.2^{\circ}$ & $10.5^{\circ}$ \\
$0.85^{\circ}$ & & & $10.5^{\circ}$ \\
$0.45^{\circ}$ & $0.7^{\circ}$ & $0.25^{\circ}$ & $10.5^{\circ}$ \\
$0.80^{\circ}$ & $1.2^{\circ}$ & $0.4^{\circ}$ & $10.5^{\circ}$ \\
$-4.0^{\circ}$ & $-3.9^{\circ}$ & $0.1^{\circ}$ & $9.5^{\circ}$ \\
$-2.6^{\circ}$ & $-2.1^{\circ}$ & $0.5^{\circ}$ & $9.5^{\circ}$ \\
$-2.4^{\circ}$ & & & $9^{\circ}$ \\
$0.5^{\circ}$ & & & $8^{\circ}$ \\
$1.2^{\circ}$ & & & $8^{\circ}$ \\
$1.3^{\circ}$ & & & $9^{\circ}$ \\
$2.2^{\circ}$ & & & $11^{\circ}$ \\
$2.15^{\circ}$ & $2.5^{\circ}$ & $0.35^{\circ}$ & $11^{\circ}$ \\
$3.1^{\circ}$ & $3.4^{\circ}$ & $0.3^{\circ}$ & $11^{\circ}$ \\
$2.9^{\circ}$ & $3.2^{\circ}$ & $0.3^{\circ}$ & $11^{\circ}$ \\
& & &
\end{tabular}

August

(From J. N. Nietsen 1904).

$$
\begin{gathered}
\text { Decline } \\
\text { Date } 100 \mathrm{~m} .200 \mathrm{~m} .
\end{gathered}
$$

\begin{tabular}{|c|c|c|c|c|c|c|c|}
\hline Mich. Sars & 114 & $61^{\circ} 8^{\prime}$ & $3^{\circ} 14^{\prime}$ & $\begin{array}{l}\text { North of Wyville } \\
\text { Thompson Ridge }\end{array}$ & $12-13 / 81910$ & $4.8^{\circ}$ & $5.5^{\circ}$ \\
\hline Arm. Hansen & 17 & $58^{\circ} 0^{\prime}$ & $11^{\circ} 0^{\prime}$ & $\begin{array}{l}\text { South of Wyville } \\
\text { Thompson Ridge }\end{array}$ & $29 / 71913$ & $3.7^{\circ}$ & $4.1^{\circ}$ \\
\hline Mich. Sars & 83 & $48^{\circ} 30^{\prime}$ & $33^{\circ} 55^{\prime}$ & Central Atlantic Ocean & $14 / 7 \quad 1910$ & $3.9^{\circ}$ & $4.5^{\circ}$ \\
\hline Mich. Sars & 10 & $45^{\circ} 26^{\prime}$ & $9^{\circ} 20^{\prime}$ & Biscay & $19-20 / 41910$ & $1.1^{\circ}$ & $1.25^{\circ}$ \\
\hline Möwe & 9 & $31^{\circ} 29^{\prime}$ & $11^{\circ} 37^{\prime}$ & West of Mogador & $1 / 61911$ & $1.5^{\circ}$ & $2.3^{\circ}$ \\
\hline Mich. Sars & 49 & $29^{\circ} 2^{\prime}$ & $25^{\circ} 30^{\prime}$ & West of the Canaries & $2 / 61910$ & $1.5^{\circ}$ & $2.2^{\circ}$ \\
\hline
\end{tabular}

(From EkMaN 1953). 
than off Europe. The annual mean temperature of $5^{\circ} \mathrm{C}$ for surface water extends from about $70^{\circ} \mathrm{N}$. lat. off Europe to about $46^{\circ} \mathrm{N}$.lat. off the east coast of North America. This illustrates the scale of the southerly shift of the isotherms in the western North Atlantic. Farther to the south, in the central part of the Atlantic, the situation is reversed due to upwelling cold bottom water off western Africa. The $25^{\circ} \mathrm{C}$ isotherm runs from about $15^{\circ} \mathrm{N}$. lat. on the African coast to about $28^{\circ} \mathrm{N}$.lat. off Florida, and the isotherms are thus spread fanlike from north to south along the eastern Atlantic coasts. The hydrography of the eastern Atlantic consequently exhibits a very uniform picture, with only slight temperature changes, no temperature break of importance, and it is relatively difficult to define faunistic boundaries (ЕKMAN 1953 and others).

Table 5. Mean Surface Temperatures and Annual Oscillation of Temperature in the North Atlantic and Adjacent Seas in ${ }^{\circ} \mathrm{C}$.

\begin{tabular}{|c|c|c|c|c|c|c|c|}
\hline & & Febr. & May & Aug. & Nov. & $\begin{array}{l}\text { Annual } \\
\text { mean } \\
\text { temp. }\end{array}$ & $\begin{array}{l}\text { Annual } \\
\text { oscill. } \\
\text { of temp. }\end{array}$ \\
\hline \multirow[t]{2}{*}{ Pacific } & Northern Japan & $1-7$ & $8-12$ & $15-20$ & $10-15$ & $10-17$ & $15-20$ \\
\hline & Bering Sea & $-1-2$ & $2-5$ & $5-9$ & $2-4$ & $2-4$ & $7-10$ \\
\hline \multirow{22}{*}{$\begin{array}{l}\text { North } \\
\text { Atlantic }\end{array}$} & N. American E. coast & $0-5$ & $2-15$ & $15-22$ & $5-15$ & $3-10$ & $>15$ \\
\hline & West Greenland & $-1-0$ & $0-2$ & $3-5$ & $-1-4$ & $-1-3$ & $5-6$ \\
\hline & Spitzbergen (Svalbard) & $-1-0$ & $-1-2$ & $0-5$ & $<2$ & 0 & $2-4$ \\
\hline & East Finmark & $0-2$ & $0-3$ & $8-10$ & 4 & $3-4$ & $7-8$ \\
\hline & West Finmark & 2 & $3-5$ & $10-11$ & $4-5$ & $4-5$ & $7-8$ \\
\hline & Lofoten & $3-5$ & 5 & $11-12$ & $5-6$ & $5-6$ & $7-8$ \\
\hline & West Norway & 5 & $5-8$ & $11-12$ & $6-8$ & $6-8$ & $9-10$ \\
\hline & South Norway & $4-5$ & $8-9$ & $15-16$ & $8-9$ & $8-9$ & $10-14$ \\
\hline & South Iceland & $5-6$ & $5-7$ & $10-11$ & $5-7$ & $5-8$ & $6-7$ \\
\hline & North Sea, Horns ] $0 \mathrm{~m}$. & 4 & 9 & 17 & 10 & 10 & 14 \\
\hline & Rev (at $0,15, \quad 15$. & 4 & 8 & 16 & 10 & 9.5 & 13 \\
\hline & and $20 \mathrm{~m}$. depth) $\int_{20}$ - & 4 & 8 & 16 & 11 & 9 & 13 \\
\hline & Öresund, Lappe ] 0 - & 2 & 10 & 18 & 8 & 9 & 17 \\
\hline & Grund (at $0,10 \quad 10$. & 3 & 8 & 17 & 9 & 9.5 & 15 \\
\hline & and $20 \mathrm{~m}$. depth) 20 . & 5 & 6 & 12 & 11 & 9 & 9 \\
\hline & England & $6-9$ & $8-11$ & $13-16$ & $9-13$ & $10-12$ & $6-12$ \\
\hline & Bay of Biscay & $10-12$ & $12-14$ & $17-20$ & $13-15$ & $13-14 \frac{1}{2}$ & $7-9$ \\
\hline & Lisbon & 14 & 16 & 19 & 16 & 16 & $5-6$ \\
\hline & Madeira & 16 & 18 & 23 & 20 & 19 & 6 \\
\hline & Azores & $15-16$ & 17 & 23 & 18 & $18-20$ & 8 \\
\hline & Canaries & $18-20$ & $18-20$ & $20-23$ & $20-21$ & 20 & 5 \\
\hline & Senegal & 20 & $22-24$ & 27 & $25-27$ & 25 & $3-7$ \\
\hline \multirow{12}{*}{$\begin{array}{l}\text { Mediter- } \\
\text { ranean }\end{array}$} & Balearics & 14 & 17 & 25 & $17-18$ & 18 & $>10$ \\
\hline & Spain & $12-14$ & 17 & 25 & $17-18$ & 18 & $>10$ \\
\hline & South France & 12 & $15-16$ & $22-24$ & 16 & 17 & $10-13$ \\
\hline & Corsica, Sardinia & $12-14$ & $16-17$ & $23-25$ & $17-18$ & $18-19$ & 13 \\
\hline & North and Central Italy & $12-13$ & $16-17$ & $23-25$ & $16-17$ & $17-18$ & $10-13$ \\
\hline & South Italy & $13-14$ & 17 & 25 & $17-18$ & 19 & $10-12$ \\
\hline & Sicily, Malta & 14 & $17-18$ & 25 & 20 & $19-20$ & 10 \\
\hline & Adriatic & $10-14$ & 17 & $24-25$ & $15-17$ & $14-19$ & 14 \\
\hline & Morea, Aggean Sea & $10-15$ & $17-18$ & 25 & $15-20$ & $18-20$ & $10-11$ \\
\hline & Syria, Agypt & $16-17$ & $20-22$ & $26-28$ & $21-23$ & $20-21$ & $<10$ \\
\hline & Tunisia, Algeria & $13-14$ & $17-18$ & $25-26$ & $17-18$ & $19-20$ & 10 \\
\hline & Black Sea & $0-7$ & $13-16$ & 23 & $11-14$ & $10-15$ & $17-20$ \\
\hline
\end{tabular}


The temperature of the surface water in parts of the North Atlantic and adjacent seas is shown in table 5 , in which the mean temperatures for the months of February, May, August, and November, the annual mean temperature, and the annual temperature oscillation of the surface water is shown. Most of the surface water temperatures are taken from Sснотт's maps (1935 and 1942), but the temperatures for the North Sea and the Öresund have been calculated from the data published by the Danish Meteorological Institute in the Nautical-Meteorological Annual for the years 1932-1956.

\section{B. Marine Faunal Regions}

Several authors have established zoogeographic subdivisions of the marine areas. In 1856 WOODWARD published a subdivision that was based on the distribution of the mollusca, and in 1896 Ortmann gave a comprehensive outline of previous attempts, rejecting most of the earlier zoogeographic systems including that by WOODWARD. In the same paper ORTMANN proposed a new classification of the marine areas on the basis of the distribution of Decapoda, emphasizing the importance of the physical properties of the individual parts of the oceans.

Considerable progress has been made in the field of zoogeography since the days of Ortmann. The works of Murray and Huorth (1912), Hesse, Allee and Schмidт $(1924,1951)$ and Ekman $(1935,1953)$ represent some of the significant steps forward during the twentieth century. Of particular interest is the paper published by HuTchins (1947) on temperature zonation based on the geographic distribution of species. In this paper Huтcнins drew attention to the significance of limiting temperatures in the geographic distribution of marine species. It is worth-while to quote the following statements (Hutchins 1947 , p. 325$)$ : "In the case of a species spreading toward the poles an extreme temperature .... is encountered first as a winter temperature. The boundary comes into being where the species is subject to winter killing. For a species spreading toward the equator the comparable boundary arises where summer temperatures first become too high, and dispersal is checked by inability of the individuals to survive the excessive heat.

The second sort of relationship to temperature stressed in distributional studies involves the critical temperatures necessary for reproduction of life cycles. In such cases species spread toward the poles as far as summer temperature conditions are adequate, and towards the equator as far as requisite low temperatures can be obtained in winter. A number of critical phenomena may lead to boundaries of this type, among them trigger temperatures necessary to induce spawning, and growing seasons of adequate duration as well as intensity". With these words Hutchins undoubtedly touches on some fundamentals of marine zoogeography.

The classifications that were established by Woodward, Ortmann and others have not been revised in detail, and WOODWARD's subdivision of the North Atlantic has generally been accepted in spite of ORTMAnN's rejection. In the Atlantic Ocean Woodward's Celtic province has been rejected as an independent province, and its area is included in the Boreal province (see e.g. Ekman 1953). The North Atlantic is, according to Woodward, subdivided into the following provinces: 1. The Arctic, 2. The Boreal, 3. The LusitanianTrans Atlantic, and 4. The West African-Carribean provinces. Ekman (1935, 
1953) has subdivided these provinces further on the basis of extensive studies of the entire known marine fauna. His classification appears to be well founded and is generally accepted, it is listed below together with WOODWARD's system.

Table 6. Marine Faunal Regions in the North Atlantic.

\begin{tabular}{|c|c|c|}
\hline \multirow[t]{2}{*}{ WOODWARD (1856) } & \multicolumn{2}{|c|}{ EKMAN (1953) } \\
\hline & American coasts & European-African coast \\
\hline Aretic & \multicolumn{2}{|c|}{$\begin{array}{l}\text { High aretic } \\
\text { Low aretic }\end{array}$} \\
\hline Boreal & $\begin{array}{l}\text { Temperate fauna of } \\
\text { North American Atlantic }\end{array}$ & Boreal fauna of Europa \\
\hline Lusitanian & & Mediterranean-Atlantic fauna \\
\hline Carribean-West African & $\begin{array}{l}\text { Tropical and Subtropical } \\
\text { faunas of the American } \\
\text { Atlantic }\end{array}$ & $\begin{array}{l}\text { Tropical and Subtropical } \\
\text { faunas of West Africa }\end{array}$ \\
\hline
\end{tabular}

It will be seen from the table that Woodward's and Ekman's subdivisions do not cover each other exactly, but the differences are of minor importance in the present connection.

The main reason why WOODWARD's molluscan provinces turned out to be valid may be that WOODWARD succeeded in defining natural faunal units which parallel significant climate zones, although the latter were not yet clearly recognized when the classification was set up. We are not yet aware of the full influence of environmental factors upon the physiological processes which affect the dispersive power of marine animals, but it is obvious that the distribution of individual species and whole faunas in the two great ocean areas are limited by temperature. From a study of the history of zoogeography it appears that useless discussions have been held concerning the importance of different animal groups in defining animal provinces. The uselessness results from the fact that life will not fit into any rigid system, and that any zoogeographic subdivision must be artificial from some point of view. In order to avoid further misconceptions it might be useful to consider the possibility of defining marine faunal regions by means of the thermal properties of the individual water masses to which the faunas obviously are related. In accordance with such a standpoint EKMAN (1953, p. 176) has subdivided the Arctic seas into high arctic and low arctic zones separated by the $0^{\circ} \mathrm{C}$ isotherm. Similarly, the boundaries of the boreal zone on the European coasts are defined by coldest and warmest temperatures and annual mean temperatures (loc. cit. p. 102) etc.

The writer has finally attempted a consistent classification of the faunal regions of the North Atlantic shelf areas off Europe and Africa, based on thermal boundaries, as shown on table 7 . The boundaries are defined by the mean temperatures of the surface water during the coldest and warmest months, and by the annual means, since these temperatures are regarded as most significant in marine faunal distribution.

It should be noted that the Tropic and Subtropic regions practically cover the warm water areas, that the Lusitanian and Boreal regions correspond to the transition zone, and that the Arctic region is identical with the cold water area 
Table 7. Temperatures at the Boundaries of Faunal Regions in the Eastern North Atlantic.

\begin{tabular}{llccc} 
& & \multicolumn{2}{c}{ Mean temperatures $\left({ }^{\circ} \mathrm{C}\right)$} \\
Faunal region & Boundary & February & August & Annual \\
Aretic region & New Foundland- & & \\
N. Iceland-E. Finmark & $0^{\circ}$ & $8^{\circ}$ & $4^{\circ}$ \\
Boreal region & $\begin{array}{l}\text { SW entrance English } \\
\text { Channel }\end{array}$ & $10^{\circ}$ & $16-17^{\circ}$ & $12^{\circ}$ \\
Lusitanian region & Cape Blanco & $18^{\circ}$ & $23-25^{\circ}$ & $20^{\circ}$ \\
Subtropic region & Cape Verde & $20^{\circ}$ & $27-28^{\circ}$ & $25^{\circ}$ \\
Tropic region & & & &
\end{tabular}

(see p. 383). Regardless of how ill-defined the individual boundaries may be from a faunal viewpoint, they approximate distributional borders of some value.

The distribution of very few species corresponds strictly to the faunal regions defined above. In particular the fauna of the Boreal region includes very few endemic species. Among the molluscs, the following are mainly restricted to the Boreal region although some overlap to the Arctic or the Lusitianian region:

$\begin{array}{ll}\text { Anomia squamula } & \text { Evalea (Auriculina) insculpta } \\ \text { Pecten tigrinus } & \text { Philine quadrata } \\ \text { Modiola modiolus } & \text { Littorina littorea } \\ \text { Cyprina islandica } & \text { Purpura (Nucella) lapillus } \\ \text { Panopea norvegica } & \text { Sipho propinquus } \\ \text { Mya arenaria } & \text { Neptunea antiqua } \\ \text { Zirphaea crispata } & \text { Taranis Mörchi }\end{array}$

Table 8 shows the temperature conditions at the distributional limits of 6 of these species. The data on distribution are compiled from the following sources: Áskelsson (1935), Harmer (1918, p. 646) Ad. S. Jensen (1900, 1902), Ad. S. Jensen \& Spärck (1934), Johnson (1934), Locard (1892), Moore (1936a), Nicol (1951), Nordmann (1912), Posselt (1898), and Schott (1942). For each species the mean temperature at the northern and southern boundaries on both the American and European coasts are shown. None of the areas of distribution coincides exactly with the Boreal area as defined above, nor do the temperatures at the distributional limits quite agree with the temperatures found at the limits of the Boreal region.

The physical properties of deep sea water are very different from those of shelf waters, especially regarding temperature and oxygen content. The thermal variations are obviously much less extreme than near the surface, and the molluscs that inhabit the deeper parts of the oceans are generally considered to be more stenothermal than shallow water molluses. Most shallow water molluscs can be referred to more than one shallow water faunal division. In case of the deep water fauna, however, it is difficult to classify the affinities of a number of species which occur at great depths at latitudes ranging from Arctic to Subtropic or Tropic regions. It is therefore reasonable to refer to such species as deep water species, and to regard the deep ocean bottom, that is relatively cool and subject to less variable temperature conditions than the shelf waters, as an independant faunal region. 
Table 8 .

Mean Temperature at the Distributional Northern $(\mathrm{N})$ and Southern $(\mathrm{S})$ Limits of some Boreal Molluscan Species in the North Atlantic.

Mean Temperatures ${ }^{\circ} \mathrm{C}$

\begin{tabular}{lrrrrrrr}
\multicolumn{1}{c}{ Species } & \multicolumn{2}{c}{ February } & \multicolumn{2}{c}{ August } & \multicolumn{2}{c}{ Annual } \\
& N. America & Europe & N. America & Europe & N. America & Europe \\
Anomia squamula & $\mathrm{N}$ & $0^{\circ}$ & $0--1^{\circ}$ & $13^{\circ}$ & $10^{\circ}$ & $4^{\circ}$ & $4^{\circ}$ \\
& $\mathrm{S}$ & $19^{\circ}$ & $12^{\circ}$ & $25^{\circ}$ & $20^{\circ}$ & $20^{\circ}$ & $15^{\circ}$ \\
Cyprina islandica & $\mathrm{N}-1^{\circ}$ & $0--1^{\circ}$ & $13^{\circ}$ & $10^{\circ}$ & $4^{\circ}$ & $4^{\circ}$ \\
& $\mathrm{S}$ & $19^{\circ}$ & $11^{\circ}$ & $25^{\circ}$ & $20^{\circ}$ & $20^{\circ}$ & $14^{\circ}$ \\
Mya arenaria & $\mathrm{N}\left(-1^{\circ}\right)$ & $0--1^{\circ}$ & $\left(13^{\circ}\right)$ & $10^{\circ}$ & $\left(4^{\circ}\right)$ & $4^{\circ}$ \\
& $\mathrm{S} 22^{\circ}$ & $12^{\circ}$ & $27^{\circ}$ & $22^{\circ}$ & $23^{\circ}$ & $15^{\circ}$ \\
Zirphaea crispata & $\mathrm{N}-1^{\circ}$ & $0--1^{\circ}$ & $13^{\circ}$ & $10^{\circ}$ & $4^{\circ}$ & $4^{\circ}$ \\
& $\mathrm{S} 22^{\circ}$ & $12^{\circ}$ & $27^{\circ}$ & $20^{\circ}$ & $23^{\circ}$ & $15^{\circ}$ \\
Littorina littorea & $\mathrm{N}-1^{\circ}$ & $0--1^{\circ}$ & $10^{\circ}$ & $10^{\circ}$ & $4^{\circ}$ & $4^{\circ}$ \\
& $\mathrm{S}$ & $5^{\circ}$ & $15^{\circ}$ & $21^{\circ}$ & $21^{\circ}$ & $14^{\circ}$ & $17^{\circ}$ \\
Purpura (Nucella) & $\mathrm{N}-1^{\circ}$ & $0--1^{\circ}$ & $5^{\circ}$ & $5^{\circ}$ & $0^{\circ}$ & $1^{\circ}$ \\
lapillus & $\mathrm{S} 3-4^{\circ}$ & $15^{\circ}$ & $20^{\circ}$ & $20^{\circ}$ & $10^{\circ}$ & $17^{\circ}$
\end{tabular}

Some shallow cold water species do occur at deeper levels toward the equator. This equatorial submergence (HaEcker 1908, EkMAN 1935, 1953, REMAne 1940), is apparently related to the temperature requirements of the species.

Table 9 shows the depth range of some molluses in the Skagerak area on the basis of investigations by C. G. Joh. Petersen (1915). Petersen's bottom samples were taken during the months of July and August in 1911 and 1914. The bottom deposits were not very different in the various sampling areas, most of the samples being taken on clay bottom. Thermal stratification was apparently most pronounced in the Oslo Fjord. A bottom temperature of $10^{\circ} \mathrm{C}$ was encountered at the following depths: about 12 metres $\mathrm{N}$ of Dröbak, about 13-25 m. S of Dröbak, and about $90 \mathrm{~m}$. in the Skagerak. The temperatures were generally higher above and lower below these levels.

It will be seen from the table that Nucula tenuis and Macoma calcarea apparently display submergent tendencies in the Skagerak. The two other cold water forms Thyasira flexuosa and Syndosmya nitida are definitely soft bottom species in which it is difficult to decide whether their occurrence at depth is the result of temperature conditions, bottom character or the combined effect of both these factors.

The temperate and boreal forms are most abundant where the temperature is above about $10^{\circ} \mathrm{C}$ during July-August i.e. the warmest period of the year.

Table 11, p. 394 is a survey of the molluscan fauna of the transition area between the North Sea and the brackish Baltic. It has been attempted to classify the species in accordance with their geographic occurrence, into "arctic", "boreo-arctic", "boreal", "boreo-lusitanian", and "deep-water" species.

This table is the result of an objective study of the literature. However, future research should rectify such erroneous inferences as have undoubtedly been made. Nevertheless the table may even in its present form, illustrate the elements of the recent boreal molluscan fauna of Europe. Faunas of other regions, and also fossil faunas, may be analyzed in a similar way. 
Table 9.

The Depth Range of some Molluscs in the Skagerak and Oslo Fjord, and Corresponding Bottom Temperatures.

(From C. G. Joh. Petersen, 1915, profiles I, II and III).

\begin{tabular}{|c|c|c|c|c|c|}
\hline \multirow[b]{2}{*}{$\begin{array}{l}\text { Thermal } \\
\text { affinity * }\end{array}$} & \multicolumn{5}{|c|}{ Bottom temperatures } \\
\hline & Species & $\begin{array}{l}\text { Depth } \\
\text { metres }\end{array}$ & Total range & $\begin{array}{l}\text { Maximum of } \\
\text { occurrence at }\end{array}$ & Remarks \\
\hline $\mathrm{t}$ & Nucula tenuis & $12-410$ & $10.2-5.5^{\circ} \mathrm{C}$ & $5.5-7^{\circ} \mathrm{C}$ & Littoral in the Aretic \\
\hline c & Nucula nitida & $14-68$ & abt. 10-abt. $7^{\circ}$ & $?$ & \\
\hline c & Thyasira flexuosa & $14-410$ & $9.6-6.4^{\circ}$ & $6-7^{\circ}$ & Soft bottom species \\
\hline $\mathrm{t}$ & Cardium fasciatum & $4-24$ & abt. $17-5.5^{\circ}$ & $10-15^{\circ}$ & \\
\hline $\mathrm{b}$ & Cyprina islandica & $7-24$ & abt. $18-5.5^{\circ}$ & $18^{\circ}$ & \\
\hline t & Macoma baltica & $0.3-13$ & abt. 18 -abt. $9^{\circ}$ & abt. $18^{\circ}$ & \\
\hline a & Macoma calcaria & $7-73$ & $18.2-5.5^{\circ}$ & abt. $7^{\circ}$ & Littoral in the Arctic \\
\hline c & Syndosmya nitida & $10-410$ & $15.2-5.5^{\circ}$ & $6-7^{\circ}$ & Soft bottom species \\
\hline t & Syndosmya alba & $6-4 I$ & abt. $18-5.5^{\circ}$ & $10-18^{\circ}$ & \\
\hline $\mathrm{t}$ & Corbula gibba & $6-320$ & abt. $18-5.5^{\circ}$ & $10-15^{\circ}$ & \\
\hline $\mathrm{t}$ & $\begin{array}{l}\text { Aporrhais pes } \\
\text { pelecani }\end{array}$ & $8-29$ & abt. $18-6.5^{\circ}$ & $8.5^{\circ}$ & \\
\hline $\mathrm{t}$ & Nassa reticulata & $4-14$ & abt. 18 -abt. $7^{\circ}$ & $15-17^{\circ}$ & \\
\hline $\mathrm{t}$ & Akera bullata & $9-14$ & 16.6-abt. $8.5^{\circ}$ & $15^{\circ}$ & \\
\hline
\end{tabular}

\section{The Effect of Salinity on Distribution}

The transition area between the North Sea and the Baltic is the best known major brackish water region as far as both hydrographic conditions and the distribution of the fauna are concerned. The temperature and salinity of the water at various depths is regularly measured from a number of lightships, particularly in Danish waters, as reported in the Nautical-Meteorological Annual of the Danish Meteorological Institute. Monthly mean values for temperature and salinity have been calculated by JACOBSEN (1908) and A. J. C. JENSEN (1937). The fauna of the sea bottom has been studied by many workers. The investigations of the animal communities by C. G. Joh. Petersen have especially contributed to our knowledge of the distribution of molluscan species in the Skagerak, the Kattegat, The Belt Sea and the Baltic (C. G. Јон. Petersen 1888, 1918). The Pelecypoda have been treated by JENSEN \& SpÄRCK (1934).

The deposits of the sea floor have been outlined by C. G. Joh. Petersen (1888, 1913) and Bratтström (1941). Nearly every kind of bottom deposit may be encountered, since the variable glacial sediments of the Quaternary form both the source and the substratum of the recent sediments over a great part of the area. The bottom deposits should therefore be suitable for the distribution of most marine species of bottom dweller, provided all other factors are equal.

The hydrography of the area has been summarized by EkMAN $(1953$, p. 105). The outstanding hydrographic feature is the flow of brackish water out from the Baltic as surface currents through the Belts around the Danish islands, and the inflowing bottom current that carries salt water from the North Atlantic into the Baltic. The two water masses are relatively well separated, although wave action and the currents themselves cause a gradual mixing. The deepest hollows

*) $\mathrm{a}=$ arctic species, $\mathrm{b}=$ boreal species, $\mathrm{c}=\mathrm{boreo-arctic}$ species, $\mathrm{t}=$ boreo-lusitanian species. 
in the sea floor contain the most saline water, and the most brackish water is found in the northern parts of the Baltic. The surface current is least saline near the west coast of Sweden. For further reference see JACOBSEN (1908), A. J. C. Jensen (1937), and Brattström (1941).

The thermal conditions of the surface water vary slightly from the marine region around North Jutland to the brackish regions around the island of Bornholm. The thermal conditions are, however, apparently more stable in the deep parts of the Baltic than in the deep parts of the Kattegat and the Belt Sea.

Reviewing the physical properties of the transition area, it becomes appearent that the only consistently variable environmental factor is salinity. Considering the multitude of different substrata, and the relatively unimportant temperature differences between the marine and brackish areas, it seems reasonable to conclude that salinity is the main limiting factor in the geographic distribution of species in the transition area. The limiting effect of salinity on the distribution of some molluses in the Baltic and in Randers Fjord (Denmark) was dealt with by JoHansen (1916, 1918). Table 11, p. 394 has been compiled to illustrate the mode of salinity control in a number of the molluses of marine origin in the entire transition area between the North Sea and the Baltic. In this table the distribution of the Pelecypoda and Gastropoda as reported by Petersen (1888), and JENSEN \& SPÄRCK (1934) are related to the salinity at the limits of distribution of the species. The average salinities listed are based on the data published by the Danish Meteorological Institute, and on JACOBSEN's (1908) and JENSEN's (1937) mean values. Although the salinities represent the best estimates, the writer is aware of their approximate character.

It should be emphasized that the variation in thickness of the surface currents accounts for the rather violent changes in salinity shown by the figures in the table. It has been preferred to list the individual species instead of giving only the numbers of species in various salinity classes, since potentially significant features of the reaction of species and genera to salinity variation would otherwise not be apparent. The thermal affinity of the species is indicated in relation to the geographic distribution of the same species in true marine regions outside the transition area, as is mentioned on page 390 . The table also records the majority of mollusca known at present from the transition area, but excludes some species living off the coast of Bohuslän (e.g. rock dwellers etc.), whose geographic distribution is obviously limited by factors other than salinity. The table has been elaborated on the basis of the following references: ALLEN (1931), Áskelsson (1935), Brøgger (1901), Bucquoy, Dautzenberg \& Dollfus (1886-1898), Dons (1931), Forbes \& Hanley (1853), Gignoux (1913), Gould (1870), Harmer (1914-1925), Jeffreys (1862-1869), Jensen (1900), (1902), (1905), Jensen \& Spärck (1934), Johnson (1934), Locard (1892), Nicol (1951), Nordmann (1912), Petersen (1888), Posselt (1898), Sars (1878), Stossich (1880), Thorson (1941), (1944), Vles (1907), and Weinkauff (18671868).

The salinity columns in table 11 refer to the following parts of the transition area: 
Table 10. Salinities in the Transition Area between the North Sea and the Baltic.

\begin{tabular}{|c|c|}
\hline I & North Sea at Esbjerg \\
\hline II & Deep parts of the Skagerak \\
\hline III & Western part of the Limfjord \\
\hline IV & Deep parts of the eastern Kattegat \\
\hline V & $\begin{array}{l}\text { Kattegat off Frederikshavn and } \mathrm{E} \text { of } \\
\text { the Limfjord. }\end{array}$ \\
\hline VI & Kattegat Anholt-Djursland \\
\hline VII & Hesselö-Hjælm \\
\hline VIII & Hjælm-Sjællands Odde-Hellebæk \\
\hline IX & Samsö \\
\hline $\mathrm{X}$ & Northern Öresund to Hven \\
\hline$X$ & Öresund at Hollænderdyb \\
\hline AI & Lillebælt, Brandsö Bredning \\
\hline XII & Storebælt, Svendborg-Langeland \\
\hline XIII & Oresund, southern part \\
\hline XIV & $\begin{array}{l}\text { Baltic, western part } \\
\text { Baltic, Kiel-Warnemünde }\end{array}$ \\
\hline XV & Baltic, deep Arkona and Bornholm basins \\
\hline XVI & Baltic, S of the Aland island \\
\hline $\begin{array}{l}\text { XVII } \\
\text { XVIII }\end{array}$ & Gulf of Bothnia \\
\hline
\end{tabular}

$\begin{array}{crc}\begin{array}{c}\text { Salinity in } \\ \text { Minimum }\end{array} & \begin{array}{c}\text { Mean } \\ \text { Mean }\end{array} & \begin{array}{c}\text { Mean Mini- } \\ \text { mum Range }\end{array} \\ 31.5 & 33 & 1-2 \\ 25-30 & 34 & 4-9 \\ 26-27 & 31 & 4-5 \\ 20-25 & 33.5 & 9-14 \\ & & \\ 22-25 & 28-32.5 & 3-11 \\ 15-20 & 32 & 12-17 \\ 15-16 & 31 & 15-16 \\ 15 & 30 & 15 \\ 13-15 & 25-30 & 12-15 \\ 10-15 & 25 & 10-15 \\ & & \\ 10-13 & 20 & 5-10 \\ 9-10 & 20 & 10-11 \\ & & \\ 8-10 & 18-20 & 10-12 \\ 8-9 & 15-20 & 6-12 \\ 7-10 & 10-20 & 10-13 \\ 5-6 & 6-10 & 1-5 \\ 4-5 & 6 & 1-2 \\ 3.4-4 & 4 & 1-2\end{array}$

From the distribution of mollusca in the North Sea-Baltic transition area we may infer that the adaptive power in relation to decreasing salinity is equally well developed in various genera of both pelecypoda and gastropoda.

Table 12, p. 399, and figure 38 summarize the data in table 11. Concerning the Pelecypoda it may be seen from the eurve in fig. 38 that the number of species has already been considerably reduced in water of $32 \frac{1}{2}-34^{\%} / 00$ salinity, and thereafter it declines steadily, although at a somewhat decreasing rate, to a salinity of about $15 \%$. This is apparently a particularly critical limit. A few pelecypod species are able to live in water of salinity as low as 3$4 \%$. In contrast to the Pelecypoda, the Gastropoda are obviously less sensitive to minor salinity variations. The major drop in the number of gastropod species oc-

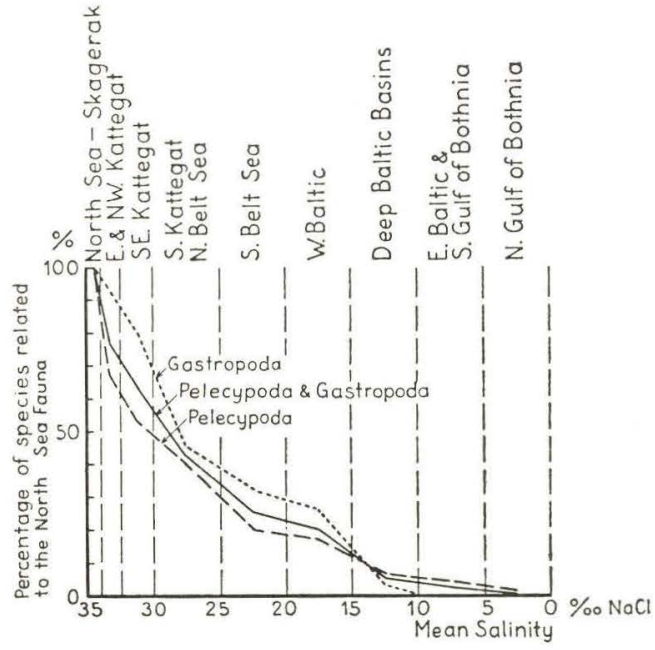

Decrease in number of molluscan species in the North Sea-Baltic transition area related to mean salinities

Fig. 38. curs at a salinity of about $30 \%$, but the $15 \%$ limit is probably as critical for Gastropoda as for Pelecypoda in the Baltic area. Considering both Pelecypoda and Gastropoda, it is remarkable that the number of marine species is halved in water of about 28 to $29 \%$ mean salinity. The decrease in the number of species with progressive dilu- 
Table 11.

\section{Distributional Limits of Recent Mollusca in the Transition Area between the North Sea and the Baltic, and Corresponding Mean Salinities.}

Distribution according to Ad. S. Jensen \& SpÄrck (1934) and C. G. JoH. Petersen (1888). Regions I-XVIII see table 10, p. 393.

Thermal affinities: $a$ : arctic species; $c(=$ cold): boreo-arctic species; $b:$ boreal species; $t$ (=temperate): boreo-lusitanian species; $d$ : deep-water species.

\begin{tabular}{|c|c|c|c|c|c|c|c|c|c|c|c|c|c|c|c|c|c|c|c|}
\hline \multirow{2}{*}{\multicolumn{2}{|c|}{$\begin{array}{l}\text { Thermal } \\
\text { affinity }\end{array}$}} & \multicolumn{18}{|c|}{ Region of lowest mean salinity inhabited } \\
\hline & & $\begin{array}{l}8 \\
0 \\
\approx \\
\approx \\
-1\end{array}$ & $\begin{array}{l}\frac{8}{0} \\
-1 \\
0 \\
\exists\end{array}$ & $\begin{array}{l}\frac{8}{0} \\
\overrightarrow{0} \\
\exists\end{array}$ & $\begin{array}{l}\frac{8}{0} \\
10 \\
\approx 0 \\
20 \\
17\end{array}$ & 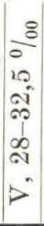 & $\begin{array}{l}8 \\
8 \\
0 \\
0 \\
0 \\
5 \\
5\end{array}$ & $\begin{array}{l}\frac{8}{a} \\
-10 \\
-7 \\
\end{array}$ & $\begin{array}{l}\frac{8}{8} \\
0 \\
0 \\
1 \\
-1\end{array}$ & $\mid \begin{array}{l}8 \\
0 \\
0 \\
0 \\
0 \\
10 \\
\text { on } \\
x \\
x\end{array}$ & $\begin{array}{l}\frac{8}{0} \\
10 \\
-1 \\
x\end{array}$ & $\begin{array}{l}\frac{8}{0} \\
8 \\
-1 \\
\pi\end{array}$ & $\begin{array}{l}\frac{8}{0} \\
0 \\
-1 \\
-1\end{array}$ & $\left|\begin{array}{c}8 \\
0 \\
0 \\
0 \\
0 \\
\infty \\
\hdashline \\
\exists \\
\exists\end{array}\right|$ & $\mid \begin{array}{ll}8 & 8 \\
0 & 0 \\
0 & 0 \\
1 & 0 \\
1 & 0 \\
B & 0 \\
B & \end{array}$ & $\begin{array}{ll}\frac{8}{0} & \frac{1}{0} \\
0 & 0 \\
0 & 1 \\
-1 & 1 \\
\frac{1}{4} & \overrightarrow{4}\end{array}$ & 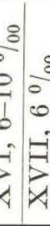 & 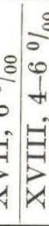 & \\
\hline$c$ & 1. Nucula tenuis (Montagu)..... & & & & $\cdots$ & . & . & $\cdots$ & . & + & & & $\cdots$ & $\cdots$ & $\cdots$ & $\cdots$ & & $\cdots$ & \\
\hline$t$ & 2. - nitida Sowerby ............ & & & $\ldots$ & . & . & $\ldots$ & . & . . & . & + & & .. . & $\ldots$. & .. . & ... & . & . & \\
\hline$d$ & 3. - tumidula MaLM..... & $\ldots$ & + & . & . & & . & .. & . & . & . & . & .. . & .. & .. & . . $\ldots$ & . . & . . & \\
\hline$t$ & 4. - nucleus L......... & $\ldots$ & . & . & . & . & . & . & $\ldots$ & + & . & . & .. & .. & ... & . . . . & .. &.. & \\
\hline$d$ & 5. - sulcata BRonn.............. & . & $\cdots$ & . & + & . & $\cdots$ & . & . & $\therefore$ & $\cdots$ & . & . . & ... & ... & . . . & . . . & . & \\
\hline$d$ & 6. Malletia obtusata (M. SARs) . . . . . . . . & . . & + & . . & . & . & . & . & . & . & $\cdots$ & .. & . . & .. & .. . & . . . & .. & . . & \\
\hline$c$ & 7. Leda pernula (MüLLER).............. & . & $\cdots$ & . & . & $\cdots$ & $\cdots$ & . & $\cdots$ & . & + & . & .. & ... & ... & . $\ldots$ & . . . & .. & \\
\hline$c$ & 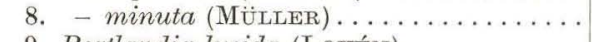 & . . & $\cdots$ & $\cdots$ & . & $\cdots$ & $\cdots$ & $\cdots$ & $\cdots$ & . & + & . & $\cdots \cdot$ & - & . $\cdot$ & . & . & . & \\
\hline$d$ & 9. Portlandia lucida (LovÉn)............ & . & + & . & . & $\cdots$ & . & $\cdots$ & $\cdots$ & . & . & . & $\cdots$. & . & ... & . & . & . & \\
\hline$c$ & 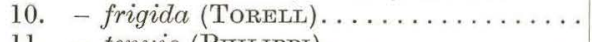 & . & + & . & . & $\cdots$ & . & $\cdots$ & $\cdots$ & $\cdots$ & . & . & $\cdots \cdot$ & $\cdots \cdot$ & & . & · & - & \\
\hline$d$ & 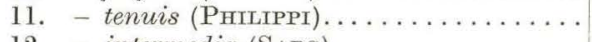 & . . & + & . & $\cdots$ & . & $\cdots$ & $\cdots$ & $\cdots$ & $\cdots$ & . & & $\cdots \cdot$ & . . . & & $\cdots \cdot \cdots$ & $\cdot \cdot \cdot$ & - & \\
\hline$d$ & 12. - intermedia (SARS)... & . & + & . & . & . & & $\cdots$ & $\cdots$ & $\cdots$ & . & & $\cdots \cdot$ & . . . & & . $\cdots$ & $\cdot \cdot \cdot$ & . & \\
\hline$d$ & 13. Arca pectunculoides (SСАсCHI) . . . . . . . & $\cdots$ & + & . & . & $\cdots$ & $\cdots$ & . & . & $\cdots$ & . & . & $\cdots \cdot$ & . . & . & $\cdots \cdots$ & $\cdot \cdot \cdot$ & . & \\
\hline$t$ & 14. - nodulosa MüLLER . . . . . . . . . . . & + & $\because$ & $\cdots$ & $\cdots$ & $\cdots$ & $\cdots$ & $\cdots$ & $\cdots$ & $\cdots$ & . & $\cdots$ & $\cdots \cdot$ & $\cdots \cdot$ & . & . $\cdots$ & $\cdot \cdot$ & . & \\
\hline$t$ & 15. - tetragona PoLr ............. & $\cdots$ & + & $\cdots$ & $\cdots$ & $\cdots$ & $\cdots$ & $\cdots$ & $\cdots$ & $\cdots$ & $\cdots$ & . & $\cdots \cdot \cdot$ & $\cdots \cdot$ & $\cdots \cdot \cdot$ & . $\cdots$ & & . & \\
\hline$t$ & 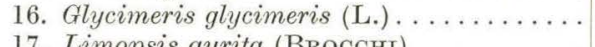 & + & $\cdots$ & $\cdots$ & $\cdots$ & $\cdots$ & $\cdots$ & $\cdots$ & $\cdots$ & $\cdots$ & $\cdots$ & $\cdots$ & $\cdots \cdot$ & $\cdots \cdot$ & - $\cdot \cdot$ & $\cdots \cdots$ & $\cdot \cdot \cdot$ & · & \\
\hline$t$ & 17. Limopsis aurita (BROCCHI) . . . . . . . . & + & $\cdots$ & $\because$ & $\cdots$ & $\cdots$ & $\cdots$ & $\cdots$ & $\cdots$ & $\cdots$ & $\cdots$ & $\cdots$ & $\cdot$ & $\cdots \cdot$ & $\cdots$ & $\cdots \cdot \cdots$ & $\cdot \cdots$ & . & \\
\hline$t$ & 18. Ostrea edulis L.............. & $\cdots$ & $\cdots$ & + & . & $\cdots$ & $\cdots$ & $\cdots$ & $\cdots$ & $\cdots$ & $\because$ & $\cdots$ & & $\cdots \cdot$ & 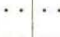 & $\cdots$ & $\cdot \cdot$ & · & \\
\hline$t$ & 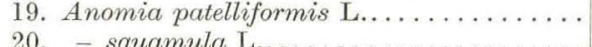 & $\cdots$ & $\cdots$ & $\cdots$ & $\cdots$ & $\cdots$ & $\cdots$ & $\cdots$ & $\cdots$ & $\cdots$ & + & $\cdots$ & & $\cdots \cdot$ & $\cdots$ & $\cdots$ & $\cdot$ & $\cdot$ & \\
\hline$b$ & 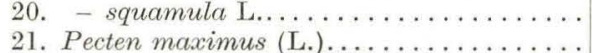 & $\cdots$ & $\cdots$ & $\cdots$ & $\ddot{i}$ & $\cdots$ & $\cdots$ & $\cdots$ & $\cdots$ & $\cdots$ & + & $\cdots$ & . & $\cdots$ & $\cdots$ & $\cdots$ & • & $\cdot$ & \\
\hline$t$ & 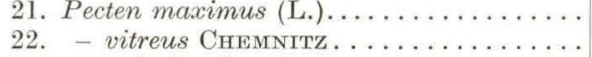 & $\cdots$ & $\ddot{t}$ & $\cdots$ & + & $\cdots$ & $\cdots$ & $\cdots$ & $\cdots$ & $\cdots$ & $\cdots$ & & & . & & $\cdots$ & 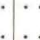 & 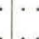 & \\
\hline$d$ & 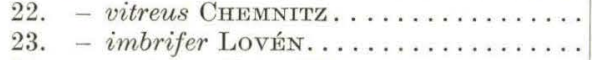 & $\ddot{+}$ & † & $\cdots$ & $\begin{array}{l}\cdots \\
\ldots\end{array}$ & & $\cdots$ & $\begin{array}{l}\cdots \\
\ldots\end{array}$ & & $\begin{array}{l}\cdots \\
\cdots\end{array}$ & $\begin{array}{l}\cdots \\
\cdots\end{array}$ & & & . & & $\cdots$ & & 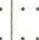 & \\
\hline $\begin{array}{l}c \\
t\end{array}$ & $\begin{array}{l}23 . \quad \text { - imbrifer Lovén. . . . . . . . . . } \ldots \ldots \ldots \\
24 .\end{array}$ & $\ldots$ & & $\begin{array}{l}\cdots \\
\ldots\end{array}$ & $\begin{array}{l}\cdots \\
\ldots\end{array}$ & & $\begin{array}{l}\cdots \\
\ldots\end{array}$ & & & $\begin{array}{l}\cdots \\
\cdots\end{array}$ & $\ddot{+}$ & & & . & & $\cdots$ & & 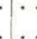 & \\
\hline$t$ & 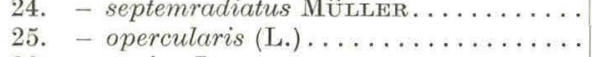 & & & $\ldots$ & $\ldots$ & & $\cdots$ & $\ldots$ & $\ldots$ & $\cdots$ & + & & & & & $\begin{array}{l}\cdots \\
\cdots\end{array}$ & & $\cdot$ & \\
\hline$t$ & 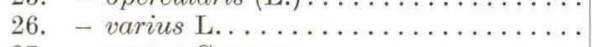 & & . & + & . & & . & . & . & . & . & .. & . . & $\ldots$ & & & & . & \\
\hline$d$ & 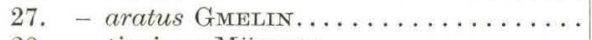 & .. & + & .. & . & & & .. & . & & .. & & . . & & & . . & & & \\
\hline$b$ & 28. - tigrinus MüLLER. . . . . . . . . . . & & & & .. & & . & .. & .. & . . & + & & . & .. . & ... & . . & 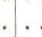 & . & \\
\hline$t$ & 29. - striatus MüLLER . . . . . . . . . . . . & .. & . & . & . & & $\cdots$ & . & . & . & + & & . . & . . . & . & $\cdots$ & t & . & \\
\hline$t$ & 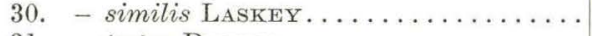 & . . & . & .. & + & . & $\cdot$ & . & & $\cdot$ & .. & & . $\cdot$ & .. . & . & $\cdots$ & $\ldots$ & & \\
\hline$t$ & 31. - testae Bivona.................. & .. & . & . & . & & . & . & & $\cdots$ & + & & . . & $\ldots$ & . & & 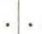 & & \\
\hline$t$ & 32. Lima hians GMeLIN.... & . & + & $\cdots$ & . & & $\therefore$ & · & $\cdots$ & $\cdots$ & $\cdots$ & & . & .. & . & & . & & . \\
\hline$t$ & 33. - Loscombi Sowerby . . . . . . . . . & $\cdots$ & $\cdots$ & $\cdots$ & $\because$ & & + & $\cdots$ & $\cdots$ & $\cdots$ & $\cdots$ & & $\cdot \cdot$ & . $\cdot$. & . & & $\cdot \cdot$ & & . \\
\hline$t$ & 34. - Gwyni Sykes... & $\cdots$ & $\cdots$ & $\cdots$ & + & & $\cdot$ & $\cdots$ & $\cdots$ & $\cdots$ & $\cdots$ & & 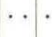 & .. $\cdot$ & . & . . . & . & & \\
\hline$d$ & 35. Lima subauriculata Montagu.......... & & $\cdot$ & $\cdots$ & + & & & & & $\cdot$ & $\cdots$ & & 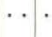 & 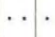 & & & . & & \\
\hline$d$ & 36. - Sarsi Lovín........ & + & . & $\cdots$ & $\cdots$ & & & $\cdot$ & . & $\cdot$ & $\because$ & & & . & & & & & \\
\hline$c$ & 37. Crenella decussata (MonTAGU)....... & & & & & & & & & & + & & & . & & & & & . \\
\hline$t$ & 38. Mytilus edulis L............... & & & & & & & & & & . & & $\cdot$ & & & . + & & & \\
\hline$t$ & 39. Modiola adriatica LAMARCK. . . . . . . . . & . & & $\cdots$ & . & & & $\cdot$ & + & $\cdot$ & . & & . & & $\cdots$ & & & & $\cdot$ \\
\hline$t$ & 40. - phaseolina PнiLIPPI............... & . & & $\cdots$ & . & & - & . & + & . & . & & $\because$. & & & & & & . \\
\hline$b$ & 41. - modiolus (L.). . . . . . . . . . . . & & & . & & & & & $\cdots$ & $\cdots$ & . & & + & $\cdots \cdot$. & & & $\cdot \cdot \cdot$ & & . \\
\hline
\end{tabular}


Table 11 (continued).

\begin{tabular}{|c|c|c|c|c|c|c|c|c|c|c|c|c|c|c|c|c|c|}
\hline \multirow[b]{2}{*}{$\begin{array}{l}\text { Thermal } \\
\text { affinity }\end{array}$} & \multirow[b]{2}{*}{ Pelecypoda } & \multicolumn{16}{|c|}{ Region of lowest mean salinity inhabited } \\
\hline & & 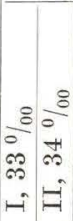 & $\begin{array}{l}\frac{8}{0} \\
-0 \\
E \\
E\end{array}$ & $\begin{array}{l}\frac{8}{8} \\
10 \\
0 \\
0 \\
10\end{array}$ & $\begin{array}{l}8 \\
0 \\
i s \\
\text { of } \\
\therefore \\
\infty \\
\text { on } \\
b\end{array}$ & 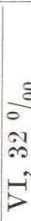 & $\begin{array}{l}\frac{8}{0} \\
-5 \\
= \\
5\end{array}$ & $\begin{array}{l}\frac{8}{0} \\
0 \\
\Xi \\
5\end{array}$ & $\begin{array}{l}\frac{8}{0} \\
0 \\
0 \\
10 \\
0 \\
x \\
1\end{array}$ & $\begin{array}{l}8 \\
0 \\
19 \\
\therefore \\
x\end{array}$ & $\begin{array}{l}\frac{8}{8} \\
0 \\
\bar{\Delta} \\
\vec{x}\end{array}$ & 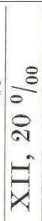 & $\left|\begin{array}{l}8 \\
0 \\
0 \\
0 \\
1 \\
0 \\
-1 \\
\exists \\
\exists\end{array}\right|$ & 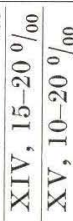 & $\begin{array}{l}8 \\
0 \\
0 \\
0 \\
0 \\
0 \\
0 \\
-1 \\
-1\end{array}$ & 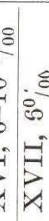 & 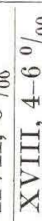 \\
\hline
\end{tabular}

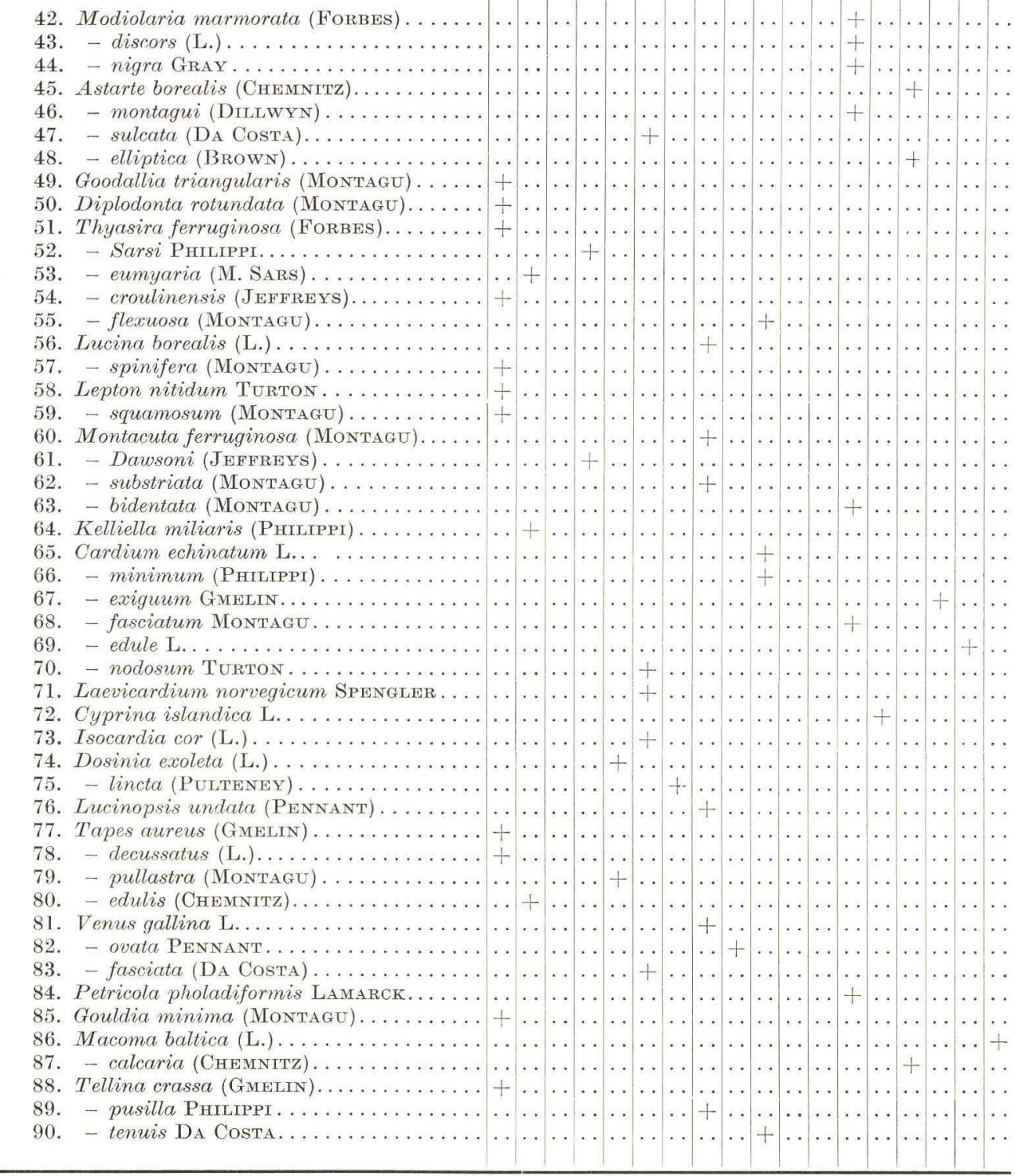


Table 11 (continued).

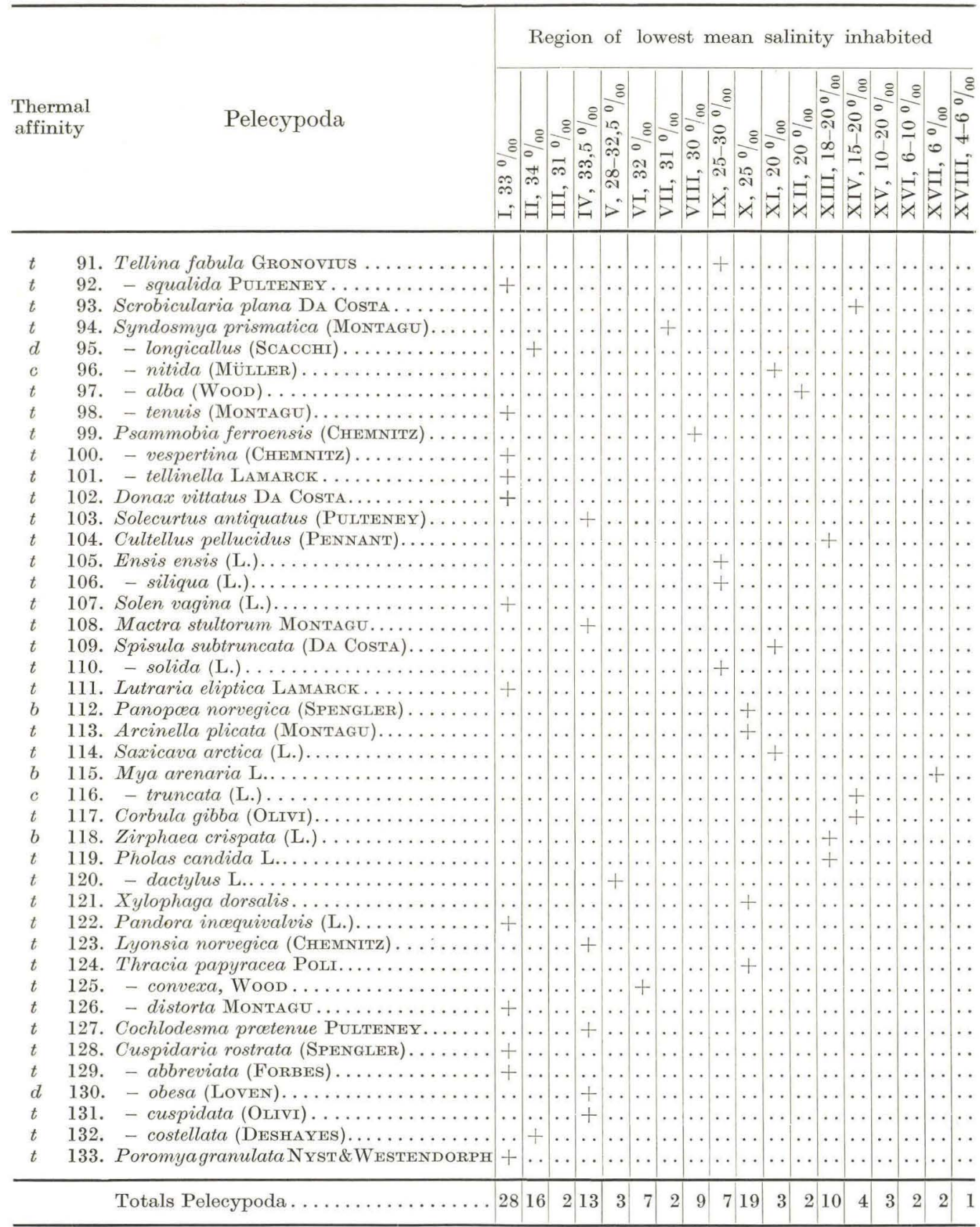


Table 11 (continued).

Thermal affinity
Region of lowest mean salinity inhabited

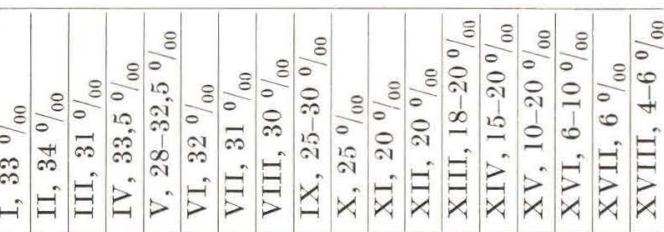

134. Acmaea testudinalis (MüLLER) .

135. - virginea (MüLleR).

136. Lepeta coeca (MüLlER). .

137. Calliostoma mitiare (Ввоссні)

138. Gibbula tumida (Montagu). .

139. - cineraria (L.).............

$\ldots \ldots$

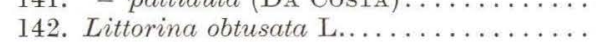

143. - rudis MAT.

144. - littorea L..

145. Onoba striata (MonTaGU)

146. - vitrea (MontAGU). .

147. Alvania punctura (Montagu)

148. - abyssicola Forbes......

149. - cimicoides (ForBES).

150. - zetlandica (Montagu).

151. Rissoa inconspicua Alder.

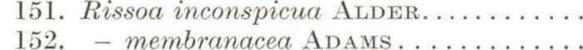

153. - parva DA Cost A. . . . . . . . . . .

154. - violacea Desm. .

155. - soluta Phil.

156. Hydrobia ulvae Pennant.

157. Turritella communis LAMARCK

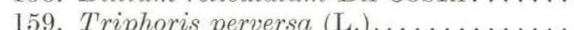

160. Scala clathrus L.

161. Clathrus clathratulus (ADAMs)

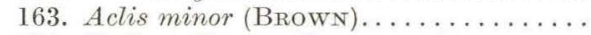

164. Eulima distorta (DEshayes).

165. - intermedia CANTratne....

166. Odostomia decussata Montagu...

167. - unidentata Montagu.

168. - eutimoides HANLEY..

169. - albella Lovén.

170. - turrita (HANLEY)

171. - umbilicaris MaLm.

172. Liostomia clavula (Lovén) . . .

173. Brachystoma rissoides (HANLEY)

174. Evalea (Auriculina) insculpta (MonTaGu)

175. Parthenia indistincta (Montagu)

$\ldots \ldots \ldots+\ldots \ldots \ldots \ldots \ldots \ldots$

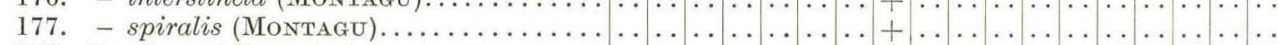

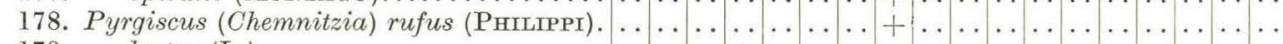

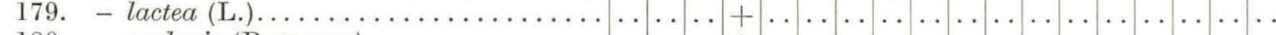

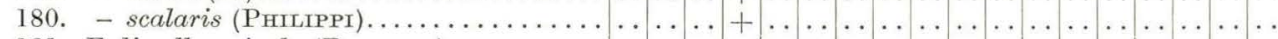
181. Eulimella acicula (PHILIPPI)

182. - scillae SCACCHI 
Table 11 (continued).

\begin{tabular}{|c|c|c|c|c|c|c|c|c|c|c|c|c|c|c|c|c|c|c|c|c|}
\hline \multirow{2}{*}{\multicolumn{2}{|c|}{$\begin{array}{l}\text { Thermal } \\
\text { affinity }\end{array}$}} & \multirow[b]{2}{*}{ Gastropoda } & \multicolumn{18}{|c|}{ Region of lowest mean salinity inhabited } \\
\hline & & & $\begin{array}{l}\frac{8}{0} \\
\approx \\
\approx \\
-1 \\
-1\end{array}$ & $\begin{array}{l}+1 \\
\text { m } \\
-1\end{array}$ & $\begin{array}{l}\frac{8}{0} \\
-5 \\
\exists \\
\Xi\end{array}$ & $\begin{array}{l}8 \\
0 \\
20 \\
\approx \\
2 \\
2\end{array}$ & $\begin{array}{l}a \\
i \\
i \\
\infty \\
\cdots \\
>\end{array}$ & $\begin{array}{l}8 \\
0 \\
\text { \%1 } \\
\vdots \\
5\end{array}$ & $\begin{array}{l}8 \\
0 \\
0 \\
-1 \\
7\end{array}$ & $\begin{array}{l}\frac{8}{8} \\
8 \\
0 \\
\exists \\
\end{array}$ & $\begin{array}{l}8 \\
0 \\
0 \\
\infty \\
i \\
\text { o } \\
x \\
\not\end{array}$ & $\begin{array}{l}8 \\
0 \\
20 \\
i 1 \\
x\end{array}$ & 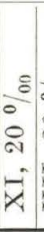 & $\begin{array}{l}\vec{A} \\
\vec{x}\end{array}$ & $\begin{array}{l}\stackrel{8}{0} \\
0 \\
0 \\
\infty \\
\infty \\
- \\
\exists \\
\exists \\
x\end{array}$ & 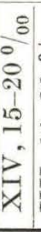 & $\begin{array}{l}\overrightarrow{1} \\
0 \\
0 \\
\vec{x} \\
\vec{x}\end{array}$ & $\begin{array}{l}8 \\
0 \\
0 \\
1 \\
1 \\
0 \\
-1 \\
-1 \\
x\end{array}$ & $\begin{array}{l}0 \\
0 \\
0 \\
5 \\
5 \\
5\end{array}$ & \\
\hline$t$ & 183. & Eulimella nitidissima (MontaGU) & $\cdots$ & $\cdots$ & $\cdots$ & . & $\cdots$ & $\cdots$ & . & $\cdots$ & $\cdots$ & $\cdots$ & + & . &. & $\cdots$ & . & & & \\
\hline$t$ & 184. & Capulus hunga & . & . & . & . & & $\cdots$ & & . & . . & + & . & 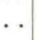 & . & . & . & & & \\
\hline$t$ & 185. & Aporrhais pes peleca & . & . & . & . & & . . & & $\ldots$ & . & . & & $\cdots$ & + & . & . & . & . & \\
\hline$c$ & 186. & opsis islandica (GME & . & & . & & & . . & & . & . & . & + & 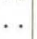 & $\cdots$ & . & 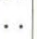 & . & .. & \\
\hline$c$ & 187. & Lunatia pallida (BRoDf & & & . & & & . & & & . & + & . & & & . & 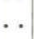 & & . & \\
\hline$c$ & 188. & - nitida (DoN & . & & . & & & . & & + & . & . & & $\cdot$ & & . & 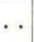 & . & . & \\
\hline$c$ & 189. & - Montagui For & . . & & . & . & & & & + & . & . & & . & & . & . & . & . & \\
\hline$t$ & 190. & Natica catena (DA Costa)... & . & & $\ldots$ & $\cdots$ & & + & & . & $\ldots$ & . & & . & & . & . & . & . & \\
\hline$c$ & 191. & - Velutina velutina (MüLLER)... & . & & $\cdots$ & $\cdots$ & & . & & $\cdots$ & $\cdots$ & . & & . & . & + & & $\cdots$ & & \\
\hline$c$ & 192. & . Trophon truncatus (STRøм) ... & . . & & $\cdots$ & $\cdots$ & & . & $\cdots$ & $\cdots$ & $\cdots$ & . & + & . & . & . & & . & & \\
\hline$b$ & 193. & $\operatorname{lus}$ (L.)......... & . . & . & $\cdots$ & . & + & $\cdots$ & . & $\cdots$ & $\cdots$ & . & & . & . & . & . & . & & \\
\hline$b$ & 194. & R) $\ldots \ldots \ldots \ldots$ & . & . & $\cdots$ & . & & . & . & + & $\cdots$ & . & & . & . & . & - & . & . & \\
\hline$b$ & 195. & $\ldots \ldots \ldots \ldots$ & . & & $\cdots$ & . & & $\cdots$ & & $\cdots$ & $\cdots$ & $\cdots$ & & . & . & + & . & . & & \\
\hline$c$ & 196. & Bucc & . & $\cdots$ & $\cdots$ & $\cdots$ & & $\cdots$ & $\cdots$ & $\cdots$ & $\cdots$ & . & & $\cdots$ & $\because$ & + & 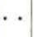 & & & \\
\hline$t$ & 197. & Nassa reticulata & . & & $\cdots$ & $\cdots$ & & $\cdots$ & & $\cdots$ & $\cdots$ & $\because$ & & $\cdots$ & + & . & 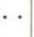 & $\cdots$ & . & \\
\hline$t$ & 198. & - pygmaea LA & . & & $\cdots$ & $\cdots$ & & $\cdots$ & $\cdots$ & $\cdots$ & $\cdots$ & + & & $\cdots$ & . & * & - & $\cdots$ & . & \\
\hline$c$ & 199. & Bela trevelyana & $\cdots$ & & $\cdots$ & . & & $\cdots$ & . & $\cdots$ & $\cdots$ & + & & $\cdots$ & & $\because$ & . & $\cdots$ & & \\
\hline c & 200. & - turricula (MonT & $\cdots$ & & $\cdots$ & $\because$ & & & - & $\cdots$ & $\cdots$ & $\cdots$ & $\cdots$ & * & . & + & · & $\cdots$ & & \\
\hline$t$ & 201. & Philbertia linearis (MONTAGU)..... . & $\because$ & . & $\cdots$ & + & & $\cdots$ & · & $\cdots$ & $\cdots$ & $\cdots$ & $\cdots$ & $\cdots$ & . & $\cdots$ & · & $\cdots$ & $\cdots$ & \\
\hline$t$ & 202. & - teres (FoR & + & & $\cdots$ & $\cdots$ & & & · & $\cdots$ & $\cdots$ & & & $\cdots$ & & - & 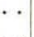 & $\cdots$ & & \\
\hline$b$ & 203. & Taranis Mörchi & $\cdots$ & + & $\cdots$ & . & & ' & . & $\because$ & $\cdots$ & $\cdots$ & . & . & & - & & $\cdots$ & & \\
\hline$t$ & 204. & Mangelia brachyst & - & & $\cdots$ & $\because$ & & $\cdots$ & & + & $\cdots$ & & 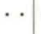 & $\cdots$ & & - & • & $\cdots$ & & \\
\hline$t$ & 205. & U) $\ldots \ldots \ldots \ldots \ldots$ & $\cdot$ & $\cdots$ & $\cdots$ & + & & . & & $\cdots$ & $\cdots$ & $\cdots$ & . & . & . & $\cdots$ & • & . & . & \\
\hline$t$ & 206. & - coarctata (For & $\cdots$ & $\cdots$ & $\cdots$ & + & . & & & . & $\cdots$ & $\cdots$ & 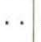 & . & . & . & 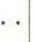 & . & $\cdots$ & \\
\hline$t$ & 207. & - nebula Mo & . & $\cdots$ & $\cdots$ & $\cdots$ & . & + & & $\cdots$ & $\cdots$ & $\cdots$ & $\cdot$ & $\cdots$ & . & $\cdots$ & $\cdots$ & $\cdots$ & $\cdots$ & \\
\hline$t$ & 208. & Actaeon $t$ & $\cdots$ & $\cdots$ & $\cdots$ & $\cdots$ & & $\cdots$ & & + & $\cdots$ & $\cdots$ & $\because$ & $\cdots$ & . & $\cdots$ & 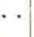 & $\cdots$ & $\cdot$ & \\
\hline$t$ & 209. & Diaphana minuta (BRON & $\cdots$ & $\cdots$ & $\cdots$ & $\cdots$ & . & . & & $\because$ & $\cdots$ & $\cdots$ & + & $\cdots$ & $\cdots$ & & $\cdots$ & $\cdots$ & $\cdots$ & \\
\hline$t$ & 210. & Cylichna cylindracea (Pennant)........ & $\cdots$ & $\cdots$ & $\cdots$ & $\because$ & $\cdots$ & $\cdots$ & $\cdots$ & + & $\cdots$ & $\cdots$ & . & $\cdots$ & $\cdots$ & $\cdots$ & $\cdots$ & $\cdots$ & $\cdots$ & \\
\hline$t$ & 211. & Rhizorus acuminatus (BRUGUIÈRE) . . . . . & $\cdots$ & $\cdots$ & $\cdots$ & + & & $\cdots$ & & $\cdots$ & $\cdots$ & $\because$ & $\cdots$ & $\cdots$ & . & & & & & \\
\hline$t$ & 212. & Retusa umbilicata (MonTAGU)........... & . . & . . & $\cdots$ & $\cdots$ & & $\cdots$ & . & & . & + & . & . & & & & & & \\
\hline$t$ & 213. & - truncatula (BRUGIÈRE). . . . . . . . . . & . & . . & $\ldots$ & $\cdots$ & & $\cdots$ & & . & $\cdots$ & $\cdots$ & . & . & + & & & & ${ }^{\circ}$ & \\
\hline$t$ & 214. & $\ldots \ldots \ldots \ldots$ & $\cdots$ & $\cdots$ & $\cdots$ & . & & $\cdots$ & & 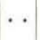 & $\cdots$ & $\cdots$ & . & $\cdots$ & . & . & + & $\cdot$ & . & \\
\hline$t$ & 215. & Scaphander lig & + & $\cdots$ & $\cdots$ & $\cdots$ & & & $\cdots$ & & $\cdots$ & $\cdots$ & $\cdot$ & & . & & & 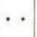 & $\cdots$ & \\
\hline$t$ & 216. & riculus (BR & . & . & $\cdots$ & + & & . & . & 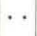 & $\cdots$ & $\cdots$ & . & $\cdots$ & $\cdots$ & & & $\cdots$ & $\cdots$ & \\
\hline$t$ & 217. & Philine aperta (L.). & & . & $\cdots$ & $\cdots$ & & . & . & 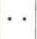 & $\cdots$ & $\cdots$ & . & $\cdots$ & + & $\cdots$ & 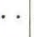 & $\cdots$ & $\cdots$ & \\
\hline$t$ & 218. & - scabra (MÜLLER). . . & & . & $\cdots$ & $\cdots$ & & - & $\cdots$ & $\cdot$ & $\cdots$ & + & $\cdots$ & $\cdots$ & ․ & $\cdots$ & & $\cdots$ & $\cdots$ & \\
\hline$b$ & 219. & - quadrata (S. WooD)... & & & $\cdots$ & & & & $\cdots$ & & $\cdots$ & + & $\because$ & $\cdot$ & & $\cdots$ & & & * & \\
\hline$t$ & 220 . & - punctata (ADAMS)..... & & & . & & & & 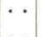 & & . & $\cdot$ & + & $\cdots$ & $\cdots$ & $\cdots$ & & & $\cdots$ & \\
\hline$t$ & 221. & - pruinosa (ClARK). . & & & & & + & & $\because$ & & $\cdots$ & 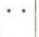 & $\cdots$ & & & & & & * & \\
\hline 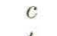 & 222. & - Loveni (MALM)...... & & & & & & & & & & & & & & & & & & \\
\hline$t$ & 223. & Akera bullata MüLLER. & & & & & & & & & & & & & & & & & & \\
\hline & & $10 t a$ & 5 & 1 & . & 9 & 3 & 7 & & 22 & 1 & 11 & 6 & & 12 & 8 & & & & \\
\hline & & & & & & & & 14 & & 31 & 8 & & 9 & & & 12 & & 2 & 2 & \\
\hline
\end{tabular}


Table 12. Decrease in number of molluscan species in the North Sea-Baltic Transition area and salinities of passage belts between the different waters of the transition area.

\begin{tabular}{|c|c|c|c|c|c|c|c|c|c|c|c|}
\hline & \multicolumn{2}{|c|}{ Salinities $\%$} & \multicolumn{9}{|c|}{ Number of molluscan species } \\
\hline & \multirow{2}{*}{$\begin{array}{l}\Xi \\
\Xi \\
\Xi \\
\Xi \\
\Xi\end{array}$} & \multirow{2}{*}{ 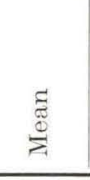 } & \multicolumn{2}{|c|}{ Pelecypoda } & \multirow{2}{*}{ 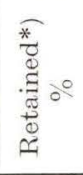 } & \multicolumn{2}{|c|}{ Gastropoda } & \multirow{2}{*}{ 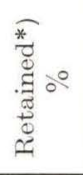 } & \multicolumn{2}{|c|}{$\begin{array}{l}\text { Pelecypoda } \\
\text { and } \\
\text { Gastropoda }\end{array}$} & \multirow{2}{*}{ 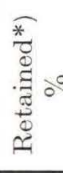 } \\
\hline & & & no. & $\%$ & & no. & $\%$ & & $\begin{array}{l}\text { Sum } \\
\text { no. }\end{array}$ & $\begin{array}{l}\text { total } \\
\%\end{array}$ & \\
\hline $\begin{array}{l}\text { North Sea- } \\
\text { Skagerak }\end{array}$ & $\ldots$ & $\ldots$ & 133 & 100 & $\ldots$ & 90 & 100 & $\ldots$ & 223 & 100 & $\ldots$ \\
\hline Passage belt 1 & 25 & 34 & $\ldots$ & $\ldots$ & 33 & $\ldots$ & $\ldots$ & 7 & $\ldots$ & $\ldots$ & 23 \\
\hline $\begin{array}{l}\text { E \& NW } \\
\text { Kattegat }\end{array}$ & $\ldots$ & $\ldots$ & 89 & 67 & $\cdots$ & 84 & 93 & $\ldots$ & 173 & 77 & $\ldots$ \\
\hline Passage belt 2 & 20 & 32.5 & $\ldots$ & $\ldots$ & 14 & $\ldots$ & $\ldots$ & 7 & $\ldots$ & $\ldots$ & 13 \\
\hline SE. Kattegat & $\ldots$ & $\ldots$ & 71 & 53 & $\ldots$ & 72 & 80 & $\ldots$ & 143 & 64 & $\ldots$ \\
\hline Passage belt 3 & 15 & 30 & $\cdots$ & $\cdots$ & 13 & $\ldots$ & $\ldots$ & 34.5 & $\ldots$ & $\ldots$ & 22 \\
\hline $\begin{array}{l}\text { S. Kattegat } \\
\text { N. Belt Sea }\end{array}$ & $\cdots$ & $\cdots$ & 53 & 40 & $\cdots$ & 41 & 45.5 & $\cdots$ & 94 & 42 & $\cdots$ \\
\hline Passage belt 4 & 12.5 & 25 & $\cdots$ & $\cdots$ & 20 & $\cdots$ & $\cdots$ & 13.5 & $\ldots$ & $\ldots$ & 17 \\
\hline S. Belt Sea & $\cdots$ & $\ldots$ & 27 & 20 & $\ldots$ & 29 & 32 & $\ldots$ & 56 & 25 & $\ldots$ \\
\hline Passage belt 5 & 10 & 20 & $\ldots$ & $\ldots$ & 4.5 & $\ldots$ & $\ldots$ & 6 & $\ldots$ & $\ldots$ & 5 \\
\hline W. Baltic & $\cdots$ & $\cdots$ & 22 & 16.5 & $\cdots$ & 23 & 26 & $\cdots$ & 45 & 20 & $\cdots$ \\
\hline Passage belt 6 & 9 & 15 & $\ldots$ & $\ldots$ & 10.5 & $\ldots$ & $\cdots$ & 23 & $\ldots$ & $\ldots$ & 15 \\
\hline $\begin{array}{l}\text { Deep Baltic } \\
\text { Basins }\end{array}$ & $\cdots$ & $\cdots$ & 8 & 6 & $\cdots$ & 3 & 3 & $\cdots$ & 11 & 5 & $\ldots$ \\
\hline Passage belt 7 & 7 & 10 & $\cdots$ & $\cdots$ & 2 & $\cdots$ & $\cdots$ & 3 & $\ldots$ & $\ldots$ & 2.8 \\
\hline $\begin{array}{l}\text { E. Baltic \& } \\
\text { S. Gulf of } \\
\text { Bothnia }\end{array}$ & $\cdots$ & $\cdots$ & 5 & 4 & $\ldots$ & $\cdots$ & $\cdots$ & $\cdots$ & 5 & 2.2 & $\ldots$ \\
\hline Passage belt 8 & 4 & 5 & $\cdots$ & $\cdots$ & 3 & $\cdots$ & $\cdots$ & $\cdots$ & $\cdots$ & $\cdots$ & 1.7 \\
\hline $\begin{array}{l}\text { N. Gulf of } \\
\text { Bothnia }\end{array}$ & $\ldots$ & $\ldots$ & 1 & 1 & $\ldots$ & $\ldots$ & $\cdots$ & $\cdots$ & 1 & 0.5 & $\ldots$ \\
\hline
\end{tabular}

tion of the sea water may thus be much more pronounced in the mollusca than in the total fauna of the Baltic, which, it was suggested by Remane $(1940$, p. 6$)$, is reduced to half at $17-18 \%$ salinity.

The behaviour of mollusca in relation to changes of salinity is further illuminated by the vertical distribution of the following species:

Mytilus edulis $L$. belongs to the epifauna; it is commonly found above $10 \mathrm{~m}$. in marine areas around Denmark, where it lives on stones, rocks etc. In the Baltic the mussel also settles on the level bottom at depths down to about 40 metres.

Astarte borealis (Снемniтz) is considered to be a relict in the Baltic area by some authors. It occurs in great numbers particularly in the deep Bornholm and Arkona basins, while it is found at shallower depths in the Kattegat, which has a higher surface salinity than the Baltic.

*) Percentage of molluses which do not occur in subsequently listed regions of lower salinities. 
Astarte elliptica (Brown) has a similar distribution in the Baltic and the Kattegat as A.borealis.

Cardium edule generally prefers the shallow waters in marine areas, and here it lives mainly at about $2-3 \mathrm{~m}$. depth. In the most brackish parts of the Baltic it is, however, found down to $20-30 \mathrm{~m}$.

Macoma baltica has a vertical range both in marine areas and in the Baltic corresponding to that of $C$.edule. It may be found to depths of $50 \mathrm{~m}$. or more in the Baltic.

Mya arenaria is found mainly above $6-7 \mathrm{~m}$. in marine areas, whereas it has invaded much deeper levels (down to about $40 \mathrm{~m}$.) in the Baltic.

Retusa obtusa lives on Zostera and other seaweeds at relatively shallow levels (above about $20 \mathrm{~m}$.) in marine areas. In the Baltic Petersen (1888) has found it at about $60 \mathrm{~m}$.

Hydrobia ulvae is a shallow water species that is mainly found above $6-8 \mathrm{~m}$. in marine water. It has been reported from about $20 \mathrm{~m}$. in the Baltic.

JoHANSEN (1916) was the first to draw attention to the peculiar vertical distribution of these molluses, with the exception of Retusa obtusa. He assumed salinity to be the limiting factor, while lack of competitors and enemies, and the relatively low temperature of the water were the causes favoured by JENSEN \& SPÄRCK (1934, p. 129). In their description of Macoma baltica, JENSEN \& SPÄRCK also mention the possibility that the higher salinity of the deep water masses may possibly account for the distribution of $M$. edulis and $M$. baltica in the Baltic.

The present writer adheres to the hypothesis that salinity is the main controlling factor. The peculiar hydrographic conditions of the Baltic are undoubtedly mainly responsible for the "abnormal" distribution of the species mentioned. The accumulation of the most saline water masses near the bottom where it fills the deep basins and hollows, and the "ceiling" of brackish water above, may favour the settling of the larvae at depth. It should, however, be added that the lack of enemies, echinoderms for instance, may well play an important part in the success of the mollusca in the Baltic, while it may be questioned whether competition from other mollusca is of significance. REMANE $(1940$, p. 16) has termed the submergence of species due to salinity (here called salinity submergence) "Brackwasser Submergenz".

The change of biotope, and the occurrence of the species under discussion at depth must undoubtedly be due mainly to salinity submergence of the larvae. This leads to the inference that even though mollusca are able to withstand considerable variation in salinity, as for instance in the case of Hydrobia ulvae, they tend to approach the optimum as closely as possible, if they have a choice.

In table 13 the salinities in the deep Bornholm basin are shown as an example of the great vertical variation of this environmental factor. It is only to be expected that the fauna will reflect these variations. The occurrence of Astarte borealis and $A$. elliptica in this basin is accordingly explained as salinity submergence.

Table 13. Salinity of the Bornholm Basin 1949-52*).

\begin{tabular}{rcclccc} 
& \multicolumn{2}{c}{$1949-50$} & & \multicolumn{3}{c}{$1951-52$} \\
Depth & Minimum & Maximum & Mean & Minimum & Maximum & Mean \\
$0 \mathrm{~m}$. & $7.41 \%$ & $8.06 \%$ & $7.77 \%$ & $7.12 \%$ & $8.21 \%$ & $7.79 \%$ \\
$50-$ & 7.96 & 12.77 & 10.26 & 8.60 & 13.77 & 10.69 \\
$60-$ & 7.96 & 15.17 & 13.21 & 12.61 & 17.70 & 15.10 \\
$100-$ & 15.43 & 17.68 & 16.78 & 19.85 & 21.09 & 20.55
\end{tabular}

*) Calculated on the basis of the data in the Nautical-Meteorological Annuals. 


\section{MARINE ANIMAL COMMUNITIES}

Aggregations of animals of similar aspect, and living under similar environmental conditions on the sea bottom, were termed animal communities by C. G. Joh. Petersen (1913) who was probably the first to introduce this concept. From quantitative studies using his bottom sampler, Petersen obtained an extensive knowledge of the various faunal regions in Danish waters. The concept of the community was established by analogy with plant associations, thus emphasizing the mutual inter-relationships between the different members of the faunal communities, and considering the animals from the viewpoint of producers and consumers in relation to their physical environment. Petersen was aware of difficulties regarding the definition of the communities, as appears from the following quotation (1913, p. 27): "It should not be thought that a very accurate eye, great experience or a very intimate knowledge is required for discovering and separating the above mentioned animal communities in the Danish waters; we can see at once, even on using the dredge that there is a great difference between them, but their characterization has been found difficult and further we have known too little about the quantity of common animals on each $\mathrm{m}^{22}$.

The communities were named after species that were considered characteristic owing to their abundance, their weight or some other quality. These species were related to the guide fossils of the geologist and were particularly chosen from among the molluses and echinoderms.

Regarding the recognition of the characteristic species Petersen says (1913, p. 4): "It is — - impossible by means of a single valuation list, giving the number and quantity of the species of animals from a certain community, to directly indicate the animals characteristic of that community. Only by experience gained from different places are we able to determine this._- - The animals, which are not seasonal and which compose an important part of the whole mass of the community owing to number or weight, will presumably be best suited for characterizing the community and must also be considered as giving a good idea of the outer conditions on which the community is dependent."

MAC GINITIE's (1939) discussion of littoral-marine communities reveals that a purely objective means of defining communities had not been found, since he said: "The first problem is to determine what constitutes a community, that is, to delimit or set boundaries. - - - I know of no way of making any hard or fast rule for determining the limits of a community other than the good judgement of the investigator".

The problem of defining the community was also discussed by Remane (1940, p. 32) who correctly pointed out that any classification such as that of communities, suffers from being schematic, and therefore has limitations. If we want to obtain a true picture of the ecologic distribution of the animals we have to realize this fact. The advice given by MAC GINITIE to ecological investigators: to present the material in a concise, understandable way, using a minimum of technical language, could also be used advantageously by other scientists. In the case of communities we should also realize that the concepts of different authors may be different.

It would carry us too far to enter further into the problems of the marine animal communities. Reference may however be made to the papers by C. G. Joh. Petersen (1911, 1913, 1914, 1915 and 1918), Ford (1923), Davis (1923), Hagmeier (1925, 1929), Blegvad (1922, 1930), Molander (1928), Gislen 
(1929, 1930), Spärck (1931, 1933, 1937), Thorson (1933, 1934), Mac Ginitie (1939), Remane (1940) and Hesse (1952) in which there are further references. Particularly the papers by GISLEN and REMANE include comprehensive bibliographies, and the discussions on methods and concepts by Spärck (1937), MaC GINITIE and REMANE give a good account of the recent state of ideas concerning the marine animal community.

What particularly concerns us is the significant relationships between the animal community and its environment, a matter to which several of the authors named above have drawn attention. Petersen (1914) emphasized the importance of the animate environment, and MoLANDER (1928) stated that it was possible to establish connections between the distribution of the communities in the Gulmar Fjord, the hydrographic conditions, and the nature of the bottom deposits.

Reviewing the literature on marine animal communities, there can hardly be any doubt that the existence of different communities is dependent on the combination of specific environmental factors and the adaptive powers of the animals concerned. However, the present state of knowledge regarding the life histories of the animals, and the characterization and distribution of the communities, does not admit of far-reaching generalizations concerning the relationship of the individual community to its physical environment.

This brief treatment of communities has been included in the discussion in spite of the extremely poor inferences which may be drawn at present, partly for the sake of completeness, and partly on account of the great importance which may be ascribed to the recognition of animal communities both in recent and fossil faunas. This topic is discussed further in the following. 


\section{THE AGE OF THE MOLLUSCAN ASSEMBLAGES OF THE ARNUM FORMATION}

\section{Remarks on Correlation Procedure}

Biostratigraphic correlation is actually a statistical science. It deals with the occurrence or non-occurrence and the frequency of occurrence of fossils and fossil biologic features, and inferences on probabilities are made on such data. Several faunal groups are generally compared with regard to the species they have in common, and similarities and differences are outlined. The inclusion of stratigraphic successions both of strata and fossils in the procedure of correlation may sometimes obscure the picture, but the statistical nature of biostratigraphy remains basically unchanged.

The use of megafossils in stratigraphy has generally been limited to the demonstration of unique species to serve as index or guide fossils, or to the comparison and correlation of faunal lists. The latter method will be briefly discussed on account of its frequent use.

A faunal list may be arranged in tabular form as shown for instance in table 14, p.422, where it includes a primary column $(A)$ in which the species of the fauna to be correlated are listed taxonomically, alphabetically, or otherwise. Secondary columns $(B, C, \ldots \ldots)$ indicate the presence or absence of the species of the primary column in other fossil localities, generalized faunas, stages, etc., which are classified stratigraphically. The percentages of the species of fauna $A$ which are also present in the faunas $B, C$, etc., are generally calculated and compared. Inferences regarding stratigraphical relations are finally made on this basis.

This or similar "percentage" methods have been applied by several workers on faunas from different formations. The following authors may be mentioned from the literature on Tertiary faunas: GotTsche (1878), GRIPP (1915), Kautsky (1925), Staesche (1930), Peyrot (1933), Sorgenfrei (1940), Vigneaux \& Magne (1951).

In 1940 the writer pointed out that percentages calculated in this way are not significant, since the total numbers of species in the faunas dealt with have an important statistical effect on the percentages.

The comparison of two faunules with respect to species is closely considered a test of whether they may be random samples of one fauna. This means that in comparing two faunules we try to estimate a statistical probability.

Species in a sample are statistical events. If $n$ designates the total number of species in a fauna, and $r$ and $s$ the number of species in two random faunules to be compared with $n$, the probabilities $P_{r}$ and $P_{s}$ of the events $r$ and $s$ are approximated by their relative frequencies in relation to $n$ :

$$
P_{r}=\frac{r}{n} \quad \text { and } \quad P_{s}=\frac{s}{n}
$$


From these equations we may derive expression for the probability $P_{\alpha}$ of the occurrence of $\alpha$ species in both $r$ and $s$ :

$$
P_{\alpha}=P_{r} P_{s}=\frac{r s}{n^{2}}
$$

It is a fact that the total number of species in fossil faunas is unknown in most cases. We are generally forced to consider sections of faunas as practical approximations to the whole faunas. In the present example we may consider fauna $n$ as the unknown total number of species in a certain fauna, and $r$ and $s$ as the two faunules to be compared with each others. If we presuppose that $r$ and $s$ are samples of one fauna, and $\alpha$ the species in common, it is possible to arrive at two further equations for the probability $P_{\alpha}$ :

The relative frequencies of $\alpha$ related to $r$ and $s$ respectively are:

$$
P_{\alpha}^{\prime}=\frac{\alpha}{r} \quad \text { and } \quad P_{\alpha}^{\prime \prime}=\frac{\alpha}{s}
$$

Hence the probability $P_{\alpha}$ of $\alpha$ species occurring both in $r$ and $s$ is:

$$
P_{\alpha}=P_{\alpha}^{\prime} P_{\alpha}^{\prime \prime}=\frac{\alpha^{2}}{r s}
$$

by applying the classical rule of the probability of simultaneous occurrence of two independent events being the product of their respective probabilities.

Since by definition:

$$
P_{\alpha}=\frac{\alpha}{n}
$$

we can substitute $\alpha$ with $n P_{\alpha}$ which in accordance with formula (1) is:

$$
n P_{\alpha}=n \frac{r s}{n^{2}}=\frac{r s}{n}
$$

in formula (2) which then may be written:

$$
P_{\alpha}=\frac{\left(\frac{r s}{n}\right)^{2}}{r s}=\frac{r s}{n^{2}}
$$

and it is thus shown that formula (2) is identical with formula (1).

$P_{\alpha}$ may finally also be expressed as the relative frequency of $\alpha$ related to $n^{\prime}=r+s-\alpha, n^{\prime}$ being considered as an approximation to fauna $n$.

$$
P_{\alpha^{\prime}}=\frac{\alpha}{n^{\prime}}=\frac{\alpha}{r+s-\alpha}
$$

The relations between equations (1), (2), and (3) can be illustrated by assuming:

$$
r \rightarrow n \text {; then } \alpha \rightarrow s,
$$

and $P_{\alpha}$ will in all three cases show the following convergence:

$$
P_{\alpha} \rightarrow \frac{s}{n}
$$

It is evident that (3) yields higher values for $P_{\alpha}$ than (1) and (2). 
$P_{\alpha}$ may serve as a preliminary estimate of the faunal affinity between groups to be compared, even in cases where age differences are obvious. If $P_{\alpha}$ is multiplied by 100, the affinity is expressed in percent.

Various objections may be raised against the use of $P_{\alpha}$ as the only criterion of correlation. One is that the number of specimens has not at all been considered. However, $P_{\alpha}$ is certainly of much greater significance than the "percentage" method explained above.

In stratigraphic correlation it is believed to be advantageous to calculate $P_{\alpha}$ by means of equation (2) which implies the smallest errors in $\mathrm{P}_{\alpha}$.

Formula (3) may possibly be more suitable for comparisons intended for use in facies relationship studies.

Only faunal lists from well defined formations which singly consist of beds of practically the same age, or display a high degree of uniformity are fitted for correlation according to the suggested correlation test. However, as it was pointed out in the introduction (p.11-19), it is unfortunalety very difficult to define Miocene molluscan faunas on the basis of data in the literature. This regretable situation has been mainly brought about by the lumping together of species from different localities in the lists of fossils, and by failure to discriminate between rock-stratigraphic and time-stratigraphic units. In the European Miocene fauna it is thus extremely difficult to obtain a clear concept of the individual faunas of the Aquitanian Basin, the Basin of Vienna and the Mediterranean area.

The writer has accordingly restricted calculation of correlation ratios to the faunas of the North Sea Basin. The faunas of the columns in table 14, p. 422 are:

Germany:

Vierlande stage

Hemmoor stage

Reinbek-Dingden stage

Glimmerton stage

$\begin{array}{cl}\text { Fauna at Itzehoe } & \text { (GRIPP 1914) } \\ -\quad \text { - Hemmoor } & \text { (KAUTSKY 1926) } \\ -\quad \text { Reinbek } & \text { (GotTsche 1878) } \\ \text { Total fauna } & \text { (BANKE RASMUSS }\end{array}$

(Banke Rasmussen 1956)

Belgium:

$\left.\begin{array}{l}\text { Boldérien } \\ \begin{array}{l}\text { Horizon of Houthaelen } \\ \text { Anversien }\end{array}\end{array}\right\}$

(GLIBERT 1945-1954)

Denmark:

Klintinghoved clay

Gram formation

(SORGENFREI 1940)

(Banke Rasmussen 1956)

The publication of the fauna of the "Middle Miocene" in Holland has not yet been completed, and the "Middle Miocene" of Denmark is not a well defined entity. The species of these stratigraphic units are accordingly of rather restricted value in stratigraphic correlation.

\section{The Biostratigraphic Record of the Miocene of the North Sea Basin}

Maximum thickness of the Miocene of Northwest Germany is about $520 \mathrm{~m}$. according to SCHAD (1947). Knowledge of the molluscan faunas of this sequence is extremely limited as indicated by the literature. The fauna of the Vierlande 
stage is known chiefly from displaced floes of the Vierlande formation in the glacial drift, and the Hemmoor fauna has been found in fossiliferous boulders which were also embedded in the glacial drift. Only the Reinbek and the Glimmerton faunas have been collected in situ.

It is particularly due to the efforts of GRIPP $(1914,1915,1933,1956)$ that the difficult correlation problem of these Miocene faunas was preliminarily solved as already stated p. 13-14. However, a completely satisfactory biostratigraphic subdivision of the Miocene in the North Sea Basin will first be approached when a sufficient number of well sections having fossiliferous beds in all important formation units have been drilled and adequately examined. The stratigraphic position of both the Vierlande and the Hemmoor faunas, as known from the glacial drift occurrences cannot be determined very exactly in drilled sections. The correlation of subsurface intervals with corresponding stages may, therefore, in many cases prove to be erroneous.

GRIPP $(1915,1933)$, KaUtsky (1925) and HrNsch $(1952,1955)$ have selected a number of index fossils for the different stages and substages of the Miocene. Some of these may be genuine index fossils, while others certainly will be found to have a more extensive vertical range than known at present. In this connection reference should be made to BANKE RASMUSSEN's discussion on the subdivision of the German Glimmerton (1956, p. 126 etc.).

Very few authors, if any, have tried to make an estimate of the total number of molluscan species in the faunas of the Tertiary seas. This is no doubt due to the fact that the need for such an estimate was not previously felt. However, the above discussion on correlation procedure and the problem of the validity of index fossils, show that it is very important to have some idea concerning the total number of species in a fauna.

An estimate of the total size of an inadequately known fossil fauna should be based on knowledge of the faunas of recent seas. It is admittedly true that we cannot be certain that the number of species was the same in fossil faunas as it is in living faunas. There is, however, a reasonable probability that the number of species was of a similar order of magnitude in fossil faunas as in related recent faunas. The following table showing the number of species in the seas around Europe are accordingly given for comparison. The numbers of species are undoubtedly too small because knowledge of the marine faunas has increased considerably since the papers from which the data have been taken were published. Exact figures are, however, not particularly important, since at best only a rough estimate of the fossil faunas can be obtained.

\footnotetext{
Number of species

Northern boreal and arctic fauna off Norway northeastwards from Lofoten (SARS 1878)

British Waters (JEFFREys 1863-1869)

Portugal (NoBRe 1932)

Mediterranean off southern France (Bucquoy, Dautzenberg \& Dollfus 1887-1898)

Mediterranean (Monterosato 1878 acc. to Bucquoy, DautZENBERG \& Dollfus 1887-1898)

The faunas of the northwest European Miocene formations were undoubtedly boreal or boreo-lusitanian as stated below, p. 415. It is reasonable therefore to conclude that each marine stage at least included 500 to 600 species, and that the richest faunas comprised 700 to 800 species.
} 
In making this inference it is of interest to notice the possibility offered by formulas (1) and (2) p. 404 of calculating the total number of species in a fauna. From these two formulas we get the equation.

whence

$$
\frac{r s}{n^{2}}=\frac{\alpha^{2}}{r s}
$$

and taking the square root

$$
n^{2}=\left(\frac{r s}{\alpha}\right)^{2}
$$

$$
n=\frac{r s}{\alpha},
$$

$n$ being the total number of species in the fauna from which the faunules $r$ and $s$ were taken.

The faunule of the Arnum formation comprises 266 species of which 141 a re in common with the Hemmoor faunule which consists of 311 species. Provided these two faunules belong to the same fauna, which well might be possible, then by using formula (4) and substituting $r, \alpha$, and $s$ with 216,141 , and 311 respectively we get the total number of species in the fauna

$$
n=\frac{266 \times 311}{141}=586.7=587 \text { species } .
$$

Provided the faunules of the Arnum formation and the Reinbek-Dingden stages belong to the same fauna then correspondingly:

$$
n=\frac{266 \times 107}{52}=547.3=547 \text { species } .
$$

The agreement between the figures thus calculated and the estimated number of species given above is remarkable. The two approaches are quite independent, and the estimate on the basis of recent faunas was made long time before the formula was developed. The suggested number of species in the Miocene formations of northwestern Europe is therefore apparently a rather close approximation.

Comparison of the estimates and the calculation of the number of Hemmoor species with the number of species now known from the different stages shows how far we are from knowing the entire Miocene fauna. A consequence of our inadequate knowledge is that considerable reserve should be exerted in the definition and use of index fossils in the present premature phase of Miocene faunal research.

\section{Correlation of the Assemblages of the Arnum Formation with known Molluscan faunas of the North Sea Basin}

The Vierlande and Hemmoor faunas are probably composite assemblages of fossils from different horizons. In correlating the faunal zones of the Arnum formation in Southern Jutland with the German faunas, it is therefore reasonable to regard all the fossiliferous beds as belonging to one fauna. This is justifiable because these fossiliferous beds are probably all parts of the same marine stage, and furthermore the dominant species occur in practically all the horizons. 
It appears from table 14, p. 434, that the correlation ratio $P_{\alpha}$ of the faunas of the Arnum formation and the Hemmoor fauna is the maximum figure, if $P_{\alpha}$ calculated by using formula (2) p. 404 is considered. If we assume about 500 species in the Miocene faunas, it is possible by means of formula (1) p. 404 to calculate the probability, $P_{\alpha_{1}}$ of the species which should be common to the fauna of the Arnum formation and the other faunas provided they were random samples of one fauna, as also shown in the table. Finally $\alpha_{1}$ has been ealculated and listed beneath the respective figures for $\alpha$.

It is obvious that the closest agreement between $\alpha$ and $\alpha_{1}$ is displayed by the faunas from Reinbek-Dingden, Houthaelen, Hemmoor, and Klintinghoved. The figures for $\alpha$ are too low in the other faunas to suggest any marked cronological affinity.

The conclusion based on this purely statistical test and on the stratigraphy of the well sections is that the fauna from South Jutland has probably the closest affinity with the Hemmoor fauna. The affinities with the Klintinghoved and Reinbek-Dingden faunas are conspicuous enough to suggest continuity in the North Sea Basin from the Klintinghoved fauna to the Hemmoor fauna, and from the latter to the Reinbek-Dingden fauna.

The reference of the Arnum fauna to the Middle Miocene as defined in Northern Germany agrees with its stratigraphic position below the upper Miocene Gram formation as stated p. 27. It is considered useless to attempt a more detailed correlation with the German sequence at present. This is substantiated by the discontinuous faunal records of Northwestern Germany compared with the Arnum formation, the composite nature of the Hemmoor fauna, etc. It is suggested, therefore, to use the Arnum formation as a reference in future biostratigraphic correlation since without any doubt it displays the best known faunal development.

It would have been very interesting to compare the Arnum fauna with the rich molluscan assemblages of the Aquitanian Basin. However, the obscurity of the formations and their correlation in the Aquitanian Basin itself renders any comparison very unsatisfactory at present. Vigneaux \& Magne (1948 \& 1952) and GRIPP \& MAGNE (1956) have recently reported the preliminary results of study of the Miocene faunas encountered in drilled wells in various parts of the Aquitanian Basin. It is claimed by these authors that both the Aquitanien and the Burdigalien are facies of one faunal stage, the Girundien. The Aquitanien is referred to as Girundien inférieure, and the Burdigalien is identified as Girundien supérieure. A number of index fossils are designated for the substages of the Girundien and the Helvétien.

It is hoped that these preliminary papers will be followed by thorough descriptions of species and faunas. Lists of index fossils such as those published, are of rather little use without documentation, and statistics on the entire faunas are necessary in order to estimate the value of the index fossils as well as the paleoecological development of the faunas. A series of fossiliferous well samples from a thick and important Miocene sequence such as the one encountered in the Aquitanian Basin, ought to be a challenge in this connection.

There is not yet any sound paleobiologic basis for a reliable and detailed correlation of the beds in the Aquitanian Basin with those in the North Sea Basin, and it will be necessary strictly to redefine the formations of the Aquitanian Basin by means of explicitly described sedimentary sections, and also to give a comprehensive record of the faunal development in each formation unit, before an exact time-stratigraphic subdivision can be established. 


\section{ANALYSIS OF THE FAUNA AND ITS DEVELOPMENT \\ Remarks on the Sedimentation of Molluscan Shells}

The assemblages of molluses in a formation or in a fossiliferous bed is generally called the molluscan "fauna" of the lithologic unit concerned. It is of importance to remember that the term "fauna" may often be inappropriate, insofar as the assemblages of shells are in many cases accumulated after the death of the animals.

JOHANSEN (1901) studied the transport of shells by wave actions and currents in Danish Waters and in the Atlantic off the Färöes and Iceland. He found that wave action forms a belt of movement parallel to the coast down to a depth of about $15 \mathrm{~m}$. along open coasts. Shells are moved up or down in this belt. An upward movement prevails on gently dipping shores, while on steep, rocky shores the shells mostly move into deeper water.

Shell accumulations in the belt of movement accordingly do not represent true molluscan animal communities.

Although the shells of molluscs living beyond the $15 \mathrm{~m}$. contour are hardly ever moved up to the shore line, it cannot be inferred that they remain where the animals lived. Very little is known about the transport of shells at depth, but it must be assumed that currents and even wave action contribute considerably to the spreading of shells on the sea bottom even below a depth of $15 \mathrm{~m}$.

The dispersal of shells on the sea bottom is of some use from a biostratigraphic point of view, but we have to realize that the paleoecological background of biostratigraphy thereby becomes rather intricate. One useful conclusion to be drawn from JoHANSEN's observation, is, however, that molluscan specimens which show traces of wave action and posthumous transport must have had their upper limit of distribution at depths less than $15 \mathrm{~m}$., provided they have not been redeposited. Another rule is that fossil molluscan assemblages are generally only approximations to the original molluscan association. This does naturally not mean that they always are poor approximations.

\section{The Significance of the Fossil Molluscan Assemblages of the Arnum Formation}

The molluscan assemblages from the well samples of the Arnum formation are not only approximations of molluscan associations on account of sedimentation, but also on account of sampling. Although the drilling method used should secure relatively well located samples from the borehole, it has to be realized that the samples include fossils from a vertical interval of the sedimentary section.

The term "fauna" has been used abundantly in the present paper for fossil assemblages of mollusca. Although it is almost a truism to say that nobody 
would think about more than the molluscan fauna in this connection, the particular application of the term should be emphasized. The statistics on the different samples have been provided in order to create a basis for a paleoecological evaluation. It should, however, be understood that our ignorance of a very large part of the fauna, including the non-molluscan benthonic and pelagic animals, constitutes a considerable limitation of our endeavours. If, therefore, terms like community, fauna, associations, etc., which have a very strict meaning in recent marine biology, are used in the following it should be remembered that this is done with all the reservation required by the nature of the material and the incomplete faunal record.

Finally an answer should be given to the question whether there is any basis at all for discussing the present molluscan assemblages as representing approximations of animal communities.

Study of the list of fossils in the samples shows that the commonest species occur in almost all the samples. A comparison of the fossil content of some of the closely spaced samples furthermore reveals that the percentages of the individual species are much the same. It seems reasonable to conclude that this is due to a rather slow change of the aspect of the fossil communities concerned. This means, however, that it is permissible to discuss the approximations to molluscan faunules (constituted by the fossil assemblages of the samples) as if they were identical with faunules.

The Faunal Development. A study of table 15, p. 436, which lists all the species found in the samples, will show that some species attain relatively high percentages in most samples. Those species which make up or exceed $1 \%$ of the fossils in a sample are shown on table 16, p. 460, and these 30 species are termed "abundant" in the following discussion, whereas the rest are termed "rare". Particularly conspicuous percentages and maximum figures for individual species are printed in heavy type. The samples from the two wells at Arnum are arranged in a single group according to depth, this has been done because the two wells are located only a few metres apart and therefore the samples can be considered representatives of one section.

The Evidence of the Abundant Species. The fossils and percentages in table 16, p. 460, should be discussed first.

The sum of percentages of this small number of species show that they constitute the most important group of the fossils by number, actually between 80 and 98 percent of the total numbers of fossils in the samples. A remarkable feature of the sum totals of the percentages is that they increase almost uniformly from the lowest to the uppermost sample in the Glejbjerg, Arnum and Toftlund wells. In case of the Gramby well the sum of the percentages is very high in all samples, practically agreeing with the figures for the uppermost samples in the other wells. The assemblage of the sample from $28-40 \mathrm{~m}$. in Arnum well 150.13 which is referred to the Gram formation is clearly different from the assemblages immediately below by its lower percentage of "abundant" species. This suggests a pronounced change in environments in passing from the Arnum to the Gram stage. The assemblage from Bramminge is of the high percentage type.

The increase in the number of specimens of abundant species during the sedimentation of the Glejbjerg, Arnum and Toftlund sections is doubtless due to 
some selective factor. The assemblages at Gramby were apparently subjected to less consistently changing factors in the environment.

A study of the sedimentary records of the the wells (p. 21-27) reveals that there is apparently no permanently increasing or decreasing quality or quantity in the sediments which could be responsible for the increase of the number of specimens. The selective factor does not therefore appear to be related to the substratum.

Since depth of water might be the unknown factor, it should be mentioned that the sample from Bramminge displays the typical features of a shore assemblage. The shells are generally very robust and are the most heavily rolled of all shells examined. This fact, and the experience that thick tests are the rule in recent litoral shells proves that the Bramminge molluscs represent a shore assemblage from the belt of movement (see p. 407). The animals concerned lived accordingly in the litoral region with their upper limit of distribution somewhere between the shore line and depths of about 15 to $20 \mathrm{~m}$.

There is good evidence for shallow conditions also in case of the $53.75 \mathrm{~m}$. horizon in the Glejbjerg well. However, the general impression is that the shells are less rolled than at Bramminge. It is reasonable, therefore, to suggest that at Bramminge the selective factor was grinding resulting from wave action and surf, which only the strongest shells could resist.

The other assemblages with high specimen percentages for the abundant species are not littoral - or at least not shore-assemblages. Accordingly the selective factor was probably not wave action. Since thus neither substratal features nor bathymetric conditions may come into account, the only solution is that the unknown factor is related to the physical properties of the water body, or that it is some biotic factor. The last possibility seems to be rather improbable since there is no evidence for such a factor.

Of the physical properties of the water, temperature and salinity are of greatest interest, but it is difficult to decide which of these is likely to have been most important. However, the relatively thin tests of the shells in the uppermost samples is weak evidence in favour of salinity being the responsible factor. It has not been possible to find any evidence in support of a temperature change which would be more significant than the suggested salinity difference.

The inference to be made from the faunal changes and properties of the sediments and shells is that there was a steady decrease in salinity during the deposition of the Arnum formation at Glejbjerg, Arnum, and Toftlund.

The Gramby assemblages apparently reflect a fundamentally different development from the other three sections. The general aspect at Gramby is similar in some respects to the topmost assemblages at Glejbjerg, Arnum, and Toftlund, while the shells are not as worn as the Bramminge shells. It seems reasonable to explain the high specimen percentages of the abundant species at Gramby by assuming that brackish conditions such as suggested during the last sedimentation at Glejbjerg, etc., prevailed all the time. Gramby is the most marginal location of all wells treated, and it should be recalled that siderite beds and concretions are a particular feature of this section. The abundance of siderite may indicate the flow of iron rich fresh water from a land area and subsequent precipitation in the more or less brackish environment. Both the character of the sediments and the rather extreme aspect of the faunal assemblages thus support the assumption of a brackish environment. 
The conclusions is that Gramby was a marginal area close to a shore where river water diluted the sea water creating extreme environments in which a fauna of a brackish water type lived.

Relations between Species. The frequency of occurrence of the individual species in table 16, p. 460 , reveals some striking relations between allied species. The most impressive distribution is displayed by the 4 species of the genus Nassa, specially arranged at the base of table 16 .

The occurrence in the Glejbjerg well is the most illustrative. Nassa cimbrica and $N$. Schlotheimi obviously dominate in the samples from $42 \mathrm{~m}$. and upwards while N. Fuchsi and N. Facki are mainly found below this depth. Comparison with the other assemblages disloses similar features in the Toftlund and Arnum wells, while the Gramby well maintains its special position.

It is very tempting to explain the occurrence of the Nassae similarly to the increase of the specimen percentage of the abundant species, by assuming a decrease in salinity to have been favourable for N. cimbrica and N. Schlotheimi, and unfavourable for N. Facki and N. Fuchsi. This hypothesis is supported by the Gramby assemblages where N. Facki and N. Fuchsi are very rare while $N$. cimbrica and $N$. Schlotheimi are found in practically all samples.

A close examination of the frequencies in the Gramby, Toftlund, and Arnum samples shows, however, that the change of salinity is not a sufficient explanation. N. cimbrica tends to increase in number during sedimentation both in the Gramby assemblages, which probably represent relatively continuous brackish environments, and in the more marine assemblages at Toftlund and Arnum. It is furthermore remarkable that the couple $N$. cimbrica-N. Schlotheimi is nearly always dominant to N. Fuchsi-N. Facki in the samples from Toftlund and Arnum in which they occur together.

It is impossible to arrive at a safe conclusion regarding the reasons for the particular vertical distribution of the 4 Nassae. The frequencies suggest N. Fuchsi and N. Facki to have been the dominant species during the lower, most marine stage of the sequence, and apparently N. Fuchsi was biologically the stronger of the two. The rare occurrence of these species at Gramby indicates that they may have been sensitive to a decrease in salinity.

$N$. cimbrica and $N$. Schlotheimi seem therefore to have been competitive to N. Fuchsi and N. Facki, the latter two species being at last almost completely conquered. It is interesting to note that $N$. cimbrica and $N$. Schlotheimi were apparently also competitors themselves. It appears that high frequencies of $N$. cimbrica were associated with low frequencies of $N$. Schlotheimi, since $N$. Schlotheimi increases considerably in the samples where $N$. cimbrica is absent or rare. With one exception (Arnum 107.5 m.) N. cimbrica is always more numerous than $N$. Schlotheimi in assemblages where they occur together.

$N$. cimbrica and $N$. Schlotheimi were undoubtedly less sensitive to a decrease in salinity than N.Fuchsi and N.Facki. However, their high frequencies compared with $N$. Fuchsi and N. Facki even in the lower assemblages of the Toftlund and Arnum sections - which have a genuine marine aspect-indicate, as is mentioned, that the superiority of $N$. cimbrica and $N$. Schlotheimi was not alone due to decrease of salinity. Their success was probably in part secured by some biological preference other than adaptability to salinity change. It is, however, not possible to verify this assumption at present.

Petersen (1915, p. 17) was possibly the first to recognize a competitive 
attitude between allied mollusean species, displayed by their distribution in different animal communities on the recent sea bottom of Danish and adjacent waters. In discussing the distribution of Macoma calcarea in the Oslo (Christiania) Fjord he writes: "HJort has (l.c.) called attention to the slight degree of circulation, and paucity of oxygen, etc., in the water of the closed fjords; even this, however, does not explain, why Macoma calcarea should exhibit particularly rich development here rather than elsewhere; if it can live here, then one might well suppose that it could live anywhere. I may in this connection refer to my remarks in Report XXI, p. 29 ff. but would here briefly mention that we have doubtless in this case to reckon with the question of competition between different species, where chemicophysical explanations alone will not suffice. In my opinion it is highly likely that the struggle of species against species may be a far more important factor in the formation of communities than is generally supposed; the destruction or exclusion of certain forms on a given ground, instead of being occasioned by the slight differences in external conditions, might well be rather due to competition on the part of other species better adapted to such conditions as there prevail.--In this connection also I recall a circumstance noted years ago on the cruises of the "Hauch"; that closely related species, especially those of the same genus, are scarcely ever found living in one and the same area of a given water; they may meet, and fight out their war on a frontier line, but are never found to cover the same area of distribution altogether. Each has its own region, its own community. The competition must be greatest between those species which are most closely related".

It is of course very difficult to decide the part played by environment and the "competitive force" in the distribution of pelecypoda, in which the "active" phase is largely identical with the larval stage, which is probably much influenced by the environment. In predatory snails such as species of Nassa, however, it is easy to immagine that some may have biological preferences by which they are able to "fight their war" more succesfully than their competitors.

The evidence of balanced frequencies in the four Nassae appears to be relatively good, and it should be mentioned that there may be another instance of antagonism in the assemblages under discussion. In question are the species Leda Westendorpii and Yoldia glaberrima which seem to alternate in frequency in the Arnum and Toftlund assemblages. It must be admitted, however, that the evidence is weaker than in the Nassae.

Before ending the discussion of the abundant species shown on table 16 , it might be useful to group them in accordance with their behaviour during the sedimentation of the sequences at Glejbjerg, Toftlund, and Arnum. The species of the progressive group generally increase their frequency from the lower to the upper assemblages, the stationary group maintains its relative frequency, and the recessive group decreases in number of specimens. Some species were considered inadequate or too poorly represented to provide a basis for an estimate.

This subdivision of the species must be considered a preliminary attempt at characterisation. Much more material is needed before it can be decided whether the subdivision is valid, and the answer to the question of the significance of recession, progression, and status quo in the individual species must also be postponed. 
Table 17. Behaviour of abundant species during sedimentation of the Glejbjerg, Toftlund and Arnum sequences.

\begin{tabular}{ll} 
Recessive & Progressive \\
Nucoloma hanseata & Leda pygmaea \\
Nassa Fuchsi & Varicorbula gibba \\
Nassa Facki & Nassa cimbrica \\
Gemmula boreoturricula & Ringicula buccinea \\
Fusiturris Duchastelii & \\
\multicolumn{2}{c}{ Stationary } \\
Leda Westendorpii & Turritella tricarinata \\
Leda emarginata & Bittium tenuispina \\
Yoldia glaberrima & Aporrhais alata \\
Kellyella rotunda & Nassa Schlotheimi \\
Thyasira cf. flexuosa & Terebra Hörnesi \\
Ervilia pusilla & Retusa umbilicata \\
Spisula subtruncata & Spiratella atlanta \\
Abra prismatica & Vaginella depressa \\
Saricava arctica &
\end{tabular}

Inanimate Environment Relations. All sedimentary evidence suggests that the assemblages here dealt with mainly lived on a silty bottom and on seaweeds growing on the bottom. The question of salinity has been discussed above in the treatment of the abundant species, on the basis of which it was inferred that salinity decreased during sedimentation. The evidence on bathymetry and temperature requirements should finally be examined.

The Bramminge assemblage is, as already mentioned, a typical shore assemblage. We may, therefore, take it as almost certain that the species contained in this assemblage lived in water shallower than $15-20 \mathrm{~m}$. Important shallow water species in this assemblage are:

\section{Leda pygmaea \\ Yoldia glaberrima \\ Varicorbula gibba \\ A porrhais alata}

\author{
Nassa Schlotheimi \\ Nassa cimbrica \\ Terebra Hörnesi \\ Ringicula buccinea
}

It is essential to notice, however, that these species were not restricted to the shallow belt of movement. Their areas of distribution undoubtedly extended deeper than this part of the sea bottom.

In trying to make an estimate of the bathymetric conditions in the areas represented by the assemblages, the high frequencies of the "shallow water" species should be particularly considered. The abundance of these species and the evidence provided by the sediments are sufficient for assuming relatively shallow water not deeper than 20 to $50 \mathrm{~m}$. during the main part of the period, and it was probably shallower during short time intervals in some parts of the area.

The temperature conditions can be estimated on the basis of still living species. The assemblages include 39 species of which representatives, or closely related species, still live in Lusitanian regions, and with few exceptions also in the Boreal region. Three species are also found in Arctic seas. 
In using these species as indicators of climatic conditions we have to realize that the temperature requirements of the species may have changed since the deposition of the Arnum formation. Since it is unlikely, however, that all species should have altered their temperature requirements to the same extent, there is obviously no risk in suggesting the assemblages to be either of a Boreal or Lusitanian type.

Two species are of particular interest on account of their significant recent distribution viz. Pecten tigerinus and Cancellaria cancellata.

Pecten tigerinus is now almost the prototype of a Boreal species in the northern Atlantic. It extends from western Finmark to northern Spain on the west coast of Europe. Cancellaria cancellata is an almost as typical Lusitanian and subtropical species which lives in the Mediterranean and in the Atlantic from the coasts of Portugal to Senegal.

Although the evidence of these two species must not be overemphasized, it suggests that the fossil assemblages lived under Boreo-Lusitanian conditions comparable with the situation off the coasts of the northwestern part of the Iberian peninsula. Mean temperatures of the surface water in the North Sea area and off northern Spain and Portugal are shown in table 18 according to the maps of G. Scнотт 1942.

Table 18.

Mean Temperature of Surface Water $\left({ }^{\circ} \mathrm{C}\right)$.

North Sea

Annual mean
February
May
August
November

$$
\begin{array}{r}
9-10^{\circ} \\
3-5^{\circ} \\
9-10^{\circ} \\
15-17^{\circ} \\
9-10^{\circ}
\end{array}
$$

Difference Portugal

$\begin{array}{rr}14-15^{\circ} & 5^{\circ} \\ 12-13^{\circ} & 8-9^{\circ} \\ 13-15^{\circ} & 4^{\circ} 5^{\circ} \\ 19-17^{\circ} & 3-4^{\circ} \\ 14-15^{\circ} & 5^{\circ}\end{array}$

The thermal situation of the Miocene Sea Basin was undoubtedly not identical to that of the Atlantic off Portugal and Spain. It is believed that there was a connection from the North Sea to the Atlantic south of England in the Channel area (GRIPP 1915, KaUtsky 1925), and the middle Miocene deposits of Holland and Belgium support this hypothesis. It has to be remembered, however, that the Miocene Channel-if it existed-was certainly narrower than the recent strait between Dover and Calais. The North Sea Basin was accordingly probably a partly closed shelf basin, as it is to day, in which temperature variation was greater than in the open Atlantic. If we therefore assume that the temperature of the North Sea Basin was in general about $5^{\circ} \mathrm{C}$ higher than it is to day, and that the annual variation was similar to that now obtaining, we may have a rather accurate picture of the Miocene conditions.

\section{Classification of the Molluscan Assemblages of the Arnum Formation}

Since the assemblages of the Arnum formation obviously approximate the animal communities of the present seas, however indefinable in precise terms the latter may be, it is suggested that the fossil assemblages be classified in a similar way. It is proposed to follow Petersen's (1913) concept of the animals on the sea bottom being either producers or consumers, and to apply assemblage 
names consisting of the species names of the most characteristic producer and consumer followed by the term "assemblage".

By comparison with living mollusca it should be possible to subdivide fossil mollusca in a very generalized way into organic detritus or plant eaters, predatory animals, and animals of unknown feeding habits. The third group will certainly prove to be the largest both among living and fossil animals since relatively little is known about the nourishment of the majority of recent molluscan species. Reference is otherwise made to BLEGVAD (1914), SpäRcK (1927), Moore (1936), Yonge (1946), Ankel (1948), and Thorson (1951).

In the case of the South Jutland fossil assemblages of the Arnum formation a detailed analysis is not intended. Interest has been concentrated on the abundant species, and it should be pointed out that the pelecypoda are classed among the producers together with species like Aporrhais alata, Turritella subangulata, and T.tricarinata. The species of the genera Nassa and Natica are without exception ranged among the consumers.

The following is the proposed classification of the assemblages of the different sections :

Glejbjerg

$23 \mathrm{~m}$. Varicorbula gibba-Nassa cimbrica

assemblage

25 - Varicorbula gibba-Nassa cimbrica

32 - A porrhais alata-Nassa cimbrica

38 - (Atypical assemblage)

42 - Spisula subtruncata-Nassa Schlotheimi

53 - Aporrhais alata-Natica

53.5 - Aporrhais alata-Nassa Fuchsi

53.75 - Aporrhais alata-Nassa Fuchsi

54 - Aporrhais alata-Nassa Fuchsi

55 - Aporrhais alata-Nassa Fuchsi

Bramminge

70-80 m. A porrhais alata-Nassa cimbrica

Ribe

113-114 m. A porrhais alata (Venus multilamella)Nassa Fuchsi

Gramby

82.7-83.8 m. Aporrhais alata-Nassa cimbrica

84.7-87.2 - Varicorbula gibba-Nassa cimbrica

90.4-92.7 - Spisula subtruncata-Nassa cimbrica

92.7-109.3 - Leda pygmaea-Nassa cimbrica

109.3-110.9 - Spisula subtruncata - Nassa cimbrica

110.9-121.5 - Varicorbula gibba (Leda pygmaea)Nassa cimbrica

Toftlund

75-100 m. Varicorbula gibba (A porrhais alata)-

Nassa cimbrica

100-105 - Aporrhais alata-Nassa cimbrica

105-110 - Aporrhais alata (Spisula subtruncata)Nassa cimbrica 
Toftlund

110-115 m. Aporrhais alata (Yoldia glaberrima)-

$$
\text { Nassa cimbrica }
$$

assemblage

Arnum

28-40 m. Leda pygmaea-Nassa Schlotheimi

62.7-62.9 - Spisula subtruncata-Nassa Schlotheimi

53-83 - Leda pygmaea-Nassa cimbrica

83-94 - Aporrhais alata-Nassa cimbrica

95.0-95.3 - Aporrhais alata-Nassa cimbrica

104.3-107.5 - Abra prismatica (Spisula subtruncata)Nassa Fuchsi

107.5 - Spisula subtruncata (Leda pygmaea)Nassa Schlotheimi

It appears as if all these assemblages are variations of the same theme: the A porrhais alata - Nassa ssp. assemblage. This assemblage may be very closely related to the type of animal communities identified by Petersen (1913) in recent seas. The A porrhais alata - Nassa ssp. "community" of the Arnum formation was apparently the comminity on the silty bottom of shallow waters, as evidenced by the Bramminge assemblage and the often small size and great numbers of individuals in the samples (see Petersen 1911). 


\section{CORRELATION OF THE WELL SECTIONS}

The well sections may be subdivided biostratigraphically by means of the species zones of Nassa Fuchsi and N. cimbrica*).

The Nassa Fuchsi zone is the lowermost biostratigraphic division of the known part of the Arnum formation. It must be noted that the lower boundary of the formation has only been encountered in the Ribe well, and that the fossil record of the drilled section in this well is rather poor. We do thus not know for certain whether N.Fuchsi is characteristic of the whole Miocene section of the Ribe well or not.

The upper boundary of the Nassa Fuchsi biostratigraphic zone is defined as the base of the Nassa cimbrica species zone. This boundary is relatively well defined in the Glejbjerg section at about $50 \mathrm{~m}$. (-25 m.).

In the Bramminge sequence we only know that the assemblage at $70-80 \mathrm{~m}$. belongs to the Nassa cimbrica species zone, which by definition is identical with the Nassa cimbrica biostratigraphic zone. The possibility exists that the base of the $N$. cimbrica zone is found below the $70-80 \mathrm{~m}$. $(-56--66 \mathrm{~m}$.) level.

The Gramby sequence as a whole must be referred to the N. cimbrica zone.

The Arnum section may represent the $N$. cimbrica zone from its top, which apparently is identical with the base of the Gram formation, to its base.

The Toftlund boring encountered only the N. cimbrica zone and stopped before the base of this zone was reached.

The base or the probable base of the $N$. cimbrica zone is shown on the cross section, fig. 2, p. 28.

It is impossible to decide with certainty on the basis of our present knowledge whether the appearance of $N$. cimbrica was a synchronous event in all sections. It has already been pointed out above that the possibility exists that $\mathrm{N}$. cimbrica is a brackish water species. However, there is some evidence for N. cimbrica being an immigrant from outside the North Sea Basin. If this is so we are entitled to regard the base of the $N$. cimbrica species zone as a synchronous level.

It is not practicable to make a more detailed subdivision and correlation of the well sections on the basis of the present fossil evidence. One parallelism between the Toftlund and Arnum sections should, however, be mentioned. In comparing the frequencies of the abundant species in table $16, p .460$, it will be noticed that the following species attain a maximum in the Toftlund $115 \mathrm{~m}$. and the Arnum 104.3-107.5 m. assemblages:

*) The term species zone is here and in the following used for the entire vertical and horizontal distribution of the species concerned. If "zone" is applied in connection with a species name it is used in this sense. 


\section{Yoldia glaberrima Abra prismatica \\ Natica ssp. \\ Nassa Fuchsi}

\section{Nassa Facki \\ Gemmula boreoturricula \\ Fusiturris Duchastelii}

This coincidence of 7 maximum frequencies out of 30 species probably means that the assemblages are closely related. We have, however, not yet any proof that this amounts to contemporaneity.

The Ribe formation which underlies the Arnum formation in the Ribe well has not been penetrated at Ribe. Its non-fossiliferous sands and gravels are undoubtedly non-marine, and a fluviatile origin is suggested.

Since the well sections treated do not provide evidence on the time stratigraphic position of the Ribe formation, except to indicate its pre-Arnum age, the log of the Tertiary section of the deep test Arnum no. 1 will be given:

\section{Arnum No. 1 (Deep test)}

D.G.U. file no. 150.24

Danish American Prospecting Co. Well drilled 1952.

Rotary drilling; no casing while drilling.

Samples: Ditch samples.

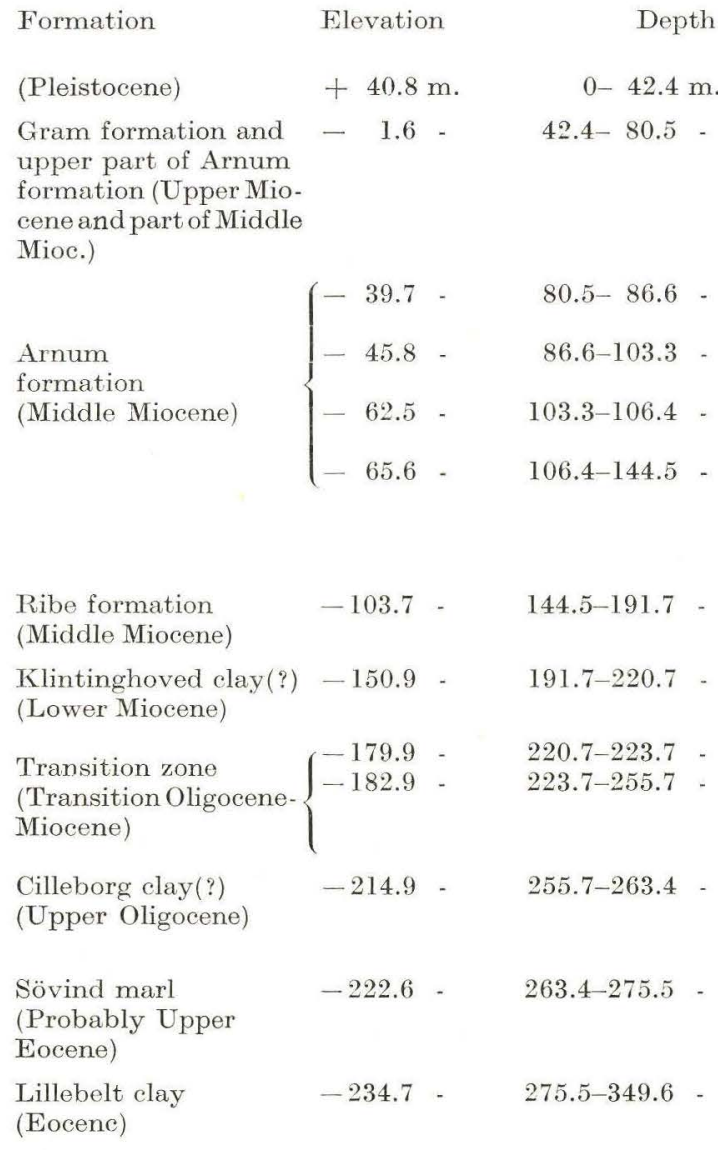

(Preliminary Log compiled by Leif Banke Rasmussen): Quaternary deposits

Mica clay, dark gray, silty, occasional fossil fragments formation (Upper Miocene and part of Middle

Quartz sand, fossiliferous, small shells

Mica clay, silty, dark gray, fossiliferous

Fossiliferous bed, Ditrupa zone

Mica clay, silty, probably with beds of mica sand and quartz sand, fossiliferous

Quartz sand and grave probably limnic-fluviatile

Mica clay, silty, brownish gray, non calcareous

Lignite

Mica clay, silty non calcareous brownish gray with lumps of lignite

Mica clay, brownish gray, glauconitic and pyritic. A few microfossils

Clay, sticky, light gray, calcareous

Clay, sticky, greenish gray 
Formation

Elevation

$-308.8 \mathrm{~m}$.

Depth
$349.6-359.4 \mathrm{~m}$

Log:

Rösnæs clay

-318.6 -

359.4-395.9

Clays with tuff, and

Kerteminde clay

(Lowermost Eocene

and Paleocene)

Kerteminde marl

(Paleocene)

$-355.9-$

$395.4-400.5$

Danian limestone

(Upper Cretaceous)

$-359.7-$

$400.5-408.1$

Clay, reddish brown, calcareous

Clay, gray, non-calcareous upper part probably with Tuff, lower part with beds of shale

Clay, light gray, calcareous, glauconitic

Bryozoan limestone

The quartz sands and gravels from 144.5 to $191.7 \mathrm{~m}$. are, as is shown, correlated with the Ribe formation, and the underlying mica clays are tentatively referred to the Klintinghoved and Cilleborg formations. Their ages are lower Miocene and upper Oligocene respectively.

The $\log$ gives an indication of the approximate thickness of the Arnum formation. The biostratigraphic analysis of the interval in this well is rather difficult on account of the mixing of fossils from different horizons due to the ack of casing, and it has therefore not yet been attempted. 


\section{REMARKS ON THE STRUCTURE OF THE AREA}

The suggested correlations indicate that some crustal movements must have taken place during or after sedimentation of the Arnum formation. It is clear that the Glejbjerg sequence is lying at a much higher level than the other sequences, and there is evidence for believing the Arnum section to be uplifted in relation to the Gramby and the Toftlund sections.

The structural evidence thus provided by the fossiliferous beds of the Miocene in South Jutland was placed at the disposal of the Danish Auerican Prospecting Co. at an early stage of the investigations in 1947. There was a remarkable agreement between the structural evidence of the Miocene sequence and the residual gravity map of the area elaborated by the GULF RESEARCH \& Development Co. The high situation of the Arnum and the Glejbjerg sections correspond to gravity highs, and the low lying Gramby, Toftlund, and Ribe sequences were located in gravity lows.

The area was subsequently investigated seismically by the DANISH AMERICAN Prospecting Co. The seismic mapping, and a number of shallow core holes and deep tests finally proved the structural significance of the fossil evidence. 
Table 14. Stratigraphic and Geographic Distributi

\section{The molluscan species of the} Arnum formation

\begin{tabular}{|c|c|c|c|c|c|c|c|c|c|c|}
\hline \multicolumn{8}{|c|}{ Mediterranean Basin } & \multicolumn{3}{|c|}{ Vienna Bas } \\
\hline Olig. & \multicolumn{4}{|c|}{ Miocene } & \multicolumn{3}{|c|}{ Pliocene } & \multicolumn{3}{|c|}{ Miocene } \\
\hline 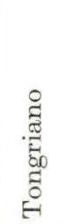 & 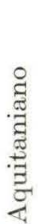 & 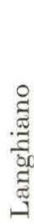 & 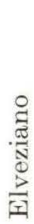 & 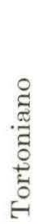 & 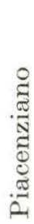 & 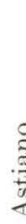 & 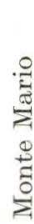 & $\begin{array}{l}\frac{0}{8} \\
8 \\
0 \\
80 \\
0 \\
0 \\
0 \\
0 \\
00 \\
00 \\
\text { 에 }\end{array}$ & 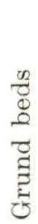 & $\frac{3}{0}$ \\
\hline
\end{tabular}

\section{Pelecypoda}

1. Nucula nucleus (LINNE)...

2. - Jeffreysi Bellardi.

3. - cromata nov. sp.

4. - cf. nitida Sowerby.

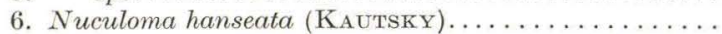

7. - cf. Haesendonckii (Nyst \& WestendorP)......

8. Leda (Jupiteria) pygmaea (Münster) . . . . . . . . .

9. - (Ledina) Westendorpii (NYST \& WESTENDORP)...

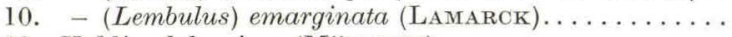

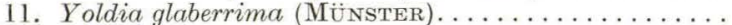

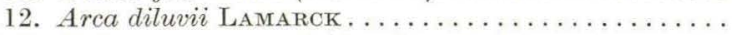

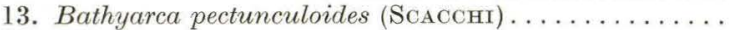

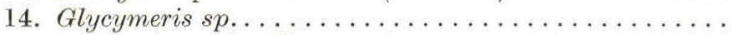

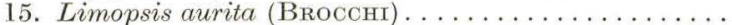

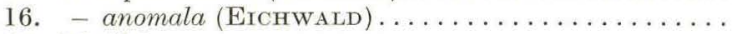

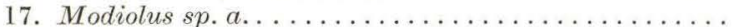

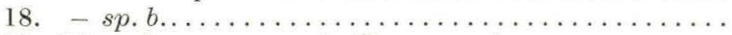

19. Musculus saucatsensis (CossmanN) . . . . . . . .

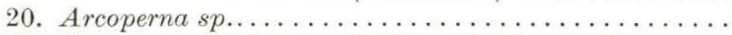

21. Pecten ex aff. Brummelii Nyst \& liberata Cossmann

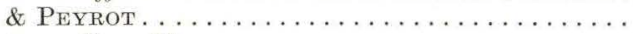

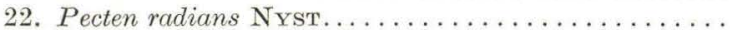

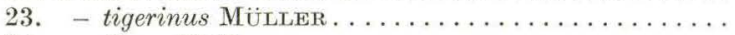

24. - Gerardii Nyst . . . . . . . . . . . . . . . .

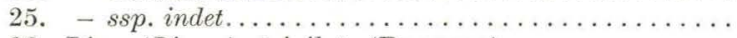

26. Lima (Limea) strigilata (BRoсcHI) . . . . . . . . .

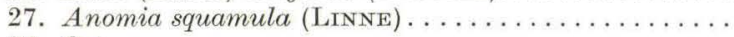

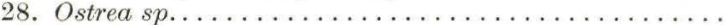

29. Astarte cf. concentrica Goldfuss . . . . . . . . . .

30. - (Goodallia) triangularis Montagu.............

31. Cardita (Cyclocardia) orbicularis (SowERBY) . . . . .

32. Kellyella (Lutetia) rotunda nov. sp.............

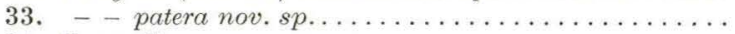

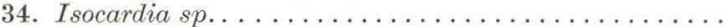

35. Sportella cimbrica KaUtsky . . . . . . . . . . .

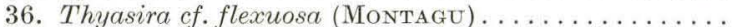

37. Phacoides of. Schloenbachi (von Koenen)..........

38. Loripes cf. niveus (EICHWALD) . . . . . . . . . . .

39. Lucina (Loripinus) Norregaardi nov. sp...........

40. Codokia jutensis nov. $s p \ldots \ldots \ldots \ldots \ldots \ldots \ldots \ldots$

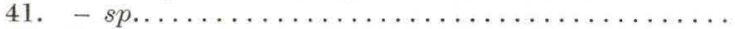
42. Erycina (Seacchia) Degrangei Cossmann \& Peyrot.

\begin{tabular}{|c|c|c|c|c|c|c|c|c|c|}
\hline . & $\cdots$ & $\cdots$ & + & $\ldots$ & + & + & + & $\ldots$ & + \\
\hline . & $\cdots$ & & $\cdots$ & $\cdots$ & + & + & + & $\ldots$ & $\ldots$ \\
\hline . & $\cdots$ & & . & & & $\cdots$ & $\ldots$ & $\ldots$ & . \\
\hline$\cdots$ & $\cdots$ & & $\cdots$ & . & + & + & + & $\ldots$ & \\
\hline . & $\cdots$ & & & & $\ldots$ & $\ldots$ & $\ldots$ & $\ldots$ & \\
\hline$\cdots$ & $\cdots$ & $\cdots$ & . & . & . & $\cdots$ & $\ldots$ & $\ldots$ & \\
\hline$\cdots$ & $\cdots$ & . & . & . & . & $\cdots$ & $\ldots$ & $\ldots$ & $\ldots$ \\
\hline$\ldots$ & $\cdots$ & . & . & . & & $\cdots$ & $\cdots$ & $\cdots$ & $\ldots$ \\
\hline$\ldots$ & $\cdots$ & . & $\cdots$ & $\cdots$ & . & $\cdots$ & $\cdots$ & $\cdots$ & $\cdots$ \\
\hline$\cdots$ & $\cdots$ & $\cdots$ & + & $\cdots$ & & $\cdots$ & $\cdots$ & $\cdots$ & + \\
\hline$\cdots$ & $\cdots$ & . & $\cdots$ & . & & $\ldots$ & $\cdots$ & $\cdots$ & $\ldots$ \\
\hline$\ldots$ & $\ldots$ & . & + & + & + & + & + & $\ldots$ & + \\
\hline . & $\cdots$ & . & + & $\cdots$ & . & $\cdots$ & + & $\cdots$ & \\
\hline . & . & & & $\cdots$ & & & . & $\cdots$ & \\
\hline . & $\ldots$ & & + & F & + & $\cdots$ & t & $\cdots$ & \\
\hline$\cdots$ & $\ldots$ & & + & $\cdots$ & + & + & + & $\cdots$ & $\cdots$ \\
\hline$\cdots$ & $\cdots$ & & $\cdots$ & & & $\cdots$ & • & $\cdots$ & \\
\hline$\because$ & $\cdots$ & & $\cdots$ & & & & & $\cdots$ & \\
\hline$\ldots$ & $\ldots$ & & & $\ldots$ & & 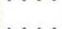 & 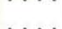 & $\cdots$ & \\
\hline & & & & & & & & & \\
\hline$\cdots$ & $\cdots$ & & & & & $\cdots$ & & $\cdots$ & \\
\hline & $\cdots$ & & $\cdots$ & $\cdots$ & $\cdots$ & . & $\cdots$ & $\ldots$ & . \\
\hline & $\cdots$ & & $\cdots$ & $\cdots$ & + & $\cdots$ & $\cdots$ & $\cdots$ & $\cdots$ \\
\hline & $\cdots$ & & $\cdots$ & $\cdots$ & $\cdots$ & $\cdots$ & $\cdots$ & $\cdots$ & \\
\hline$\ldots$ & & & $\cdots$ & $\cdots$ & $\because$ & $\cdots$ & $\cdots$ & $\cdots$ & . \\
\hline$\ldots$ & $\cdots$ & $\cdots$ & T & + & & + & T & $\cdots$ & $\cdots$ \\
\hline & & $\cdots$ & T & $\cdots$ & $T$ & + & + & $\cdots$ & \\
\hline$\ldots$ & & . & $\cdots$ & $\cdots$ & $\cdots$ & $\cdots$ & $\cdots$ & $\cdots$ & \\
\hline$\cdots$ & & & $\cdots$ & $\cdots$ & $\cdots$ & $\cdots$ & $\cdots$ & $\cdots$ & $\cdots$ \\
\hline$\cdots$ & & & & $\cdots$ & & $\cdots$ & $\cdots$ & $\cdots$ & $\cdots$ \\
\hline$\ldots$ & & & & $\cdots$ & & $\cdots$ & $\cdots$ & $\cdots$ & \\
\hline$\ldots$ & . & & & $\cdots$ & & & & $\cdots$ & \\
\hline$\ldots$ & $\cdots$ & & & & & & $\ldots$ & $\ldots$ & \\
\hline$\ldots$ & $\cdots$ & & & & & & . . & . . & \\
\hline$\ldots$ & $\ldots$ & $\cdots$ & & $\cdots$ & & . & + & $\ldots$ & \\
\hline$\ldots$ & $\ldots$ & & & . & & & $\ldots$ & . & \\
\hline$\cdots$ & $\cdots$ & & $\cdots$ & . & & & & $\cdots$ & \\
\hline$\cdots$ & $\ldots$ & $\ldots$ & $\cdots$ & . & $\cdots$ & $\cdots$ & $\cdots$ & . & \\
\hline$\cdots$ & $\cdots$ & & $\cdots$ & $\cdots$ & $\cdots$ & & $\cdots$ & $\cdots$ & \\
\hline$\cdots$ & $\cdots$ & & $\cdots$ & $\cdots$ & $\cdots$ & & & $\cdots$ & 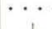 \\
\hline$\cdots$ & $\cdots$ & & & . & & & & . & 7 \\
\hline
\end{tabular}




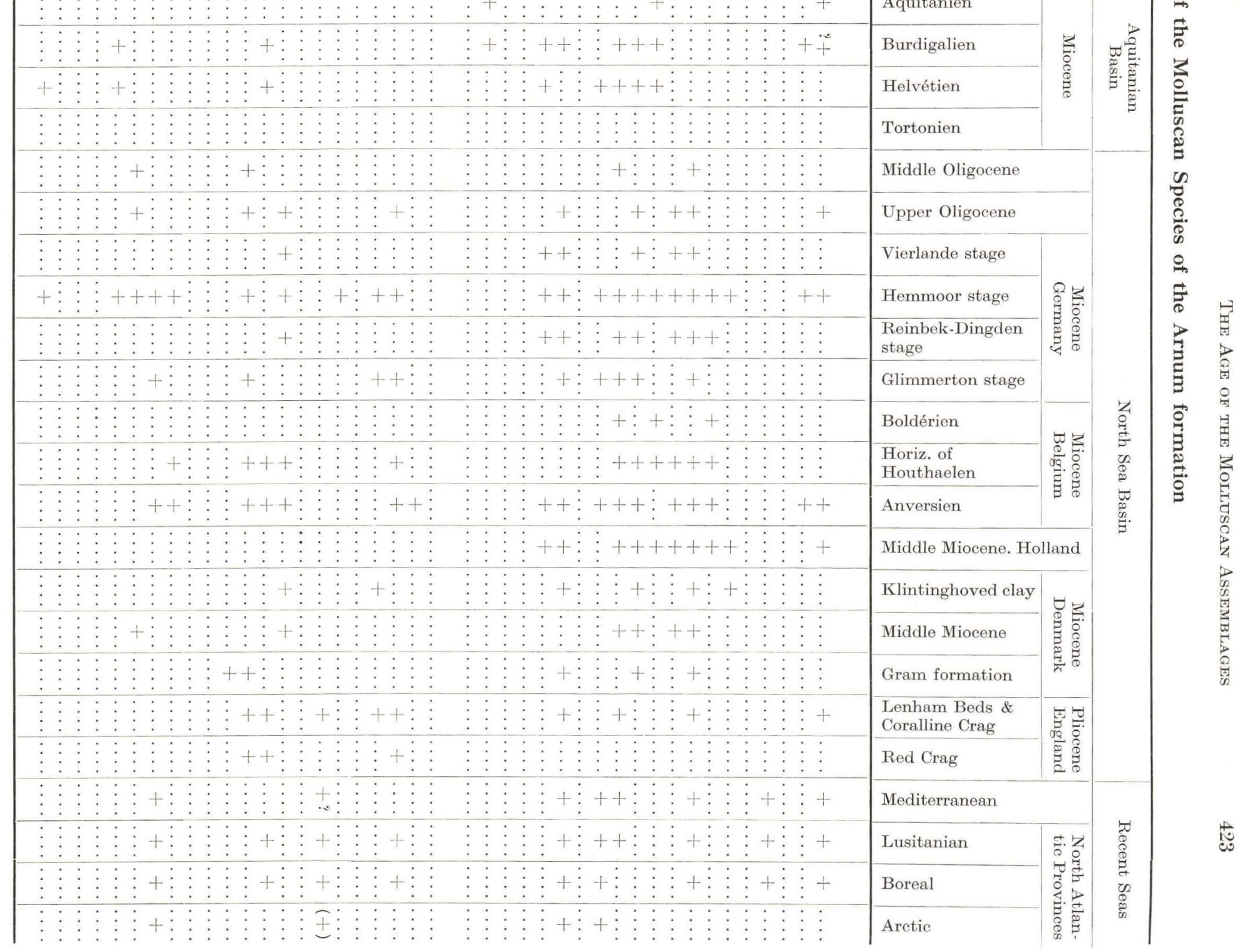


Table 14 (continued).

The molluscan species of the Arnum formation

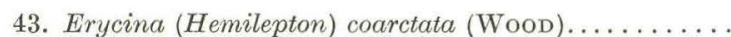

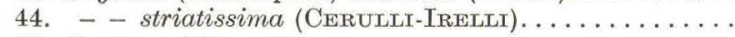

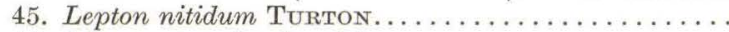

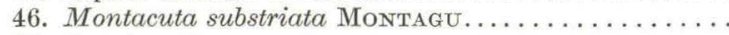

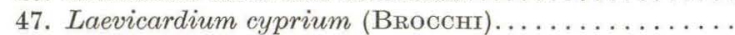

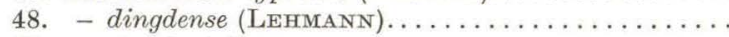

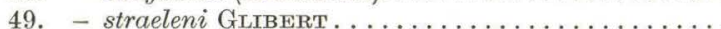

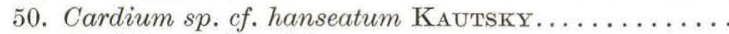

51. Gouldia minima (Montagu) . . . . . . . . . . .

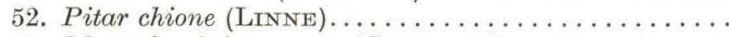

53. Meretrix cf. incrassata (SowerBy) . . . . . . . . . .

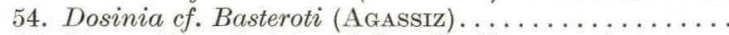

55. Venus (Ventricola) multilamella (LAMARCK) . . . . . .

56. Ervilia pusilla (PHILIPPI) . . . . . . . . . . . .

57. Spisula subtruncata (DA Costa) var. . . . . . . . . .

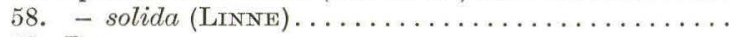

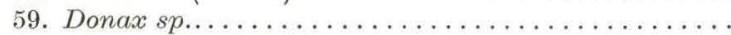

60. Abra prismatica (Montagu) var. . . . . . . . . .

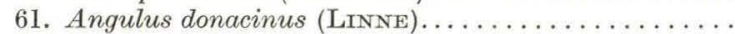

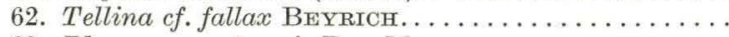

63. Pharus saucatsensis Des Movlins..............

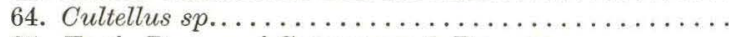

65. Ensis Degrangei Cossmann \& Peyrot ...........

66. Saxicava arctica (LINNE) . . . . . . . . . . . . .

67. Saxicavella pusilla nov. $s p \ldots \ldots \ldots \ldots \ldots \ldots \ldots \ldots$

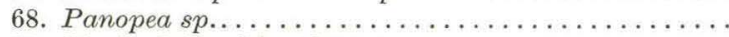

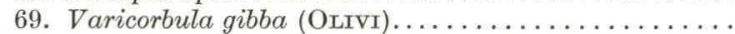

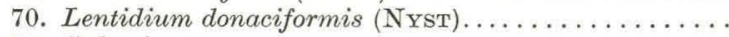

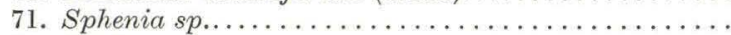

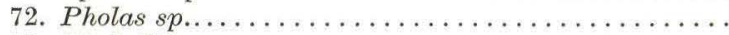

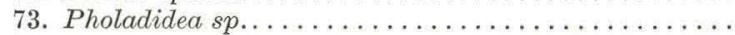

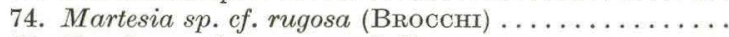

75. Teredo sp. cf. saucatsensis BenoIst . . . . . . . . .

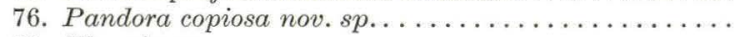

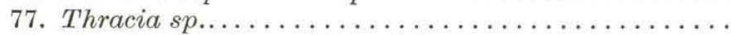

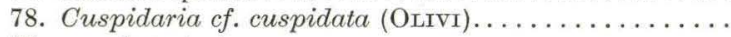

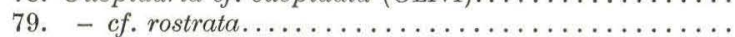

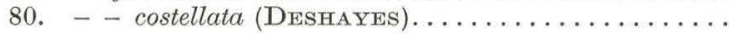

\section{Scaphopoda}

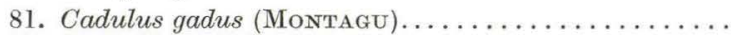

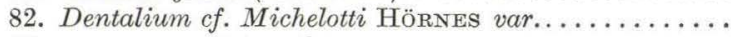

83. - novemcostatum LAMARCK . . . . . . . . . . . . . .

84. - sp. cf. badensis PARTSCH. . . . . . . . . . . .

\begin{tabular}{|c|c|c|c|c|c|c|c|c|c|c|}
\hline \multicolumn{8}{|c|}{ Mediterranean Basin } & \multicolumn{3}{|c|}{ Vienna Basir } \\
\hline Olig. & & Mio & ene & & & ioc & & & ioce & \\
\hline 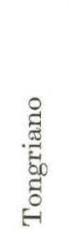 & 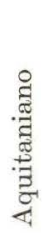 & 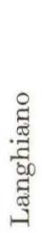 & 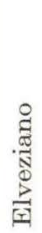 & 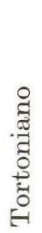 & 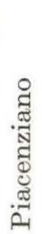 & 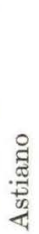 & 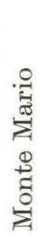 & 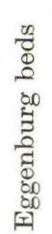 & 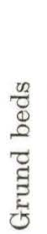 & \\
\hline
\end{tabular}




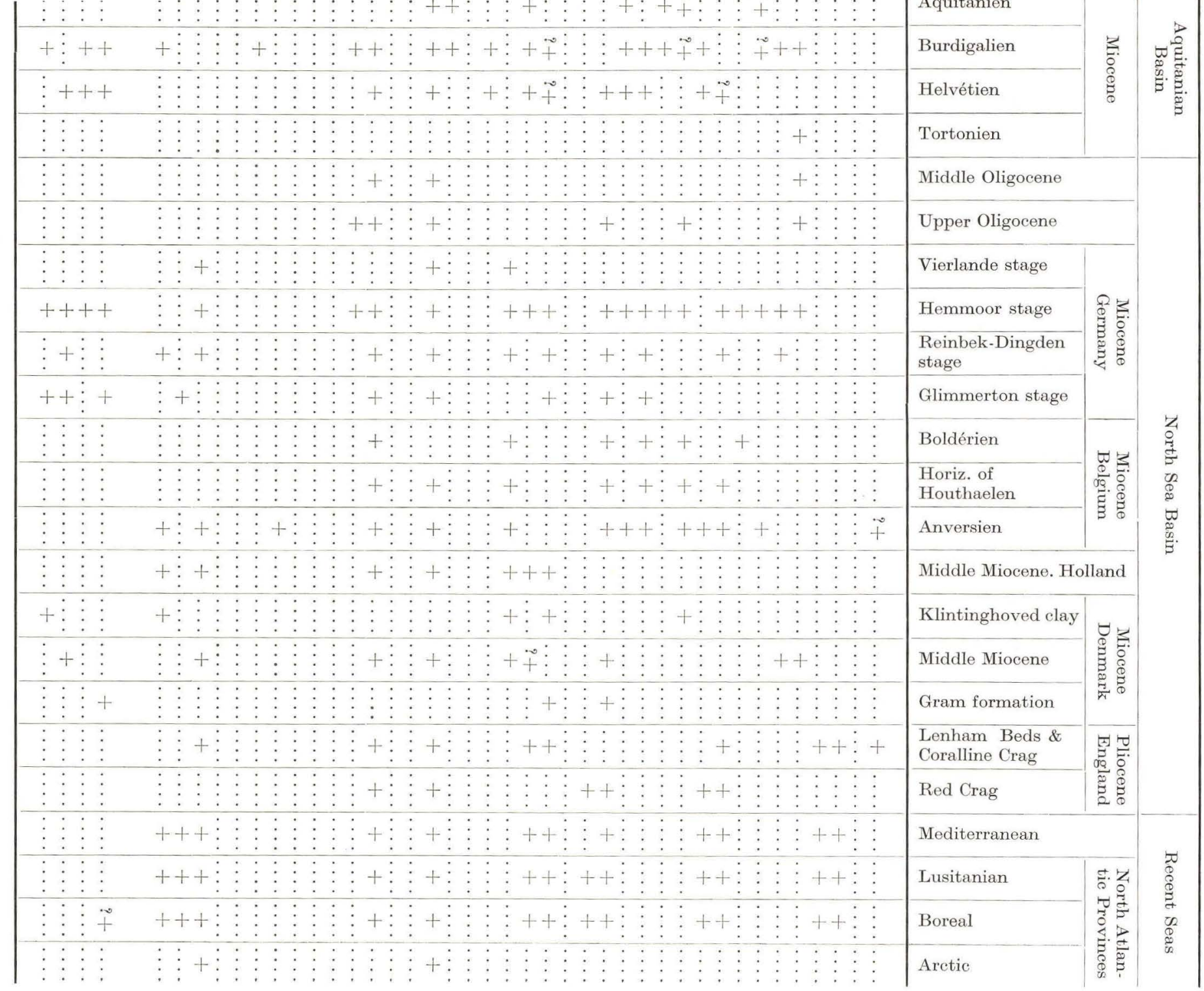


Table 14 (continued).

The molluscan species of the

Arnum formation
Mediterranean Basin

Vienna Basir

\begin{tabular}{|c|c|c|c|c|c|c|c|c|c|c|}
\hline Olig. & \multicolumn{4}{|c|}{ Miocene } & \multicolumn{3}{|c|}{ Pliocene } & \multicolumn{3}{|c|}{ Miocene } \\
\hline 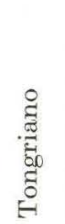 & 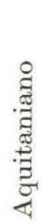 & 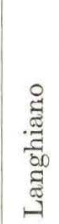 & 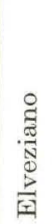 & 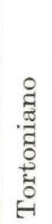 & 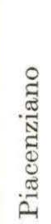 & 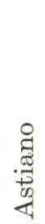 & 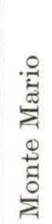 & 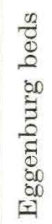 & 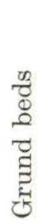 & 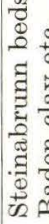 \\
\hline
\end{tabular}

\section{Gastropoda}

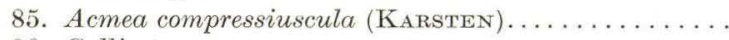

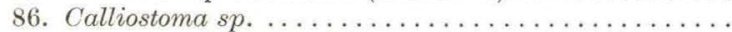

87. Starkeyna hanseata (KAUTSKY) . . . . . . . . . . .

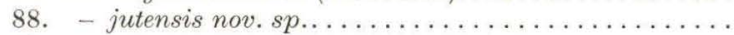

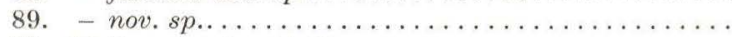

90. Liotia miosuturalis KAUTSKY . . . . . . . . . . .

91. Alvania Partschi (Hörnes) . . . . . . . . . . .

92. Rissoa Ravni nov. $s p \ldots \ldots \ldots \ldots \ldots \ldots \ldots \ldots \ldots \ldots$

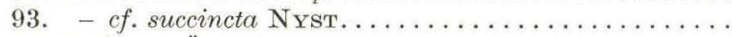

94. Rissoina Ödumi nov. sp..................

95. Adeorbis subcirculus Cossmann \& Peyrot.........

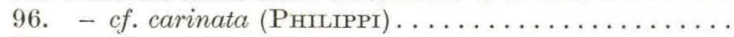

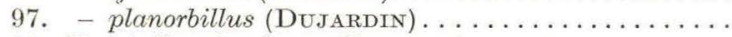

98. Turritella tricarinata (BRocCHI) . . . . . . . . .

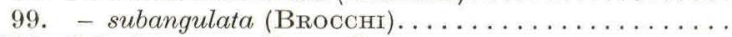

100. Solarium carocollatum LAMARCK...............

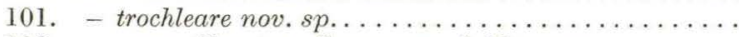

102. - angustiforatum CossMANN \& PEYROT . . . . . . .

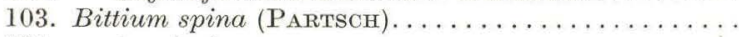

104. - tenuispina nov. sp....................

105. Cerithiopsis Vignali Cossmann \& Peyrot........

106. Triphora perversa (LINNE) . . . . . . . . . . . .

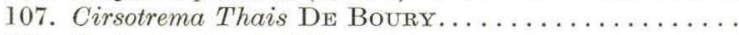

108. Scala frondicula (Wood) . . . . . . . . . . . . . . .

109. - (Acrilla) ef. amoena PHILtPpi . . . . . . . . . . .

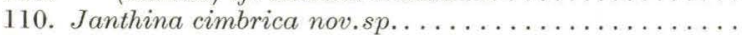

111. Niso acarinatoconica Cossmann \& Peyrot.......

112. Melanella similis (D'ORBIGNY) . . . . . . . . . .

113. - taurostricta (Cossmann \& Peyrot) . . . . . . . .

114. Calyptraea chinensis (LINNE) . . . . . . . . . . .

115. Xenophora Deshayesi (Micheцотті)............

116. A porrhais alata (EICHWALD) . . . . . . . . . . . .

117. Natica (Lunatia) catena (DA CostA) . . . . . . . .

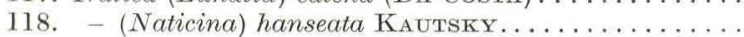

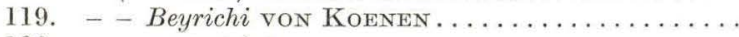

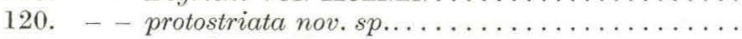

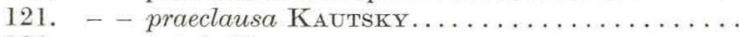

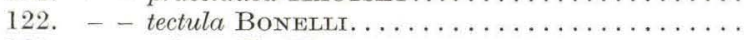

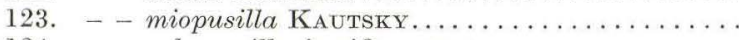

124. - - submamillaris D'ORBIGNY . . . . . . . . . .

125. - (Polynices) affinis (GMenin) . . . . . . . . . .

126. - (Neverita) Josephinia (RIsso). . . . . . . . . .

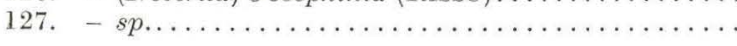

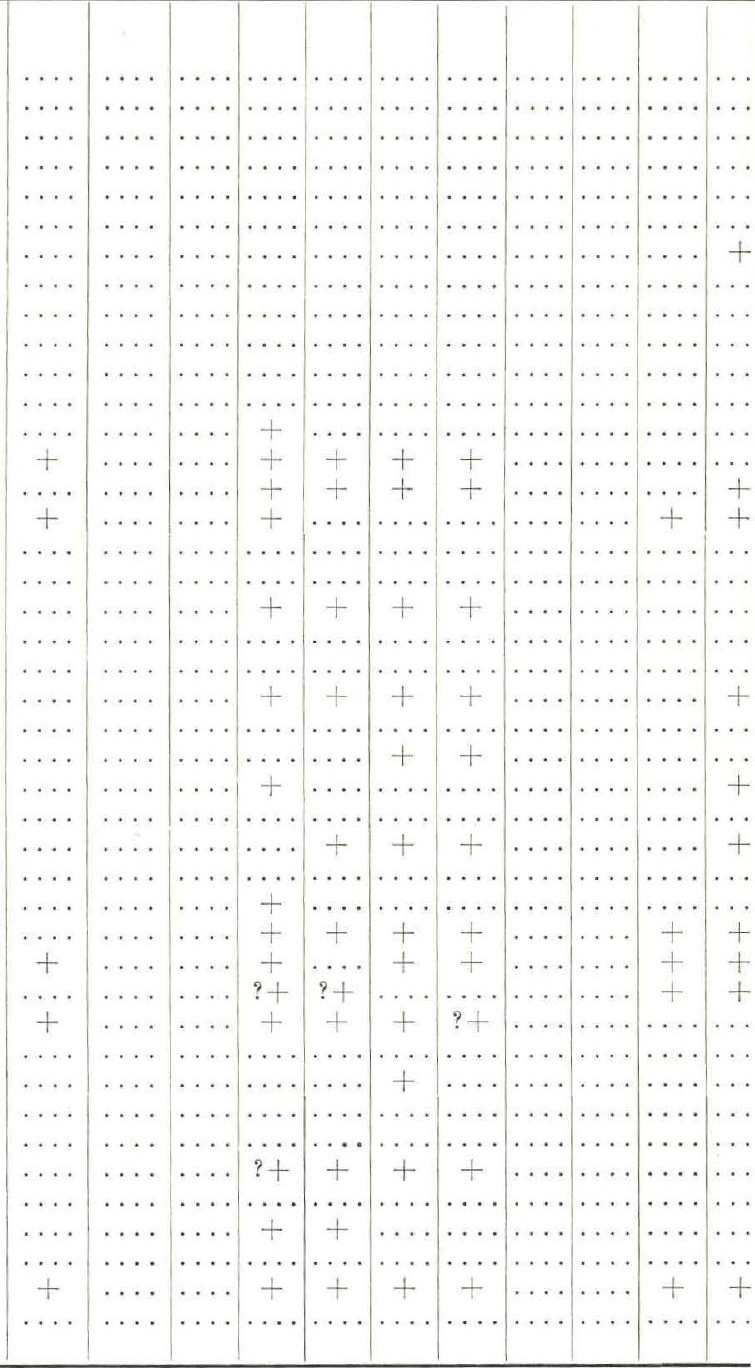


Table 14 (continued).

The molluscan species

of the

Arnum formation

128. Globularia $s p \ldots \ldots \ldots \ldots \ldots \ldots \ldots \ldots \ldots \ldots \ldots$

129. Sigaretus sulcatus (Grateloup)

130. - cf. aquensis RECLUZ . . . . . . . . . . . . .

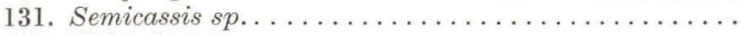

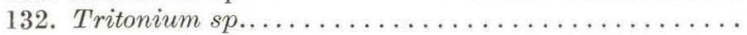

133. Pyrula simplex Beyrich . . . . . . . . . . . .

134. - condita Brongmiart. . . . . . . . . .

135. Murex of. aturensis Cossmann \& Peyrot..........

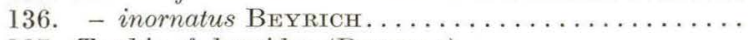

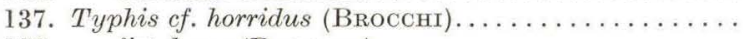

138. - fistulosus (BRоссні) . . . . . . . . . . . .

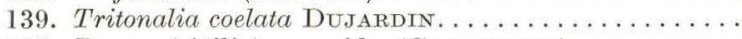

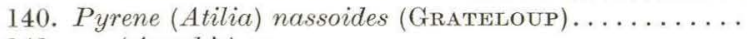

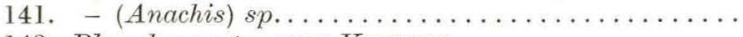

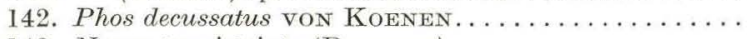

143. Nassa tenuistriata (BEYRTCH) $\ldots \ldots \ldots \ldots \ldots \ldots$

144. - serraticosta (BRoNn) . . . . . . . . . . . . .

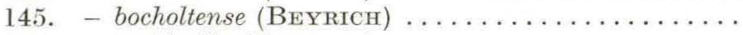

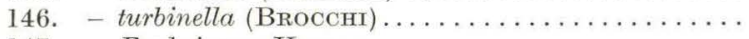

147. - Fuchsi von Koenen . . . . . . . . . . . .

148. - Schlotheimi (BEYRICH) . . . . . . . . . . .

149. - holsatica (BEYRICH) . . . . . . . . . . . .

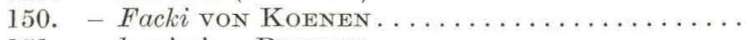

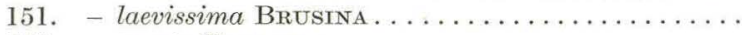

152. - cavata Bellard. . . . . . . . . . . . . . .

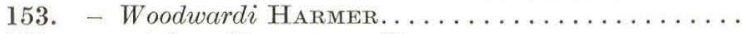

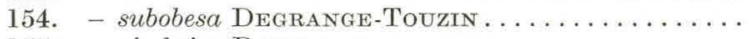

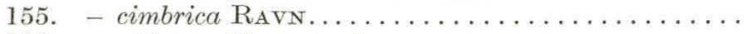

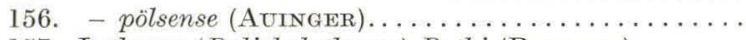

157. Lathyrus (Dolicholathyrus) Rothi (ВEYRICH)........

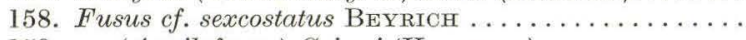

159. - (Aquilofusus) Grippi (KaUTSKY) . . . . . . .

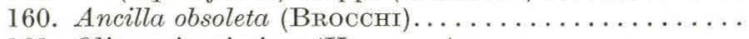

161. Oliva minutissima (KAUTSKY) $\ldots \ldots \ldots \ldots \ldots \ldots$

162. Mitra of. Bellardii Hoennes \& Auinger..........

163. - cf. planicosta BELLARDI . . . . . . . . . . .

164. Cancellaria (Cancellaria) cancellata Linne.........

165. - - contorta Basterot . . . . . . . . . . . .

166. - (Trigonostoma) acutangula FAUJAS DE SAINT FOND

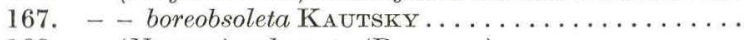

168. - (Narona) calcarata (BRocCHI) . . . . . . . . .

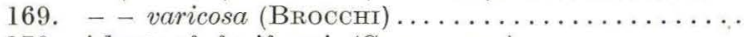

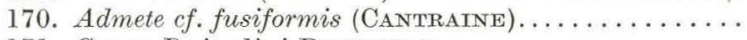

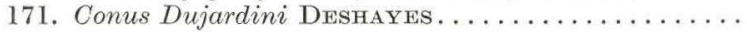

\begin{tabular}{|c|c|c|c|c|c|c|c|c|c|c|}
\hline \multicolumn{8}{|c|}{ Mediterranean Basin } & \multicolumn{3}{|c|}{ Vienna Basin } \\
\hline Olig. & & Mic & ene & & & ioc & & & ioce & \\
\hline 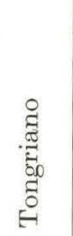 & 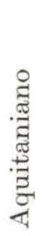 & 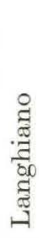 & 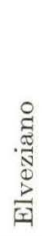 & 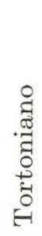 & 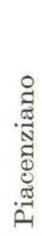 & 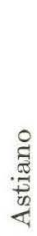 & 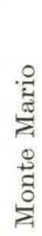 & 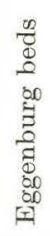 & 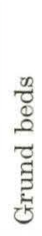 & 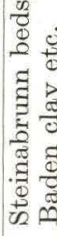 \\
\hline
\end{tabular}


Table 14 (continued).

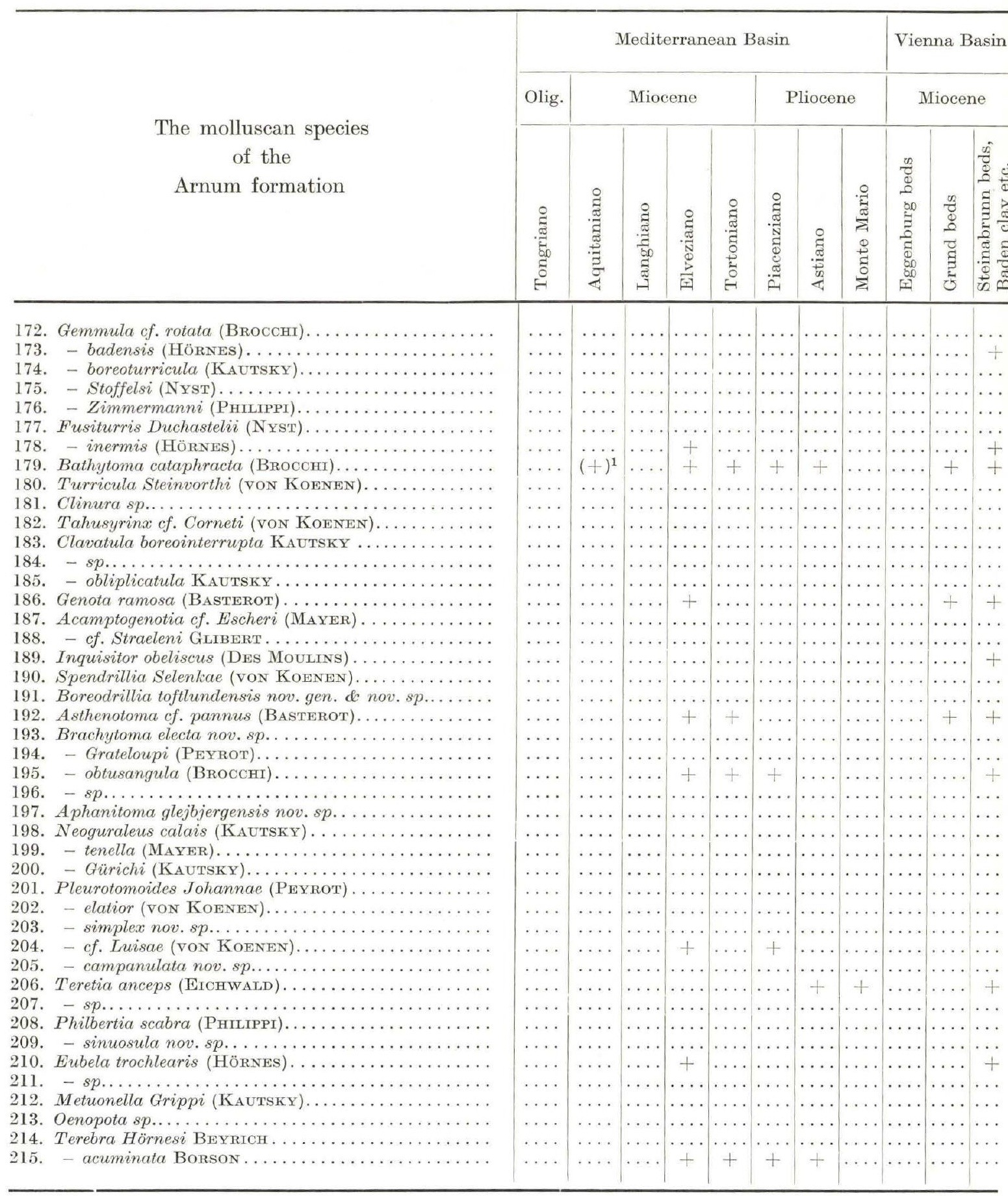

$(+)^{1}$ "Miocene inferiore" 


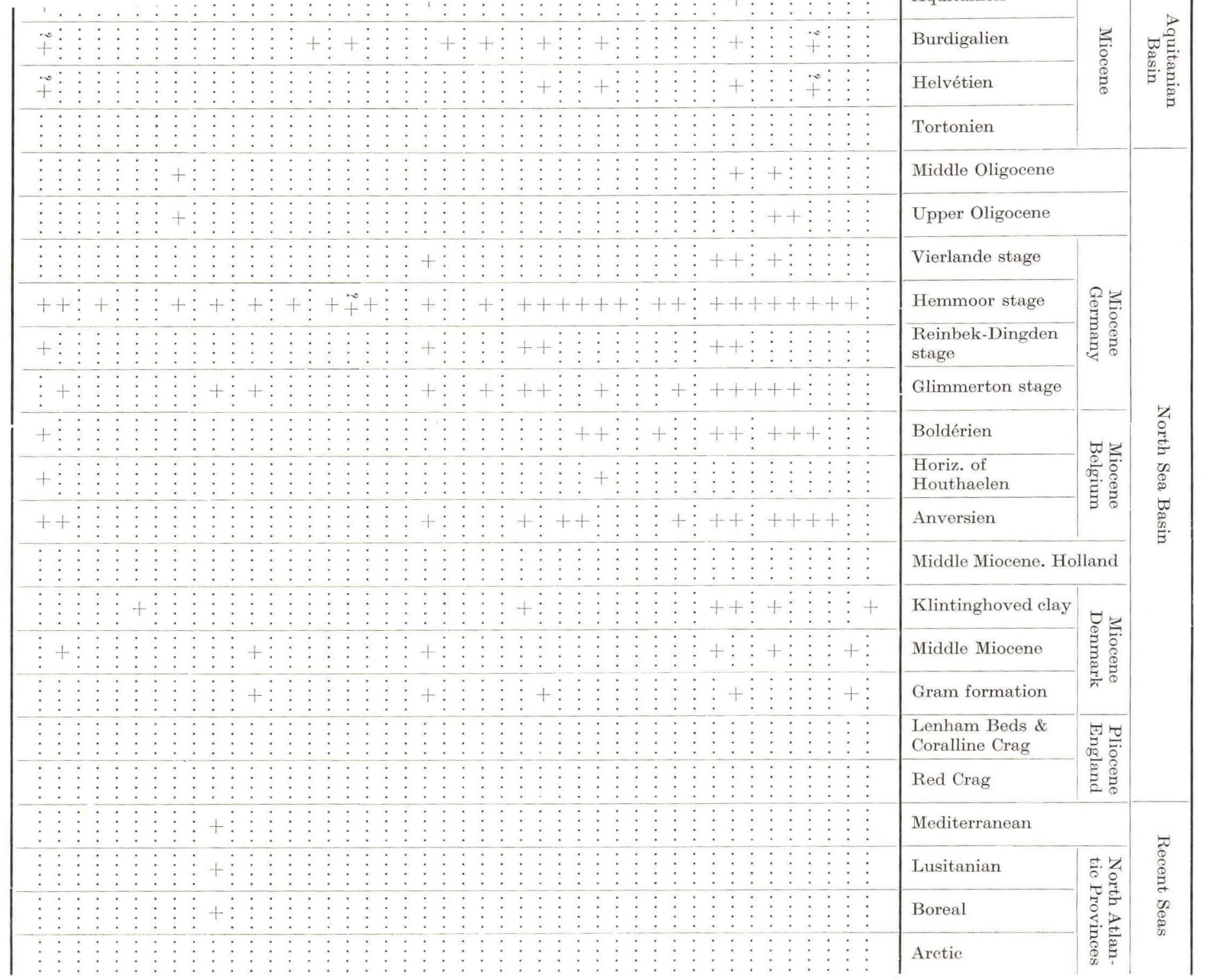


Table 14 (continued).

The molluscan species

of the

Arnum formation
216. Acteon semistriatus (BASTEROT)

217. - laevigatus (GRATELOUP).

218. - cf. pinguis D'ORBIGNY

219. - arnumensis nov. sp. .

220. - tornatilis (LINNE).

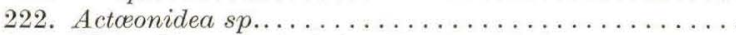

223. Chrysallida ef. cimbrica (KAUTSKY). .

224. - nodifera nov. $s p \ldots \ldots \ldots \ldots \ldots \ldots \ldots \ldots \ldots \ldots$

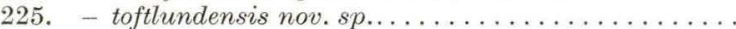

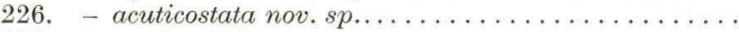

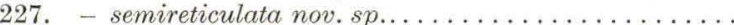

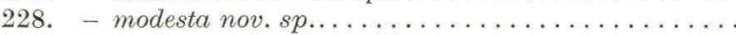

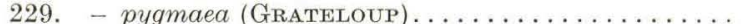

230. Kleinella (Leucotina) Nordmanni nov. sp.........

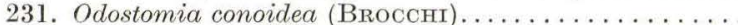

232. - subintermedia (Cossmann \& PeYrot) . . . . . . .

233. - sallespissensis (CossManN \& РеYRot)..........

234. - pallidaeformis (SACCO)

235. - mutinensis (SACCO).......

236. - (Syrnola) subumbilicata (GRATELOUP) . . . . . . . .

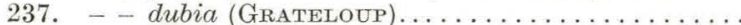

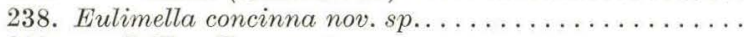

239. - Scillae (ScAcchI)...

240. - acicula (PHILIPPI).

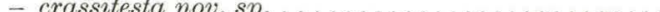

242. Turbonilla costellata (Grateloup) .

243. - lactea (LINNE)

244. - rufa (РнiLtтPI) . . . . . . . . . . . . . . .

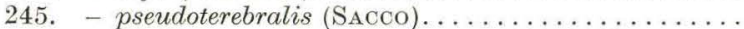

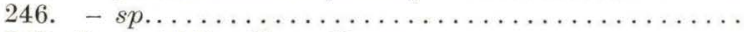

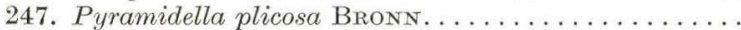

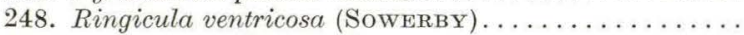

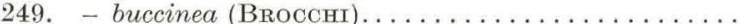

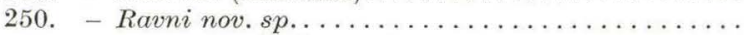

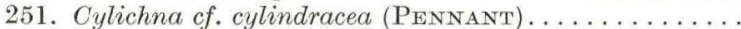

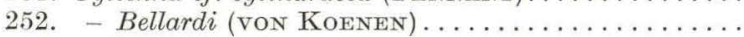

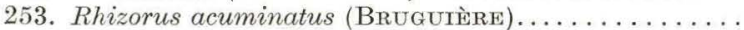

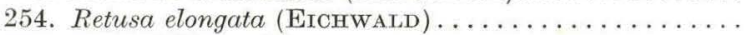

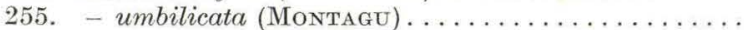

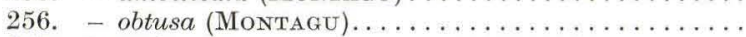

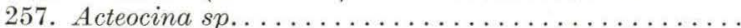

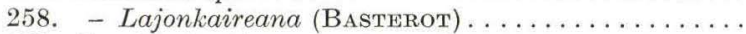

259. Scaphander lignarius (LINNE).

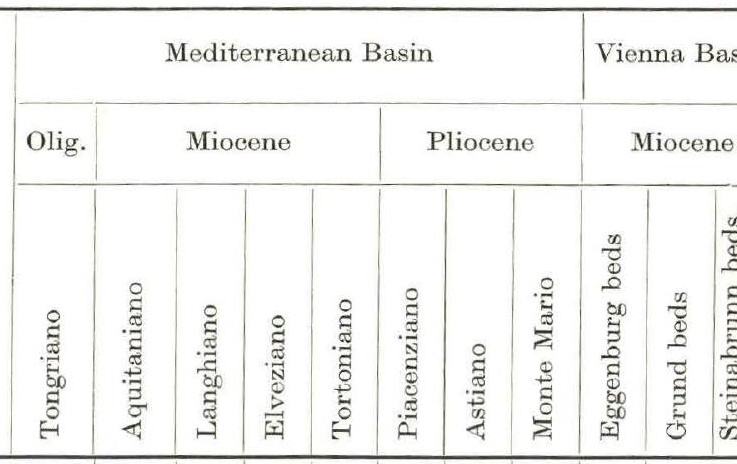


Table 14 (continued).

The molluscan species

of the

Arnum formation

260. Roxania utriculus (BRocCHI)

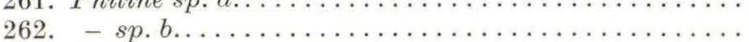

263. Spiratella atlanta (МøвсH).

264. - cf. valvatina (REuss).

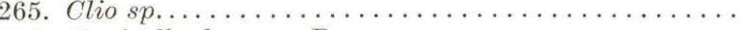

266. Vaginella derressa DAUDIN.

Number of dubious cases of species in common....

Recorded number of species in common $(\alpha) \ldots \ldots$.

1) Calculated number of species in common (in accordance with formula $(1))\left(\alpha_{1}\right) \ldots \ldots \ldots \ldots \ldots$

Total number of species in the individual faunas $(s)$ :

Correlation ratio $P_{\alpha}=\frac{\alpha^{2}}{r s} 100 \% \quad(2) \ldots \ldots \ldots \ldots$

Mediterranean Basin

Vienna Basi

\begin{tabular}{|c|c|c|c|c|c|c|c|c|c|c|}
\hline \multicolumn{8}{|c|}{ Mediterranean Basin } & \multicolumn{3}{|c|}{ Vienna Basi } \\
\hline Olig. & & Mic & ene & & & ioc & & & ioce & \\
\hline 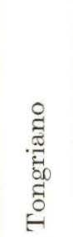 & 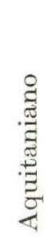 & 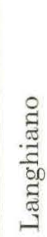 & 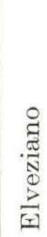 & 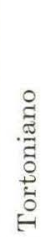 & है⿴囗大) & 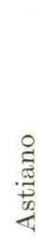 & 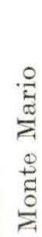 & 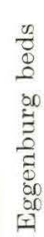 & 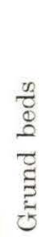 & 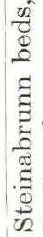 \\
\hline
\end{tabular}

Correlation ratio $P_{\alpha_{1}}=\frac{r s}{n^{2}} 100 \%$

(1) $\ldots \ldots \ldots$

$n=500$ (assumed total number of species in the individual faunas).

$r=266$ (number of species in the Arnum formation).

1) For discussion of the formulas see p.401-408. 


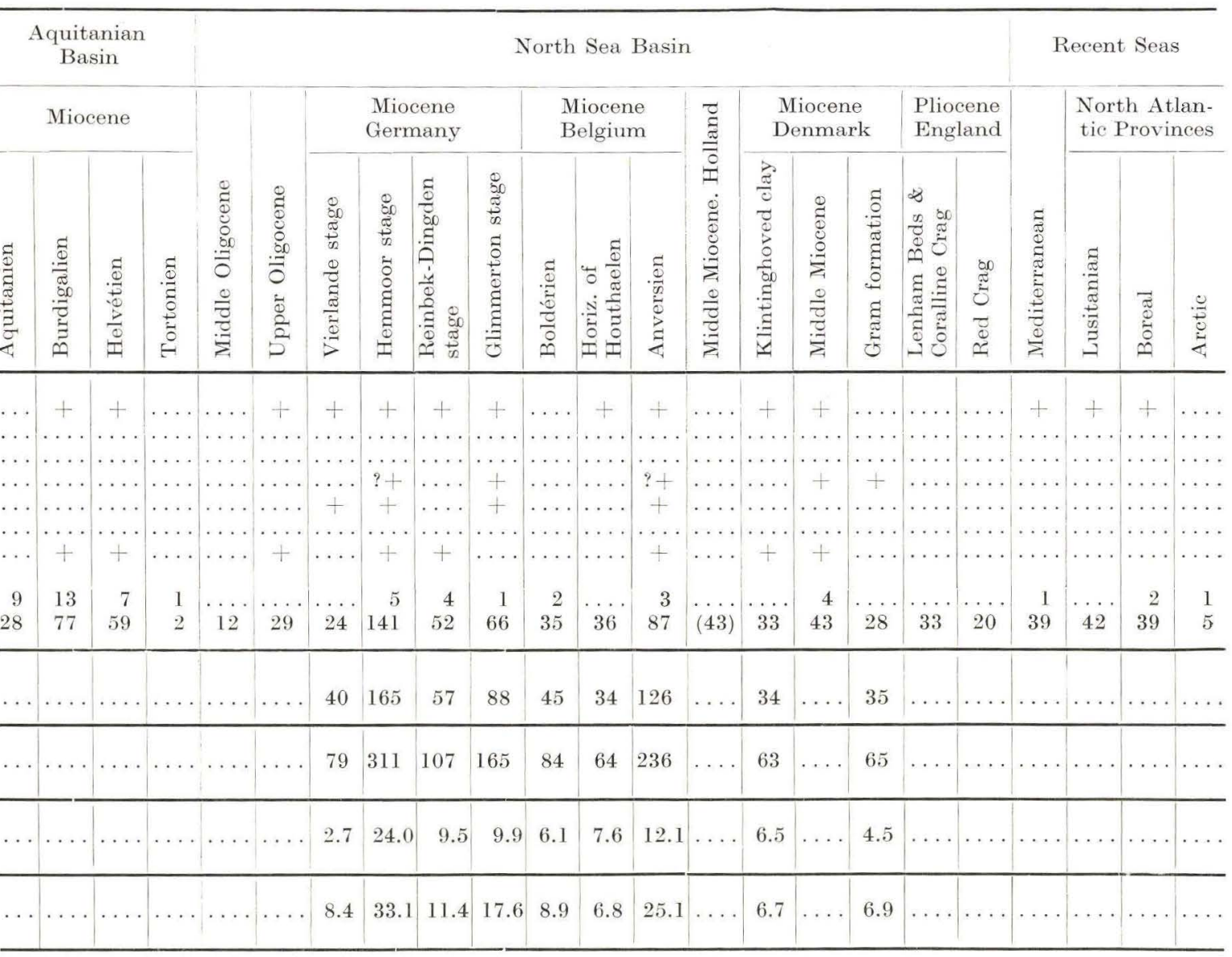


Table 15, (part 1). The Frequencies of th Roman types: per cent

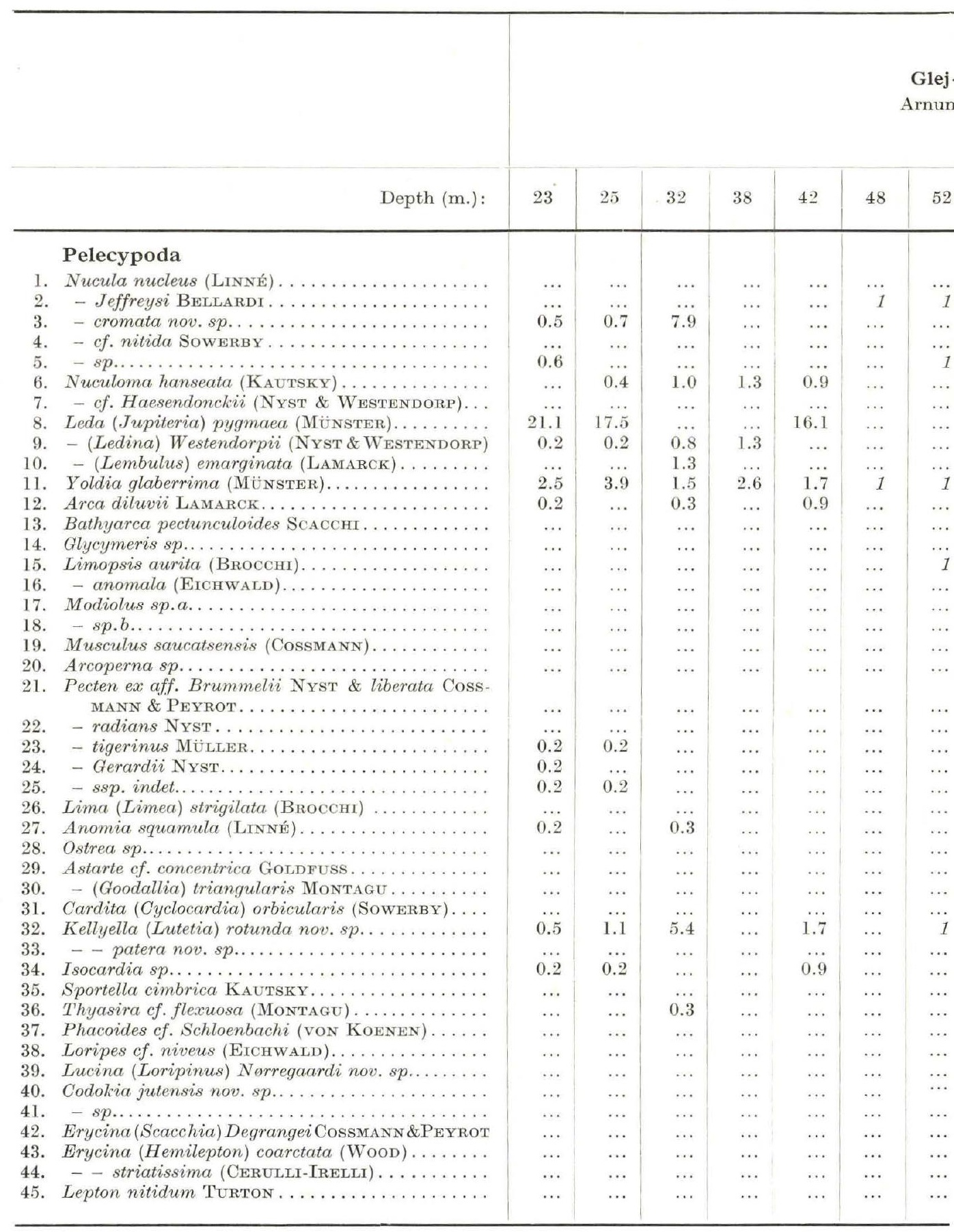




\section{Molluscan Species in the Well Sections}

Italics: number of specimen

bjerg

formation
है है

Ribe

Arnum formation

\begin{tabular}{|c|c|c|c|c|c|c|c|c|c|c|c|c|c|c|c|c|c|}
\hline 53 & 53.5 & 53.75 & 54 & 55 & $70-80$ & $\begin{array}{r}113 \\
114\end{array}$ & $\begin{array}{c}114 \\
115\end{array}$ & $\begin{array}{r}115 \\
116\end{array}$ & $\begin{array}{r}116 \\
117\end{array}$ & $\begin{array}{c}117- \\
118\end{array}$ & $\begin{array}{c}118 \\
119\end{array}$ & $\begin{array}{c}119 \\
120\end{array}$ & $\begin{array}{r}120 \\
121\end{array}$ & $\begin{array}{r}121- \\
122\end{array}$ & $\begin{array}{c}122 \\
123\end{array}$ & $\begin{array}{c}123 \\
124\end{array}$ & $\begin{array}{r}124 \\
125\end{array}$ \\
\hline
\end{tabular}


Table 15, part 1 (continued).

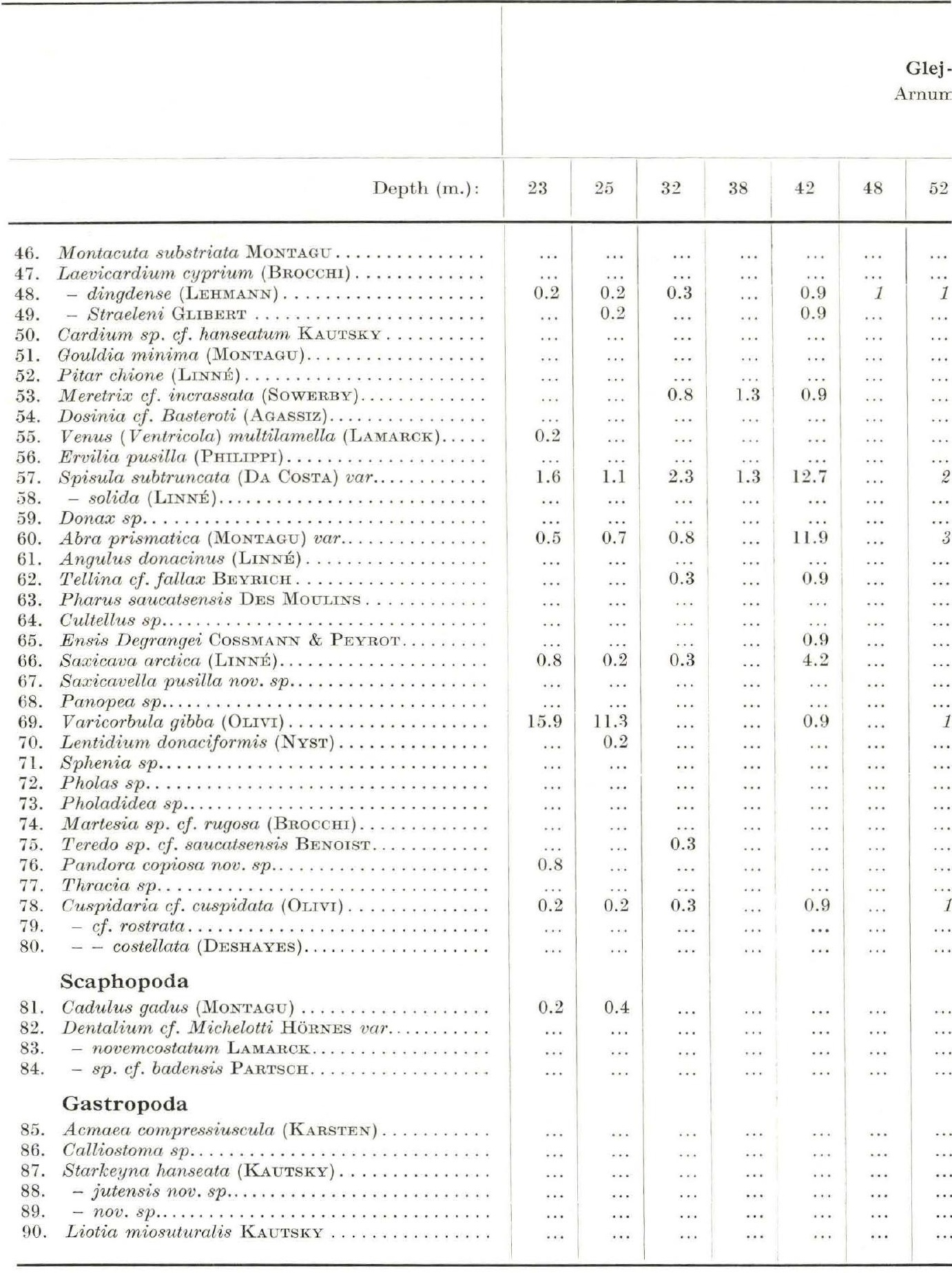




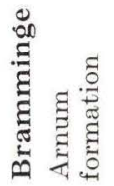

formatior

Ribe

Arnum formation

\begin{tabular}{|c|c|c|c|c|c|c|c|c|c|c|c|c|c|c|c|c|c|c|}
\hline 53 & 53.5 & 53.75 & 54 & 55 & $70-80$ & $\begin{array}{r}113 \\
114\end{array}$ & $\begin{array}{l}114 \\
115\end{array}$ & $-\begin{array}{c}115 \\
116\end{array}$ & $\begin{array}{cc}-116 \\
6 & 11\end{array}$ & $\begin{array}{ll}71 \\
7 & 11\end{array}$ & \begin{tabular}{l|l}
$7-$ & 11 \\
8 & 11
\end{tabular} & \begin{tabular}{l|l}
$18-1$ \\
19
\end{tabular} & $\begin{array}{c}119- \\
120\end{array}$ & $\begin{array}{c}120- \\
121\end{array}$ & $\begin{array}{l}121- \\
122\end{array}$ & $-\begin{array}{c}122- \\
123\end{array}$ & $\begin{array}{c}123- \\
124\end{array}$ & $\begin{array}{r}124- \\
125\end{array}$ \\
\hline
\end{tabular}

\begin{tabular}{|c|c|c|c|c|c|c|c|c|c|c|c|c|c|c|c|c|c|}
\hline$\ldots$ & $\ldots$ & $\ldots$ & $\ldots$ & $\ldots$ & $\ldots$ & $\ldots$ & $\ldots$ & $\ldots$ & $\ldots$ & $\ldots$ & $\ldots$ & $\ldots$ & $\ldots$ & $\ldots$ & $\ldots$ & $\ldots$ & $\ldots$ \\
\hline & & $\ldots$ & $\ldots$ & $\ldots$ & & 1 & $\ldots$ & $\ldots$ & $\ldots$ & $\ldots$ & $\ldots$ & $\ldots$ & $\ldots$ & $\ldots$ & $\ldots$ & $\ldots$ & $\ldots$ \\
\hline 1.4 & 0.1 & $\ldots$ & 1 & $\ldots$ & 0.045 & $\ldots$ & $\ldots$ & $\ldots$ & $\ldots$ & $\ldots$ & $\ldots$ & $\ldots$ & $\ldots$ & $\ldots$ & $\ldots$ & $\ldots$ & $\ldots$ \\
\hline$\ldots$ & 0.1 & $\ldots$ & $\ldots$ & $\ldots$ & $\ldots$ & 1 & $\ldots$ & $\ldots$ & $\ldots$ & $\ldots$ & $\ldots$ & $\ldots$ & $\ldots$ & $\ldots$ & $\ldots$ & $\ldots$ & $\ldots$ \\
\hline$\ldots$ & $\ldots$ & $\ldots$ & $\cdots$ & $\ldots$ & $\ldots$ & $\ldots$ & $\ldots$ & $\ldots$ & $\ldots$ & $\ldots$ & $\ldots$ & $\ldots$ & $\ldots$ & $\ldots$ & $\ldots$ & $\ldots$ & $\ldots$ \\
\hline$\ldots$ & $\ldots$ & $\ldots$ & $\ldots$ & $\ldots$ & 0.027 & $\ldots$ & $\ldots$ & $\ldots$ & $\ldots$ & $\ldots$ & $\ldots$ & $\ldots$ & $\ldots$ & $\ldots$ & $\ldots$ & $\ldots$ & $\ldots$ \\
\hline$\ldots$ & 0.1 & 0.3 & $\ldots$ & 0.3 & $\ldots$ & $\ldots$ & $\ldots$ & $\ldots$ & $\ldots$ & $\ldots$ & $\ldots$ & $\ldots$ & $\ldots$ & $\ldots$ & $\ldots$ & $\ldots$ & $\ldots$ \\
\hline$\ldots$ & 0.1 & 0.3 & 1 & 0.3 & 0.003 & 1 & $\ldots$ & $\ldots$ & $\ldots$ & $\ldots$ & $\cdots$ & $\ldots$ & $\cdots$ & $\ldots$ & $\ldots$ & $\cdots$ & $\ldots$ \\
\hline$\ldots$ & $\ldots$ & $\ldots$ & $\ldots$ & $\ldots$ & $\ldots$ & $\cdots$ & $\cdots$ & $\cdots$ & $\cdots$ & $\cdots$ & $\cdots$ & $\cdots$ & $\cdots$ & $\cdots$ & $\cdots$ & $\cdots$ & $\cdots$ \\
\hline$\cdots$ & 0.1 & $\ldots$ & $\ldots$ & 0.3 & 0.003 & 3 & $\cdots$ & $\cdots$ & $\cdots$ & $\cdots$ & $\cdots$ & $\ldots$ & $\ldots$ & $\ldots$ & $\ldots$ & $\cdots$ & $\ldots$ \\
\hline 4. & 38 & - & $\cdots$ & & 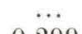 & $\cdots$ & $\cdots$ & $\cdots$ & $\cdots$ & $\cdots$ & $\cdots$ & $\cdots$ & $\cdots$ & $\cdots$ & $\cdots$ & $\cdots$ & $\cdots$ \\
\hline 4.3 & 3.8 & 2.7 & 1 & 3.2 & 0.299 & $\cdots$ & $I$ & 1 & $\cdots$ & $\cdots$ & $\cdots$ & $\cdots$ & $\cdots$ & $\cdots$ & $\cdots$ & $\cdots$ & $\cdots$ \\
\hline$\cdots$ & $\cdots$ & $\ldots$ & $\cdots$ & $\ldots$ & $\cdots$ & $\cdots$ & $\cdots$ & $\ldots$ & $\ldots$ & $\cdots$ & $\cdots$ & $\cdots$ & $\cdots$ & $\cdots$ & $\cdots$ & $\cdots$ & $\cdots$ \\
\hline 3.6 & 2.9 & 1.8 & $\cdots$ & 1.. & 0.051 & $\begin{array}{l}\ldots \\
\ldots\end{array}$ & $\begin{array}{l}\cdots \\
\ldots\end{array}$ & $\cdots$ & $\begin{array}{l}\cdots \\
\ldots\end{array}$ & $\begin{array}{l}\cdots \\
\ldots\end{array}$ & $\begin{array}{l}\cdots \\
\ldots\end{array}$ & $\begin{array}{l}\cdots \\
\ldots\end{array}$ & $\begin{array}{l}\cdots \\
\ldots\end{array}$ & $\begin{array}{l}\cdots \\
\cdots\end{array}$ & $\begin{array}{l}\cdots \\
\ldots\end{array}$ & $\begin{array}{l}\cdots \\
\ldots\end{array}$ & $\cdots$ \\
\hline$\ldots$ & $\cdots$ & $\ldots$ & $\ldots$ & 0.3 & . & $\ldots$ & $\ldots$ & $\ldots$ & $\ldots$ & $\ldots$ & $\ldots$ & $\ldots$ & $\ldots$ & $\ldots$ & 1 & $\ldots$ & $\ldots$ \\
\hline 0.7 & 0.1 & 0.3 & $\ldots$ & $\ldots$ & 0.042 & $\ldots$ & $\ldots$ & $\ldots$ & $\ldots$ & $\ldots$ & $\ldots$ & $\ldots$ & $\ldots$ & $\ldots$ & $\ldots$ & $\ldots$ & $\ldots$ \\
\hline$\ldots$ & $\ldots$ & $\ldots$ & $\ldots$ & $\ldots$ & $\ldots$ & $\ldots$ & $\ldots$ & $\ldots$ & $\ldots$ & $\ldots$ & $\ldots$ & $\ldots$ & $\ldots$ & $\ldots$ & $\ldots$ & $\ldots$ & $\ldots$ \\
\hline$\ldots$ & $\ldots$ & $\ldots$ & $\cdots$ & $\ldots$ & $\cdots$ & $\ldots$ & $\ldots$ & $\ldots$ & $\ldots$ & $\cdots$ & $\cdots$ & $\ldots$ & $\ldots$ & $\ldots$ & $\ldots$ & $\cdots$ & $\ldots$ \\
\hline$\ldots$ & $\ldots$ & $\ldots$ & $\ldots$ & $\ldots$ & $\cdots$ & $\ldots$ & $\ldots$ & $\ldots$ & $\ldots$ & $\ldots$ & $\ldots$ & $\ldots$ & $\ldots$ & $\ldots$ & $\ldots$ & $\ldots$ & $\ldots$ \\
\hline$\ldots$ & 0.1 & 0.3 & $\ldots$ & $\ldots$ & 0.039 & 1 & $\ldots$ & $\ldots$ & $\ldots$ & $\ldots$ & $\ldots$ & $\ldots$ & $\ldots$ & $\ldots$ & $\ldots$ & $\ldots$ & $\ldots$ \\
\hline$\ldots$ & $\ldots$ & $\ldots$ & $\ldots$ & $\ldots$ & $\ldots$ & $\ldots$ & $\ldots$ & $\ldots$ & $\ldots$ & $\ldots$ & $\ldots$ & $\ldots$ & $\ldots$ & $\ldots$ & $\ldots$ & 1 & $\ldots$ \\
\hline$\therefore 0$ & $\cdots$ & 10 & $\cdots$ & $\because$ & $\ldots$ & $\cdots$ & $\cdots$ & $\cdots$ & $\ldots$ & $\cdots$ & $\cdots$ & $\cdots$ & $\cdots$ & $\cdots$ & $\cdots$ & $\cdots$ & . \\
\hline 2.2 & 1.9 & 1.8 & $\ldots$ & 2.5 & 7.88 & 4 & $\ldots$ & 1 & $\ldots$ & $\ldots$ & $\ldots$ & $\ldots$ & $\ldots$ & $\ldots$ & & 1 & 2 \\
\hline$\cdots$ & $\cdots$ & $\ldots$ & $\cdots$ & $\cdots$ & $\cdots$ & $\cdots$ & $\ldots$ & $\cdots$ & $\cdots$ & $\cdots$ & $\cdots$ & $\cdots$ & $\cdots$ & $\cdots$ & $\cdots$ & $\cdots$ & $\cdots$ \\
\hline$\ldots$ & $\ldots$ & $\ldots$ & $\ldots$ & $\ldots$ & $\ldots$ & $\ldots$ & $\ldots$ & $\ldots$ & $\ldots$ & $\ldots$ & $\ldots$ & $\ldots$ & $\ldots$ & $\ldots$ & $\ldots$ & $\ldots$ & $\cdots$ \\
\hline$\ldots$ & $\ldots$ & $\ldots$ & $\ldots$ & $\ldots$ & $\ldots$ & $\ldots$ & $\ldots$ & $\ldots$ & $\ldots$ & $\ldots$ & $\cdots$ & $\ldots$ & $\ldots$ & $\ldots$ & $\ldots$ & $\cdots$ & $\cdots$ \\
\hline$\cdots$ & $\cdots$ & $\ldots$ & $\cdots$ & $\cdots$ & $\ldots$ & $\cdots$ & $\ldots$ & $\cdots$ & $\cdots$ & $\cdots$ & $\cdots$ & $\ldots$ & $\cdots$ & $\cdots$ & $\cdots$ & $\cdots$ & $\cdots$ \\
\hline$\ldots$ & $\ldots$ & $\ldots$ & $\ldots$ & $\ldots$ & $\ldots$ & $\ldots$ & $\ldots$ & $\ldots$ & $\ldots$ & $\ldots$ & $\cdots$ & $\ldots$ & $\ldots$ & $\ldots$ & $\cdots$ & $\cdots$ & $\cdots$ \\
\hline$\ldots$ & 0.1 & $\ldots$ & $\ldots$ & $\ldots$ & $\ldots$ & $\ldots$ & $\ldots$ & $\ldots$ & $\ldots$ & $\ldots$ & $\ldots$ & $\ldots$ & $\cdots$ & $\ldots$ & $\cdots$ & $\cdots$ & $\cdots$ \\
\hline$\ldots$ & $\ldots$ & $\ldots$ & $\ldots$ & $\ldots$ & $\cdots$ & $\cdots$ & $\ldots$ & $\cdots$ & $\cdots$ & $\ldots$ & $\cdots$ & $\ldots$ & $\ldots$ & $\ldots$ & $\ldots$ & $\ldots$ & $\ldots$ \\
\hline$\ldots$ & 0.1 & $\ldots$ & $\ldots$ & $\ldots$ & 0.006 & 1 & $\ldots$ & $\ldots$ & $\ldots$ & $\ldots$ & $\ldots$ & $\ldots$ & $\ldots$ & $\ldots$ & $\ldots$ & $\ldots$ & $\ldots$ \\
\hline$\ldots$ & 0.1 & 0.3 & $\ldots$ & 0.1 & 0.015 & $\ldots$ & $\ldots$ & $\ldots$ & $\ldots$ & $\ldots$ & $\ldots$ & $\ldots$ & $\ldots$ & $\ldots$ & $\ldots$ & $\ldots$ & $\ldots$ \\
\hline$\ldots$ & $\ldots$ & $\ldots$ & $\ldots$ & $\ldots$ & $\ldots$ & $\cdots$ & $\ldots$ & $\ldots$ & $\ldots$ & $\ldots$ & $\ldots$ & $\ldots$ & $\ldots$ & $\ldots$ & $\ldots$ & $\ldots$ & $\ldots$ \\
\hline$\cdots$ & $\cdots$ & $\ldots$ & $\cdots$ & $\cdots$ & $\cdots$ & $\cdots$ & $\cdots$ & $\ldots$ & $\cdots$ & $\cdots$ & $\cdots$ & $\ldots$ & $\cdots$ & $\cdots$ & $\ldots$ & $\cdots$ & $\ldots$ \\
\hline$\ldots$ & $\cdots$ & $\cdots$ & $\ldots$ & $\ldots$ & 0.198 & $\ldots$ & $\ldots$ & $\ldots$ & $\ldots$ & $\ldots$ & $\ldots$ & $\ldots$ & $\ldots$ & $\ldots$ & $\ldots$ & $\ldots$ & 1 \\
\hline$\ldots$ & $\because$ & $\ldots$ & $\ldots$ & 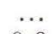 & 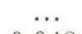 & $\ldots$ & $\ldots$ & $\ldots$ & $\ldots$ & $\ldots$ & $\ldots$ & $\ldots$ & $\ldots$ & $\ldots$ & $\ldots$ & $\cdots$ & $\ldots$ \\
\hline$\ldots$ & 1.0 & 1.2 & 2 & 0.6 & 0.048 & 1 & 1 & $\ldots$ & $\ldots$ & $\ldots$ & $\ldots$ & $\ldots$ & $\ldots$ & $\ldots$ & $\ldots$ & $\ldots$ & $\ldots$ \\
\hline$\ldots$ & $\ldots$ & 0.3 & $\ldots$ & $\ldots$ & 0.003 & 1 & $\ldots$ & $\ldots$ & $\ldots$ & $\ldots$ & $\ldots$ & $\ldots$ & $\ldots$ & $\ldots$ & $\ldots$ & $\cdots$ & $\cdots$ \\
\hline$\ldots$ & 0.1 & $\ldots$ & $\ldots$ & 0.3 & $\cdots$ & 1 & $\ldots$ & $\ldots$ & $\ldots$ & $\ldots$ & $\ldots$ & $\ldots$ & $\ldots$ & $\ldots$ & $\ldots$ & $\ldots$ & $\ldots$ \\
\hline$\ldots$ & $\ldots$ & $\ldots$ & $\ldots$ & $\ldots$ & $\ldots$ & 1 & $\ldots$ & $\ldots$ & $\ldots$ & $\ldots$ & $\ldots$ & $\ldots$ & $\ldots$ & $\ldots$ & $\ldots$ & $\ldots$ & $\cdots$ \\
\hline$\ldots$ & $\ldots$ & $\ldots$ & $\ldots$ & $\ldots$ & $\ldots$ & $\ldots$ & $\ldots$ & $\cdots$ & $\ldots$ & $\ldots$ & $\ldots$ & $\ldots$ & $\ldots$ & $\ldots$ & $\ldots$ & $\ldots$ & $\cdots$ \\
\hline$\ldots$ & $\cdots$ & $\ldots$ & $\ldots$ & $\ldots$ & $\cdots$ & $\cdots$ & $\cdots$ & $\cdots$ & $\ldots$ & $\cdots$ & $\cdots$ & $\ldots$ & $\cdots$ & $\cdots$ & $\ldots$ & $\cdots$ & $\cdots$ \\
\hline$\cdots$ & $\cdots$ & $\ldots$ & $\cdots$ & $\cdots$ & $\ldots$ & $\ldots$ & $\ldots$ & $\ldots$ & $\ldots$ & $\cdots$ & $\cdots$ & $\ldots$ & $\ldots$ & $\ldots$ & $\ldots$ & $\ldots$ & $\cdots$ \\
\hline$\ldots$ & $\ldots$ & 0.3 & $\ldots$ & 0.3 & $\ldots$ & $\ldots$ & $\ldots$ & $\cdots$ & $\ldots$ & $\cdots$ & $\ldots$ & $\ldots$ & $\cdots$ & $\ldots$ & $\cdots$ & $\ldots$ & $\ldots$ \\
\hline
\end{tabular}


Table 15, part 1 (continued).

\begin{tabular}{|c|c|c|c|c|c|c|c|}
\hline Depth (m.): & 23 & 25 & 32 & 38 & 42 & 48 & 52 \\
\hline 91. Alvania Partschi (Hörnes).............. & & & $\cdots$ & $\cdots$ & $\cdots$ & $\cdots$ & \\
\hline 92. Rissoa Ravni nov. sp.................. & 0.3 & 0.9 & $\ldots$ & $\ldots$ & $\ldots$ & $\ldots$ & $\ldots$ \\
\hline 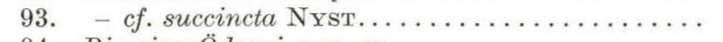 & $\ldots$ & $\ldots$ & $\ldots$ & $\cdots$ & $\ldots$ & $\ldots$ & $\cdots$ \\
\hline 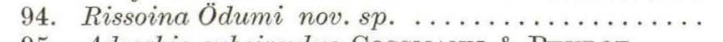 & $\ldots$ & $\cdots$ & $\cdots$ & $\ldots$ & $\cdots$ & $\ldots$ & $\cdots$ \\
\hline 95. Adeorbis subcirculus Cossmann \& Реyrot..... & $\cdots$ & $\cdots$ & $\cdots$ & $\cdots$ & $\cdots$ & $\ldots$ & $\cdots$ \\
\hline 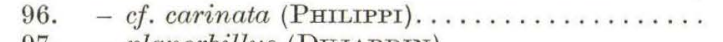 & $\cdots$ & $\cdots$ & $\cdots$ & $\cdots$ & $\cdots$ & $\cdots$ & $\cdots$ \\
\hline 97. - planorbillus (DUJARDIN) . . . . . . . . . . . & $\ldots$ & & $\cdots$ & $\cdots$ & $\cdots$ & $\cdots$ & $\cdots$ \\
\hline 98. Turritella tricarinata (Ввоссні) . . . . . . . . . & 0.2 & 0.2 & $\cdots$ & $\cdots$ & $\cdots$ & $\cdots$ & $\cdots$ \\
\hline 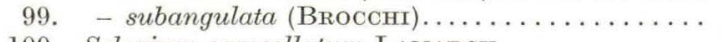 & $\cdots$ & $\cdots$ & $\cdots$ & $\cdots$ & $\cdots$ & $\cdots$ & $\cdots$ \\
\hline 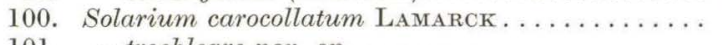 & $\cdots$ & $\cdots$ & $\cdots$ & $\cdots$ & $\cdots$ & $\cdots$ & $\cdots$ \\
\hline 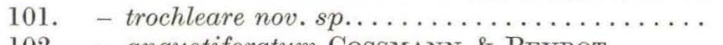 & $\cdots$ & $\cdots$ & $\cdots$ & $\cdots$ & $\cdots$ & $\cdots$ & $\cdots$ \\
\hline 102. - angustiforatum CossManN \& PeYRot....... & $\cdots$ & $\cdots$ & $\cdots$ & $\cdots$ & $\cdots$ & $\cdots$ & $\cdots$ \\
\hline 103. Bittium spina (РАRTsCH) $\ldots \ldots \ldots \ldots \ldots \ldots \ldots$ & $\cdots$ & $\ldots$ & $\cdots$ & $\cdots$ & $\cdots$ & $\cdots$ & $\cdots$ \\
\hline 104. - tenuispina nov. $s p \ldots \ldots \ldots \ldots \ldots \ldots \ldots \ldots$ & 1.1 & 0.4 & $\cdots$ & $\cdots$ & $\cdots$ & $\cdots$ & $\cdots$ \\
\hline 105. Cerithiopsis Vignali Cossmann \& PeYrot. . . . . & $\cdots$ & $\cdots$ & $\cdots$ & $\cdots$ & $\cdots$ & $\cdots$ & $\cdots$ \\
\hline 106. Triphora perversa (LINNÉ) $\ldots \ldots \ldots \ldots \ldots \ldots$ & $\cdots$ & $\cdots$ & $\cdots$ & $\cdots$ & $\cdots$ & $\cdots$ & $\cdots$ \\
\hline 107. Cirsotrema Thais DE BouRY . . . . . . . . . . & $\cdots$ & $\cdots$ & $\cdots$ & $\cdots$ & $\cdots$ & $\cdots$ & $\cdots$ \\
\hline 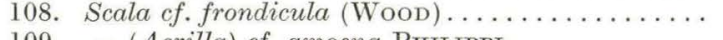 & $\cdots$ & $\cdots$ & $\cdots$ & $\cdots$ & $\cdots$ & $\cdots$ & $\cdots$ \\
\hline 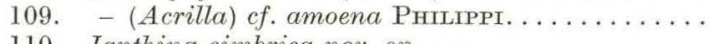 & $\cdots$ & $\cdots$ & 0.3 & $\cdots$ & $\cdots$ & $\cdots$ & $\cdots$ \\
\hline 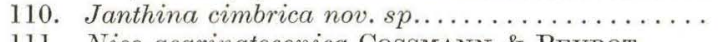 & $\cdots$ & $\cdots$ & $\cdots$ & $\cdots$ & $\cdots$ & $\cdots$ & $\cdots$ \\
\hline 111. Niso acarinatoconica Cossmann \& Рeyrot..... & $\cdots$ & $\cdots$ & $\cdots$ & $\cdots$ & $\cdots$ & $\cdots$ & $\cdots$ \\
\hline 112. Melanella similis (D'ORBIGNY) . . . . . . . . . & $\cdots$ & $\cdots$ & $\cdots$ & $\cdots$ & $\cdots$ & $\cdots$ & $\cdots$ \\
\hline 113. - taurostricta (COSSMANN \& PEYROT)........ & $\cdots$ & $\cdots$ & $\cdots$ & $\cdots$ & $\cdots$ & $\cdots$ & . \\
\hline 114. Calyptraea chinensis (LINNÉ) $\ldots \ldots \ldots \ldots \ldots \ldots$ & $\cdots$ & $\cdots$ & $\cdots$ & $\cdots$ & $\ddot{0}$ & $\cdots$ & . \\
\hline 115. Xenophora Deshayesi (Мтснецотті) . . . . . . . . . & $\because$ & $\cdots$ & $\cdots$ & $\because$ & 0.9 & $\cdots$ & 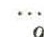 \\
\hline 116. A porrhais alata (ErcHWALD) . . . . . . . . . . & 2.3 & 1.1 & 31.5 & 1.3 & $\cdots$ & $\cdots$ & \\
\hline 117. Natica (Lunatia) catena (DA CostA) . . . . . . . & $\cdots$ & $\cdots$ & 3.1 & $\cdots$ & $\cdots$ & $\cdots$ & $\cdots$ \\
\hline 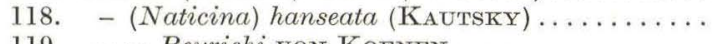 & $\cdots$ & $\cdots$ & 0.5 & $\cdots$ & $\cdots$ & $\cdots$ & $\cdots$ \\
\hline 119. - - Beyrichi von Koenen . . . . . . . . . & $\cdots$ & $\cdots$ & $\cdots$ & $\cdots$ & $\cdots$ & $\cdots$ & . \\
\hline 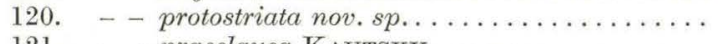 & 0.2 & $\cdots$ & $\cdots$ & $\cdots$ & $\cdots$ & $\cdots$ & $\cdots$ \\
\hline 121. - praeclausa KaUTSKY . . . . . . . . . & $\cdots$ & $\cdots$ & $\cdots$ & $\cdots$ & $\cdots$ & $\cdots$ & $\cdots$ \\
\hline 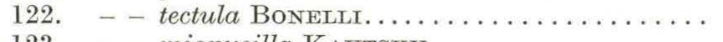 & $\ldots$ & $\cdots$ & $\cdots$ & $\cdots$ & $\cdots$ & $\cdots$ & 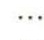 \\
\hline 123. $\quad-\quad$ miopusilla KaUTSKY $\ldots \ldots \ldots \ldots \ldots \ldots$ & 0.6 & 0.4 & 0.8 & $\cdots$ & $\cdots$ & $\cdots$ & 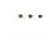 \\
\hline 124. - - submamillaris D'ORBIGNY . . . . . & $\cdots$ & $\cdots$ & $\cdots$ & $\cdots$ & $\cdots$ & $\cdots$ & $\ldots$ \\
\hline - (Polynices) affinis (GMELIN)........... & $\cdots$ & $\cdots$ & $\cdots$ & $\cdots$ & $\cdots$ & $\cdots$ & \\
\hline 126. $\quad-($ Nerita) Josephinia (RIsso) . . . . . . . . . & $\cdots$ & & $\ldots$ & $\dddot{0}$ & $\cdots$ & 1 & \\
\hline 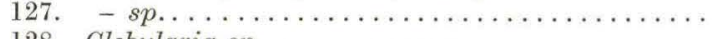 & 1.7 & 0.7 & 0.3 & 9.1 & $\cdots$ & $\cdots$ & \\
\hline 128. Globularia $\operatorname{sp} \ldots \ldots \ldots \ldots \ldots \ldots \ldots \ldots \ldots \ldots$ & $\cdots$ & $\cdots$ & $\cdots$ & $\cdots$ & $\cdots$ & $\cdots$ & \\
\hline 129. Sigaretus sulcatus (GRATELoUP) . . . . . . . . & $\cdots$ & $\cdots$ & $\cdots$ & $\cdots$ & $\cdots$ & $\cdots$ & \\
\hline 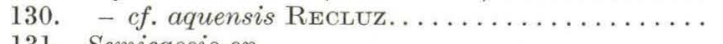 & $\cdots$ & $\cdots$ & 0.3 & $\cdots$ & $\cdots$ & $\cdots$ & \\
\hline 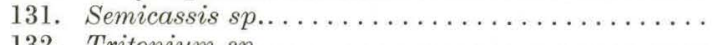 & $\cdots$ & $\cdots$ & $\cdots$ & $\cdots$ & $\cdots$ & $\cdots$ & 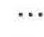 \\
\hline 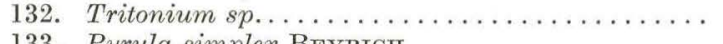 & $\cdots$ & $\cdots$ & $\cdots$ & $\cdots$ & $\cdots$ & $\cdots$ & $\cdots$ \\
\hline 133. Pyrula simplex BEYRICH. .............. & $\cdots$ & & & $\cdots$ & $\ddot{0}$ & $\cdots$ & \\
\hline 134. - condita BRongnIART............ & $\cdots$ & 0.2 & 0.3 & $\cdots$ & 0.9 & $\cdots$ & \\
\hline 135. Murex ef. aturensis Cossmann \& РеYROT...... & $\cdots$ & $\cdots$ & $\cdots$ & $\cdots$ & $\cdots$ & $\cdots$ & \\
\hline 136. - inornatus BEYRICH $\ldots \ldots \ldots \ldots \ldots \ldots \ldots$ & $\cdots$ & $\cdots$ & $\cdots$ & $\cdots$ & $\cdots$ & $\cdots$ & \\
\hline 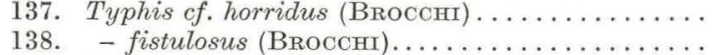 & $\begin{array}{l}\cdots \\
\cdots\end{array}$ & $\ldots .2$ & $\cdots$ & $\cdots$ & $\cdots$ & $\cdots$ & \\
\hline 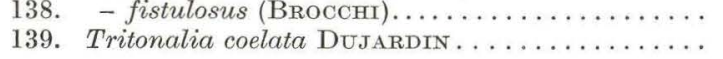 & $\ldots$ & \begin{tabular}{c|c}
0.2 \\
$\ldots$
\end{tabular} & $\cdots$ & $\cdots$ & $\cdots$ & $\cdots$ & \\
\hline 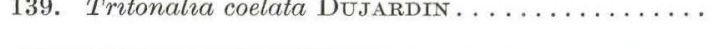 & & $\cdots$ & $\cdots$ & $\cdots$ & $\cdots$ & $\cdots$ & \\
\hline
\end{tabular}




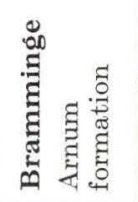

Ribe

Arnum formation

\begin{tabular}{|c|c|c|c|c|c|c|c|c|c|c|c|c|c|c|c|c|c|}
\hline 53 & 53.5 & 53.75 & 54 & 55 & $70-80$ & $\begin{array}{c}113 \\
114\end{array}$ & $\begin{array}{c}114 \\
115\end{array}$ & $\begin{array}{l}115 \\
116\end{array}$ & $\begin{array}{l}116 \\
117\end{array}$ & $\begin{array}{c}117 \\
118\end{array}$ & $\begin{array}{c}118 \\
119\end{array}$ & $\begin{array}{l}119 \\
120\end{array}$ & $\begin{array}{c}120- \\
121\end{array}$ & $\begin{array}{c}121- \\
122\end{array}$ & $\begin{array}{c}122- \\
123\end{array}$ & $\begin{array}{c}123- \\
124\end{array}$ & $\begin{array}{l}124 \\
125\end{array}$ \\
\hline$\cdots$ & $\cdots$ & $\cdots$ & $\cdots$ & $\cdots$ & 0.036 & $\cdots$ & $\ldots$ & $\ldots$ & $\cdots$ & $\cdots$ & $\cdots$ & $\cdots$ & $\cdots$ & $\cdots$ & $\cdots$ & $\ldots$ & $\cdots$ \\
\hline .. & $\ldots$ & $\ldots$ & $\ldots$ & $\ldots$ & 0.003 & $\cdots$ & $\cdots$ & $\ldots$ & $\ldots$ & $\ldots$ & $\ldots$ & $\ldots$ & $\ldots$ & $\ldots$ & $\ldots$ & $\ldots$ & $\ldots$ \\
\hline$\ldots$ & $\ldots$ & $\ldots$ & $\ldots$ & $\ldots$ & $\ldots$ & $\ldots$ & $\ldots$ & $\ldots$ & $\ldots$ & $\ldots$ & $\ldots$ & $\ldots$ & $\ldots$ & $\ldots$ & $\ldots$ & $\ldots$ & $\ldots$ \\
\hline$\ldots$ & $\ldots$ & $\ldots$ & $\ldots$ & $\ldots$ & & $\ldots$ & $\ldots$ & $\ldots$ & $\ldots$ & $\ldots$ & $\ldots$ & $\ldots$ & $\ldots$ & $\cdots$ & $\ldots$ & $\ldots$ & $\ldots$ \\
\hline$\ldots$ & $\ldots$ & $\ldots$ & $\ldots$ & $\ldots$ & 0.003 & $\ldots$ & $\ldots$ & $\ldots$ & $\ldots$ & $\ldots$ & $\cdots$ & $\ldots$ & $\ldots$ & $\ldots$ & $\ldots$ & $\ldots$ & $\ldots$ \\
\hline$\ldots$ & $\ldots$ & $\ldots$ & $\ldots$ & $\ldots$ & $\ldots$ & $\ldots$ & $\ldots$ & $\ldots$ & $\ldots$ & $\ldots$ & $\ldots$ & $\ldots$ & $\ldots$ & $\ldots$ & $\ldots$ & $\ldots$ & $\ldots$ \\
\hline$\ldots$ & $\ldots$ & $\ldots$ & $\ldots$ & & & $\ldots$ & $\ldots$ & $\ldots$ & $\ldots$ & $\ldots$ & $\ldots$ & $\ldots$ & $\ldots$ & $\cdots$ & $\ldots$ & $\ldots$ & $\cdots$ \\
\hline$\ldots$ & $\ldots$ & $\ldots$ & $\ldots$ & 0.3 & 0.41 & 1 & $\ldots$ & $\ldots$ & $\ldots$ & $\ldots$ & $\ldots$ & $\ldots$ & $\ldots$ & $\cdots$ & $\ldots$ & $\ldots$ & $\cdots$ \\
\hline$\ldots$ & $0 . \mathrm{I}$ & $\ldots$ & $\ldots$ & $\ldots$ & 0 & $\ldots$ & $\ldots$ & $\ldots$ & $\ldots$ & $\ldots$ & $\ldots$ & $\ldots$ & $\ldots$ & $\ldots$ & $\ldots$ & $\ldots$ & $\cdots$ \\
\hline$\ldots$ & 0.1 & $\ldots$ & $\cdots$ & 0.3 & 0.045 & $\cdots$ & $\cdots$ & $\ldots$ & $\ldots$ & $\ldots$ & $\cdots$ & $\cdots$ & $\ldots$ & $\cdots$ & $\cdots$ & $\cdots$ & $\cdots$ \\
\hline$\cdots$ & & $\ldots$ & $\ldots$ & $\cdots$ & $\cdots$ & $\cdots$ & $\cdots$ & $\cdots$ & $\cdots$ & $\cdots$ & $\cdots$ & $\cdots$ & $\cdots$ & $\cdots$ & $\cdots$ & $\cdots$ & $\cdots$ \\
\hline$\cdots$ & & $\ldots$ & $\cdots$ & $\cdots$ & & $\ldots$ & $\ldots$ & $\cdots$ & $\ldots$ & $\cdots$ & $\cdots$ & $\cdots$ & $\cdots$ & $\cdots$ & $\cdots$ & $\ldots$ & $\ldots$ \\
\hline .. & 0.2 & 0.3 & $\ldots$ & $\ldots$ & 0.012 & $\ldots$ & $\cdots$ & $\cdots$ & $\cdots$ & $\cdots$ & $\cdots$ & $\cdots$ & $\cdots$ & $\cdots$ & $\cdots$ & $\cdots$ & $\ldots$ \\
\hline$\cdots$ & $\ldots$ & $\ldots$ & $\ldots$ & 0.3 & 0.518 & 1 & 1 & $\cdots$ & $\ldots$ & $\cdots$ & $\cdots$ & $\cdots$ & $\cdots$ & $\ldots$ & $\cdots$ & 1 & $\cdots$ \\
\hline$\cdots$ & $\cdots$ & $\cdots$ & $\cdots$ & $\cdots$ & $\cdots$ & $\cdots$ & $\cdots$ & $\cdots$ & $\cdots$ & $\cdots$ & $\cdots$ & $\cdots$ & $\cdots$ & $\cdots$ & $\cdots$ & $\cdots$ & $\cdots$ \\
\hline$\cdots$ & $\ldots$ & $\cdots$ & $\cdots$ & $\cdots$ & & $\cdots$ & $\cdots$ & $\cdots$ & $\cdots$ & $\cdots$ & $\cdots$ & . & $\cdots$ & $\cdots$ & $\cdots$ & $\cdots$ & $\cdots$ \\
\hline$\ldots$ & . & $\ldots$ & $\ldots$ & $\ldots$ & 0.051 & $\cdots$ & $\cdots$ & $\cdots$ & $\cdots$ & $\cdots$ & $\cdots$ & $\cdots$ & $\cdots$ & $\cdots$ & $\cdots$ & $\ldots$ & $\cdots$ \\
\hline$\ldots$ & & $\ldots$ & $\ldots$ & $\ldots$ & & $\ldots$ & $\ldots$ & $\ldots$ & $\ldots$ & $\ldots$ & $\ldots$ & $\cdots$ & $\cdots$ & $\ldots$ & $\ldots$ & $\ldots$ & $\ldots$ \\
\hline$\ldots$ & 0.1 & $\ldots$ & $\ldots$ & $\ldots$ & 0.093 & $\ldots$ & 1 & $\ldots$ & $\ldots$ & $\ldots$ & $\cdots$ & $\ldots$ & $\cdots$ & $\ldots$ & $\ldots$ & $\ldots$ & $\ldots$ \\
\hline$\ldots$ & $\ldots$ & $\ldots$ & $\ldots$ & 0.3 & 0.00 & $\ldots$ & $\ldots$ & $\ldots$ & $\ldots$ & $\ldots$ & $\ldots$ & $\ldots$ & $\ldots$ & $\ldots$ & $\ldots$ & $\ldots$ & $\ldots$ \\
\hline$\cdots$ & $\cdots$ & $\ldots$ & $\ldots$ & $\ldots$ & 0.027 & $\cdots$ & $\ldots$ & $\ldots$ & $\cdots$ & $\ldots$ & $\cdots$ & $\cdots$ & $\ldots$ & $\cdots$ & $\cdots$ & $\ldots$ & $\cdots$ \\
\hline$\cdots$ & & $\cdots$ & $\cdots$ & $\cdots$ & & $\cdots$ & $\cdots$ & $\cdots$ & $\cdots$ & $\ldots$ & $\cdots$ & $\cdots$ & $\cdots$ & $\cdots$ & $\cdots$ & $\cdots$ & $\cdots$ \\
\hline$\cdots$ & 0.1 & $\cdots$ & $\cdots$ & $\cdots$ & 0.006 & $\cdots$ & $\ldots$ & $\cdots$ & $\cdots$ & $\cdots$ & $\cdots$ & $\cdots$ & $\cdots$ & $\cdots$ & $\ldots$ & $\cdots$ & $\cdots$ \\
\hline & & $\cdots$ & $\cdots$ & $\ldots$ & & $\cdots$ & $\cdots$ & $\cdots$ & $\cdots$ & $\cdots$ & $\cdots$ & $\cdots$ & $\cdots$ & $\cdots$ & $\cdots$ & $\cdots$ & $\cdots$ \\
\hline .7 & & . & $\ldots$ & 0.3 & 00 & 1 & $\ldots$ & $\ldots$ & $\cdots$ & $\cdots$ & $\cdots$ & $\cdots$ & $\ldots$ & $\cdots$ & $\ldots$ & $\cdots$ & $\ldots$ \\
\hline 1.7 & 31.0 & 24.7 & 4 & 36.5 & 42.4 & 3 & 1 & $\ldots$ & $\ldots$ & $\ldots$ & 1 & 1 & 1 & 1 & $\ldots$ & 1 & 1 \\
\hline 2.2 & 5.0 & 0.3 & $\ldots$ & 2.9 & 0 & $\ldots$ & $\cdots$ & $\ldots$ & $\ldots$ & $\ldots$ & $\ldots$ & $\ldots$ & $\ldots$ & $\ldots$ & $\ldots$ & $\ldots$ & $\ldots$ \\
\hline$\cdots$ & - & $\cdots$ & $\ldots$ & $\ldots$ & 0 & $\ldots$ & $\cdots$ & $\ldots$ & $\ldots$ & $\ldots$ & $\ldots$ & $\cdots$ & $\ldots$ & $\ldots$ & $\ldots$ & $\ldots$ & $\cdots$ \\
\hline .'. & .. & $\cdots$ & $\ldots$ & $\ldots$ & 0.015 & $\cdots$ & $\cdots$ & $\cdots$ & $\cdots$ & $\ldots$ & $\cdots$ & $\cdots$ & $\cdots$ & $\ldots$ & $\ldots$ & $\ldots$ & $\cdots$ \\
\hline$\cdots$ & • & $\ldots$ & $\ldots$ & $\ldots$ & & $\cdots$ & $\ldots$ & $\cdots$ & $\cdots$ & $\ldots$ & $\cdots$ & $\cdots$ & $\cdots$ & $\cdots$ & $\cdots$ & $\cdots$ & $\cdots$ \\
\hline 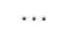 & . & $\ldots$ & $\ldots$ & $\ldots$ & 0 & $\cdots$ & $\cdots$ & $\ldots$ & $\cdots$ & $\ldots$ & $\ldots$ & $\ldots$ & $\ldots$ & $\ldots$ & $\ldots$ & $\ldots$ & $\cdots$ \\
\hline$\cdots$ & & & . & $\ldots$ & 0. & $\cdots$ & - & $\cdots$ & • & .. & . & . & • & . & .. & . & $\cdots$ \\
\hline$\ldots$ & $0 . \tilde{5}$ & 0.3 & $\cdots$ & $\cdots$ & 0.09 & $\ldots$ & $\cdots$ & $\cdots$ & $\cdots$ & $\cdots$ & $\cdots$ & $\cdots$ & $\cdots$ & $\cdots$ & $\ldots$ & $\ldots$ & $\cdots$ \\
\hline & $\cdots$ & 0.6 & $\cdots$ & $\ldots$ & & $\cdots$ & $\cdots$ & $\cdots$ & $\cdots$ & $\cdots$ & $\cdots$ & $\cdots$ & $\cdots$ & $\cdots$ & $\cdots$ & $\cdots$ & $\cdots$ \\
\hline 0.7 & & $\ldots$ & $\ldots$ & $\ldots$ & 0.039 & .. & $\ldots$ & $\ldots$ & $\cdots$ & $\ldots$ & . & $\cdots$ & $\ldots$ & $\ldots$ & $\ldots$ & $\ldots$ & $\ldots$ \\
\hline 2.2 & 0.2 & & $\ldots$ & & & $\cdots$ & $\ldots$ & $\cdots$ & $\cdots$ & $\cdots$ & $\cdots$ & $\cdots$ & $\ldots$ & $\ldots$ & $\ldots$ & $\ldots$ & $\ldots$ \\
\hline$\cdots$ & $\cdots$ & 3 & $\ldots$ & 3.5 & 1.92 & $\ldots$ & $\cdots$ & $\ldots$ & $\ldots$ & $\ldots$ & $\cdots$ & $\cdots$ & $\ldots$ & $\ldots$ & $\ldots$ & $\ldots$ & $\ldots$ \\
\hline$\cdots$ & $\ldots$ & 0.3 & $\ldots$ & 0.3 & $\ldots$ & $\ldots$ & $\cdots$ & $\cdots$ & $\ldots$ & $\ldots$ & $\ldots$ & $\ldots$ & $\ldots$ & $\ldots$ & $\ldots$ & $\ldots$ & $\ldots$ \\
\hline . & & $\ldots$ & $\ldots$ & & & $\ldots$ & $\ldots$ & $\ldots$ & $\ldots$ & $\ldots$ & $\ldots$ & $\ldots$ & $\ldots$ & $\ldots$ & $\ldots$ & $\ldots$ & $\ldots$ \\
\hline & 0.1 & $\cdot$ & $\ldots$ & 0.3 & 0.006 & $\cdots$ & $\ldots$ & $\ldots$ & $\cdots$ & $\ldots$ & $\cdots$ & $\cdots$ & $\cdots$ & $\ldots$ & $\cdots$ & $\ldots$ & $\cdots$ \\
\hline 0.7 & $\cdots$ & $\cdots$ & $\cdots$ & $\cdots$ & $\ldots$ & $\cdots$ & $\ldots$ & $\ldots$ & $\cdots$ & $\ldots$ & $\cdots$ & $\cdots$ & $\ldots$ & $\ldots$ & $\ldots$ & $\ldots$ & $\ldots$ \\
\hline$\cdots$ & & $\cdots$ & $\cdots$ & $\cdots$ & $\ldots$ & $\cdots$ & $\ldots$ & $\cdots$ & $\cdots$ & $\ldots$ & $\cdots$ & $\cdots$ & $\cdots$ & $\cdots$ & $\cdots$ & $\cdots$ & $\cdots$ \\
\hline ‥ & & 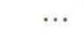 & .. & . & & 1 & $\cdots$ & .. & $\cdots$ & $\cdots$ & $\cdots$ & $\cdots$ & $\ldots$ & $\ldots$ & $\cdots$ & $\cdots$ & $\cdots$ \\
\hline & 0.1 & $\cdots$ & $\ldots$ & $\ldots$ & 0.009 & 1 & $\cdots$ & $\ldots$ & $\ldots$ & 1 & $\cdots$ & $\cdots$ & $\cdots$ & $\cdots$ & $\cdots$ & $\cdots$ & $\cdots$ \\
\hline & 0 & & .. & & 0.012 & $\cdots$ & $\ldots$ & $\ldots$ & $\cdots$ & $\cdots$ & $\cdots$ & $\ldots$ & $\ldots$ & $\ldots$ & $\cdots$ & $\cdots$ & $\cdots$ \\
\hline 0.7 & 0.6 & 0.3 & $\ldots$ & 0.3 & 0.189 & $\cdots$ & $\cdot$ & $\ldots$ & $\cdots$ & $\ldots$ & $\ldots$ & $\cdots$ & $\ldots$ & $\ldots$ & $\ldots$ & $\ldots$ & $\cdots$ \\
\hline . & .. & $\ldots$ & $\ldots$ & & & $\ldots$ & $\cdots$ & $\ldots$ & $\ldots$ & $\ldots$ & $\ldots$ & $\ldots$ & $\ldots$ & $\ldots$ & $\ldots$ & $\ldots$ & $\ldots$ \\
\hline 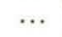 & 0.2 & $\ldots$ & $\ldots$ & 0.3 & 0.8 & $\ldots$ & $\ldots$ & $\ldots$ & $\ldots$ & $\ldots$ & $\ldots$ & $\ldots$ & $\ldots$ & $\ldots$ & $\ldots$ & $\ldots$ & $\ldots$ \\
\hline .. & $\cdots$ & $\ldots$ & $\cdots$ & $\cdots$ & 0.006 & $\cdots$ & $\cdots$ & $\ldots$ & $\cdots$ & $\ldots$ & $\cdots$ & $\cdots$ & $\cdots$ & $\cdots$ & $\cdots$ & $\cdots$ & $\cdots$ \\
\hline
\end{tabular}


Table 15, part 1 (continued).

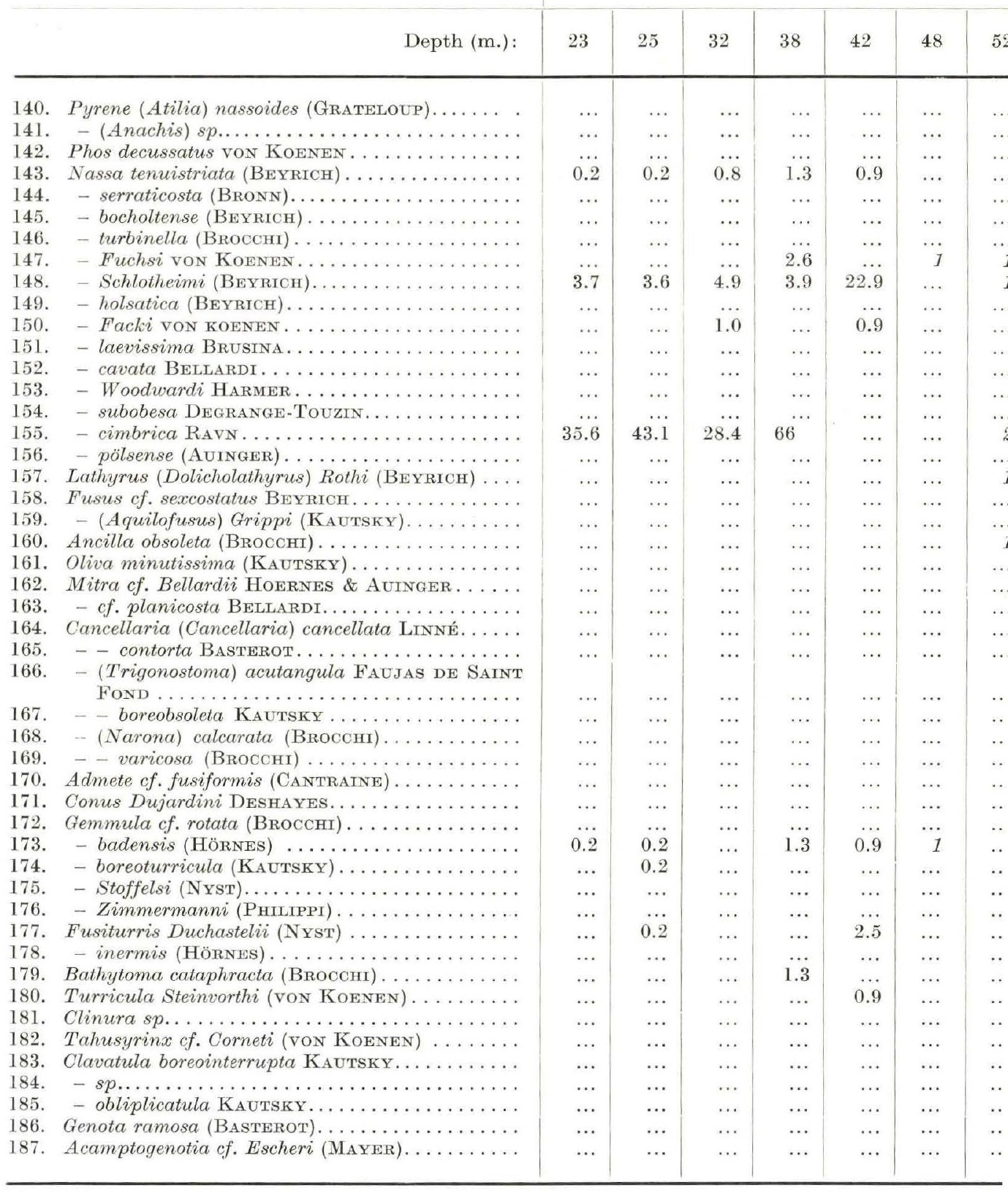




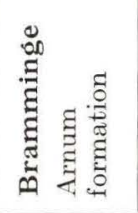

Ribe

Arnum formation

\begin{tabular}{|c|c|c|c|c|c|c|c|c|c|c|c|c|c|c|c|c|c|}
\hline 53 & 53.5 & 53.75 & 54 & $5 \tilde{5}$ & $70-80$ & $\begin{array}{l}113- \\
114\end{array}$ & $\begin{array}{c}114 \\
115\end{array}$ & $\begin{array}{l}11 \tilde{-} \\
116\end{array}$ & $\begin{array}{c}116 \\
117\end{array}$ & $\begin{array}{l}117- \\
118\end{array}$ & $\begin{array}{c}118 \\
119\end{array}$ & $\begin{array}{c}119 \\
120\end{array}$ & $\begin{array}{c}120 \\
121\end{array}$ & $\begin{array}{c}121- \\
122\end{array}$ & $\begin{array}{c}122 \\
123\end{array}$ & $\begin{array}{l}123- \\
124\end{array}$ & $\begin{array}{c}124- \\
125\end{array}$ \\
\hline & 0.2 & 0.3 & $\ldots$ & $\ldots$ & 0.018 & $\ldots$ & $\ldots$ & $\ldots$ & $\ldots$ & $\cdots$ & $\ldots$ & $\ldots$ & $\ldots$ & $\ldots$ & $\cdots$ & $\ldots$ & $\cdots$ \\
\hline . & $\ldots$ & $\ldots$ & $\ldots$ & $\ldots$ & 03 & $\ldots$ & $\ldots$ & $\ldots$ & $\ldots$ & $\ldots$ & $\ldots$ & $\ldots$ & $\ldots$ & $\ldots$ & $\ldots$ & $\ldots$ & $\ldots$ \\
\hline$\cdot$ & $\ldots$ & $\ldots$ & $\ldots$ & & 0.003 & $\ldots$ & $\ldots$ & $\ldots$ & $\ldots$ & $\ldots$ & $\ldots$ & $\ldots$ & $\ldots$ & $\ldots$ & $\ldots$ & $\ldots$ & $\ldots$ \\
\hline . & 1.0 & 1.2 & 1 & 1.3 & 0.132 & $\ldots$ & $\ldots$ & $\ldots$ & $\ldots$ & $\ldots$ & $\ldots$ & $\ldots$ & 1 & $\ldots$ & $\ldots$ & $\ldots$ & $\ldots$ \\
\hline . & $\ldots$ & $\cdots$ & $\cdots$ & $\ldots$ & & $\ldots$ & $\ldots$ & $\ldots$ & $\ldots$ & $\ldots$ & $\ldots$ & $\ldots$ & $\ldots$ & $\ldots$ & $\ldots$ & ... & $\ldots$ \\
\hline . & $\ldots$ & $\ldots$ & $\ldots$ & $\ldots$ & 0.003 & $\ldots$ & $\ldots$ & $\ldots$ & $\ldots$ & $\ldots$ & $\ldots$ & $\ldots$ & $\ldots$ & $\ldots$ & $\ldots$ & $\ldots$ & $\ldots$ \\
\hline & $\ldots$ & $\ldots$ & $\ldots$ & $\ldots$ & & $\ldots$ & $\ldots$ & $\ldots$ & $\ldots$ & $\ldots$ & $\ldots$ & $\ldots$ & $\ldots$ & $\ldots$ & $\ldots$ & $\ldots$ & $\ldots$ \\
\hline 7 & 22.2 & 28.0 & 10 & 11.8 & 0.549 & 5 & 1 & $\ldots$ & $\ldots$ & $\ldots$ & $\ldots$ & $\ldots$ & $\ldots$ & 1 & 1 & 1 & $\ldots$ \\
\hline$\cdots$ & 0.4 & $\ldots$ & $\ldots$ & $\ldots$ & 2.47 & 1 & $\ldots$ & $\ldots$ & $\ldots$ & $\ldots$ & $\ldots$ & $\ldots$ & $\ldots$ & $\ldots$ & $\ldots$ & $\ldots$ & $\ldots$ \\
\hline & $\because$ & & $\ldots$ & $\ldots$ & 0.036 & $\ldots$ & $\ldots$ & $\ldots$ & $\ldots$ & $\ldots$ & $\ldots$ & $\ldots$ & $\ldots$ & $\cdots$ & $\ldots$ & 1 & $\ldots$ \\
\hline 0.7 & 0.9 & 0,9 & $\ldots$ & 1.3 & 0.255 & $\ldots$ & $\ldots$ & $\cdots$ & $\ldots$ & $\ldots$ & $\ldots$ & $\ldots$ & $\ldots$ & $\cdots$ & $\cdots$ & $\cdots$ & $\ldots$ \\
\hline . & $\ldots$ & $\ldots$ & $\ldots$ & $\ldots$ & 0.036 & $\ldots$ & $\ldots$ & $\ldots$ & $\ldots$ & $\cdots$ & $\cdots$ & $\ldots$ & $\cdots$ & $\cdots$ & $\cdots$ & $\cdots$ & $\cdots$ \\
\hline ". & $\ldots$ & $\ldots$ & $\ldots$ & $\ldots$ & 0.006 & $\ldots$ & $\ldots$ & $\ldots$ & $\ldots$ & $\ldots$ & $\ldots$ & $\ldots$ & $\ldots$ & $\ldots$ & $\cdots$ & $\ldots$ & $\cdots$ \\
\hline$\ldots$ & $\ldots$ & $\ldots$ & $\ldots$ & $\ldots$ & & $\ldots$ & $\ldots$ & $\ldots$ & $\ldots$ & $\ldots$ & $\ldots$ & $\ldots$ & $\ldots$ & $\ldots$ & $\ldots$ & $\ldots$ & $\ldots$ \\
\hline$\ldots$ & $\ldots$ & $\ldots$ & $\ldots$ & $\ldots$ & 0.031 & $\ldots$ & $\ldots$ & $\ldots$ & $\ldots$ & $\ldots$ & $\ldots$ & $\ldots$ & $\ldots$ & $\ldots$ & $\ldots$ & $\ldots$ & $\ldots$ \\
\hline$\ldots$ & $\ldots$ & $\ldots$ & $\ldots$ & $\ldots$ & 16.7 & $\ldots$ & $\ldots$ & $\ldots$ & $\ldots$ & $\ldots$ & $\ldots$ & $\ldots$ & $\ldots$ & $\ldots$ & $\ldots$ & $\ldots$ & $\ldots$ \\
\hline$\ldots$ & 0.1 & $\ldots$ & $\ldots$ & $\ldots$ & & $\ldots$ & $\ldots$ & $\ldots$ & $\ldots$ & $\ldots$ & $\ldots$ & $\ldots$ & $\ldots$ & $\ldots$ & $\ldots$ & $\ldots$ & $\ldots$ \\
\hline .. & 0.6 & $\ldots$ & $\ldots$ & $\ldots$ & 0.069 & $\ldots$ & $\ldots$ & $\ldots$ & $\ldots$ & $\ldots$ & $\ldots$ & $\ldots$ & $\ldots$ & $\ldots$ & $\ldots$ & $\ldots$ & $\ldots$ \\
\hline & 0.1 & $\ldots$ & $\ldots$ & $\ldots$ & 0.102 & $\ldots$ & $\ldots$ & $\ldots$ & $\ldots$ & $\ldots$ & $\ldots$ & $\ldots$ & $\ldots$ & $\ldots$ & $\ldots$ & $\ldots$ & $\ldots$ \\
\hline 0.7 & 0.1 & $\ldots$ & $\ldots$ & $\ldots$ & $\ldots$ & $\ldots$ & $\ldots$ & $\ldots$ & $\ldots$ & $\ldots$ & $\ldots$ & $\ldots$ & $\ldots$ & $\ldots$ & $\cdots$ & $\cdots$ & $\cdots$ \\
\hline . & 0.1 & $\ldots$ & $\ldots$ & $\ldots$ & 0.102 & $\ldots$ & $\ldots$ & $\ldots$ & $\ldots$ & $\cdots$ & $\ldots$ & $\ldots$ & $\ldots$ & $\cdots$ & $\cdots$ & $\ldots$ & $\ldots$ \\
\hline .. & 0.1 & $\ldots$ & $\ldots$ & $\ldots$ & 0.006 & $\ldots$ & $\ldots$ & $\cdots$ & $\ldots$ & $\ldots$ & $\ldots$ & $\ldots$ & $\cdots$ & $\ldots$ & $\ldots$ & $\ldots$ & $\cdots$ \\
\hline$\ldots$ & $\ldots$ & $\ldots$ & $\ldots$ & $\ldots$ & & $\ldots$ & $\cdots$ & $\cdots$ & $\cdots$ & $\cdots$ & $\cdots$ & $\cdots$ & $\cdots$ & $\cdots$ & $\cdots$ & $\cdots$ & $\cdots$ \\
\hline .. & $\ldots$ & $\ldots$ & $\ldots$ & $\ldots$ & 0.012 & $\ldots$ & $\cdots$ & $\cdots$ & $\cdots$ & $\cdots$ & $\cdots$ & $\cdots$ & $\cdots$ & $\cdots$ & $\cdots$ & $\cdots$ & $\cdots$ \\
\hline .. & & $\ldots$ & $\ldots$ & $\ldots$ & $\ldots$ & $\ldots$ & $\ldots$ & $\ldots$ & $\ldots$ & $\cdots$ & $\ldots$ & $\ldots$ & $\ldots$ & $\ldots$ & $\ldots$ & $\ldots$ & $\cdots$ \\
\hline$\ldots$ & 0.1 & $\ldots$ & $\ldots$ & $\ldots$ & $\ldots$ & $\ldots$ & $\ldots$ & $\ldots$ & $\ldots$ & $\ldots$ & $\ldots$ & $\ldots$ & $\ldots$ & $\ldots$ & $\ldots$ & $\ldots$ & $\ldots$ \\
\hline .. & $\ldots$ & 0.3 & $\ldots$ & $\cdots$ & 0.003 & $\cdots$ & $\cdots$ & $\ldots$ & $\ldots$ & $\cdots$ & $\ldots$ & $\cdots$ & $\ldots$ & $\cdots$ & $\ldots$ & $\ldots$ & $\cdots$ \\
\hline$\ldots$ & $\ldots$ & $\ldots$ & $\ldots$ & $\ldots$ & & $\ldots$ & $\ldots$ & $\ldots$ & $\ldots$ & $\ldots$ & $\ldots$ & $\ldots$ & $\ldots$ & $\ldots$ & $\cdots$ & $\ldots$ & $\cdots$ \\
\hline$\ldots$ & . & $\cdots$ & $\ldots$ & .. & 0 & $\ldots$ & $\ldots$ & $\ldots$ & $\ldots$ & $\ldots$ & $\ldots$ & $\ldots$ & $\ldots$ & $\ldots$ & $\ldots$ & $\ldots$ & $\ldots$ \\
\hline$\ldots$ & & & $\ldots$ & & 0.063 & $\ldots$ & $\ldots$ & $\ldots$ & $\ldots$ & $\ldots$ & $\ldots$ & $\ldots$ & $\ldots$ & $\ldots$ & $\ldots$ & $\ldots$ & $\ldots$ \\
\hline & 0.2 & 0.6 & $\ldots$ & 0.3 & 0.036 & $\ldots$ & $\ldots$ & $\ldots$ & $\ldots$ & $\ldots$ & $\ldots$ & $\ldots$ & $\ldots$ & $\ldots$ & $\ldots$ & $\ldots$ & $\ldots$ \\
\hline 0.7 & 0.1 & & $\ldots$ & 0.6 & 0 & $\ldots$ & $\ldots$ & $\ldots$ & $\ldots$ & $\ldots$ & $\ldots$ & $\ldots$ & $\ldots$ & $\ldots$ & $\ldots$ & $\ldots$ & $\ldots$ \\
\hline$\cdots$ & 0.2 & 0 & $\ldots$ & 0 & 0 & $\ldots$ & $\ldots$ & $\ldots$ & $\ldots$ & $\ldots$ & $\ldots$ & $\ldots$ & $\ldots$ & $\ldots$ & $\ldots$ & $\ldots$ & $\ldots$ \\
\hline 1.4 & 1.2 & & $\ldots$ & 1. & & $\ldots$ & $\ldots$ & $\ldots$ & $\ldots$ & $\ldots$ & $\ldots$ & $\ldots$ & $\ldots$ & $\ldots$ & $\ldots$ & $\ldots$ & $\ldots$ \\
\hline .. & 0.6 & 0.6 & 1 & 1. & 0. & 1 & $\ldots$ & $\ldots$ & $\ldots$ & $\ldots$ & $\ldots$ & $\ldots$ & $\ldots$ & $\ldots$ & $\ldots$ & $\ldots$ & 1 \\
\hline$\ldots$ & 0.1 & 0.3 & $\ldots$ & 0.3 & 0. & $\ldots$ & $\ldots$ & $\ldots$ & $\ldots$ & $\ldots$ & $\ldots$ & $\ldots$ & $\ldots$ & $\ldots$ & $\ldots$ & $\cdots$ & $\ldots$ \\
\hline . & $\cdots$ & & $\ldots$ & $\cdots$ & 0.0 & $\ldots$ & $\ldots$ & $\ldots$ & $\ldots$ & $\ldots$ & $\ldots$ & $\ldots$ & $\ldots$ & $\ldots$ & $\ldots$ & $\ldots$ & $\ldots$ \\
\hline . & 0.7 & $\ldots$ & $\ldots$ & 1.3 & 0.2 & $\ldots$ & $\ldots$ & $\ldots$ & $\ldots$ & $\ldots$ & $\ldots$ & $\ldots$ & $\ldots$ & $\ldots$ & $\ldots$ & $\ldots$ & $\ldots$ \\
\hline . & & & $\ldots$ & $\cdots$ & 0.084 & $\ldots$ & $\ldots$ & $\ldots$ & $\ldots$ & $\ldots$ & $\cdots$ & $\ldots$ & $\ldots$ & $\cdots$ & $\ldots$ & $\cdots$ & $\ldots$ \\
\hline & 0.1 & 0.3 & 1 & 0.3 & 0.042 & 1 & $\ldots$ & $\ldots$ & $\ldots$ & $\ldots$ & $\ldots$ & $\ldots$ & $\ldots$ & $\cdots$ & $\ldots$ & $\ldots$ & $\cdots$ \\
\hline 0.7 & 0.1 & $\ldots$ & $\ldots$ & $\ldots$ & 0.006 & $\ldots$ & $\ldots$ & $\ldots$ & $\ldots$ & $\ldots$ & $\ldots$ & $\ldots$ & $\ldots$ & $\ldots$ & $\ldots$ & $\ldots$ & $\ldots$ \\
\hline$\ldots$ & 0.1 & $\ldots$ & $\ldots$ & $\ldots$ & $\ldots$ & $\ldots$ & $\ldots$ & $\ldots$ & $\ldots$ & $\ldots$ & $\ldots$ & $\ldots$ & $\ldots$ & $\ldots$ & $\ldots$ & $\ldots$ & $\ldots$ \\
\hline$\ldots$ & $\ldots$ & $\ldots$ & $\ldots$ & $\ldots$ & .. & 1 & $\ldots$ & $\ldots$ & $\cdots$ & $\ldots$ & $\ldots$ & $\ldots$ & $\ldots$ & $\ldots$ & $\ldots$ & $\ldots$ & $\ldots$ \\
\hline$\ldots$ & $\ldots$ & .. & $\ldots$ & $\ldots$ & & $\ldots$ & $\ldots$ & $\ldots$ & $\cdots$ & $\ldots$ & $\ldots$ & $\ldots$ & $\ldots$ & $\ldots$ & $\ldots$ & $\ldots$ & $\ldots$ \\
\hline & $\ldots$ & 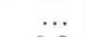 & & $\ldots$ & 0.003 & $\ldots$ & $\ldots$ & $\ldots$ & $\cdots$ & $\ldots$ & $\ldots$ & $\ldots$ & $\ldots$ & $\ldots$ & $\ldots$ & $\ldots$ & $\ldots$ \\
\hline 1.4 & $\ldots$ & 0.3 & $\ldots$ & 0.3 & 0.012 & $\ldots$ & $\ldots$ & $\ldots$ & $\ldots$ & $\ldots$ & $\ldots$ & $\ldots$ & $\ldots$ & $\ldots$ & $\ldots$ & $\ldots$ & $\ldots$ \\
\hline$\cdots$ & $\ldots$ & $\ldots$ & $\ldots$ & 0.3 & 0.036 & $\ldots$ & $\ldots$ & $\ldots$ & $\ldots$ & $\ldots$ & $\ldots$ & $\ldots$ & $\ldots$ & $\ldots$ & $\ldots$ & $\ldots$ & $\ldots$ \\
\hline$\ldots$ & $\cdots$ & $\cdots$ & $\ldots$ & $\ldots$ & $\ldots$ & $\cdots$ & $\cdots$ & $\cdots$ & $\cdots$ & $\cdots$ & $\cdots$ & $\cdots$ & $\cdots$ & $\cdots$ & $\cdots$ & $\cdots$ & $\cdots$ \\
\hline
\end{tabular}


Table 15, part 1 (continued).

\begin{tabular}{|c|c|c|c|c|c|c|c|c|}
\hline & Depth (m.): & 23 & 25 & 32 & 38 & 42 & 48 & 52 \\
\hline 188. & Acamptogenotia cf. Straeleni GLtBert. . . . . . . . & $\ldots$ & $\ldots$ & & $\ldots$ & $\ldots$ & $\cdots$ & \\
\hline 189. & Inquisitor obeliscus (Des MouLrNs).......... & $\ldots$ & $\cdots$ & 0.3 & $\ldots$ & $\ldots$ & $\cdots$ & \\
\hline 190. & Splendrillia Selenkae (von Konnen)........... & $\ldots$ & ... & $\cdots$ & $\cdots$ & $\cdots$ & $\cdots$ & \\
\hline 191. & Boreodrillia toftlundensis nov.gen. \& nov.sp..... & $\ldots$ & $\ldots$ & $\ldots$ & $\ldots$ & & $\ldots$ & \\
\hline 192. & Asthenotoma cf. pannus (ВАSTEROT).......... & $\ldots$ & $\cdots$ & $\cdots$ & $\cdots$ & 1.7 & $\ldots$ & \\
\hline 193. & Brachytoma electa nov. sp................. & $\ldots$ & $\cdots$ & $\cdots$ & $\cdots$ & $\ldots$ & $\ldots$ & \\
\hline 194. & - Grateloupi (РечRоT). . . . . . . . . . . . . & $\ldots$ & ... & $\ldots$ & ... & $\therefore$ & $\ldots$ & \\
\hline 195. & - obtusangula (Ввосснг)................ & $\cdots$ & $\ldots$ & $\cdots$ & $\cdots$ & $\cdots$ & $\cdots$ & \\
\hline 196. & 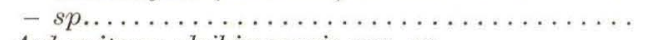 & $\ldots$ & $\cdots$ & $\ldots$ & $\ldots$ & $\ldots$ & $\ldots$ & \\
\hline 197. & Aphanitoma glejbjergensis nov. sp.......... & $\ldots$ & & $\ldots$ & $\ldots$ & $\ldots$ & $\ldots$ & \\
\hline 198. & Neoguraleus calais (KAUTSKY)............. & 0.2 & 0.2 & $\cdots$ & 1.3 & ... & ... & \\
\hline 199. & - tenella (MAYER). . . . . . . . . . . . . . . & 0.2 & 0.2 & $\cdots$ & 1.3 & $\cdots$ & $\cdots$ & \\
\hline 200. & - Gürichi (KAUTSKY) . . . . . . . . . . . . . & $\ldots$ & $\cdots$ & $\cdots$ & $\cdots$ & $\cdots$ & $\cdots$ & \\
\hline 201. & Pleurotomoides Johannae (РеуRот)........... & $\cdots$ & $\cdots$ & $\cdots$ & $\cdots$ & $\cdots$ & $\cdots$ & \\
\hline 202. & - elatior (von KoEnEN) . . . . . . . . . . . . & $\cdots$ & $\cdots$ & $\cdots$ & $\cdots$ & $\cdots$ & $\cdots$ & \\
\hline 203. & - simplex nov. $s p \ldots \ldots \ldots \ldots \ldots \ldots \ldots \ldots \ldots$ & $\cdots$ & $\cdots$ & $\cdots$ & $\cdots$ & $\cdots$ & $\cdots$ & \\
\hline 204. & - cf. Luisae (von KoEnEN) . . . . . . . . . . . . & $\cdots$ & $\cdots$ & $\cdots$ & $\cdots$ & $\cdots$ & $\cdots$ & \\
\hline 205. & - campanulata nov. sp.................. & $\cdots$ & $\cdots$ & $\cdots$ & $\cdots$ & $\cdots$ & $\cdots$ & \\
\hline 206. & Teretia anceps (ЕICHWALD) . . . . . . . . . . . . & $\cdots$ & $\cdots$ & $\cdots$ & $\cdots$ & $\cdots$ & $\cdots$ & \\
\hline 207. & 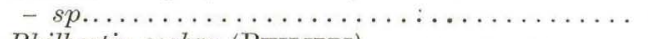 & $\ldots$ & $\cdots$ & $\cdots$ & $\cdots$ & $\cdots$ & $\cdots$ & \\
\hline 208. & Philbertia scabra (РнILIPPI) . . . . . . . . . . . . & $\cdots$ & $\cdots$ & $\cdots$ & $\cdots$ & $\cdots$ & $\cdots$ & \\
\hline 209. & - sinuosula nov. $\operatorname{sp\ldots \ldots \ldots \ldots \ldots \ldots \ldots \ldots \ldots }$ & $\cdots$ & $\cdots$ & $\cdots$ & $\cdots$ & $\cdots$ & $\cdots$ & \\
\hline 210. & Eubela trochlearis (HöRnEs) . . . . . . . . . . . & $\cdots$ & $\cdots$ & $\cdots$ & $\cdots$ & $\cdots$ & $\cdots$ & \\
\hline 211. & 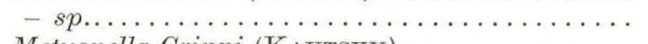 & $\cdots$ & $\cdots$ & $\ldots$ & $\cdots$ & $\cdots$ & $\cdots$ & \\
\hline 212. & 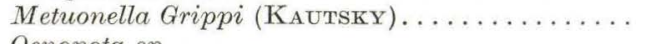 & $\cdots$ & $\cdots$ & $\cdots$ & $\cdots$ & $\cdots$ & $\cdots$ & \\
\hline 213. & 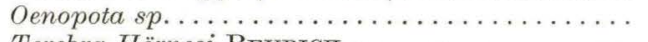 & $\ldots$ & $\ldots$ & $\cdots$ & $\cdots$ & $\cdots$ & $\cdots$ & \\
\hline 214. & Terebra Hörnesi BEYRICH. . . . . . . . . . . . . . & 0.3 & 0.4 & 0.3 & $\cdots$ & 0.9 & $\cdots$ & \\
\hline 215. & - acuminata BoRson.................... & $\ldots$ & $\cdots$ & $\cdots$ & $\cdots$ & $\cdots$ & $\cdots$ & \\
\hline 216. & Acteon semistriatus (BASTEROT). . . . . . . . . . & 0.2 & & $\cdots$ & $\cdots$ & 0.9 & $\cdots$ & \\
\hline 217. & - laevigatus (GRATELOUP)................. & $\cdots$ & 0.2 & $\cdots$ & $\cdots$ & $\cdots$ & $\cdots$ & \\
\hline 218. & - $c f$. pinguis D'ORBIGNY $\ldots \ldots \ldots \ldots \ldots \ldots$ & $\cdots$ & $\cdots$ & $\cdots$ & $\cdots$ & $\cdots$ & $\cdots$ & \\
\hline 219. & 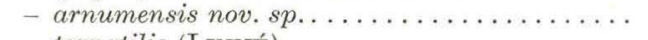 & $\cdots$ & $\cdots$ & $\cdots$ & $\cdots$ & $\cdots$ & $\cdots$ & \\
\hline 220. & - tornatilis (LINNÉ).......... & $\cdots$ & $\cdots$ & $\cdots$ & $\cdots$ & $\cdots$ & $\cdots$ & \\
\hline 221. & $-s p \ldots \ldots \ldots \ldots \ldots \ldots \ldots \ldots \ldots \ldots$ & $\cdots$ & $\ldots$ & $\cdots$ & $\ldots$ & $\cdots$ & $\cdots$ & \\
\hline 222. & 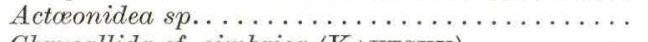 & $\ldots$ & $\ldots$ & $\ldots$ & $\ldots$ & $\ldots$ & $\cdots$ & \\
\hline 223. & Chrysallida cf. cimbrica (KaUTSKY)............ & $\ldots$ & $\ldots$ & $\cdots$ & 1.3 & $\cdots$ & $\cdots$ & \\
\hline 224. & 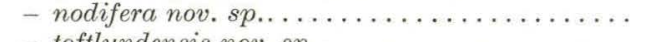 & 0.5 & 0.7 & $\cdots$ & $\cdots$ & $\cdots$ & $\cdots$ & \\
\hline 225. & 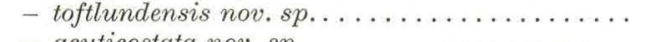 & $\cdots$ & $\cdots$ & $\cdots$ & $\cdots$ & $\cdots$ & $\cdots$ & \\
\hline 226. & - acuticostata nov. sp................... & $\cdots$ & $\cdots$ & $\cdots$ & $\cdots$ & $\cdots$ & $\cdots$ & \\
\hline 227. & - semireticulata nov. sp................. & $\cdots$ & $\cdots$ & $\cdots$ & $\cdots$ & $\cdots$ & $\cdots$ & \\
\hline 228. & - modesta nov. sp..................... & $\cdots$ & $\cdots$ & $\cdots$ & $\cdots$ & $\cdots$ & $\cdots$ & \\
\hline 229. & - pygmaea (GRATELOUP).......... & & & $\cdots$ & $\cdots$ & $\cdots$ & $\cdots$ & \\
\hline 230. & Kleinella (Leucotina) Nordmanni nov. sp... & 0.1 & 0.2 & 0.5 & $\cdots$ & $\cdots$ & $\cdots$ & \\
\hline 231. & Odostomia conoidea (ВRосснт). . . . . . . . . . . . & $\cdots$ & $\cdots$ & $\cdots$ & $\cdots$ & $\cdots$ & $\cdots$ & \\
\hline 232. & - subintermedia (COSSMann \& PeYrot)....... & 0.1 & $\cdots$ & $\cdots$ & $\cdots$ & $\cdots$ & $\cdots$ & \\
\hline 233. & - sallespissensis (Cossmann \& Peyrot). . . . . . & $\cdots$ & $\cdots$ & $\cdots$ & $\cdots$ & $\cdots$ & $\cdots$ & \\
\hline 234. & 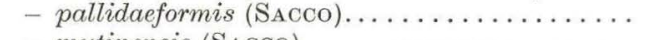 & $\cdots$ & $\cdots$ & $\cdots$ & $\cdots$ & ‥ & $\cdots$ & \\
\hline 235. & 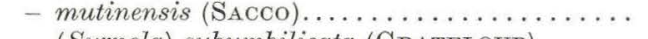 & $\cdots$ & $\dddot{0}$ & $\cdots$ & $\cdots$ & 2.5 & $\cdots$ & \\
\hline 236. & - (Syrnola) subumbilicata (GRATELOUP)....... & & 0.2 & $\cdots$ & $\cdots$ & $\cdots$ & $\cdots$ & \\
\hline
\end{tabular}


Table 15, part 1 (continued)

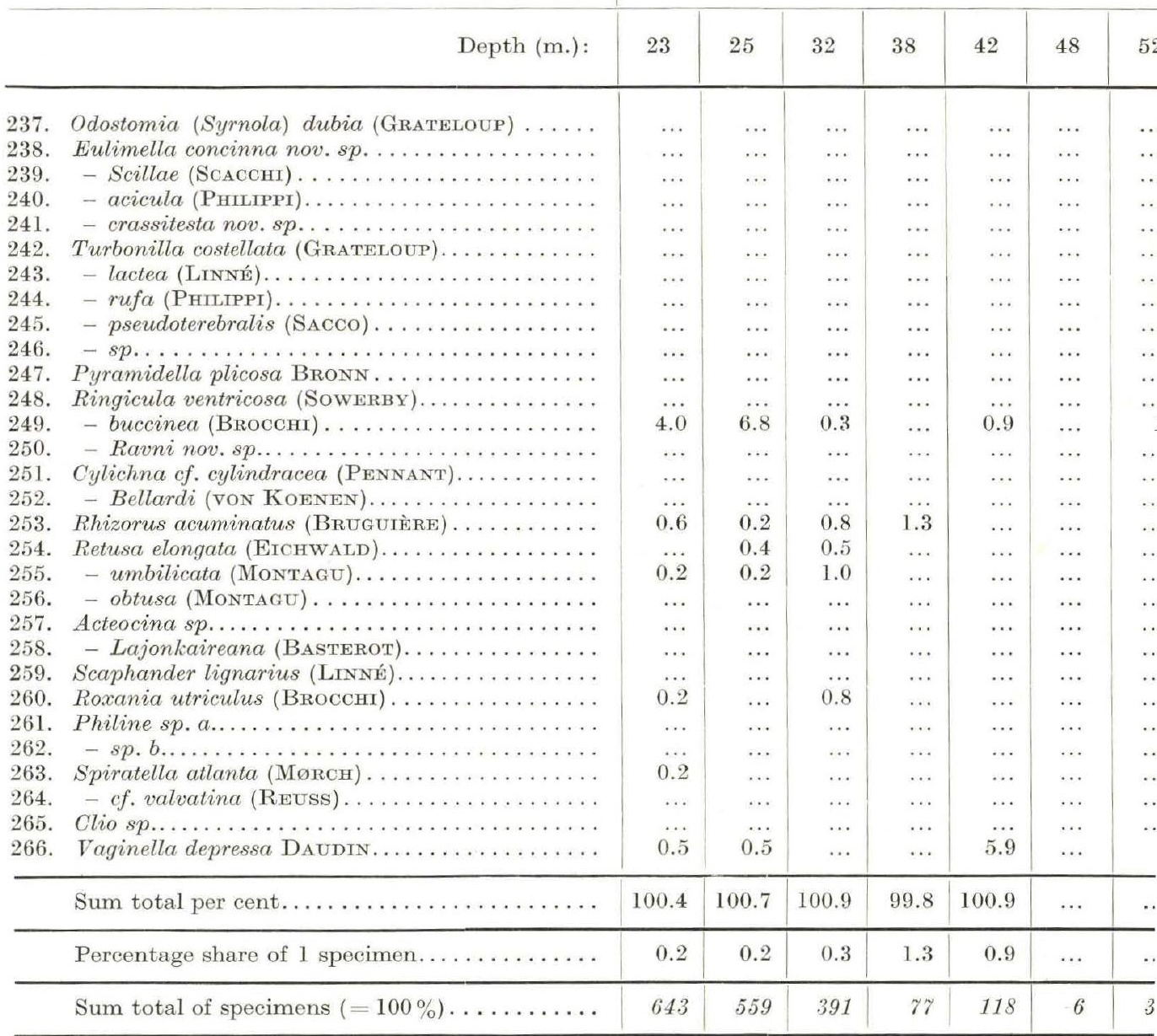




\section{है}

Ribe

Arnum formation

\begin{tabular}{|c|c|c|c|c|c|c|c|c|c|c|c|c|c|c|c|c|c|}
\hline 53 & 53.5 & 53.75 & 54 & 55 & $70-80$ & $\begin{array}{c}113- \\
114\end{array}$ & $\begin{array}{c}114 \\
115\end{array}$ & $\begin{array}{l}115 \\
116\end{array}$ & $\begin{array}{l}116- \\
117\end{array}$ & $\begin{array}{c}117 \\
118\end{array}$ & $\begin{array}{c}118 \\
119\end{array}$ & $\begin{array}{c}119- \\
120\end{array}$ & $\begin{array}{c}120 \\
121\end{array}$ & $\begin{array}{c}121- \\
122\end{array}$ & $\begin{array}{r}122 \\
123\end{array}$ & $\begin{array}{c}123- \\
124\end{array}$ & $\begin{array}{l}124- \\
125\end{array}$ \\
\hline .. & $\cdots$ & $\cdots$ & $\cdots$ & $\cdots$ & 0.003 & $\ldots$ & $\cdots$ & $\cdots$ & $\cdots$ & $\cdots$ & $\cdots$ & $\cdots$ & $\cdots$ & $\cdots$ & $\cdots$ & $\cdots$ & $\cdots$ \\
\hline$\cdots$ & $\ldots$ & $\cdots$ & $\ldots$ & $\ldots$ & $\cdots$ & 1 & $\cdots$ & $\ldots$ & $\cdots$ & $\ldots$ & $\cdots$ & $\ldots$ & $\ldots$ & $\ldots$ & $\ldots$ & $\ldots$ & $\ldots$ \\
\hline .' & $\ldots$ & $\ldots$ & $\ldots$ & $\ldots$ & $\cdots$ & $\cdots$ & $\ldots$ & $\cdots$ & $\cdots$ & $\cdots$ & $\cdots$ & $\ldots$ & $\ldots$ & $\cdots$ & $\cdots$ & $\cdots$ & $\cdots$ \\
\hline .. & $\cdots$ & $\cdots$ & $\cdots$ & $\cdots$ & & $\cdots$ & $\cdots$ & $\cdots$ & $\cdots$ & $\cdots$ & $\cdots$ & $\cdots$ & $\cdots$ & $\ldots$ & $\cdots$ & $\cdots$ & $\ldots$ \\
\hline .. & $\ldots$ & $\cdots$ & $\ldots$ & $\ldots$ & 0 & $\ldots$ & $\ldots$ & $\ldots$ & $\ldots$ & $\ldots$ & $\ldots$ & $\ldots$ & $\cdots$ & $\ldots$ & $\cdots$ & $\cdots$ & $\cdots$ \\
\hline$\cdot \cdot$ & $\ldots$ & $\cdots$ & $\ldots$ & $\ldots$ & & $\ldots$ & $\cdots$ & $\ldots$ & $\cdots$ & $\ldots$ & $\ldots$ & $\ldots$ & $\cdots$ & $\ldots$ & $\ldots$ & $\ldots$ & $\ldots$ \\
\hline$\cdots$ & $\ldots$ & $\cdots$ & $\ldots$ & $\ldots$ & 0 & $\ldots$ & $\cdots$ & $\ldots$ & $\cdots$ & $\cdots$ & $\cdots$ & $\cdots$ & $\cdots$ & $\cdots$ & $\cdots$ & $\cdots$ & $\cdots$ \\
\hline$\cdots$ & $\cdots$ & $\cdots$ & $\ldots$ & $\cdots$ & 003 & $\cdots$ & . & $\ldots$ & $\cdots$ & $\cdots$ & $\cdots$ & $\cdots$ & $\cdots$ & $\cdots$ & $\cdots$ & $\cdots$ & $\cdots$ \\
\hline & $\cdots$ & $\cdots$ & $\cdots$ & $\ldots$ & 02 & $\cdots$ & $\cdots$ & $\cdots$ & $\cdots$ & $\cdots$ & $\cdots$ & $\cdots$ & $\cdots$ & $\cdots$ & $\cdots$ & $\cdots$ & $\cdots$ \\
\hline$\cdots$ & & & $\cdots$ & & 0 & $\ldots$ & $\cdots$ & $\cdots$ & $\cdots$ & $\cdots$ & $\cdots$ & $\cdots$ & $\cdots$ & $\cdots$ & $\cdots$ & $\cdots$ & $\cdots$ \\
\hline . & 0.2 & 9 & $\cdots$ & 0.6 & 0.102 & $\cdots$ & $\cdots$ & $\cdots$ & . & $\cdots$ & $\cdots$ & $\cdots$ & $\cdots$ & $\cdots$ & $\cdots$ & $\cdots$ & $\cdots$ \\
\hline & 6.9 & & $\cdots$ & & & $\cdots$ & . & $\cdots$ & $\cdots$ & $\cdots$ & $\cdots$ & .. & . & $\cdots$ & $\cdots$ & $\cdot$ & $\cdots$ \\
\hline & & & & 4.8 & 7.53 & 2 & . & $\cdots$ & $\cdots$ & $\cdots$ & $\cdots$ & $\cdots$ & $\cdots$ & $\cdots$ & $\cdots$ & $\cdots$ & .. \\
\hline$\cdots$ & ... & $\cdots$ & $\cdots$ & . & $\cdots$ & $\cdots$ & . & $\cdots$ & $\cdots$ & $\cdots$ & $\cdots$ & $\cdots$ & $\cdots$ & $\cdots$ & $\cdots$ & $\cdots$ & $\cdots$ \\
\hline & & & . & $\cdots$ & & $\cdots$ & $\cdots$ & $\cdots$ & $\cdots$ & $\cdots$ & $\cdots$ & $\cdots$ & $\cdots$ & $\cdots$ & $\cdots$ & $\cdots$ & $\cdots$ \\
\hline 4 & & & . & & 0.0 & 1 & $\cdots$ & $\cdots$ & $\cdots$ & $\cdots$ & $\cdots$ & $\cdots$ & $\cdots$ & $\cdots$ & $\cdots$ & $\cdots$ & $\cdots$ \\
\hline & & & $\cdots$ & 0.3 & 0 & $\cdots$ & $\cdots$ & $\cdots$ & $\cdots$ & $\cdots$ & $\cdots$ & $\cdots$ & $\cdots$ & $\cdots$ & $\cdots$ & $\cdots$ & $\cdots$ \\
\hline & 0.1 & 0.3 & $\cdots$ & 0.3 & 0.072 & $\cdots$ & $\cdots$ & $\cdots$ & $\cdots$ & $\cdots$ & $\cdots$ & $\cdots$ & $\cdots$ & $\cdots$ & $\cdots$ & $\cdots$ & $\cdots$ \\
\hline & & 8 & $\cdots$ & $\cdots$ & $\cdots$ & $\cdots$ & $\cdots$ & $\cdots$ & $\cdots$ & $\cdots$ & $\cdots$ & $\cdots$ & $\cdots$ & $\cdots$ & $\cdots$ & $\cdots$ & $\cdots$ \\
\hline & $\cdots$ & $\cdots$ & $\cdots$ & $\cdots$ & $\cdots$ & $\cdots$ & $\cdots$ & $\cdots$ & $\cdots$ & $\cdots$ & $\cdots$ & $\cdots$ & $\cdots$ & $\cdots$ & $\cdots$ & $\cdots$ & $\cdots$ \\
\hline & & $\cdots$ & $\cdots$ & $\cdots$ & $\cdots$ & $\cdots$ & $\cdots$ & $\cdots$ & $\cdots$ & $\cdots$ & $\cdots$ & $\cdots$ & $\cdots$ & $\cdots$ & $\cdots$ & $\cdots$ & $\cdots$ \\
\hline ... & 0 & 3 & $\ldots$ & 0.3 & $\ldots$ & $\cdots$ & .. & $\cdots$ & 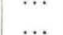 & $\cdots$ & $\cdots$ & 1 & $\cdots$ & $\cdot$ & $\cdots$ & $\cdot \cdots$ & $\cdots$ \\
\hline$\ldots$ & 0.4 & 0.3 & $\ldots$ & $\ldots$ & 0.045 & $\ldots$ & $\ldots$ & $\ldots$ & $\ldots$ & $\ldots$ & $\begin{array}{l}\cdots \\
\ldots\end{array}$ & $\ldots$ & $\cdots$ & $\cdots$ & $\cdots$ & $\cdots$ & $\cdots$ \\
\hline$\cdots$ & $\cdots$ & $\cdots$ & $\ldots$ & $\ldots$ & $\cdots$ & $\ldots$ & $\cdots$ & $\ldots$ & $\cdots$ & $\ldots$ & $\ldots$ & $\ldots$ & $\cdots$ & $\cdots$ & $\ldots$ & $\ldots$ & $\cdots$ \\
\hline ... & $\cdots$ & $\cdots$ & $\ldots$ & $\cdots$ & $\ldots$ & $\ldots$ & $\cdots$ & $\ldots$ & $\ldots$ & $\ldots$ & $\ldots$ & $\ldots$ & . & $\cdots$ & $\cdots$ & $\cdots$ & $\cdots$ \\
\hline$\ldots$ & $\cdots$ & $\cdots$ & $\ldots$ & $\cdots$ & $\ldots$ & $\ldots$ & $\ldots$ & $\ldots$ & $\cdots$ & $\ldots$ & $\ldots$ & $\ldots$ & $\cdots$ & $\cdots$ & ... & $\cdots$ & $\cdots$ \\
\hline . & $\cdots$ & $\ldots$ & $\ldots$ & $\ldots$ & $\ldots$ & $\ldots$ & $\ldots$ & $\cdots$ & 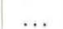 & - & 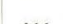 & & 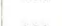 & & 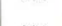 & $\cdots$ & $\cdots$ \\
\hline$\ldots$ & & & $\ldots$ & $\cdots$ & & $\ldots$ & $\cdots$ & $\ldots$ & $\cdots$ & $\cdots$ & $\cdots$ & $\cdots$ & $\ldots$ & $\cdot$ & . &. & \\
\hline . & 0.1 & 0.3 & 1 & $\ldots$ & 0.162 & $\ldots$ & $\ldots$ & 1 & $\ldots$ & $\ldots$ & $\ldots$ & $\ldots$ & $\cdots$ & $\cdots$ & $\ldots$ & $\cdots$ & $\ldots$ \\
\hline .5 & 98.7 & 97.6 & & 99.5 & 99.777 & 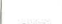 & 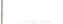 & & 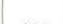 & 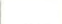 & s & & & & & & \\
\hline & & & & & & & & & & & & & & & & $\cdots$ & $\cdots$ \\
\hline 0.7 & 0.1 & 0.3 & $\ldots$ & 0.3 & 0.003 & $\cdots$ & $\cdots$ & $\cdots$ & $\cdots$ & $\cdots$ & $\cdots$ & $\cdots$ & $\cdots$ & $\cdots$ & $\cdots$ & $\cdots$ & $\cdots$ \\
\hline & 821 & 336 & 31 & 315 & 33165 & 59 & 9 & 7 & 1 & 4 & 1 & 4 & 2 & 3 & 4 & 8 & 19 \\
\hline
\end{tabular}


Table 15, (part 2). The Frequencies of th Roman types: per cen

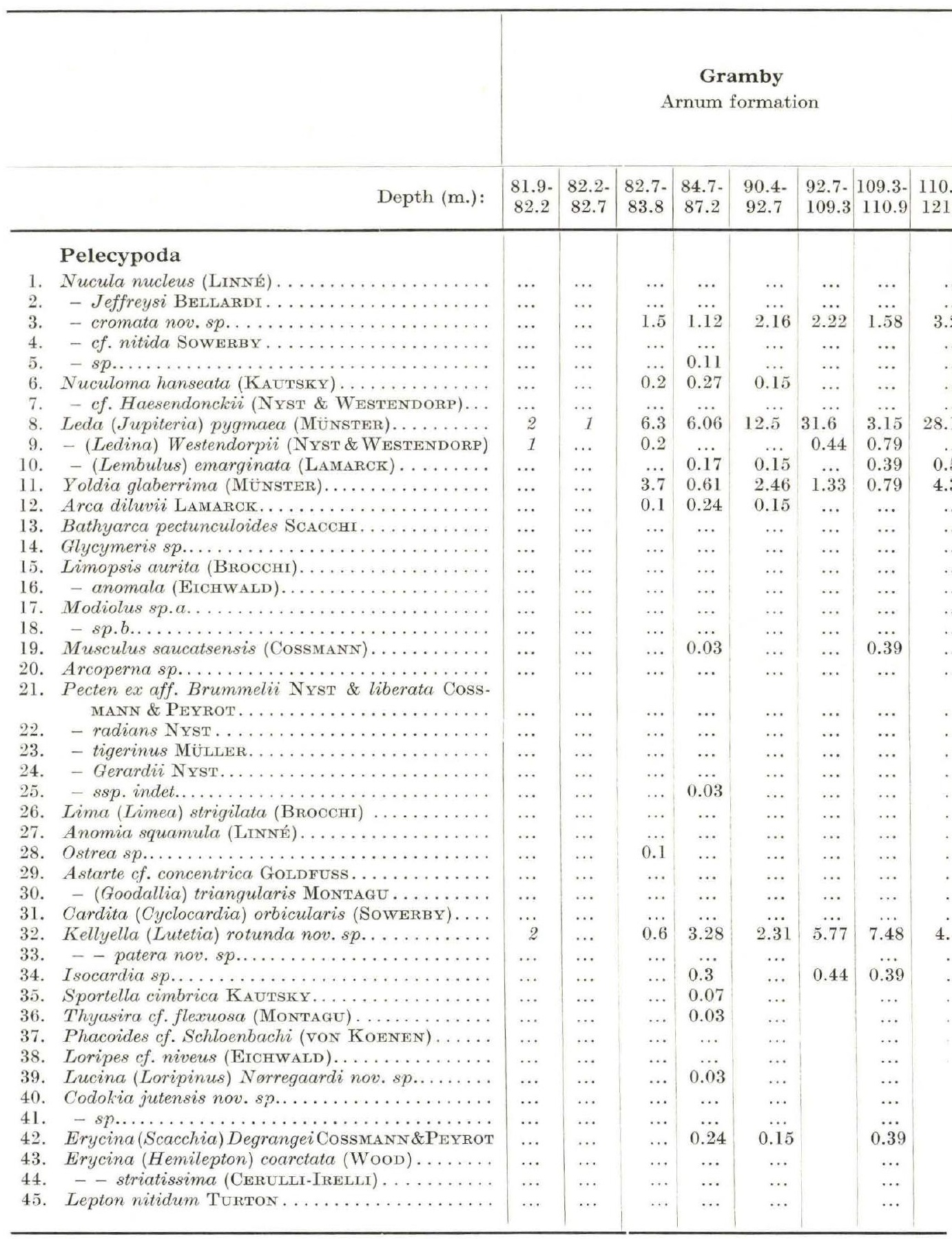




\section{Molluscan Species in the Well Sections}

talics: number of specimen

\begin{tabular}{|c|c|c|c|c|c|c|c|c|c|c|c|c|}
\hline & & & & & \multicolumn{8}{|c|}{ Arnum } \\
\hline \multirow{2}{*}{\multicolumn{5}{|c|}{$\begin{array}{c}\text { Toftlund } \\
\text { Arnum formation }\end{array}$}} & \multicolumn{3}{|c|}{ Well no. 150.13} & \multicolumn{5}{|c|}{ Well no. $150.25 \mathrm{~b}$} \\
\hline & & & & & \multirow{2}{*}{ 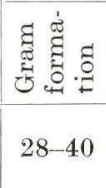 } & \multicolumn{2}{|c|}{$\begin{array}{l}\text { Arnum } \\
\text { formation }\end{array}$} & \multicolumn{5}{|c|}{ Arnum formation } \\
\hline $\begin{array}{l}75- \\
100\end{array}$ & $\begin{array}{c}100- \\
105\end{array}$ & $\begin{array}{c}105- \\
110\end{array}$ & $\begin{array}{l}110- \\
115\end{array}$ & 115 & & $53-83$ & $83-94$ & $\begin{array}{c}62.7- \\
62.9\end{array}$ & $\begin{array}{c}95.0- \\
95.3\end{array}$ & $\begin{array}{c}101.0- \\
104.3\end{array}$ & $\begin{array}{c}104.3- \\
107.5\end{array}$ & 107.5 \\
\hline 0.0223 & & 0.008 & & 0.14 & $\ldots$ & & $\cdots$ & $\ldots$ & 3.36 & $\ldots$ & 0.19 & $\ldots$ \\
\hline$\ldots$ & 0.49 & 0.361 & 0.28 & $\ldots$ & $\ldots$ & $\cdots$ & 0.6 & . & 0.23 & $\ldots$ & $\ldots$ & $\ldots$ \\
\hline 0.585 & 0.014 & & $\ldots$ & $\ldots$ & $\ldots$ & 0.96 & $\ldots$ & 3.48 & $\ldots$ & $\ldots$ & $\ldots$ & $\ldots$ \\
\hline 0.0004 & 0.014 & 0.008 & $\ldots$ & $\ldots$ & $\ldots$ & $\ldots$ & $\ldots$ & 0.046 & $\ldots$ & $\ldots$ & $\ldots$ & $\ldots$ \\
\hline 0.382 & 0.27 & $\ldots$ & $\ldots$ & $\ldots$ & 4.3 & $\ldots$ & $\ldots$ & 0.828 & & 1 & $\ldots$ & $\ldots$ \\
\hline 0.286 & 0.20 & 2.13 & 2.2 & 1.76 & $\ldots$ & 0.073 & 1.2 & 0.006 & 2.36 & 1 & 0.76 & 1.4 \\
\hline 5.27 & 25.7 & 1.02 & 5.32 & $\begin{array}{l}\cdots \\
0.47\end{array}$ & 14.3 & 21.82 & 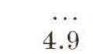 & 12.2 & 1.3 & $\dddot{11}$ & 7.9 & 18.7 \\
\hline 0.492 & 1.41 & 5.54 & 3.97 & 1.42 & $\ldots$ & 0.129 & 0.6 & 0.029 & 11.6 & 2 & 1.32 & 1.4 \\
\hline 0.0318 & $\ldots$ & 0.084 & 0.07 & 0.14 & $\ldots$ & 0.073 & $\ldots$ & 0.017 & & $\ldots$ & & $\ldots$ \\
\hline 1.022 & 3.57 & 1.31 & 1.23 & 5.43 & 2.5 & 0.184 & 1.2 & 2.9 & 2.52 & 2 & 6.24 & 0.7 \\
\hline 0.0272 & 0.014 & 0.092 & 0.26 & 0.20 & 0.6 & 0.055 & $\ldots$ & 0.145 & 0.08 & 1 & $\ldots$ & 0.7 \\
\hline$\ldots$ & $\ldots$ & $\ldots$ & $\ldots$ & & $\ldots$ & $\ldots$ & $\ldots$ & $\ldots$ & $\ldots$ & $\ldots$ & 0.19 & $\ldots$ \\
\hline$\ldots$ & $\ldots$ & $\ldots$ & $\ldots$ & 0.07 & $\ldots$ & $\ldots$ & $\ldots$ & $\ldots$ & $\ldots$ & $\ldots$ & $\ldots$ & $\ldots$ \\
\hline$\ldots$ & $\ldots$ & & & $\ldots$ & $\ldots$ & $\ldots$ & $\ldots$ & $\ldots$ & & $\ldots$ & $\ldots$ & $\ldots$ \\
\hline 0.0008 & $\ldots$ & 0.023 & 0.09 & $\ldots$ & $\ldots$ & $\cdots$ & $\ldots$ & $\ldots$ & 0.08 & $\cdots$ & $\ldots$ & $\ldots$ \\
\hline$\ldots$ & $\ldots$ & $\ldots$ & $\ldots$ & $\ldots$ & $\ldots$ & $\ldots$ & $\ldots$ & 0.006 & $\ldots$ & $\ldots$ & $\ldots$ & $\ldots$ \\
\hline$\ldots$ & $\ldots$ & & 0.024 & $\ldots$ & $\ldots$ & $\ldots$ & $\ldots$ & $\ldots$ & $\ldots$ & $\ldots$ & $\ldots$ & $\ldots$ \\
\hline$\ldots$ & 0.014 & 0.023 & 0.05 & 0.07 & $\ldots$ & $\ldots$ & $\ldots$ & $\ldots$ & 0.15 & $\ldots$ & $\ldots$ & 0.7 \\
\hline$\cdots$ & $\cdots$ & $\cdots$ & $\cdots$ & $\cdots$ & $\cdots$ & $\cdots$ & $\cdots$ & $\ldots$ & $\cdots$ & $\cdots$ & $\cdots$ & $\cdots$ \\
\hline 0.0087 & 0.014 & 0.008 & 0.024 & 0.07 & $\ldots$ & 0.037 & $\ldots$ & $\ldots$ & $\cdots$ & $\ldots$ & $\ldots$ & $\ldots$ \\
\hline 0.0004 & 0.014 & 0.008 & 0.024 & 0.07 & $\ldots$ & $\ldots$ & $\ldots$ & $\ldots$ & 0.08 & $\ldots$ & $\ldots$ & $\ldots$ \\
\hline$\ldots$ & $\ldots$ & 0 & 0.024 & 0.07 & $\ldots$ & $\ldots$ & $\ldots$ & $\ldots$ & $\ldots$ & $\ldots$ & $\ldots$ & \\
\hline$\ldots$ & $\ldots$ & 0.008 & $\ldots$ & $\ldots$ & $\ldots$ & $\ldots$ & $\ldots$ & & $\ldots$ & $\ldots$ & $\ldots$ & 0.7 \\
\hline$\ldots$ & 0.014 & $\ldots$ & $\ldots$ & $\ldots$ & $\ldots$ & $\ldots$ & $\ldots$ & 0.006 & $\ldots$ & $\ldots$ & $\ldots$ & $\ldots$ \\
\hline$\ldots$ & 0.014 & & $\ldots$ & $\ldots$ & $\ldots$ & $\ldots$ & $\ldots$ & $\ldots$ & $\ldots$ & $\ldots$ & $\ldots$ & $\ldots$ \\
\hline 0.014 & 0.158 & 0.338 & 0.21 & 0.07 & $\ldots$ & 0.018 & $\ldots$ & $\ldots$ & 0.23 & $\ldots$ & 0.19 & $\ldots$ \\
\hline 0.0011 & 0.043 & 0.008 & 0.024 & $\ldots$ & $\ldots$ & $\ldots$ & $\ldots$ & $\ldots$ & $\ldots$ & $\ldots$ & $\ldots$ & $\ldots$ \\
\hline$\ldots$ & $\ldots$ & $\ldots$ & 0.024 & $\ldots$ & $\ldots$ & $\ldots$ & $\ldots$ & $\ldots$ & 0.15 & $\cdots$ & $\ldots$ & $\ldots$ \\
\hline$\ldots$ & $\ldots$ & $\ldots$ & 0.024 & $\ldots$ & $\ldots$ & $\ldots$ & $\ldots$ & & $\ldots$ & $\ldots$ & $\cdots$ & $\ldots$ \\
\hline 0.706 & $\begin{array}{c}\ldots \\
2.09\end{array}$ & 1.12 & 3.73 & $\ldots .54$ & $\begin{array}{l}0.6 \\
1.9\end{array}$ & 0.496 & $\cdots$ & $\begin{array}{l}0.006 \\
4.8\end{array}$ & 3.89 & $\cdots$ & $\begin{array}{l}\ldots \\
3.02\end{array}$ & 11.5 \\
\hline 800 & & & & & $\ldots$ & 0.018 & & & & & & \\
\hline .0113 & 0.014 & 0.123 & 0.84 & 0.68 & $\ldots$ & 0.037 & $\ldots$ & 0.017 & 0.53 & 3 & 0.57 & 4.3 \\
\hline .0042 & 0.043 & 0.015 & 0.05 & $\ldots$ & $\ldots$ & $\ldots$ & $\ldots$ & 0.029 & $\ldots$ & $\ldots$ & 0.38 & $\ldots$ \\
\hline 0.0125 & 0.058 & 0.454 & 0.47 & 0.14 & $\ldots$ & $\ldots$ & $\ldots$ & 0.012 & 1.14 & 2 & 1.89 & 1.4 \\
\hline$\ldots$ & $\ldots$ & $\ldots$ & 0.024 & $\ldots$ & $\ldots$ & & $\ldots$ & $\ldots$ & $\ldots$ & $\ldots$ & $\ldots$ & $\ldots$ \\
\hline$\ldots$ & $\ldots$ & $\ldots$ & $\ldots$ & $\ldots$ & $\ldots$ & 0.018 & $\ldots$ & $\ldots$ & $\ldots$ & $\ldots$ & $\cdots$ & $\ldots$ \\
\hline 0.0057 & $\ldots$ & 0.031 & 0.05 & $\ldots$ & $\ldots$ & 0.018 & $\ldots$ & & $\ldots$ & $\ldots$ & $\ldots$ & $\ldots$ \\
\hline$\ldots$ & $\ldots$ & 0.008 & 0.07 & $\ldots$ & $\ldots$ & $\ldots$ & $\ldots$ & 0.006 & $\ldots$ & $\ldots$ & 0.19 & $\ldots$ \\
\hline 00180 & $\ldots$ & & & $\cdots$ & $\cdots$ & & $\cdots$ & & & $\cdots$ & & \\
\hline 0.0189 & 0.014 & 0.092 & 0.12 & $\cdots$ & $\cdots$ & 0.018 & $\cdots$ & 0.017 & 0.08 & $\cdots$ & 0.19 & 0.7 \\
\hline$\ldots$ & 0.014 & 0.031 & $\cdots$ & $\cdots$ & $\cdots$ & 0.018 & $\ldots$ & $\ldots$ & $\cdots$ & $\cdots$ & $\ldots$ & $\cdots$ \\
\hline 0.0004 & $\cdots$ & 0.008 & $\cdots$ & $\cdots$ & $\cdots$ & $\ldots$ & $\ldots$ & $\ldots$ & $\cdots$ & $\cdots$ & $\ldots$ & $\cdots$ \\
\hline 0.0004 & $\ldots$ & 0.008 & $\cdots$ & $\cdots$ & $\cdots$ & $\cdots$ & $\ldots$ & $\ldots$ & $\cdots$ & $\cdots$ & $\cdots$ & $\cdots$ \\
\hline
\end{tabular}


Table 15, part 2 (continued).

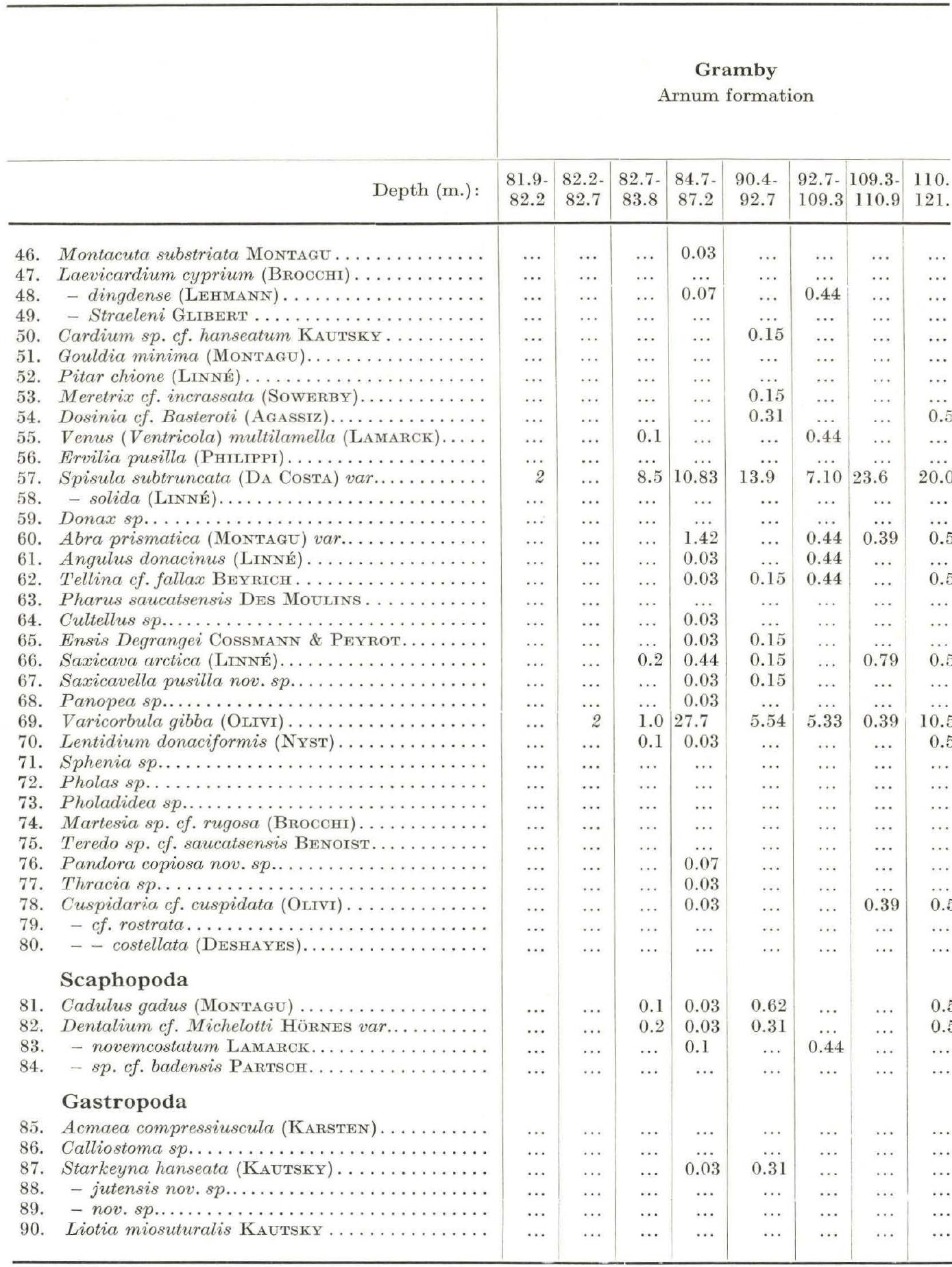


Arnum

Toftlund

Arnum formation

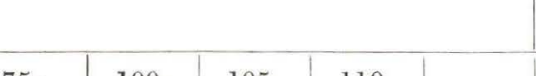

75

\begin{tabular}{|c|c|c|c|c|c|c|c|c|c|c|}
\hline $\begin{array}{c}100- \\
105\end{array}$ & $\begin{array}{c}105- \\
110\end{array}$ & $\begin{array}{c}110- \\
115\end{array}$ & 115 & $28-40$ & $53-83$ & $83-94$ & $\begin{array}{c}62.7- \\
62.9\end{array}$ & $\begin{array}{c}95.0 \\
95.3\end{array}$ & $\begin{array}{c}101.0- \\
104.3\end{array}$ & $\begin{array}{l}104.3 \\
107.5\end{array}$ \\
\hline
\end{tabular}

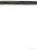

0.0011

0.0165

0.0064

0.0072

0.0004

0.0004

0.026

2.85

0.133

0.149

0.003

$\ldots$

$\cdots$

0.173

0.0004

$0 . \tilde{5}$

0.0019

.

0.0008

0.0079

0.0004

0.171

0.0068

0.0242

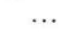

0.0061

\begin{tabular}{|c|c|}
\hline$\ldots$ & $\ldots$ \\
0.029 & 0.054 \\
0.043 & 0.038 \\
0.014 & 0.061
\end{tabular}

\begin{tabular}{l|l}
0.043 & 0.038
\end{tabular}

\begin{tabular}{|l|l|}
0.014 & 0.061 \\
\hline
\end{tabular}

\begin{tabular}{c|c|c|}
\hline$\ldots$ & $\ldots$ \\
0.058 & 0.038
\end{tabular}

\begin{tabular}{l|l}
$\ldots$ & $\ldots .14$ \\
$\ldots$ & 0.14
\end{tabular}

0.12

\begin{tabular}{l|l}
0.12 & 0.41 \\
0.14 & 0.2
\end{tabular}

0.14

\begin{tabular}{|l|l|l|l|}
\hline .058 & 0.038 & 0.024 & 0.07 \\
\hline
\end{tabular}

\begin{tabular}{c|c|c|}
$\ldots$ & $\ldots$ & $\ldots$ \\
$\ldots$ & 0.745 & 0.09 \\
\hline
\end{tabular}

\begin{tabular}{c|c|c}
$\ldots$ & $\ldots$ & $\ldots$ \\
0.014 & 0.023 & 0.07
\end{tabular}

7.61

\begin{tabular}{l|l}
0.038 & 0.43
\end{tabular}

\begin{tabular}{c|}
$\cdots$ \\
$\cdots$ \\
0.244
\end{tabular}

\begin{tabular}{l|l}
6.71 & 14.7
\end{tabular}

$\cdots$
0.208

0.008

$\begin{array}{ll}0.029 & 0.023\end{array}$

...

0.25

\begin{tabular}{l|l}
0.7 & 5.36 \\
\hline
\end{tabular}

0.14

...

\begin{tabular}{|c|c|c|c|c|c|}
\hline & & \multicolumn{4}{|c|}{ Arnum } \\
\hline \multicolumn{3}{|c|}{ Well no. 150.13} & \multicolumn{3}{|c|}{ Well no } \\
\hline ⿷ี & \multicolumn{2}{|c|}{$\begin{array}{l}\text { Arnum } \\
\text { formation }\end{array}$} & \multicolumn{3}{|c|}{ Arnum } \\
\hline $28-40$ & $53-83$ & $83-94$ & $\begin{array}{c}62.7- \\
62.9\end{array}$ & $\begin{array}{c}95.0- \\
95.3\end{array}$ & $\begin{array}{l}10 \\
1\end{array}$ \\
\hline$\cdots$ & $\cdots$ & $\ldots$ & $\cdots$ & & \\
\hline$\ldots$ & & $\ldots$ & & 0.08 & \\
\hline & 0.018 & 0.6 & 0.012 & $\ldots$ & \\
\hline 0.6 & 0.018 & $\ldots$ & 0.017 & 0.08 & \\
\hline$\ldots$ & & $\ldots$ & & & \\
\hline$\ldots$ & 0.037 & $\ldots$ & 0.029 & 0.08 & \\
\hline$\cdots$ & $\cdots$ & $\cdots$ & & & \\
\hline$\cdots$ & $\cdots$ & $\cdots$ & 0.012 & 0.84 & \\
\hline$\cdots$ & $\ldots$ & $\cdots$ & 0.006 & $\ldots$ & \\
\hline & $\ldots$ & $\ldots$ & 0.012 & 0.08 & \\
\hline 1.2 & 0.165 & $\ldots$ & 2.43 & 0.15 & \\
\hline 8.7 & 1.32 & 1.2 & 12.70 & 3.84 & \\
\hline$\cdots$ & $\cdots$ & $\cdots$ & $\cdots$ & $\cdots$ & \\
\hline$\cdots$ & & $\cdots$ & & & \\
\hline 1.9 & 0.055 & $\ldots$ & 0.585 & 0.31 & \\
\hline$\ldots$ & 0.018 & $\ldots$ & 0.029 & $\ldots$ & \\
\hline$\cdots$ & $\ldots$ & 0.6 & & $\ldots$ & \\
\hline$\cdots$ & $\ldots$ & $\cdots$ & 0.012 & $\cdots$ & \\
\hline$\cdots$ & $\cdots$ & $\cdots$ & $\cdots$ & $\cdots$ & \\
\hline $\begin{array}{l}\ldots \\
0.6\end{array}$ & 0.312 & $\begin{array}{l}\ldots \\
\ldots\end{array}$ & $0 . \overline{55}$ & $\begin{array}{c}\ldots \\
0.61\end{array}$ & \\
\hline$\ldots$ & $\ldots$ & $\ldots$ & $\ldots$ & $\ldots$ & \\
\hline$\ldots$ & $\ldots$ & $\ldots$ & $\ldots$ & & \\
\hline 1.9 & 2.53 & 1.9 & 0.84 & 1.37 & \\
\hline$\cdots$ & $\cdots$ & $\cdots$ & $\ldots$ & $\ldots$ & \\
\hline$\cdots$ & $\cdots$ & $\cdots$ & $\cdots$ & 0.08 & \\
\hline$\cdots$ & $\ldots$ & $\ldots$ & 0.006 & $\cdots$ & \\
\hline$\cdots$ & $\cdots$ & $\cdots$ & $\cdots$ & $\cdots$ & \\
\hline$\ldots$ & $\ldots$ & $\ldots$ & $\ldots$ & $\ldots$ & \\
\hline$\cdots$ & & $\cdots$ & & 0.08 & \\
\hline$\cdots$ & 0.018 & $\cdots$ & 0.006 & 0.23 & \\
\hline$\ldots$ & & $\ldots$ & & & \\
\hline$\ldots$ & 0.018 & .. & 0.162 & 0.38 & \\
\hline$\ldots$ & $\ldots$ & $\ldots$ & $\ldots$ & $\ldots$ & \\
\hline$\ldots$ & $\ldots$ & $\ldots$ & $\ldots$ & $\ldots$ & \\
\hline
\end{tabular}

(

\begin{tabular}{c|c|}
$\cdots$ & 0.008 \\
$\cdots$ & $\ldots$
\end{tabular}

\begin{tabular}{c|c|c|c|}
\hline$\ldots$ & 0.323 & 0.83 & 0.20 \\
$\cdots$ & $\ldots$ & $\ldots$ & $\ldots$ \\
$\cdots$ & 0.015 & 0.024 & 0.07 \\
$\cdots$ & $\cdots$ & $\cdots$ & $\cdots$ \\
\hline
\end{tabular}

$\cdots$
$\cdots$

0.115

0.014

$\begin{array}{ll}0.043 & 0.154\end{array}$

\begin{tabular}{l|l}
... 0.008 \\
\hline
\end{tabular}

0.014

\begin{tabular}{ll}
$0.014 \quad 0.015$ \\
\hline
\end{tabular}

$\begin{array}{ll}\text {... } & 0.192\end{array}$

\begin{tabular}{l|l}
... & 0.008
\end{tabular}

0.024

0.008

0.008

$\cdots$

$\cdots$

0.17

0.12

$\cdots$

0.14

-..

-..

0.17

0.19

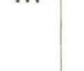

-...

\begin{tabular}{c|c}
0.1 & $\ldots$ \\
0.024 & $\cdots$ \\
$\ldots$ & $\cdots$
\end{tabular}

0.07

0.024

\begin{tabular}{|c|c|c|c|c|c|c|c|}
\hline \multicolumn{3}{|c|}{ Well no. 150.13} & \multicolumn{5}{|c|}{ Well no. $150.25 \mathrm{~b}$} \\
\hline 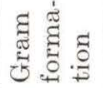 & $\begin{array}{r}\text { Ar } \\
\text { form }\end{array}$ & $\begin{array}{l}\mathrm{um} \\
\text { tion }\end{array}$ & & Arnur & a forma & tion & \\
\hline $28-40$ & $53-83$ & $83-94$ & $\begin{array}{c}62.7- \\
62.9\end{array}$ & $\begin{array}{c}95.0- \\
95.3\end{array}$ & $\begin{array}{c}101.0- \\
104.3\end{array}$ & $\begin{array}{c}104.3- \\
107.5\end{array}$ & 107.5 \\
\hline
\end{tabular}

\begin{tabular}{|c|c|c|c|c|c|c|c|}
\hline \multicolumn{8}{|c|}{ Arnum } \\
\hline \multicolumn{3}{|c|}{ Well no. 150.13} & \multicolumn{5}{|c|}{ Well no. $150.25 \mathrm{~b}$} \\
\hline$\overbrace{0}^{\pi}$ & \multicolumn{2}{|c|}{$\begin{array}{l}\text { Arnum } \\
\text { formation }\end{array}$} & \multicolumn{5}{|c|}{ Arnum formation } \\
\hline $28-40$ & $53-83$ & $83-94$ & $\begin{array}{c}62.7- \\
62.9\end{array}$ & $\begin{array}{l}95.0- \\
95.3\end{array}$ & $\begin{array}{l}101.0- \\
104.3\end{array}$ & $\begin{array}{l}104.3 \\
107.5\end{array}$ & $107 . \tilde{2}$ \\
\hline$\cdots$ & $\ldots$ & $\ldots$ & $\cdots$ & $\cdots$ & $\ldots$ & & \\
\hline$\ldots$ & & $\ldots$ & & 0.08 & $\ldots$ & 0.19 & 0.7 \\
\hline$\ldots$ & 0.018 & 0.6 & 0.012 & $\ldots$ & $\ldots$ & 0.38 & 0.7 \\
\hline 0.6 & 0.018 & $\ldots$ & 0.017 & 0.08 & 1 & 0.19 & 0.7 \\
\hline$\cdots$ & & $\cdots$ & & & $\cdots$ & & $\cdots$ \\
\hline$\ldots$ & 0.037 & $\cdots$ & 0.029 & 0.08 & $\ldots$ & 0.19 & $\ldots$ \\
\hline ... & $\ldots$ & $\ldots$ & & $\ldots$ & $\ldots$ & $\ldots$ & $\ldots$ \\
\hline$\ldots$ & $\ldots$ & $\ldots$ & 0.012 & 0.84 & $\ldots$ & $\ldots$ & $\ldots$ \\
\hline$\cdots$ & $\ldots$ & $\ldots$ & 0.006 & $\ldots$ & $\ldots$ & $\ldots$ & $\ldots$ \\
\hline$\ldots$ & $\ldots$ & $\cdots$ & 0.012 & 0.08 & $\cdots$ & $\ldots$ & $\ldots$ \\
\hline 1.2 & 0.165 & $\ldots$ & 2.43 & 0.15 & 1 & 0.19 & 0.7 \\
\hline 8.7 & 1.32 & 1.2 & 12.70 & 3.84 & 5 & 10.59 & 10.8 \\
\hline$\ldots$ & $\ldots$ & $\ldots$ & $\ldots$ & $\ldots$ & $\ldots$ & & $\ldots$ \\
\hline$\ldots$ & & $\ldots$ & & & $\ldots$ & 0.19 & $\ldots$ \\
\hline 1.9 & 0.055 & $\ldots$ & 0.585 & 0.31 & 5 & 12.65 & 2.9 \\
\hline$\ldots$ & 0.018 & $\ldots$ & 0.029 & $\ldots$ & $\ldots$ & $\ldots$ & $\ldots$ \\
\hline$\ldots$ & $\ldots$ & 0.6 & & $\ldots$ & $\ldots$ & 0.38 & 0.7 \\
\hline$\cdots$ & $\ldots$ & $\cdots$ & 0.012 & $\ldots$ & $\cdots$ & $\cdots$ & $\ldots$ \\
\hline$\ldots$ & $\cdots$ & $\cdots$ & $\cdots$ & $\ldots$ & $\cdots$ & 0.19 & $\ldots$ \\
\hline $\begin{array}{l}\ldots \\
0.6\end{array}$ & 0.312 & $\begin{array}{l}\cdots \\
\ldots\end{array}$ & 0.555 & $\begin{array}{c}\ldots \\
0.61\end{array}$ & $\cdots$ & 0.94 & $\dddot{4.3}$ \\
\hline$\ldots$ & $\ldots$ & $\cdots$ & $\ldots$ & $\ldots$ & $\ldots$ & $\ldots$ & $\ldots$ \\
\hline & & & & & $\ldots$ & & $\ldots$ \\
\hline 1.9 & 2.53 & 1.9 & 0.84 & 1.37 & 1 & 0.19 & $\ldots$ \\
\hline$\ldots$ & $\ldots$ & $\ldots$ & $\ldots$ & $\ldots$ & $\ldots$ & 0.19 & $\ldots$ \\
\hline ... & $\ldots$ & $\ldots$ & $\ldots$ & 0.08 & $\ldots$ & $\ldots$ & $\ldots$ \\
\hline$\ldots$ & $\ldots$ & $\ldots$ & 0.006 & $\ldots$ & $\ldots$ & $\ldots$ & $\ldots$ \\
\hline$\cdots$ & $\ldots$ & $\ldots$ & $\cdots$ & $\cdots$ & $\ldots$ & $\ldots$ & $\ldots$ \\
\hline$\cdots$ & $\ldots$ & $\ldots$ & $\ldots$ & $\ldots$ & $\ldots$ & $\ldots$ & $\ldots$ \\
\hline$\ldots$ & & $\ldots$ & & 0.08 & $\ldots$ & 0.19 & $\ldots$ \\
\hline$\cdots$ & 0.018 & $\ldots$ & 0.006 & 0.23 & $\ldots$ & 0.38 & $\ldots$ \\
\hline$\cdots$ & 0.018 & $\ldots$ & 0160 & 0.28 & $\cdots$ & 궁 & $\ldots$ \\
\hline$\ldots$ & $\begin{array}{c}0.010 \\
\ldots\end{array}$ & $\cdots$ & 0.162 & 0.38 & $I$ & 0.19 & 1.4 \\
\hline$\ldots$ & $\cdots$ & $\begin{array}{l}\cdots \\
\cdots\end{array}$ & $\begin{array}{l}\cdots \\
\ldots\end{array}$ & $\begin{array}{l}\cdots \\
\cdots\end{array}$ & $\begin{array}{l}\cdots \\
\ldots\end{array}$ & $\begin{array}{l}\cdots \\
\ldots\end{array}$ & $\begin{array}{l}\cdots \\
\ldots\end{array}$ \\
\hline
\end{tabular}

\begin{tabular}{|c|c|c|c|c|c|c|c|}
\hline \multicolumn{8}{|c|}{ Arnum } \\
\hline \multicolumn{3}{|c|}{ Well no. 150.13} & \multicolumn{5}{|c|}{ Well no. $150.25 \mathrm{~b}$} \\
\hline हี & \multicolumn{2}{|c|}{$\begin{array}{l}\text { Arnum } \\
\text { formation }\end{array}$} & \multicolumn{5}{|c|}{ Arnum formation } \\
\hline-40 & $53-83$ & $83-94$ & $\begin{array}{c}62.7- \\
62.9\end{array}$ & $\begin{array}{l}95.0- \\
95.3\end{array}$ & $\begin{array}{l}101.0- \\
104.3\end{array}$ & $\begin{array}{l}104.3 \\
107.5\end{array}$ & 107. \\
\hline & $\cdots$ & $\cdots$ & $\cdots$ & & $\cdots$ & & \\
\hline & 0.018 & $\begin{array}{l}\ldots \\
0.6\end{array}$ & 0.012 & $\begin{array}{c}0.08 \\
\ldots\end{array}$ & $\begin{array}{l}\cdots \\
\ldots\end{array}$ & $\begin{array}{l}0.19 \\
0.38\end{array}$ & $\begin{array}{l}0.7 \\
0.7\end{array}$ \\
\hline 0.6 & 0.018 & $\ldots$ & 0.017 & 0.08 & 1 & 0.19 & 0.7 \\
\hline & & $\cdots$ & & & & & \\
\hline & 0.037 & $\cdots$ & 0.029 & 0.08 & $\cdots$ & 0.19 & $\cdots$ \\
\hline & $\cdots$ & $\cdots$ & & $\cdots$ & $\cdots$ & $\cdots$ & $\cdots$ \\
\hline & $\cdots$ & $\cdots$ & 0.012 & 0.84 & $\cdots$ & $\cdots$ & $\cdots$ \\
\hline & $\cdots$ & $\ldots$ & 0.006 & $\ldots$ & $\ldots$ & $\ldots$ & $\cdots$ \\
\hline & $\ldots$ & $\cdots$ & 0.012 & 0.08 & $\ldots$ & $\ldots$ & $\ldots$ \\
\hline 2 & 0.165 & $\ldots$ & 2.43 & 0.15 & 1 & 0.19 & 0.7 \\
\hline 3.7 & 1.32 & 1.2 & 12.70 & 3.84 & 5 & 10.59 & 10.8 \\
\hline & $\cdots$ & $\cdots$ & $\cdots$ & $\cdots$ & $\cdots$ & $\ldots$ & $\cdots$ \\
\hline & & $\ldots$ & & $\ldots$ & $\cdots$ & 0.19 & $\ldots$ \\
\hline 1.9 & 0.055 & $\ldots$ & 0.585 & 0.31 & $\tilde{j}$ & 12.65 & 2.9 \\
\hline & 0.018 & $\ldots$ & 0.029 & $\ldots$ & $\cdots$ & & $\cdots$ \\
\hline & $\cdots$ & 0.6 & $\ldots$ & $\cdots$ & $\cdots$ & 0.38 & 0.7 \\
\hline & $\cdots$ & $\cdots$ & 0.012 & $\cdots$ & $\cdots$ & & $\ldots$ \\
\hline & $\cdots$ & $\cdots$ & $\cdots$ & $\cdots$ & $\cdots$ & 0.19 & $\cdots$ \\
\hline 0.6 & 0.312 & $\begin{array}{l}\cdots \\
\cdots\end{array}$ & 0.555 & $\begin{array}{c}\ldots \\
0.61\end{array}$ & $\cdots$ & 0.94 & $\dddot{4.3}$ \\
\hline & $\ldots$ & $\ldots$ & $\ldots$ & $\ldots$ & $\ldots$ & $\ldots$ & $\ldots$ \\
\hline & & $\ldots$ & & & $\cdots$ & & $\ldots$ \\
\hline 1.9 & 2.53 & 1.9 & 0.84 & 1.37 & 1 & 0.19 & $\ldots$ \\
\hline & $\cdots$ & $\cdots$ & $\cdots$ & $\ldots$ & $\cdots$ & 0.19 & $\cdots$ \\
\hline & $\cdots$ & $\cdots$ & 0000 & 0.08 & $\cdots$ & $\cdots$ & $\cdots$ \\
\hline & $\cdots$ & $\cdots$ & 0.000 & $\cdots$ & $\cdots$ & $\cdots$ & $\cdots$ \\
\hline & $\cdots$ & $\cdots$ & $\cdots$ & $\cdots$ & $\cdots$ & $\cdots$ & $\cdots$ \\
\hline & $\cdots$ & $\begin{array}{l}\cdots \\
\ldots\end{array}$ & & 0.08 & $\begin{array}{l}\cdots \\
\ldots\end{array}$ & 0.19 & \\
\hline & 0.018 & $\ldots$ & 0.006 & 0.23 & $\ldots$ & 0.38 & $\cdots$ \\
\hline & 0018 & $\cdots$ & 0108 & 0.9 & $\cdots$ & 0 & $\cdots$ \\
\hline & 0.018 & $\ldots$ & 0.162 & 0.38 & 1 & 0.19 & 1.4 \\
\hline & $\cdots$ & $\cdots$ & $\cdots$ & $\cdots$ & $\cdots$ & $\ldots$ & $\ldots$ \\
\hline & $\ldots$ & $\ldots$ & $\ldots$ & $\ldots$ & $\ldots$ & $\ldots$ & $\ldots$ \\
\hline
\end{tabular}

\begin{tabular}{|c|c|c|c|c|c|c|c|}
\hline \multicolumn{8}{|c|}{ Arnum } \\
\hline \multicolumn{3}{|c|}{ Well no. 150.13} & \multicolumn{5}{|c|}{ Well no. $150.25 \mathrm{~b}$} \\
\hline हี & \multicolumn{2}{|c|}{$\begin{array}{l}\text { Arnum } \\
\text { formation }\end{array}$} & \multicolumn{5}{|c|}{ Arnum formation } \\
\hline-40 & $53-83$ & $83-94$ & $\begin{array}{c}62.7- \\
62.9\end{array}$ & $\begin{array}{l}95.0- \\
95.3\end{array}$ & $\begin{array}{l}101.0- \\
104.3\end{array}$ & $\begin{array}{l}104.3 \\
107.5\end{array}$ & 107. \\
\hline & $\cdots$ & $\ldots$ & $\cdots$ & & $\cdots$ & & 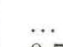 \\
\hline & 0.018 & $\begin{array}{l}\ldots .6 \\
0.6\end{array}$ & 0.012 & $\begin{array}{c}0.08 \\
\ldots\end{array}$ & $\ldots$ & $\begin{array}{l}0.19 \\
0.38\end{array}$ & $\begin{array}{l}0.7 \\
0.7\end{array}$ \\
\hline 0.6 & 0.018 & $\ldots$ & 0.017 & 0.08 & 1 & 0.19 & 0.7 \\
\hline & & $\cdots$ & & & & & $\cdots$ \\
\hline & 0.037 & $\ldots$ & 0.029 & 0.08 & $\cdots$ & 0.19 & $\cdots$ \\
\hline & $\cdots$ & $\cdots$ & & & $\cdots$ & $\cdots$ & $\cdots$ \\
\hline & $\cdots$ & $\cdots$ & 0.012 & 0.84 & $\cdots$ & $\cdots$ & $\cdots$ \\
\hline & $\ldots$ & $\cdots$ & 0.006 & $\ldots$ & $\ldots$ & $\ldots$ & .. \\
\hline & $\ldots$ & $\ldots$ & 0.012 & 0.08 & $\ldots$ & $\ldots$ & $\ldots$ \\
\hline 1.2 & 0.165 & $\ldots$ & 2.43 & 0.15 & 1 & 0.19 & 0.7 \\
\hline 8.7 & 1.32 & 1.2 & 12.70 & 3.84 & 5 & 10.59 & 10.8 \\
\hline & $\cdots$ & $\cdots$ & $\cdots$ & $\cdots$ & $\cdots$ & & $\cdots$ \\
\hline & & $\ldots$ & & & $\cdots$ & 0.19 & .. \\
\hline 1.9 & 0.055 & $\ldots$ & 0.585 & 0.31 & $\tilde{j}$ & 12.65 & 2.9 \\
\hline & 0.018 & $\ldots$ & 0.029 & $\ldots$ & $\ldots$ & $\ldots$ & $\ldots$ \\
\hline & $\ldots$ & 0.6 & & $\ldots$ & $\ldots$ & 0.38 & 0.7 \\
\hline & $\cdots$ & $\cdots$ & 0.012 & $\ldots$ & $\cdots$ & . & $\ldots$ \\
\hline & $\cdots$ & $\cdots$ & $\cdots$ & $\cdots$ & $\cdots$ & 0.19 & $\ldots$ \\
\hline 6 & 0.312 & $\begin{array}{l}\cdots \\
\ldots\end{array}$ & 0.555 & 0.61 & $\cdots$ & 0.94 & ... \\
\hline & $\ldots$ & $\ldots$ & $\ldots$ & $\ldots$ & $\ldots$ & $\ldots$ & $\ldots$ \\
\hline & & & & & $\cdots$ & & $\ldots$ \\
\hline .9 & 2.53 & 1.9 & 0.84 & 1.37 & 1 & 0.19 & $\cdots$ \\
\hline & $\ldots$ & $\ldots$ & $\ldots$ & $\ldots$ & $\ldots$ & 0.19 & $\cdots$ \\
\hline & $\ldots$ & $\ldots$ & $\ldots$ & 0.08 & $\ldots$ & $\ldots$ & $\ldots$ \\
\hline & $\ldots$ & $\ldots$ & 0.006 & $\ldots$ & $\ldots$ & $\ldots$ & $\ldots$ \\
\hline & $\cdots$ & $\cdots$ & $\cdots$ & $\cdots$ & $\cdots$ & $\cdots$ & $\ldots$ \\
\hline & $\cdots$ & $\cdots$ & $\cdots$ & $\cdots$ & $\ldots$ & $\cdots$ & $\ldots$ \\
\hline & & $\ldots$ & & 0.08 & $\cdots$ & 0.19 & $\ldots$ \\
\hline & 0.018 & $\cdots$ & 0.006 & 0.23 & $\cdots$ & 0.38 & .. \\
\hline & 0.018 & $\begin{array}{l}\cdots \\
\cdots\end{array}$ & 0.162 & 0.38 & $\cdots$ & 0.19 & i. \\
\hline & $\ldots$ & $\ldots$ & $\ldots$ & $\ldots$ & $\ldots$ & $\ldots$ & $\ldots$ \\
\hline & $\cdots$ & $\ldots$ & $\ldots$ & $\ldots$ & $\ldots$ & $\ldots$ & . \\
\hline
\end{tabular}

\begin{tabular}{|l|l|l|l}
$\ldots$ & $\ldots$ & $\ldots$ & $\ldots$ \\
$\ldots$ & $\ldots$ & $\ldots$ & 0.012 \\
$\ldots$ & $\ldots$ & $\ldots$ & 0.006
\end{tabular}

\begin{tabular}{l|l|l|l}
$\ldots$ & $\ldots$ & $\ldots$ & 0.006 \\
$\ldots$ & $\ldots$ & $\ldots$ & 0.012
\end{tabular}

\begin{tabular}{l|l|l|l}
1.2 & 0.165 & $\ldots$ & 2.43
\end{tabular}

\begin{tabular}{l|l|l|r}
8.7 & 1.32 & 1.2 & 12.70 \\
\hline
\end{tabular}

\begin{tabular}{l|l|l}
\hline$\cdots$ & $\cdots$ & $\cdots$ \\
$\cdots$ & $\cdots$ &
\end{tabular}

\begin{tabular}{c|c|c|c}
$\cdots$ & $\cdots$ & $\cdots$
\end{tabular}

\begin{tabular}{c|c|c|}
$\ldots$ & 0.018 & $\ldots$ \\
$\ldots$ & $\ldots$ & 0.6
\end{tabular}

\begin{tabular}{l|l|l}
$\cdots$ & $\cdots$ & \\
$\cdots$ & $\cdots$ & \\
$\cdots$ & $\cdots$
\end{tabular}

\begin{tabular}{l|c|c}
$\cdots$ & $\ldots$ & $\cdots$ \\
\hline 0.6 & 0.312 & $\cdots$
\end{tabular}

\begin{tabular}{l|l} 
& .6 \\
$\cdots$
\end{tabular}

$1.9 \quad 2.5$

\begin{tabular}{l|l|l}
1.9 & & \\
$\cdots$ & $\cdots$
\end{tabular}

\begin{tabular}{l|l|l}
$\ldots$ & $\ldots$ & \\
$\ldots$ & $\ldots$ & \\
$\ldots$ & $\ldots$ &
\end{tabular}

$\cdots$
$\cdots$

$\cdots$
$\cdots$

$\cdots$

\begin{tabular}{c|c|c|}
$\cdots$ & 0.018 \\
$\cdots$ & $\ldots$ & \\
$\cdots$ & 0.018 &
\end{tabular}

\begin{tabular}{c|c|c}
$\ldots$ & $\ldots$ & $\cdots$ \\
$\ldots$ & 0.018 & $\ldots$ \\
$\ldots$ & $\ldots$ & $\ldots$
\end{tabular}$$
\cdots
$$

\begin{tabular}{c|c}
$\cdots$ & 0.008 \\
$\cdots$ & $\ldots$ \\
$\cdots$ & 0.023 \\
$\cdots$ & 0.008
\end{tabular}

$\cdots$

\begin{tabular}{l|l} 
& $\cdots$ \\
\hline & $\cdots$
\end{tabular}

\begin{tabular}{l|l}
$\cdots$ & $\cdots$
\end{tabular}

$0.19 \quad \ldots$

\begin{tabular}{r|r}
10.59 & 10.8
\end{tabular}

\begin{tabular}{c|c}
$\ldots .19$ & $\cdots$
\end{tabular}

$12.65 \quad 2.9$

$0.38 \quad 0.7$

\begin{tabular}{l|l} 
& \\
.. &
\end{tabular}

\begin{tabular}{l|l}
$0.19 \quad \ldots$ \\
\hline
\end{tabular}

$0.94 \quad \dddot{4} .3$

\begin{tabular}{l|l}
... ... \\
\hline
\end{tabular}

$\begin{array}{cc}\ldots & \ldots\end{array}$

\begin{tabular}{l|l}
0.19 & $\cdots$ \\
0.19 &
\end{tabular}

$\begin{array}{ll}\ldots & \ldots\end{array}$

.. $\ldots$

․ $\quad \cdots$

$\begin{array}{ll}\cdots & \cdots \\ 0.19 & \ldots\end{array}$

$0.38 \quad \ldots$

$\begin{array}{lll}0.19 & 1.4\end{array}$

...

... ..

\begin{tabular}{l|c|c|c|c|c|c|c} 
& & & & & & & \\
1.2 & 0.551 & 1.2 & 0.122 & $\ldots$ & $\ldots$ & $\ldots$ & $\ldots$ \\
$\ldots$ & 0.018 & 0.6 & 0.035 & 0.53 & $\ldots$ & $\ldots$ & $\ldots$ \\
$\ldots$ & 0.018 & $\ldots$ & 0.006 & $\ldots$ & $\ldots$ & $\ldots$ & $\ldots$ \\
$\ldots$ & $\ldots$ & $\ldots$ & $\ldots$ & $\ldots$ & $\ldots$ & $\ldots$ & $\ldots$ \\
& & & & & & & \\
$\ldots$ & $\ldots$ & $\ldots$ & $\ldots$ & $\ldots$ & $\ldots$ & $\ldots$ & $\ldots$ \\
$\ldots$ & $\ldots$ & 0.6 & $\ldots$ & 0.08 & $\ldots$ & $\ldots$ & $\ldots$ \\
$\ldots$ & 0.018 & $\ldots$ & 0.243 & $\ldots$ & $\ldots$ & $\ldots$ & $\ldots$ \\
$\ldots$ & $\ldots$ & $\ldots$ & $\ldots$ & 0.08 & $\ldots$ & $\ldots$ & $\ldots$ \\
$\ldots$ & $\ldots$ & $\ldots$ & $\ldots$ & $\ldots$ & $\ldots$ & $\ldots$ & $\ldots$ \\
$\ldots$ & $\ldots$ & $\ldots$ & $\ldots$ & $\ldots$ & $\ldots$ & $\ldots$ & $\ldots$ \\
\hline
\end{tabular}


Table 15, part 2 (continued).

\begin{tabular}{|c|c|c|c|c|c|c|c|c|}
\hline \multirow[b]{2}{*}{ Depth (m.): } & \multicolumn{8}{|c|}{$\begin{array}{c}\text { Gramby } \\
\text { Arnum formation }\end{array}$} \\
\hline & $\begin{array}{l}81.9- \\
82.2\end{array}$ & $\begin{array}{l}82.2- \\
82.7\end{array}$ & $\begin{array}{c}82.7- \\
83.8\end{array}$ & $\begin{array}{c}84.7- \\
87.2\end{array}$ & $\begin{array}{l}90.4- \\
92.7\end{array}$ & $\begin{array}{l}92.7-1 \\
109.3\end{array}$ & $\begin{array}{r}109.3- \\
110.9\end{array}$ & \\
\hline 91. Alvania Partschi (HöRnes) . . . . . . . . . . . & ... & .. & ... & & 0.15 & .. & ... & \\
\hline 92. Rissoa Ravni nov. sp.................. & 1 & $\ldots$ & $\ldots$ & 0.03 & $\ldots$ & $\ldots$ & $\cdots$ & \\
\hline 93. cf. succincta Nysт..................... & $\ldots$ & $\ldots$ & $\ldots$ & 0.03 & $\ldots$ & $\ldots$ & $\ldots$ & \\
\hline 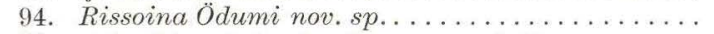 & $\ldots$ & $\ldots$ & $\ldots$ & & $\ldots$ & $\ldots$ & $\ldots$ & \\
\hline 95. Adeorbis subcirculus Cossmann \& Peyrot..... & $\ldots$ & $\ldots$ & $\ldots$ & 0.07 & $\ldots$ & $\ldots$ & $\ldots$ & \\
\hline 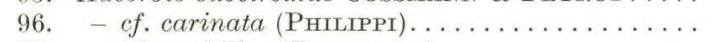 & $\ldots$ & $\ldots$ & $\ldots$ & $\ldots$ & $\ldots$ & $\ldots$ & $\ldots$ & \\
\hline 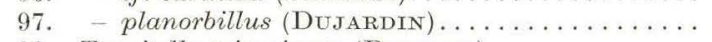 & $\ldots$ & $\cdots$ & $\ldots$ & $\ldots$ & & & & \\
\hline 98. Turritella tricarinata (ВRосСНI) ........... & $\ldots$ & $\ldots$ & $\ldots$ & $\ldots$ & 0.92 & 0.89 & 0.39 & \\
\hline 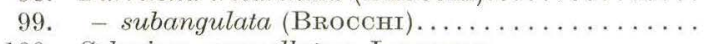 & $\ldots$ & $\ldots$ & $\cdots$ & $\cdots$ & $\ldots$ & $\ldots$ & $\ldots$ & \\
\hline 100. Solarium carocollatum LaMARCK.............. & $\cdots$ & $\cdots$ & $\ldots$ & $\ldots$ & $\ldots$ & $\ldots$ & $\ldots$ & \\
\hline 101. - trochleare nov. sp.................. & $\ldots$ & $\cdots$ & $\ldots$ & $\ldots$ & $\ldots$ & $\ldots$ & $\ldots$ & \\
\hline 102. - angustiforatum Cossmann \& PeYrot....... & $\ldots$ & $\cdots$ & $\ldots$ & $\ldots$ & $\ldots$ & $\ldots$ & $\ldots$ & \\
\hline 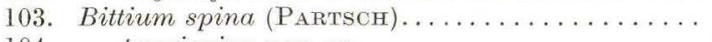 & $\cdots$ & $\cdots$ & 0.1 & & & & $\cdots$ & \\
\hline 104. - tenuispina nov. sp.................. & $\ldots$ & $\ldots$ & 0.6 & 0.88 & 0.62 & 4.89 & 0.79 & \\
\hline 105. Cerithiopsis Vignali Cossmann \& Рeyrot..... & $\ldots$ & $\ldots$ & $\ldots$ & $\ldots$ & $\ldots$ & $\ldots$ & $\ldots$ & \\
\hline 106. Triphora perversa (Linné) . . . . . . . . . . . & $\ldots$ & $\ldots$ & $\ldots$ & $\ldots$ & ... & $\ldots$ & $\ldots$ & \\
\hline 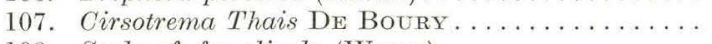 & $\cdots$ & $\ldots$ & $\ldots$ & $\ldots$ & $\cdots$ & $\cdots$ & $\ldots$ & \\
\hline 108. Scala cf. frondicula (Wood)................. & $\cdots$ & $\cdots$ & $\cdots$ & $\cdots$ & $\cdots$ & $\cdots$ & $\cdots$ & \\
\hline 109. - (Acrilla) cf. amoena РнiLippi.............. & $\cdots$ & $\cdots$ & ... & & $\cdots$ & $\cdots$ & $\cdots$ & \\
\hline 110. Janthina cimbrica nov. $s p \ldots \ldots \ldots \ldots \ldots \ldots \ldots$ & $\cdots$ & $\cdots$ & $\cdots$ & 0.03 & $\cdots$ & $\cdots$ & $\cdots$ & \\
\hline 111. Niso acarinatoconica Cossmann \& Peyrot..... & $\cdots$ & $\ldots$ & $\ldots$ & $\ldots$ & .. & $\cdots$ & $\cdots$ & \\
\hline 112. Melanella simitis (D'ORBIGNY) . . . . . . . . . & $\cdots$ & $\cdots$ & $\ldots$ & & $\ldots$ & $\ldots$ & $\ldots$ & \\
\hline 113. - taurostricta (COSSMANN \& PEYROT)......... & $\ldots$ & $\ldots$ & $\ldots$ & 0.10 & 0.15 & $\ldots$ & 0.39 & \\
\hline 114. Calyptraea chinensis (LINNÉ). . . . . . . . . . & $\ldots$ & $\ldots$ & $\ldots$ & $\ldots$ & $\ldots$ & $\ldots$ & $\ldots$ & \\
\hline 115. Xenophora Deshayesi (Мгонецотті)........... & $\ldots$ & $\ldots$ & $\ldots$ & $\ldots$ & $\ldots$ & & & \\
\hline 116. A porrhais alata (EICHWALD) . . . . . . . . . . . & 1 & 1 & 11.0 & 3.48 & 2.16 & 0.89 & 0.39 & \\
\hline 117. Natica (Lunatia) catena (DA Costa).......... & $\ldots$ & $\ldots$ & 0.9 & 0.1 & $\ldots$ & $\ldots$ & $\ldots$ & \\
\hline 118. - (Naticina) hanseata KaUtsky ............. & $\cdots$ & $\ldots$ & $\ldots$ & 0.14 & $\cdots$ & $\ldots$ & $\ldots$ & \\
\hline 119. - Beyrichi von Konnen.............. & $\ldots$ & $\ldots$ & & & $\cdots$ & $\cdots$ & $\ldots$ & \\
\hline 120. $\quad--$ protostriata nov. $s p \ldots \ldots \ldots \ldots \ldots \ldots$ & $\ldots$ & $\ldots$ & 0.1 & 0.03 & 0.15 & $\ldots$ & $\ldots$ & \\
\hline 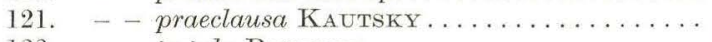 & $\ldots$ & $\ldots$ & 0.1 & 0.07 & $\ldots$ & $\ldots$ & $\ldots$ & \\
\hline 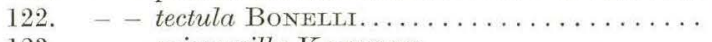 & $\ldots$ & $\ldots$ & $\ldots$ & & $\ldots$ & $\ldots$ & $\ldots$ & \\
\hline - - miopusilla KaUtSKY . ............... & $\ldots$ & $\ldots$ & $\ldots$ & 0.03 & $\ldots$ & $\ldots$ & $\ldots$ & \\
\hline 124. - - submamillaris D'ORBIGNY.. & $\ldots$ & $\ldots$ & $\ldots$ & $\ldots$ & $\ldots$ & $\ldots$ & $\ldots$ & \\
\hline 125. - (Polynices) affinis (GMELIN)............. & $\ldots$ & $\ldots$ & $\ldots$ & 0.07 & $\ldots$ & $\ldots$ & $\ldots$ & \\
\hline - (Nerita) Josephinia (Risso). . & $\ldots$ & $\ldots$ & & & $\cdots$ & $\cdots$ & $\cdots$ & \\
\hline 127. $\quad-s p \ldots \ldots \ldots \ldots \ldots \ldots \ldots \ldots$ & $\cdots$ & $\cdots$ & 0.2 & 0.51 & $\cdots$ & $\cdots$ & $\cdots$ & \\
\hline 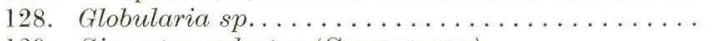 & $\ldots$ & $\ldots$ & $\ldots$ & $\cdots$ & $\cdots$ & $\cdots$ & $\cdots$ & \\
\hline 129. Sigaretus sulcatus (GRATELOUP).. & $\ldots$ & $\ldots$ & $\ldots$ & $\cdots$ & .. & $\cdots$ & $\cdots$ & \\
\hline 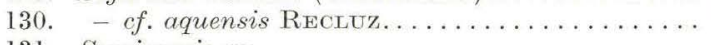 & $\cdots$ & $\cdots$ & $\cdots$ & & $\cdots$ & $\cdots$ & $\cdots$ & \\
\hline 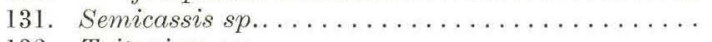 & $\cdots$ & $\cdots$ & $\ldots$ & 0.03 & $\cdots$ & $\cdots$ & $\cdots$ & \\
\hline 132. Tritonium $\operatorname{sp} \ldots \ldots \ldots \ldots \ldots \ldots \ldots \ldots \ldots \ldots \ldots$ & $\ldots$ & $\ldots$ & $\cdots$ & $\cdots$ & $\cdots$ & $\cdots$ & $\cdots$ & \\
\hline 133. Pyrula simplex Beyrich................. & $\ldots$ & $\ldots$ & $\ldots$ & & $\ldots$ & $\ldots$ & $\ldots$ & \\
\hline 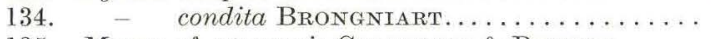 & $\ldots$ & $\ldots$ & $\ldots$ & 0.03 & $\ldots$ & $\ldots$ & $\ldots$ & \\
\hline 135. Murex cf. aturensis Cossmann \& Peyrot...... & $\ldots$ & $\ldots$ & ... & ... & $\cdots$ & $\ldots$ & .. & \\
\hline 136. - inornatus BEYRICH . . . . . . . . . . . . & $\cdots$ & $\cdots$ & $\cdots$ & $\cdots$ & $\cdots$ & $\cdots$ & $\cdots$ & \\
\hline 137. Typhis cf. horridus (Ввоссні). & $\ldots$ & $\ldots$ & & & & $\cdots$ & $\cdots$ & \\
\hline 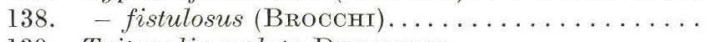 & $\cdots$ & $\cdots$ & 0.6 & 0.07 & 0.15 & $\cdots$ & $\cdots$ & \\
\hline 139. Tritonalia coelata DUJARDIN . . . . . . . . . & $\cdots$ & $\cdots$ & $\cdots$ & $\cdots$ & $\cdots$ & $\cdots$ & $\cdots$ & \\
\hline
\end{tabular}


Arnum formation

Arnum

Toftlund

A.mum formation

\begin{tabular}{|c|c|c|c|c|c|c|c|c|c|c|c|c|}
\hline & Arnt & forn & & & हี & $\begin{array}{l}\text { Arr } \\
\text { form }\end{array}$ & $\begin{array}{l}\text { m } \\
\text { ion }\end{array}$ & & Arn & forme & tion & \\
\hline $\begin{array}{l}75- \\
100\end{array}$ & $\begin{array}{l}100- \\
105\end{array}$ & $\begin{array}{l}105- \\
110\end{array}$ & $\begin{array}{l}110- \\
115\end{array}$ & 115 & $28-40$ & $53-83$ & $83-94$ & $\begin{array}{c}62.7- \\
62.9\end{array}$ & $\begin{array}{l}95.0- \\
95.3\end{array}$ & $\begin{array}{l}101.0- \\
104.3\end{array}$ & $\begin{array}{c}104.3- \\
107.5\end{array}$ & 107.5 \\
\hline 0344 & 0.043 & $\ldots$ & & & $\cdots$ & 0.092 & $\cdots$ & 0.017 & & $\cdots$ & $\cdots$ & $\ldots$ \\
\hline .0803 & 0.014 & $\ldots$ & 0.024 & 0.14 & $\cdots$ & 0.165 & $\ldots$ & 0.266 & 0.08 & $\ldots$ & $\cdots$ & $\ldots$ \\
\hline$\cdots$ & $\cdots$ & $\cdots$ & $\cdots$ & $\cdots$ & $\cdots$ & $\cdots$ & $\cdots$ & $\ldots$ & $\cdots$ & $\cdots$ & $\cdots$ & $\cdots$ \\
\hline ... & $\cdots$ & $\ldots$ & $\ldots$ & $\cdots$ & $\cdots$ & $\ldots$ & $\cdots$ & 0.006 & & $\cdots$ & $\cdots$ & $\cdots$ \\
\hline .0129 & $\cdots$ & 0.038 & 0.05 & $\cdots$ & $\cdots$ & 0.037 & $\cdots$ & $\cdots$ & 0.08 & $\cdots$ & $\cdots$ & $\cdots$ \\
\hline $\begin{array}{l}0.0034 \\
0.0129\end{array}$ & $\cdots$ & $\cdots$ & $\cdots$ & $\cdots$ & $\cdots$ & 0018 & $\cdots$ & $\cdots$ & $\cdots$ & $\cdots$ & $\cdots$ & $\cdots$ \\
\hline $\begin{array}{l}0.0129 \\
0.0829\end{array}$ & 0.115 & & 0.36 & $\begin{array}{c}\cdots \\
1.36\end{array}$ & $\cdots$ & & $\begin{array}{l}0.6 \\
0.6\end{array}$ & 4.35 & 0,61 & $\cdots$ & & $\cdots$ \\
\hline $\begin{array}{l}0.0829 \\
0.0038\end{array}$ & $\begin{array}{c}0.115 \\
\ldots\end{array}$ & $\begin{array}{l}0.108 \\
0.031\end{array}$ & $\begin{array}{r}0.36 \\
\ldots\end{array}$ & $\begin{array}{c}1.36 \\
\ldots\end{array}$ & 1.9 & 0.477 & 0.6 & 4.35 & 0.61 & 1 & 0.19 & $\cdots$ \\
\hline 0.0038 & 0.014 & $\begin{array}{l}0.031 \\
0.008\end{array}$ & $\begin{array}{l}\cdots \\
\ldots\end{array}$ & $\begin{array}{l}\cdots \\
\ldots\end{array}$ & $\cdots$ & 0.202 & $\begin{array}{l}\cdots \\
\ldots\end{array}$ & $\cdots$ & 0.08 & $\cdots$ & $\cdots$ & $\cdots$ \\
\hline 0.028 & $\begin{array}{l}0.014 \\
0.014\end{array}$ & $\begin{array}{c}0.008 \\
\ldots\end{array}$ & $\begin{array}{l}\cdots \\
\ldots\end{array}$ & $\begin{array}{l}\cdots \\
\cdots\end{array}$ & $\cdots$ & 0.055 & $\begin{array}{l}\ldots \\
\ldots\end{array}$ & $\cdots$ & $\cdots$ & $\cdots$ & $\cdots$ & $\cdots$ \\
\hline$\ldots$ & 0.014 & 0.008 & & & $\cdots$ & $\cdots$ & $\begin{array}{l}\ldots \\
\ldots\end{array}$ & $\cdots$ & $\cdots$ & $\cdots$ & $\cdots$ & $\cdots$ \\
\hline 0.067 & 0.086 & 0.015 & 0.12 & 0.14 & $\begin{array}{l}\cdots \\
\cdots\end{array}$ & 0.294 & $\ldots$ & 0.006 & $\begin{array}{c}\ldots .91 \\
0.91\end{array}$ & $\begin{array}{l}\cdots \\
\ldots\end{array}$ & $\cdots$ & $\cdots$ \\
\hline 1.135 & 1.7 & 0.254 & 0.95 & $\ldots$ & 15.5 & 8.39 & 1.2 & 26.98 & 0.31 & 1 & 1.14 & $\begin{array}{l}\cdots \\
\ldots\end{array}$ \\
\hline$\ldots$ & $\ldots$ & 0.008 & 0.05 & $\ldots$ & $\ldots$ & $\ldots$ & $\ldots$ & $\ldots$ & $\ldots$ & $\ldots$ & $\ldots$ & $\cdots$ \\
\hline$\ldots$ & $\ldots$ & 0.008 & $\ldots$ & $\ldots$ & $\ldots$ & $\ldots$ & $\ldots$ & $\ldots$ & $\ldots$ & $\ldots$ & $\ldots$ & $\ldots$ \\
\hline 0.0072 & $\ldots$ & 0.008 & $\ldots$ & $\ldots$ & $\ldots$ & $\ldots$ & $\ldots$ & $\ldots$ & $\ldots$ & $\ldots$ & $\ldots$ & $\ldots$ \\
\hline$\ldots$ & 0.014 & 0.023 & $\ldots$ & ... & $\ldots$ & $\ldots$ & $\ldots$ & $\ldots$ & $\ldots$ & $\ldots$ & $\ldots$ & $\ldots$ \\
\hline 0.0004 & $\ldots$ & 0.023 & 0.024 & 0.07 & $\ldots$ & 0.037 & $\ldots$ & $\ldots$ & 0.08 & $\ldots$ & $\ldots$ & 0.7 \\
\hline$\ldots$ & $\ldots$ & $\ldots$ & $\ldots$ & & $\ldots$ & $\ldots$ & $\ldots$ & 0.006 & $\ldots$ & 1 & $\ldots$ & $\ldots$ \\
\hline 0.0189 & 0.029 & $\ldots$ & 0.024 & 0.07 & $\ldots$ & $\cdots$ & $\ldots$ & 0.058 & $\ldots$ & $\ldots$ & $\ldots$ & $\cdots$ \\
\hline 0.0023 & $\ldots$ & $\ldots$ & $\ldots$ & $\ldots$ & $\ldots$ & $\ldots$ & $\ldots$ & $\cdots$ & $\ldots$ & $\cdots$ & $\cdots$ & $\ldots$ \\
\hline 0.0322 & $\ldots$ & 0.008 & $\ldots$ & $\ldots$ & $\ldots$ & 0.018 & 0.6 & 0.029 & $\ldots$ & $\cdots$ & $\cdots$ & $\cdots$ \\
\hline 0.0004 & 0.014 & 0.015 & $\ldots$ & 0.07 & $\ldots$ & $\ldots$ & $\ldots$ & $\ldots$ & $\ldots$ & $\ldots$ & $\ldots$ & $\ldots$ \\
\hline 0.0113 & $\ldots$ & 0.031 & 0.024 & 0.07 & $\ldots$ & $\ldots$ & $\ldots$ & 0.017 & 0.08 & $\ldots$ & $\ldots$ & 0.7 \\
\hline 4.66 & 11.49 & 8.22 & 3.81 & 9.22 & 0.6 & 0.807 & 34.6 & $\ldots$ & 20.8 & $\ldots$ & 0.57 & 0.7 \\
\hline 0.236 & 0.187 & 0.038 & 2.67 & 0.75 & $\ldots$ & 0.514 & 1.2 & $\ldots$ & $\ldots$ & $\ldots$ & 1.51 & 5.0 \\
\hline 0.112 & 0.029 & 0.031 & 0.05 & 0.14 & $\ldots$ & 0.239 & $\ldots$ & $\ldots$ & $\ldots$ & $\ldots$ & $\ldots$ & $\ldots$ \\
\hline 0.0295 & & $\ldots$ & $\ldots$ & 0.35 & $\ldots$ & & $\ldots$ & $\ldots$ & $\ldots$ & $\ldots$ & $\ldots$ & ... \\
\hline 0.076 & 0.072 & $\cdots$ & $\ldots$ & $\ldots$ & $\ldots$ & 0.220 & $\ldots$ & $\ldots$ & $\ldots$ & $\ldots$ & $\cdots$ & $\ldots$ \\
\hline 0.0768 & 0.101 & $\ldots$ & $\ldots$ & $\ldots$ & 0.6 & 0.055 & $\ldots$ & $\cdots$ & 0.08 & $\ldots$ & $\cdots$ & $\ldots$ \\
\hline 0.106 & 0.115 & 0.015 & $\ldots$ & 0.54 & $\ldots$ & 0.112 & $\ldots$ & $\ldots$ & $\ldots$ & $\cdots$ & $\cdots$ & $\ldots$ \\
\hline 0.431 & 0.072 & 0.092 & 0.21 & 1.9 & $\ldots$ & 0.073 & $\ldots$ & $\ldots$ & $\ldots$ & $\cdots$ & 1.51 & $\ldots$ \\
\hline 0.0117 & 0.014 & & $\ldots$ & $\ldots$ & $\ldots$ & & $\ldots$ & $\cdots$ & $\cdots$ & $\cdots$ & $\cdots$ & $\cdots$ \\
\hline 0.171 & $\ldots$ & 0.008 & $\ldots$ & $\ldots$ & $\ldots$ & 0.037 & 1.2 & $\cdots$ & $\cdots$ & $\cdots$ & $\cdots$ & 0.7 \\
\hline 0.0356 & & $\ldots$ & $\ldots$ & $\ldots$ & 0.6 & 0.018 & $\ldots$ & $\ldots$ & $\cdots$ & $\cdots$ & $\cdots$ & $\ldots$ \\
\hline$\ldots$ & 0.316 & 1.69 & 0.12 & 7.32 & $\cdots$ & 0.477 & 0.6 & 1.06 & 2.44 & 2 & 3.21 & 4.3 \\
\hline ( & $\cdots$ & $\cdots$ & $\cdots$ & $\cdots$ & $\ldots$ & $\cdots$ & $\ldots$ & $\ldots$ & $\cdots$ & $\cdots$ & $\cdots$ & $\ldots$ \\
\hline 0.0011 & $\ldots$ & & $\ldots$ & $\ldots$ & $\ldots$ & $\ldots$ & $\ldots$ & $\ldots$ & $\ldots$ & $\cdots$ & $\cdots$ & $\ldots$ \\
\hline 0.0011 & $\ldots$ & 0.015 & $\ldots$ & $\ldots$ & $\cdots$ & $\ldots$ & $\ldots$ & $\ldots$ & $\ldots$ & $\ldots$ & $\ldots$ & $\ldots$ \\
\hline 0.0011 & $\ldots$ & 0.008 & $\ldots$ & 0.20 & $\cdots$ & $\ldots$ & $\ldots$ & $\ldots$ & 0.08 & 1 & 0.19 & $\ldots$ \\
\hline$\ldots$ & $\ldots$ & $\ldots$ & $\ldots$ & 0.07 & $\cdots$ & $\cdots$ & $\cdots$ & $\cdots$ & $\cdots$ & $\cdots$ & $\cdots$ & $\cdots$ \\
\hline$\ldots$ & $\cdots$ & 0.008 & & & $\cdots$ & & 0.6 & & $\cdots$ & $\cdots$ & 0.19 & $\cdots$ \\
\hline $\begin{array}{l}0.0011 \\
0.0015\end{array}$ & $\ldots$ & 0.023 & 0.024 & 0.07 & $\cdots$ & $\begin{array}{l}0.018 \\
0.018\end{array}$ & $\begin{array}{l}0.6 \\
\ldots\end{array}$ & 0.006 & $\cdots$ & 1 & 0.19 & $\cdots$ \\
\hline $\begin{array}{l}0.0015 \\
0.0079\end{array}$ & 0.144 & 0.246 & 0.21 & $\begin{array}{c}\ldots \\
0.07\end{array}$ & $\begin{array}{l}\cdots \\
\ldots\end{array}$ & 0.165 & $\ldots .6$ & $\cdots$ & 0.08 & $\cdots$ & $\cdots$ & \\
\hline $\begin{array}{c}0.0079 \\
\ldots\end{array}$ & & $\begin{array}{c}0.246 \\
\ldots\end{array}$ & $\begin{array}{l}0.21 \\
0.024\end{array}$ & 0.07 & & & & $\cdots$ & 0.08 & $\cdots$ & $\cdots$ & 0.7 \\
\hline 0.0855 & 0.029 & $0 . \check{577}$ & $\begin{array}{l}0.024 \\
0.17\end{array}$ & 0.20 & $\ldots$ & 0.073 & $\ldots$ & 0.127 & 0.31 & $\begin{array}{l}\cdots \\
\cdots\end{array}$ & $\begin{array}{l}\cdots \\
\ldots\end{array}$ & $\begin{array}{l}\cdots \\
\ldots\end{array}$ \\
\hline 0.0008 & $\ldots$ & $\cdots$ & $\ldots$ & $\cdots$ & $\ldots$ & $\ldots$ & $\ldots$ & $\cdots$ & $\cdots$ & $\cdots$ & $\ldots$ & $\ldots$ \\
\hline
\end{tabular}


Table 15, part 2 (continued).

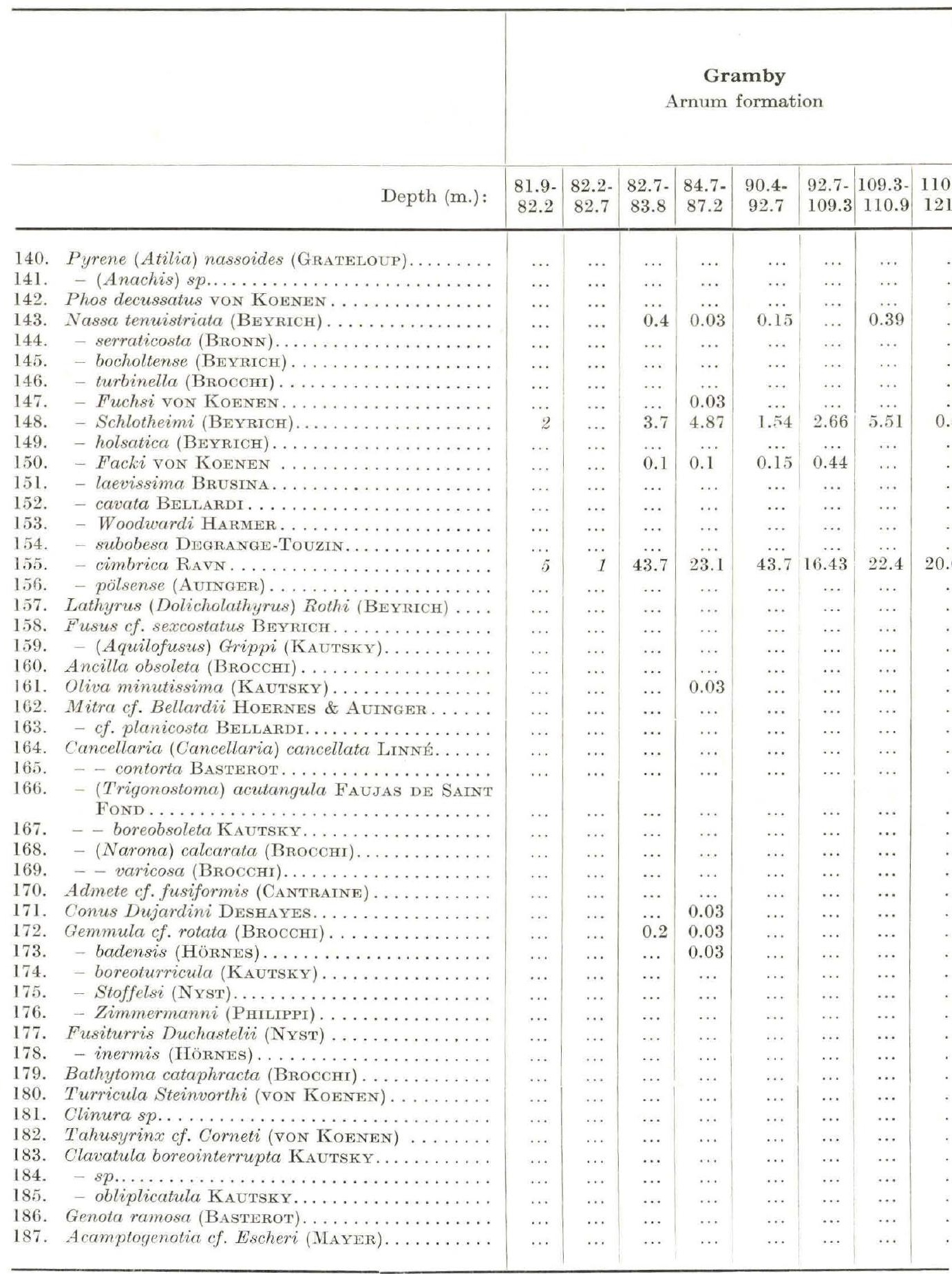


Arnum formation

Arnum

Toftlund

Arnum

\begin{tabular}{|c|c|c|c|c|c|c|c|c|c|c|c|c|}
\hline & Arnu & $\mathrm{a}$ forma & & & घี हี & $\begin{array}{l}\text { Arr } \\
\text { form }\end{array}$ & $\begin{array}{l}\text { m } \\
\text { ion }\end{array}$ & & Arnur & n forme & tion & \\
\hline $\begin{array}{l}75- \\
100\end{array}$ & $\begin{array}{l}100- \\
105\end{array}$ & $\begin{array}{c}105- \\
110\end{array}$ & $\begin{array}{l}110- \\
115\end{array}$ & 115 & $28-40$ & $53-83$ & $83-94$ & $\begin{array}{l}62.7 \\
62.9\end{array}$ & $\begin{array}{c}95.0- \\
95.3\end{array}$ & $\begin{array}{l}101.0- \\
104.3\end{array}$ & $\begin{array}{c}104.3- \\
107.5\end{array}$ & 107.5 \\
\hline .0011 & $\ldots$ & 0.008 & 0.05 & $\ldots$ & $\ldots$ & $\cdots$ & $\cdots$ & 0.006 & $\cdots$ & $\ldots$ & $\cdots$ & $\cdots$ \\
\hline$\ldots$ & $\ldots$ & 0.008 & $\ldots$ & & $\ldots$ & $\ldots$ & $\ldots$ & 0.006 & $\ldots$ & $\ldots$ & $\ldots$ & $\ldots$ \\
\hline .0064 & & 0.054 & 0.07 & 0.47 & $\ldots$ & & 0.6 & $\ldots$ & $\ldots$ & $\ldots$ & $\ldots$ & $\ldots$ \\
\hline .201 & 0.101 & 0.292 & 0.33 & 0.54 & $\ldots$ & 0.092 & 0.6 & 0.041 & 0.76 & 1 & 0.19 & $\ldots$ \\
\hline .003 & $\cdots$ & $\cdots$ & 0.024 & $\cdots$ & $\cdots$ & $\cdots$ & $\cdots$ & $\cdots$ & $\cdots$ & $\cdots$ & $\cdots$ & $\cdots$ \\
\hline$\ldots$ & $\cdots$ & $\cdots$ & $\cdots$ & $\cdots$ & $\cdots$ & $\cdots$ & $\cdots$ & $\cdots$ & $\cdots$ & $\cdots$ & $\cdots$ & $\cdots$ \\
\hline $\begin{array}{l}.0034 \\
.18\end{array}$ & $\begin{array}{c}\ldots \\
0.259\end{array}$ & $\begin{array}{c}\ldots \\
1.375\end{array}$ & $\begin{array}{l}\ldots \\
1.85\end{array}$ & $\begin{array}{l}\ldots .15 \\
\end{array}$ & $\begin{array}{l}\cdots \\
\ldots\end{array}$ & 0.165 & $\begin{array}{l}\ldots \\
1.9\end{array}$ & $\begin{array}{l}\ldots \\
\ldots\end{array}$ & $\begin{array}{c}\ldots \\
1.98\end{array}$ & $\cdots$ & 12.3 & 0.7 \\
\hline .44 & 3.14 & 10.82 & 9.06 & 9.5 & 23.6 & 4.15 & 6.2 & 6.89 & 5.11 & $\tilde{l}$ & 2.83 & 5.0 \\
\hline .0008 & $\ldots$ & & $\ldots$ & $\cdots$ & $\ldots$ & 0.018 & $\ldots$ & & & $\ldots$ & . & $\ldots$ \\
\hline .17 & 0.058 & 0.169 & 0.38 & 2.78 & $\ldots$ & 0.239 & $\ldots$ & 0.006 & 0.46 & 1 & 3.21 & 0.7 \\
\hline .0038 & $\ldots$ & $\ldots$ & $\ldots$ & $\cdots$ & $\ldots$ & 0.073 & $\ldots$ & & $\cdots$ & $\ldots$ & $\cdots$ & $\cdots$ \\
\hline .0004 & $\cdots$ & 0.054 & 0.59 & 0.81 & $\ldots$ & $\ldots$ & $\ldots$ & 0.023 & $\ldots$ & $\cdots$ & 1.32 & $\cdots$ \\
\hline$\ldots$ & $\cdots$ & $\cdots$ & 0.07 & 2.64 & $\cdots$ & $\cdots$ & $\cdots$ & $\ldots$ & $\cdots$ & $\cdots$ & $\cdots$ & $\cdots$ \\
\hline .152 & $\cdots$ & & $\cdots$ & $\cdots$ & $\cdots$ & & & $\cdots$ & 0.15 & $\cdots$ & $\cdots$ & $\ldots$ \\
\hline 5.1 & 29.8 & 44.6 & 27.0 & 13.57 & $\cdots$ & 41.8 & 21.6 & $\cdots$ & 18.4 & $\cdots$ & $\cdots$ & 2.2 \\
\hline .0008 & $\begin{array}{l}\ldots \\
\ldots\end{array}$ & 0.023 & $\ldots$ & $\ldots$ & $\cdots$ & $\begin{array}{l}\cdots \\
\ldots\end{array}$ & $\cdots$ & $\cdots$ & 0.08 & $\cdots$ & $\cdots$ & $\cdots$ \\
\hline .0034 & 0.058 & 0.077 & 0.14 & 0.27 & $\begin{array}{l}\cdots \\
\ldots\end{array}$ & 0.037 & $\begin{array}{l}\cdots \\
\cdots\end{array}$ & $\begin{array}{l}\cdots \\
\ldots\end{array}$ & $\begin{array}{c}\ldots \\
0.23\end{array}$ & $\cdots$ & $\cdots$ & $\cdots$ \\
\hline$\cdots$ & & & $\ldots$ & & $\ldots$ & & $\begin{array}{l}\cdots \\
\cdots\end{array}$ & $\begin{array}{l}\cdots \\
\cdots\end{array}$ & $\ldots$ & $\begin{array}{l}\cdots \\
\ldots\end{array}$ & $\begin{array}{l}\cdots \\
\cdots\end{array}$ & $\begin{array}{l}\cdots \\
\ldots\end{array}$ \\
\hline 0.0023 & 0.014 & 0.038 & $\ldots$ & 0.14 & $\ldots$ & 0.018 & $\ldots$ & $\ldots$ & $\ldots$ & $\ldots$ & $\ldots$ & $\ldots$ \\
\hline 0.0079 & $\ldots$ & & $\cdots$ & $\ldots$ & $\ldots$ & 0.055 & $\ldots$ & $\ldots$ & $\ldots$ & $\ldots$ & $\ldots$ & $\ldots$ \\
\hline 0.0004 & $\ldots$ & 0.008 & $\ldots$ & $\ldots$ & $\cdots$ & $\ldots$ & 1.2 & $\cdots$ & $\cdots$ & $\cdots$ & $\ldots$ & $\cdots$ \\
\hline$\cdots$ & $\cdots$ & $\cdots$ & $\cdots$ & $\ldots$ & $\cdots$ & $\cdots$ & $\cdots$ & $\cdots$ & $\cdots$ & $\ldots$ & $\ldots$ & $\cdots$ \\
\hline$\cdots$ & $\cdots$ & $\cdots$ & $\cdots$ & 0.07 & $\cdots$ & $\cdots$ & $\cdots$ & $\cdots$ & $\cdots$ & $\cdots$ & 0.38 & $\cdots$ \\
\hline$\cdots$ & $\cdots$ & $\cdots$ & $\cdots$ & $\cdots$ & $\ldots$ & $\cdots$ & 0.6 & $\cdots$ & $\cdots$ & $\cdots$ & $\cdots$ & $\cdots$ \\
\hline$\ldots$ & $\cdots$ & 0.008 & $\cdots$ & 0.07 & $\cdots$ & $\cdots$ & $\cdots$ & $\cdots$ & $\cdots$ & $\cdots$ & $\cdots$ & $\cdots$ \\
\hline$\cdots$ & $\cdots$ & $\cdots$ & $\ldots$ & 0.07 & $\ldots$ & $\cdots$ & $\cdots$ & $\cdots$ & $\cdots$ & $\cdots$ & $\cdots$ & $\cdots$ \\
\hline 0.0102 & 0.014 & 0015 & $\ldots$ & & $\cdots$ & $\begin{array}{l}\cdots \\
\ldots\end{array}$ & $\begin{array}{l}\cdots \\
0.6\end{array}$ & $\cdots$ & 0.08 & $\cdots$ & $\cdots$ & $\cdots$ \\
\hline 0.0136 & $\ldots$ & $\begin{array}{l}0.013 \\
0.1\end{array}$ & $\begin{array}{l}0.024 \\
0.07\end{array}$ & $\begin{array}{l}0.27 \\
0.07\end{array}$ & $\begin{array}{l}\cdots \\
\cdots\end{array}$ & 0.018 & $\ldots$ & 0.017 & 0.08 & $\begin{array}{l}\cdots \\
\cdots\end{array}$ & 0.57 & 0.7 \\
\hline 0.0466 & 0.043 & 0.038 & 0.024 & 0.07 & $\ldots$ & 0.129 & 0.6 & 0.006 & $\ldots$ & $\ldots$ & $\cdots$ & $\ldots$ \\
\hline 0.0934 & 0.201 & 0.261 & 0.12 & 0.20 & 0.6 & 0.018 & $\ldots$ & 0.157 & $\ldots$ & 1 & $\ldots$ & $\ldots$ \\
\hline 0.065 & 0.173 & 0.123 & 0.19 & 0.68 & $\ldots$ & 0.184 & 0.6 & $\ldots$ & 0.15 & $\ldots$ & $\ldots$ & $\ldots$ \\
\hline 0.014 & 0.014 & 0.115 & 0.33 & 2.64 & $\ldots$ & $\ldots$ & 0.6 & $\ldots$ & & $\ldots$ & 3.78 & 0.7 \\
\hline 0.0125 & $\ldots$ & 0.038 & 0.09 & 0.75 & $\ldots$ & 0.055 & 0.6 & $\ldots$ & $\ldots$ & $\ldots$ & $\cdots$ & $\ldots$ \\
\hline 0.0219 & 0.014 & 0.169 & $\begin{array}{c}\ldots \\
0.36\end{array}$ & 1.83 & $\begin{array}{l}\cdots \\
\ldots\end{array}$ & $\begin{array}{l}\cdots \\
\cdots\end{array}$ & 0.6 & 0.006 & 0.61 & $\begin{array}{l}\cdots \\
\cdots\end{array}$ & 1.51 & 0.7 \\
\hline 0.0182 & $\ldots$ & 0.038 & 0.024 & 0.07 & $\ldots$ & 0.037 & $\ldots$ & 0.006 & 0.08 & $\ldots$ & $\ldots$ & 0.7 \\
\hline .0015 & 0.014 & 0.054 & 0.17 & 0.14 & 0.6 & $\ldots$ & $\ldots$ & 0.006 & & $\ldots$ & 0.19 & $\ldots$ \\
\hline .0061 & $\ldots$ & 0.008 & $\ldots$ & 0.41 & $\ldots$ & $\cdots$ & $\ldots$ & $\ldots$ & & $\ldots$ & 0.38 & $\ldots$ \\
\hline$\cdots$ & $\cdots$ & $\cdots$ & $\cdots$ & $\cdots$ & $\cdots$ & $\cdots$ & $\cdots$ & $\cdots$ & & $\cdots$ & $\cdots$ & $\cdots$ \\
\hline$\cdots$ & $\cdots$ & & $\cdots$ & $\cdots$ & $\cdots$ & $\cdots$ & $\cdots$ & $\cdots$ & & $\cdots$ & $\cdots$ & $\cdots$ \\
\hline$\cdots$ & & 0.015 & 0.024 & $\cdots$ & $\ldots$ & 0.018 & 0.6 & 0.041 & & $\cdots$ & $\cdots$ & $\cdots$ \\
\hline$\ldots$ & 0.014 & 0.031 & $\cdots$ & $\cdots$ & $\cdots$ & $\cdots$ & $\cdots$ & 0.017 & & $\cdots$ & $\cdots$ & $\cdots$ \\
\hline .0008 & $\cdots$ & 0.015 & $\cdots$ & $\cdots$ & $\cdots$ & $\cdots$ & $\cdots$ & $\cdots$ & & $\cdots$ & $\cdots$ & $\cdots$ \\
\hline$\ldots$ & $\begin{array}{l}\cdots \\
\ldots\end{array}$ & 0.010 & $\cdots$ & $\cdots$ & $\cdots$ & $\cdots$ & $\cdots$ & $\cdots$ & & $\cdots$ & $\cdots$ & $\cdots$ \\
\hline & $\cdots$ & $\cdots$ & $\cdots$ & 0.21 & $\cdots$ & $\cdots$ & $\cdots$ & $\cdots$ & & $\cdots$ & $\cdots$ & $\cdots$ \\
\hline
\end{tabular}


Table 15, part 2 (continued).

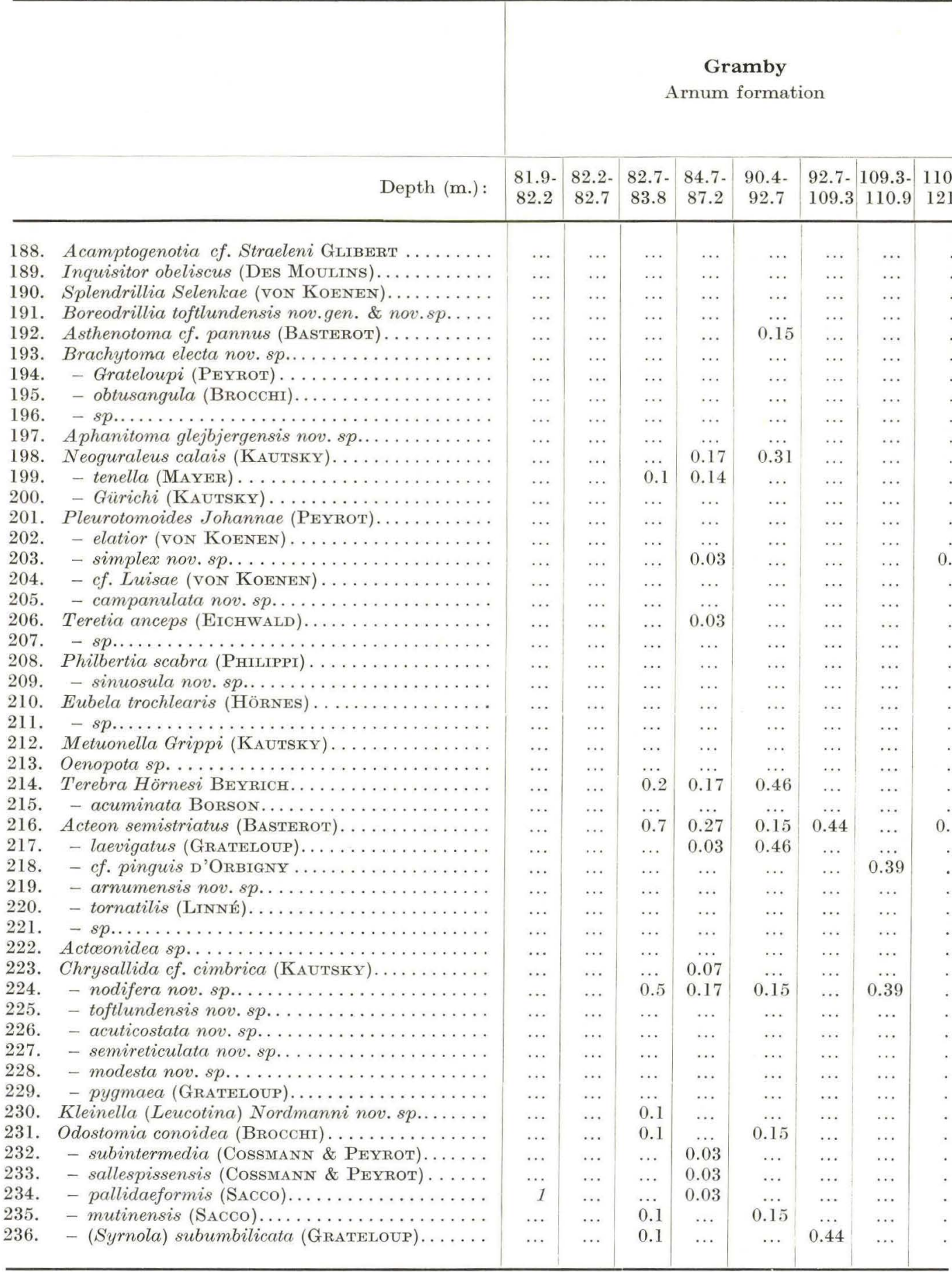




\begin{tabular}{|c|c|c|c|c|c|c|c|c|c|c|c|c|}
\hline & & & & & \multicolumn{8}{|c|}{ Arnum } \\
\hline \multirow{2}{*}{\multicolumn{5}{|c|}{$\begin{array}{c}\text { Toftlund } \\
\text { Arnum formation }\end{array}$}} & \multicolumn{3}{|c|}{ Well no. 150.13} & \multicolumn{5}{|c|}{ Well no. $150.25 \mathrm{~b}$} \\
\hline & & & & & \multirow{2}{*}{ 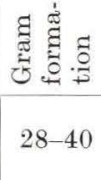 } & \multicolumn{2}{|c|}{$\begin{array}{c}\text { Arnum } \\
\text { formation }\end{array}$} & \multicolumn{5}{|c|}{ Arnum formation } \\
\hline $\begin{array}{l}75- \\
100\end{array}$ & $\begin{array}{c}100- \\
105\end{array}$ & $\begin{array}{c}105- \\
110\end{array}$ & $\begin{array}{l}110- \\
115\end{array}$ & 115 & & $53-83$ & $83-94$ & $\begin{array}{c}62.7- \\
62.9\end{array}$ & $\begin{array}{l}95.0- \\
95.3\end{array}$ & $\begin{array}{l}101.0- \\
104.3\end{array}$ & $\begin{array}{l}104.3- \\
107.5\end{array}$ & 107.5 \\
\hline & & & & 0.07 & $\cdots$ & & $\cdots$ & $\cdots$ & & $\cdots$ & & $\cdots$ \\
\hline 0.0405 & 0.043 & 0.046 & 0.09 & 0.88 & $\ldots$ & 0.112 & $\cdots$ & $\ldots$ & 0.31 & $\ldots$ & 0.19 & $\ldots$ \\
\hline 0.0004 & $\cdots$ & 0.008 & $\ldots$ & $\ldots$ & $\cdots$ & 0.018 & $\cdots$ & $\cdots$ & $\cdots$ & $\cdots$ & $\cdots$ & $\cdots$ \\
\hline 0.0061 & 0014 & $\ldots$ & 0.024 & & $\cdots$ & & $\cdots$ & $\cdots$ & $\cdots$ & $\cdots$ & & $\cdots$ \\
\hline $\begin{array}{l}0.0061 \\
0.0004\end{array}$ & 0.014 & 0.015 & 0.024 & 0.20 & $\cdots$ & 0.018 & $\ldots$ & $\ldots$ & $\ldots$ & $\cdots$ & 0.19 & $\cdots$ \\
\hline $\begin{array}{l}0.0004 \\
0.0514\end{array}$ & & & $\cdots$ & $\cdots$ & $\cdots$ & $\ldots$ & $\cdots$ & $\ldots$ & $\cdots$ & $\cdots$ & $\cdots$ & $\cdots$ \\
\hline $\begin{array}{l}0.0514 \\
0.0711\end{array}$ & 0.072 & 0.038 & $\ldots$ & $\ldots$ & $\cdots$ & 0.092 & $\cdots$ & 0.023 & $\cdots$ & $\cdots$ & $\cdots$ & $\cdots$ \\
\hline $\begin{array}{c}0.0711 \\
\ldots\end{array}$ & 0.043 & 0.284 & 0.20 & 0.08 & $\cdots$ & 0.073 & $\cdots$ & 0.035 & 0.31 & 1 & 1.89 & 1.4 \\
\hline $\begin{array}{l}\cdots \\
\cdots\end{array}$ & $\cdots$ & $\begin{array}{l}\cdots \\
\cdots\end{array}$ & $\begin{array}{l}\cdots \\
\cdots\end{array}$ & $\begin{array}{l}\cdots \\
\cdots\end{array}$ & $\begin{array}{l}\cdots \\
\cdots\end{array}$ & $\cdots$ & $\cdots$ & $\cdots$ & $\cdots$ & $\cdots$ & $\cdots$ & $\cdots$ \\
\hline 0.165 & 0.101 & 0.054 & 0.28 & 0.20 & $\ldots$ & 0.312 & $\ldots$ & $\cdots$ & 0.15 & $\cdots$ & $\cdots$ & $\begin{array}{l}\cdots \\
\ldots\end{array}$ \\
\hline 0.239 & 0.058 & 1.33 & 0.59 & 0.54 & $\ldots$ & 0.331 & $\ldots$ & 0.052 & 0.23 & $\ldots$ & $\ldots$ & 0.7 \\
\hline 0.0113 & 0.043 & 0.084 & 0.05 & 0.14 & $\cdots$ & 0.055 & $\cdots$ & $\cdots$ & 0.08 & $\cdots$ & $\cdots$ & $\cdots$ \\
\hline$\ldots$ & $\ldots$ & $\ldots$ & $\ldots$ & $\ldots$ & $\cdots$ & $\begin{array}{l}\ldots .000 \\
\ldots\end{array}$ & $\begin{array}{l}\cdots \\
\ldots\end{array}$ & $\begin{array}{l}\cdots \\
\ldots\end{array}$ & $\begin{array}{l}0.00 \\
\ldots\end{array}$ & $\begin{array}{l}\cdots \\
\ldots\end{array}$ & $\begin{array}{l}\cdots \\
\ldots\end{array}$ & $\begin{array}{l}\cdots \\
\ldots\end{array}$ \\
\hline 0.0367 & $\ldots$ & $\ldots$ & $\ldots$ & $\ldots$ & $\ldots$ & 0.055 & $\ldots$ & 0.023 & $\ldots$ & $\ldots$ & $\ldots$ & $\cdots$ \\
\hline$\cdots$ & $\cdots$ & $\ldots$ & $\cdots$ & $\cdots$ & $\cdots$ & $\ldots$ & $\cdots$ & $\cdots$ & $\cdots$ & $\ldots$ & $\cdots$ & $\ldots$ \\
\hline$\ldots$ & $\ldots$ & $\ldots$ & 0.07 & 0.07 & $\cdots$ & $\ldots$ & $\ldots$ & ... & $\cdots$ & $\cdots$ & $\ldots$ & 0.7 \\
\hline 0.0068 & $\ldots$ & $\ldots$ & $\cdots$ & $\cdots$ & $\cdots$ & 0.073 & $\ldots$ & 0.035 & $\ldots$ & $\ldots$ & $\ldots$ & $\ldots$ \\
\hline & $\ldots$ & & $\cdots$ & $\cdots$ & $\cdots$ & 0.018 & $\cdots$ & 0.023 & $\ldots$ & $\cdots$ & & $\cdots$ \\
\hline $\begin{array}{l}0.0076 \\
0.0057\end{array}$ & & 0.046 & 0.07 & 0.27 & $\cdots$ & 0.055 & $\cdots$ & $\ldots$ & $\cdots$ & $\cdots$ & 0.38 & $\ldots$ \\
\hline $\begin{array}{c}0.0007 \\
\ldots\end{array}$ & 0.043 & 0.161 & 0.07 & 0.14 & $\cdots$ & 0.018 & $\cdots$ & $\cdots$ & $\cdots$ & $\cdots$ & $\ldots$ & $\ldots$ \\
\hline$\ldots$ & 0.0 & $\cdots$ & $\cdots$ & $\cdots$ & $\cdots$ & $\cdots$ & $\cdots$ & $\cdots$ & $\cdots$ & $\cdots$ & $\cdots$ & $\cdots$ \\
\hline$\ldots$ & 0.014 & 0008 & $\cdots$ & $\cdots$ & $\cdots$ & $\cdots$ & $\cdots$ & $\cdots$ & $\cdots$ & $\cdots$ & $\cdots$ & $\cdots$ \\
\hline$\ldots$ & $\begin{array}{l}\cdots \\
\ldots\end{array}$ & $\begin{array}{c}0.000 \\
\ldots\end{array}$ & 0.024 & 0.06 & $\cdots$ & $\cdots$ & $\cdots$ & $\cdots$ & 0.08 & $\cdots$ & $\cdots$ & $\cdots$ \\
\hline 0.375 & 0.55 & 1.07 & 0.97 & 1.15 & 1.9 & 0.9 & 0.6 & 1.18 & 0.31 & $\cdots$ & 0.38 & $\begin{array}{l}\cdots \\
\ldots\end{array}$ \\
\hline & & & 0.024 & $\cdots$ & $\ldots$ & & $\ldots$ & & & $\ldots$ & $\cdots$ & $\ldots$ \\
\hline 0.201 & 0.417 & 0.323 & 0.76 & 0.34 & 0.6 & 0.55 & $\ldots$ & 0.064 & 0.31 & $\ldots$ & 0.75 & $\ldots$ \\
\hline 0.037 & 0.014 & $\ldots$ & $\ldots$ & $\ldots$ & $\cdots$ & $\ldots$ & $\ldots$ & $\ldots$ & $\cdots$ & $\cdots$ & $\ldots$ & $\cdots$ \\
\hline$\ldots$ & $\cdots$ & $\ldots$ & $\ldots$ & 0.14 & $\cdots$ & & $\ldots$ & $\cdots$ & $\cdots$ & $\cdots$ & $\cdots$ & $\cdots$ \\
\hline & 0.014 & $\cdots$ & $\cdots$ & $\cdots$ & $\cdots$ & 0.055 & $\cdots$ & 0.261 & $\ldots$ & $\cdots$ & $\ldots$ & $\cdots$ \\
\hline 0.0019 & $\cdots$ & $\cdots$ & $\ldots$ & $\cdots$ & $\cdots$ & $\cdots$ & $\ldots$ & $\cdots$ & $\cdots$ & $\ldots$ & $\ldots$ & $\cdots$ \\
\hline 0.0019 & $\ldots$ & $\ldots$ & $\cdots$ & $\cdots$ & $\cdots$ & $\cdots$ & $\cdots$ & $\cdots$ & $\cdots$ & $\cdots$ & $\cdots$ & $\cdots$ \\
\hline 0.0011 & $\ldots$ & $\ldots$ & & 0.07 & $\cdots$ & $\ldots$ & $\cdots$ & & $\cdots$ & $\cdots$ & $\cdots$ & $\cdots$ \\
\hline 0.0291 & 0.014 & 0.061 & 0.024 & $\ldots$ & 0.6 & 0.073 & $\ldots$ & 0.318 & $\cdots$ & $\cdots$ & $\cdots$ & $\cdots$ \\
\hline 0.128 & 0.115 & 0.008 & 0.12 & $\cdots$ & $\cdots$ & 0.98 & $\cdots$ & 0.65 & 0.08 & $\cdots$ & $\cdots$ & 0.7 \\
\hline 0.0004 & $\ldots$ & $\ldots$ & $\cdots$ & $\cdots$ & $\cdots$ & $\cdots$ & $\cdots$ & & $\cdots$ & $\cdots$ & $\cdots$ & $\cdots$ \\
\hline 0.0008 & $\cdots$ & 0.008 & $\cdots$ & $\cdots$ & $\cdots$ & $\cdots$ & $\cdots$ & 0.09 & $\cdots$ & $\cdots$ & $\cdots$ & $\cdots$ \\
\hline$\ldots$ & $\cdots$ & $\ldots$ & $\cdots$ & $\begin{array}{l}\cdots \\
\ldots\end{array}$ & $\cdots$ & … & $\cdots$ & 0.012 & $\cdots$ & $\cdots$ & $\cdots$ & $\cdots$ \\
\hline 0.0231 & $\cdots$ & 0.008 & $\cdots$ & 0.14 & $\begin{array}{l}\cdots \\
\ldots\end{array}$ & $\begin{array}{l}0.037 \\
0.037\end{array}$ & $\cdots$ & 0.058 & $\cdots$ & $\cdots$ & $\cdots$ & $\cdots$ \\
\hline ำ & $\ldots$ & 0.008 & $\begin{array}{l}\ldots \\
\ldots\end{array}$ & $\ldots$ & $\begin{array}{l}\cdots \\
\cdots\end{array}$ & $\begin{array}{l}0.037 \\
0.037\end{array}$ & $\begin{array}{l}\cdots \\
\ldots\end{array}$ & $\cdots$ & $\begin{array}{c}\cdots \\
0.08\end{array}$ & $\cdots$ & 0.19 & $\cdots$ \\
\hline 0.0522 & $\begin{array}{l}0.029 \\
0.316\end{array}$ & 0.015 & 0.73 & $0.4 \mathrm{I}$ & $\begin{array}{l}\cdots \\
\cdots\end{array}$ & $\begin{array}{l}0.037 \\
0.055\end{array}$ & $\begin{array}{l}\cdots \\
\ldots\end{array}$ & 0.017 & $\begin{array}{l}0.08 \\
0.46\end{array}$ & 1 & 0.38 & $\dddot{0.7}$ \\
\hline $\begin{array}{c}0.0847 \\
\ldots\end{array}$ & 0.316 & $\begin{array}{c}0.346 \\
\ldots\end{array}$ & 0.73 & $\ldots$ & $\ldots$ & $\begin{array}{l}0.005 \\
0.055\end{array}$ & $\begin{array}{l}\cdots \\
\cdots\end{array}$ & $\begin{array}{l}0.017 \\
0.255\end{array}$ & $\begin{array}{c}0.40 \\
\ldots\end{array}$ & $\begin{array}{l}I \\
\ldots\end{array}$ & $\begin{array}{l}0.00 \\
\ldots\end{array}$ & $\ldots$. \\
\hline 0.0284 & 0.043 & 0.008 & 0.05 & $\ldots$ & $\ldots$ & 0.220 & $\ldots$ & 0.029 & $\ldots$ & $\ldots$ & $\ldots$ & $\ldots$ \\
\hline 0.0284 & 0.029 & 0.064 & 0.048 & $\ldots$ & $\ldots$ & 0.239 & $\ldots$ & 0.313 & $\ldots$ & $\ldots$ & $\ldots$ & $\ldots$ \\
\hline 0.0473 & 0.058 & 0.267 & 0.352 & 0.07 & $\ldots$ & 0.055 & $\ldots$ & 0.029 & 0.15 & $\ldots$ & $\ldots$ & 0.7 \\
\hline 0.0231 & 0.043 & 0.008 & 0.05 & $\ldots$ & $\ldots$ & 0.112 & $\ldots$ & 0.017 & $\ldots$ & $\ldots$ & $\ldots$ & $\ldots$ \\
\hline
\end{tabular}


Table 15, part 2 (continued).

\begin{tabular}{|c|c|c|c|c|c|c|c|c|}
\hline Depth.(m.): & $\begin{array}{c}81.9- \\
82.2\end{array}$ & $\begin{array}{c}82.2- \\
82.7\end{array}$ & $\begin{array}{c}82.7- \\
83.8\end{array}$ & $\begin{array}{c}84.7- \\
87.2\end{array}$ & $\begin{array}{l}90.4- \\
92.7\end{array}$ & $\begin{array}{l}92.7- \\
109.3\end{array}$ & $\begin{array}{r}109.3- \\
110.9\end{array}$ & $\begin{array}{c}110.9 \\
121 .\end{array}$ \\
\hline 237. Odostomia (Syrnola) dubia (Grateloup) ...... & & $\cdots$ & $\cdots$ & & $\cdots$ & $\cdots$ & $\cdots$ & \\
\hline 238. Eulimella concinna nov. sp............... & $\ldots$ & $\ldots$ & $\ldots$ & 0.03 & $\cdots$ & $\ldots$ & $\ldots$ & \\
\hline 239. - Scillae (ScAcCHI) . . . . . . . . . . . . . & $\ldots$ & $\ldots$ & $\ldots$ & $\ldots$ & $\cdots$ & $\ldots$ & $\ldots$ & \\
\hline 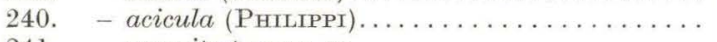 & $\ldots$ & $\ldots$ & $\ldots$ & $\ldots$ & ... & $\ldots$ & $\cdots$ & \\
\hline 241. - crassitesta nov sp................. & $\cdots$ & $\cdots$ & .. & $\cdots$ & & $\cdots$ & .. & \\
\hline 242. Turbonilla costellata (Grateloup)............ & $\ldots$ & $\ldots$ & ... & ... & 0.15 & ... & ... & \\
\hline 243. - lactea (LINNÉ) . . . . . . . . . . . . . . . & $\cdots$ & $\cdots$ & $\cdots$ & & 0.15 & , & $\cdots$ & \\
\hline 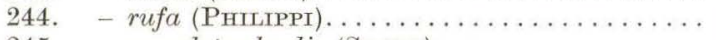 & ... & .. & $\ldots$ & 0.03 & ... & 0.44 & $\cdots$ & \\
\hline 245. - pseudoterebralis $\left(\mathrm{SACCO}_{1}\right) \ldots \ldots \ldots \ldots \ldots \ldots$ & $\cdots$ & $\cdots$ & $\cdots$ & $\cdots$ & $\cdots$ & $\cdots$ & $\cdots$ & \\
\hline 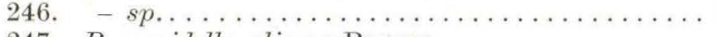 & $\cdots$ & $\cdots$ & $\cdots$ & & & & $\cdots$ & \\
\hline 247. Pyramidella plicosa Bronn . . . . . . . . . . . & $\cdots$ & $\cdots$ & $\cdots$ & 0.07 & 0.15 & 0.44 & $\cdots$ & \\
\hline 248. Ringicula ventricosa (SowerBy) ............. & $\cdots$ & $\cdots$ & $\cdots$ & $\cdots$ & $\ldots$ & . & & \\
\hline 249. - buccinea (BRоссні) . . . . . . . . . . . & $\cdots$ & 1 & 6.9 & 3.69 & 2.31 & 5.77 & 0.79 & \\
\hline 250. - Ravni nov. sp........... & $\cdots$ &. & $\cdots$ & $\cdots$ & $\cdots$ & $\ldots$ & 0.39 & \\
\hline 251. Cylichna cf. cylindracea (Pennant).......... & ... & ... & .. & $\cdots$ & . & $\cdots$ & $\cdots$ & \\
\hline 252. - Bellardi (von Koenen)............. & $\ldots$ & $\ldots$ & $\ldots$ & $\therefore$ & $\ldots$ & $\ldots$ & $\ldots$ & \\
\hline 253. Rhizorus acuminatus (BRUGUIÈRE) . . . . . . . & 1 & $\ldots$ & 0.2 & 0.17 & & $\ldots$ & - & \\
\hline 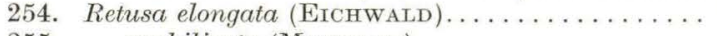 & $\ldots$ & $\cdots$ & $\ldots$ & 0.17 & 0.31 & $\ldots$ & 0.39 & \\
\hline 255. - umbilicata (MonTAGU)................ & $\cdots$ & $\ldots$ & $\cdots$ & 0.41 & 0.15 & 2.22 & $\cdots$ & \\
\hline 256. - obtusa (MoNTAGU) . . . . . & $\cdots$ & $\cdots$ & $\cdots$ & $\cdots$ & $\cdots$ & $\cdots$ & $\cdots$ & \\
\hline 257. Acteocina sp........... & $\cdots$ & $\cdots$ & $\ldots$ & $\cdots$ & $\cdots$ & $\cdots$ & $\cdots$ & \\
\hline 258. - Lajonkaireana (BASTEROT) . . . . . . . & $\cdots$ & $\cdots$ & $\cdots$ & 0.03 & $\cdots$ & $\cdots$ & $\cdots$ & \\
\hline 259. Scaphander lignarius (LINNÉ)... & . & $\cdots$ & $\cdots$ & $\cdots$ & $\cdots$ & $\cdots$ & $\cdots$ & \\
\hline 260. Roxania utriculus (ВRосснI)... & . & . & 0.4 & 0.1 & $\cdots$ & $\cdots$ & $\cdots$ & \\
\hline 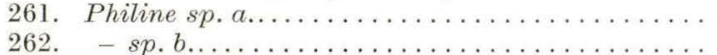 & . & $\because$ & $\begin{array}{l}\cdots \\
\cdots\end{array}$ & 0.03 & & $\begin{array}{l}\cdots \\
\cdots\end{array}$ & $\begin{array}{l}\cdots \\
\ldots\end{array}$ & \\
\hline 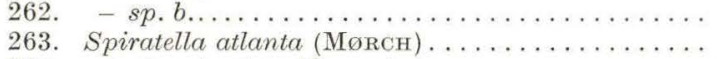 & $\ddot{5}$ & $\cdots$ & $\dddot{2.7}$ & 3.05 & 0.62 & 0.89 & 24.4 & \\
\hline 264. - cf. valvatina (Reuss)................. & $\ldots$ & $\ldots$ & $\ldots$ & 0.68 & $\ldots$ & $\ldots$ & $\ldots$ & \\
\hline 265. Clio sn.............. & & $\cdots$ & $\ldots$ & $0-1$ & & $\ldots$ & & \\
\hline 266. Vaginella depressa DAUdIN.. & 2 & $\cdots$ & 2.6 & 2.71 & 2.46 & 6.22 & 1.97 & \\
\hline Sum total per cent.......... & $\cdots$ & $\cdots$ & 99.3 & 99.9 & 100.04 & 99.93 & 99.89 & \\
\hline Percentage share of 1 specimen... & $\cdots$ & ... & 0.1 & 0.03 & 0.15 & 0.44 & 0.39 & \\
\hline Sum total of specimens $(=100 \%) \ldots \ldots \ldots \ldots$ & 25 & 6 & 810 & 2954 & 650 & 225 & 254 & \\
\hline
\end{tabular}




\begin{tabular}{|c|c|c|c|c|c|c|c|c|c|c|c|c|}
\hline & & & & & \multicolumn{8}{|c|}{ Arnum } \\
\hline \multirow{2}{*}{\multicolumn{5}{|c|}{$\begin{array}{c}\text { Toftlund } \\
\text { Arnum formation }\end{array}$}} & \multicolumn{3}{|c|}{ Well no. 150.13} & \multicolumn{5}{|c|}{ Well no. $150.25 \mathrm{~b}$} \\
\hline & & & & & \multirow{2}{*}{ 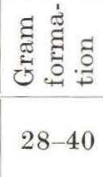 } & \multicolumn{2}{|c|}{$\begin{array}{l}\text { Arnum } \\
\text { formation }\end{array}$} & \multicolumn{5}{|c|}{ Arnum formation } \\
\hline $\begin{array}{l}75- \\
100\end{array}$ & $\begin{array}{l}100- \\
105\end{array}$ & $\begin{array}{c}105- \\
110\end{array}$ & $\begin{array}{l}110- \\
115\end{array}$ & 115 & & $53-83$ & $83-94$ & $\begin{array}{l}62.7- \\
62.9\end{array}$ & $\begin{array}{c}95.0- \\
95.3\end{array}$ & $\begin{array}{l}101.0- \\
104.3\end{array}$ & $\begin{array}{l}104.3- \\
107.5\end{array}$ & 107.5 \\
\hline 0.0023 & 0.043 & 0.208 & 0.26 & 0.07 & $\begin{array}{l}\ldots \\
\ldots\end{array}$ & 0.018 & 0.6 & 0.017 & 0.15 & $\begin{array}{l}\cdots \\
\ldots\end{array}$ & 0.38 & $\begin{array}{l}\cdots \\
\cdots\end{array}$ \\
\hline ... & $\ldots$ & 0.015 & $\ldots$ & $\ldots$ & $\cdots$ & $\ldots$ & $\ldots$ & & 0.08 & $\ldots$ & $\ldots$ & $\ldots$ \\
\hline$\cdots$ & $\cdots$ & $\cdots$ & $\cdots$ & $\cdots$ & $\cdots$ & 0.018 & $\cdots$ & 0.006 & $\cdots$ & $\ldots$ & $\ldots$ & $\ldots$ \\
\hline$\ldots$ & $\cdots$ & $\cdots$ & $\cdots$ & $\cdots$ & $\cdots$ & $\ldots$ & $\cdots$ & & $\cdots$ & $\cdots$ & $\cdots$ & $\cdots$ \\
\hline .0026 & $\ldots$ & $\cdots$ & $\ldots$ & $\ldots$ & $\ldots$ & 0.018 & $\ldots$ & 0.017 & & $\ldots$ & & $\ldots$ \\
\hline 0.0038 & 0.029 & 0.131 & 0.05 & 0.07 & 0.6 & 0.037 & $\ldots$ & 0.116 & 0.23 & $\ldots$ & 0.19 & $\cdots$ \\
\hline 0.0117 & 0.014 & $\ldots$ & 0.024 & $\cdots$ & $\cdots$ & 0.055 & $\cdots$ & 0.012 & $\ldots$ & $\cdots$ & $\cdots$ & $\cdots$ \\
\hline 0.0057 & $\cdots$ & 0.015 & $\cdots$ & 0.07 & $\cdots$ & $\cdots$ & $\cdots$ & $\cdots$ & 0.84 & $\cdots$ & $\cdots$ & $\cdots$ \\
\hline$\ldots$ & 6 & & 0.024 &. & $\cdots$ & & $\cdots$ & & $\cdots$ & $\cdots$ & 0.8 & $\cdots$ \\
\hline $\begin{array}{c}0.0424 \\
\ldots\end{array}$ & $\begin{array}{c}0.086 \\
\ldots\end{array}$ & $\begin{array}{c}0.131 \\
\ldots\end{array}$ & 0.12 & $\begin{array}{l}0.81 \\
0.07\end{array}$ & $\ldots$ & 0.257 & $\cdots$ & 0.023 & 0.15 & $\cdots$ & 0.38 & $\cdots$ \\
\hline 3 & 3.35 & 0.369 & 0.54 & 1.36 & 5.6 & 2.52 & $\cdots$ & 4.31 & 0.91 & 1 & 1.70 & $\begin{array}{l}\cdots \\
\ldots\end{array}$ \\
\hline$\ldots$ & $\ldots$ & 1.09 & 1.37 & 0.88 & $\ldots$ & & 0.6 & & $\ldots$ & 2 & 0.94 & $\ldots$ \\
\hline 0.084 & $\ldots$ & $\ldots$ & 0.05 & $\ldots$ & $\ldots$ & 0.018 & $\ldots$ & 0.098 & $\ldots$ & $\ldots$ & $\ldots$ & $\ldots$ \\
\hline $0 . \ddot{245}$ & 0.345 & $0 . \ddot{806}$ & 0.66 & 0.75 & $\begin{array}{l}\ldots \\
1.9\end{array}$ & 0.496 & $\ldots$ & 0.046 & 0.76 & ${ }_{1}$ & 0.19 & $\dddot{0.7}$ \\
\hline 0.099 & 0.101 & 0.115 & 0.38 & 0.95 & $\ldots$ & 0.459 & $\ldots$ & 0.041 & 0.61 & $\ldots$ & 0.19 & $\ldots$ \\
\hline 0.127 & 0.517 & 0.231 & 0.73 & 0.27 & 2.5 & 0.974 & $\ldots$ & 1.57 & 0.91 & $\ldots$ & 0.38 & 2.2 \\
\hline 0.0004 & $\ldots$ & $\ldots$ & $\ldots$ & $\ldots$ & $\ldots$ & $\cdots$ & $\ldots$ & & & $\ldots$ & & $\ldots$ \\
\hline$\ldots$ & 0.014 & 0.008 & $\ldots$ & $\ldots$ & $\ldots$ & 0.037 & $\ldots$ & 0.017 & 0.23 & $\ldots$ & 0.19 & $\ldots$ \\
\hline 0.0333 & $\ldots$ & 0.008 & 0.17 & - & $\ldots$ & 0.037 & $\ldots$ & 0.006 & 0.08 & $\ldots$ & & $\ldots$ \\
\hline 0.0004 & 0.014 & 0.054 & 0.05 & 0.27 & & $\ldots$ & $\ldots$ & $\ldots$ & 0.08 & $\ldots$ & 0.19 & $\ldots$ \\
\hline 0.175 & 0.187 & 0.254 & 0.14 & 0.33 & ... & 0.275 & 0.6 & 0.052 & 0.15 & 1 & 0.57 & 0.7 \\
\hline$\cdots$ & $\cdots$ & & $\ldots$ & $\ldots$ & $\cdots$ & $\ldots$ & $\cdots$ & $\ldots$ & $\cdots$ & $\ldots$ & $\ldots$ & $\cdots$ \\
\hline$\cdots$ & $\ldots$ & 0.008 & & $\cdots$ & $\cdots$ & $\ldots$ & $\ldots$ & $\ldots$ & & $\cdots$ & $\ldots$ & $\ldots$ \\
\hline 0.0178 & 0.058 & 0.054 & 0.12 & $\cdots$ & 0.6 & 1.87 & $\ldots$ & 6.92 & 0.69 & 5 & 0.94 & 0.7 \\
\hline$\cdots$ & $\cdots$ & $\cdots$ & $\cdots$ & $\cdots$ & $\cdots$ & $\cdots$ & $\cdots$ & $\ldots$ & 0.61 & $\cdots$ & $\cdots$ & $\cdots$ \\
\hline 1.78 & 1.63 & 0.215 & 0.99 & 0.61 & 1.2 & $0.7 \ddot{35}$ & $\dddot{2.5}$ & $\begin{array}{l}0.023 \\
0.794\end{array}$ & 0.31 & $\cdots$ & 3.78 & $\dddot{0.7}$ \\
\hline 9.9317 & 100.553 & 100.412 & 99.062 & 100.06 & 99.8 & 101.262 & 99.4 & 100.077 & 100.21 & $\ldots$ & 99.98 & 99.2 \\
\hline 0.0004 & 0.014 & 0.008 & 0.024 & 0.07 & 0.6 & 0.018 & 0.6 & 0.006 & 0.08 & $\ldots$ & 0.19 & 0.7 \\
\hline 64167 & 6951 & 13022 & 4226 & 1474 & 161 & 5449 & 162 & 17266 & 1311 & 74 & 529 & 139 \\
\hline
\end{tabular}


Table 16. The Frequencies of Abundan

Roman types: per cent

\begin{tabular}{|c|c|c|c|c|c|c|c|c|c|c|c|c|c|}
\hline \multirow[b]{2}{*}{ Depth (m.): } & \multicolumn{12}{|c|}{$\begin{array}{c}\text { Glejbjerg } \\
\text { Arnum formation }\end{array}$} & \multirow{2}{*}{ 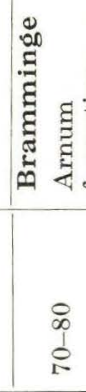 } \\
\hline & $\approx$ & â & $\cong$ & $\stackrel{\infty}{\bullet}$ & $\stackrel{9}{7}$ & $\stackrel{\infty}{\rightarrow}$ & ชิ & i̊ & 10. & î & 20 & 20 & \\
\hline 1. Nucula nucleus (LinNÉ) . . . . . . . . . . . . . . . & & & & $\cdots$ & $\ldots$ & & $\cdots$ & $\cdots$ & 0.1 & $\ldots$. & $\cdots$ & & 0.00 \\
\hline 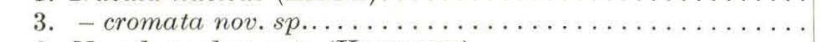 & 0.5 & 0.7 & 7.9 & $\ldots$ & & & $\cdots$ & $\cdots$ & $\ldots$ & $\ldots$ & $\cdots$ & 0.3 & 0.01 \\
\hline 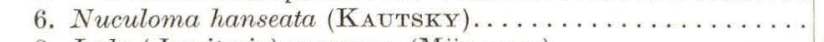 & & 0.4 & 1.0 & 1.3 & 0.9 & & $\cdots$ & 7.9 & 0.9 & 1.2 . & ... & 0.3 & 0.11 \\
\hline 8. Leda (Jupiteria) pygmaea (MǗnster) . . . . . . . . . . & 21.1 & 17.5 & $\ldots$ & $\ldots$ & 16.1 . & ... & $\cdots$ & $\ldots$ & 0.2 & $\ldots$. & $\cdots$ & 1.0 & 7.92 \\
\hline 9. - (Ledina) Westendorpii (NYST \&WESTENDORP) . . . . . . & 0.2 & 0.2 & 0.8 & 1.3 & $\ldots$ & ... & $\cdots$ & $\ldots$ & 0.1 & 0.3 & 1 & 0.3 & 0.51 \\
\hline 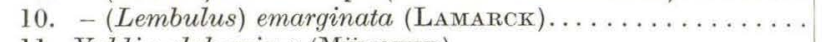 & $\ldots$ & & 1.3 & $\ldots$ & $\ldots$ & & ... & $\ldots$ & $\ldots$ & $\ldots$. & $\cdots$ & & \\
\hline 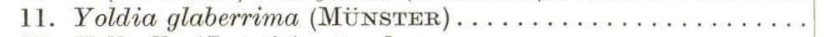 & 2.5 & 3.9 & 1.5 & 2.6 & 1.7 & 1 & 1 & 2.9 & 5.6 & 5.4 & 1 & 8.3 & 3.19 \\
\hline 32. Kellyella (Lutetia) rotunda nov. sp.............. & $0 . \tilde{5}$ & 1.1 & 5.4 & $\ldots$ & 1.7 & $\ldots$ & 1 & $\ldots$ & 0.1 & $\ldots$. & $\ldots$ & $\ldots$ & 0.03 \\
\hline 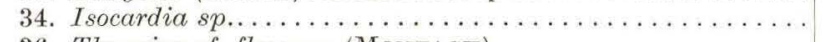 & 0.2 & 0.2 & $\ldots$ & $\ldots$ & 0.9 & ... & $\ldots$ & 0.7 & 0.1 & $\ldots$. & $\cdots$ & 0.3 & 0.01 \\
\hline 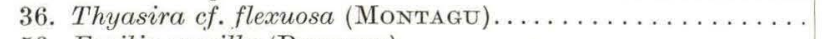 & $\ldots$ & $\ldots$ & 0.3 & $\ldots$ & $\ldots$ & & $\ldots$ & $\ldots$ & 0.1 & $\ldots$. & ... & $\ldots$ & \\
\hline ๖6. Ervilia pusilla (PHILIPPI)..................... & $\ldots$ & $\ldots$ & & $\cdots$ & & & & $\ldots$ & $\ldots$ & $\ldots$. & ... & . & \\
\hline 57. Spisula subtruncata (DA Costa) var............... & 1.6 & 1.1 & 2.3 & 1.3 & 12.7 & $\ldots$ & 2 & 4.3 & 3.8 & 2.7 & 1 & 3.2 & 0.30 \\
\hline 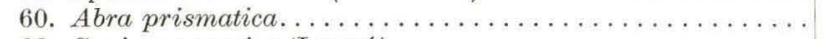 & 0.5 & 0.7 & 0.8 & $\ldots$ & 11.9 & $\ldots$ & 3 & 3.6 & 2.9 & 1.8 & 1 & 1.3 & 0.05 \\
\hline 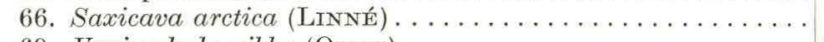 & 0.8 & 0.2 & 0.3 & $\ldots$ & 4.2 & $\ldots$. & $\ldots$ & $\ldots$ & 0.1 & 0.3 . & ... & $\ldots$ & 0.04 \\
\hline 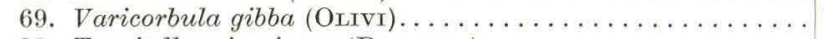 & 15.9 & 11.3 & $\ldots$ & $\ldots$ & 0.9 & ... & 1 & 2.2 & 1.9 & 1.8 . & ... & 2.5 & 7.88 \\
\hline 98. Turritella tricarinata (BRocCHI) . . . . . . . . . . . & 0.2 & 0.2 & $\ldots$ & $\ldots$ & $\ldots$ & $\ldots$ & $\ldots$ & $\ldots$ & $\ldots$ & $\ldots$ & $\ldots$ & 0.3 & 0.41 \\
\hline 104. Bittium tenuispina nov. sp.................. & 1.1 & 0.4 & & $\ldots$ & $\ldots$ & ... & $\ldots$ & & $\ldots$ & & $\ldots$ & 0.3 & 0.5 \\
\hline 116. A porrhais alata (EтснWAID). . . . . . . . . . . & 2.3 & 1.1 & 31.5 & 1.3 & $\ldots$ & .. & 9 & 51.7 & 31.0 & 24.7 & 4 & 36.5 & 42.4 \\
\hline 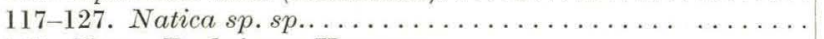 & 2.5 & 1.1 & 4.7 & 9.1 & $\ldots$ & .... & $\ldots$ & 5.1 & 5.7 & 4.5 & ... & 6.4 & $=2.21$ \\
\hline 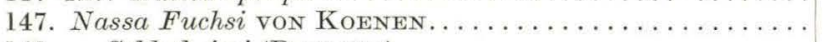 & $\ldots$ & 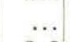 & $\ldots$ & 2.6 & & 1 & 1 & 0.7 & 22.2 & 28.0 & 10 & 11.8 & 0.55 \\
\hline 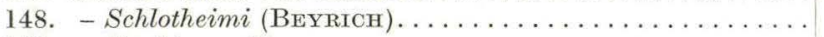 & 3.7 & 3.6 & 4.9 & 3.9 & 22.9 & $\ldots$ & 1 & $\ldots$ & 0.4 & ... & & & 2.4 \\
\hline 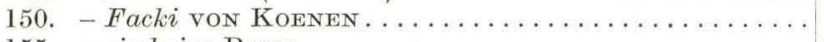 & & & 1.0 & & 0.9 & $\cdots$ & $\ldots$ & 0.7 & 0.9 & 0.9 . & ... & 1.3 & 0.2 \\
\hline 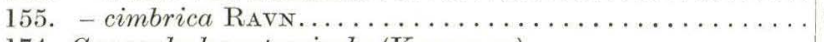 & 35.6 & 43.1 & 28.4 & 66 & $\ldots$ & $\ldots$ & 2 & $\ldots$ & $\ldots$ & $\ldots$. & ... & $\ldots$ & 16.7 \\
\hline 174. Gemmula boreoturricula (KAUTSKY) . .............. & $\ldots$ & 0.2 & $\ldots$ & $\ldots$ & & ... & $\ldots$ & $\ldots$ & 0.6 & 0.6 & 1 & 1.0 & 0.1 \\
\hline 177. Fusiturris Duchastelii (NYsT) . . . . . . . . . . . . & $\ldots$ & 0.2 & $\ldots$ & $\ldots$ & 2.5 & $\ldots$. & $\ldots$ & $\ldots$ & 0.7 & $\ldots$. & ... & 1.3 & 0.25 \\
\hline 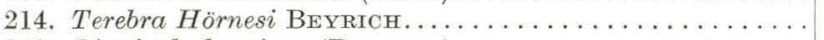 & 0.3 & 0.4 & 0.3 & $\ldots$ & 0.9 & $\ldots$. & $\ldots$ & 2.9 & 0.9 & 2.4 . & ... & 1.0 & 1.2 \\
\hline 249. Ringicula buccinea (Ввоссні) . . . . . . . . . . . . . & 4.0 & 6.8 & 0.3 & ... & 0.9 & ... & 1 & 0.7 & 6.9 & 7.4 & 1 & 4.8 & 7.53 \\
\hline 255. Retusa umbilicata (MontaGU) . . . . . . . . . . . . & 0.2 & 0.2 & 1.0 & $\cdots$ & $\cdots$ & $\cdots \cdot$ & $\cdots$ & $\cdots$ & 0.1 & 0.3 . & $\cdots$ & $\cdots$ & . \\
\hline 263. Spiratella atlanta (Мøвсн) . . . . . . . . . . . . . & 0.2 & $\cdots$ & $\cdots$ & $\cdots$ & - & . & $\ldots$ & $\cdots$ & $\ldots$ & $\ldots$. & $\cdots$ & $\cdots$ & \\
\hline 266. Vaginella depressa Daudin $\ldots \ldots \ldots \ldots \ldots \ldots \ldots$ & 0.5 & 0.5 & $\cdots$ & $\cdots$ & 5.9 & & 1 & $\cdots$ & 0.1 & 0.3 & 1 & $\ldots$ & 0.16 \\
\hline Sum total per cent. . . . . . . . . . & 94.4 & 95.1 & 93.7 & 89.4 & 85.0 & $\cdots$. & $\cdots$ & 83.4 & 85.4 & 82.6 & $\cdots$ & 82.2 & 94.8 \\
\hline Percentage share of 1 specimen...... & 0.2 & 0.2 & 0.3 & 1.3 & 0.9 & $\cdots$. & $\cdots$ & 0.7 & 0.1 & 0.3 . & $\cdots$ & 0.3 & 0.00 \\
\hline Sum total of specimens $(=100 \%) \ldots \ldots \ldots \ldots \ldots \ldots$ & 643 & 559 & 391 & 77 & 118 & 63 & 30 & 139 & 821 & 336 & 31 & 315 & $3316 t$ \\
\hline \multicolumn{14}{|l|}{ Frequencies of the abundant Nassidae: } \\
\hline 155. Nassa cimbrica RAvN..... & 35.6 & 43.1 & 28.4 & 66 & & & 2 & & & & & & \\
\hline 148. - Schlotheimi (BEYRICH).... & 3.7 & 3.6 & 4.9 & 3.9 & 22.9 & & 1 & $\ldots$ & 0.4 & $\cdots$ & & $\ldots$ & 2. \\
\hline 150. - Facki von Koenen . . . . . . & $\cdots$ & $\cdots$ & 1.0 & $\cdots$ & 0.9 & & $\cdots$ & 0.7 & 0.9 & 0.9 & & 1.3 & 0. \\
\hline 147. - Fuchsi von Koenen . . . . . . . . . . . . . & $\cdots$ & $\cdots$ & $\cdots$ & 2.6 & $\cdots$ & 1 & 1 & 0.7 & 22.2 & 28.0 & 10 & 11.8 & \\
\hline
\end{tabular}




\section{Molluscan Species in the Well Sections}

talies: number of specimens

\begin{tabular}{|c|c|c|c|c|c|c|c|c|c|c|c|c|c|c|c|c|c|c|c|}
\hline & & & & & & & & & & & & & & & Arnun & & & & \\
\hline & & Arnur & $\begin{array}{l}\text { Gramt } \\
\text { im forn }\end{array}$ & $\begin{array}{l}\text { by } \\
\text { mation }\end{array}$ & & & & $\begin{array}{r}\text { T } \\
\text { Arnur }\end{array}$ & $\begin{array}{l}\text { oftlund } \\
\mathrm{n} \text { format }\end{array}$ & tion & & 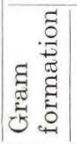 & & $\begin{array}{l}\text { Arn } \\
\text { (Wells } \\
\text { combine }\end{array}$ & $\begin{array}{c}\text { num f } \\
\text { no. } 1 \\
\text { led to }\end{array}$ & $\begin{array}{l}\text { ormati } \\
50.13 \\
\text { one s }\end{array}$ & $\begin{array}{l}\text { ion } \\
\& 2\end{array}$ & $\begin{array}{l}\text { b } \\
\text { on) }\end{array}$ & \\
\hline 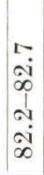 & $\begin{array}{l}\infty \\
\infty \\
\infty \\
1 \\
1 \\
0 \\
\infty\end{array}$ & $\begin{array}{l}9 \\
1 \\
\infty \\
1 \\
1 \\
+1 \\
\infty\end{array}$ & $\begin{array}{l}\tilde{y} \\
\dot{\sigma} \\
\dot{0} \\
\dot{0}\end{array}$ & $\begin{array}{l}\stackrel{\leftrightarrow}{0} \\
\stackrel{0}{0} \\
1 \\
1 \\
\stackrel{1}{0}\end{array}$ & 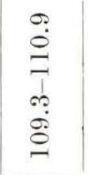 & 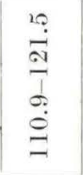 & $\frac{8}{\frac{8}{12}}$ & $\begin{array}{l}\frac{10}{9} \\
\frac{1}{8}\end{array}$ & $\frac{0}{1}$ & $\begin{array}{l}10 \\
0 \\
0\end{array}$ & $\stackrel{10}{=}$ & $\begin{array}{l}\stackrel{0}{+} \\
\text { do } \\
\stackrel{1}{*}\end{array}$ & 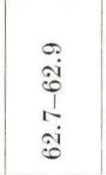 & $\begin{array}{l}\ddot{\infty} \\
\dot{0} \\
i 0\end{array}$ & $\begin{array}{l}+ \\
\infty \\
\infty\end{array}$ & $\begin{array}{l}0 \\
10 \\
0 \\
0 \\
13\end{array}$ & $\begin{array}{l}\stackrel{n}{0} \\
\stackrel{0}{1} \\
0 \\
=\end{array}$ & $\begin{array}{l}\stackrel{0}{0} \\
\stackrel{0}{0} \\
\stackrel{1}{0} \\
\stackrel{0}{0}\end{array}$ & $\stackrel{20}{\stackrel{20}{0}}$ \\
\hline & $\cdots$ & & & & & & 0.02 & & 0.01 & & 0.14 & & & & & 3.36 & & 0.19 & \\
\hline & 1.5 & 1.12 & 2.16 & 2.22 & 1.58 & 3.24 & 0.59 & 0.14 & & & & . & 3.48 & 0.96 & & & & & \\
\hline$\ldots$ & 0.2 & 0.27 & 0.15 & & & & 0.29 & 0.2 & 2.13 & 2.2 & 1.76 & & 0.01 & 0.07 & 1.2 & 2.36 & 1 & 0.76 & 1.4 \\
\hline 1 & 6.3 & 6.06 & 12.5 & 31.6 & 3.15 & 28.1 & 15.27 & 25.7 & 1.02 & 5.32 & 0.47 & 14.3 & 12.2 & 21.82 & 4.9 & 1.3 & .11 & 7.9 & 18.7 \\
\hline & 0.2 & & & 0.44 & 0.79 & & 0.49 & 1.41 & 5.54 & 3.97 & 1.42 & $\ldots$ & 0.03 & 0.13 & 0.6 & 11.6 & 2 & 1.32 & 1.4 \\
\hline$\ldots$ & $\ldots$ & 0.17 & 0.15 & $\ldots$ & 0.39 & 0.54 & $=0.03$ & & 0.084 & 0.07 & 0.14 & $\ldots$ & 0.02 & 0.07 & & & 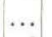 & & \\
\hline$\ldots$ & 3.7 & 0.61 & 2.46 & 1.33 & 0.79 & 4.32 & 1.02 & 3.57 & 1.31 & 1.23 & 5.43 & 2.5 & 2.9 & 0.18 & 1.2 & 2.52 & 2 & 6.24 & 0.7 \\
\hline$\ldots$ & 0.6 & 3.28 & 2.31 & 5.77 & 7.48 & 4.16 & 0.71 & 2.09 & 1.12 & 3.73 & 0.54 & 1.9 & 4.8 & 0.50 & $\ldots$ & 3.89 & 6 & 3.02 & 11.5 \\
\hline$\ldots$ & $\ldots$ & 0.3 & $\ldots$ & 0.44 & 0.39 & $\ldots$ & 0.01 & 0.01 & 0.12 & 0.84 & 0.68 & $\ldots$ & 0.02 & 0.04 & $\ldots$ & 0.53 & 3 & 0.57 & 4.3 \\
\hline$\ldots$ & $\ldots$ & 0.03 & $\ldots$ & $\ldots$ & $\ldots$ & $\ldots$ & 0.01 & 0.06 & 0.45 & 0.47 & 0.14 & $\ldots$ & 0.01 & $\ldots$ & $\ldots$ & 1.14 & 2 & 1.89 & 1.4 \\
\hline & $\ldots$ & & & $\ldots$ & & & 0.05 & $\cdots$ & 0.04 & 0.43 & 0.14 & 1.2 & 2.43 & 0.17 & $\ldots$ & 0.15 & 1 & 0.19 & 0.7 \\
\hline & 8.5 & 10.8 & 13.9 & 7.10 & 23.6 & 20.0 & 2.85 & 7.61 & 6.71 & 14.7 & 5.36 & 8.7 & 12.7 & 1.32 & 1.2 & 3.84 & 5 & 10.59 & 10.8 \\
\hline ‥ & $\ldots$ & 1.42 & & 0.44 & 0.39 & 0.54 & 0.15 & 0.24 & 0.21 & 1.47 & 2.85 & 1.9 & 0.59 & 0.06 & $\ldots$ & 0.31 & 5 & 12.65 & 2.9 \\
\hline$\ldots$ & 0.2 & 0.44 & $=0.15$ & & 0.79 & 0.54 & 0.17 & 0.26 & 0.58 & 0.76 & 0.34 & 0.6 & 0.56 & 0.31 & & 0.61 & 1 & 0.94 & 4.3 \\
\hline 2 & 1.0 & 27.7 & 5.54 & 5.33 & 0.39 & 10.50 & 10.58 & 0.88 & 0.32 & 0.83 & 0.20 & 1.9 & 0.84 & 2.53 & 1.9 & 1.37 & 1 & 0.19 & $\ldots$ \\
\hline$\cdots$ & $\ldots$ & & 0.92 & 0.89 & 0.39 & 0.54 & 0.08 & 0.11 & 0.11 & 0.36 & 1.36 & 1.9 & 4.35 & 0.48 & 0.6 & 0.61 & 1 & 0.19 & $\ldots$ \\
\hline$\ldots$ & 0.6 & 0.88 & 0.62 & 4.89 & 0.79 & 0.54 & $=1.14$ & 1.7 & 0.25 & 0.95 & & 15.5 & 26.98 & 8.39 & 1.2 & 0.31 & 1 & 1.14 & \\
\hline 1 & 11.0 & 3.48 & 2.16 & 0.89 & 0.39 & 1.08 & 4.66 & 11.49 & 8.22 & 3.81 & 9.22 & 0.6 & $\ldots$ & 0.81 & 34.6 & 20.8 & $\ldots$ & 0.57 & 0.7 \\
\hline ... & 1.3 & 0.96 & 0.15 & $\ldots$ & $\ldots$ & $\ldots$ & 1.29 & 0.91 & 1.87 & 3.05 & 11.00 & 1.2 & 1.06 & 1.75 & 3.0 & 2.52 & 2 & 6.23 & 10.0 \\
\hline$\ldots$ & $\ldots$ & 0.03 & $\quad \ldots$ & $\ldots$ & & & 0.18 & 0.26 & 1.38 & 1.85 & 5.15 & $\ldots$ & $\ldots$ & 0.17 & 1.9 & 1.98 & 2 & 12.3 & 0.7 \\
\hline & 3.7 & 4.87 & 1.54 & 2.66 & 5.51 & 0.54 & $=4.44$ & 3.14 & 10.82 & 9.06 & 9.5 & 23.6 & 6.89 & 4.15 & 6.2 & 5.11 & 1 & 2.83 & 5.0 \\
\hline & 0.1 & 0.1 & 0.15 & 0.44 & $\ldots$ & & 0.17 & 0.06 & 0.17 & 0.38 & 2.78 & $\ldots$ & 0.01 & 0.24 & $\ldots$ & 0.46 & 1 & 3.21 & 0.7 \\
\hline 1 & 43.7 & 23.1 & 43.7 & 16.43 & 22.4 & 20.60 & 45.1 & 29.8 & 44.6 & 27.0 & 13.57 & $\ldots$ & $\ldots$ & 41.8 & 21.6 & 18.4 & $\ldots$ & & 2.2 \\
\hline$\cdots$ & $\ldots$ & $\ldots$ & $\ldots$ & $\ldots$ & $\ldots$ & & 0.01 & 0.01 & 0.12 & 0.33 & 2.64 & $\ldots$ & & & 0.6 & & & 3.78 & 0.7 \\
\hline$\ldots$ & $\ldots$ & & & $\ldots$ & & & 0.02 & 0.01 & 0.17 & 0.36 & 1.83 & & 0.01 & & 0.6 & 0.61 & $\ldots$ & 1.51 & 0.7 \\
\hline$\ldots$ & 0.2 & 0.17 & 0.46 & & & & 0.38 & 0.55 & 1.07 & 0.97 & 1.15 & 1.9 & 1.18 & 0.9 & 0.6 & 0.31 & $\ldots$ & 0.38 & $\ldots$ \\
\hline 1 & 6.9 & 3.69 & 2.31 & 5.77 & 0.79 & 1.08 & 4.3 & 3.35 & 0.37 & 0.54 & 1.36 & 5.6 & 4.31 & 2.52 & $\ldots$ & 0.91 & 1 & 1.70 & \\
\hline$\ldots$ & $\ldots$ & 0.41 & 0.15 & 2.22 & & & 0.13 & 0.52 & 0.23 & 0.73 & 0.27 & 2.5 & 1.57 & 0.97 & $\ldots$ & 0.91 & $\ldots$ & 0.38 & 2.2 \\
\hline ... & 2.7 & 3.05 & 0.62 & 0.89 & 24.4 & 0.54 & $=0.02$ & 0.06 & 0.05 & 0.12 & $\ldots$ & 0.6 & 6.92 & 1.87 & $\ldots$ & 0.69 & 5 & 0.94 & 0.7 \\
\hline$\cdots$ & 2.6 & 2.71 & 2.46 & 6.22 & 1.97 & 1.08 & 1.78 & 1.63 & 0.22 & 0.99 & 0.61 & 1.2 & 0.79 & 0.74 & 2.5 & 0.31 & 5 & 3.78 & 0.7 \\
\hline . & 95.0 & 95.65 & 94.56 & 95.97 & 96.38 & 97.94 & $=95.94$ & 95.77 & 89.294 & 86.52 & 80.05 & 87.6 & 94.66 & 92.95 & 84.4 & 86.91 & $\cdots$ & 85.39 & 82.4 \\
\hline$\cdots$ & 0.1 & 0.03 & 0.15 & 0.44 & 0.39 & 0.54 & $=0.0004$ & 0.014 & 0.008 & 0.024 & 0.07 & 0.6 & 0.006 & 0.018 & 0.6 & 0.08 & $\ldots$ & 0.19 & 0.7 \\
\hline 6 & 810 & 2954 & 650 & 225 & 254 & 185 & 264167 & 6951 & 13022 & 4226 & 1474 & 161 & 17266 & 5449 & 162 & 1311 & 74 & 529 & 139 \\
\hline
\end{tabular}

\begin{tabular}{|l|l|l|l|l|l|l|l|}
1 & 43.7 & 23.1 & 43.7 & 16.43 & 22.4 & 20.6 & 45.1 \\
\hline
\end{tabular}

\begin{tabular}{|l|l|l|l|l|l|l|}
3.7 & 4.87 & 1.54 & 2.66 & 5.51 & 0.54 & 4.44 \\
\hline
\end{tabular}

\begin{tabular}{r|l|r|r|r|r|r|}
0.1 & 0.1 & 0.15 & 0.44 & $\ldots$ & $\ldots$ & 0.17 \\
\hline
\end{tabular}

\begin{tabular}{|c|c|c|c|c|c|c|c|c|c|c|c}
29.8 & 44.6 & 27.0 & 13.57 & $\ldots$ & $\ldots$ & 41.8 & 21.6 & 18.4 & $\ldots$ & $\ldots$ & 2.2 \\
3.14 & 10.82 & 9.06 & 9.5 & 23.6 & 6.89 & 4.15 & 6.2 & 5.11 & 1 & 2.83 & 5.0 \\
0.06 & 0.17 & 0.38 & 2.78 & $\ldots$ & 0.01 & 0.24 & $\ldots$ & 0.46 & 1 & 3.21 & 0.7 \\
0.26 & 1.38 & 1.85 & 5.15 & $\ldots$ & $\ldots$ & 0.17 & 1.9 & 1.98 & 2 & 12.3 & 0.7 \\
\hline
\end{tabular}


DANSK SAMMENDRAG

\section{MOLLUSK SELSKABER FRA DET MARINE] MELLEM-MIOCAN I SYD- OG SØNDERJYLLAND OG DERES MILJ Ø}

\section{Indledning}

Miocænstratigrafiens udvikling i Europa afspejler den biostratigrafiske metodes fortrin og mangler på iøjnefaldende måde. Dette skyldes ikke, at kendskabet til miocænseriens formationer og fossilindhold er særligt ringe, eller at metoderne til miocænets udforskning er principielt afvigende sammenlignet med andre formationsintervaller. Det er tværtimod således, at miocænets fossiler har været studeret ret indgående af et stort antal forskere, og at de miocæne formationers udbredelse er kortlagt ret detailleret. Man kan også i litteraturen møde den opfattelse, at man ved korrelationerne og inddelingerne har fulgt: »stratigrafiens metoder og de almindelige palæontologiske regler (MAYER-EYMaR 1857).

Tertiærtidens sedimentationsområder i Europa grupperer sig i følgende aflejringsbassiner :

1. Nordsøbassinet og tilgrænsende områder i Sydengland, Nordfrankrig, Belgien, Holland, Danmark, Nordtyskland og Polen.

2. Marginale sedimentationsområder ved Atlanterhavskysten omfattende det Aquitanniske bassin, Loire bassinet og Guadalquivir bassinet.

3. De mediterrane aflejringsområder omfattende bl. a. Podalen i Norditalien samt Wienerbassinet.

4. Aflejringsområderne vest og nord for Alperne repræsenteret ved Rhone dalen og Molassebassinet i Schweiz, Sydtyskland og det nordlige Østrig.

I alle disse sedimentationsområder er aflejret lag, som er henført til miocænserien.

Fremgangsmåden ved studiet og paralleliseringen af de miocæne dannelser har været, at man i de enkelte bassiner på palæontologisk grundlag har grupperet de mange adskilte formationsdele $\mathrm{i}$ biostratigrafiske systemer. Man har dernæst jævnført de opstillede stratigrafiske enheder i de forskellige aflejringsområder med hverandre så godt det kunne gennemføres. Endelig har man på denne basis etableret en tidsstratigrafisk inddeling, hvis universelle gyldighed efterhånden stiltiende er akcepteret af stratigrafer og palæontologer verden over.

Den historiske gennemgang, som danner indledningen til den engelske tekst, 
viser, at man til forskellige tider har været klar over, at der var en ret stor usikkerhed ved korrelationerne mellem f. eks. aflejringsområderne i Sydvestfrankrig og i de mediterran-alpine områder (Mayer-Eymar 1857, Rutsch 1929, Magne \& Vigneaux 1948, Janoschek 1951). Det er dog ganske betegnende, at man i det store og hele derved ikke er kommet ind på en vurdering af den stratigrafiske metode, som er anvendt ved korrelationerne.

Idet usikkerheden og vanskelighederne ved dateringer og korrelationer uden tvivl står i forbindelse med de anvendte metoder, er det værd at fremhæve, at de kritiske punkter i en stratigrafisk forskningsgang først og fremmest er at søge i korrelationen af adskilte eller ikke direkte iagttagelige formationer.

I almindelighed kan biostratigrafiske korrelationer karakteriseres ved følgende tre stadier.

1. Til trods for, at det ikke altid formuleres klart, forsøger de fleste forskere at finde frem til »edefossiler«. Dette forudsætter, at begrebet »ledefossil« er en realitet, d.v.s. at der findes arter med universel horisontal og begrænset vertikal udbredelse. Et formodet ledefossil bliver ofte meget hurtigt betragtet som et gyldigt korrelationsredskab.

2. Ifald ledefossiler ikke forefindes, eller såfremt lagenes faunaer ikke fremviser særligt iøjnefaldende lighedstræk, består det næste skridt i en vurdering af lagenes relative alder på grundlag af deres fossilindhold.

3. Den endelige korrelation gennemføres dernæst hovedsagelig ved en sammenligning af lagenes indhold af arter. Et lag korreleres i almindelighed med den formation udenfor dets eget aflejringsområde, hvormed det har flest arter fælles. Procenten af fællesarter udregnes i forhold til artsantallet $\mathrm{i}$ laget, der skal korreleres, men stilles normalt ikke i relation til artsantallene $\mathrm{i}$ formationerne, hvormed man korrelerer.

Denne metode medfører uundgåeligt muligheder for fejlslutninger, idet fossilmaterialets bevis- og bærekraft overvurderes, således som det fremgår af følgende:

a. Ledefossilernes gyldighed er meget sjældent baseret på statistiske undersøgelser $\mathrm{i}$ et tilstrækkelig stort antal lagserier. De postulerede ledefossilers betydning bliver derved yderst begrænset.

b. Tilstedeværelsen eller ikke tilstedeværelsen af en art behøver ikke alene at være en funktion af tiden. Palæo-miljøforholdenes indflydelse kan ofte være mere afgørende for en arts udbredelse end tidsfaktoren.

c. Tendensen til at negligere miljøforholdene som kontrollerende faktorer synes at vokse proportionalt med afstanden mellem lagserierne, der sammenlignes.

d. Den ved korrelationer almindeligt anvendte "procentmetode«, som er omtalt ovenfor, kan medføre alvorlige dateringsfejltagelser. Til eksempel nævnes det i 1940 fremhævede forhold at $52 \%$ af molluskarterne ved Norges kyster er fælles med Middelhavsfaunaen, mens disse fællesarter kun udgør ca. $25 \%$ af Middelhavets meget større molluskfauna. Antallet af fællesarter afhænger altså af artsantallet i begge de to faunaer, som sammenlignes.

c. Antallet af arter i et faunaselskab kan betragtes som een af dyreverdenens reaktioner overfor de miljøforhold, som naturen har stillet til rådighed. Et andet udtryk for faunaens reaktion overfor miljøet er de enkelte arters individantal. 
f. En løselig gennemgang af den biostratigrafiske litteratur viser, at oplysninger om arters hyppighed med få undtagelser er holdt i meget ubestemte vendinger som: "hyppig", "sjælden", "almindelig" o.s.v. Ofte findes ingen oplysninger om hyppighed.

g. Mangelen på statistiske oplysninger om arternes hyppighed og sedimenternes fysiske egenskaber har hindret erkendelsen af fossile arters og dyresamfunds afhængighed af miljøet. Det har derfor ikke været muligt klart at skelne mellem tidsfaktorens og miljøfaktorernes indflydelse på faunaen.

Der er ingen tvivl om, at vort kendskab til de miocæne aflejringer i Europa endnu er yderst begrænset, og at en del af de hidtil gennemførte korrelationer er udført på et for tidligt stadium af vor erkendelse af fossilernes stratigrafiske bærekraft. Ved fremtidige undersøgelser må man utvivlsomt stræbe efter først og fremmest at nå frem til en mere sikker opfattelse af sedimentationshistorien og den faunistiske udvikling i hvert enkelt bassin. Man bør stile efter klare beskrivelser af formationsenhederne og så enkle definitioner af disse som muligt.

Studiet af boreprofiler og prøver fra boringer, der almindeligvis omfatter større lagserier end daglokaliteter, vil kunne yde overordentlig værdifulde data, hvis arbejdet på dette felt gennemføres på rette måde.

Beskrivelsen af boreprofilerne fra Syd- og Sønderjylland og af molluskselskaberne fra boringernes miocæne lagserier, som fremlægges i dette arbejde, er tænkt som et bidrag til forståelsen af den geologiske historie for en lille del af det miocæne Nordsøbassin ud fra disse synspunkter.

Afsnittet om de miocæne aflejringer i Sønderjylland er en meget kortfattet oversigt over formationerne ved basis af kvartæret, og kapitlet vedrørende de behandlede boringer giver en detailleret beskrivelse af boreprofilerne og boreprøverne. Endelig defineres Arnum og Ribe formationerne, og der sluttes med følgende samlede oversigt over vort nuværende kendskab til sedimentationsudviklingen i Syd- og Sønderjylland fra linien Vejlefjord-Varde til grænsen:

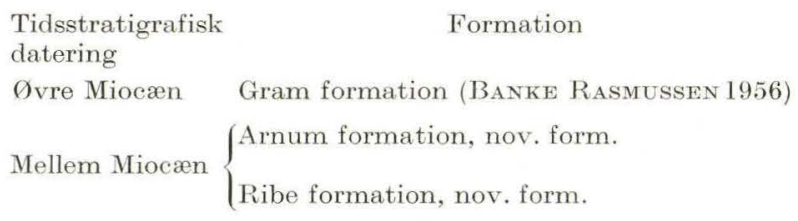

Øvre Miocæn Gram formation (BAnke Rasmussen 1956)

Mellem Miocæn $\left\{\begin{array}{l}\text { Arnum formation, nov. form. } \\ \text { Ribe formation, nov. form. }\end{array}\right.$

Mellem-nedre miocæn

Vejlefjord formation (DINESEN \& LARSEN 1956)

Nedre Miocæn
Facies

ler og finsand, marint

hovedsagelig finsand, marint

finsand, sand og grus, sandsynligvis limnisk fluviatilt

øverst: finsand og sand, sandsynligvis hovedsagelig marint

nederst: ler og finsand, sandsynligvis hovedsagelig marint

ler, marint

\section{Den palæontologiske del}

Indledningsvis diskuteres det palæontologiske artsbegreb, idet opfattelsen af den fossile art og artsdefinitionen anses for at være af fundamental betydning for biostratigrafiske konklusioner. Det vises, at man indenfor 
palæontologien må lade sig nøje med en så primitiv morfologisk definition på arten som f. eks. foreslået af ARK ELL \& Mox Thomas (1940, p. 395). Ifølge disse to forfattere er den palæontologiske art: "a practical and convenient unit by which fossils are distinguished«. Heraf følger det elementære krav, at fossiler, som ikke kan skelnes fra hverandre ved væsentlige morfologiske forskelle bør henregnes til samme palæontologiske art.

Samtidig med denne kraftige metodiske begrænsning af forskningen med hensyn til den systematiske klassifikation af fossiler må opgaven indenfor denne del af biologien dog naturligvis være at tilstræbe en så stor overensstemmelse med systematiken indenfor den levende verden som muligt. Dette må nævnes, selvom det oftest opfattes som en selvfølge, idet man ikke gør sig klart, hvor principielt forskellige mulighederne for artserkendelse indenfor palæontologien og neontologien er. Det er vigtigt at understrege, at den palæontologiske art er et mindre objektivt begreb end den recente art, og at fuldkommen overensstemmelse mellem de to artsbegreber måske aldrig opnås.

Med hensyn til den »s ys te matiske værdi « af molluskskallens morfologiske bygningstræk henledes opmærksomheden på, at den herskende systematik bygger på evolutionstanken, som forudsætter kontinuert morfologisk udvikling $\mathrm{og}$ en vis variation af de fleste morfologiske egenskaber. Til trods for denne kendsgerning postuleres ikke sjældent $\mathrm{i}$ diskussioner, at visse morfologiske egenskaber er af »større systematisk betydning« end andre, hvilket i praksis oftest har til følge, at de andre egenskaber negligeres.

Efter en diskussion af protoconch og teleoconch og deres betydning for den systematiske forskning sluttes med et citat af THовPE (1940, p. 342), hvori det understreges, at en art er nøje karakteriseret ved biologiske og fysiologiske egenskaber i ethvert af dens udviklingsstadier. Heraf drages den slutning, at man ikke bør udelukke nogen del af dyret eller noget stadium af dets udvikling ved bedømmelsen af molluskers systematiske stilling.

Den systematiske inddeling af molluskerne støtter sig til THIELE's Handbuch der systematischen Weichtierkunde (1931-35). Det må imidlertid fremhæves, at THIELE's systematiske inddeling er mere eller mindre subjektiv som enhver anden inddeling af denne art, og at materialemængden indenfor den systematiske malakologi efterhånden er blevet så omfattende, at en virkelig kritisk vurdering af de mange opstillede arter øjensynlig vanskeligt kan gennemføres. Såvel i THIELE's håndbog som i andre lignende værker savnes velfunderede begrundelser for opretholdelsen af de mange slægter og underslægter, ligesom også argumentationen for inddelingen i familier, ordener m.v. ofte synes at være ret tilfældig og svag. Grundene hertil er sandsynligvis at søge dels i det uoverkommelige i en gennemført verifikation, og dels i manglende typemateriale, utilstrækkelige definitioner o.s.v.

Af den almindelige usikkerhed følger, at de systematiske kategorier, som. ligger over arten, lige fra underslægter, slægter og familier m.v. har mindre objektiv værdi end arten. På grund af den stadige risiko for fejlvurderinger i eksisterende systematiske inddelinger har jeg kun betragtet dem som foreløbige praktiske løsninger på et ordningsproblem. Jeg har tilstræbt en binær nomenklatur, idet jeg med få undtagelser har undgået at henføre til underslægter. Dette er i overensstemmelse med mit synspunkt, at der i de fleste tilfælde savnes en konsekvent linie og begrundelse for inddelingen i underslægter. Endvidere er den videnskabelige og praktiske nytte af underslægtsbegrebet efter min opfattelse ofte ret problematisk.

Undersøgelsen af materialet omfatter dels en bestemmelse af de en- 
kelte arter i prøverne samt en statistisk behandling af skalmaterialet, idet antallet af individer i prøverne er bestemt ved tælling. Hvert umbonalparti af en pelecypodskal er talt som et halvt individ, og hvert fragment af en gastropodskal med protoconch er talt som et individ. Nærmere enkeltheder vedrørende talte eksemplarer og undtagelser fra nævnte fremgangsmåde (A porrhais alata og Turritellidae) er omtalt side 33 .

Ved beskrivelsen af arterne er der tilstræbt en så nøjagtig omtale af væsentlige træk i skallens morfologiske bygning som muligt, idet finere detailler er undersøgt under mikroskop og tegnet. Der er anvendt tegneprisme ved tegningen af skalomridsene.

Da det for erkendelsen af arten i almindelighed og for den palæontologiske art i særdeleshed er meget vigtigt at kende grænserne for de morfologiske egenskabers variation, er der lagt vægt på en statistisk behandling af skulpturelementer og skalform, hvor dette var muligt. Bestemmelsen af arterne har måttet ske ved hjælp af litteraturen. Da der i en del tilfælde har været tale om ret mangelfuld dokumentation i den tilgængelige litteratur, har det sikkert ikke kunnet undgås, at der er indtruffet fejlbestemmelser. Det er mit håb, at den store målestok, hvori illustrationerne er tegnet, samt den i de fleste tilfælde ret detaillerede beskrivelse af skalmaterialet vil gøre en identifikation og sammenligning med udenlandsk skalmateriale forholdsvis let til trods for eventuelle fejlbestemmelser.

Ved beregningen af middelværdierne for $\frac{L}{H}$ og $\frac{H}{D}$ forholdene*) er de almindelige statistiske beregningsmetoder fulgt (se f. eks. Keмp 1942). Grænserne for de beregnede middelværdier er i hvert tilfælde $\pm 3 e$ hvor $e=\frac{s}{\sqrt{n}}(n=$ antallet af observationer, $s=$ standard afvigelsen).

Artsbeskrivelserne omfatter en synonymliste med de vigtigste referencer til litteraturen. Hovedværker med gode afbildninger og enkelte andre betydningsfulde værker er citeret, idet hensigten har været at belyse den enkelte arts udbredelse i Middelhavsområdet, Atlanterhavsområdet og Nordsøbassinet i tertiærtiden. En fuldstændig synonymliste har ikke været tilsigtet.

Såvidt muligt er den originale diagnose, beskrivelse eller uddrag deraf citeret. Derefter følger en oversigt over det til arten henførte skalmateriale fra boringerne, og derpå beskrivelsen af skalmorfologien. I afsnittet »Remarks» findes eventuelle bemærkninger til beskrivelsen, diskussioner o.s.v.

Oversigten over udbredelsen er ordnet stratigrafisk og regionalgeologisk efter de enkelte marine aflejringsområder. Kilderne til denne oversigt findes almindeligvis i synonymlisten. Hvor dette ikke er tilfældet, er der henvist med forfatter og årstal til det arbejde, hvorfra oplysningen stammer. Det vil kunne findes i litteraturlisten.

\section{Generelle slutninger vedrørende skalmorfologien.}

Til trods for, at kun et ringe antal arter har kunnet undersøges med hensyn til variationen af skalformen, er det muligt at udlede en række lovmæssigheder af målingerne, ligesom det også er lykkedes at påvise morfologiske ejendommeligheder hos visse grupper af arter.

*) $L=$ længde, $H=$ højde, $D=$ diameter. 
Resultaterne fra undersøgelsen af f.eks Yoldia glaberrima, Leda Westendorpii, Leda pygmaea, Spisula subtruncata og Varicorbula gibba tyder på, at forholdet længde/højde hos pelecypodskaller meget sjældent er konstant, men er underkastet en bestemt lovmæssig ændring under væksten. Dette er en vigtig regel, som en række forfattere øjensynlig ikke er klar over, at dømme efter de ikke få tilfælde, hvor man har udregnet middelværdier for dette eller lignende forhold uden at angive de pågældende skallers størrelsesinterval. Sådanne middelværdier er naturligvis af ret problematisk værdi.

Bestemmelsen af skaller tilhørende arter af slægten Nucula er ofte temmelig vanskelig på grund af den ringe morfologiske variation af en række arter. Undersøgelsen af recente skaller af $N$. nitida og af Nuculiderne, som er behandlet i dette arbejde, har vist, at antallet af hængseltænder ikke er konstant, men tiltager med væksten af skallen. Man kan udtrykke tandantallets afhængighed af skalvæksten grafisk som vist på fig. 5, s. 42.

Antallet af radialelementer i det ydre skallag hos arter af slægten Nucula synes at være ret uforandret under væksten af skallen, idet disse elementer yderst sjældent forgrener sig. Det kan endnu ikke afgøres, om radialelementernes antal er så artskonstant, at deres middeltal kan bruges som artskarakterer.

Ved undersøgelsen af Pectiniderne viste det sig, at der kan skelnes mellem tre skalstadier: 1. prodissoconchen, 2. dissoconchens initialstadium og 3. den egentlige dissoconch. Hvert stadium er karakteriseret ved sin særlige skulptur (eller mangel på skulptur). På side 74 er givet en oversigt over de tre skalstadiers udseende hos de recente: Pecten septemradiatus, P.opercularis, P.varius, $P$. tigerinus og $P$. islandicus. Den biologiske betydning af dissoconchens initialstadium har jeg endnu ikke kunnet klarlægge.

Under tegningen af Varicorbula gibba opdagedes en ejendommelig pore på bagenden af højreskallen på overgangen mellem skallens prismelag og det indre skallag. På lukkede skaller findes poren udenfor venstreskallens rand. Denne marginalpore, som hos levende dyr er fyldt med en geléagtig dannelse, er ikke fundet omtalt i litteraturen. Tegneren, som har fremstillet illustrationerne til Vokes' (1945) monografi over Corbuliderne, har gengivet poren på en række arter, som findes opført side 131, men den er ikke omtalt af VoKEs. Marginalporen synes således at være karakteristisk for en del af familien. Dens funktion er endnu ukendt.

En parallel til længde/højde forholdet hos pelecypoder er højde/diameter forholdet hos gastropoder. Variationen af dette forhold, som er belyst ved Nassa Schlotheimi, N. subobesa, N. cimbrica og Ringicula buccinea er korreleret med skallens vækst, hvilket navnlig er iøjnefaldende hos de tre Nassider. Der er grund til at tro, at denne regel vil gælde for de fleste gastropodarter. $\mathrm{På} \mathrm{baggrund} \mathrm{heraf} \mathrm{må} \mathrm{det} \mathrm{endnu} \mathrm{engang} \mathrm{understreges,} \mathrm{at} \mathrm{alle} \mathrm{middelværdi-}$ beregninger over relationer mellem skaldimensioner bør være ledsaget af oplysninger om skalmaterialets størrelsesforhold.

Statistiken over collabrale skulpturelementer hos Bittium tenuispina, Nassa Schlotheimi, N. subobesa, Terebra Hörnesi o. a. illustrerer den velkendte erfaring, at collabrale elementers antal ikke er konstant hos adskillige arter. Almindeligvis tiltager antallet af ribber under væksten, den modsatte tendens kan dog også gøre sig gældende, ligesom et omtrent konstant antal ribber kan findes hos enkelte arter og eksemplarer. Hos de undersøgte Nassider synes det at være en regel, at den første teleoconchvinding har et større antal ribber end vinding nr. 2, hvorefter ribbeantallet pr. vinding atter tiltager med væksten. 
Hos arterne af familien Turridae er protoconchen meget karakteristisk. Med protoconchen hos arter af slægten Daphnella som udgangspunkt har jeg inddelt protoconchens helicoconus i tre afsnit: 1. det initiale, let heterostrofe afsnit, 2. medial afsnittet, som hos Daphnelliderne har en fin, diagonal netskulptur, og 3. terminal afsnittet, der er udviklet med køl hos en del Daphnellider. Ved den systematiske inddeling af arterne har jeg i princippet fulgt Powell's (1944) systematik, som er baseret på protoconchens morfologi.

Den biologiske værdi og betydning af protoconchens tre stadier hos Turriderne er endnu ukendt. Det er ikke usandsynligt, at initialstadiet kunne svare til dyrets larvestadium før torsionen. Udforskningen af larvestadierne af nulevende arter af familien ville være af stor betydning for den fremtidige forståelse af Turridernes meget artsrige familie.

\section{Marine pelecypoder og gastropoder i forhold til deres miljø}

Da fossilers anvendelse som stratigrafisk hjælpemiddel i så høj grad beror på kendskabet til lovene for de fossile dyrs reaktioner overfor miljøet og dets forandringer, er dette kapitel om recente molluskers afhængighed af deres fysiske og biologiske omgivelser gjort ret omfattende. Målet har været ved eksempler fra litteraturen at belyse sider af molluskbiologien og -økologien, der på en eller anden måde har indflydelse på skallens bygning og arternes spredning, og som derved er af særlig interesse for palæobiologien og biostratigrafien.

Jeg har måttet se bort fra, at jeg som ikke-specialist på dette felt kan savne visse forudsætninger for den økologiske vurdering, og at jeg kan være ukendt med vigtige arbejder og betydningsfulde fremskridt, som burde have været medtaget i oversigten. I et grænseområde mellem to forskningsgrene som palæoog neobiologien må risikoen for ufuldstændig behandling altid være til stede, hvad enten man vover sig ind i området med den ene eller anden disciplin som udgangspunkt.

\section{Kontrollerende miljøfaktorer}

I dette afsnit diskuteres velkendte faktorer, som har afgørende indflydelse på marine molluskers udbredelse. 1. føde, 2. saltholdighed, 3. temperaturforhold, 4. vanddybde, 5 . fjender og konkurrenter samt 6 . bundens beskaffenhed, anses for at være de vigtigste. Disse faktorers betydning for molluskernes forskellige udviklingsstadier belyses som det fremgår af det følgende ved eksempler fra den recente marinbiologi.

\section{Træk af marine molluskers biologi}

A. Dyrets vækst og variationen af skalegenskaber.

ORTON (1926) har undersøgt væksten af Cardium edule i tidevandsområdet ved Yealm flodens munding ved Plymouth. Bateson (1889) og PURchon (1939) har undersøgt saltholdighedens indflydelse på skalformer hos C. edule henholdsvis i saltsøområder ved Aralsøen og ved den engelske kanalkyst ved Plymouth. På grundlag af disse undersøgelser og vækstundersøgelser af: Mytilus californianus og M. edulis (RICHARds 1946), Littorina littorea (Moore 1937), Purpura lapillus (Moone 1936, 1938), Mya arenaria, Tellina baltica og Buccinum undatum (BRANDT 1897) kan man drage følgende konklusioner: 
1. Dyrets vækst er karakteriseret ved årlige rytmer.

2. Den største væksthastighed falder øjensynlig ofte sammen med og er betinget af den enkelte arts temperaturoptimum.

3. Den totale årlige størrelsestilvækst når et maksimum på et intermediært alderstrin, hvorefter den årlige tilvækst aftager.

4. Alderen ved den maksimale årlige tilvækst synes hos nogle arter at være ret veldefineret, mens der er betydelig variation hos andre arter (f. eks. hos Littorina littorea).

5. Gydningsperioden markeres i almindelighed ved aftagende vækst både af det levende væv og af skallen, bortset fra de arter, hvor væksten standses helt ved kønsmodenhed.

6. Saltholdigheden har en betydelig indflydelse på væksten. Saltholdigheder over og under den enkelte arts optimum synes at resultere $\mathrm{i}$ aftagende størrelse og skaltykkelse.

7. Forskellige saltholdigheder kan forårsage, at der udvikles forskellige skalformer og -farver hos en $\mathrm{og}$ samme art.

8. Forskellige kombinationer af faktorer, som udgør biotopen, kan give anledning til udviklingen af forskellige morfologiske typer af samme art.

9. Fødens beskaffenhed har i nogle tilfælde indflydelse på skallens form og farve.

Der foreligger ingen oplysninger om hvorvidt de under 6-9 nævnte forandringer er arvelige.

B. Forplantning.

De sidste 20 års marinbiologisk forskning har resulteret i overordentlig store fremskridt med hensyn til kendskabet til molluskernes forplantning. Der kan især henvises til THorson's banebrydende arbejde fra 1946, hvori der iøvrigt findes en meget fyldig litteraturliste over tidligere arbejder.

Indenfor molluskernes forplantningscyklus kan man skelne mellem følgende faser, som ikke alle behøver at være repræsenteret hos den enkelte art, og som også kan være modificeret på forskellig vis: a. forplantningsorganernes modning, b. befrugtning, c. gydning, d. klækning, e. larvestadiet, f. metamorfosen.

Endnu er kendskabet til miljøfaktorernes indflydelse på de enkelte faser ret mangelfuldt. Saltholdighed og temperatur har en betydelig indflydelse. I afsnittet behandles ernæringsforholdenes, saltholdighedens og temperaturens virkninger på de enkelte faser, forsåvidt oplysninger herom foreligger.

Hovedsynspunktet ved analysen af saltholdighedens og temperaturens indflydelse har været, at hvert udviklingsstadium har sin øvre og nedre grænse for saltholdighed og temperatur med mellemliggende optimum. Kendskabet til disse salinitets- og termalintervaller er endnu ret begrænset. Deres betydning for en række stadier hos enkelte arter diskuteres, idet der især lægges vægt på termalintervallernes spredningsbiologiske konsekvenser.

Der konkluderes, at årstidsbetonet gydning er almindelig i områder, hvor der er en tydelig variation af temperaturen med årstiderne. Gydningen efter årstid behøver ikke altid at være tegn på en temperaturregulering af de pågældende forplantningsfaser. Hvis en art hele året lever indenfor forplantningsfasernes termalintervaller, vil andre cyklisk varierende faktorer, der har indflydelse på forplantningsaktiviteten, som f. eks. ernæringen, kunne forårsage, at gydningen knyttes til bestemte årstider. 
C. Det pelagiske larvestadium.

Dette stadium har meget stor spredningsbiologisk betydning, og den omstændighed, at larvestadiets skal ofte kan studeres på fossile mollusker, gør det ikke mindre interessant for paleobiologisk forskning. Larvestadiets varighed og transporten af larverne i havet belyses ved få eksempler. Også på dette felt er konkret viden øjensynlig ret begrænset.

D. Det voksne stadiums krav med hensyn til bundforhold.

Molluskerne synes at have ret stor tilpasningsevne overfor bundforholdene, selv om også de seneste undersøgelser (Thorson 1946) viser, at larverne indenfor visse grænser er i stand til at vælge og vrage mellem de muligheder, der byder sig. De fleste arter er knyttet til infauna eller epifauna miljøet. En række arter, deriblandt visse rovsnegle, trives i begge miljøerne.

\section{E. Tilpasning.}

Alle i de tidligere afsnit diskuterede livsstadier og -processer afspejler molluskernes tilpasningsevne. I foreliggende afsnit behandles kun den osmotiske tilpasning og stofskiftetilpasningen hos et par arter. Af særlig interesse er stofskiftetilpasningen til forskellige temperaturforhold, således som SpÄrck's (1936) undersøgelser over Mytilus edulis, Astarte borealis, A. eliptica, A. Montagui og Saxicava arctica viser.

\section{Den geografiske udbredelse}

En arts naturlige geografiske udbredelse kan betragtes som et udtryk for summen af dens sprednings- og tilpasningsevne. Temperaturforhold og saltholdigheden er uden tvivl af den største betydning som regionalt begrænsende faktorer.

Som indledning gives en oversigt over Atlanterhavets temperaturforhold, idet den nordlige kolde og den sydlige varme vandmasse samt overgangsbæltet mellem dem karakteriseres.

I afsnittet om faunabelterne diskuteres WoODWARD's (1856) zoneinddeling, som sammenstilles med EkMAN's (1953) seneste afgrænsning af Atlanterhavets faunaprovinser i tabel 6 , side 388 . I oversigtsskemaet side 389 er fremsat et forslag til en definition af grænserne mellem WoODWARD's provinser baseret på geografiske lokaliteter og konkrete middeltemperaturer. Dernæst diskuteres enkelte boreale arters udbredelse.

De særlige hydrografiske forhold i dybhavet omtales, og ved en række molluskarters udbredelse i Skagerakområdet (efter C. G. Joh. Petersen 1915) vises, at der er en antydning af korrelation mellem arternes temperaturaffinitet, som den kendes fra deres geografiske udbredelse, og deres optræden i forhold til temperaturzonerne i Skagerak (temperatur submergens).

Som eksempel på saltholdighedens indflydelse på den marine fauna analyseres molluskfaunaens udbredelse fra Nordsøen til Østersøens mest ferske områder. I oversigtstabel 11, side 394 vises de enkelte arters omtrentlige inderste udbredelsesgrænse i Kattegat, Belthavet og Østersøen, og de tilsvarende omtrentlige middelsaltholdigheder er opført i tabel 10, side 393 .

Antallet af marine arter er omtrent halveret ved en middelsaltholdighed mellem 28 og $29 \%$ og $15 \%$ grænsen er øjensynlig særlig kritisk både for pelecypoder og gastropoder. Meget få marine mollusker kan leve i vand med en middelsaltholdighed på $3-4 \%$. 
Ligesom A. C. Johansen (1916) sætter jeg den vertikale udbredelse af Mytilus edulis, Astarte borealis, A. eliptica, Cardium edule, Macoma baltica, Mya arenaria, og Hydrobia ulvae i Østersøen i relation til saltholdigheden, og til denne række føjes yderligere Retusa obtusa. Arternes tendens til at gå ned på større dybde på grund af saltholdigheden er af Remane (1940) kaldt "Brackwasser Submergens». Betegnelsen salinitets submergens, der anses for mere adækvat, foreslås i stedet for.

\section{Marine dyresamfund}

I en meget kort oversigt gøres rede for begrebet det marine dyresamfund med udgangspunkt i C. G. Joh. Petersens arbejder og med henvisninger til vigtige diskussioner om emnet i litteraturen. Dyresamfundenes afhængighed af miljøet er endnu et ret uoplyst felt. I enkelte tilfælde har man kunnet påvise, at samfundene er betinget bl. a. af hydrografiske forhold og bundens beskaffenhed (Molander 1928).

\section{Alderen af Arnum formationens molluskselskaber}

\section{Bemærkninger om fremgangsmåden ved korrelation}

Biostratigrafisk korrelation er nærmere betragtet en statistisk videnskab, idet man ved denne metode beskæftiger sig med fossilers tilstedeværelse eller ikke tilstedeværelse. Et antal faunagrupper sammenlignes med hensyn til deres artsindhold og antallet af fællesarter, og ligheder og uligheder i faunasammensætningen belyses. At man også benytter stratigrafiske data som præmisser ved konklusionerne ændrer ikke biostratigrafiens statistiske præg.

Anvendelsen af makrofossiler ved stratigrafisk forskning har som nævnt tidligere i mange tilfælde indskrænket sig til påvisningen af såkaldte ledefossiler eller til sammenligningen af faunalister. Den sidstnævnte fremgangsmåde skal diskuteres på grund af dens almindelige anvendelse.

En faunaliste kan være opstillet i form af en tabel, således som $\mathrm{f}$. eks. vist på tabel 14, side 422 . Tabellen består af en primær søjle $(A)$ i hvilken arterne i faunaen, som skal korreleres, er opført i systematisk, alfabetisk eller anden rækkefølge. Sekundære søjler $(B, C, \ldots K)$ angiver de enkelte arters tilstedeværelse eller ikke tilstedeværelse på andre lokaliteter eller i andre faunaer, etager el. lign., som har faet en stratigrafisk placering. Man udregner derefter, hvor stor procentdel af sit artsantal fauna $A$ har tilfælles med henholdsvis fauna $B, C, D$ o.s. v. og procenterne sammenlignes. De endelige slutninger om fauna $A$ 's stratigrafiske relationer drages ofte på grundlag af en sådan sammenligning.

Fra tertiærlitteraturen kan følgende eksempler nævnes: GotTsche (1878), Gripp (1915), Kautsky (1925), Staesche (1930), Peyrot (1933), Sorgenfrei (1940), Vigneaux \& Magne (1951).

Jeg har som nævnt i 1940 fremhævet, at procenter udregnet på den ovenfor skitserede måde ikke er karakteriserende, fordi de er afhængige af summen af arter i de enkelte faunaer, som sammenlignes. I det følgende gøres rede for andre simple statistiske fremgangsmåder, som tager hensyn til faunaernes samlede artsantal ved beregningen af sandsynlighederne for faunaernes identitet.

Sammenlignes to faunaer med hensyn til graden af deres lighed på grundlag 
af de indeholdte arter, vil det sige, at man undersøger sandsynligheden for, at de to faunaer er tilfældigt udtagne prøver af een og samme tredie fauna.

Arter i en prøve er statistiske begivenheder. Lad $n$ betegne det samlede antal arter i en fauna og $r$ og $s$ antallet af arter i de to tilfældige prøver, som er udtaget af $n$. Sandsynlighederne $P_{r}$ og $P_{s}$ for begivenhederne $r$ og $s$ kan herefter udtrykkes ved de relative hyppigheder for $r$ og $s$ i forhold til $n$ :

$$
P_{r}=\frac{r}{n} \quad \text { og } \quad P_{s}=\frac{s}{n}
$$

Ved hjælp af disse ligninger kan man bestemme sandsynligheden $P_{\alpha}$ for, at der samtidig i $r$ og $s$ forekommer $\alpha$ arter:

$$
P_{\alpha}=P_{r} \cdot P_{s}=\frac{r \cdot s}{n^{2}}
$$

Da det samlede antal arter i fossile faunaer praktisk taget aldrig kendes, er $n$ en ubekendt størrelse. Man har derfor kun den udvej i formel (1) at indsætte en tilnærmet værdi for $n$ eller at udlede et andet udtryk for sandsynligheden $P_{\alpha}$.

I det forelagte eksempel, hvor vi går ud fra, at $r$ og $s$ er tilfældige prøver af een og samme fauna, og at $\alpha$ er antallet af fællesarter, kan man udlede yderligere to ligninger for $P_{\alpha}$ forskellige fra ligning (1).

De relative hyppigheder af $\alpha$ i forhold til henholdsvis $r$ og $s$ er:

$$
P_{\alpha}^{\prime}=\frac{\alpha}{r} \quad \text { og } \quad P_{\alpha}^{\prime \prime}=\frac{\alpha}{s}
$$

Sandsynligheden $P_{\alpha}$ for at der optræder $\alpha$ arter samtidig i både $r$ og $s$ er efter den klassiske regel om, at sandsynligheden for, at to hændelser, der er uafhængige af hinanden, begge indtræffer, er lig med produktet af sandsynligheden for hver af dem:

$$
P_{\alpha}=P_{\alpha}^{\prime} \cdot P_{\alpha}^{\prime \prime}=\frac{\alpha^{2}}{r \cdot s}
$$

Ifølge definitionen for sandsynlighed er

$$
P_{\alpha}=\frac{\alpha}{n}
$$

heraf og af formel (1) følger:

$$
\alpha=n P_{\alpha}=\frac{r s}{n}
$$

Ved at indsætte dette udtryk i formel (2) fås:

$$
P_{\alpha}=\frac{\left(\frac{r s}{n}\right)^{2}}{n}=\frac{r s}{n^{2}}
$$

hvorved umiddelbart fremgår, at ligning (2) er identisk med (1). 
Endelig kan sandsynligheden for fællesarternes tilstedeværelse også udtrykkes som den relative hyppighed af $\alpha$ i forhold til $n^{\prime}=r+s-\alpha$

$$
P_{\alpha^{\prime}}=\frac{\alpha}{n^{\prime}}=\frac{\alpha}{r+s-\alpha}
$$

Relationerne mellem ligningerne (1), (2) og (3) kan illustreres ved at antage at:

heraf følger:

$$
r \rightarrow n \text {, }
$$$$
\alpha \rightarrow s \text {, }
$$

hvilket viser, at både $P_{\alpha}$ og $P_{\alpha^{\prime}}$ konvergerer $\bmod \frac{s}{n}$

$P_{\alpha}$ eller de tilnærmede udtryk $P_{\alpha^{\prime}}$, som i det følgende vil blive kaldt korrelationsforhold, kan anvendes som sammenligningsgrundlag og som udtryk for affinitet også i tilfælde, hvor aldersforskellen mellem de sammenlignede faunaudsnit er udenfor diskussion. Korrelationsforholdene udtrykkes i procent ved at multipliceres med 100 .

Selv om der kan rejses indvendinger mod at anvende korrelationsforhold beregnet efter ovenstående formler som eneste korrelationsprøve er sammenligninger på grundlag af korrelationsforhold uden tvivl en bedre metode end "procentmetoden «.

Ved stratigrafisk korrelation er det sandsynligvis mest fordelagtigt at udregne $P_{\alpha}$ ved hjælp af ligning (2), som giver de mindste fejl for $P_{\alpha}$.

Formel (3) er muligvis velegnet ved sammenligninger, som har studiet af faciesindflydelser til formål.

Kun faunalister fra velafgrænsede formationer, hvis enkelte lagserier er tilstrækkeligt ensartede, kan bruges ved stratigrafiske korrelationer efter den her foreslåede metode. Som allerede nævnt i indledningen er det desværre meget vanskeligt at få et overblik over de forskellige europæiske molluskfaunaer på basis af oplysningerne i litteraturen. Dette skyldes navnlig, at man i fossillisterne ofte finder arter fra flere lokaliteter blandet sammen, og at man ikke altid klart har skelnet mellem bjærgartsstratigrafiske og tidsstratigrafiske enheder. Det er således endnu yderst vanskeligt at nå til en klar opfattelse af de forskellige faunaer $i$ det aquitaniske bassin, i Wienerbassinet og i de mediterrane områder. På grund af denne usikkerhed er beregningen af korrelationsforhold kun foretaget for aflejringerne i Nordsøbassinet.

De forskellige faunaer, som er opført i korrelationslisten tabel 14, side 422, refererer til følgende etager, faunaer og forfattere:

Tyskland:

Vierlande etage

Hemmoor etage

Reinbek-Dingden etage

Glimmerton etage

Belgien:

Boldérien

Houthaelen etage

Anversien

Itzehoe faunaen
Hemmoor faunaen
Reinbek faunaen
Hele faunaen

(GRIPP 1914)

(KAUTSKY 1925)

(GOTTSCHE 1878)

(Banke Rasmussen 1956)

Hele faunaen

Hele faunaen

Hele faunaen

Danmark :

Klintinghoved ler

Gram formation
Hele faunaen

Hele faunaen
(GLIBERT 1945-54)

(Sorgentrei 1940)

(Banke Rasmussen (1956) 
Den samlede fauna fra Hollands mellemmiocæn er endnu ikke offentliggjort, og de tidligere til det danske mellemmiocæn henførte molluskselskaber udgør øjensynlig ikke nogen veldefineret enhed. Arterne fra disse to formationsintervaller har derfor ingen større værdi ved den stratigrafiske korrelation.

\section{Den biostratigrafiske dokumentation indenfor Nordsøbækkenets miocæn}

I dette afsnit gives en kort oversigt over, hvor mangelfuldt kendskabet til molluskfaunaerne i de forskellige afdelinger af de maksimalt $520 \mathrm{~m}$ mægtige miocænaflejringer i Nordsøbækkenet er. Ved at sammenligne med recente faunaer langs Vesteuropas kyster antages molluskfaunaen i hvert stadium at have omfattet $500-800$ arter.

Ved at gå ud fra formlerne (1) og (2) side 472 kan det samlede artsantal $n$ i en fauna, hvorfra der foreligger to tilfældige prøver med artsantallet $r$ og $s$ og med fællesantallet $\alpha$ beregnes, idet:

$$
\frac{r s}{n^{2}}=\frac{\alpha^{2}}{r s}
$$

Ved at løse denne ligning for $n$ fås:

$$
n=\frac{r s}{\alpha}
$$

Faunaen fra Arnum formationen omfatter 266 arter, af hvilke 143 er fælles med Hemmoor faunaen, der består af 311 arter. Forudsat at disse to molluskselskaber stammer fra samme fauna fås artsantallet $n$ i denne efter (4):

$$
n=\frac{266 \cdot 311}{141}=586,7=587 \text { arter. }
$$

Hvis Arnum formationens og Reinbek-Dingden etagens mollusker hører til een og samme fauna fås tilsvarende:

$$
n=\frac{266 \cdot 107}{52}=547,3=547 \text { arter. }
$$

De beregnede artsantal svarer påfaldende godt til artsantallet, som blev anslået på grundlag af de recente molluskfaunaers størrelse. Da der er tale om helt uafhængige metoder, er der grund til at antage, at der herved er nået til en forholdsvis god tilnærmelse for antallet af molluskarter i den mellemmiocæne Nordsø's enkelte udviklingsstadier.

\section{Den biostratigrafiske korrelation af Arnum formationens molluskselskaber}

Da der ikke kan herske tvivl om, at Vierlande og Hemmoor faunaerne samt de belgiske faunaer i nogen grad hidrører fra forskellige fossilzoner, er arterne fra Arnum formationens fossilhorisonter betragtet under eet ved korrelationen med de hidtil fra Nordsøområdet kendte faunaer. Dette kan også forsvares ud fra synspunktet, at Arnum formationen temmelig sikkert repræsenterer 
kun eet marint stadium, og at de dominerende arter praktisk taget optræder i alle niveauer.

De udregnede værdier for $P_{\alpha}$ og $P_{\alpha 1}$ ved foden af tabel 14, side 434 viser, at Arnum formationens fauna har størst affinitet til Hemmoorfaunaen, og ReinbekDingden faunaen, som den også korreleres med stratigrafisk og aldersmæssigt. Samtidig er der imidlertid også ret stor affinitet til Klintinghoved faunaen. Dette kunne tyde på faunistisk kontinuitet i de dybere dele af Nordsøbækkenet fra Klintinghoved etagen over Hemmoor etagen og videre til Reinbek etagen.

Det anses for unyttigt at forsøge en mere præcis korrelation med det nordvesttyske mellemmiocæn i øjeblikket. Det tyske fossilmateriale tillader ikke dette. Faunaudviklingen i Arnum formationen er nu den bedst kendte, derfor egner denne formation sig bedre til at være standard profil end det nordvesttyske mellemmiocæn.

\section{Analyse af faunaudviklingen i Arnum formationen}

\section{Bemærkninger om sedimentationen af molluskskaller}

Da molluskskallerne efter dyrets død er underkastet de samme love for transport som sedimenterne på havbunden, behøver fossile molluskselskaber ikke at være identiske med dyresamfundene, hvorira de stammer.

På grundlag af A. C. Johansens (1901) studier over transporten af molluskskaller i forskydningszonen langs det åbne havs kyster kan man slutte, at fossile molluskselskaber med tydeligt littoralt præg i form af tykskallede individer og rullede skaller stammer fra mollusksamfund, hvis arter havde deres øvre bathymetriske grænse ovenfor ca. $15 \mathrm{~m}$ dybdekurven.

\section{Betydningen af de behandlede molluskselskaber fra Arnum formationen}

De undersøgte molluskselskaber er kun tilnærmede udsnit af mollusksamfund ikke alene på grund af eventuel transport af skalmaterialet efter dyrenes død, men også i kraft af, at de som boreprøver repræsenterer et vist sedimentationsinterval.

\section{Faunaudvikling og betydningen af hyppige arter}

Diskussionen af den faunistiske udvikling baseret på den statistiske oversigt over de enkelte prøvers fossilindhold i tabellerne 15 (p. 436) og 16 (p. 460). Tabel 15 viser alle bestemte og talte individer, mens tabel 16 indeholder alle »hyppige« arter, d.v.s. arterne som i en eller flere af prøverne repræsenterer $1 \%$ eller mere af de samlede antal fossiler i prøven. Prøverne fra de to Arnumboringer, som kun ligger med et par meters afstand, er ordnet i eet faunaprofil i tabel 16.

De hyppige arter udgør mellem $80 \mathrm{og} 98 \%$ af fossilerne i prøverne. Det er bemærkelsesværdigt, at deres andel i faunaen stiger op gennem lagserien i boringerne Glejbjerg, Arnum og Toftlund. I Gramby boringen ligger procenterne højt $\mathrm{i}$ alle prøver og svarer til procenterne i de øverste prøver $\mathrm{i}$ Glejbjerg, Arnum og Toftlund profilerne. En undtagelse fra reglen om høje procenter i de øverste prøver er prøven fra 28-40 m i Arnum boringen (150.13). Bramminge faunaen hører til typen med høje procenter for de hyppige arter.

Forøgelsen af de hyppige arters individantal i Glejbjerg, Arnum og Toftlund profilerne skyldes uden tvivl en selektiv faktor, som antages at være aftagende saltholdighed under sedimentationen af Arnum formationen. 
Gramby profilets høje procenter for de hyppige arter forklares ved at antage, at sedimentationsområdet lå i nærheden af kysten under hele sedimentationsforløbet, og at vandet var mere eller mindre brakt på grund af udstrømmende ferskvand fra landområdet øst herfor. Denne forklaring støttes ved betragtninger over sedimenterne i profilet.

Bramminge molluskselskabet er en typisk strandakkumulation fra forskydningsbæltet. Det synes rimeligt at antage, at den høje procent af hyppige arter ved Bramminge er et udtryk for sekundær selektion som følge af bølgebevægelse og brænding, hvorved kun de kraftigste skaller har undgået at blive ødelagt.

\section{Forholdet mellem arterne}

De enkelte arters hyppighed i tabel 16 afslører visse påfaldende relationer mellem beslægtede arter. Særligt iøjnefaldende er forholdet mellem Nassa cimbrica, N. Schlotheimi, N. Fuchsi og N.Facki, hvis procenter er uddraget og sammenstillet særskilt forneden på tabel 16 .

Det er fristende at forklare Nassaernes optræden på lignende måde som ændringen i de hyppige arters procenter ved at antage, at en ændring af saltholdigheden har favoriseret $N$. cimbrica og $N$. Schlotheimi på de to andre arters bekostning. En sådan forklaring støttes af procenterne i prøverne fra Gramby, som netop alle formodes at repræsentere brakvandsfaunaer.

En nøjere undersøgelse af hyppighederne i Gramby, Toftlund og Arnum prøverne tyder dog på, at salinitetsændringen ikke er hele forklaringen. N.cimbrica tiltager opefter både i Gramby, Toftlund og Arnum profilerne, og det er endvidere bemærkelsesværdigt, at $N$, cimbrica og $N$. Schlotheimi altid dominerer over N. Fuchsi-N. Facki i prøver, hvor de optræder samtidig.

Det er vanskeligt på nuværende tidspunkt at nå til nogen helt sikker opfattelse af årsagssammenhængen i dette forhold. Alt tyder på, at N. Fuchsi og N. Facki har domineret i Arnum formationens nedre del, og at N. Fuchsi har været den biologisk stærkeste af de to arter. Deres sjældne optræden ved Gramby tyder på, at de har været følsomme overfor aftagende saltholdigheder.

$N$. cimbrica og $N$. Schlotheimi synes at have dannet en konkurrerende gruppe overfor N. Fuchsi og N. Facki, som de tilsidst har fortrængt. N. cimbrica og N. Schlotheimi konkurrerede øjensynlig også indbyrdes, idet høje procenter for $N$. cimbrica svarer til lave værdier for $N$. Schlotheimi. Det er ligeledes påfaldende, at $N$. Schlotheimi tiltager betydeligt i de prøver, hvor $N$. cimbrica ikke findes, eller hvor den er sjældnere. Med en enkelt undtagelse (Arnum (25b) $107.5 \mathrm{~m}$ ) ligger procenterne for $N$. cimbrica altid over $N$. Schlotheimi i molluskselskaberne, hvori de begge forekommer.

De to arter var uden tvivl mindre følsomme overfor aftagende saltholdighed end N. Fuchsi og N. Facki. Deres høje procenter i de nederste prøver fra Arnum og Toftlund - hvor alle fire arter optræder samtidig — tyder imidlertid på, at $N$. cimbrica og N. Schlotheimi også havde andre biologiske fortrin end tilpasningsevnen overfor forandringer i saltholdighed, hvorved de var i stand til at udkonkurrere N. Fuchsi og N. Facki.

Sandsynligheden for, at der foreligger en biologisk balance mellem de nævnte 4 Nassa-arter er således ret stor.

Hyppighederne for Leda Westendorpii og Yoldia glaberrima i prøverne fra Toftlund og Arnum tyder på, at der også mellem disse arter er en eller anden form for antagonisme. 
De almindelige arter reagerer forskelligt med hensyn til deres hyppighed i løbet af sedimentationen af lagserierne ved Glejbjerg, Toftlund og Arnum. Nedenfor er arterne grupperet i tre grupper, idet et par ukarakteristiske arter dog er udeladt. Den recessive gruppes arter aftager, den progressive gruppes arter tiltager, og den stationære gruppes procenter er nærmest uforandret i løbet af Arnum formationens dannelse.

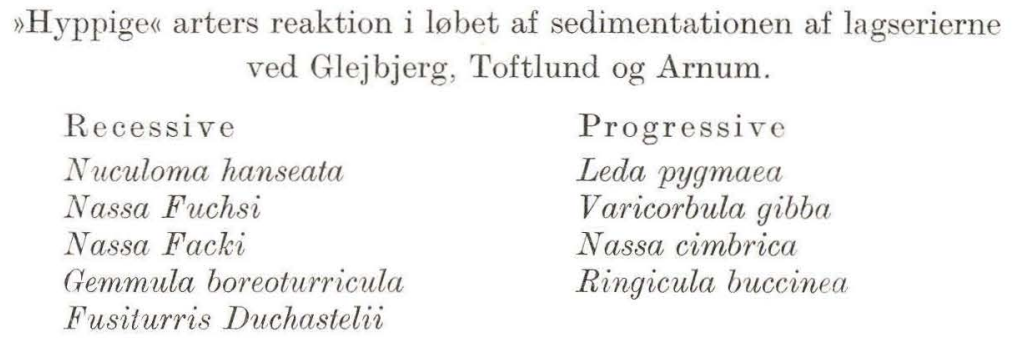

Stationære

$\begin{array}{ll}\text { Leda Westendorpii } & \text { Turritella tricarinata } \\ \text { Leda emarginata } & \text { Bittium tenuispina } \\ \text { Yoldia glaberrima } & \text { Aporrhais alata } \\ \text { Kellyella rotunda } & \text { Nassa Schlotheimi } \\ \text { Thyasira cfr. flexuosa } & \text { Terebra Hörnesi } \\ \text { Ervilia pusilla } & \text { Retusa umbiticata } \\ \text { Spisula subtruncata } & \text { Spiratella atlanta } \\ \text { Abra prismatica } & \text { Vaginella depressa }\end{array}$

Denne karakteristik af arterne er naturligvis kun foreløbig. Det er nødvendigt at undersøge mere materiale før inddelingens værdi kan siges at være endelig belyst. Svaret på spørgsmålet om årsagerne til arternes reaktioner må også udskydes indtil videre. En vis indkredsning af problemstillingen kan dog opnås ved et studium af Bramminge faunaen, der som nævnt er en lavvandsfauna. Vigtige lavvandsarter i molluskselskabet fra Bramminge er:
Leda pygmaea
Yoldia glaberrima
Nassa Schlotheimi
Varicorbula gibba
Nassa cimbrica
A porrhais alata
Terebra Hörnesi
Ringicula buccinea

Det bør dog understreges, at disse arters udbredelse sikkert ikke alene var knyttet til dybder ovenfor 15-20 m, men at de også fandtes nedenfor dette niveau.

De fysiske miljøforhold er delvis blevet omtalt i diskussionen over de hyppige arter, hvor et spørgsmål som aflejringsområdets saltholdighed blev drøftet. De bathymetriske forhold strejfedes ovenfor ved omtalen af lavvandsarterne ved Bramminge.

Ser man på lavvandsarternes hyppighed i prøverne og på sedimenternes 
beskaffenhed, er det rimeligt at slutte, at vanddybden i det undersøgte område var ret ringe, formodentlig mellem $20 \mathrm{og} 50 \mathrm{~m}$.

Temperaturforholdene kan man med nogen tilnærmelse slutte sig til ved at gå ud fra udbredelsen af de endnu eksisterende arter i nutidens have. Molluskselskaberne omfatter 39 arter, som endnu findes i lusitanske og boreale områder, mens 3 arter også findes i arktiske have. Selv med de nødvendige forbehold overfor eventuelle ændringer af arternes miljøkrav i løbet af den tid, der er gået siden Arnum formationens dannelse, synes der således at være stor sandsynlighed for, at dens fauna var en boreal eller lusitansk fauna.

Blandt de nulevende arter har Pecten tigerinus og Cancellaria cancellata særlig interesse. $P$. tigerinus er næsten paradigmatisk boreal i sin nutidige udbredelse, og C. cancellata er omtrent lige så typisk lusitansk. Uden at overdrive disse to arters betydning kan man derfor slutte, at man i Arnum formationens aflejringsperiode har haft temperaturforhold i Nordsøområdet, der omtrent svarede til temperaturen i nutiden i havet ved det nordlige Spanien og Portugal, hvor de to arter mødes. En oversigt over havets middeltemperatur ved Nordspanien og Portugal og en diskussion af temperaturligheden mellem dette område og den miocæne Nordsø findes side 415.

Ind delingen af Arnum formationens molluskselskaber. På side 455 findes en redegørelse for inddelingen af molluskselskaberne. I oversigtstabellerne karakteriseres de enkelte fossilselskaber ved dominerende producenter og konsumenter.

Alle molluskselskaber synes at være derivater af Aporrhais alata - Nassa ssp. samfundet, som således kan betragtes som det typiske grundthavssamfund i den miocæne Nordsø.

\section{Korrelation af boreprofilerne}

Boreprofilerne kan inddeles biostratigrafisk ved hjælp af Nassa Fuchsi og N. cimbrica species zonerne*).

Nassa Fuchsi zonen er den nederste biostratigrafiske afdeling af den kendte del af Arnum formationen. Det må dog understreges, at formationens nedre grænse kun er nået i Ribe boringen og at fossilmaterialet fra denne boring er ret utilstrækkeligt som stratigrafisk dokumentationsmateriale. Vi ved således ikke, om Nassa Fuchsi er karakteristisk for hele det marine interval ved Ribe eller ej.

Den øvre grænse for den biostratigrafiske Nassa Fuchsi zone defineres som basis af $N$. cimbrica zonen. Denne grænse ligger ved ca. $50 \mathrm{~m}(-25 \mathrm{~m})$ i Glejbjerg profilet.

Med hensyn til Bramminge profilet ved vi kun, at laget ved $70-80 \mathrm{~m}$ hører til Nassa cimbrica zonen. Det er muligt at zonens nedre grænse ligger dybere end $80 \mathrm{~m}$ dybde $(-66 \mathrm{~m})$.

Hele Gramby serien må henføres til $N$. cimbrica zonen.

Arnum profilet repræsenterer $N$. cimbrica zonen fra dens top ved basis af

*) Betegnelsen species zone er her brugt som synonym for biozone (se f. eks. Troelsen \& SoRGENFrei 1956), som af forskellige grunde er en mindre konsekvent betegnelse. Ved species zone forstås en arts totale vertikale og horisontale udbredelse. I de tilfælde, hvor der $\mathrm{i}$ det følgende anvendes et artsnavn efterfulgt af betegnelsen 'zone', menes hermed species zone. 
Gram formationen til den nedre grænse, som øjensynlig lige er nået. Toftlund boringen nåede tilsyneladende ikke gennem $N$. cimbrica zonen.

Det er umuligt på nuværende tidspunkt at afgøre, om N.cimbrica's opdukken er samtidig i alle profilerne. Det er allerede nævnt tidligere, at $N$. cimbrica måske er en brakvandsart. På den anden side tyder meget på, at arten er indvandret udefra. I så fald er det berettiget at betragte Nassa cimbrica zonens basis som et synkront niveau.

Det er vanskeligt at nå til en mere detailleret korrelation af de enkelte boreprofiler på grundlag af de fossilførende lag. En enkelt parallelitet mellem Toftlund og Arnum profilet er dog omtalt. Ved en sammenligning af hyppighederne af arterne i tabel 16 for prøverne Toftlund $115 \mathrm{~m}$ og Arnum 104.3-107.5 m ses, at følgende arter fremviser maksimale frekvenser i begge prøver:

\section{Yoldia glaberrima Abra prismatica \\ Natica sp. sp. \\ Nassa Fuchsi}

\author{
Nassa Facki \\ Gemmula boreoturricula \\ Fusiturris Duchastelii
}

Denne sammenfalden af 7 maksima ud af 30 muligheder viser, at de to molluskselskaber ligner hinanden meget. Vi har dog endnu ikke beviset for, at dette betyder, at de er synkrone.

For at give en oversigt over de omtrentlige formationstykkelser og den tertiære lagserie i Sønderjylland, anføres boreprofilet for dybdeboringen Arnum no. 1 fra terræn og til basis af daniets bryozokalk. Arnum formationens fossilserie i denne boring er kun repræsenteret ved skylleprøver, der endnu ikke er analyseret nærmere på grund af deres ringe kvalitet, idet der er boret uden forerør.

\section{Bemærkninger om områdets struktur}

Korrelationen af boreprofilerne (fig. 2) viser, at der må have fundet tektoniske bevægelser sted under og efter Arnum formationens aflejringer. Glejbjerg serien ligger i et højere niveau end de andre lagserier, og der er tilstrækkelig begrundelse for at antage, at lagserien ved Arnum er hævet i forhold til Gramby og Toftlund områderne.

Allerede på et tidligt tidspunkt af mine undersøgelser (1947) blev de foreløbige biostratigrafiske resultater stillet til rådighed for Danish American ProspectING Co. ved fortolkningen af selskabets geofysiske og geologiske undersøgelser i Sønderjylland. Det viste sig, at der var en bemærkelsesværdig overensstemmelse mellem strukturerne, som antydedes af den miocæne lagserie, og residualtyngdekortet udarbejdet af Gulf Research \& Development Co. Lagseriens høje beliggenhed ved Arnum og Glejbjerg svarede til maxima på tyngdekortet, og de lavere liggende Gramby, Toftlund og Ribe profiler svarede til lokale tyngdeminima.

Området er senere undersøgt seismisk af Danish American Prospecting Co. De seismiske undersøgelser og en række strukturboringer har bekræftet rigtigheden af den strukturelle fortolkning, som den miocæne lagserie gav anledning til. 


\section{BIBLIOGRAPHY}

Agassiz, L. 1845. Iconographie des Coquilles Tertiaires. Nouv. Mém. Soc. Helvét. sci. nat. Neuchatel.

AдвRеснт, J. C. H. und W. VALK. 1943. Oligocäne Invertebraten von Süd-Limburg. Meded. Geol. Sticht. Ser. C-IV-1-No. 3. Maastricht.

Allee, W. C., A. E. Emerson, O. Park, T. Park and K. P. Schmidt. 1949. Principles of Animal Ecology. Philadelphia and London.

Alten, E. J. (Editor) 1931. Plymouth Marine Fauna. Compiled from the Records of the Laboratory of the Marine Biological Association. Devon.

Andersen, A. F., Harald Bohr og Richard Petersen. 1949. Lærebog i matematisk Analyse. IV. København.

Anket, W. E. 1948. Die Nahrungsaufnahme der Pyramidelliden. Verh. Deutsch. Zoologen in Kiel 1948. p. 478. Leipzig.

Apeltöf, A. 1912. Über die Beziehung zwischen Fortpflanzung und Verbreitung mariner Tierformen. Verh. d. VIII. internationalen Zoologen-Kongresses zu Graz 1910. p. 303. Jena.

Arketi, W. J. and J. A. Moy-Thomas. 1940. Palaeontology and the Taxonomic Problem. (In Huxley 1940. The New Systematics. p. 395). Oxford.

Áskelsson, J. 1935. Some Remarks on the Distribution of the Species Zirphaea crispata L. and Purpura lapillus L. on the North-Coast of Iceland. Vidensk. Medd. fra Dansk naturhist. Foren. Bd. 99. p. 65. København.

Bárbarson, G. G. 1920. Om den marine Molluskfauna ved Vestkysten af Island. Kgl. Danske Vid. Selsk. Biol. Medd. II, 3. København.

Barker Jørgensen, D. 1946. See Thorson, 1946.

Basterot, M. B. 1825, Mémoire Géologique sur les environs de Bordeaux. Paris.

Bateson, W. 1889. On some Variations of Cardium edule apparently correlated to the conditions of life. Philos. Trans. of the Roy. Soc. of London A. Vol. 180. London.

Bewts, C. 1946. The Pliocene and Lower Pleistocene Gastropods in the Collections of the Geological Foundation in the Netherlands. Meded. Geol. Sticht. Ser. C-IV-1-No. 6. Maastricht.

Bellardi, L. et F. Sacco 1872-1904. I Molluschi dei terreni terziari del Piemonte e della Liguria. 1: 1872, 2: 1877, 3: 1882, 4: 1884, 5-7:1890, 8-10:1891; 11, 12:1892; 13, 14: $1893 ; 15,16: 1894 ; 17-19: 1895 ; 20,21: 1896 ; 22-24: 1897 ; 25,26: 1898 ; 27: 1899$, 28: 1900, 29: 1901, 30: 1904. Part 1-6 also published in: Mem. Real. Accad. Sci. Torino 1873, 1878, 1883, 1886, 1888, 1890. Torino.

Benoist, A. E. 1873. Catalogue synonymique et raisonné des Testacés Fossiles recueillis dans les faluns miocènes des communes de la Brède et de Saucats. Actes Soc. Lin. Bordeaux. 29. p. 5-78 et 265-460. Bordeaux.

- 1876. Monographie des Tubicolés, Pholadaires et Solenacées Fossiles recueillis dans l'étage miocène du Sud-Ouest de la France. Actes Soc. Lin. Bordeaux. 31. p. 312. Bordeaux.

Beyrich, E. 1853-1856. Die Conchylien des norddeutschen Tertiärgebirges. Berlin.

- 1854. Die Stellung der Hessischen Tertiärbildungen. Ber. über d. Verh. d. Berliner Akad. D. Wiss. p. 640. Berlin.

- 1856. Über den Zusammenhang der norddeutschen Tertiärbildungen. Abh. d. Königl. Akad. d. Wiss. zu Berlin. phys. Kl. Jahrg. 1855. p. 1. Berlin.

- 1858. Über die Abgrenzung der oligocänen Tertiärzeit. Monatsber. u. d. Verh. d. Berliner Akad. d. Wiss. p. 51. Berlin.

Buegvad, H. 1922. Animal Communities in the Southern North Sea. Proc. Zool. Soc. London. p. 27. London.

- 1930. Quantitative Investigations of Bottom Invertebrates in the Kattegat with 
Special Reference to the Plaice Food. Reports of the Danish Biological Station Vol. XXXVI. Copenhagen.

Boysen-Jensen, P. 1920. Valuation of the Limfjord I. Reports of the Danish Biological Station Vol. XXVI. Copenhagen.

Brander, G. 1766. Fossilia Hantoniensia collecta et in Museo Britannico deposita. London.

Brandt, K. 1897. Die Fauna der Ostsee, insbesondere die der Kieler Bucht. Verh. d. Deutschen zool. Ges. d. siebenten Jahresvers. zu Kiel. Leipzig.

Bratrström, H. 1941. Studien über die Echinodermen des Gebietes zwischen Skagerak und Ostsee, besonders des Öresunds, mit einer Übersicht über die physische Geographie. Lund.

Brocchi, G. 1814. Conchiologia Fossile Subapennina. Milano.

Brongniart, A. 1823. Mémoir sur les Terrains de Sédiment supérieure Calcaréo-Trappéens $\mathrm{du}$ Vicentin. Paris.

Bronn, H. G. 1831. Italiens Tertiärgebilde. Heidelberg.

- 1853-56. Lethaea Geognostica. 3. Stuttgart.

Brugutere 1789-1792. Histoire Naturelle des Vers. Encyclopédie Méthodique. T. Sixième. p. 376. Paris.

Brusina, S. 1877. Fragmenta Vindobonensia. Journ. de Conchyliogie. Vol. 25, p. 368. Paris.

BRÖGGER, W. C. 1901. Om de senglaciale og postglaciale nivåforandringer i Kristianiafeltet (Molluskfaunan). Kristiania.

Bucquoy, E., Ph. Dautzenberg et G. Dollfus. 1886-1898. Les Mollusques Marins du Roussillon. Paris.

BULLOCK, T. H. 1955. Compensation for temperature in the metabolism and activity of poikilotherms. Biol. Reviews. Vol. 30. p. 311 . Cambridge.

Cantratne. 1835. Notice contenant les diagnoses ou descriptions succintes de quelques espèces nouvelles de mollusques. Bull. d. l'Acad. Roy. d. Sci. t. 2. Bruxelles.

Cerulli-Irelit, S. 1909-16. Fauna malacologica mariana. Palaeontographia Italica. Vol. XIII-XXII. Pisa.

Chenu, J. C. 1845-46. Bibliothèque Conchyliologique. Paris.

Coe, W. R. and D. L. Fox. 1942. Biology of the California Sea-Mussel (Mytilus californianus) I. Influence of Temperature, Food Supply, Sex and Age on the Rate of Growth. Journ. of Experimental Zool. Vol. 90. p. 1-30. Philadelphia.

Costa, E. M. DA. 1778. Historia Naturalis Testacearum Britanniæ. London.

Cossuann, M. 1895-1925. Essais de Paléoconchologie comparée. T. 1-13. Paris.

- et Peyrot. 1909-34. Conchologie Néogénique de l'Aquitaine. Actes Soc. Lin. de Bordeaux. Vol. 63-66: 1909-12; 68-70: 1914-18; 73-75: 1921-23; 77-79: 1925-28; 82-86: 1930-34. Bordeaux.

Cox, L. R. 1955. Observations on Gastropod Descriptive Terminology. Proc. Malac. Soc. Vol. 31. p. 190. London.

Craven, A. E. 1877. Monographie du Genre Sinusigera, D'Orb. Annales de la SociétéMalacologique de Belgique. T. XII. p. 105. Bruxelles.

Cuvier, G. 1831. Sur un travail de M. Deshayes ayant pour titre: Tableaux comparatifs des Coquilles vivantes, avec les Fossiles des terrains tertiaires de l'Europe. Ann. d. Sci. Nat. 24. p. 176-184. Paris.

— et A. Brongniart. 1811. Essai sur la Géographie Minéralogique des Environs de Paris. Paris.

— - 1822. Description géologique des environs de Paris. Paris.

Dald, W. H. 1889. Reports on the Results of Dredging, under the Supervision of Alexander Agassiz, in the Gulf of Mexico (1877-78) and in the Caribbean Sea (1879-80), by the U.S. Coast Survey Steamer "Blake". 29. Rep. on the Mollusca Pt. 2. Gastropoda and Scaphopoda. Cambridge.

- 1934. On the value of nuclear characters in the classification of marine gastropods. Journ. Wash. Acad. Sci. Vol. 14. No. 8. p. 177. Baltimore.

DAUDIN 1800. Nouveau genre de ver à tube calcaire, voisin des serpules et des dentales. Bull. d. Sci. par la Soc. Philomathique. No. 43, p. 145. Paris.

Davies, A. M. 1935. Tertiary Faunas. I 1935, II 1934. London.

- G. M. 1939. Geology of London and South-East England. London.

Davis, F. M. 1923. Quantitative studies on the fauna of the sea bottom. No. 1. Preliminary investigation of the Dogger Bank. Min. of Agr. and Fish. Invest. Ser. 2. Vol. 6. No. 2. London. - No. 2. 1925. Rep. of the Invest. of the southern North Sea 1921-1924. Ibid. Ser. 2. Vol. 8. No. 4. London.

Deevey, Edward S. Jr. 1950. Hydroids from Louisiana and Texas, with Remarks on the 
Pleistocene Biogeography of the Western Gulf of Mexico. Ecology. Vol. 31, No. 3, p. 334. Lancaster, Pa.

Degrange-Touzin, A. 1894. Étude préliminaire des Coquilles fossiles des Faluns des environs d'Orthez et de Salies-de-Béarn.

Depéret. 1892. Note sur la classification et la parallélisme du système Miocène. Bull. Soc. Géol de France. T. 20. p. CXLV. Paris.

- 1893. Sur la classification et le parallélisme du système Miocène. Bull. Soc. Géol. de France. T. 21. p. 170. Paris.

Deshayes. 1830. Tableau comparatif des espèces de coquilles vivantes avec les espèces de coquilles fossiles des terrains tertiaires de l'Europe, et des espèces de fossiles de ces terrains entr'eux. Bull. Soc. Géol. de France. T. 1. p. 185. Paris.

Deshayes, P. 1831. See Cuvier 1831.

Deshayes, G. P. et H. Milne Edwards 1845. Histoire Naturelle des Animaux sans Vertèbres. 2. Edit. t. 11. Paris.

Des Moulins, C. 1842. Révision de quelques espèces de Pleurotomes. Actes Soc. Lin. Bordeaux. 1842. p. 109.

Dexter, R. W. 1947. The Marine Communities of a Tidal Inlet at Cape Ann. Massachusetts: A Study in Bio-Ecology. Ecological Monographs. Vol. 17. p. 261. Durham. N. C. Dinesen, A. see G. Larsen.

Dons, C. 1931. Nordgrenser for endel muslinger. Det Kongelige Norske Videnskabers Selskabs Forh. Bd. IV. Nr. 18. p. 62. Oslo.

Dujardin, F. 1835. Mémoir sur les Couches du Sol en Touraine. Mém. Soc. Géol. France. 2, p. 211. Paris.

Dumont, A. 1851. Note sur la position géologique de l'argile rupelienne et sur le synchronisme des formations tertiaires de la Belgique, de l'Angleterre et du nord de la France. Bull. Acad. Roy. d. Sci. No. 7. p. 179. Bruxelles.

Eichwald, Eduard. 1830. Naturhistorisehe Skizze von Lithauen, Volhynien und Podolien. Wilna.

- 1853. Lethaea Rossica. Stuttgart.

Ekman, Sven. 1935. Tiergeographie des Meeres. Leipzig.

- 1953. Zoogeography of the Sea. London.

Faujas-De-Saint-Fond. 1817. Notice sur quelques coquilles fossiles des environs de Bordeaux. Mém. du Mus. d'Hist. Nat. T. 3. p. 195. Paris.

Férussac, De. 1821. Tableaux Systématiques des Animaux Mollusques. Paris.

Field, J. A. 1911. The Food Value of Sea Mussels. Bull. Bur. Fisheries 29, p. 87.

Finlay, H. J. 1931. On Austrosassia, Austroharpa, and Austrolithes, New Genera with some Remarks on the Gasteropod Protoconch. Trans. and Proc. New Zealand Inst. Vol. 62. p. 7-19. Dunedin.

Frscher, P. 1887. Manuel de Conchyliologie. Paris.

— et R. Tournouer, 1873. Invertèbres Fossiles du Mont Léberon. Dans: Gaudry, A. Animaux Fossiles du Mont Léberon. p. 113. Paris.

Fischer-Piette, E. 1941. Croissance, taille maxima et longévité possible de quelques animaux intercotidaux, en fonction du milieu. Ann. de l'Inst. Océanographique. Nouv. Sér. t. XXI - fasc. 1. Paris.

FISH, C. J. 1925. Seasonal Distribution of the Plankton of the Woods Hole Region. Bull. Bur. Fish., 41. p. 91.

Fisher, R. A. 1954. Statistical Methods for Research Workers. Edinburgh.

Forbes, E. and S. Hanley. 1853. A History of British Mollusea. London.

Ford, E. 1923. Animal Communities of the Level Sea-bottom in the Waters Adjacent to Plymouth. Journ. of the Marine Biol. Ass. of the United Kingdom. Vol. XIII (N.S.) p. 164. Plymouth.

Fox, D. L. see Cok, W.R.

Franzén, Áke. 1955. Comparative Morphological Investigations into the Spermiogenesis among Mollusca. Zool. bidrag. Uppsala. Bd. 30. p. 399. Uppsala.

Fretter, V. and Graham, A. 1949. The structure and mode of life of the Pyramidellidae, parasitic opisthobranchs. Journ. Mar. Biol. Ass. Vol. 28. p. 493. Cambridge.

Gignoux, M. 1913. Les Formations Marines Pliocènes et Quaternaires de l'Italie du Sud et de la Sicile. Ann. de l'Univ. de Lyon. Nouv. Sér. I. Fasc. 36. Paris.

- 1950. Géologie Stratigraphique. Paris.

Gislén, Torsten. 1929-1930. Epibioses of the Gullmar Fjord I-II. A Study in Marine Sociology. Kristinebergs Zoologiska Station 1877-1927. Uppsala.

Glibert, M. 1945. Faune Malacologique du Miocène de la Belgique. I. Pélécypodes. Mém. du Mus. Roy. d'Hist. Nat. de Belgique no. 103. Bruxelles. 
Glibert, M. 1952. a. II. Gastropodes. Ibid. no. 121. Bruxelles.

- 1949 et 1952. b. Gastropodes du Miocène Moyen du Bassin de la Loire. Inst. Roy. Sci. Nat. de Belgique. 2. sér. fasc. 30 et 46 . Bruxelles.

- 1954. L'Oligocène Inférieure Belge. Volume Jubilaire Victor van Straelen. Bruxelles.

- 1954. Pleurotomes du Miocène de la Belgique et du Bassin de la Loire. Inst. Roy. des Sci. Nat. de Belgique. Mém. No. 129. Bruxelles.

Goldfuss, A. 1837-1844. Petrefacta Germaniae. 2-3. Düsseldorf.

Gоттsснe, C. 1878. Ueber das Miocän von Reinbeck und seine Molluskenfauna. Verh. d. Ver. f. Naturwiss. in Hamburg. Bd. III. Hamburg.

- 1887. Die Mollusken-Fauna des Holsteiner Gesteins. Festschr. z. Feier d. 50 jähr. Best. d. Naturwiss. Ver. in Hamburg. Hamburg.

- 1901. Der Untergrund Hamburgs. Hamburg.

Gould, A. A. 1870. Invertebrata of Massachusetts. Ed. by W. G. Binney. Boston.

Görates, J. 1941. Die Oberoligocänfauna von Rumeln am Niederrhein. Decheniana, Bd. 100 A. p. 115 . Bonn.

Grabau, A. W. 1902. Studies of Gastropoda. The American Naturalist. Vol. 36. p. 917. Boston.

Grateloup. 1838. Conchyliologie Fossile du Bassin de l'Adour. Famille des Plicacés. Actes Soc. Lin. de Bordeaux. T. 10. p. 251. Bordeaux.

- 1840. Conchyliologie fossile des terrains tertiaires du bassin de l'Adour. 1. Univalves. Atlas. Bordeaux.

- 1845. Description de plusieurs espèces de coquilles fossiles des environs de Dax (Landes). Bull. d'Hist. Nat. Soc. Lin. Bordeaux. 2. 2me éd. p. 3.

Gripp, K. 1912. see КосH, E.

— 1914. Über eine untermiozäne Molluskenfauna von Itzehoe. Jahrb. Hamburg. Wiss. Anst. 5 Beih. Hamburg.

- 1915. Über das marine Altmiocän im Nordseebecken. Neues Jahrb. f. Min. Geol. u. Pal. Beil.-Bd. XLI. p. 1. Stuttgart.

- 1920. see КосH, E.

- 1922. Marines Pliocän und Hipparion gracile KAuP. vom Morsumkliff auf Sylt. Zeitschr. Deutsch. Geol. Ges. Bd. 74. Jahrg. 1922. Abh. 2-4. Berlin.

- 1933. Geologie von Hamburg. Hamburg.

- 1940. Cardita laevicosta weingärtneriana n. var. und Astarte magdalena n. sp. aus dem tiefsten obermiozänen Glimmerton. Arch. Moll. 72. s. 145. Frankfurt.

— und A. Magne. 1956. Neues zur Gliederung des Miozäns in Westeuropa. Neues Jb. Geol. Paläontol. Mh. 6. p. 273. Stuttgart.

Hagmeier, A. 1925. Vorläufiger Bericht über die vorbereitenden Untersuchungen der Bodenfauna der Deutschen Bucht mit dem Petersen-Bodengreifer. Ber. d. Deutschen wiss. Komm. f. Meeresforschung. N. F. Bd. I. p. 247. Berlin.

- 1929. Eine Fluktuation von Mactra (Spisula) subtruncata da Costa an der ostfriesischen Küste. Ber. d. Deutschen wiss. Komm. f. Meeresforschung N. F. Bd. V. p. 126. Berlin.

- 1929. Die Bodenfauna der Ostsee im April 1929 nebst einigen Vergleichen mit April 1925 und Juli 1926. Ber. d. Deutschen wiss. Komm. f. Meeresforschung N. F. Bd. V. p. 156. Berlin.

Harder, P. 1913. De oligocæne Lag i Jærnbanegennemskæringen ved Aarhus Station. Danmarks Geol. Unders. II. Række. Nr. 22. Résumé en français. København.

Harmer, F. W. 1914-1925. The Pliocene Mollusca of Great Britain. The Paleontographical Society. London.

Haug, E. 1908-1911. Traité de Géologie. II. Paris.

Hayes, F. R. 1927. The Effect of Environmental Factors on the Development and Growth of Littorina littorea. Proc. and Trans, of the Nova Scotian Institute of Science. Vol. XVII. pt. 1. p. 6-13. Halifax.

Hedberg, Hollis D. 1951. Nature of Time-Stratigraphic Units and Geologie Time Units. Bull. Am. Ass. of Petroleum Geologists. Vol. 35. No. 5. p. 1077. Tulsa.

Hedley, Сн. 1903. Mollusca. Part II. Scaphopoda and Gastropoda in: Scientific Results of the Trawling Expedition of H.M.C.S. "Thetis" off the Coast of New South Wales in Febr. and March 1898. Aust. Mus. Mem. IV. Part 6. p. 327. Sydney.

- 1905. Mollusca from one hundred and eleven fathoms, East of Cape Byron, New South Wales. Rec. Australian Mus. Vol. 6. p. 41. Sydney.

- 1907. The Results of Deep-Sea Investigation in the Tasman Sea. Rec. Aust. Mus. Vol. VI. p. 283. Sydney.

- 1922. A Revision of the Australian Turridae. Rec. Aust. Mus. Vol. XIII. No. 6. p. 213. Sydney. 
Heering, J. 1942. Die oligocänen taxodonten Bivalven aus dem Peelgebiete. Meded. Geol. Sticht. Ser. C-IV-1-No. 2. Maastricht.

- 1944. Die oberoligocänen Bivalven (Mit Ausnahme der Taxodonten) aus dem Peelgebiete. Meded. Geol. Sticht. C-IV-1-No. 4. Maastricht.

- 1950. a. Pelecypoda (and Scaphopoda) of the Pliocene and Older-Plistocene Deposits of the Netherlands. Meded. Geol. Stichting. Ser. C-IV-1-No. 9. Maastricht.

- 1950. b. Miocene Pelecypoda of the Netherlands (Peel-Region). Meded. Geol. Stichting. Ser. C. $-\mathrm{IV}-1-\mathrm{No}$.10. Maastricht.

Hesse, R., W. C. Allee and K. P. Schmidt. 1924 and 1951. Ecological Animal Geography. First and Sec. Ed. New York and London.

Hinsch, W. 1952. Leitende Molluskengruppen im Obermiozän und Unterpliozän des östlichen Nordseebeckens. Geol. Jahrb. Bd. 67. S. 143. Hannover.

- 1955. Miozängliederung in den Erdölfeldern Heide und Bramstedt. Neues Jb. Geol. Paläontol. Mh. 8. p. 348. Stuttgart.

HJorth see Murray.

Hoernes, R. und M. Autnger. 1879-1891. Die Gasteropoden der Meeresablagerungen der ersten und zweiten Miocänen Mediterran-Stufe in der Österreichisch-Ungarischen Monarchie. Wien.

Hörnes, M. 1856-1870. Die fossilen Mollusken des Tertiær-Beckens von Wien. 1-2. Abh. K. K. geol. Reichsanst. 3-4. Wien.

Hutchins, L. W. 1947. The Bases for Temperature Zonation in Geographical Distribution. Ecological Monographs. 17. p. 325. Durham, N. C.

Huxley, J. 1940. The New Systematics. Oxford.

International Geological Congress. 1950. XVIII Sess. Proc. of Sect. H. The PliocenePleistocene Boundary. London.

IJspeert, C. 1942. Monographie der miozänen taxodonten Bivalven aus dem Peelgebiete. Meded. Geol. Sticht. Ser. C-IV-1-No. 1. Maastricht.

Iredale, T. 1910. On Marine Mollusca from the Kermadec Islands, and on the "Sinusigera apex". Proc. Malacol. Soc. London. Vol. IX. pt. I. p. 68-79. London.

- 1911. On the Value of the Gastropod Apex in Classification. Proc. Malacological Soc. Vol. 9. p. 319. London.

- 1915. Some more misused Molluscan generic names. Proc. Malacological Society. 11. p. 291. London.

JACOBSEN, J. P. 1908. Mittelwerte von Temperatur und Salzgehalt. Bearbeitet nach hydrographischen Beobachtungen in dänischen Gewässern 1880-1907. Medd. fra Kommissionen for Havundersøgelser. Ser. Hydrografi Bd. I. København.

Janoscheк, R. 1951. Das Inneralpine Wiener Becken. See Schaffer, 1951. p. 525.

Jeffreys, J. G. 1862-1869. British Conchology. London.

Jensen, A. J. C. 1937. Fluctuations in the Hydrography of the Transition Area during 50 Years. Conseil Permanent International pour l'Exploration de la Mer. Rapp. et Procès-Verbaux des Réunions Vol. C. II. Copenhagen.

- 1940. The Influence of the Currents in the Danish Waters on the Surface Temperature in Winter, and on the Winter Temperature of the Air. Medd. Komm. Danmarks Fiskeri og Havunders. Ser. Hydrografi. Bd. 3. Copenhagen.

Jensen, Ad. S. 1900. Studier over nordiske Mollusker. I. Mya. Vidensk. Medd. fra Dansk naturhist. Foren. p. 133. København.

- 1902. Studier over nordiske Mollusker. II. Cyprina islandica. Vidensk. Medd. fra Dansk naturhist. Foren. p. 33. København.

- 1905. a. Studier over nordiske Mollusker. III. Tellina (Macoma). Vidensk. Medd. fra Dansk naturhist. Foren. p. 21. København.

- 1905. b. On the Mollusea of East-Greenland. I. Lamellibranchiata. Medd. om Grönland. Vol. 29. p. 289. København.

- og R. Spärck. 1934. Bløddyr. II. Saltvandsmuslinger. Danmarks Fauna 40. København.

Johansen, A. C. 1901. a. On the Variations Observable in some Northern Species of Littorina. Vidensk. Medd. Naturh. Foren. i Kjøbenhavn. p. 295. København.

- 1901. b. Om Aflejringen af Molluskernes Skaller i Indsøer og i Havet. Vid. Medd. naturh. Foren. København.

- 1913. Om Forandringer i Ringkøbing Fjords Fauna. Mindeskrift for Japetus Steenstrup. København.

- 1916. Om hydrografiske Faktorers Indflydelse paa Molluskernes Udbredelse i Østersøen. Forh. 16. skandinaviske naturforskermøde. p. 633. Stockholm.

- 1918. Randers Fjords Naturhistorie. København. 
Johnson, C. W. 1934. List of Marine Mollusca of the Atlantic Coast from Labrador to Texas. Proc. Boston Soc. of Nat. Hist. Vol. 40. No. 1. p. 1. Boston.

Jørgensen, C. Barker. see G. Thorson 1946.

KARsten, H. 1849. Verzeichniss der im Rostocker academischen Museum befindlichen Versteinerungen aus dem Sternberger Gestein. Rectorats-Program. Rostock.

Kautsky, F. 1925. Das Miocän von Hemmoor und Basbeck-Osten. Abh. d. Preuss. Geol. Landesanst. N. F. H. 97. Berlin.

- 1928. Die biostratigraphische Bedeutung der Pectiniden des niederösterreichischen Miozäns. Ann. d. Naturh. Mus. in Wien. Bd. XLII. p. 425. Wien.

- 1939. Die Erycinen des niederösterreichischen Miocaen. Ann. d. Naturh. Mus. in Wien. 50. p. 584. pl. 19-22. Wien.

Kemp, T. 1942. Statistiske Metoder i Medicin og Biologi. København.

Kesteven, H. L. 1912. The Constitution of the Gastropod Protoconch: Its Value as a Taxonomic Feature and the Significance of some of its Forms. Proc. Linn. Soc. New South Wales. Vol. 37. p. 49-82. Sydney.

Kiтtu, Ernst. 1886. Ueber die miocenen Pteropoden von Oesterreich-Ungarn. Ann. d. K. K. Hofmus. 1. p. 48.

KnIPowitsch, N. 1900. Zur Kenntniss der geologischen Geschichte der Fauna des Weissen und des Murman-Meeres. Set. Petersburg.

Koch, E., K. Gripp u. A. Franke. 1912. Die staatlichen Tiefbohrungen XIV, XV, XVI, XVII in den Vierlanden bei Hamburg. Mitt. a. d. Min.-Geol. Inst. in Hamburg. p. 1. Hamburg.

- und K. GRTPP, 1920. Zur Stratigraphie des Jungtertiärs in Nordwestdeutschland. Jb. Hamburg. Wiss. Anst. Bh. 36. (1918). Hamburg.

- 1927. Beiträge zur Geologie des Untergrundes von Hamburg und Umgebung. Mitt. a. d. Min.-Geol. Staatsinst. in Hamburg. H. IX. p. 1. Hamburg.

Koch, F. E. und C. M. WiechmanN. 1872. Die Mollusken-Fauna des Sternberger Gesteins in Mecklenburg. Arch. d. Ver. d. Freunde d. Naturgesch. in Mecklenburg. 25. Jg. Neubrandenburg.

Koenen, A. von. 1867. Das marine Mittel-Oligocän Norddeutschlands und seine MolluskenFauna I. Palaeontographica 16. Cassel.

- 1872. Das Miocaen Nord-Deutschlands und seine Mollusken-Fauna. I. Schr. d. Ges. z. Beförderung d. ges. Naturwiss. z. Marburg. Bd. 10. p. 139. Cassel. 1882. II. N. Jahrb. f. Min. etc. Beil.-Bd. II. p. 223. Stuttgart.

- 1886. Über das norddeutsche und belgische Ober-Oligocän und Miocän. N. Jahrb. f. Min. etc. Bd. I. p. 81. Stuttgart.

- 1892. Das Norddeutsche Unter-Oligocän und seine Mollusken-Fauna. IV. Abh. z. geol. Spez. k. v. Preussen u. d. Thür. St. Bd. 10. H. 4.

Koert, W. 1900. Zwei neue Aufschlüsse von marinem Ober Oligocän im nördlichen Hannover. Jahrb. d. Königl. Preuss. geol. Landesanst. XXI. p. 187. Berlin.

- 1911. Geologische und paläontologische Mitteilungen über die Gasbohrung von Neuengamme. Jahrb. d. Königl. Preuss. Geol. Landesanst. Bd. 33. H. 1. p. 162. Berlin.

Krogh, A. 1914. The quantitative relation between temperature and standard metabolism in animals. Internat. Zeitschr. f. physik.-chem. Biol. V. I.

- 1939. Osmotic Regulation in Aquatic Animals. Cambridge.

LA Cour, V. 1941. Vort Folks Oprindelse og ældste Historie indtil Vikingetiden og Danevældens Slutning. Schultz Danmarkshistorie. Bd. I. København.

Lamarck, J. B. 1818-1822. Histoire Naturelle des Animaux sans Vertèbres. 5-7. Paris.

- 1845. 11. 2. me. ed. par Deshayes et Milne Edwards.

Larsen, G. og A.Dinesen. 1957. Tertiæret ved Brejning. Sedimenter og foraminiferfauna. Medd. Dansk Geol. Foren. Bd. 13, p. 266. København.

Larsen, Knud. 1936. Bunddyrenes Fordeling, Biologi og Betydning som Fiskeføde i Dybsø Fjord. Beretning fra Den danske biologiske Station XLI. København.

Laursen, Dan. 1953. The Genus Ianthina. Dana-Report No. 38. Copenhagen.

Lebour, M. V. 1932. a. The Larval Stages of Simnia patula. Journ. of the Marine Biol. Ass. of the United Kingdom N. S. Vol. XVIII. p. 107. Plymouth.

- 1932. b. The Eggs and Early Larvae of Two Commensal Gastropods, Stilifer stylifer and Odostomia eulimoides. Journ. of the Marine Biol. Ass. of the United Kingdom N. S. Vol. XVIII. p. 117. Plymouth.

- 1932. c. Limacina retroversa in Plymouth Waters. Journ. of the Marine Biol. Ass. of the United Kingdom. N. S. Vol. XVIII, p. 123. Plymouth.

- 1933. a. The British Species of Trivia: T. aretica and T. monacha. Journ. of the Marine Biol. Ass. of the United Kingdom. N.S. Vol. XVIII, p. 477. Plymouth. 
Lebour. M. V. 1933. b. The Larval Stages of Erato voluta (Montagu). Journ. of the Marine Biol. Ass. of the United Kingdom. N.S. Vol. XVIII. p. 485. Plymouth.

- 1933 c. The Life-Histories of Cerithiopsis tubercularis (Montagu), C. barleei Jeffreys and Triphora perversa (L.) Journ. of the Marine Biol. Ass. of the United Kingdom. N.S. Vol. XVIII. p. 491. Plymouth.

- 1933. d. The Eggs and Larvae of Turritella communis Lamarck and Aporrhais pespelicani (L.). Journ. of the Marine Biol. Ass. of the United Kingdom. N.S. Vol. XVIII. p. 499. Plymouth.

- 1933. e. The Eggs and Larvae of Philbertia gracilis (Montagu). Journ, of the Marine Biol. Ass. of the United Kingdom. N.S. Vol. XVIII. p. 507. Plymouth.

- 1937. a. Larval and Post-larval Lima from Plymouth. Journ. of the Marine Biol. Ass. of the United Kingdom. N.S. Vol. XXI. p. 705. Plymouth.

- 1937. b. The eggs and larvae of the British prosobranchs with special reference to those living in the plankton. Journ. of the Marine Biol. Ass. of the United Kingdom. N.S. Vol. XXII. p. 105. Plymouth.

- 1938. a. The life history of Kellia suborbicularis. Journ. of the Marine Biol. Ass. of the United Kingdom N.S. Vol. XXII. p. 447. Plymouth.

- 1938. b. Notes on the Breeding of some Lamellibranchs from Plymouth and their Larvae. Journ. of the Marine Biol. Ass. of the United Kingdom. N.S. Vol. XXIII. p. 119. Plymouth.

Lemmann, F. 1892. Die Lamellibranchiaten des Miocäns von Dingden. 1. Verh. nat. Ver. Rheinl. Westf. u. Osnabrück. 49. p. 198. 2. Ibid. 1893. 50. p. 273.

Lenche, H. 1948. Northern and Arctic Tectibranch Gastropods. Det Kongelige Danske Videnskabernes Selskabs Biologiske Skrifter. Bd. V. Nr. 3. København.

LrNn \&US, C. 1758. Systema Naturæ. Editio Decima. Holmiæ. 1788. Editio Tredecim, cura GMELIN.

Locard, A. 1892. Les coquilles marines des côtes de France. Ann. d. 1. Soc. Linnéenne de Lyon. T. 37. Paris.

Lyelt, C. 1833. Principles of Geology III. London.

- 1852. On the Tertiary Strata of Belgium and French Flanders. Part II. The Lower Tertiaries of Belgium. The Geol. Journ. Vol. 8. p. 277-368. London.

Mac Ginitie, G. E. 1939. Littoral Marine Communities. The American Midland Naturalist. Vol. 21. p. 28. Notre Dame, Ind.

Madsen, V., H. Øрum og H. GRy. 1935. Boringerne ved Langbrogaard ved Sønderborg. Danmarks Geol. Unders. 2. Række. Nr. 55. København.

Magne, A. et M. Vigneaux. 1948. Les gisements de Saubriques et de Saint-Jean-deMarsacq (Landes). Soe. Géol. de France. Compte Rendu Somm. d. Seances. no. 13-14. p. 293. Paris.

Mayer (-Eymar), Kard. 1857. Versuch einer neuen Klassifikation der Tertiär-Gebilde Europa's. Verh. d. allgem. schweiz. Ges. f. d. ges. Naturwiss. p. 165. Trogen.

Mayer, M. C. 1858. Descriptions de coquilles fossiles des étages supérieurs des terrains tertiaires. Journ. de Conchyliologie 2. sér. t. 3. p. 387. Paris.

- 1861. Description de coquilles fossiles des terrains tertiaires supérieures. Journ. de Conchyliologie. 9. p. 358. Paris.

Mayer, A. Goldsborough, 1914. The Effects of Temperature upon Tropical Marine Animals. Papers from the Tortugas Laboratory of the Carnegie Institution of Washington. Vol. VI. p. 1. Washington.

Melvill, J.C. 1910. Descriptions of Twenty-nine Species of Marine Mollusea from the Persian Gulf, Gulf of Oman, and North Arabian Sea. Ann. and Mag. of Nat. Hist. London.

- 1917. A Revision of the Turridae (Pleurotomidae) occurring in the Persian Gulf, Gulf of Oman, and North Arabian Sea, as evidenced mostly through the results of dredgings carried out by Mr. F. W. Townsend, 1893-1914. Proc. Malacological Soc. Vol. 12, p. 140. London.

Molander, A. R. 1928. Animal communities on soft bottom areas in the Gullmar fjord. Kristinebergs Zoologiska Station 1877-1927. Uppsala.

MolengraAF, G. A. F. und W. A.S. M. van Waterschoot van der Gracht, 1913. Niederlande. Handbuch der Regionalen Geologie. 1. 3. Heidelberg.

Montagu, G. 1803. Testacea Britannica. London.

Moore, H. B. 1936. The Biology of Purpura lapillus. I. Shell Variation in Relation to Environment. Journ. of the Marine Biol. Ass. of the United Kingdom. N.S. Vol. XXI. p. 61. Plymouth.

- 1937. The Biology of Littorina littorea. Part I. Growth of the Shell and Tissues, 
Spawning, Length of Life and Mortality. Journ of the Marine Biol. Ass. of the United Kingdom. Vol. XXI (N.S.) p. 721. Plymouth.

Moone, H. B. 1938. a. The Biology of Purpura lapillus. Part II. Growth. Journ. of the Marine Biol. Ass. of the United Kingdom. N.S. Vol. XXIII. p. 57. Plymouth.

- 1938. b. The Biology of Purpura lapillus. Part III. Life History and Relation to Environmental Factors. Journ. of the Marine Biol. Ass. of the United Kingdom. N.S. Vol. XXIII. p. 67. Plymouth.

Moy-Thomas. 1940. see Arkell.

Müller, O. F. 1776. Zoologiæ Danicæ Prodromus. Havniæ.

Münster, G. zu. 1835. Bermerkungen über einige tertiäre Meerwasser-Gebilde im nordwestlichen Deutschland, zwischen Osnabrück und Cassel. Neues Jb. f. Min. Geogn. Geol. u. Petr. K. C. von Leonhard u. H. G. Bronn. p. 420. Stuttgart.

Murray, John and Johan HJort. 1912. The Depths of the Ocean. London.

Mørсн, O. 1865. On the Systematic Value of the Organs which have been employed as Fundamental Characters in the Classification of Mollusca. Ann. and Mag. Nat. Hist. p. 385. London.

- 1874. Om nye Tertiærforsteninger i Danmark. Forh. v. de skandinav. Naturforskeres 11 te Møde. p. 274. København

Nautical-Meteorological Annuals of the Danish Meteorological Institute 1932-1956.

NickLìs, M. 1950. Mollusques testacés marins de la côte occidentale d'Afrique. Man. Ouest-Africains. Vol. 3. Paris.

Nrcol, D. 1951. Recent species of the veneroid pelecypod Arctica. Journ. of the Washington Acad. of Sciences. Vol. 41. p. 102. Baltimore.

Nietsen, J. N. 1904. Hydrography of the Waters by the Faroe Islands and Iceland During the Cruises of the Danish Research Steamer "Thor" in the Summer 1903. Meddelelser fra Kommissionen for Havundersøgelser. Serie: Hydrografi. Bd. I. København.

Nobre, Augusto. 1932. Moluseos Marinhos de Portugal. Porto.

Nordmann, V. 1912. Anomia squamula som Kvartær-Fossil paa Spitzbergen. Medd. fra Dansk Geologisk Foren. Bd. 4. p. 75. København.

Nyst, H. 1836. Recherches sur les Coquilles Fossiles de Kleyn-Spauwen et Housselt. (Province du Limbourg). Messager des Sciences et des Arts de la Belgique. 4. p. 139. Gand.

- et G. D. Westendorp. 1839. Nouvelles recherches sur les coquilles fossiles de la province d'Anvers. Bull. Acad. Roy. etc. de Belgique. p. 393. Bruxelles.

- 1843. Description des Coquilles et des Polypiers Fossiles des Terrains Tertiaires de la Belgique. Bruxelles.

- 1861. a. Description succintes de dix espèces nouvelles, de coquilles fossiles du crag noir d'Edeghem, près d'Anvers. Bull. Acad. Roy. etc. de Belgique. p. 188. Bruxelles.

- 1861. b. Notice sur un nouveau gîte de fossiles ses rapportant aux espèces faluniennes du midi de l'Europe, découvert à Edeghem, près d'Anvers. Bull. Acad. Roy. etc. de Belgique. p. 29. Bruxelles.

- 1864. Notice sur une nouvelle espèce de Pecten et observations sur le Pecten Duwelsii. Bull. Acad. Roy. etc. de Belgique. p. 26. Bruxelles.

Nørregaard, E. M. 1916. a. Mellem-miocæne Blokke fra Esbjerg. Danmarks Geol. Unders. IV.r. nr. 5. København.

- 1916. b. Mellem-Miocænet i Danmark. Forh. ved 16. skand. naturforskermøte. p. 429 Kristiania.

ODHNer, NILs H.J. 1914. Beiträge zur Kenntnis der marinen Mollusken-fauna von Rovigno in Istrien. Zool. Anzeiger. Bd. XLIV. p. 156. Leipzig-Berlin.

Olivi, A. G. 1792. Zoologia Adriatica. Bassano.

D'Orbigny, A. 1852. Prodrome de Paléontologie. III. Paris.

Ortmann, A. E. 1896. Grundzüge der marinen Tiergeographie. Jena.

Orton, J.H. 1920. Sea-Temperature, Breeding and Distribution in Marine Animals. Journ. of the Marine Biol. Ass. of the United Kingdom. Vol. XII (N.S.). p. 339. Plymouth.

- 1923. Some Experiments on Rate of Growth in a Polar Region (Spitzbergen) and in England. "Nature". p. 146. London.

- 1924. On Early Sexual Maturity in the Molluscs, Syndosmya alba and Cardium fasciatum. "Nature" p. 244. London.

- 1926. On the Rate of Growth of Cardium edule. Part I. Experimental Observations. Journ. of the Marine Biol. Ass. of the United Kingdom. N.S. Vol. XIV. No. 2. p. 239. Plymouth. 
Orton, J. H. 1933. Strange Spatfall of the Common Mussel on the Common Cockle. "Nature" p. 513. London.

- 1937. Some Interrelations between Bivalve Spatfalls, Hydrography and Fisheries. "Nature" p. 505. London.

PARr, A. E. 1933. a. Geographical-Ecological Analysis of the Seasonal Changes in Shallow Water Along the Atlantic Coast of the United States. Bull. of the Bingham Oceanographic Collection. Vol. IV. 3. N. Haven.

Pearl, R. 1940. Introduction to Medical Biometry and Statisties. London.

Pennant, Thomas. 1777. British Zoology. 4. London.

Pelseneer, P. 1901. Sur le degré d'eurythermie de certaines larves marines. Bull d. 1. Classe de Sciences. Acad. Roy. de Belgique. p. 279. Bruxelles.

Petersen, C. G. Joh. 1888. De skalbærende Molluskers Udbredningsforhold i de danske Have indenfor Skagen. København.

- and P. Boysen Jensen, 1911. Valuation of the Sea. I. Animal Life of the Sea Bottom, its food and quantity. Rep. of the Danish Biological Station XX. Copenhagen.

- 1914. The animal communities of the sea bottom and their importance for marine zoogeography. Rep. of the Danish Biological Station XXI. Copenhagen.

- 1915. On the Animal Communities of the Sea Bottom in the Skagerak, the Christiania Fjord and the Danish waters. Rep. of the Danish Biological Station XXIII. Copenhagen.

- 1915. Appendix to Report XXI. Rep. of the Danish Biological Station XXII. Copenhagen.

- 1918. The Sea Bottom and its Production of Fish-Food. Rep. of the Danish Biological Station XXV. Copenhagen.

Pettersson, Hans. 1939. Oceanografi. Stockholm.

Philippi, R. A. 1836.-1844. Enumeratio Molluscorum Siciliæ 1. Berlin. 1836. 2. Halle 1844.

- 1843. Beiträge zur Kenntniss der Tertiärversteinerungen des nordwestlichen Deutschlands. Kassel.

- 1851. Verzeichnis der in der Gegend von Magdeburg aufgefundenen Tertiärversteinerungen. Palaeontographica. 1. p. 42. Cassel.

Plymouth Marine Fauna. Second Ed. 1931.

PoLI, J. X. 1791. Testacea utriusqve Siciliae eorumqve Historia et anatome Tabulis Aeneis Illustrata. Parma.

Posseit, H. J. 1898. (ved Ad. S. Jensen). Grønlands Brachiopoder og Bløddyr. Medd. om Grønland. Bd. 23. p. 1. København.

Powell, A. W. 1944. The Australian Tertiary Mollusca of the Family Turridae. Rec. Auckland Inst. Mus. 3. no. 1. Wellington.

Purchon, R. Denison. 1939. The Effect of the Environment upon the Shell of Cardium edule. Proc. of the Malac. Soc. of London. Vol. XXIII. p. 256. London.

Prevost, C. 1820. Essai sur la constitution physique et géognostique du bassin à l'ouverture duquel est située la ville de Vienne en Autriche. Journ. de Physique, de Chimie et d'Hist. Nat. T. XCL. p. 347 et 460 . Paris.

Rasmussen, L. Banke, 1956. The Marine Upper Miocene of South Jutland and its Mollusean Fauna. Danmarks Geol. Unders. II. r. nr. 81. København.

RAvN, J. P. J. 1907. Molluskfaunaen i Jyllands Tertiæraflejringer. Résumé en français. D. Kgl. Danske Vid. Selsk. Skr. 7. R. nat. og mat. Afd. III. 2. København.

Remane, A. 1940. Einführung in die zoologische Ökologie der Nord- und Ostsee. Die Tierwelt der Nord- und Ostsee. I. Leipzig.

Reuss, A. E. 1867. Die fossile Fauna der Steinsalzablagerung von Wieliczka in Galizien. Sitzungsber. d. Kais. Akad. d. Wiss. 55. Wien.

Richards, O. W. 1935-37. Growth of the mussel (Mytilus edulis) at Woods Hole, Mass. (Abstracts.) Biol. Bull. 54 and 64 .

- 1946. Comparative Growth of Mytilus californianus at la Jolla Calif., and Mytilus edulis at Woods Hole Mass. Ecology. Vol. 27. No. 4. p. 370. Brooklyn N.Y.

Risso, A. 1826. Histoire naturelle des principales productions de l'Europe méridionale et particulièrement de celles des environs de Nice et des Alpes Maritimes. (vol. 1-5) Paris.

Roger, J. 1939. Le genre Chlamys dans les formations néogènes de l'Europe. Mém. Soc. Géol. France No. 40. Paris.

Roth V. Telegd, K. 1914. Eine ober-oligozäne Fauna aus Ungarn. Geologica Hungarica. T. 1. Fase. 1. Budapest.

Runnström, Sven. 1928. Über die Thermopathie der Fortpflanzung und Entwicklung mariner Tiere in Beziehung zu ihrer geographischen Verbreitung. Bergens Museums Årbok 1927. Naturvid. rekke. nr. 2. Bergen. 
Runnström, Sven. 1936. Die Anpassung der Fortpflanzung und Entwicklung mariner Tiere an die Temperaturverhältnisse verschiedener Verbreitungsgebiete. Bergens Museums Årbok 1936. Naturvid. rekke. nr. 3. Bergen.

Rutsch, R. 1929. Die Gastropoden des subalpinen Helvétien der Schweiz und des Vorarlbergs. Abh. d. Schweiz. Pal. Ges. Bd. IL. Basel.

Sacco, F. see Bellardi 1872-1904.

SARs, G. O. 1878. Bidrag til Kundskaben om Norges arktiske Fauna. I. Mollusca Regionis Arcticæ Norvegiæ. Christiania.

SCACCHI, A. 1836. Notizie intorno alle Conchiglie ed a'zoofiti fossili che si trovano nelle vicinanze di Gravina in Puglia. In Ann, civ. Napoli.

- 1836. Catalogus Conchyliorum Regni Napolitani. Napoli.

Schad, A. 1947. Neue stratigraphische Ergebnisse im nordwestdeutschen Tertiär. 94-98. Jahr. ber. d. Naturhist. Ges. 2. Hannover. Hannover.

Schaffer, F. X. 1910. Das Miocän von Eggenburg. Die Fauna der I. Mediterranstufe des Wiener Beckens. Abh. K. K. Geol. Reichsanst. Bd. 22. Wien.

- 1927. Der Begriff der "miozänen Mediterranstufen" ist zu streichen. Verh. d. Geol. Bundesanst. Nr. 2, 3. p. 86. Wien.

- 1951. Geologie von Österreich. 2. Auflage. Wien.

Schenk, H. G. 1935. Neotypes of Nucula nucleus (Linné). Proc. Malac. Soc. Vol. 21. p. 258. London.

Sснотт, G. 1935. Geographie des Indischen und Stillen Ozeans. Hamburg.

- 1942. Geographie des Atlantischen Ozeans. Hamburg.

Semper, O. 1861. Paläontologische Untersuchungen. Neubrandenburg.

Steber, R. 1937. Die miozänen Potamiden, Cerithiidae, Cerithiopsidae und Triphoridae Niederösterreichs. Festschr. Embrik Strand. p. 473. Riga.

Simpson, G. G. and A. Row. 1939. Quantitative Zoology. New York.

Smidt, E. L. B. 1944. Das Wattenmeer bei Skallingen. Folia Geographica Danica. T. 2. No. 3. København.

- 1951. Animal Production in the Danish Waddensea. Medd. fra Komm. for Danmarks Fiskeri- og Havundersøgelser Serie: Fiskeri. Bd. XI. Nr. 6. 1951. København.

Smith, Burnett. 1907. Note on the Value of the Gastropod Apex as a Means of Classification. Proc. Acad. Nat. Sci. Philadelphia. Vol. LIX. p. 194. Philadelphia.

Solander, see Brander.

Sorgenfrei, Th. 1937. Some Remarks on the Hinge of Nuculids and Ledids. Vid. Medd. Dansk naturh. Foren. Bd. 100. p. 369. København.

- 1940. Marint Nedre-Miocæn i Klintinghoved paa Als. Et Bidrag til Løsning af Aquitanien-Spørgsmaalet. (Deutsche Zusammenfassung). Danmarks Geol. Underse. II. r. nr. 65. København.

- 1949. Nyere undersøgelser over Fyns undergrund. Medd. Dansk Geol. Foren. Bd. 11. p. 490. København.

- 1951. Oversigt over prækvartærets topografi, stratigrafi og tektonik i området Fyn-Sydsjælland-Lolland-Falster-Møn. Medd. Dansk Geol. Foren. Bd. 12. p. 166. København.

- 1956, see Troelsen.

Sowerby, F. 1818. The Mineral Conchology of Great Britain 2. London.

- G. B. 1841. Conchological Illustrations. London.

Spärck, R. 1925. Studies on the Biology of the Oyster (Ostrea edulis) in the Limfjord, with special Reference to the Influence of Temperature on the Sex Change. Reports of the Danish Biological Station. XXX. Copenhagen.

- 1927. Studies on the Biology of the Oyster (Ostrea edulis) II-IV. Reports of the Danish Biological Station. XXXIII. Copenhagen.

- 1931. Some quantitative investigations on the bottom-fauna at the west coast of Italy, in the Bay of Algiers, and at the coast of Portugal. Rep. on the Danish Oceanographical Expeditions 1908-10 to the Mediterranean and Adjacent Seas. Vol. III. No. 7. Copenhagen.

- 1933. Contribution to Animal Ecology of the Franz Joseph Fjord and Adjacent East Greenland Waters I-II. Medd. om Grønland. Bd. 100. Nr. 1. København.

- 1934. Se Ad. S. Jensen.

- 1936. On the Relation Between Metabolism and Temperature in some Marine Lamellibranchs, and its Zoogeographical Significance. Det Kgl. Danske Videnskabernes Selskab. Biol. Medd. XIII. 5. København.

- 1937. The Benthonic Animal Communities of the Coastal Waters. The Zoology of Iceland. Vol. I. Pt. 6. Copenhagen and Reykjavík.

- og J. Lieberkind. 1921. Om Udbredelsen og Individantallet af Bunddyrene i Løgstør 
Bredning. Vidensk. Medd. fra Dansk naturhist. Foren. Bd. 72. p. 221. English Summary. København.

Spengler. 1793. Beskrivelse over et nyt Slægt af de toskallede Konkylier, forhen af mig kaldet Chæna saa og over det Linnæiske Slægt Mya, hvilket nøjere bestemmes, og inddeles i tvende Slægter. Skrivter af Naturhistorie-Selskabet. 3. Bd. 1. 4. p. 16. København.

Speyer, O. 1864. Die Tertiär-Fauna von Söllingen bei Jerxheim im Herzogthum Braunschweig. Cassel.

- 1866. Die ober-oligocänen Tertiärgebilde und deren Fauna im Fürstenthum LippeDetmold. Cassel.

- 1870. Die Conchylien der Casseler Tertiärbildungen. 1. Univalven. Cassel.

- und A. von Koenen. 1884. Die Bivalven der Casseler Tertiärbildungen. Abh. Geol. Spezialk. v. Preuss. u. d. Thüring. Staaten. Bd. 4. H. 4. Berlin.

Stafsche, K. 1930. Zur Gliederung des obermiozänen Glimmertons. Jb. Preuss. Geol. Landesanst. Bd. 51. p. 55. Berlin.

- 1938. Die Gliederung des nordwestdeutschen Tertiärs auf Grund von Mikrofossilien. Jb. Preuss. Geol. Landsanst. Bd. 58. p. 730. Berlin.

- und H. Hiltermann, 1940. Mikrofaunen aus dem Tertiär Nordwestdeutschlands. Abh. Reichsst. f. Bodenforschung N. F. H. 201. Berlin.

Steemann Nielsen, E. 1944. Havets Planteverden. Komm. f. Danmarks Fiskeri- og Havunders. No. 13. København.

Stephen, A. C. 1933. Notes on the Biology of some Lamellibranchs in the Clyde Area. Journ. of the Marine Biol. Ass. of the United Kingdom. N.S. Vol. XIIX. p. 51. Plymouth.

Stossich, M. 1880. Prospetto della Fauna del mare Adriatico. Bol. d. Soc. adriatica di scienze nat. Vol V. fasc. 2. p. 55.

Sumner, F. G., R. C. Osburn, and L. J. Cole. 1911. A Biological Survey of the Waters of Woods Hole and Vicinity. Bull. U.S. Bur. Fish. 31. parts I. II.

Sykes, E. R. 1905. The Molluses and Brachiopods of Ballynakill and Boffin Harbours, Co. Galway, and of the Deep Water off the West and South-West Coast of Ireland. Ann. Rep. Fish. Treland. 1902-03. Pt. 2. App. 3.

Tavernier, R. 1943. Le Néogène de la Belgique. Bull. Soc. Belge de Géol. de Pal. et d'Hydrol. T. LII. p. 7. Bruxelles.

Ten Dam, A. u. Th. Reinhold. 1942. Die stratigraphische Gliederung des niederländischen Oligo-Miozäns nach Foraminiferen. Meded. Geol. Stichting. Ser. C-V-No. 2. Maastricht.

Tesch, P. 1942. De Nordzee van historisch-geologiseh standpunt. Meded. v. Rijks Geol. Dienst. Ser. A. No. 9. 's Gravenhage.

Thamdrup, H. M. 1935. Beiträge zur Ökologie der Wattenfauna auf experimenteller Grundlage. Medd. fra Komm. for Danmarks Fiskeri- og Havundersøgelser. Serie: Fiskeri. Bd. X. Nr. 2. 1935. København.

Thiele, Jон аnnes. 1931-35. Handbuch der Systematischen Weichtierkunde. 1-2. Jena.

Thimet, S. 1941. Die Stratigraphie und Paläogeographie des Jungtertiärs in SchleswigHolstein. N. Jb. f. Min. etc. Beil.-Bd. 85. Abt. B.p. 1. Stuttgart.

Thorpe, W. H. 1940. Ecology and the Future of Systematics. Huxley 1940. The New Systematics. p. 341. Oxford.

THORson, G. 1933. Investigation on Shallow Water Animal Communities in the Franz Joseph Fjord (East Greenland) and Adjacent Waters. Medd. om Grønland. Bd. 100. Nr. 2. København.

- 1934. Contributions to the Animal Ecology of the Scoresby Sound Fjord Complex (East Greenland). Hydrography by H. Ussing. Medd. om Grønland Bd. 100. Nr. 3. København.

- 1935. Studies on the Egg-Capsules, and Development of Arctic Marine Prosobranchs. Medd. om Grønland. Bd. 100. Nr. 5. København.

- 1936. The Larval Development, Growth, and Metabolism of Aretic Marine Bottom Invertebrates Compared with those of other Seas. Medd. om Grønland. Bd. 100. København.

- 1941. The Zoology of Iceland. Marine Gastropoda Prosobranchiata. Vol. IV. part. 60. Copenhagen and Reykjavík.

- 1944. The Zoology of East Greenland. Marine Gastropoda Prosobranchiata. Medd. om Grønland. Bd. 121. Nr. 13. København.

- 1946. Reproduction and Larval Development of Danish Marine Bottom Invertebrates. With a section on Lamellibranch larvae by C. BARker Jørgensen. 
Medd. fra Komm. f. Danmarks Fiskeri- og Havundersøgelser. Serie: Plankton, Bd. 4. Nr. 1. København.

Thorson, G. 1951. Zur jetzigen Lage der marinen Bodentier-Ökologie. Verh. Deutsch. Zool. Ges. Wilhelmshaven. Leipzig.

Tromlsen, J.C. og Th. Sorgenfrei. 1956. Principerne for stratigrafisk inddeling og nomenklatur (Procedure and Terminology in Stratigraphic Classification). Medd. Dansk Geol. Foren. Bd. 13. p. 145.

Turton, W. 1822. Conchylia Insularum Britannicarum. London.

VAN de Poel, Luc. 1955. Structure du test et classification des Nucules. Bull. d. l'Inst. Roy. d. Sci. nat. de Belgique. t. 31. no. 3. Bruxelles.

Van Voorthuysen, J. H. 1944. Miozäne Gastropoden aus dem Peelgebiet. Meded. Geol. Sticht. Ser. C-IV-1-No. 5. Maastricht.

- 1945. Eenige opmerkingen over den bouw van de protoconch der gastropodenschaal in verband met de waarde hiervan voor de phylogenie. Gedenkboek Dr. Ir. P. TescH M.I. Verh. Geol.-Mijnbouwk. Gen. voor Nederl. en Kolon. Geol. Ser. XIV. p. 531. s'Gravenhage.

Van Waterschoot van der Gracht 1913, see Molengraaf.

- W. A. J. M. 1916. Eindverslag de onderzoekingen. en uitkomsten van den Dienst der Rijksopsporingen van Delftstoffen in Nederland 's-Gravenhage.

Vernon, H. M. 1899. The Death Temperature of Certain Marine Organisms. Journ. of Physiology. Vol. XXV. p. 131. Cambridge.

Verrill, A. E. and K.J.Bush. 1898. Revision of the Deep-Water Mollusea of the Atlantic Coast of North America, with Descriptions of New Genera and Species. 1. Bivalvia. Proc. U.S. Nat. Mus. Vol. 20. p. 775. Washington.

Vigneaux, Michel, et André Magne. 1951. Position du falun de Saubrigues (Landes) dans l'échelle stratigraphique. C.R. l'Acad. d. Sci. T. 232. p. 1860. Paris.

— et André Magne. 1952. Nouvelles Observations sur le forage de Morcenx (Landes). Soc. Borda, Dax.

- André Magne, Mauricette Veillon et Jean Moyes. 1954. Aquitanien et Burdigalien. C. R. I'Acad. d. Sci. T. 239. p. 818-820. Paris.

Vuṫs. 1907. Sur la présence de la Mye dans la Méditerranée. Bull. de l'Inst. Océanographique de Monaco. no. 94. Paris.

Vokes, H. E. 1945. Supraspecific Groups of the Pelecypod Family Corbulidae. Bull. Am. Mus. Nat. Hist. Vol. 86. 1. New York.

Weinkauff, H. C. 1867-1868. Die Conchylien des Mittelmeeres, ihre geographische und geologische Verbreitung. I-II. Cassel.

Wells, A. K. 1951. Outline of Historical Geology. 3d. ed. London.

Wenz, W. 1938-1944. Gastropoda. Handbuch der Paläozoologie. Berlin.

Werner, B. 1939. Über die Entwicklung und Artunderscheidung von Muschellarven des Nordseeplanktons, unter besonderer Berücksichtigung der Schalenentwicklung. Zool. Jahrbücher. Abt. f. Anat. u. Ontog. d. Tiere. Bd. 66. p. 1. Jena.

Wicher, C. A. 1942. Praktikum der angewandten Mikropaläontologie. Berlin.

Wick, W. 1939. Versuch einer biostratigraphischen Gliederung des jüngeren Tertiärs auf Grund von Foraminiferen. Jb. Preuss. Geol. Landesanst. Bd. 59. Berlin.

Wirtz, D. 1949. Die Fauna des Sylter Crag und ihre Stellung im Neogen der Nordsee. Mitt. Geol. Staatsinst. H. 19. p. 57. Hamburg.

- u. H. Illies. 1951. Plio-Pleistozängrenze und Günzeiszeit in Nordwestdeutschland. "Eiszeitalter und Gegenwart". Bd. 1. S. 73. Öhringen.

Wood, Searles V. 1848-61, and Supplement 1872-74. A Monograph of the Crag Mollusca 1-2. Palæontographical Society. London.

Woods Hole Oceanographic Institution. 1952 : Marine Fouling and its Prevention. Contribution No. 580. Menasha, Wisconsin.

Woodward, S. P. 1868. A Manual of the Mollusca. 1880. Fourth Ed. by Ralph Tate. London.

Yonge, C. M. 1946. On the Habits and Adaptations of Aloidis (Corbula) gibba. Journ. Mar. Biol. Ass. Vol. 24. p. 358.

Young, R. T. 1946. Spawning and Setting Season of the Mussel, Mytilus californianus. Ecology. Vol. 27. No. 4. p. 354. Laneaster, PA.

Øрum, H. 1935. See Madsen, V. 


\title{
INDEX OF NAMES
}

\author{
(Exclusive names of authors in the Description of Species)
}

Allee 378, 387

Allen 392

Ankel 416

Apellöf 374,376

Áskelsson 389, 392

Banke Rasmussen 20, 405

Barker Jørgensen 30, 373, 378

Basterot 10

Bateson 363

Beyrich 11

Blegvad 401, 416

Brandt 363

Brattström 391

Brocehi 10

Brongniart 10

Brögger 375, 392

Buequoy 392

Bucquoy, Dautzenberg \& Dolfus 392

Coe \& Fox 366,368

Cossmann 32

Cox 36

Craven 380

Cuvier 10

Dall 30

Dautzenberg 392

Davis 401

Deshayes 10

Dollfus 392

Dons 392

Dumont 10

Ekman 375, 377, 382, 383, 387, 390, 391

Field 367

Finlay 30, 31

Fischer-Piette 368

Fish 367

Fisher 36

Forbes \& Hanley 392

Ford 401

Franzen 31

Fretter \& Graham 31
Gignoux 9, 16, 18, 392

Gislen 401

Glibert 15, 405

Goldsborough Mayer 382

Gottsche 12, 403, 405

Gould 392

Grabau 30

Gripp 9, 13, 14, 18, 403, 405,

406, 408

Haecker 390

Hagmeier 401

Harmer 389, 392

Hayes 373

Hedley 30

Hesse 378, 387, 402

Hinsch 406

Hjorth 387

Hutchins 376, 387

Huxley 29

Iredale 30,31

Jacobsen 391

Janoschek 17

Jeffreys 392

Jensen, Ad. S. 376, 389, 391, 392,400

Jensen, A. J. C. 391

Jensen, Boysen 378

Jensen \& Spärck 392

Johnson 389,392

Johansen 392, 400

Jørgensen, Barker 30, 373, 378

Kautsky 9, 14, 403, 405

Kemp 36

Kesteven 30

Koch 14

Krogh 382

Larsen, K. 364

Lebour $30,31,373,379$

Lemche 30, 31, 380

Locard 389, 392

Loppens 365

Lyell 10

Mac Ginitie 401

Magne 408
Magne \& Vigneau 16

Mayer-Eymar 11

Molander 401

Molengraaf 15

Moore 360, 368, 389, 416

Morley Davies 32

Myrray 387

Mørch 12

Nicol 389, 392

Nordmann 389, 392

Odhner 30, 373

Ortmann 387

Orton $359,360,362,374,376$

Parr 377

Pearl 36

Pelseneer 375

Petersen, C. G. Joh. 359, $381,390,391,392,400,401$, 412, 415

Peyrot 403

Posselt 389, 392

Powell 30

Prevost 10

Purchon 362, 363, 364

Rasmussen, Banke 20, 405

Ravn 13

Reinhold 15

Remane 382, 390, 399, 401

Richards 360, 366, 368

Runnström 374, 382

Rutsch 16

Sars 392

Schad 405

Schaffer 17

Schmidt 387

Schott 383, 389

Smidt 360

Smith 30

Sorgenfrei 9, 20, 403, 405

Spärck 374, 378, 382, 389, $391,400,402,416$

Staesche 403

Stephen 360

Stossich 392 
Tavernier 15

Ten Dam 15

Thamdrup 360,382

Thiele 32

Thorpe 32

Thorson 30, 31, 373, 375,

$378,379,382,392,402$, 416

Van Voorthuysen 31
Van Waterschoot van der Gracht 15

Vernon 382

Vigneaux 408

Vigneaux \& Magne 403

Vles 392

Von Koenen 12

Weinkauf 392

Wells 9

Wenz 32
Werner 373

Wicher 33

Wirtz 18

Woodward 387

Yonge 416

Young 366, 368

Ødum 20

\section{INDEX OF SUBJECTS}

(Exclusive subjects in the Description of Species)

Abu Kir 364

Abundance of species 19

Abundant molluscan species, Arnum formation, frequencies 460

- species, evidence of 410

Adaptation 381

- metabolic 382

- osmotic 382

Animal communities 19, 401,417

- - definition of 401

Anversien 12, 15

Aquitanian Basin 9, 10, 13, 408

Aquitaniano 17

Aquitanien 12, 13, 14, 16

Aralo-Caspian region 17

Aral Sea 363

Aretic region 388

Ardennes 15

Argillaceous Miocene 11

Arnum 419, 449, 461

- formation 28, 419

- - decrease in salinity 411

- - distribution of molluscan species 423

- frequencies of abundant molluscan species 460

- - frequencies of molluscan species 436

- molluscan assemblages, classification 415

- $\log 26,27$

Astarte clay 20

Atlantic Ocean, temperature 385

Austria 13,17
Balanced frequencies 413

Baltic Basin 366

Baltic-North Sea, transition area 390,391

- _ - decrease of mollu. scan species 393

— - distributional

limits of mollusea 394

- sea 359

Bay of Kiel 366

Belgium 12,15

Biostratigraphic correlation 403

- record, Miocene, North Sea Basin 405

Biotope, change of 381,400

Boldérien 12,15

Bordelais 13

Boreal molluscan species, distributional limits 390

- region 388, 389

Bottom temperature 383 , 391

Brackwasser Submergenz 400

Bramminge 416, 460

- $\log 23$

Bregenz 16

Burdigalien 13, 14, 16, 17

Change of biotope 381,400

Chattien 16

Cilleborg clay 419

Clays with tuff 419

Cold water species 376

Competition of species 412

Correlation 18

- procedure 403

- well sections 418
Crag 10,14

Critical limits of salinity 393

- - of temperature 375 , 376

Danian limestone 420

Deep sea, faunal region 389

- - temperature conditions 385

- water, physical properties 389

- water species 389

Denmark 12, 13

Depth range, molluses 391

Description of species, gen-

eral comments 36

Dispersal 379,387

Distribution and salinity 391

- molluscan species, Arnum formation 422

Dybsø Fjord 364

Eggs, temperature range 374

- normal development 375

Elveziano 17

Environment, Baltic Sea 359

- competitors 359

- enemies 359

- factors 19, 358

- hydrography 359

- observation of data 360

— salinity 359

- temperature 359

- variation of 360

Eocene 10

Esbjerg 20

Étage falunien 10

European Miocene faunas, size of 406 
Falster-Fyn Uplift 20

Faunal evolution 19

— region of the deep sea 389

- regions 387

— - boundaries 389

Flensburg 20

Formation names 11

Fossil evidence 18

- material, method of investigation 33

— - statistical treatment 33

- molluscan assemblages, significance of 409

France 9, 10, 13, 16, 408

Frequencies, molluscan species, Arnum formation 436 , 460

Fribourg 16

Gastropoda and Pelecypoda, review of growth 372

- life histories 360

Geographic distribution 382

Germany 11, 12, 13, 16, 18, 405

Glejbjerg 416, 436, 460

- $\log 21$

Glimmerton 12, 14, 18

Gram 20

- clay 20

- formation 28, 419

Gramby $416,461,448$

- $\log 25$

Grund beds 17

- sands 11

Guadalquivir Basin 9

Guide fossils 18, 381

Gulf of Bothnia 366

— - Finland 366

- - the Lower Rhine 15

Hamburg area 14

- clay 14

Helvetien 12, 13, 14, 16

Hemmoor fauna 407

- formation 14

Hipparion 18

- gracile Kaup 14

Holland 14

Holsteiner Gestein 11, 12, 13,14

Horizon of Bolderberg 15

- - Edeghem 15

- Houthaelen 15

Hungary 17

Inanimate environment re-

lations 414

Index forms 18, 381

Istanboul 18

Italy $10,13,16,17$
Jaksi Klich 364

Jannan Klich 364

Kerteminde clay 419

- marl 420

Klintinghoved clay 419

- fauna 408

Laekenien 10

La Jolla, California 366

Langbrogaard 20

Langhiano 17

Langhien 13

Larvae, pelagic stage, dispersal 380

Larval shells 30

- stage, duration 379

— — pelagic 379

La. Sime 17

Lillebelt clay 419

Limonitsandstein 14, 18

Loire Basin 9, 10

London Basin 10

Lower Brown-coal sands 14

Lusitanian region 388

Lyon area 18

Marine animal, communities 401

- faunal regions 387

- faunas, size of 406

Mayencien 12, 13

Mecklenburg 11

Mediterranean Basin 9, 13

- stages 17

Metabolic adaptation 382

Mica clay 13,20

Miocene 10

— faunas, size of 406

- North Sea basin, biostratigraphic record 405

- Northwest Germany, thickness 405

- Subdivision 11

— time-stratigraphic classification 15

- -Pliocene boundary 14, 18

Molasse Basin 9

Molluscan assemblages of the Arnum formation 403

- species, related to salinity 399

Morsum Kliff 14

Natural classification 30

North Atlantic, faunal regions 388

- - surface temperatures 386

North Sea-Baltic, transition area 390,391
North Sea-Baltic, decrease of molluscan species 393

- - - distributional limits of mollusca 394 salinities 393

- Basin 9,11,12

- - Miocene, bio-

stratigraphic record 405

Northern Germany 11

- Italy 16

Northwest Germany, Miocene, thickness 405

Number of specimens of marine faunas 406

- - Arnum 35

- - Bramminge 34

— - Glejbjerg 34

- - - Gramby 35

- - Ribe 34

- - Toftlund 35

Ocean temperature 383

Oligocene 11, 20

Osmotic adaptation 382

Paleoenvironments 18

Paris Basin 10

Pelagic larvae, Danish 380

Pelagic larval stage 379

— — - dispersal 380

Pelecypoda,life histories 360

- and Gastropoda, review of growth 372

Percentage of species 18

Phylogenetic significance 30

Physiological races 382

Plaisancien 16

Pliocene 10

Plymouth 364, 368

Pontien 13, 14, 16

Pont-Levoy 17

Po Valley Basin 9

Prever 17

Prodissoconch 30

Protoconch 30

Provence 18

Recent mollusca, distributional limits 394

Reinbek formation 14

- deposits 12

- Dingden fauna 408

Relation between species 412

Relative age 18

Reproduction 373

- rate of 378

- related to food 373

— — - salinity 373

— — - temperature 374

- stages of 373

Reproductive stages, rela- 
ted to temperature and distribution 376

Rhine Mountains 15

Rhone Valley 13

- B Basin 9

Ribe 416,437

- formation 28, 419

- $\log 24$

River Elbe 11

Roumania 17

Rösnæs clay 419

Rupelien 10

Saint-Jean-de-Marsacq 16

Salinity and distribution 391

- and number of molluscan species 399

- Bornholm Basin 400

- controlling factor 400

- deep water 400

- limits 393

- submergence 400

Salles 17

Samples, grain size, quality 21

Sarmatien 13, 14, 16

Saubrigues 16

Savigne 17

Sedimentary history 19

Sedimentation of molluscan shells 409

Shell colour and diet 371

- features, significance of 30

- variation of 360

- growth and temperature 362

- related to salinity 363
Shell length, annual increment of 362

- maximum growth of 362,369

- minimum growth of 369

- morphology, nomenclature 36

Shells, sedimentation of 409

Shore assemblage 411

Shumish Kul 363

Sicily 10

Size of marine faunas 406

Southeastern Europe 16, 17

South Jutland 20

- Miocene sequence 20

Southern Germany 13,18

- Russia 17

Southwestern France 16

Sövind marl 419

Spawning seasons 374

Species, concept 29

- definition 29

Sternberger Gestein 11

Stratigraphic methods 18

Structural displacements 20, 421

Subappenine formation 10

Substratum requirements of adult stage 381

Subtropic region 389

Surface water, mean temperature 415

Switzerland 13, 16

Sønderborg 20

Taxonomic significance 30 - subdivision 32

Taxonomy, goal of 29

Temperature conditions of the oceans 383
Temperature control, mechanism 376

- critical factor of 374

— - limits 376

— limits 378

- ocean bottom 383

Tertiary Basins 9

- subdivision 10

Thermal intervals 376,377

- limits 378

Thickness, Miocene, North-

west Germany 405

Time factor 19

Toftlund 416, 449, 461

- $\log 27$

Tongrien 10

Tortona 16

Tortoniano 17

Tortonien 12, 13, 16

Tropic region 389

Turkey 18

Type areas 16

Upper Brown-coal 14

— - sands 14

Varde 13

Variates, analysis of 36

Viborg 13

Vienna Basin 9, 10, 11

- Tegel 11

Vierlande fauna 407

- formation 14

Warm water species 377

Well sections 21

Woods Hole Massachusetts 366

\title{
INDEX OF MOLLUSCA
}

\author{
(Main reference with Italics)
}

Abra 119

Acamptogenotia 267

acarinatoconica, Niso 176

acicula, Eulimella 324

- Melania 324

- Odostomia 324

Acmaea 147, 381

Acmaeidae 147

Acrilla 174

Actaeon 221

Actæonidea 304

Acteocina 348

Acteon 298, 304
Acteonidae 298

aculeata, Anomia 80

- Monia 81

acuminata, Bulla 344

- Cyclichna 344

- Ovula 344

— Terebra 297

- Volvula 344

acuminatum, Terebrum 297

acuminatus, Rhizorus 344

acuta, Volvulella 344

acutangula, Cancellaria

(Trigonostoma) 241 acutangula, Gulia 241

- Ventrilia 241

acuticostata, Chrysallida 307,308

Adansoni, Dosinia 110

Adeorbiidae 156

Adeorbis 156

Admete 246

adversa mut. miocænica,

Triphora 172

adversum, Cerithium 171

affinis, Nerita 193

- Natica (Polynices) 193 
alabamiensis, Caryocorbula 131

alata, Aporrhais 33, 182, 414,416

- Chenopus 182

- Rostellaria 182

alba, Abra 360

- Cylichna 347

- Syndosmya 391

Allionii, Conus 249

Alvania 153

amoena, Scala (Acrilla) 174

- Scalaria 174

- var. subreticula, Acrilla 175

Anachis 208

anceps, Daphnella 250, 287

- Pleurotoma 287

- Raphitoma 287

- Teres 287

- Teretia 287

Ancilla 236

angulosa, Abra 119

- Syndosmya 119

Angulus 120

angustiforatum, Pseudotorinia 164

- Solarium 164

angyglossa, Natica 193

Annae, Gemmula 255

anomala, Limopsis 69

- Pectuneulina 69

- Trigonocoelia 69

- var. minuta, Limopsis 69

anomalus, Pectunculus 69

Anomia 80

Anomiidae 80

antiqua, Neptunea 389

Aoteadrillia 271

Aphanitoma 277

Aporrhaidae 182

Aporrhais 182

aquensis Deshayesi, Sigaretus 197

— Sigaretus 197

Aquilofusus 235

Arca 63

Arcidae 63

Arcoperna 73

aretica, Mya 125

- Saxicava 125, 382, 414

- Saxicava, breeding in 375

- Yoldia 376

arenaria, Mya 366, 372, $389,390,400$

- Mya, duration of larval stage 380

arnumensis, Acteon 302

asperulata, Clavatula 266

Astarte 83

Astartidae 83

Asthenotoma 272

Atilia 206 atlanta, Spiratella 352,414

- Valvatina 352

attenuata, Pyrene 207

aturensis, Murex 201

- Poirieria 201

Aturia 355

auriculata var. buccinea, Ringicula 334

_ - ventricosa, Ringicula 333,334

aurita, Arca 67

- Limopsis 66

badense, Dentalium 146

- Entalis 147

badensis, Dentalium 146

- Entalis 147

- Gemmula 252

- Pleurotoma 252

- Turris 252

baltica, Macoma 360, 366, $372,391,400$

Basteroti, Arthemis 110

- Dosinia 110

- Terebra 295

Bathytoma 250, 260

behmi, Cancellaria 242

- Ventrilia 242

Bellardi, Acera 343

- Drillia 273

Bellardii, Bulla 343

- Cylichna 343

- Mitra 238

Benedenii, Tellina 122

Benoisti, Cardium 103

- Nucula 39

Beyrichi, Natica (Naticina) 187

- var. Goodmani, Natica 187

bicoronata, Semicassis 198

bidentata, Montacuta, lar-

vae of 374

Bittium 165

Bocholtense, Buccinum 213

bocholtense, Nassa 213

bocholtensis, Nassa 213, 218

- Telasco 213

Boehmi, Pleurotomoides 284

borealis, Astarte 382, 399 boreobsoleta, Cancellaria (Trigonostoma) 242

- Ventrilia 242

Boreodrillia 271

boreointerrupta, Clavatula 264

boreoturricula, Gemmula 254, 414, 419

- Hemipleurotoma 254

- Pleurotoma 254

- Turris 254

Brachytoma 273, 277

Broeckiana, Sinusigera 380
Brummelii, Pecten 74

buceinea, Ringicula 334 , $341,356,414$

Buccinidae 208

bullata, Akera 391

burdigalensis, Chenopus 182

- Corbulomya 133

Cadulus 143

calais, Daphnella 278

- Neoguraleus 278

- Raphitoma 278

calcarata, Calcarata 243

- Cancellaria (Narona) 243

- var. mioparva, Calcarata 243

— - Sveltia 243

- Voluta 243

calcarea, Macoma 390, 391, 413

californianus, Mytilus 360, 366

Calliope, Clinura 292

Calliostoma 148

Calyptraea 180

Calyptraeidae 180

campanulata, Pleurotomoides 285,286

canaliculata, Hemipleurotoma 256

- Pleurotoma 256

Cancellaria 239

Cancellariidae 239

cancellata Bivetia 239

- Cancellaria 239, 415

- Sinusigera 380

- var. praecedens, Bivetia 239

- Voluta 239

eandida, Pholas 375

Cardiidae, 100

Cardita 85

Carditidae 85

Cardium 102

- edule, growth rate 362

- growth of 369

carinata, Adeorbis 158

- Delphinula 158

carocollatum, Solarium 162 Cassidae 198

castanea var. pusilla, Ervilia 113

castor, Nucula 38

cataphracta, Bathytoma 260

- Dolichotoma 261

- Pleurotoma 260

cataphractus, Murex 260

catena, Cochlea 185

- helicina, Lunatia 185

- Polynices 185

- Natica (Lunatia) 185

- Naticina 185

_ var. helicina, Natica 185 
catena, var. mioaperta \& var depressa, Natica. (Naticina) 185

- - prohelicina, Natica

cavata, Hima 223

- Nassa 223, 226, 356

Cavolinidae 354

Cephalopoda 355

Cerithiidae 165

Cerithiopsidae 170

Cerithiopsis 170

chinensis, Calyptraea 180

- Patella 180

- taurostriatellata, Calyptraea 180

chione, Callista 107

- Cytherea 107

- Meretrix 107

- Paradione 107

- Pitar 107

- Pitaria 107

- Venus 107

Chrysallida 304

cimbrica, Chrysallida 305, 307

- Hima 228

- Janthina 176

- Nassa 228, 230, 356, 412, 414, 416, 418

- Pitaria 108

- Pyrgulina 305

- Sportella 89

cingulatum, Cardium 100

Circulus 156

Cirsotrema 173

clathurella, Nassa 219

Clavatula 264, 265

Cleodora 354

Clinura 264

Clio 354

coarctata, Erycina 98

- Erycina (Hemilepton) 96

- Kellia 96

- Montacuta (Montacuta) 96

Codokia 93

coelata, Hadriania 206

- Tritonalia 206

coelatus, Fusus 206

Columbellidae 206

comatulum, Cardium 100

communis, Turritella 160

complanata, Corbulomya

133

compressiuscula, Acmaea 147

- Patella 147

concentrica, Astarte 83

- var. gracilis. Astarte 83 concinna, Eulimella 321

condita, Ficus 200

- Musculus 73

- Pirula 200 condita Pyrula 200

Conidae 248

conoidea, Megastomia 312

- Odontostomia 312

- Odostomia 312

conoideum, Ptychostomon 312

conoideus, Turbo 312

contorta, Cancellaria (Cancellaria) 240

- Contortia 240

- Merica 241

conulus, Bulla 345

Conus 248

convexorude, Bittium 165

convoluta, Bulla 342

copiosa, Pandora 138

Corbulidae 129, 356

Corneti, Pleurotoma 264

- Tahusyrinx 264

Cornety, Ancistrosyrinx 264

- Surcula 264

coronata, Gemmula 251

- Turris 251

costellata, Acteon 325

- Auricula 325

- Cardiomya 142

- Corbula 142

- Cuspidaria 142

- Neaera 142

- Turbonilla 325, 328

Cranchii, Atys 350

crassicostatum, Cirsotrema 173

crassitesta, Eulimella 325

crispata, Zirphaea 389,390

crispoides, Fusus 232

crispus, Fusus 232

cromata, Nucula $38,41,42$, 44,46

Cultellus 124

Cuspidaria 140

Cuspidariidae 140

cuspidata, Cuspidaria 140

- Neaera 140

- Tellina 140

Cyclocardia 85

Cyclostromatidae 156

Cylichna 342

cylindracea, Bulla 342

- Bullinella 342, 346

- Cylichna 342

cymbrica, Hima 228

- Nassa 228

cypria, Venus 100

cyprium, Laevicardium 100. 102

Daphnella 250

Daphnellinae 295

decussata (Poli) var. sublævigata, Codokia 94 decussatus, Phos 208 decussatus, Tapes, breeding period 374

Degrangei, Abra 119

- Ensis 124

- Erycina 96, 98

- Erycina (Sacchia) 94

- Pandora 139

denseplicata, Turbonilla 327

Dentaliidae 144

Dentalium 144

dentata Bast. var. laevigata, Lucina (Loripes) 91

denticula, Gemmula 252

depressa, Vaginella 354, 414

- var. austriaca, Vaginella 354

Deshayesi, Phorus 181

- Xenophora 181

diluvii, Anadara 63

- Arca 63

dingdense, Laevicardium 101

discors, Musculus 73

disjuncta, Pleurotoma 156

Dolicholathyrus 232

Donacidae 118

donaciformis, Corbula 133

- Corbulomya 133

- Lentidium 133

donacina, Moerella 121

- Tellina 120

donacinus, Angulus 120

Donax 118

Dosinia 110

dosinioides, Circe 105

- Gouldia 105

d'Orbigny, Sinusigera 380

dubia, Acteon 321

- Auricula 321

- Odostomia (Syrnola) 321

- Sinusigera 380

Duchasteli, Hemipleurotoma 258

Duchastelii, Fusiturris 258, 414,419

- Pleurotoma 258

Dufresnei, Oliva 237

Dujardini, Conospira 248

- Conus 248

- Mangelia 278

Dumasi, Limopsis 67, 68

- Yoldia 60

eburnea, Niso 176

edule, Cardium 360, 365, $366,372,381,400$

- Cardium, assymmetry of shells 365

- - reproduction 374

edulis, Mytilus 360, 366, $372,374,375,382$, 399 
edulis, Mytilus, duration of larval stage 380

- Ostrea 374, 381

— - breeding period 374

- - larvae 374

elatior, Clathurella 283

- Mangilia 283

- Pleurotoma 283

- Pleurotomoides 283, 284

electa, Brachytoma 273

elegantissima, Chemnitzia 326

- Daphnella 279

- gastaldi, Turbonilla 327

- Raphitoma 279

- Turbonilla 326

elliptica, Astarte 382, 400

- Mactra 117

elongata, Bulla 345

- Bullinella 345

- Cylichna 345

- Cylichnina 345

- Retusa 345

emarginata, Leda 414

- - (Lembulus) 57

- Nucula 57

Ensis 124

ephippium, Anomia 80

epiglottina var. exfunicu-

lata, Natica 187

Ervilia 113

Erycina 94

Erycinidae 94

eryna, Haustator 160

- Turritella 160

Escheri, Acamptogenotia 267

- Pleurotoma 267

- Pseudotoma 267

Eubela 291, 293

Eulimella 321

fabula, Tellina 360

Facki, Amycla 220

- Amyclina 220

- Nassa 220, 223, 412, 414, 419

fallax, Angulus 122

- Tellina 122

Fallotti, Turbonilla 328

fasciata, Tornatella 303

fasciatum, Cardium 391

Fasciolariidae 232

festiva, Asthenotoma 272 , 273

- Pleurotoma 272

fistulosus, Cyphonochelus 205

- Cyphonochilus 204

- Murex 204

- Typhis 204

flexuosa, Lucina 89

— Tellina 89 flexuosa, Thyasira, 89, 390,

391,414

flexuosus, Axinus 89

fornicatus, Latirus 232

foveolata, Terebra 297

fragile, Cardium 100

fragilis, Leda 56

- Loripinus 93

frondicula, Hirtoscala 174

- Linetoscala 174

- Scala 174

- Scalaria 174

- Spiniscala 174

frondosa, Cucumaria 374

Fuchsi, Nassa 214, 215, 412,

414, 418, 419

fuscata, Subula 297

- Terebra 297

fusiformis, Admete 246

- Babylonella 246

- Cancellaria 246

- var. subangulosa, Admete (Babylonella) 246

Fusiturris 258

Fusus, 233

gadus, Cadulus 143

- Dentalium 143

- Gadila 143

Gastaldii, Turbonilla 327

Gastropoda 147

- duration of larval stage 379

Gemmula 251

Genota 266

geometra var. berilla, Pyrula 200

Gérardi, Lissochlamys 78

- Pecten 78

- Pseudamussium 78

Gérardii, Pecten 78

gibba, Agina 130

- Aloidis 130

- Corbula 31, 381, 391

- Tellina 129

- Varicorbula 129, 414, 416

girondica, Lutetia 87

glaberrima, Nucula 59

- Yoldia 59, 62, 356, 413,

414, 417, 419

glejbjergensis, Aphanitoma 277

Globularia 196

Glycymeridae 66

Glycymeris 66

Goodallia 84

Gouldia 105

gracillina, Gadila 143

granum, Pandora 139

Grateloupi, Bellardi 273

- Brachytoma 274

- Daphnella 274

- Raphitoma 274

- Xenophora 182
Grateloupii, Turbonilla 322

Grippi, Bellardiella 293

- Daphnella 293

- Eurodike 235

- Fusus (Aquilofusus) 235

- Metuonella 293

Gürichi, Mangilia 281

- Neoguraleus 281

Haesendonckii, Nucula 50

hanleyi, Nucula 39

- Nucula nucleus 39, 46

hanseata, Natica (Naticina) 186

- Nucula 48

- Nuculoma 48, 414

- Starkeyna 149, 151

- Tinostoma 149

hanseatum, Acanthocardia 104

- Cardium 104

hanseatus, Cryptodon 90

haudmuticus, Haustellum 202

- Murex 202

helicina, Natica 185

Hemilepton 96

henckeliusiana, Caestocor-

bula 131

hispidula var. laevigatior, Daphnella 279

- Raphitoma 279

holsatica, Nassa 219

- Telasco 219

Holsaticum, Buccinum 219

Hörnesi, Natica 188

- Terebra 295, 356, 414

horridus, Murex 204

— Tiphys 204

- Typhis 204

hydrobiopsis, Eulimella 325

inaequivalvis, Pandora 139

incrassata, Amiantis 108

- Cordiopsis 108

- Meretrix 108

- Nassa, duration of larval stage 379

— nysti, Cordiopsis 108

- - Pitar 108

- Venus 108

inermis, Fusiturris 259

- Hemipleurotoma 260

- Pleurotoma 259

inflatus, Actaeon 301

inornatus, Murex 202

Inquisitor 268

insculpta, Evalea (Auricu-

lina) 389

intercalaris, Cordiopsis 108

islandica, Cyprina 381, 389, 390,391

islandicus, Pecten 73 
Isocardia 88

Isocardiidae 88

Janthina 176

Janthinidae 176

Jeffreysi Nucula 41, 43, 44, 45,46

jenkinsi, Hydrobia 382

Johannæ, Clathurella 282

- Mangelia 282

- Pleurotomoides 282

- 285

Josephinia, Natica 192

- - (Neverita) 194

jouanneti, Cardita 14

Jupiteria 51

jutensis Codokia 93

— Starkeyna 150

Kellyella 86

Kellyellidae 86

Kickxi, Astarte 83

Kleinella 310

Kochi, Cardium 102, 103

- Parvicardium 102

labellum, Aphanitoma 277

labiosum, Buccinum 220

lactea, Chemnitzia 327

- Odostomia 326

- Turbonilla 326

lacteus, Turbo 326

Laevicardium 100

laevicosta, Cardita, var. weingärtneriana 14

laevigata, Nucula 50

- Tornatella 300

laevigatus, Actæon 300

- Acteon 300

laevissima, Amyela 222

- Nassa 221

- Nassa 222

Laevissimum, Buccinum$$
222
$$

læviuscula, Pyramidella 332

Lajonkaireana, Acteocina 348

- Bulla 348

- Bullina 348

- Tornatina 348

Lajonkaireanus, Utriculus 348

lapillus, Purpura 360,373

- Purpura, diet and shell colour 371

- Purpura, growth 371

- Purpura (Nucella) 389, 390

latesulcata, Area 63

Lathyrus 232

Ledina 54

legumen, Pharus 123

Lembulus 57
Lentidium 133

leognanense, Cardium 104

leptocolpatum, Cardium 100

- Lævicardium 100

Lepton 98

Leucotina 310

levidensis, Acteon 302

liberata, Pecten 75

lignaria, Bulla 349

lignarius, Scaphander 349

- var. Grateloupi, Scaphander 349

Lima 79

Limidae 79

Limopsidae 66

Limopsis 66

Liotia 152

littorea, Littorina 360,366 , $368,372,373,375$, 389,390

- duration of larval stage 379

— - eggs 373

- - growth 369

_ — - of females and males 371

Loripes 91

Loripinus 92

Lucina 92

Lucinidae 81

Luisae, Clathurella 285

- Defrancia 285

- Lienardia 285

- Mangilia 285

- Pleurotomoides 285

Lunatia 185

lupinus var. Basteroti, Dosinia 110

Lutetia 86

Mactridae 114

major, Ringicula 333

- Ringiculella 333

Manidrillia 271

Martesia 136

Mayeri, Astarte 84

- Goodallia 84

megapolitana, Semicassis

198

Melanella 178

Melanellidae 176

membranacea, Rissoa, dura-

tion of larval stage 379

Merelina 153

Meretrix 108

Mesodesmatidae 113

Metuonella 293

Michaudi var. exclathrata, Sigaretotrema 197

__— Sigaretus 197

Michelottii, Dentalium 144
Michelottii, var. costulatior, Dentalium 144

talium 144

micromphalus, Solarium

164

minima, Circe 105

- Gouldia 105

- Sinusigera 380

- Venus 105

minuta, Diaphana 380

- Limopsis 69

- Pectunculina 69

minutissima, Lamprodoma 237

- Oliva 237

- Olivella 237

mio-bosqueti, Hemipleurotoma 256

- - Pleurotoma 256

mioincrassata, Hadriania

206

miolaevigata, Semicassis

198

miopusilla, Natica (Naticina) 191

- Tectonatica 191

mio-Roemeri, Daphnella 279

- - Raphitoma 279

miorostralis, Spiratella 352

- Spirialis 352

miosuturalis, Liotia 152

mioturbida, Bathytoma 261

Mitra 238

Mitridae 238

modesta, Chrysallida 309

Modiolaria 71

Modiolus 71

modiolus, Modiola 389

monilifera, Natica 185

monilis, Pleurotoma 252, 25.5

Montacuta 99

Montacutidae 99

Montagui, Astarte 382

Mörchi, Taranis 389

Morreni, Genotia 268

- Pseudotoma 268

multicostata, Turbonilla 328

multilamella, Chione 111

- Cytherea 111

- Dosina 111

- Ventricoloidea 111

- Venus 416

- Venus (Ventricola) 111

Murex 201

Muricidae 201

Musculus 71

mutabile, Dentalium 145

mutinensis, Cyclodostomia 317

- Odostomia 31\%, 331, 356 
Mya 376

Myidae 134

Mytilidae 71

Mytilus, growth of 369

Narona 243, 244

Nassa 210

Nassidae 210

nassoides, Atilia 207

- Columbella 207

- Fusus 206

- Macrurella 207

- Mitrella 207

- Pyrene (Atilia) 206

Natica 185,419

Naticidae 184

Naticina 186

navalis, Teredo 138

Neoguraleus 278

Neuvillei, Nassa 216

- Telasco 216

Neverita 194

Niso 176

nitida, Kellia 98

- Natica 189

- Nucula 38, 41, 42, 46, 391

- Syndosmya 390, 391

nitidissima, Eulimella, lar-

vae of 374

nitidum, Lepton 98

nivea, Lucina 91

niveus, Loripes 91

- Microloripes 91

nodifera, Chrysallida 306 , 307

Nörregaardi, Lucina (Loripinus) 92

Nordmanni, Kleinella (Leueotina) 310

norvegica, Panopea 389

novemcostatum, Dentalium 145

- var. mutabilis, Antale 145

nucleus, Arca 39

- Corbula 129

- Nucula 38, 39, 41, 42, 44, 45

Nucula 38, 356

Nuculidae 38

Nuculoma $38,48,50$

obeliscus, Crassispira 269

- Drillia 269

- Inquisitor 268

- Pleurotoma 268

- Turris 269

obesa, Nassa 228

obliplicatula, Clavatula 266

- Perrona 266

oblita, Nassa 221

obsoleta, Anchilla 236

- Anchillaria 236 obsoleta, Sparella 236

obsoletum, Buccinum 236

obtusa, Brachytoma 274, 275

- Bulla 347

- Clavus 275

- Cylichna 347

- Mangilia 275

- Raphitoma 275

- Retusa 347, 400

- Tornatina 347

- var. plioparva, Retusa 347

obtusangulus, Drillia 275

- Murex 275

obtusata, Littorina, larvae of 375

obtusus, Utriculus 347

Odostomia 312

Ödumi, Rissoina 156

Oenopota 295

Oliva 237

Olividae 236

olla, Natica 195

- Neverita 195

opercularis, Pecten 31,73

- - larvae 378

Opisthobranchiata 298

orbicularis, Cardita (Cyclocardia) 85

- Cyclocardia 85

- Pteromeris 85

- Venericardia 85

orientalis, Cancilla 238

- Mitra 238

Ostrea 82

Ostreidae 82

pallidaeformis, Odostomia 316,356

- Odontostomia 316

pallidula, Lacuna 375

Pandora 138

Pandoridae 138

pannus, Asthenotoma 272

- Oligotoma 272

- Pleurotoma 272

panopæoides, Sphenia 135

Panopea 129

pantecolpatum, Cardium 101

- Laevicardium 101

papillosum, Cardium 103

Partschi, Alvania 153

- Rissoa 153

Patella 381

patera, Kellyella (Lutetia) 87

paucispinatus, Haustellum 202

- Murex 202

Pecchiolii, Aphanitoma 278

Pectinidae 73, 356

— juvenile shell stages 74 pectunculoides, Arca 65

- Bathyarea 65

Pelecypoda 38

- duration of larval stage 380

pella, Leda 57

pellucidus, Cultellus 124

- - larvae of 374

perversa, Sinusigera 380

- triforis 171

- Triphora 171

- var. borealis, Triphora 172

perversum, Cerithium 171

perversus, Triforis 171

- Trochus 171

- var. adversa, Monopho-

rus 172

pes pelicani, Aporrhais 391

— - - larvae 374

- - var. taurominor et

var. dertominor, Chenopus 182

peyreirense, Antale 144

- Dentalium 144

peyreirensis, Ampullina 196

- Lathyrus 232

Phacoides 81

Pharus 123

Philbertina 289

Philine 352

phoenix, Acrilla 175

Pholadidea 135

Pholas 135

Phos 208

pinguis, Acteon 301

Pirulidae 199

Pitar 107

planicostata, Mitra 238

planorbillus, Adeorbis 159

- Solarium 159

- Tornus 159

planulatum, Solarium 165

Pleurotomoides 282, 288

plicatelloides, Natica 188

plicatula, Turbonilla 329

plicosa, Pyramidella 332

pölsense, Buccinum 231

- Nassa 231

- Phrontis 231

- Tritia 231

polyfasciata, Bathyarca 66

polygonum, Phos 208

Polynices 193

polysarcula, Odontostomia

312

praecedens, Adeorbis 156, 159

- Circulus 159

praeclausa, Natica (Naticina) 189

- Tectonatica 189

prismatica, Abra 119, 414, 417,419 
prismatica, Ligula 119

- Serobicularia 119

- Syndosmya 119

propinquus, Sipho 389

Prosobranchiata 147

protostriata, Natica 188 , 190,198

- Natica (Naticina) 188

pseudo-auricula, Pyrgolampros 329

— - Turbonilla 329, 331

pseudopertusa Terebra 297

pseudoterebralis, Pyrgolampros 329

- Turbonilla 329, 331

Pteropoda 352

pungens, Typhis 204

pusilla, Ervilia 113, 414

- Erycina 113

- Saxicavella 128

pygmea, Acteon 309

- Chrysallida 305, 308, 309

- Leda 51, 356, 414, 416

- Leda (Jupiteria) 51

- Nucula 51

- Portlandia 51

- Turbonilla 309

- var. postica, Pyrgulina 309

- - subtypica, Pyrgulina 309

Pyramidella 332

Pyramidellidae 31, 304, 380

pyrenaica, Sveltia 246

Pyrene 206

- (Anachis) 208

Pyrula 199

quadrata, Philine 389

radians, Aequipecten 76

- Pecten 76

radiata, Nucula 39

ramosa elisae, Genota 267

- Genota 266

- Genotia 267

- parvicarinata, Genota 267

- Pleurotoma 266

Rappardi, Mangelia 289

- Mangilia 289

- Pleurotoma 289

Ravni, Ringicula 340

- Rissoa 154

Regulbiensis, Bulla 347

Reimersi, Astarte 27, 28, 69

reticosa, Actaeon 304

reticulata, Ficula 200

- Nassa 375, 391

- - duration of larval stage 379

- Pyrula 200

- Sinusigera 380 reticulatum, Bittium, dura-

tion of larval stage 379

Retusa 345

Rhizorus 344

Ringicula 333

Ringiculidae 333

Rissoa 154

Rissoidae 153

Rissoina 156

rostrata, Cuspidaria 141

- Mya 141

- Neaera 141

rotata, Gemmula 251

- Pleurotoma 251

- Pleurotoma 252

rotatus, Murex 251

Rothi, Fusus 232

- Lathyrus (Dolicholathyrus) 232

- Pseudolathyrus 232

rotunda, Kellyella 414

- Kellyella (Lutetia) 86

Roxania 221, 350

Rozieri, Hima 212

- Nassa 212

rufa, Chemnitzia 328

- Melania 328

- Odostomia 328

- Pyrgostelis 328

- Turbonilla 328

rugosa, Aspidopholas 136

- Martesia 136

- Pholas 136

- Saxicava 125

- Ventricola 111

- Venus 111

Saccoi, Turbonilla 328

sallespissensis, Odontostoma 315

- Odostomia 315

salomacense, Cirsotrema

173

salomacensis, Fusus 234

- Aptyxis 234

Sarsii, Rissoa 155

saucatsensis, Modiolaria 71

- Musculus 71

- Pharus 123

- Planimodiola 71

- Polia 123

- Teredo 137

Saxicava 125,376

Saxicavella 128

Saxicavidae 125

scabra, Daphnella 250, 251, 289

- Philbertia 289

- Pleurotomella 289

scabrum, Pleurotoma 289

Seacchia 94

Scala 174

Sealidae 173

Scaphander 349
Scaphopoda 143

Scillae, Eulima 322

- Eulimella 322

- Melania 322

- Odostomia 322

Schloenbachi, Lucina 91

- Phacoides 91

Schlotheimi, Buccinum 215 , 216

- Nassa 216, 356, 412, 414,416

- Tiphys 204

Schröderi, Nassa 216

- Telasco 216

scrobiculata, Mitra 238

Seguini, Clavatula 266

Selenkae, Clavus 270

- Cymatosyrinx 270

- Pleurotoma 270

- Splendrillia 270

Semelidae 119

Semicassis 198

semireticulata, Chrysallida 308

semistriata, Nassa 221

— Tornatella 298

semistriatus, Acteon 298, 299,301

septemradiatus, Pecten 73

seriliola, Heterocithara 250

serraticosta, Buccinum 212

- Hima 212

- Nassa 212

sexcostatus, Fusus 233

- Streptochetus 233

Sigaretus 189, 196

similis, Eulima 178

- Melanella 178

simplex, Ficus 199

- Pirula 199

- Pleurotomoides 284, 287

- Pyrula 199

sinensis, Calyptraea 180

sinuosula, Philbertia 290

Sinusigera larvae 380

Sipho 235

Siphonodentaliidae 143

Sismondae, Murex 203

Skeneidae 149

Solariidae 162

Solarium 162

Solen 381

Solenidae 123

solida, Mactra 117

- Spisula 117

solidum, Cardium 117

sonense, Cardium 103

Sphenia 134

spina, Bittium 165, 168, 170,356

- Cerithium 165

- var. convexorudis, Bit-

tium 165

spinifera, Cancellaria 242 
Spiratella 352

Spiratellidae 352

Spisula 114

Splendrillia 270

Sportella 89

Sportellidae 89

squamula, Anomia 80, 389, 390

- Anomia, larvae 374

- Heteranomia 80

Starkeyna 149,151

Steinvorthi, Pleurotoma 262

- Surcula 262

Steinvorthi, Turricula 262

Stipator 149

stoffelsi, $\alpha$-Gemmula 256

Stoffelsi, Gemmula 256

- Pleurotoma 256

stoffelsi, Turris 256

Straeleni, Acamptogenotia 268

- Cardium 102, 105

striata, Ringicula 334

- Sinusigera 380

striatissima, Erycina $(\mathrm{He}$ milepton) 97

striatissimum, Lepton 97

striatulata, Turricula 263

strigilata, Ostrea 79

- Lima Limea 79

subangistoma, Bullinella 346

- Cylichnina 346

subangulata, Turritella 161, 416

- var. spirata, Turritella 161

- - Zaria 161

- subacutangulata, Turritella 161

- Zaria 161

subangulatus, Turbo 161 subangulosa, Cancellaria 246

subcancellata, Bivetia 139 subcirculus, Adeorbis 157

\section{- Tornus 157}

subfusiformis, Cadulus 144 subinornata, Pleurotoma 259

subintermedia, Odontostomia 314

- Odostomia 314, 315

sublavata, Ocinebrina 206

submamillaris dertomamilla, Polynices 193

- Natica (Naticina) 192

- Polinices 192

subobesa, Nassa 226, 356

- Phrontis 226

subreticulata, Scalaria 174 substriata, Ligula 99

- Montacuta 99 subtruncata, Mactra 114

- Spisula 114, 356, 416

- Trigonella 114

subulata, Pyrene 207

- var. taurostricta, Eulima 179

- - Subularia 179

subumbilicata, Acteon 320

- mut. bearnensis, Syrnola 320

- Odostomia (Syrnola) 320

- turoniensis, Odostomia 320

- - Syrnola 320

subutricula, Roxania 351

succincta, Rissoa 155

sulcata, Corbula 131

- Natica 196

- Tornatella 301

sulcatus, Sigaretotrema 196

- Sigaretus 196

Syrnola 320,322

Tahusyrinx 264

tauroglandula, Pseudavene 344

taurostricta, Melanella 179

tectula, Natica (Naticina) 190

- Tectonatica 190

Teinostoma 149

Tellina 122

Tellinidae 120

tenella, Daphnella 279

- Neoguraleus 279

- Pleurotoma 279

- Raphitoma 279

tenuis, Leda 51

- Nucula 390, 391

- Tellina 360

tenuispina, Bittium 16\%,

$170,356,414$

tenuistriata, Nassa 210

tenuistriatum, Buccinum 210

- Hima 210

- Nassa 210

terebellum var. acarinatoconica, Niso 177

- - eburnea, Niso 177

Terebra 295

terebralis var. perlonga,

Anachis 208

Terebridae 295

Teredinidae 137

Teredo 137

teres, Defrancia 287

- Mangelia 287

- Pleurotoma 287

Teretia 287,288

Thais, Cirsotrema 173

Thracia 140

Thraciidae 140
Thyasira 89

tigerina, Chlamys 77

- Palliolum 77

tigerinus, Pecten 73, 75, $7 \%, 389,415$

tigrinus var. laeviligustica, Flexopecten 77

77

toftlundensis, Chrysallida 307

- Boreodrillia 271

tornatilis, Actaeon 299

- Actæon 303

- Acteon 303

- Voluta 303

Tornus 156

Tournoueri, Ringicula 341

triangula, Mactra 114

triangularis, Astarte 84

- Goodallia 84

- Mactra 84

tricarinata, Filodrillia 250

- Turritella 160, 414, 416

- var. communis, Turri-

tella 160

tricarinatus, Turbo 160

Trigonostoma 241

trigonostoma, Adeorbis

159

trigonula, Nucula 39

trinacria, Mactra 114

Triphora 171

Triphoridae 171

Tritonalia 206

Tritonidae 199

Tritonium 199

Trochidae 148

trochleare, Solarium 163

trochlearis, Clinura 291

- Eubela 291

- Genotia 292

- Pleurotoma 291

truncata, Mya 378

- - breeding 375

- larvae 378

tuberculata, Cardita 85

- Venericardia 85

turbida, Dolichotoma 261

- Pleurotoma 261

turbinella, Nassa 214, 216

- Telasco 214

turbinellus, Buccinum 214

- Nassa 214

- Uzita 214

Turbinidae 152

Turbonilla 325,331

Turricula 262

Turridae 31, 249, 356

turris, Haustator 160

- Turritella 160

Turritella 160

Turritellidae 33, 160

Typhis 204 
ulvae, Hydrobia 400 umbilicata, Bulla 346 - Bullinella 346

- Cylichna 346

- Cylichnina 346

- Retusa 346, 414 umbilicatus, Utriculus 346

undatum, Buccinum 366 , 372

undatus, Lembulus 57 undulata, Pyrgolampros 331

- Turbonilla 331

Ungulinidae 89

utricula, Bulla 351

- Damoniella 351

- Sabatia 351

utriculata, Bulla 350

utriculus, Atys 351

- Bulla 350

- Roxania 350
Vaginella 354

valvatina, Spiratella 353

- Spirialis 353

Varicorbula 129

varicosa, Cancellaria 244

- Sveltia 244

- Voluta 244

varius, Pecten 73,75

Veneridae 105

Ventricola 111

ventricosa, Auricula 333

- Ringicula 333

Venus 111

venusta, Daphnella 275

- Raphitoma 275

vepratica, Pleurotoma 250

- Veprecula 250

vicaria, Nothocorbula 131

Vignali, Cerithiopsis 170

viminea, Bothrocorbula 131

vineta, Lacuna 381

vulgata, Patella, larvae 375

— - reproduction 374 vulgatissima, Nassa 213

- Uzita 213

Westendorpii, Leda 54, 356, 413,414

- - (Ledina) 54

Westendorpii, Trigonocoelia 54

Woodwardi, Nassa 224, 225, 356

- Phrontis 225

Xenophora 181

Xenophoridae 181

Yoldia 59

Yoldiidae 59

Zimmermanni, Gemmula 257

- Pleurotoma 257

- Turris 257 
PLATES 


\section{Plate 1.}

Location Depth Length Height WidthPage

la-b. Nucula nucleus (LiNNÉ) Toftlund

$75-100 \mathrm{~m} . \quad 5.7 \quad 5.1$

39

Right valve. $(\times 10)$.

2a-c. Nucula Jeffreysi BeLLARd I Glejbjerg

$53.5-$

a-b. Right valve, c paired valves,

$$
\mathrm{a}-\mathrm{b}: 3.39
$$

2.93

dorsal view. $(\times 18)$.

c: 2.54

1.35

4a-b. Nucula cf. nitida SowerBy Toftlund Left valve. $(\times 12)$.

Shell dimensions in millimeters 

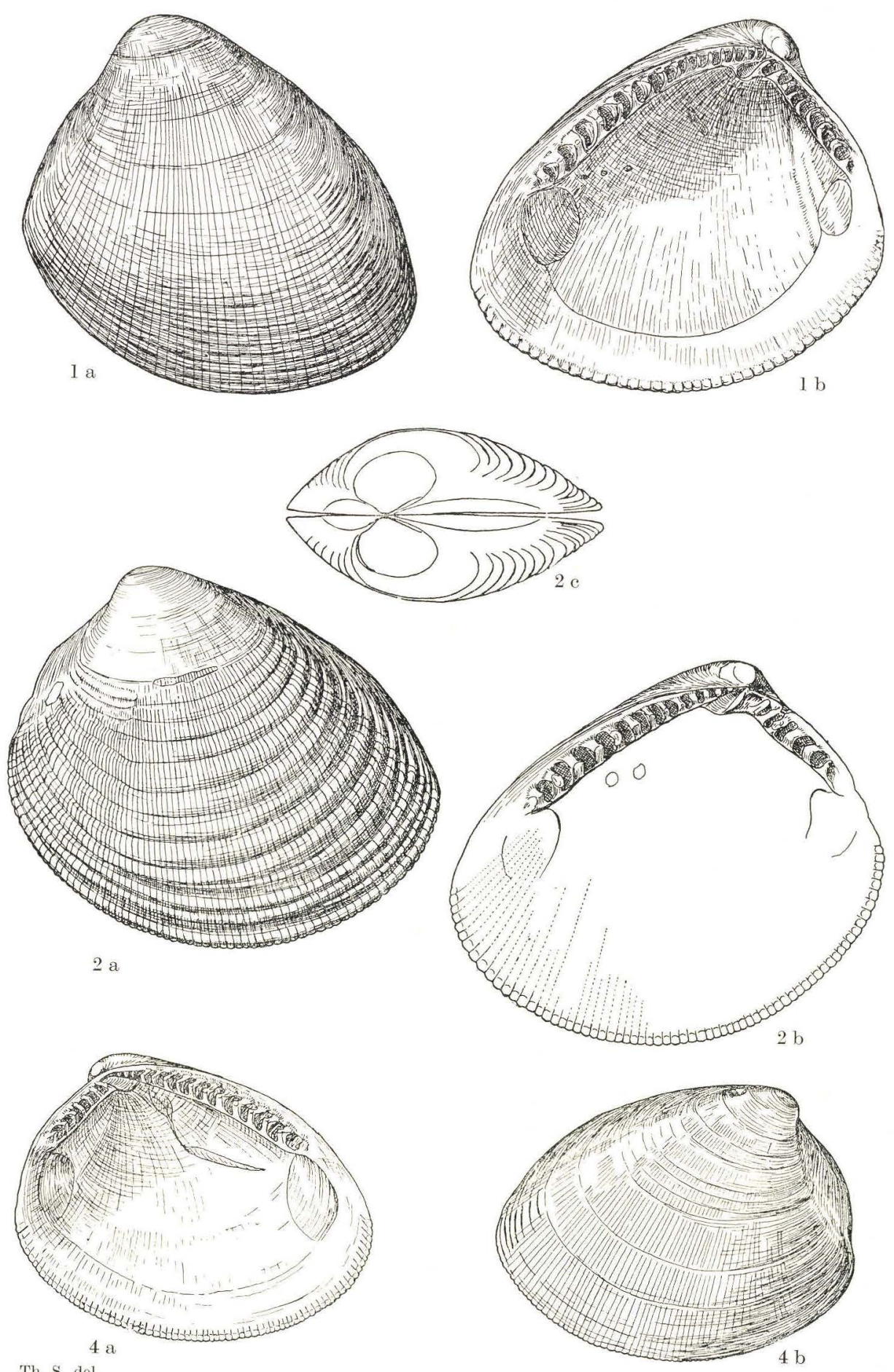

Th. S. del. 


\section{Plate 2.}

\author{
3a-b. Nucula cromata nov. sp. \\ Right valve. $(\times 11)$.

\section{Holotype}

8a-b. Leda (Jupiteria) pygmaea

\begin{tabular}{|c|c|c|c|c|c|}
\hline $\begin{array}{l}\text { (MÜNSTER). Left valve. } \\
(\times 12.5)\end{array}$ & Toftlund & $75-100$ & - & 3.95 & 2.78 \\
\hline
\end{tabular}

10a-e. Leda (Lembulus) emarginata
(LAMARCK).
Toftlund
75-100 .

a. Left valve with widely spaced

concentric ribs and oblique lines. $(\times 12)$.

$\mathrm{b}-\mathrm{d}$. Right valve, concentric ribs obliter-

ated, few oblique lines. $(\times 12)$.

c. Paired valves, dorsal view. $(\times 12)$.

e. Right valve narrowly spaced concentric ribs and oblique lines. ( $\times 12)$.
Depth Length Height Width Page

$75-100 \mathrm{~m} . \quad 5.20 \quad 4.65$

44

I

57
$5.02 \quad 2.75$

$3.40 \quad 1.33$

$4.55 \quad 2.82$

Shell dimensions in millimeters. 

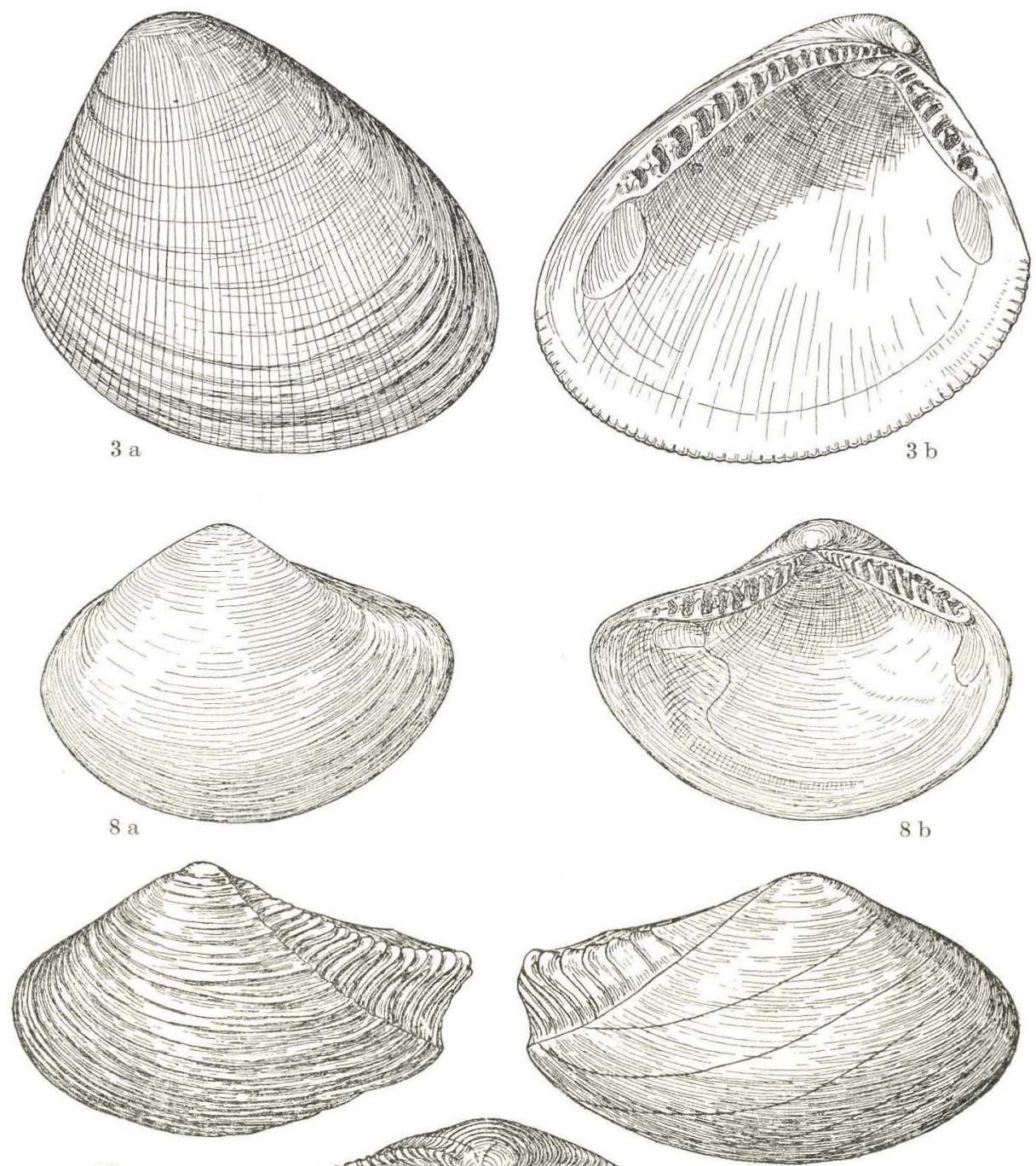

$10 \mathrm{a}$

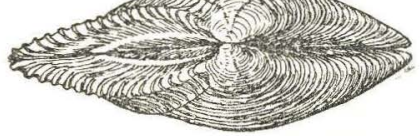

$10 \mathrm{~b}$
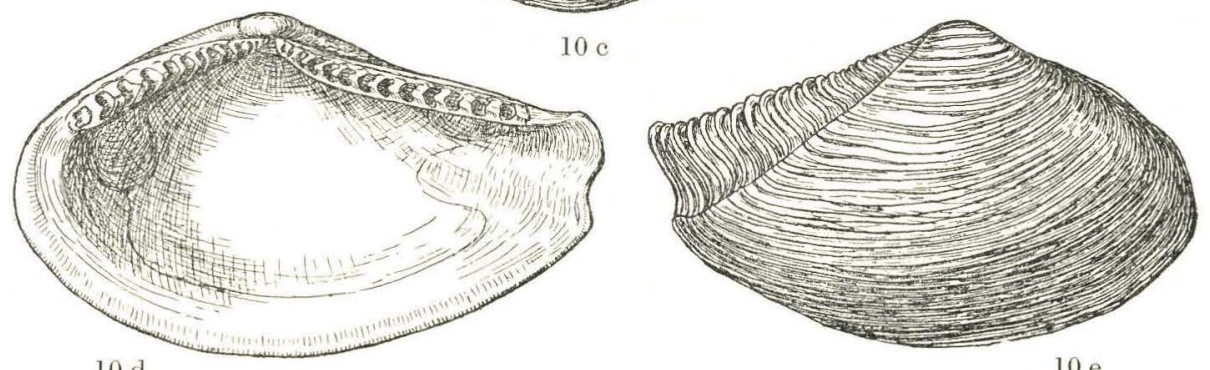

Th. S. del. 


\section{Plate 3.}

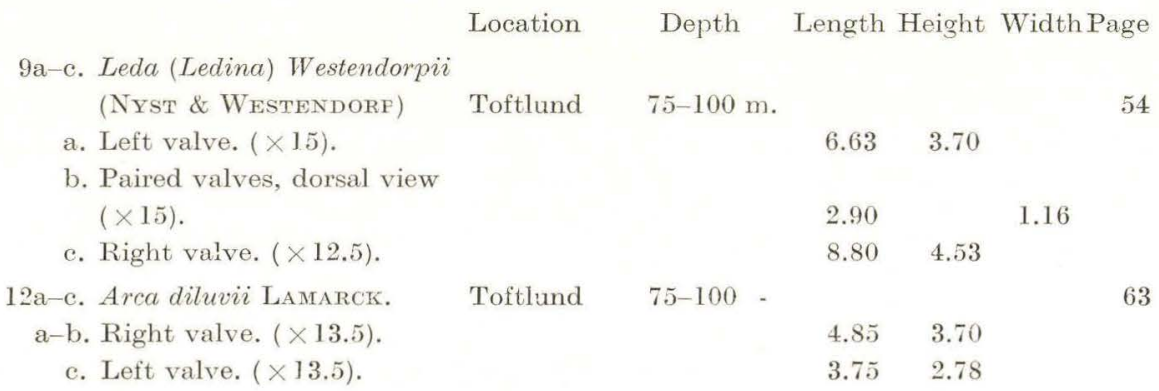

Shell dimensions in millimeters. 


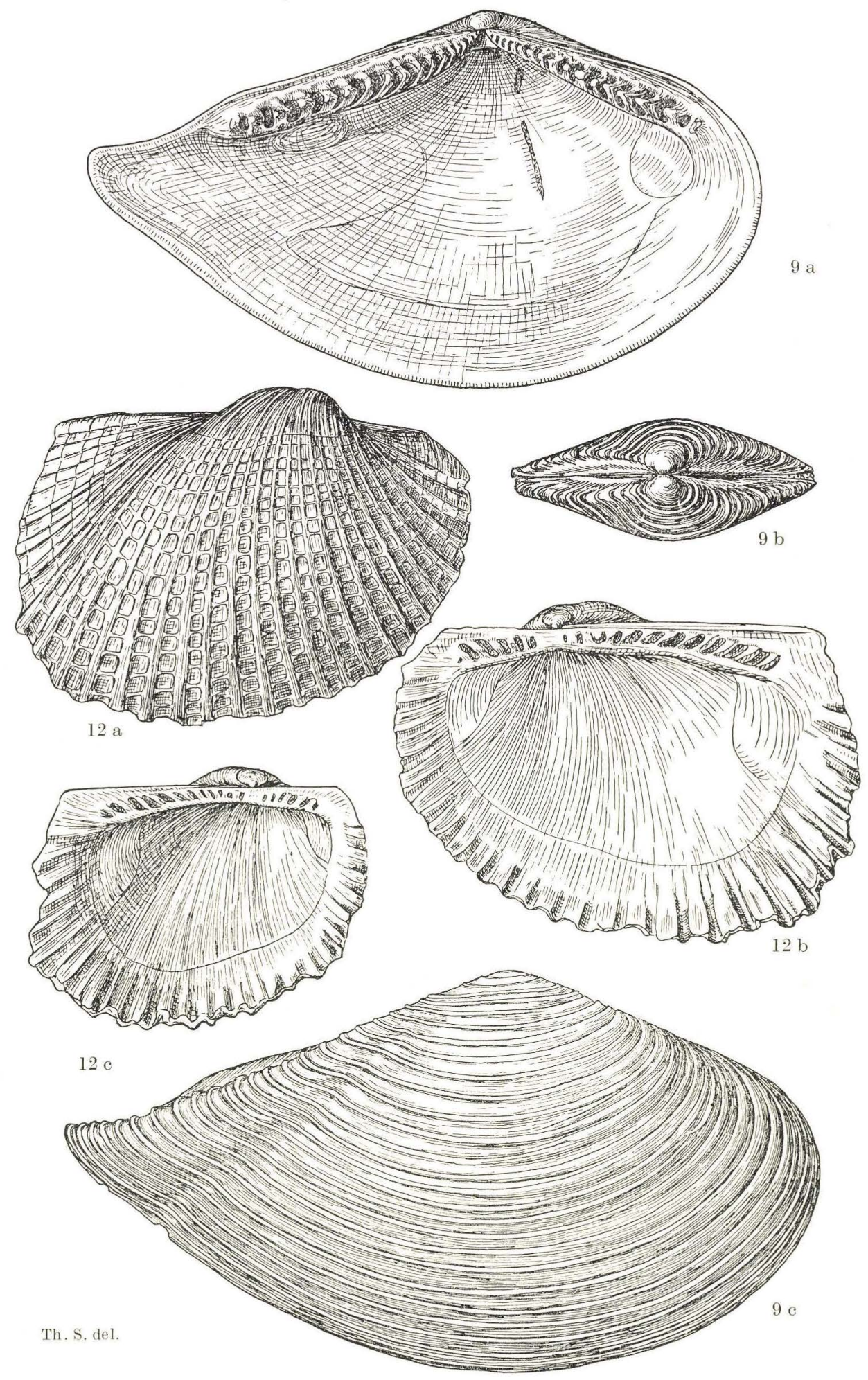




\section{Plate 4.}

Location Depth Length Height Page

11a-b. Yoldia glaberrima (MüNsTeR)

Toftlund

$75-100 \mathrm{~m} . \quad 7.82$

3.95

59

Left valve. $(\times 15)$.

16a-b. Limopsis anomala (EICHWALD) $\quad$ Toftlund $\quad 75-100 \quad-\quad 4.28 \quad 4.10 \quad 69$ Left valve. $(\times 13.5)$.

Shell dimensions in millimeters. 
Plate 4

D.G.U. II. Ser. No. 79.
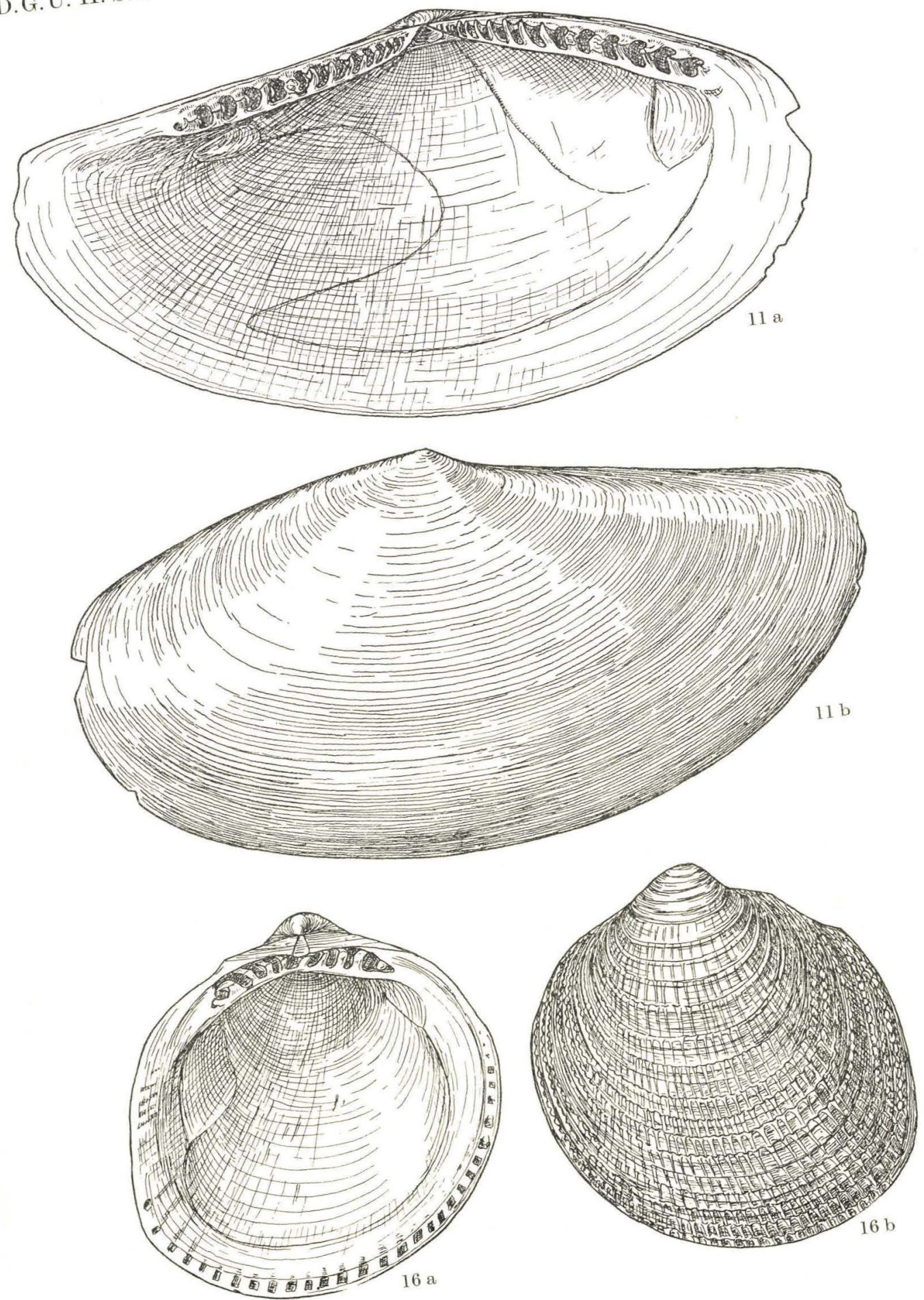

Th. S. del. 


\section{Plate 5.}

Location Depth Length Height Page

17a-b. Modiolus sp. a. Left valve. (×33). Arnum(25b) 62.7-62.9 m. $\quad 1.37 \quad 71$

$18 \mathrm{a}-$ b. Modiolus sp. b. Right valve. $(\times 33)$. Toftlund $\quad 110-115$ - $\quad 0.85 \quad 71$

19a-d. Musculus saucatsensis (CossmanN)

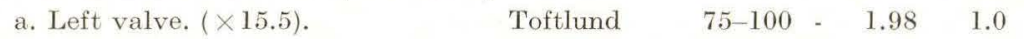

b. Left valve. $(\times 15.5)$. Toftlund $\quad 105-110-1.29 \quad 1.24$

$\begin{array}{llllll}\text { c-d. Left valve. }(\times 15.5) . & \text { Toftlund } & 105-110 & - & 4.33 & 2.77\end{array}$

24. Pecten Gerardi Nyst

$\begin{array}{llllll}\text { Left valve }(\times 20) . & \text { Arnum(25b) } & 107.5 & - & 2.74 & 78\end{array}$

Shell dimensions in millimeters. 
D. G. U. II. Ser. No. 79.

Plate 5

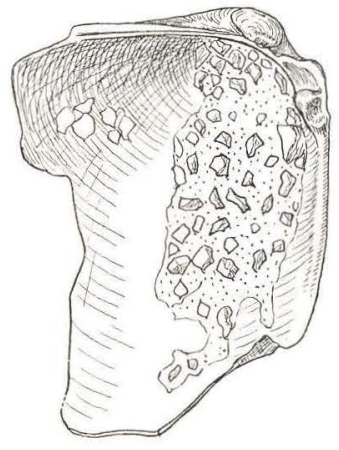

17 a

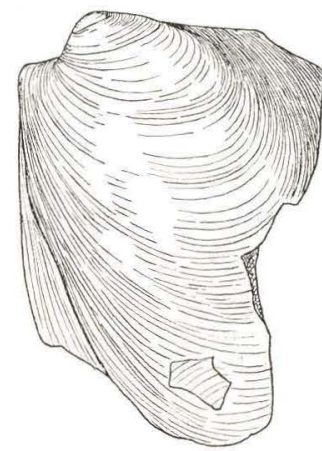

$17 \mathrm{~b}$

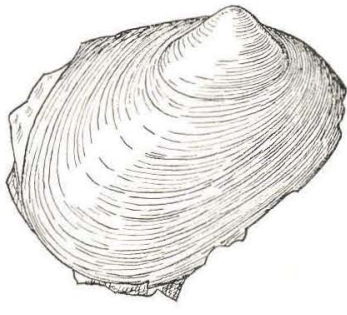

$18 \mathrm{a}$

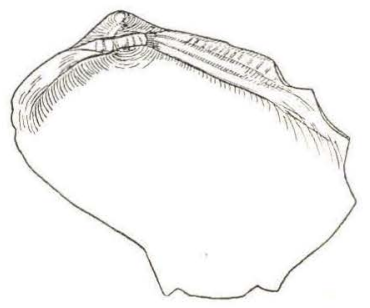

$18 \mathrm{~b}$

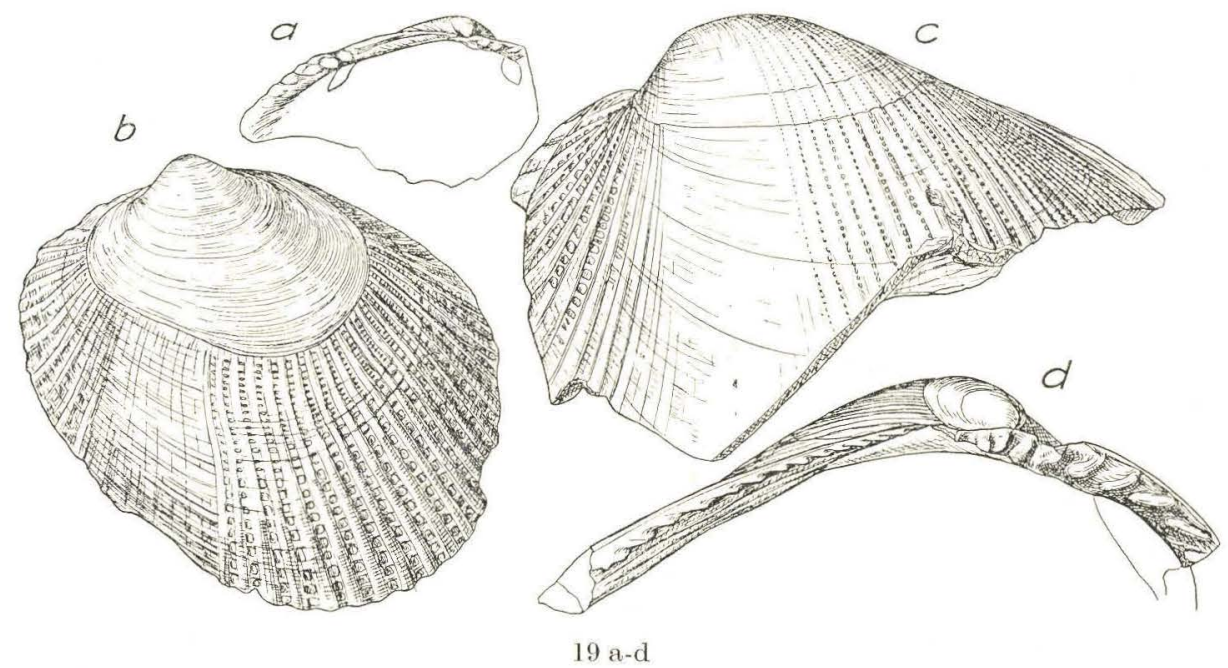

Th. S. del.

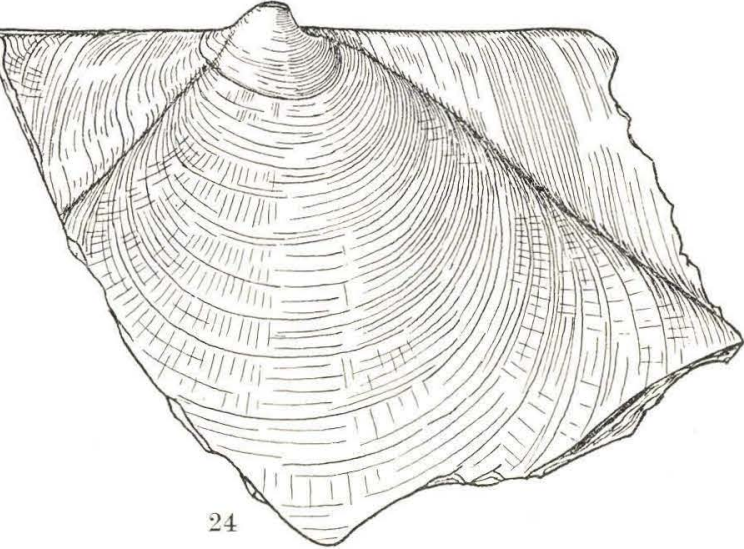


Plate 6.

26a-c. Lima (Limea) strigilata

$\begin{array}{lllllll}(\text { Brocchi }) & \text { Toftlund } & 100-105 \mathrm{~m} . & 1.55 & 1.82 & 0.57 & 79 \\ \text { Right valve. }(\times 35) . & & & & & & \end{array}$

27a-c. Anomia squamula Linné $\quad$ Toftlund $105-110 \quad-\quad 2.31 \quad 2.31 \quad 0.77 \quad 80$ Left valve. $(\times 18)$.

Shell dimensions in millimeters. 

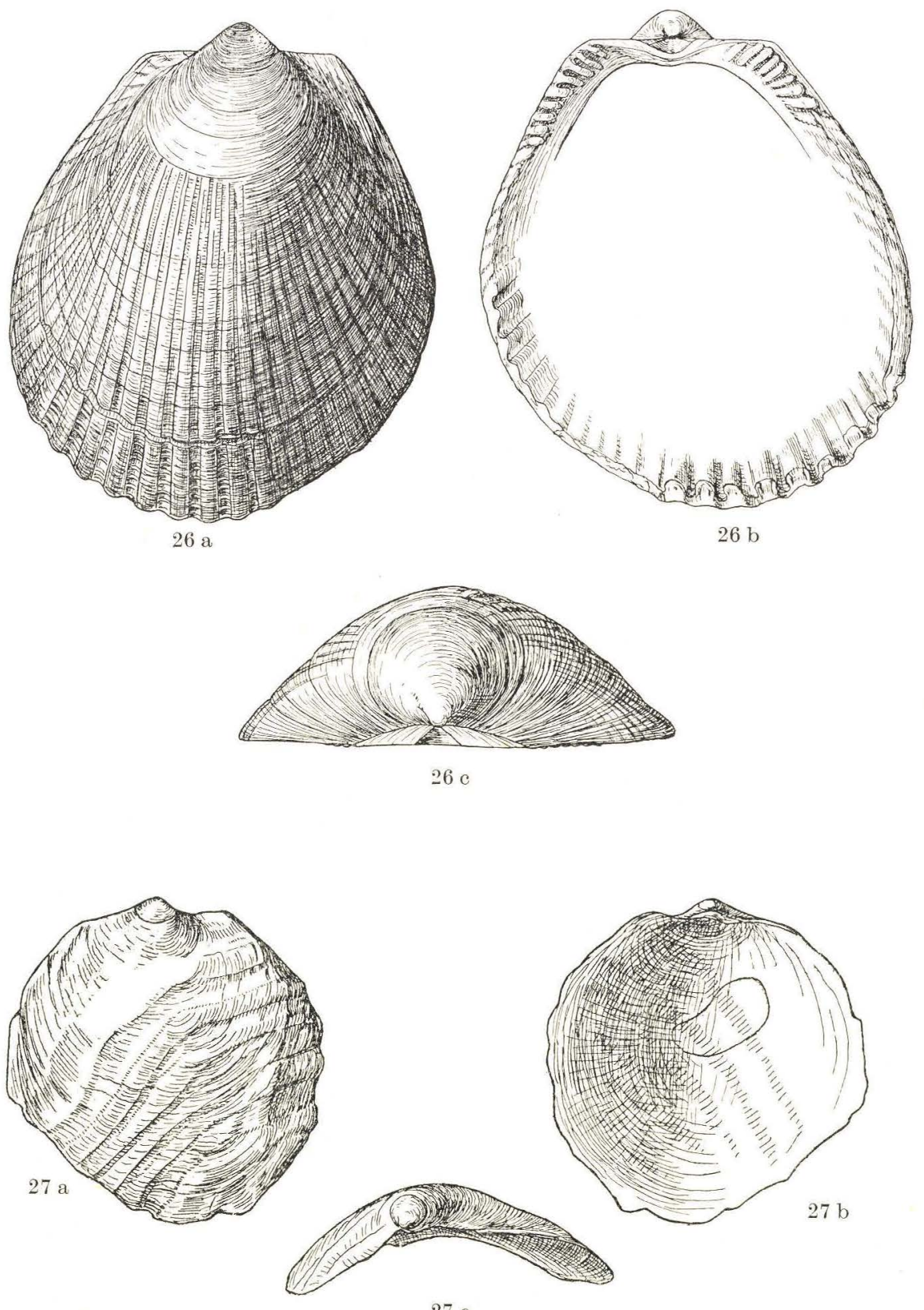

Th. S. del 


\section{Plate 7.}

Location Depth Length Height Page

21a-d. Pecten ex. aff. liberata Cossmann

\& Peyrot

a-b. Left valve. $(\times 15)$.

c-d. Right valve. $(\times 15)$.
Toftlund $\quad 75-100 \mathrm{~m}$.

$4.95 \quad 5.4$

Greatest dimension: $6.05 \mathrm{~mm}$.

Shell dimensions in millimeters. 
D. G. U. II. Ser. No. 79.

Plate 7

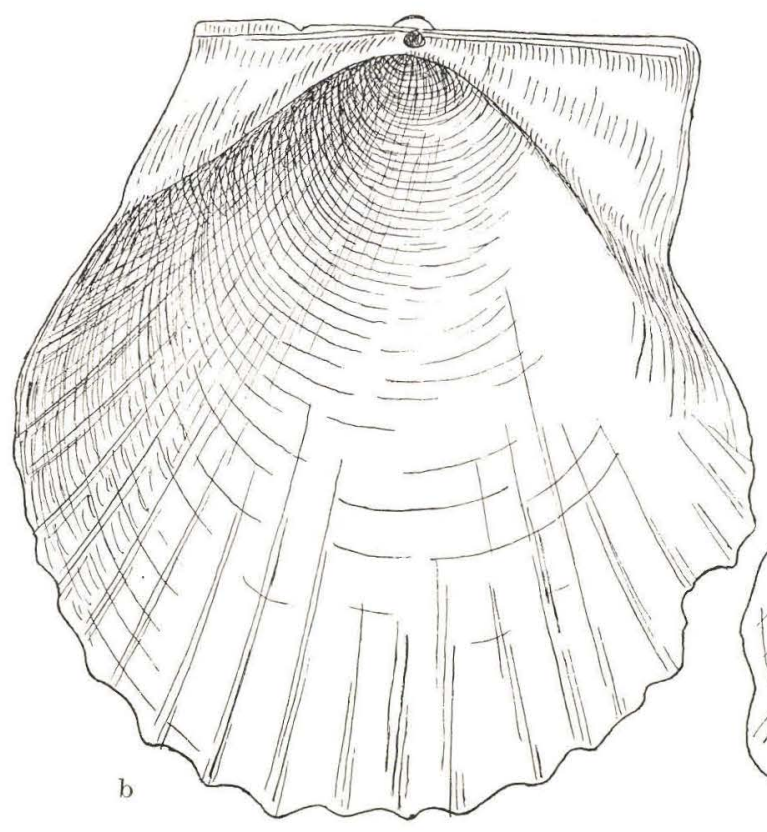

21
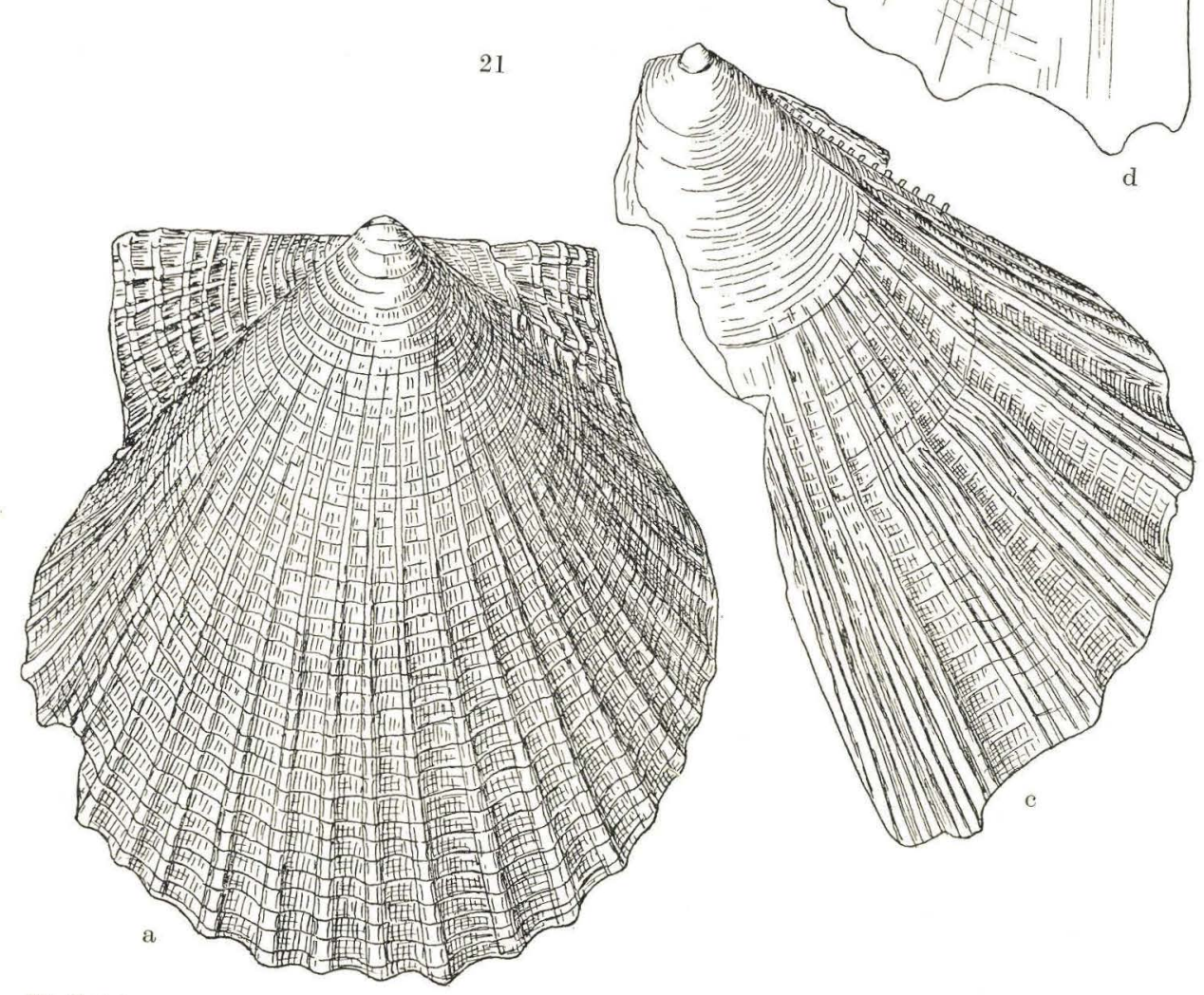

Th. S. del 
Plate 8.

22. Pecten radians NysT

Right valve. $(\times 18)$.

Location

Depth

Height

Page

Toftlund

$115 \mathrm{~m}$.

4.67

76

23. Pecten tigerinus MüLLER Left valve. $(\times 21)$.

Shell dimensions in millimeters. 


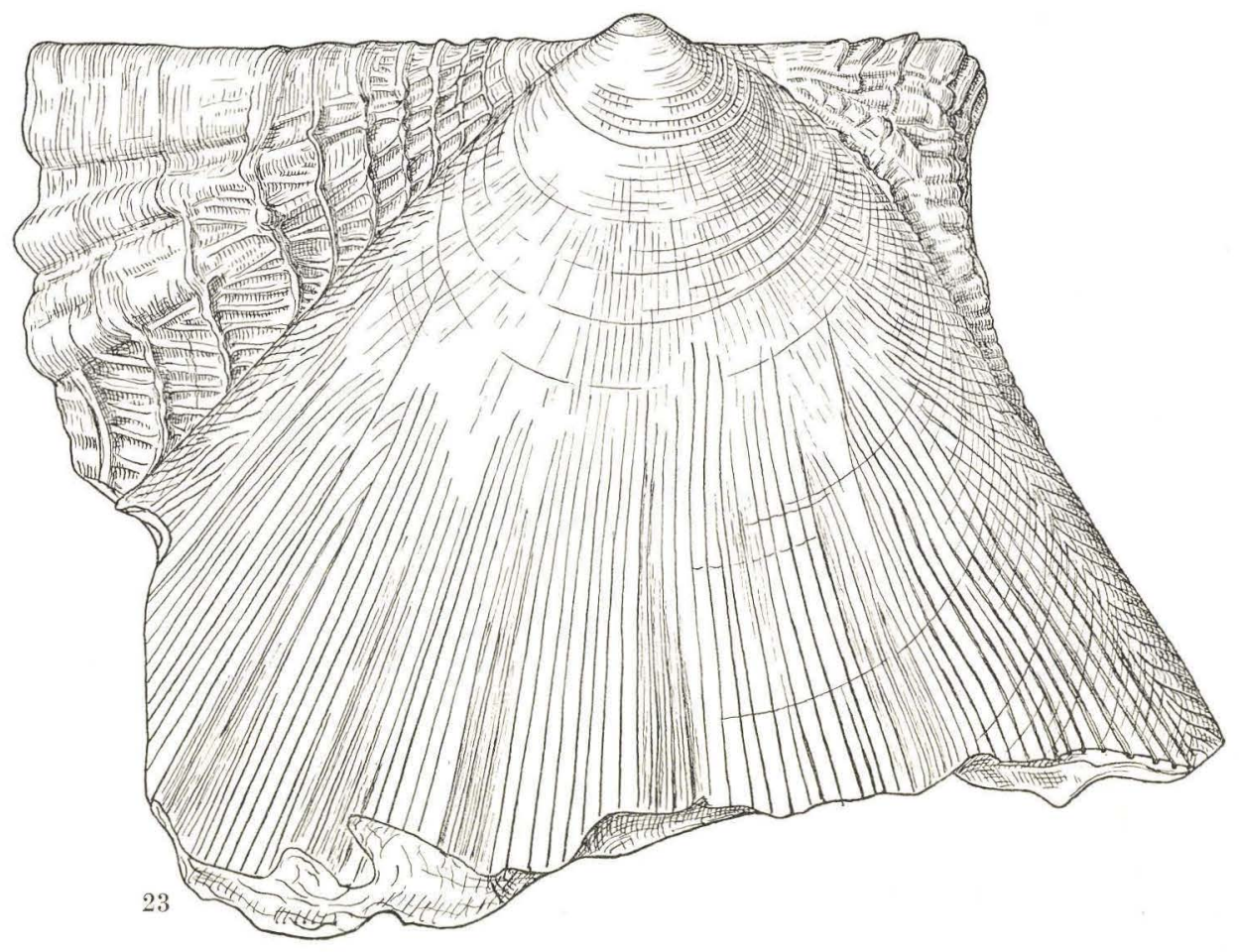

Th. S. del.

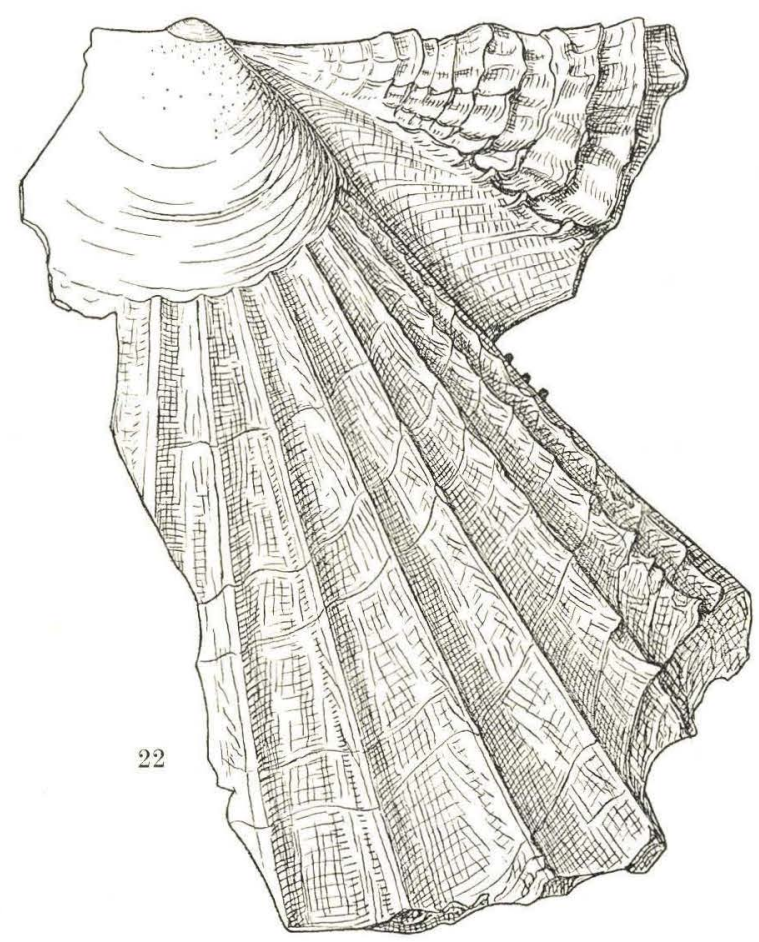




\section{Plate 9.}

Location Depth Length Height Width Page

28a-i. Ostrea $s p$.

a-c. Right valve. $(\times 18)$.

d-f. Right valve. $(\times 18)$.

Toftlund

$100-105 \mathrm{n}$

$\begin{array}{lll}2.81 & 3.2 & 0.62\end{array}$

g-i. Right valve. $(\times 25)$.

Toftlund 100-105 -

2.17

$\begin{array}{ll}2.68 & 0.69\end{array}$

Toftlund

$75-100$

Shell dimensions in millimeters. 
D. G. U. II. Ser. No. 79.
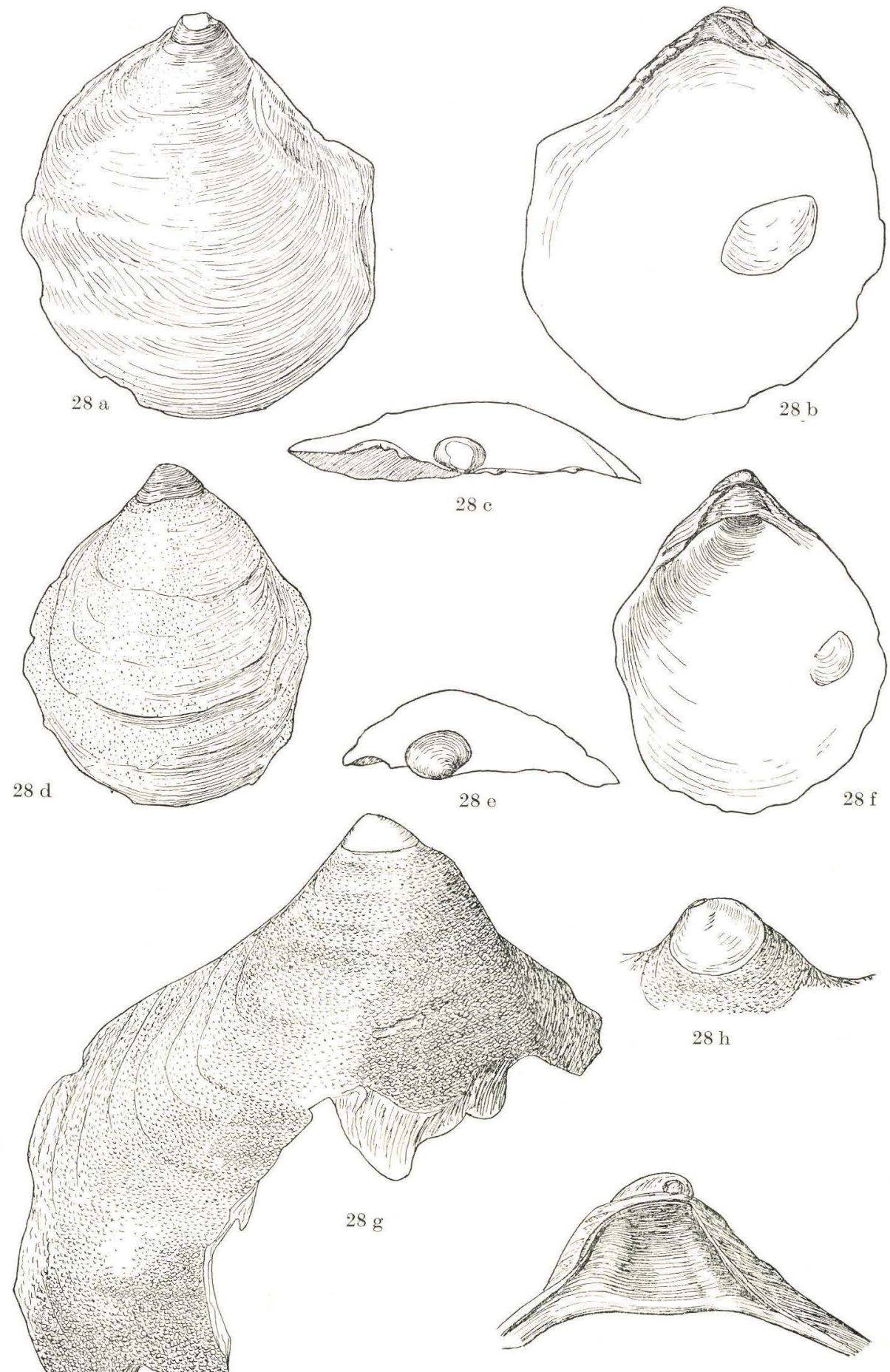

$28 \mathrm{i}$

Th. S. del. 


\section{Plate 10.}

27a-e. Anomia squamula Linné Left valve. $(\times 17.5)$.

30a-c. Astarte (Goodallia) triangularis (MoNTAGU) $(\times 20)$.

32a-e. Kellyella (Lutetia) rotunda nov. $s p$.

a-b. Left valve. $(\times 30)$.

c-d. Right valve. $(\times 30)$. Holotype.

e. Left valve. $(\times 30)$.
Location Depth Length Height Width Page

Toftlund $\quad 100-105 \mathrm{~m}, \quad 3.45 \quad 3.56 \quad 1.33 \quad 80$

$\begin{array}{lllllll}\text { Toftlund } & 110-115 & - & 2.3 & 1.76 & 0.47 & 84\end{array}$

Arnum(13) 53-83 -

$\begin{array}{lll}1.71 & 1.75 & 0.6\end{array}$

$1.50 \quad 1.46$

$1.16 \quad 1.16$

Shell dimensions in millimeters. 

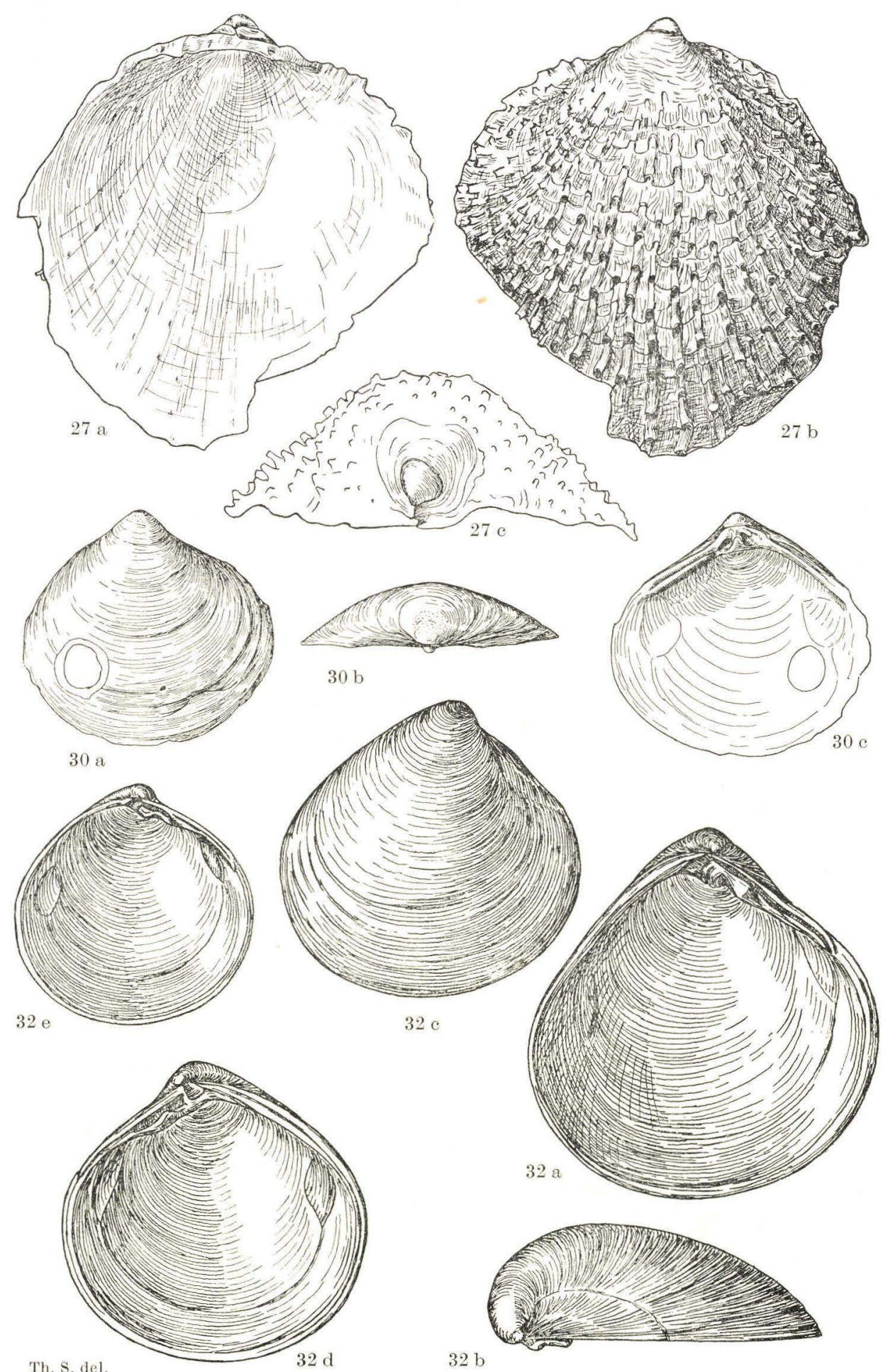


\section{Plate 11.}

33a-b. Kellyella patera nov. sp. Right valve. $(\times 28,5)$. Holotype.

34a-f. Isocardia sp.

a-b. Right valve. $(\times 32)$.

e-d. Right valve. $(\times 30)$.

e-f. Left valve. $(\times 30)$.

35a-b. Sportella cimbrica KAUTsky Left valve. $(\times 12)$.

36a-b. Thyasira of. flexuosa (Montagu) Left valve. $(\times 15)$.
Location Depth Length Height Page Arnum (13) $53-83 \mathrm{~m}$.

Arnum (13) 53-83 -

Shell dimensions in millimeters. 
D. G. U. II. Ser. No. 79.

Plate 11
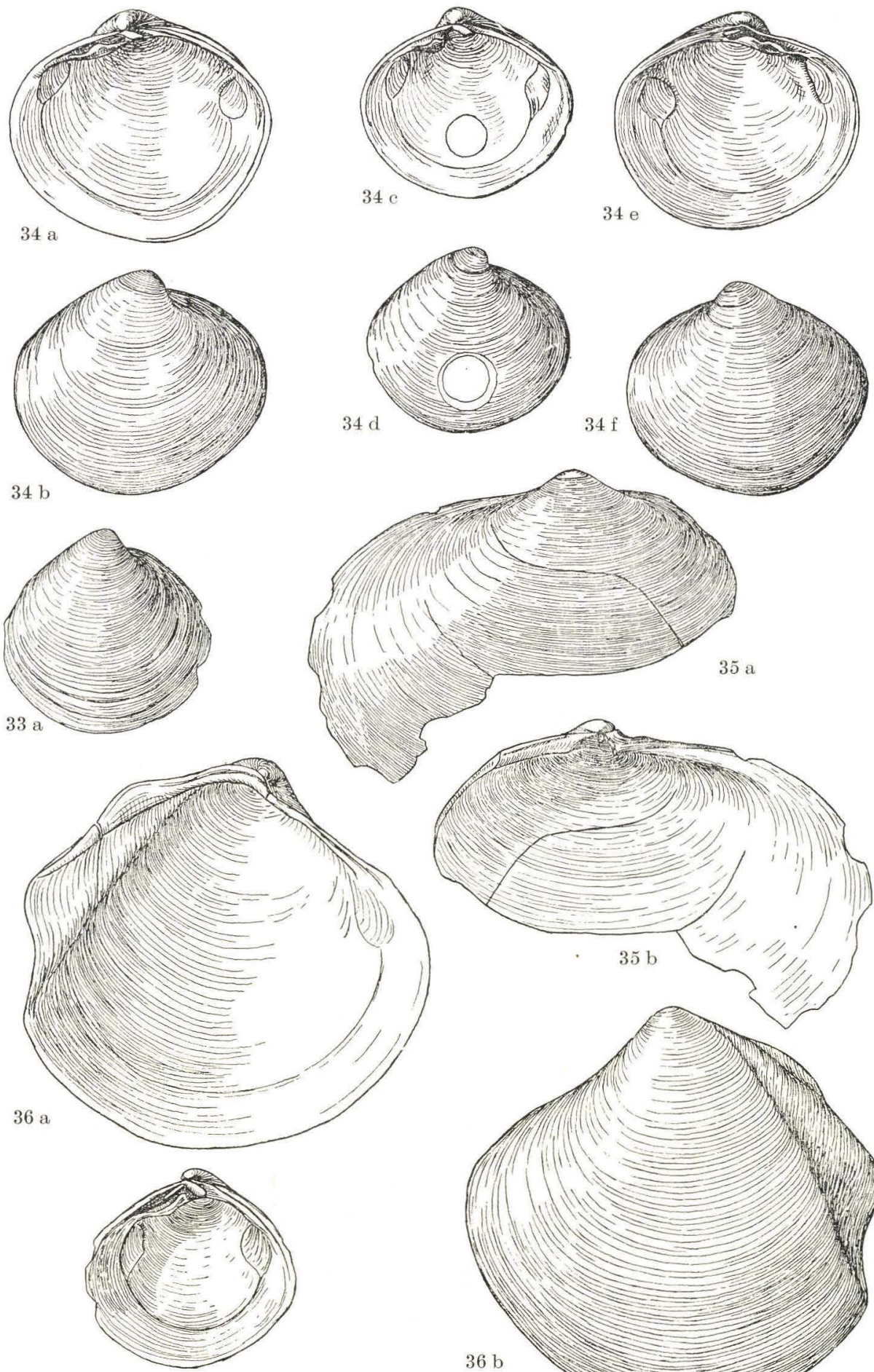

Th. S. del.

$33 \mathrm{~b}$

$36 \mathrm{~b}$

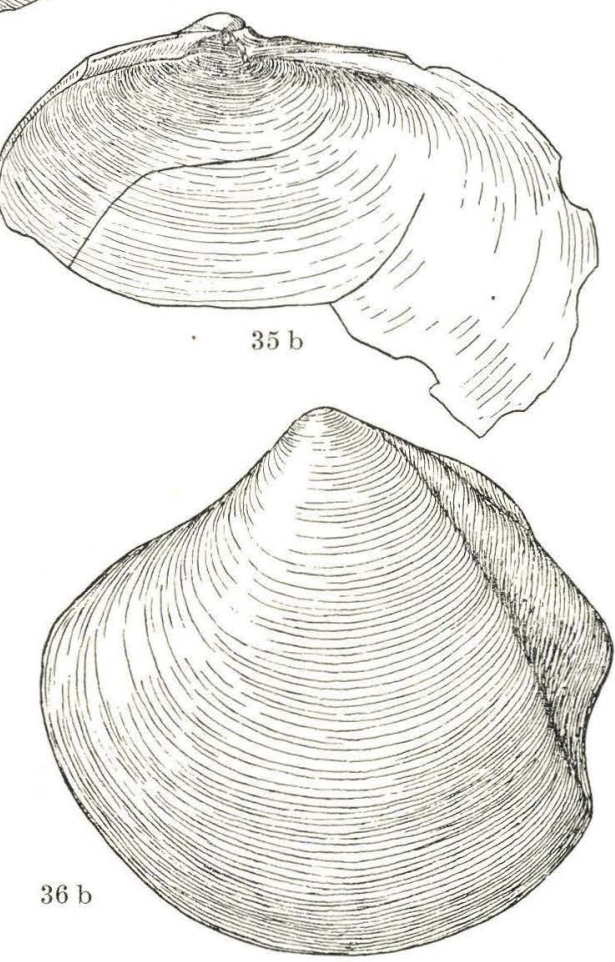




\section{Plate 12.}

Location Depth Length Height Width Page

37a-c. Phacoides cf. Schloenbachi.

(vON KOENEN).

Toftlund $\quad 110-115 \mathrm{~m} . \quad 1.05 \quad 0.9 \quad 0.30 \quad 91$

Right valve. $(\times 40)$.

38a-c. Loripes cf. niveus (EICH-

WALD) Right valve. $(\times 30)$. Arnum (13) $53-83 \quad-\quad \begin{array}{lllll}1.1 & 1.08 & 0.33 & 91\end{array}$

39a-b. Lucina (Loripinus) Nörre-

gaardi nov. sp.

Right valve. $(\times 15)$. (ef.) Toftlund $75-100$ - abt. $4 \quad 92$

$\begin{array}{lllllll}\text { c-e. Right valve. }(\times 40) \text {. } & \text { Toftlund } & 110-115 & - & 1.35 & 1.24 & 0.37\end{array}$

Holotype.

Shell dimensions in millimeters. 
D. G. U. II. Ser. No. 79.

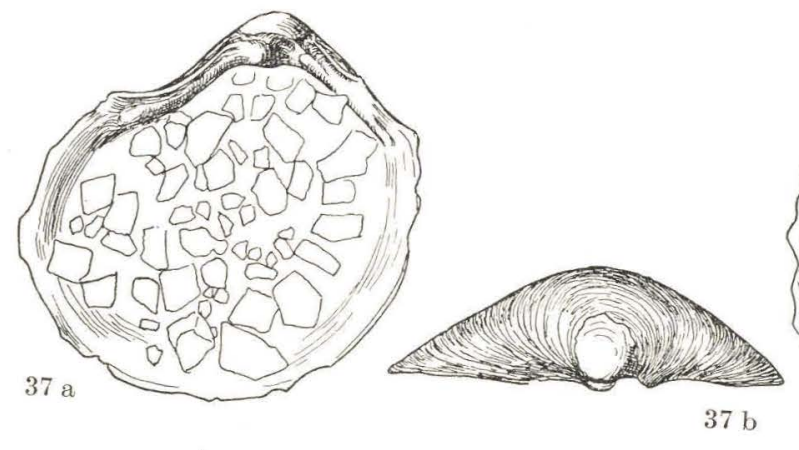

Plate 12

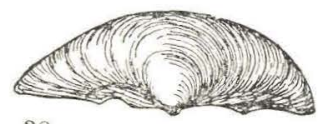

$38 \mathrm{a}$
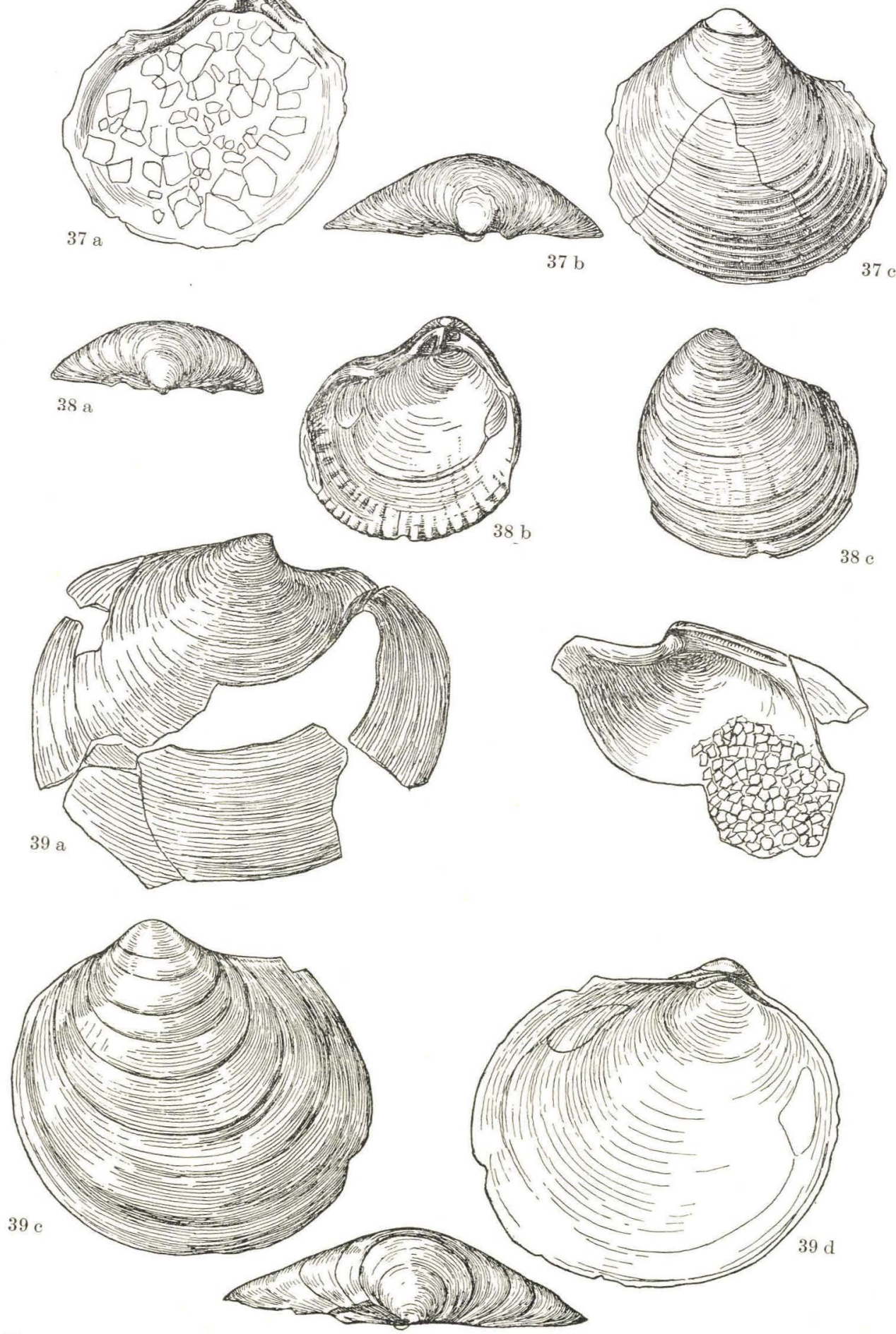

Th. S. del.

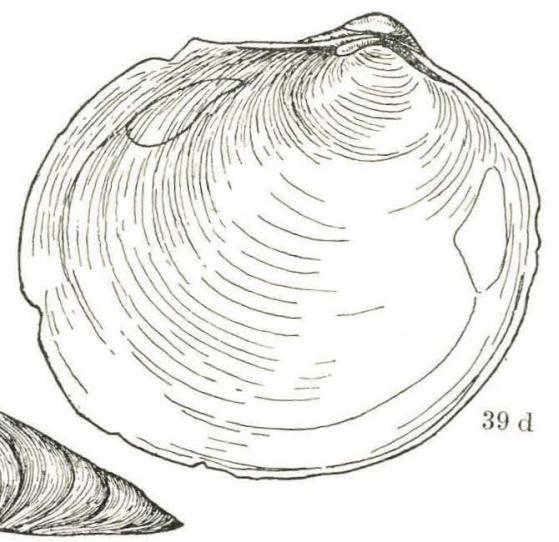

39 e 


\section{Plate 13.}

40a-h. Codolia jutensis nov. sp.

Location Depth Length Height Width Page

a-d. Paired valves. $(\times 39)$.

$110-115 \mathrm{~m}$.

93

a-b. Left valves. $(\times 39)$.

$0.94 \quad 0.84$

c-e. Right valve. $(\times 39)$.

Toftlund

(10-115

$$
0.94
$$

f-h. Left valve, holotype. $(\times 19)$.

$\begin{array}{lll}2.70 & 2.41 & 0.59\end{array}$

42a-b. Erycina (Scacchia) Degrangei Cossmann \& Peyrot.

$\begin{array}{llllllll}\text { Right valve. }(\times 30) . & \text { Arnum }(13) & 53-83 & - & 1.76 & 1.41 & 0.44 & 94\end{array}$

$43 \mathrm{a}-\mathrm{b}$. Erycina (Hemilepton) coarc-

tata (Wood).

Right valve. $(\times 30)$.

$\begin{array}{lll}1.56 & 0.98 & 0.27\end{array}$

96

Shell dimensions in millimeters. 

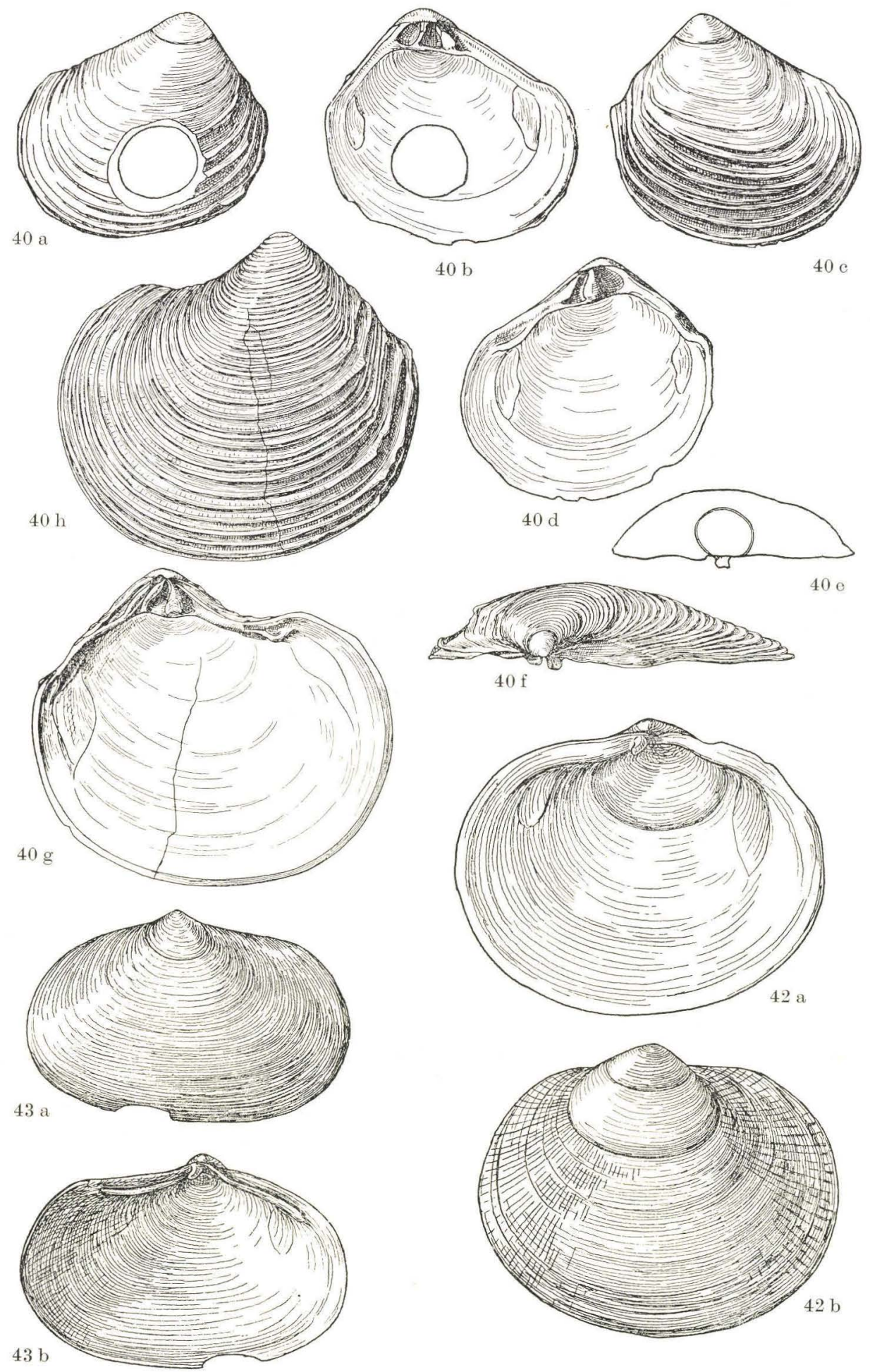

Th. S, del. 
Plate 14.

Location Depth Length Height Width Page 46a-b. Montacuta substriata (MoN-
TAGU) $(\times 33)$
Gramby $\quad 84.66-87.16$ m. $\quad 1.24$
$1.14 \quad 0.255 \quad 99$

50a-b. Cardium of. hanseatum KaUtSKY

$\begin{array}{llllllll}\text { Right valve. }(\times 21) . & \text { Toftlund } & 75-100 & - & 2.8 & 2.8 & 0.94 & 104\end{array}$

5la-c. Gouldia minima (Montagu)

a-b. Left valve. $(\times 16)$.

Toftlund 75-100 -

$\begin{array}{llll}3.17 & 2.95 & 0.69 & 105\end{array}$

c. Right valve. $(\times 16)$.

Arnum (13) 53-83 -

$2.33 \quad 2.25 \quad 0.59$

Shell dimensions in millimeters. 
D. G. U. II. Ser. No. 79.

Plate 14
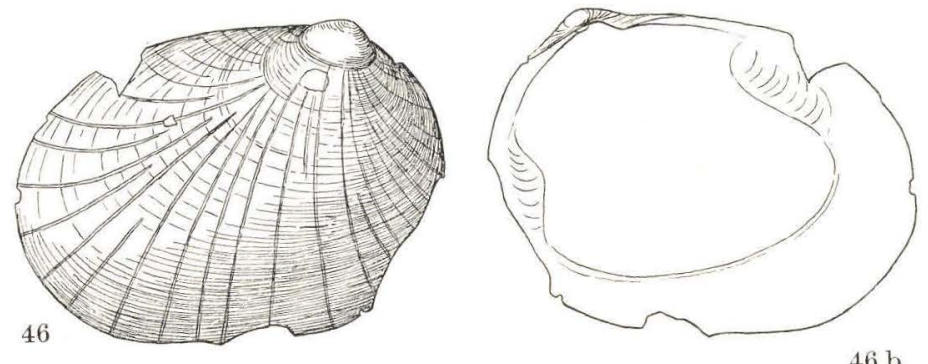

$46 \mathrm{~b}$
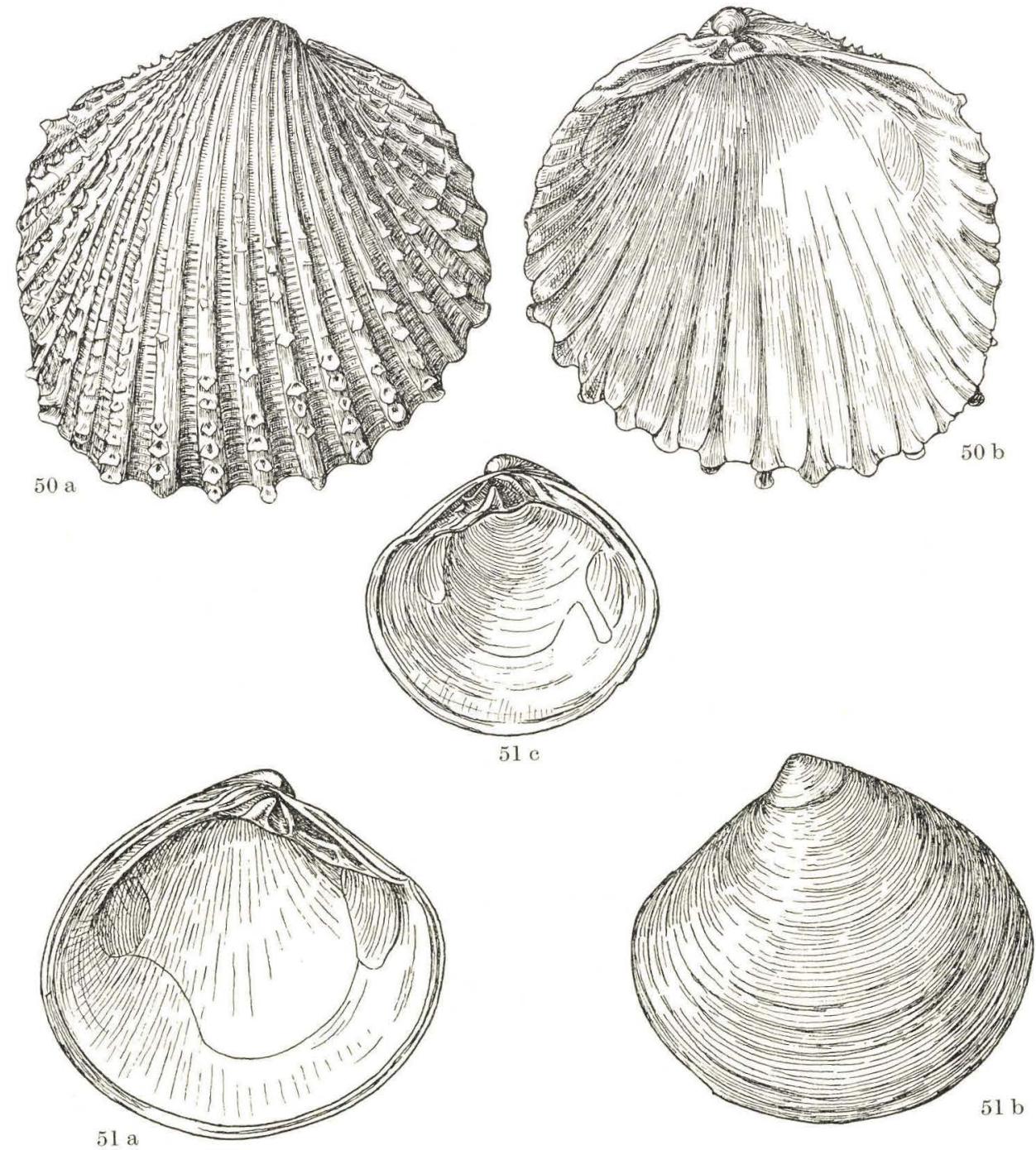

Th. S. del. 
Plate 15.

44a-f. Erycina (Hemilepion) stria-

tissima (Ceruldi-Ireltr) Toftlund 105-110 m.

Location Depth Length Height Width Page a-c. Left valve. $(\times 30)$.

$\begin{array}{lll}1.8 & 1.41 & 0.33\end{array}$

d-f. Right valve. $(\times 30)$.

$2.2 \quad 1.6 \quad 0.40$

45a-b. Lepton nitidum TURToN $(\times 16)$.

Toftlund 75-100

Shell dimensions in millimeters.

abt. $3.2 \quad 2.5$ 
D. G. U. II. Ser. No. 79.

Plate 15
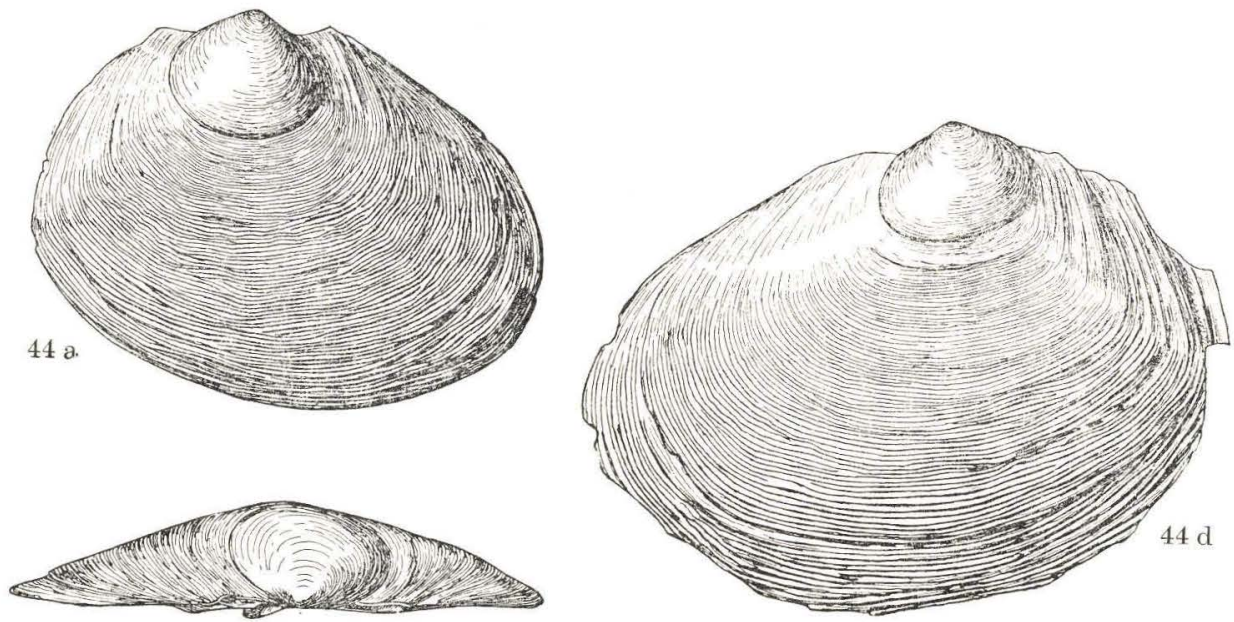

$44 \mathrm{~b}$
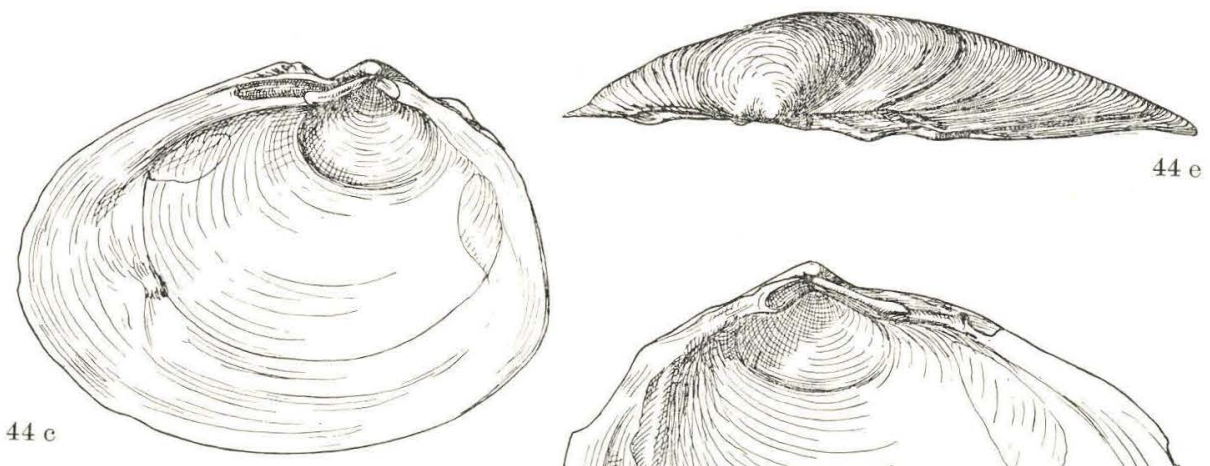

$44 \mathrm{e}$
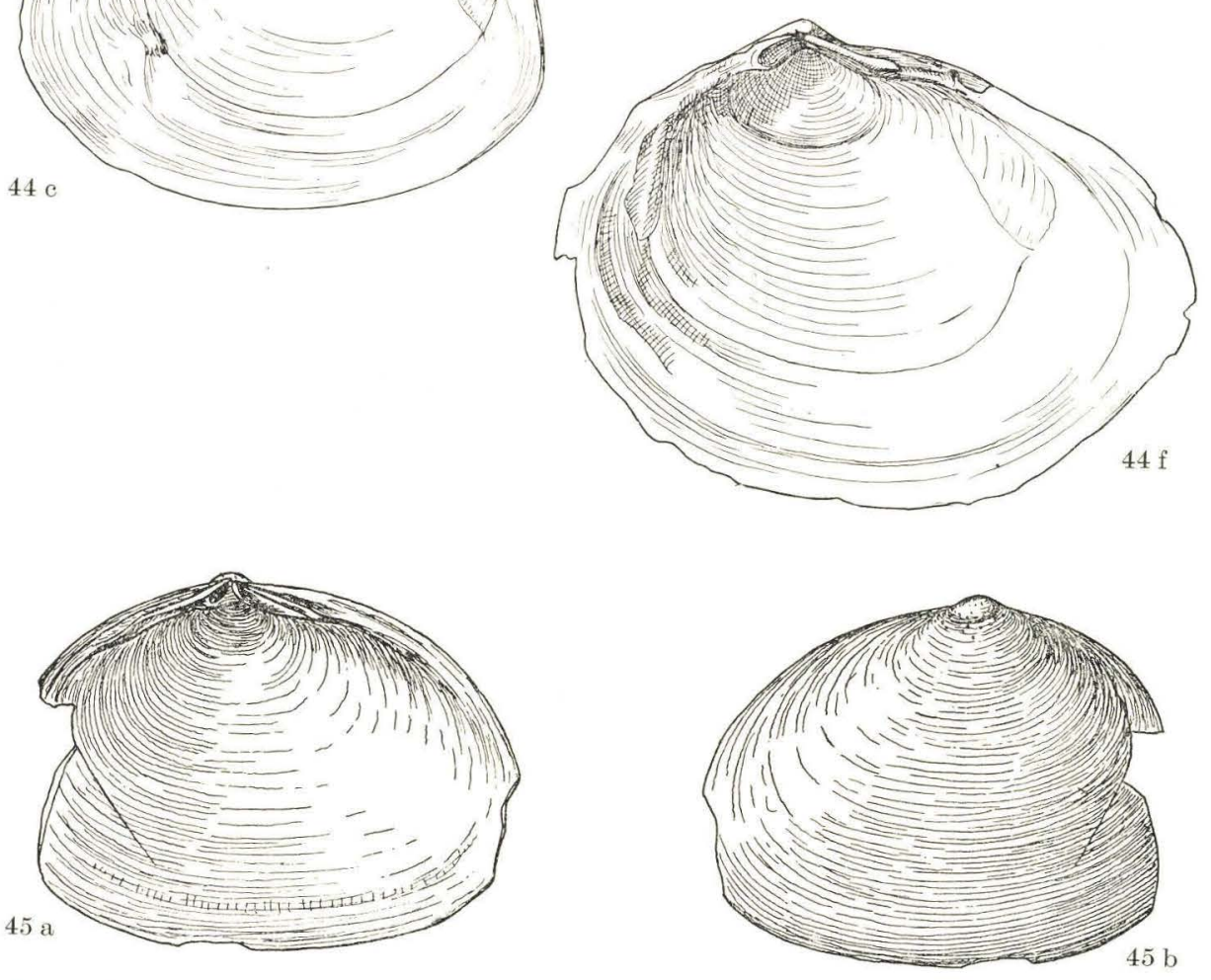

Th. S. del. 
Plate 16.

48a-e. Laevicardium dingdense

Location Depth Length Height Width Page

(LEHMANN)

101

a-c. Juvenile shell, right valve. Toftlund

$105-110 \mathrm{~m}$

1.93

1.890 .65 $(\times 30)$.

d-e. Adult shell, right valve. Toftlund

$75-100-$

ca. 6.25

$(\times 10.5)$.

49a-b. Cardium Straeleni GLIBERT

Right valve. $(\times 30)$.

Toftlund $\quad 75-100$

Shell dimensions in millimeters. 

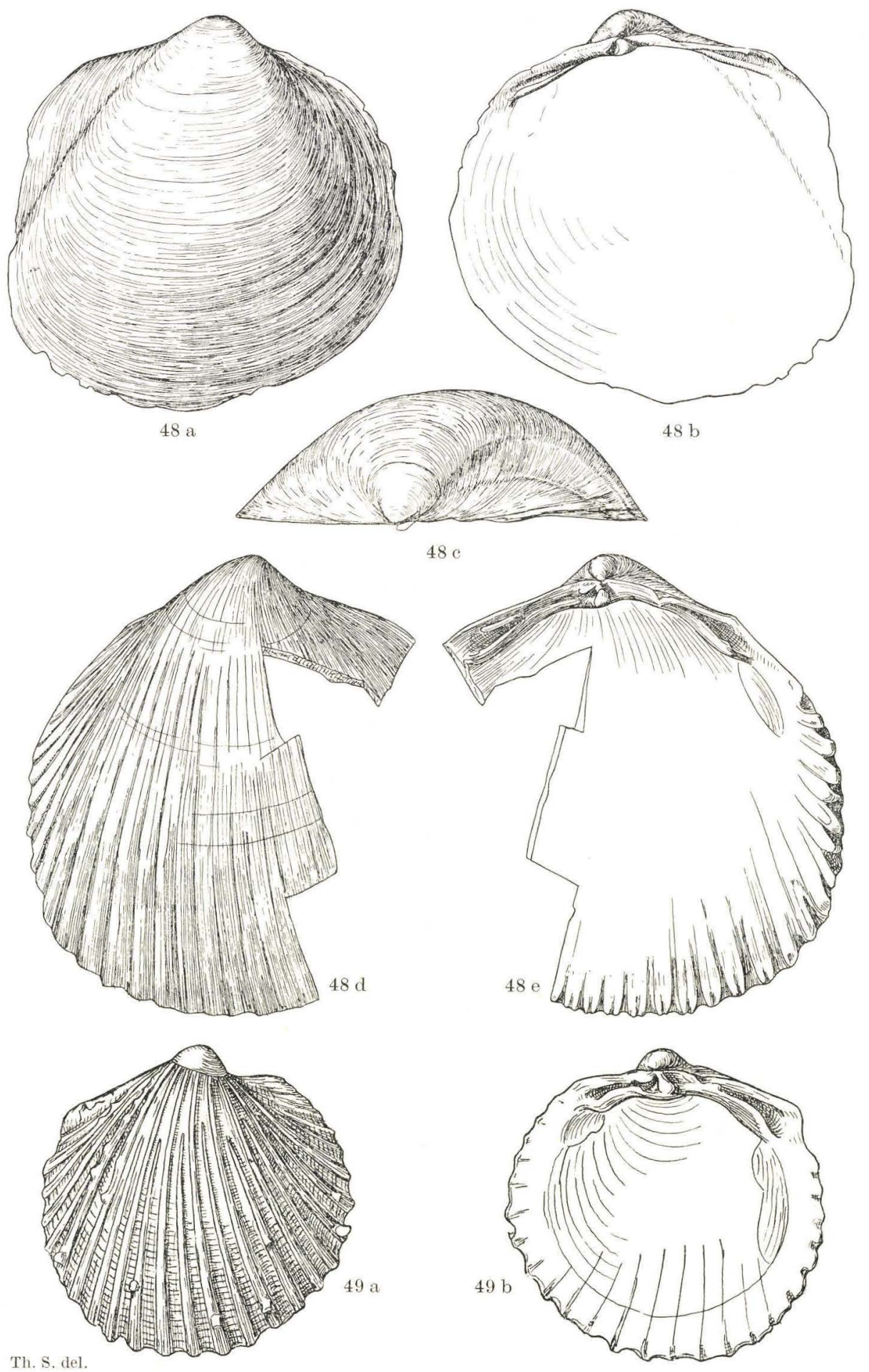


\section{Plate 17.}

52a-b. Pitar chione (LinNé)

Location Depth Length Height Page Fragment of right valve. $(\times 12.5)$.

53a-b. Meretrix cf. incrassata (Sowerby) Toftlund $\quad \begin{array}{lllll}75-100 & - & 3.73 & 3.40 & 108\end{array}$ Left valve. $(\times 15)$.

Shell dimensions in millimeters. 
D.G.U. II. Ser. No. 79.

Plate 17
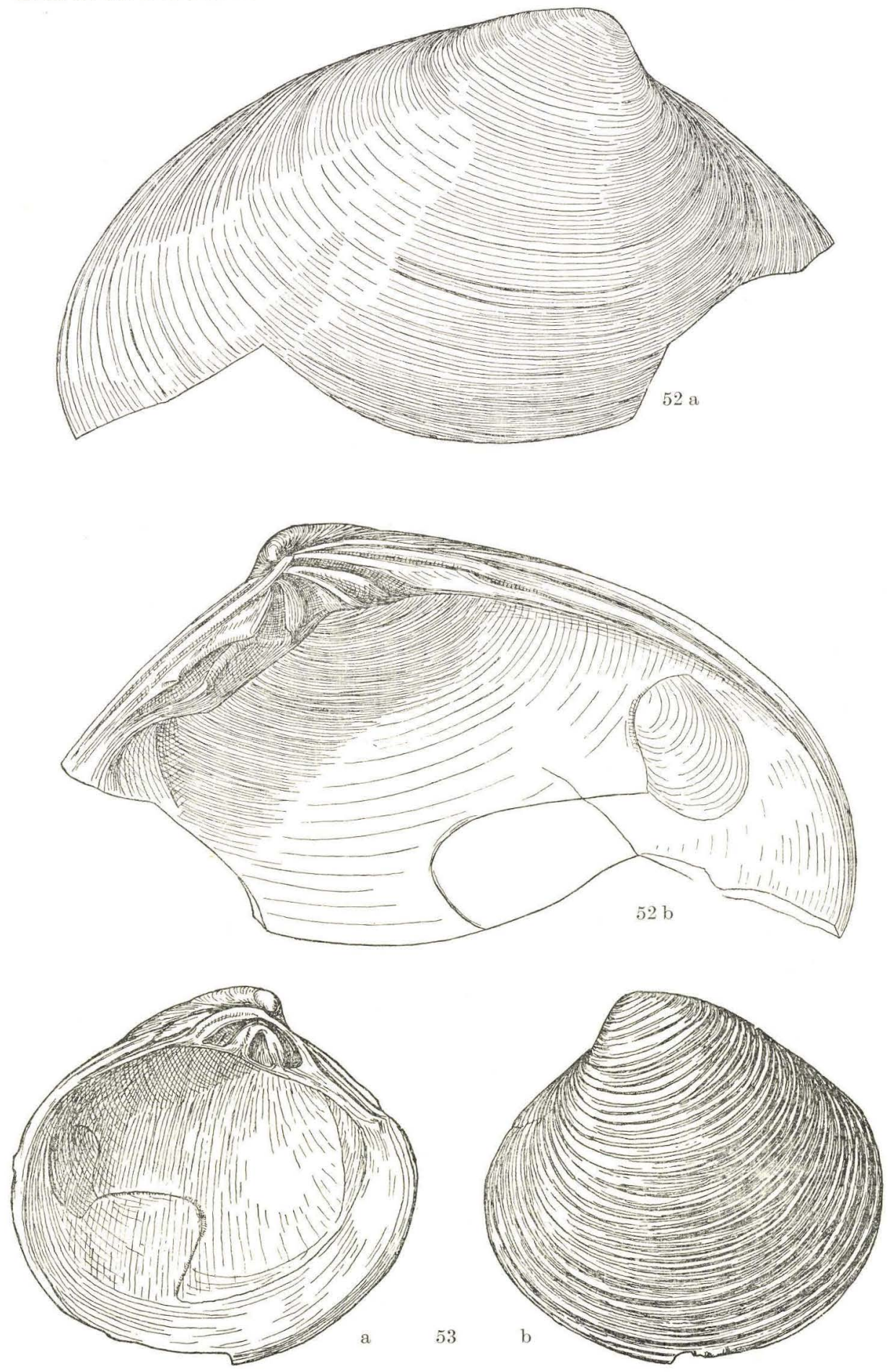

Th. S. del. 
Plate 18.

54a-b. Dosinia cf. Basteroti (AgAs-

Location Depth Length Height Width Page

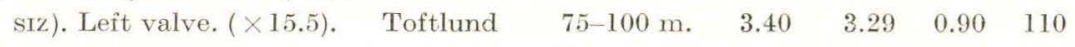

55a-d. Venus (Ventricola) multilamella (LAMARCK)

Toftlund $75-100$ -

a-c. Right valve. $(\times 15)$.

$\begin{array}{lll}3.27 & 3.1 & 0.9\end{array}$

d. Left valve. $(\times 15)$.

$\begin{array}{lll}2.19 & 2.12 & 0.6\end{array}$

56a-d. Ervilia pusilla (РнHгPP) Arnum (13) 53-83 -

$2.25 \quad 1.81 \quad 0.6$

$2.0 \quad 1.5$

d. Left valve. $(\times 15.5)$.

Shell dimension in millimeters. 

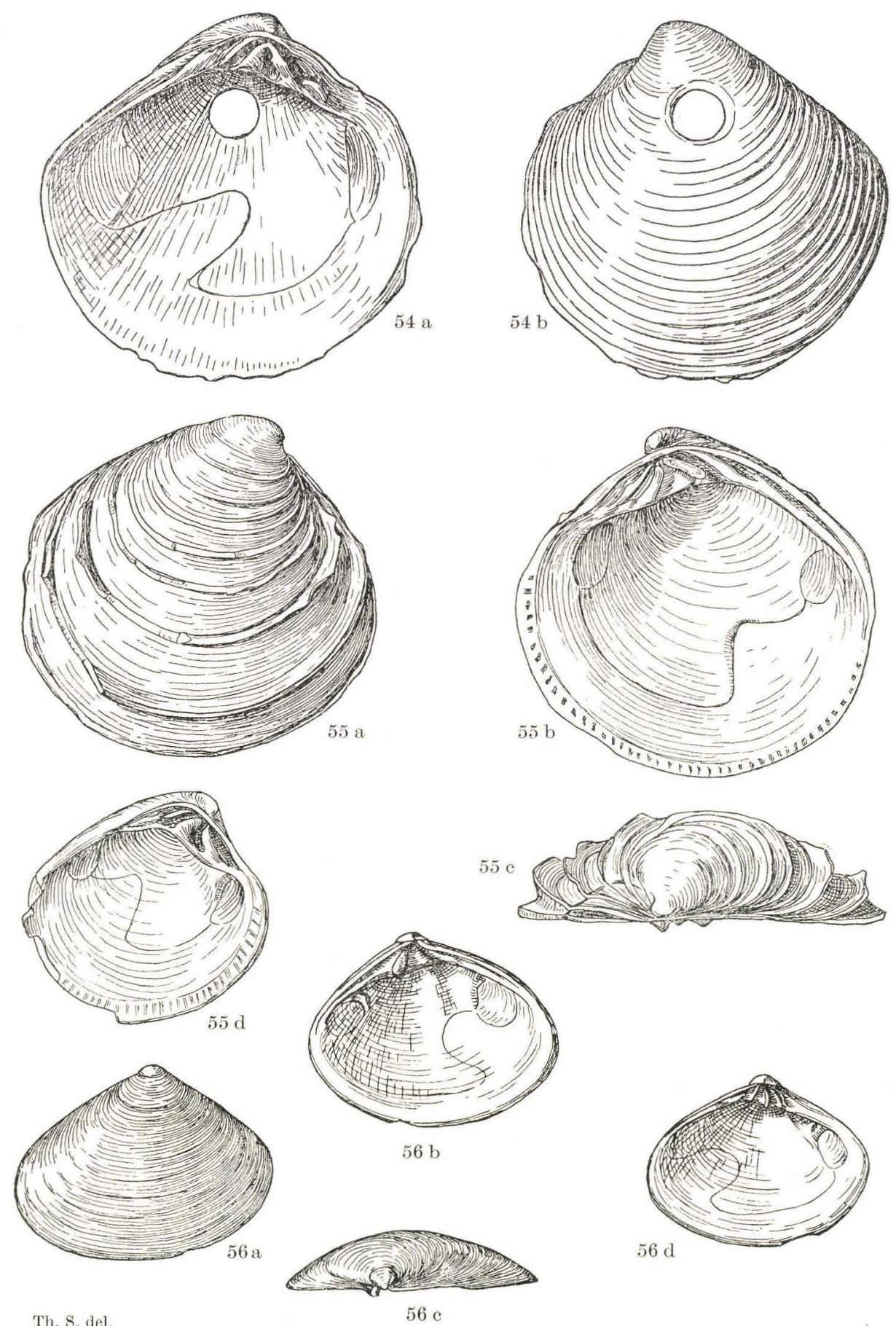

Th. S. del.

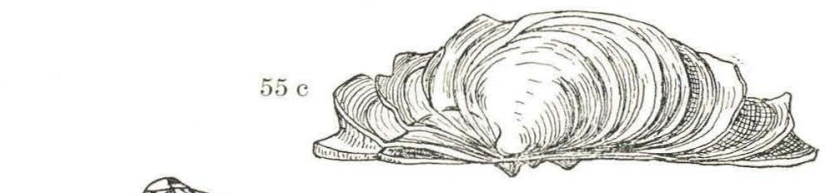




\section{Plate 19.}

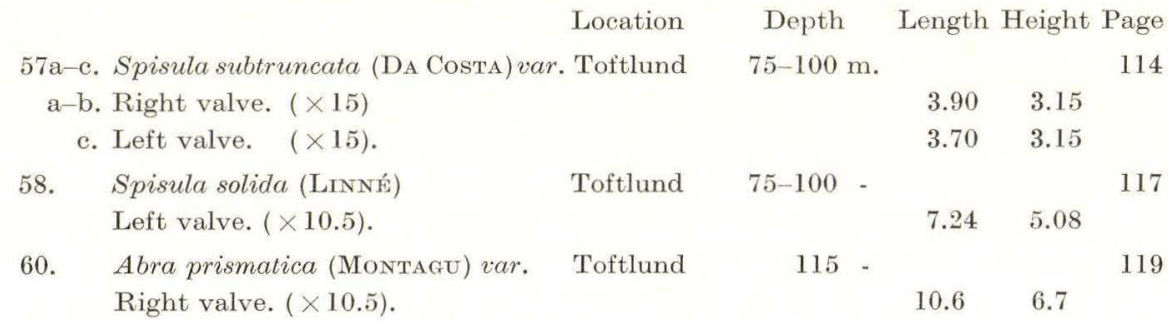

Shell dimensions in millimeters. 
D. G. U. II. Ser. No. 79.

Plate 19

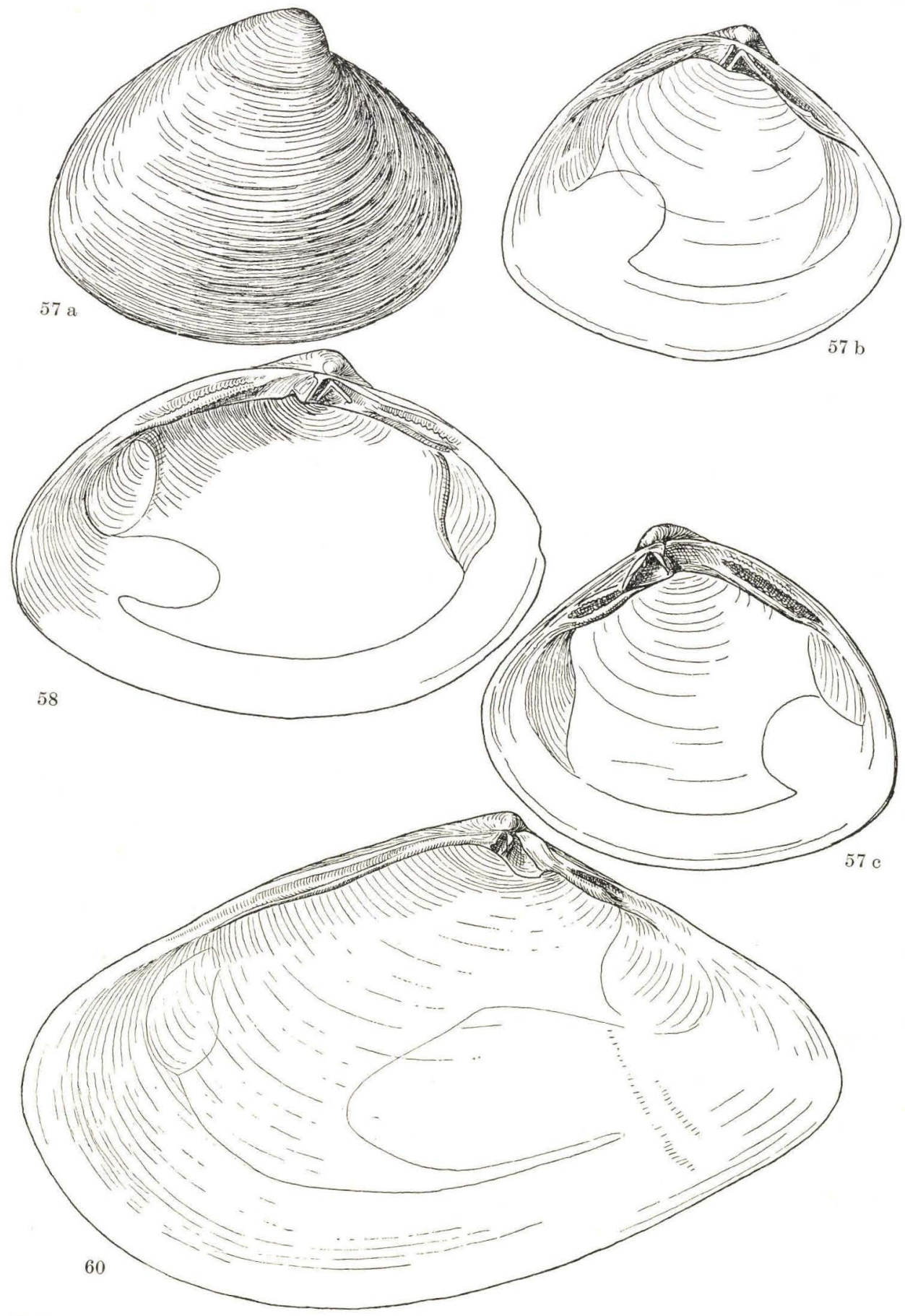

Th. S. del. 
Plate 20.

Location Depth Length Height Width Page

6la-b. Angulus donacinus (Linné) Glejbjerg

$55 \mathrm{~m} . \quad 7.55$

120

Fragment of left valve.

( $\times 15)$.

66a-e. Saxicava arctica (LINNÉ)

a-b. Right valve. $(\times 13)$.

Toftlund 75-100.

125

c-d. Left valve. $(\times 13)$.

$3.25 \quad 1.83$

$\begin{array}{lll}3.40 & 1.83 & 1.8\end{array}$

Shell dimensions in millimeters. 

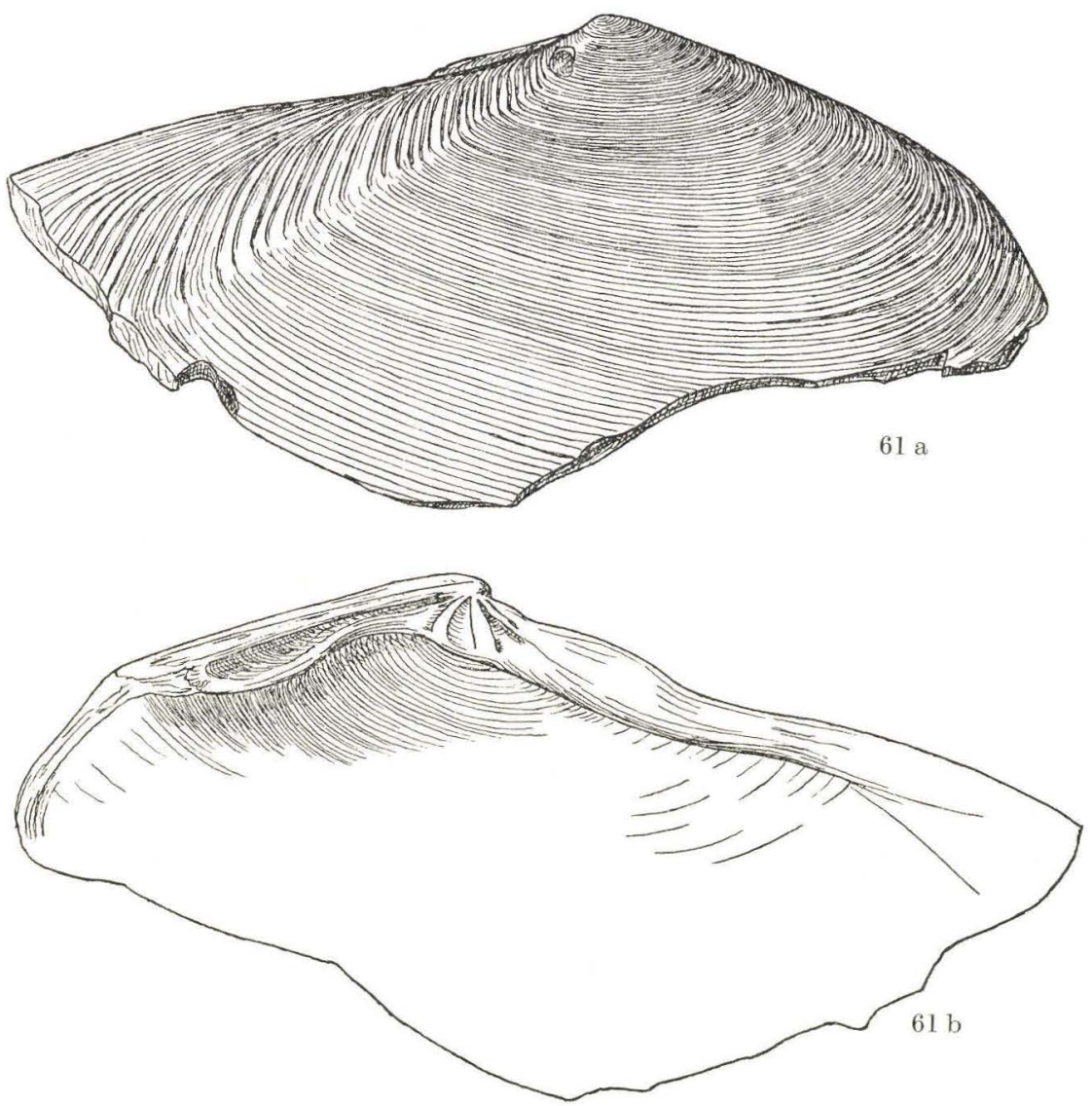

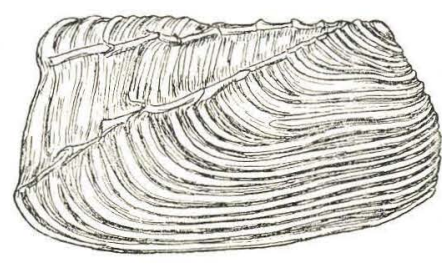

66 a

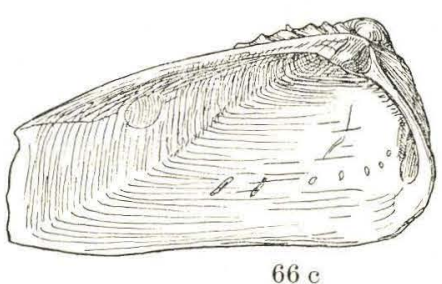

Th. S. de].

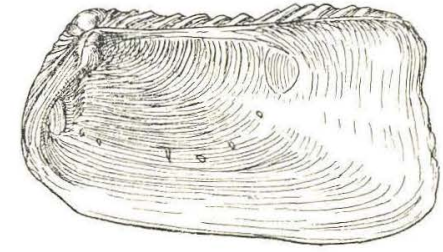

$67 \mathrm{~b}$

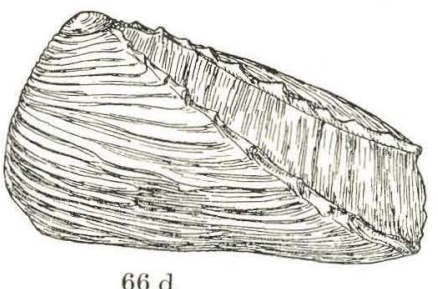

$66 \mathrm{~d}$

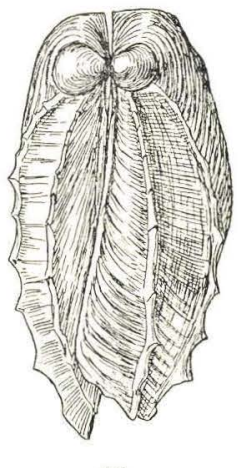

$66 \mathrm{e}$ 
Plate 21.

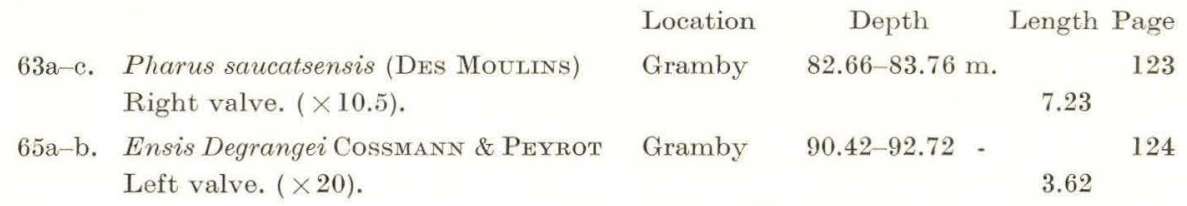

Shell dimensions in millimeters. 
D.G.U. II. Ser. No. 79.

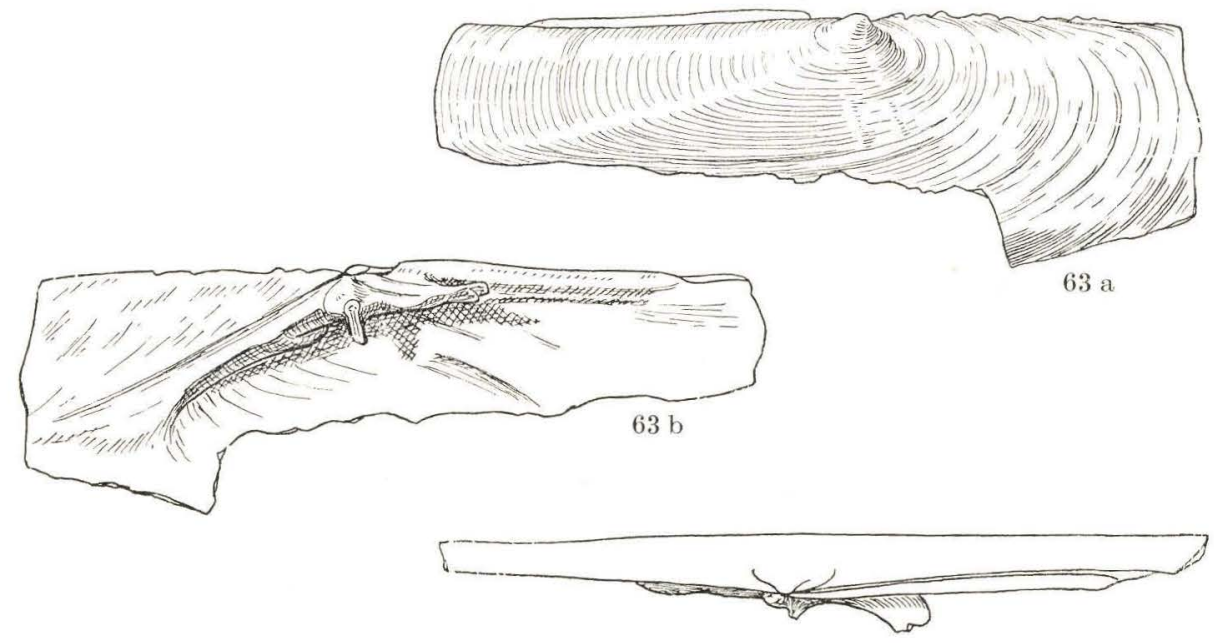

$63 \mathrm{c}$

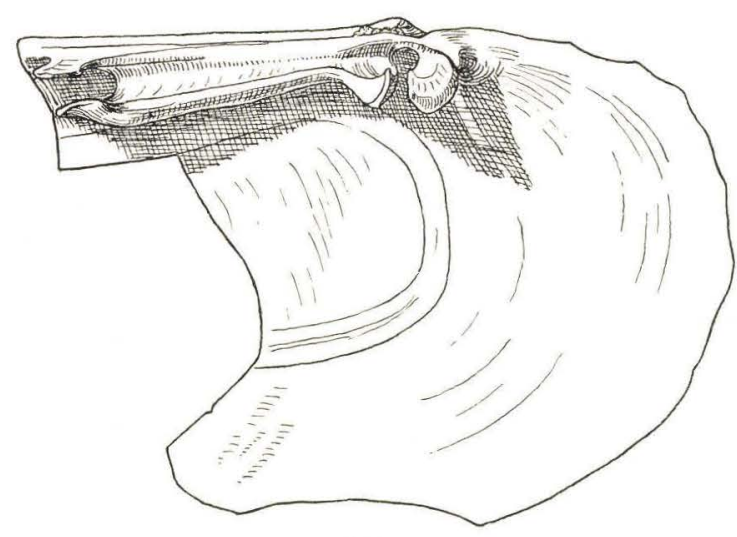

$65 \mathrm{a}$

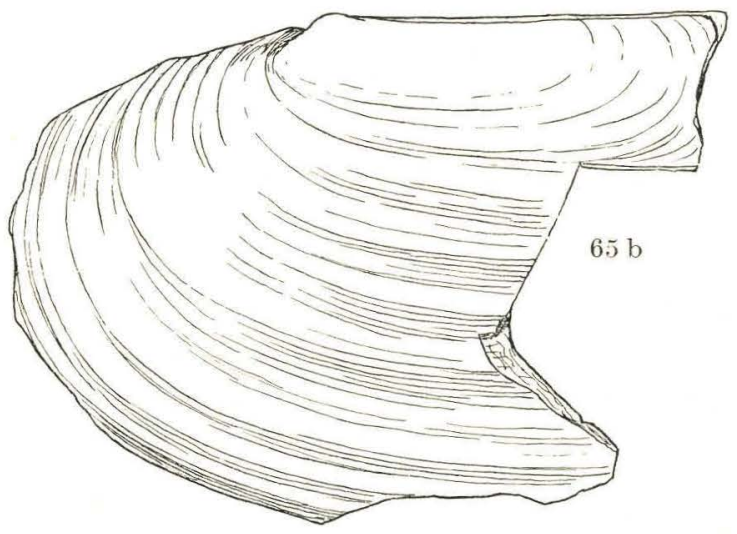

Th. S. del. 
Plate 22.

64a-b. Cultellus sp. $(\times 37)$.

Location Depth Length Page

Arnum (25b) $\quad 62.7-62.9 \mathrm{~m} . \quad 2.52 \quad 124$

Shell dimensions in millimeters. 
D. G. U. II. Ser. No. 79.

Plate 22
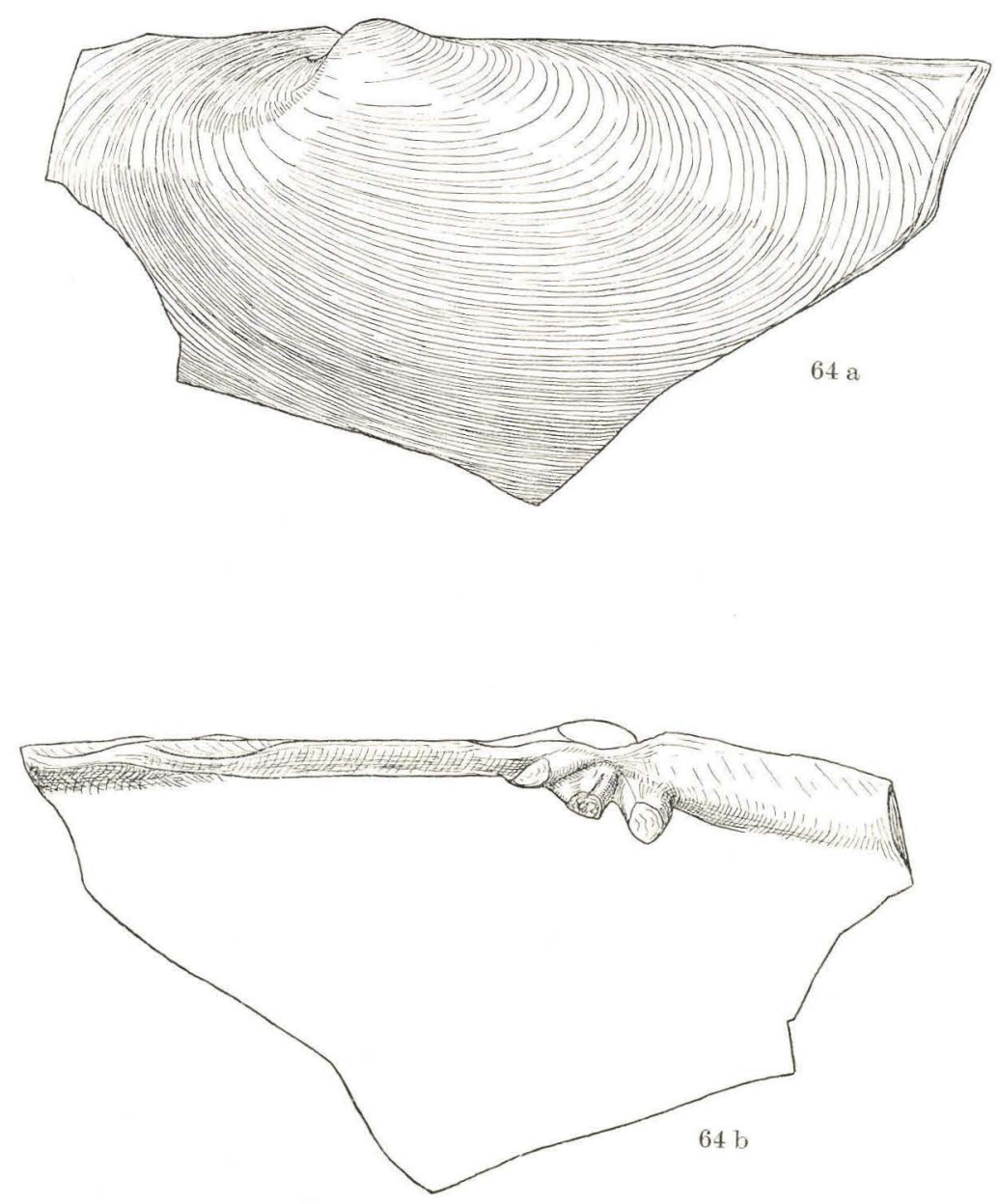

Th. S. del. 


\section{Plate 23.}

69a-h. Varicorbula gibba (OLIVI)

Location Depth Length Height Page

a. T Paired valves with marginal

Toftlund $75-100 \mathrm{~m}$.

b. $\int$ pore in right valve. $(\times 12.8)$.

c-d. Right valve with marginal pore.

4,06

$(\times 12.8)$

e. Fragment of right valve with marginal pore. $(\times 15.5)$.

f. Same fragment with detached internal shell layer showing the trend of the marginal pore in the outer shell layer. $(\times 15.5)$.

$\mathrm{g}-\mathrm{h}$. Left valve. $(\times 15.5)$.
$4.27 \quad 3.45$

$4.54 \quad 3.99$

$3.15 \quad 2.62$

Shell dimensions in millimeters. 
D. G. U. II. Ser. No. 79.

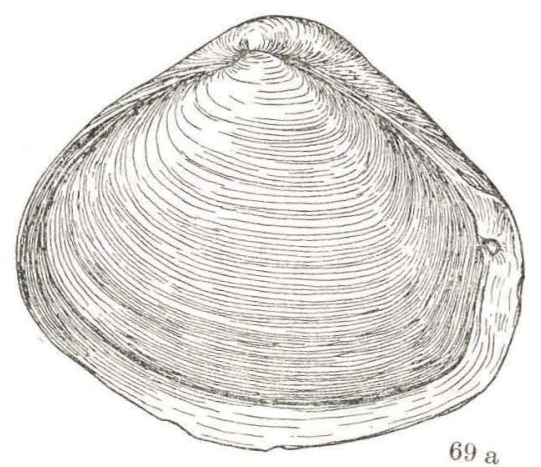

Plate 23
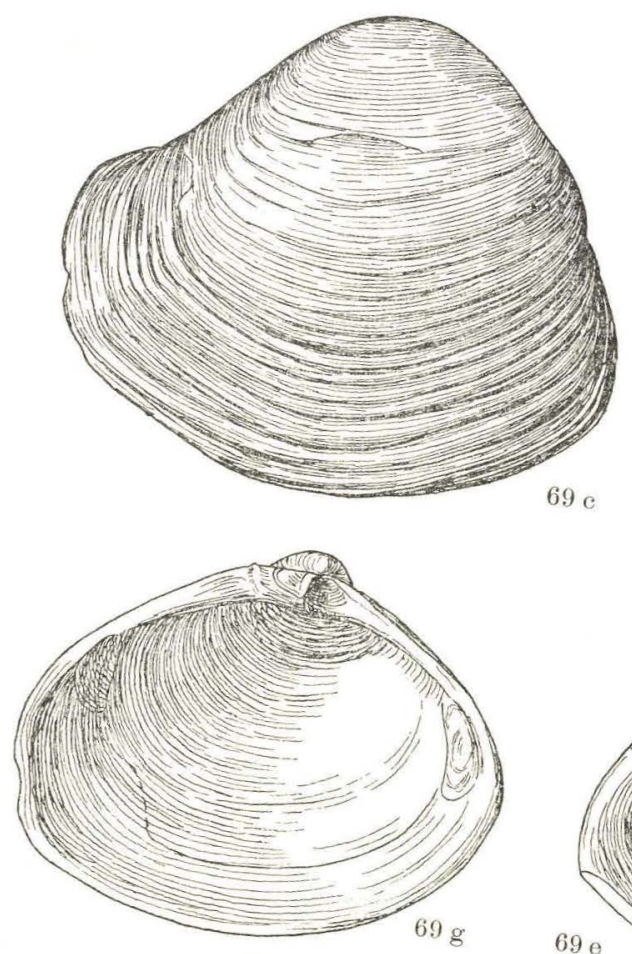

$69 \mathrm{c} \quad 69 \mathrm{~d}$
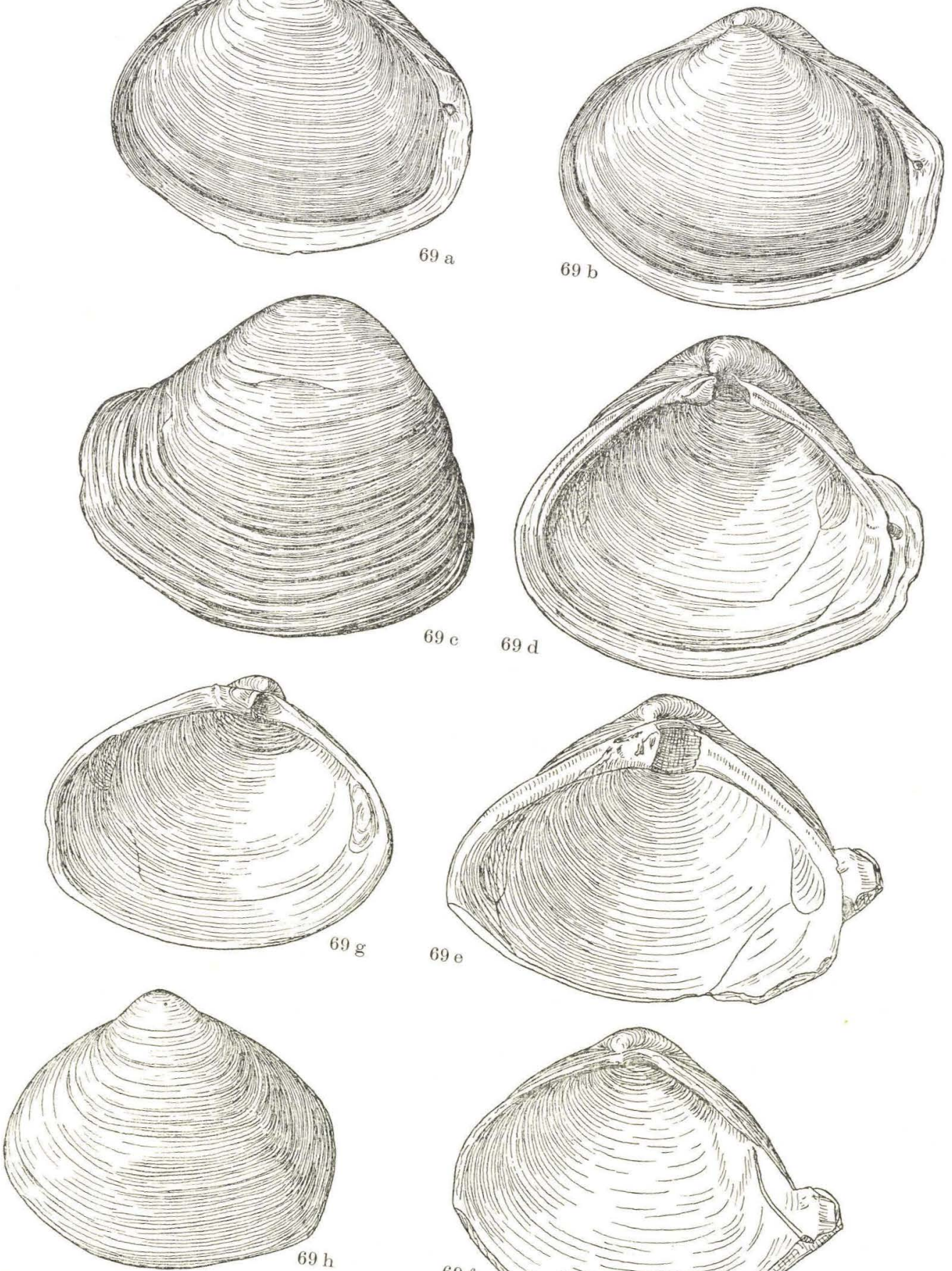

Th. S. deI.

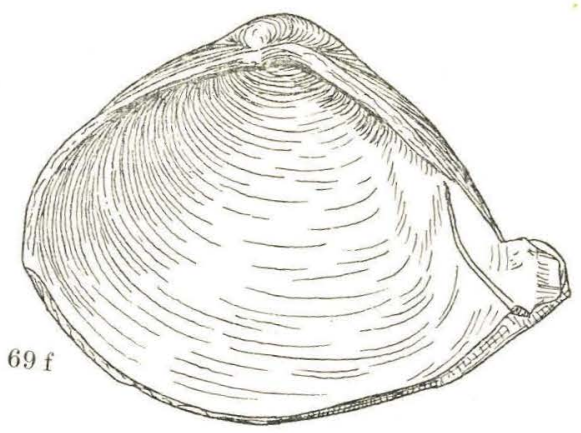


Plate 24.

Location Depth Length Height Width Page

67a-c. Saxicavella pusilla nov.sp. Toftlund $\quad 75-100 \mathrm{~m} . \quad 1.6 \quad 1.05 \quad 0.31 \quad 128$ Left valve. Holotype. $(\times 30)$.

70 a-c. Lentidium donaciformis

(NYST)

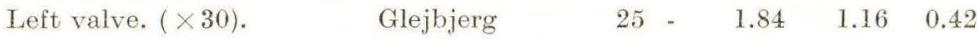

Right valve. $(\times 21)$ Gramby $84.66-87.16 \quad-\quad 2.23 \quad 1.51$

76a-e. Pandora copiosa nov. sp.

a-c. Left valve. Holotype. $(\times 9)$. Toftlund $\quad 105-110-6.10 \quad 3.28 \quad 1.21$

d-e. Right valve. ( $\times 17.5)$

Toftlund

$100-105-1.73$

0.92

Shell dimensions in millimeters. 
D. G. U. II. Ser. No. 79.
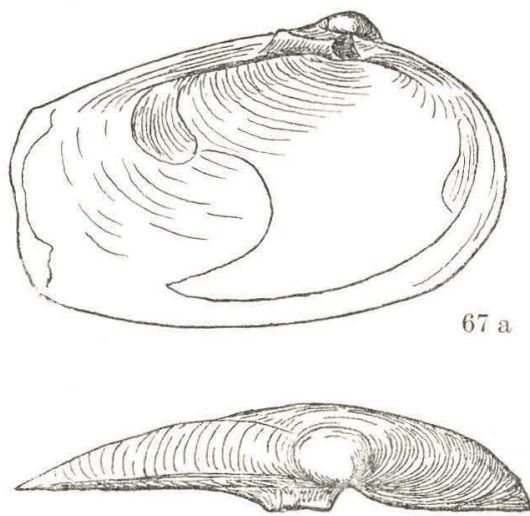

$67 \mathrm{c}$
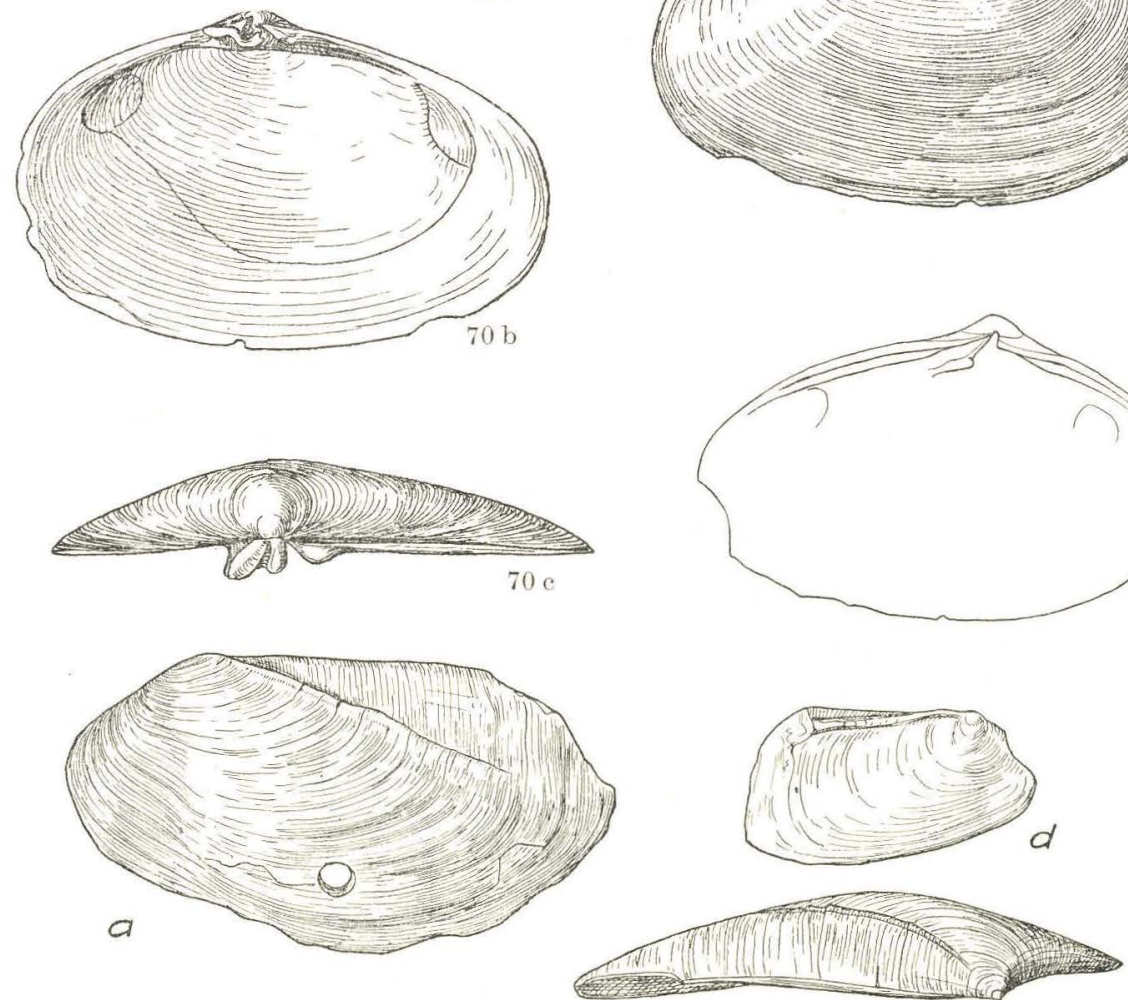

c
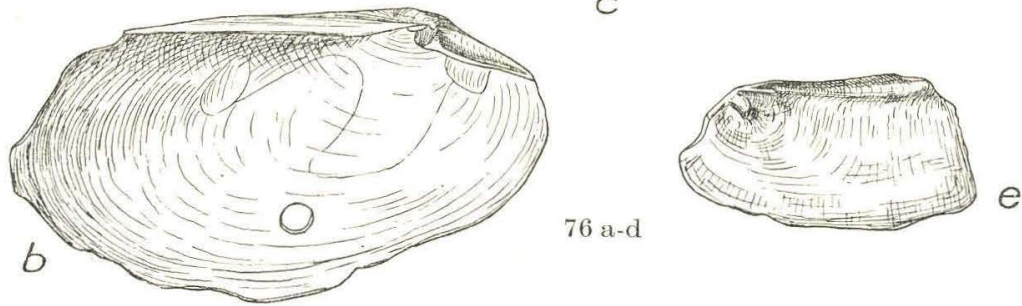

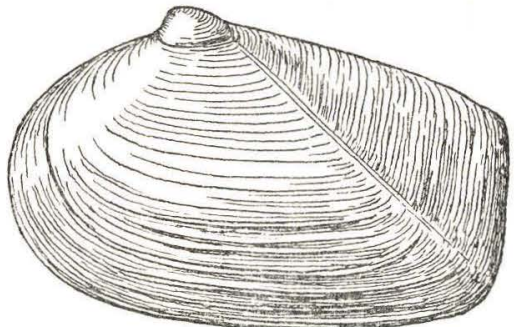

$67 \mathrm{~b}$
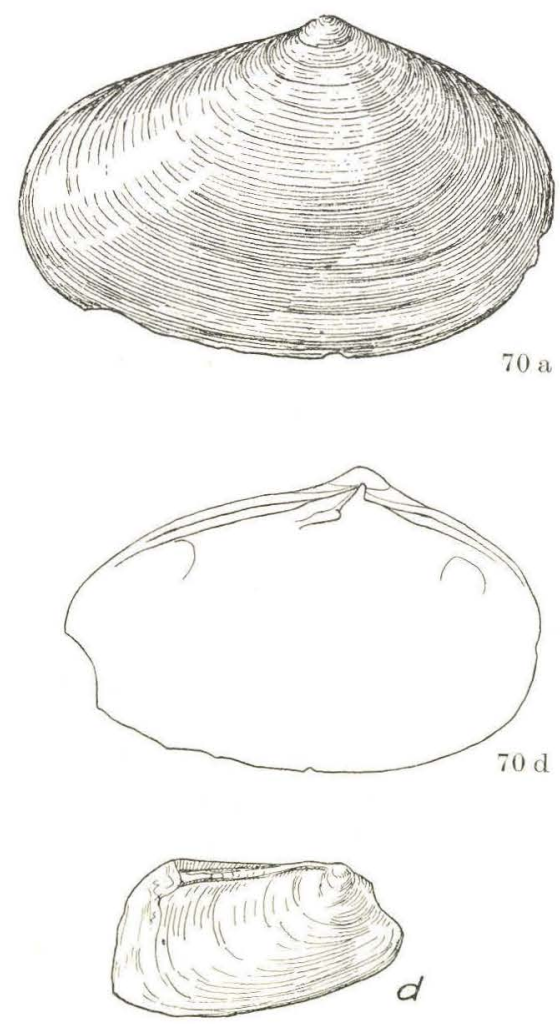

Th. S. del. 


\section{Plate 25.}

7la-c. Sphenia sp. Left valve $(\times 21)$.

72a-b. Pholas sp. Left valve. $(\times 21)$.

73a-b. Pholadidea sp. Left valve. $(\times 21)$.
Location Depth Length Height Page

Toftlund $\quad 105-110 \mathrm{~m}$.

3.0

Arnum(25b) 62.7-62.9 -

135

Toftlund 110-115 -

135

74a-b. Martesia of. rugosa (BrocchI). $(\times 21)$.

Shell dimensions in millimeters. 

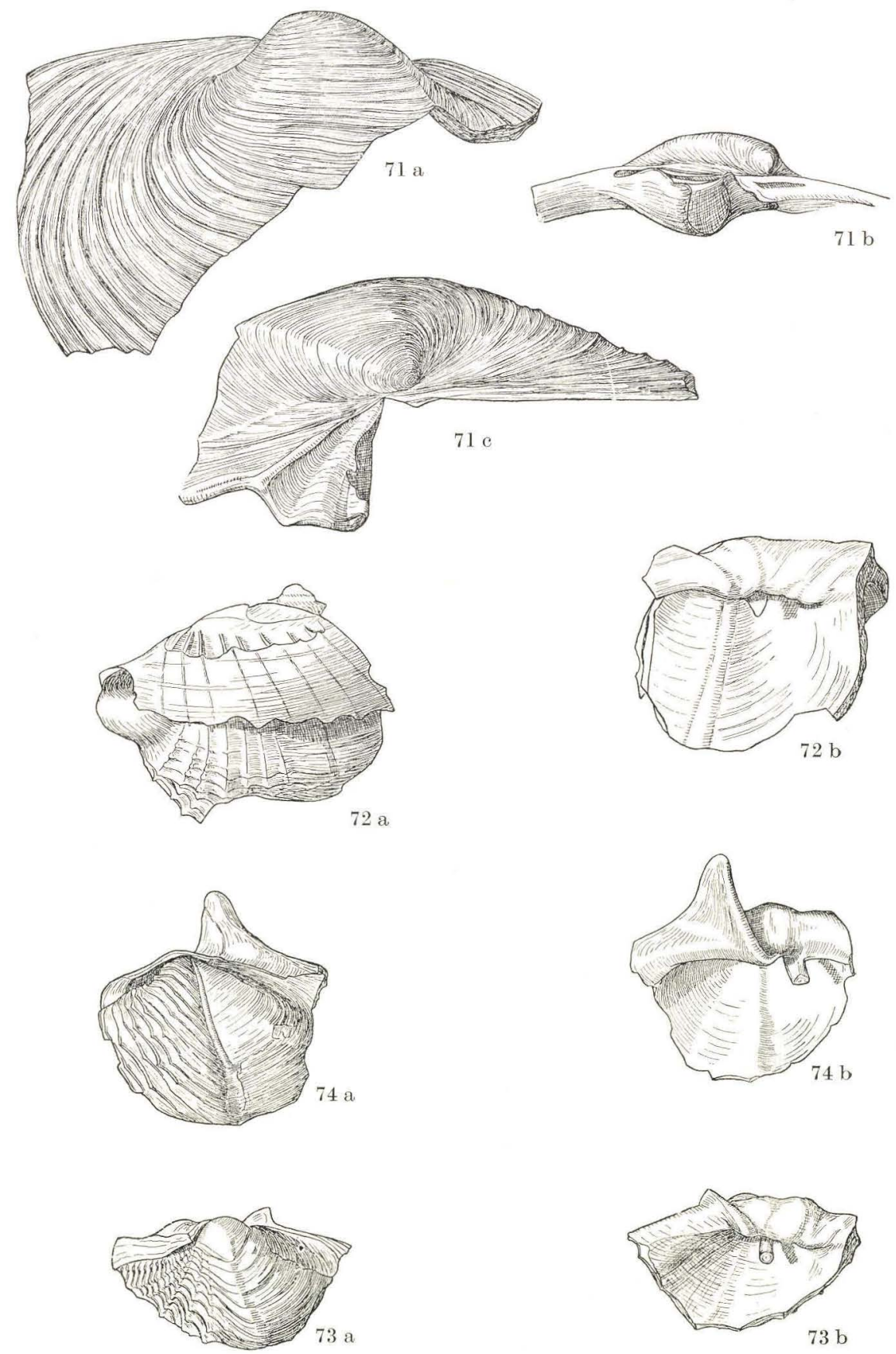

Th. S. del. 
Plate 26.

$75 \mathrm{a}-\mathrm{c}$. Teredo $\mathrm{cf}$. saucatsensis BenOIST. ( $\times 32)$.

Location Depth Length Height Width Page $\begin{array}{llllll}\text { Toftlund } & 105-110 \mathrm{~m} . & 1.97 & 2.08 & 0.77 & 137\end{array}$

Shell dimensions in millimeters. 

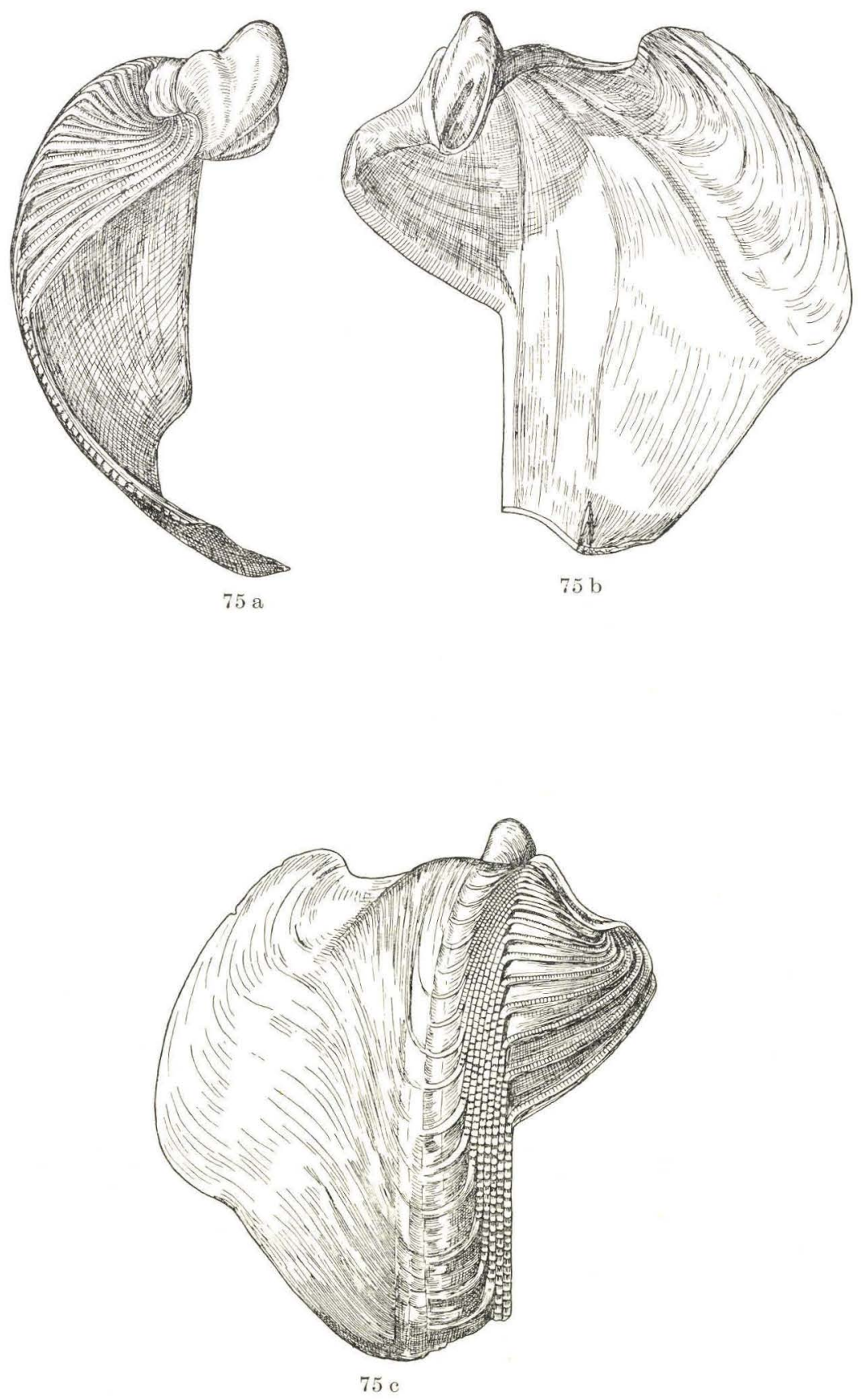

Th. S. del. 


\section{Plate 27.}

$$
\text { Location Depth Diameter Height Page }
$$

87a-c. Starkeyna hanseata (KAUTSKY).

$\begin{array}{lllllll}(\times 31) . & \text { Toftlund } & 75-100 \mathrm{~m} . & 1.56 & 0.68 & 149\end{array}$

$88 \mathrm{a}-\mathrm{c}$. Starkeyna jutensis nov. sp. $(\times 25)$. Toftlund $105-110-1.64 \quad 0.61 \quad 150$ Holotype.

90a-c. Liolia miosuturalis KAUTSKY.

$\begin{array}{lllllll}(\times 15) . & \text { Glejbjerg } & 55 & - & 2.3 & 1.65 & 152\end{array}$

91a-c. Alvania Partschi Hörnes. ( $\times 30)$. Arnum (13) $53-83-0.77 \quad 1.16 \quad 153$

d-e. Alvania Partschi Hönnes. $(\times 26)$. Toftlund $\quad 75-100 \quad-\quad 1.06 \quad 1.96 \quad 153$

Shell dimensions in millimeters. 
D. G. U. II. Ser. No. 79.

Plate 27
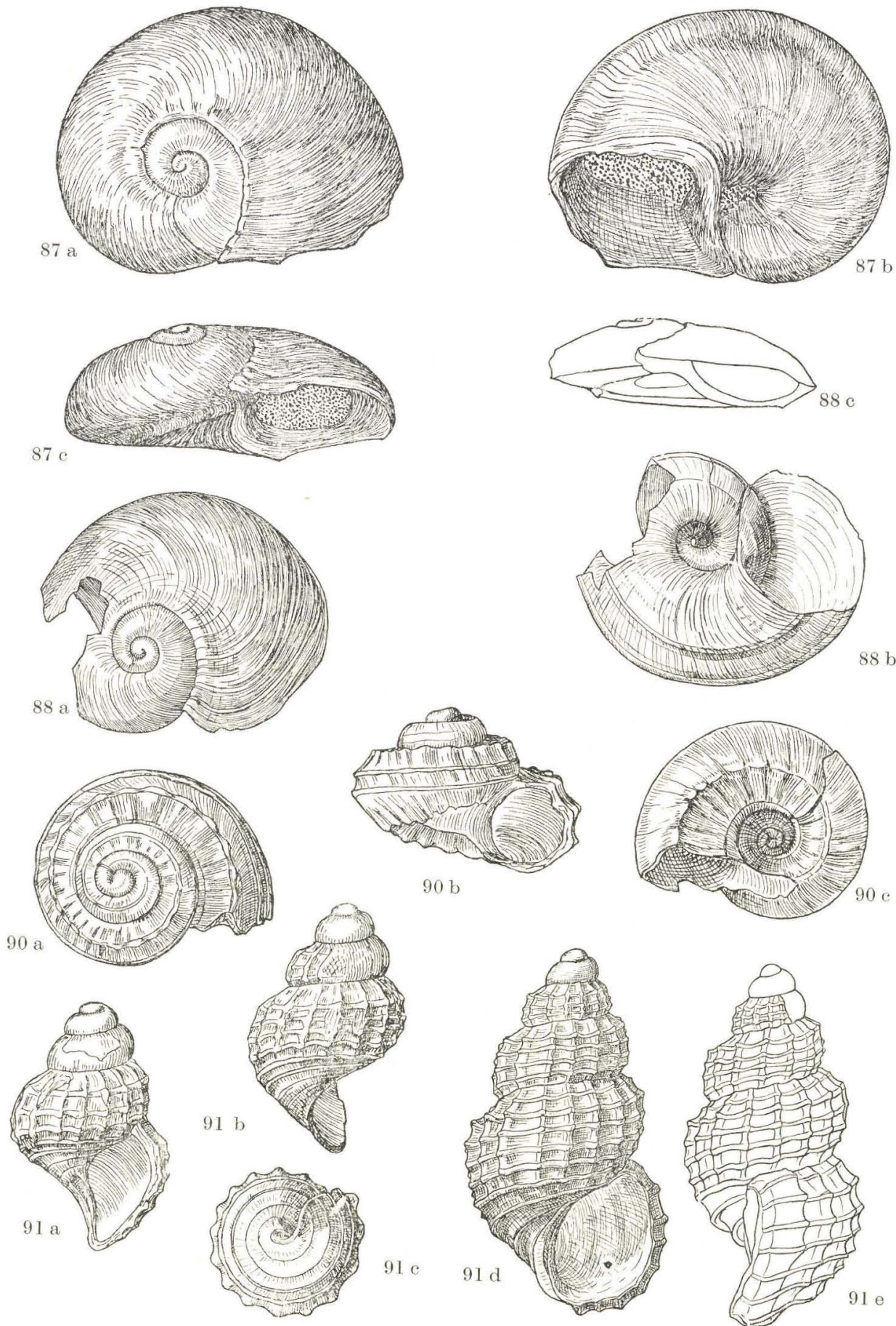

Th. S. del.
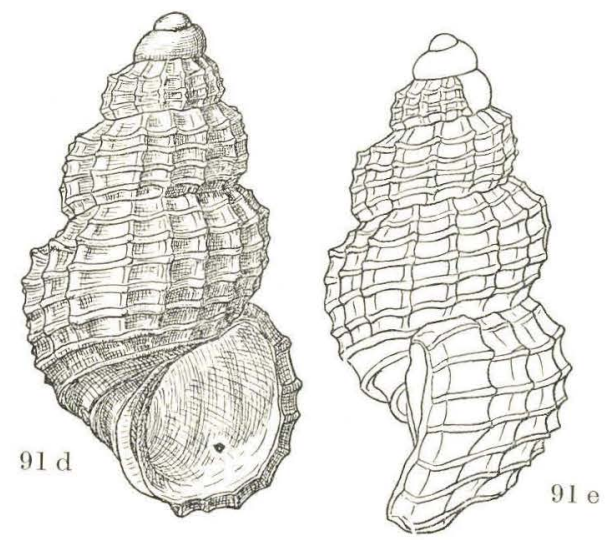


\section{Plate 28.}

Location Depth Diameter Height Page

95a-c. Adeorbis subcirculus (Cossmann \&

Toftlund $\quad 75-100 \mathrm{~m} . \quad 2.54 \quad 1.12 \quad 157$

96a-c. Adeorbis cf. carinata (PHILIPPI)

$\begin{array}{llllllll}(\times 25) . & \text { Toftlund } & 75-100 & - & 2.14 & 0.97 & 158\end{array}$

97a-c. Adeorbis planorbillus (DUJARDIN).

$(\times 27)$.

Arnum (13) $\quad 53-83 \quad-\quad 1.47 \quad 0.74 \quad 159$

Shell dimensions in millimeters. 
D. G. U. II. Ser. No. 79.

Plate 28
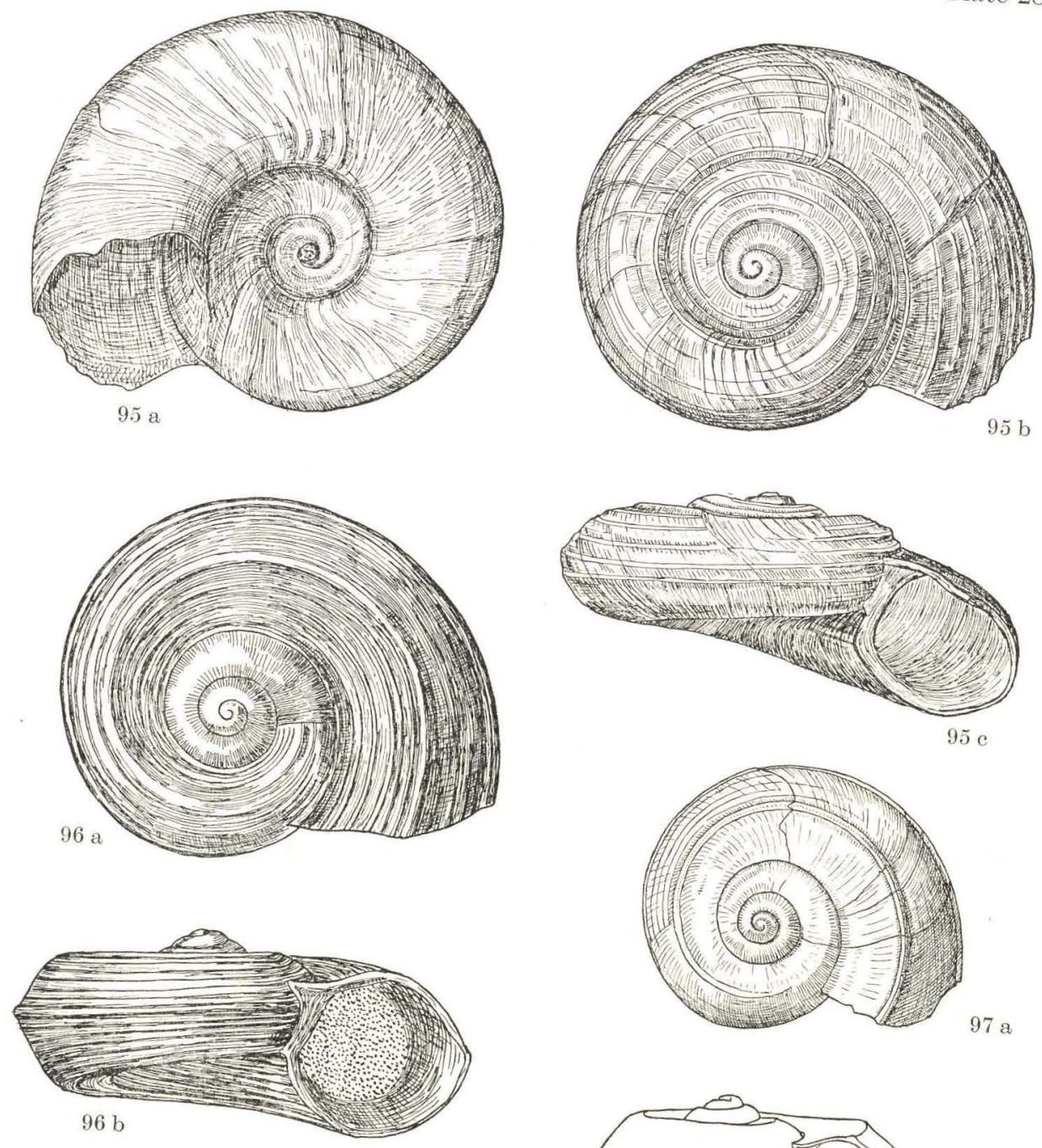

97 a
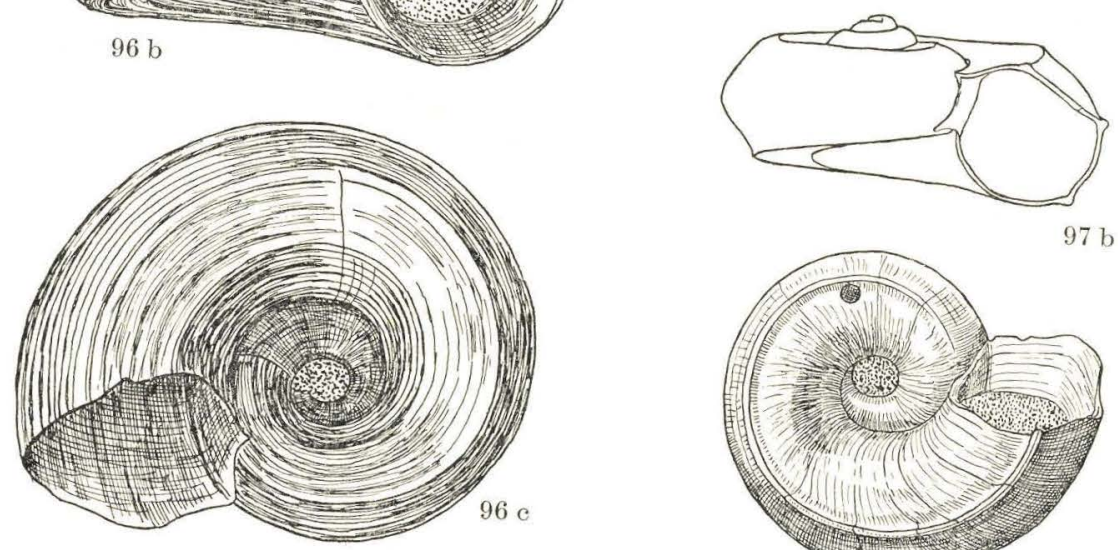

$97 \mathrm{~b}$

Th. S. del.

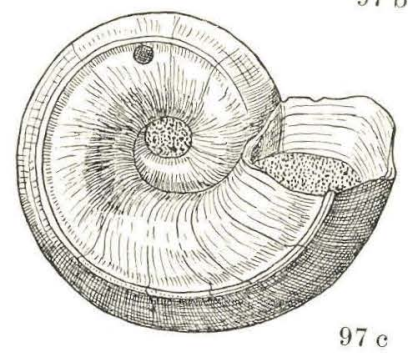


Plate 29.

Location Depth Diameter Height Page

98a-b. Turritella tricarinata (BROCCHI).

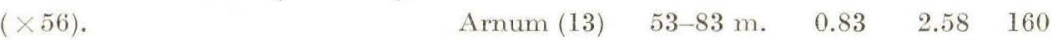

100a-c. Solarium carocollatum LAMARck.

$\begin{array}{lllllll}(\times 15) . & \text { Toftlund } & 75-100 & - & 5.23 & 1.95 & 162\end{array}$

Shell dimensions in millimeters. 
D. G. U. II. Ser. No. 79.

Plate 29
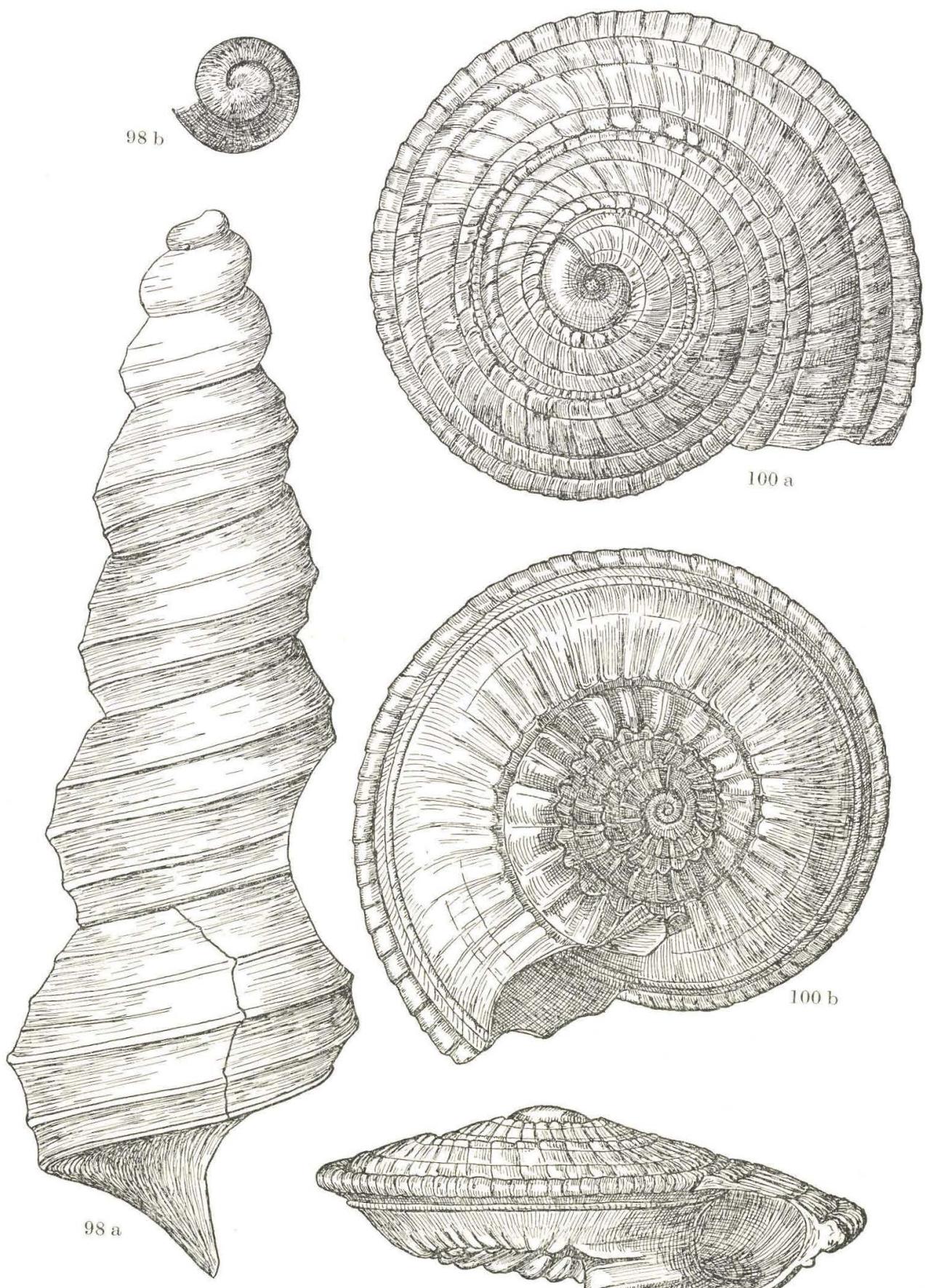

Th. S. del. 
Plate 30.

Location Depth Diameter Height Page

92. Rissoa Ravni nov. sp.

$\begin{array}{llllll}\text { Holotype. }(\times 60) . & \text { Arnum }(13) & 53-83 \mathrm{~m} . & 0.81 & 1.02 & 154\end{array}$

94. Rissoina Ödumi nov. sp.

$\begin{array}{llllll}\text { Holotype. }(\times 27) . & \text { Arnum }(25 b) & 62.7-62.9- & 0.65 & 1.14 & 156\end{array}$

$99 \mathrm{a}-\mathrm{b}$. Turritella subangulata

(BrocснI). $(\times 60) . \quad$ Arnum $(13) \quad 53-83 \quad-\quad 0.50 \quad 0.83 \quad 161$

101a-c. Solarium trochleare nov. sp.

Holotype. $(\times 20.5)$.

Toftlund $\quad 100-105 \quad-\quad 3.14 \quad 1.40 \quad 163$

Shell dimensions in millimeters. 

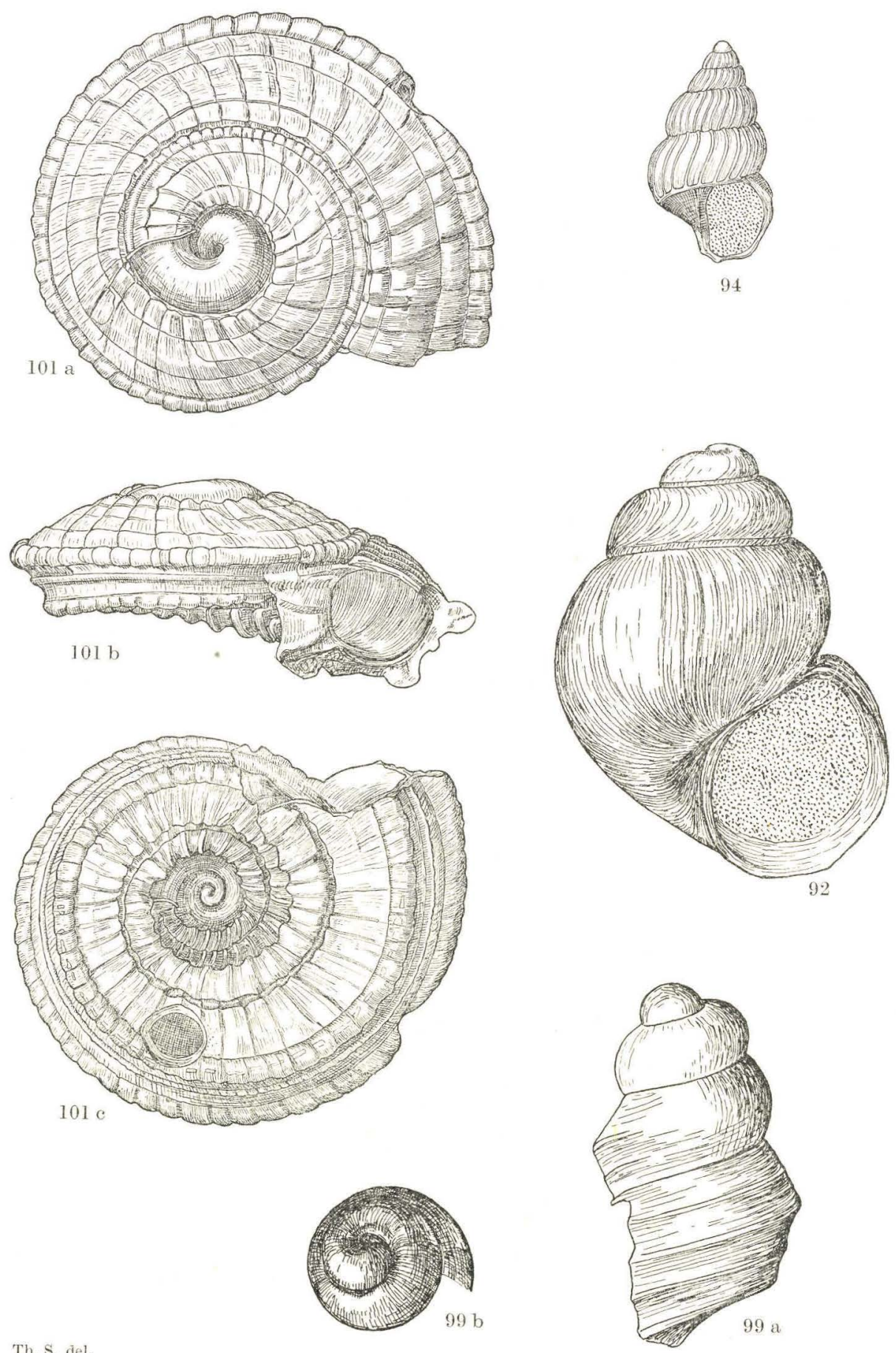

Th. S. del. 


\section{Plate 31.}

Location Depth Diameter Height Page

102a-d. Solarium angustiforatum CossMANN \& PEYROT. $(\mathrm{a}-\mathrm{e} \times 15 ; \mathrm{d} \times 60)$. Glejbjerg $\begin{array}{llll}53.5 \mathrm{~m} . & 2.8 & 1.14 & 164\end{array}$

103. Bittium spina (PARTSCH). $(\times 30)$. Toftlund $\quad 75-100-4.66 \quad 4.52 \quad 165$

104. Bitium tenuispina nov. sp. $\quad$ Toftlund $\quad 75-100 \quad-\quad 1.49 \quad 4.48 \quad 167$ Holotype. ( $\times 29)$.

105a-b. Cerithiopsis Vignali Cossmann \& Peyrot.

a. $(\times 40)$

Toftlund

Toftlund

$110-115$

0.74

1.96

b. $(\times 18)$.

$105-110-0.83 \quad 2.35$

Shell dimensions in millimeters. 
D. G. U. II. Ser. No. 79.
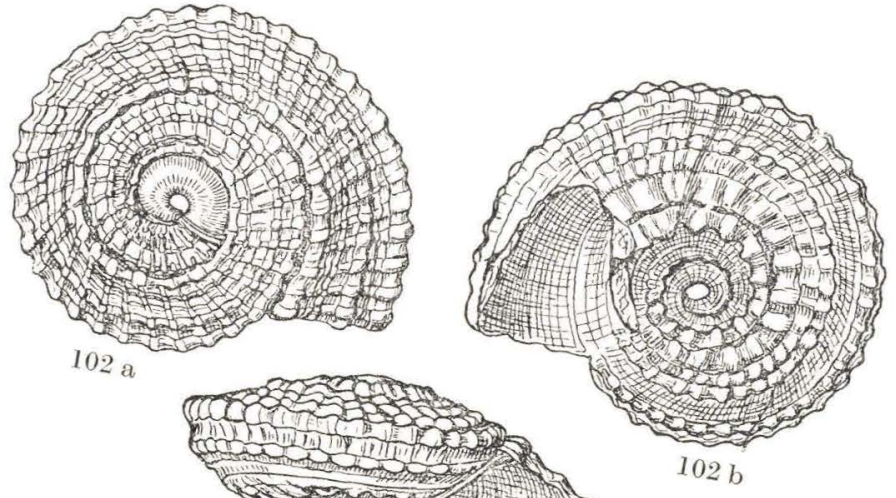

Plate 31
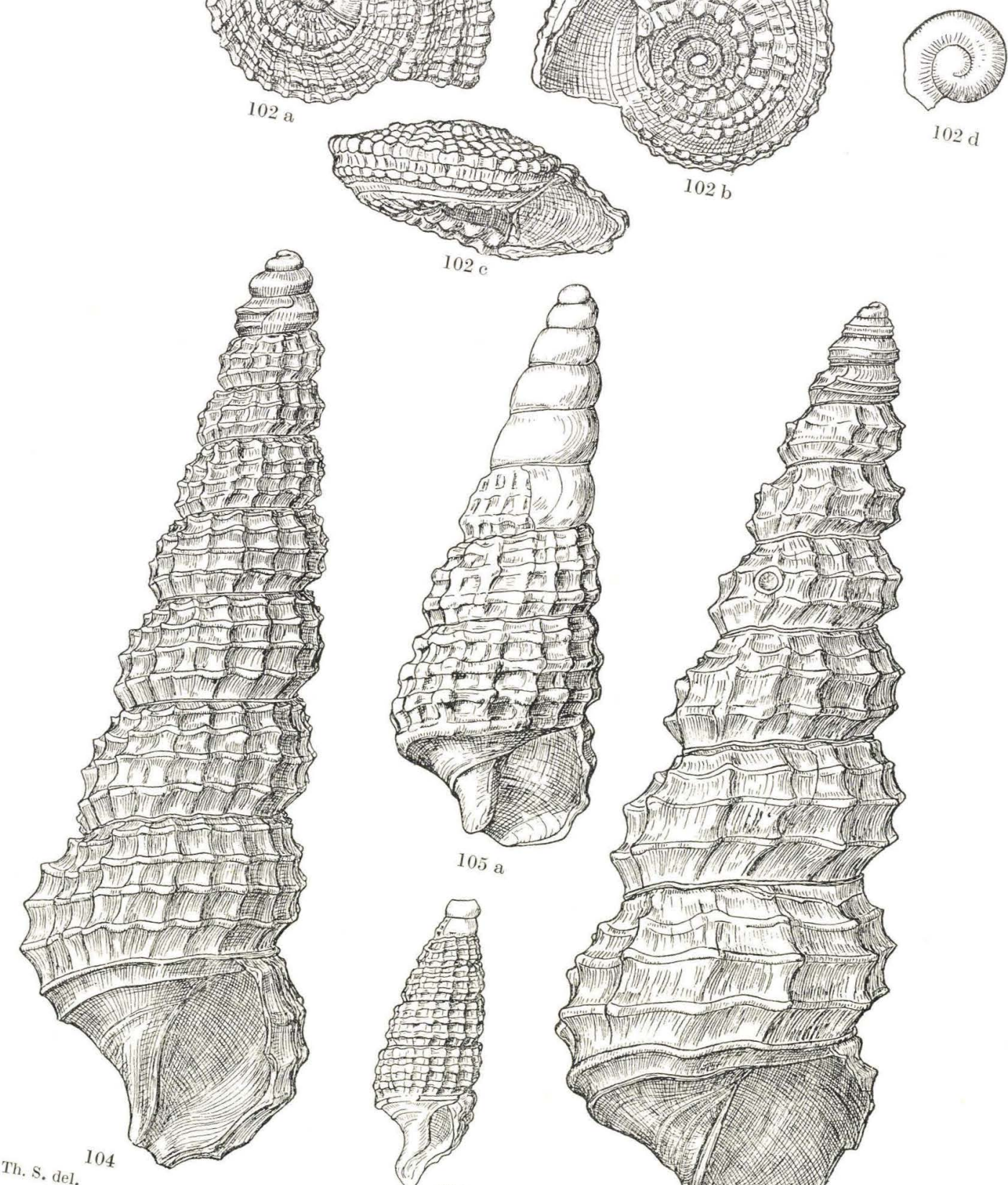

$102 \mathrm{~d}$
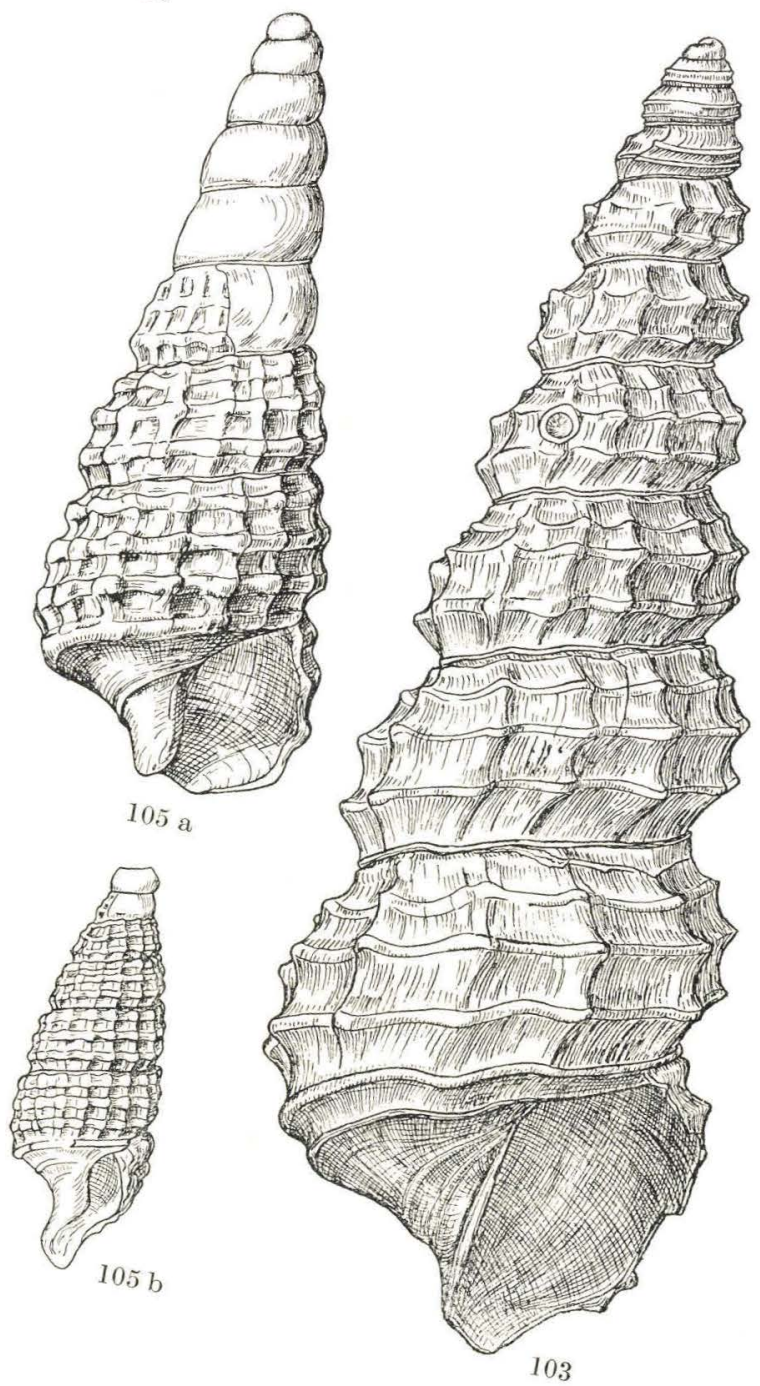
Plate 32.

Location Depth Diameter Height Page

106. Triphora perversa (Linné). $(\times 30)$. Toftlund $105-110 \mathrm{~m} . \quad 1.16 \quad 1.77 \quad 171$

107. Cirsotrema Thais DE Boury. $(\times 25)$. Toftlund $\quad 75-100 \quad-\quad 2.83 \quad 4.60 \quad 173$

109. Scala (Acrilla) cf. amoena PHI-

LIPII. $(\times 12.5)$ Toftlund $\quad 75-100 \quad-\quad 3.07 \quad 7.08 \quad 174$

110. Janthina cimbrica nov. sp. $\quad$ Glejbjerg $\quad 55-1.37 \quad 1.68 \quad 176$ Holotype. $(\times 30)$.

111. Niso acarinatoconica

Cossmann \& Peyrot. $(\times 25)$. Toftlund $75-100-2.16 \quad 4.78$

Shell dimensions in millimeters. 
D. G. U. II. Ser. No. 79.

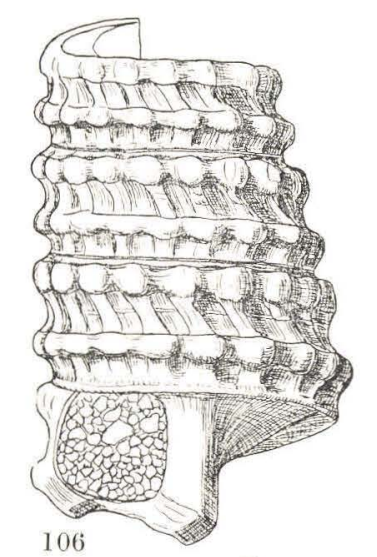

Plate 32

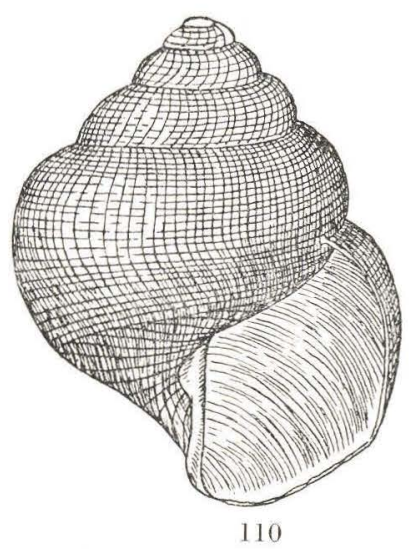

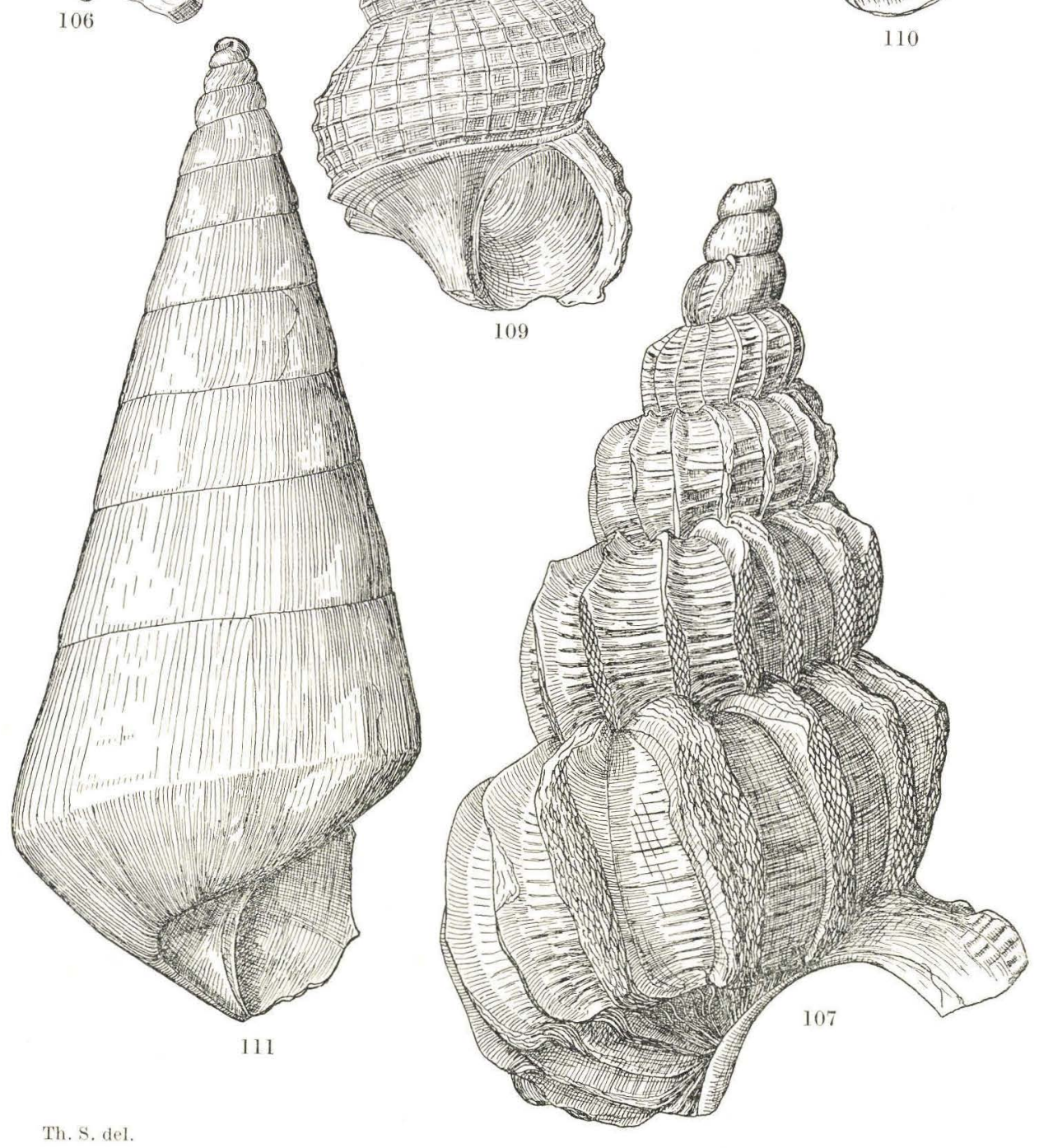




\section{Plate 33.}

\section{Location Depth Diameter Height Page}

112. Melanella simitis D'ORBIGNY.

$(\times 27)$.

Toftlund $\quad 115 \mathrm{~m} . \quad 0.90 \quad 2.36 \quad 178$

113a-b. Melanella taurostricta (Cossmann

\& Perrot). $(\times 30) . \quad$ Toftlund $\quad 75-100 \quad-\quad 1.16 \quad 4.14 \quad 179$

114a-b. Calyptraea chinensis (LINNÉ).

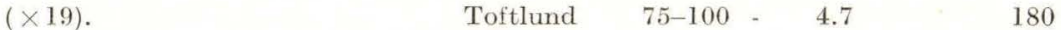

116. Aporrhais alata (EICHWALD). $\quad$ Arnum $\quad 53-83 \quad-\quad 1.08 \quad 1.10 \quad 182$ Protoconch. $(\times 30)$.

Shell dimensions in millimeters. 
D. G. U. II. Ser. No. 79.
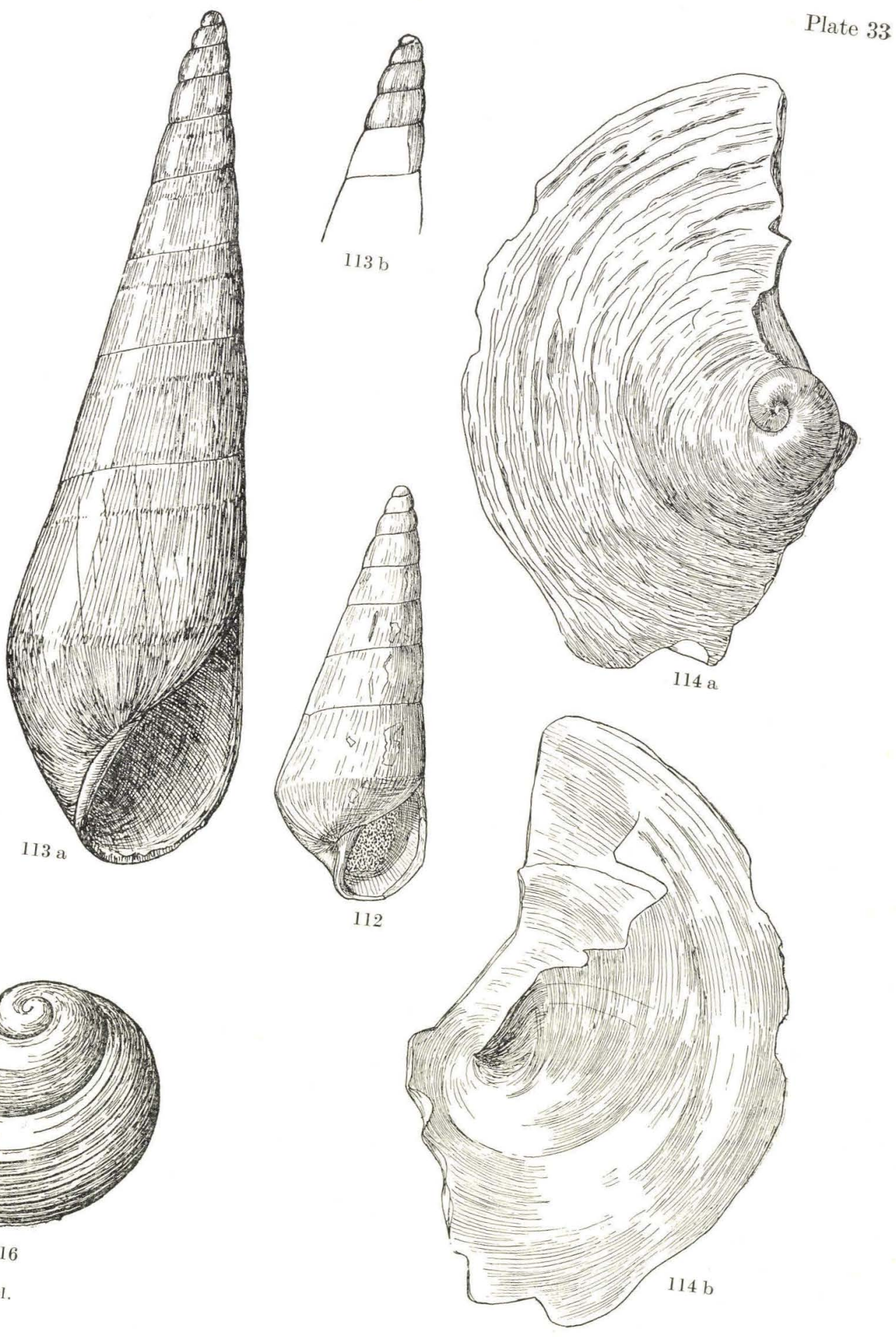


\section{Plate 34.}

Location Depth Diameter Height Page

115a-c. Xenophora Deshayesi(Michelotti) Toftlund $75-100 \mathrm{~m} . \quad 2.41 \quad 1.83 \quad 181$ c. Protoconch. $(\times 25)$.

117a-b. Natica (Lunatia) catena (DACostA) Toftlund $\quad 75-100 \quad-\quad 3.35 \quad 3.60 \quad 185$ b. Protoconch. $(\times 25)$.

$118 \mathrm{a}-$ b. Natica (Naticina) hanseata KAUTSKY. $(\times 23)$.

Toftlund $\quad 75-100 \quad-\quad 2.50 \quad 2.53 \quad 186$ Shell dimensions in millimeters. 
D. G.U. II. Ser. No. 79.

Plate 34
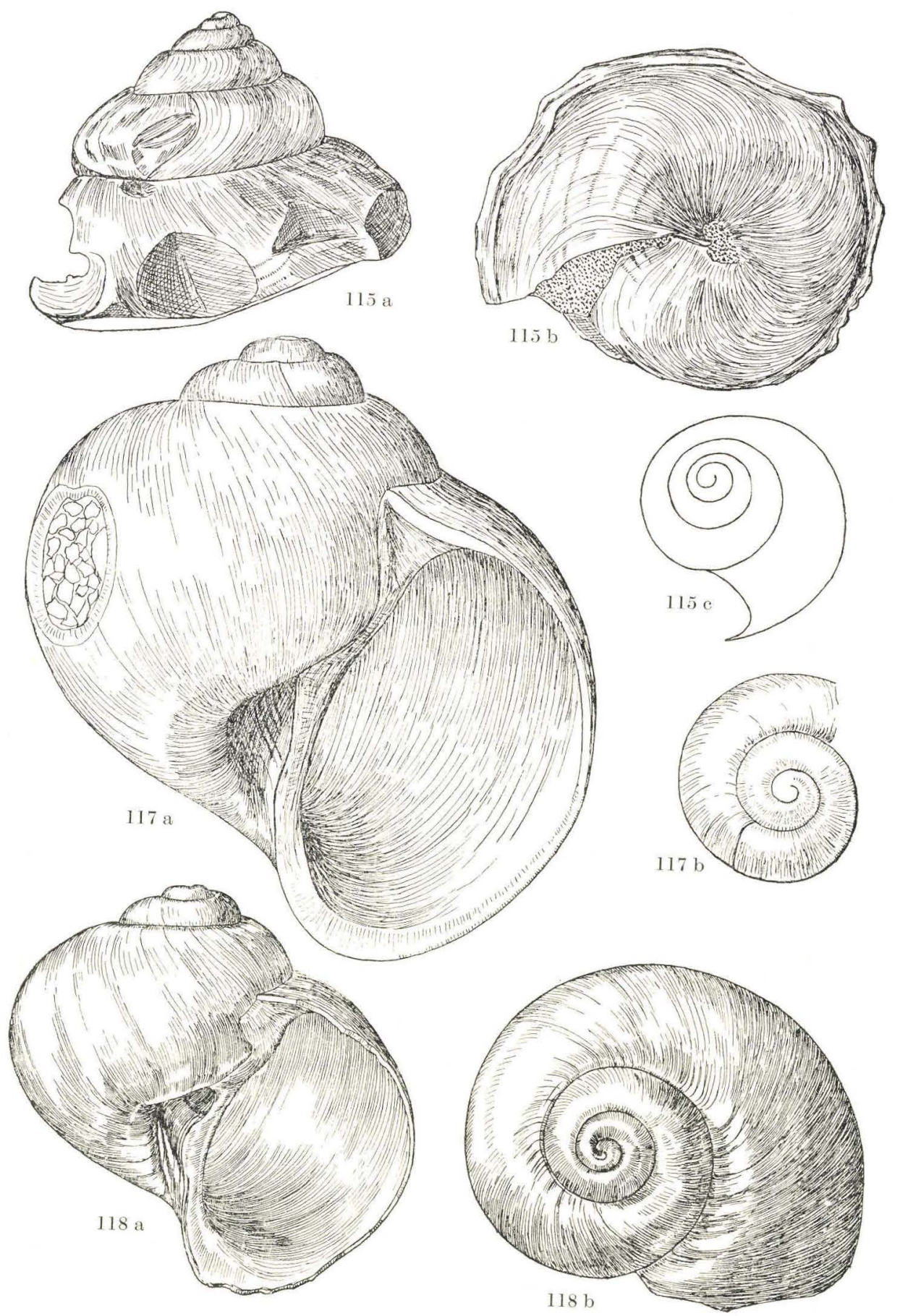

Th. S. del 
Plate 35.

Location Depth Diameter Height Page

119a-c. Natica (Naticina) Beyrichi voN

Konnen. b. Protoconch. $(\mathrm{a}-\mathrm{b} \times 20$;

Toftlund $\quad 75-100 \mathrm{~m} . \quad 3.56 \quad 3.56 \quad 187$

12la-c. Natica (Naticina) praeclausa KaUtSKY. $(\times 25)$.

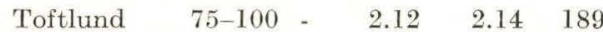

Shell dimensions in millimeters. 
D. G. U. II. Ser. No. 79.
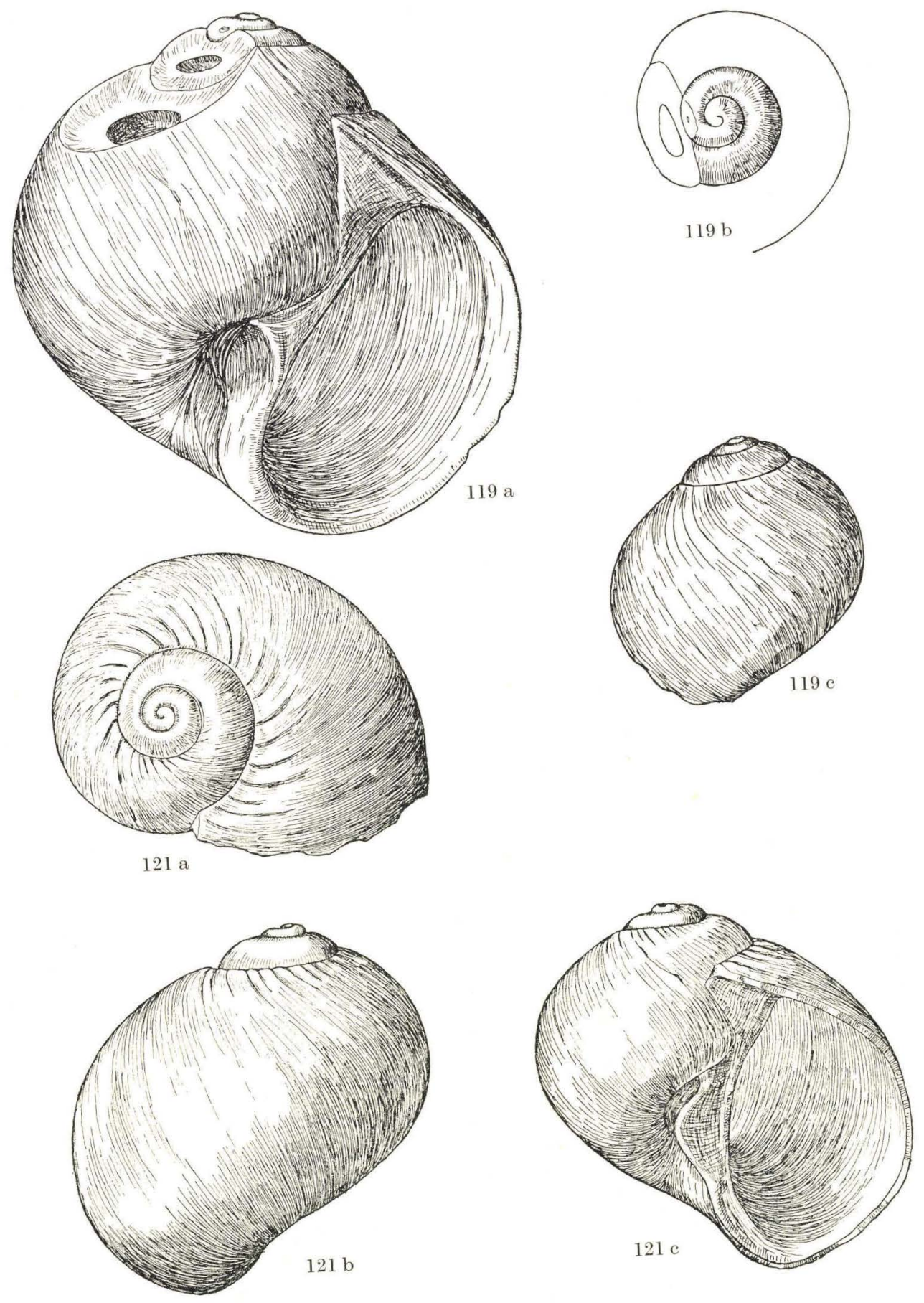

Th. S. del. 


\section{Plate 36.}

Location Depth Diameter Height Page

120a-b. Natica (Naticina) protostriata nov.

$\begin{array}{llllll}s p . \text { Holotype. }(\times 30) . & \text { Toftlund } & 75-100 \mathrm{~m} . & 1.96 & 2.13 & 188\end{array}$

124a-c. Natica (Naticina) submamillaris

D'Orbigny. $(\mathrm{a}-\mathrm{b} \times 25 ; \mathrm{c} \times 12.5)$. Toftlund $\quad 75-100-3.32 \quad 3.41 \quad 192$

Shell dimensions in millimeters. 
D. G. U. II. Ser. No. 79.
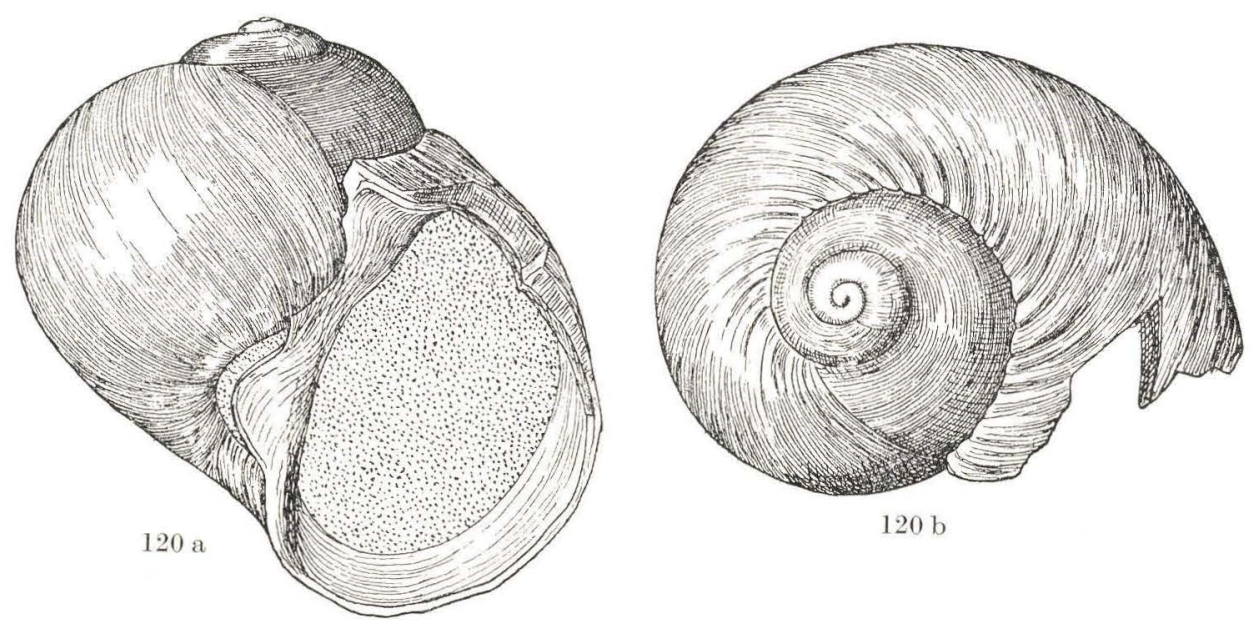

$120 \mathrm{~b}$

Plate 36
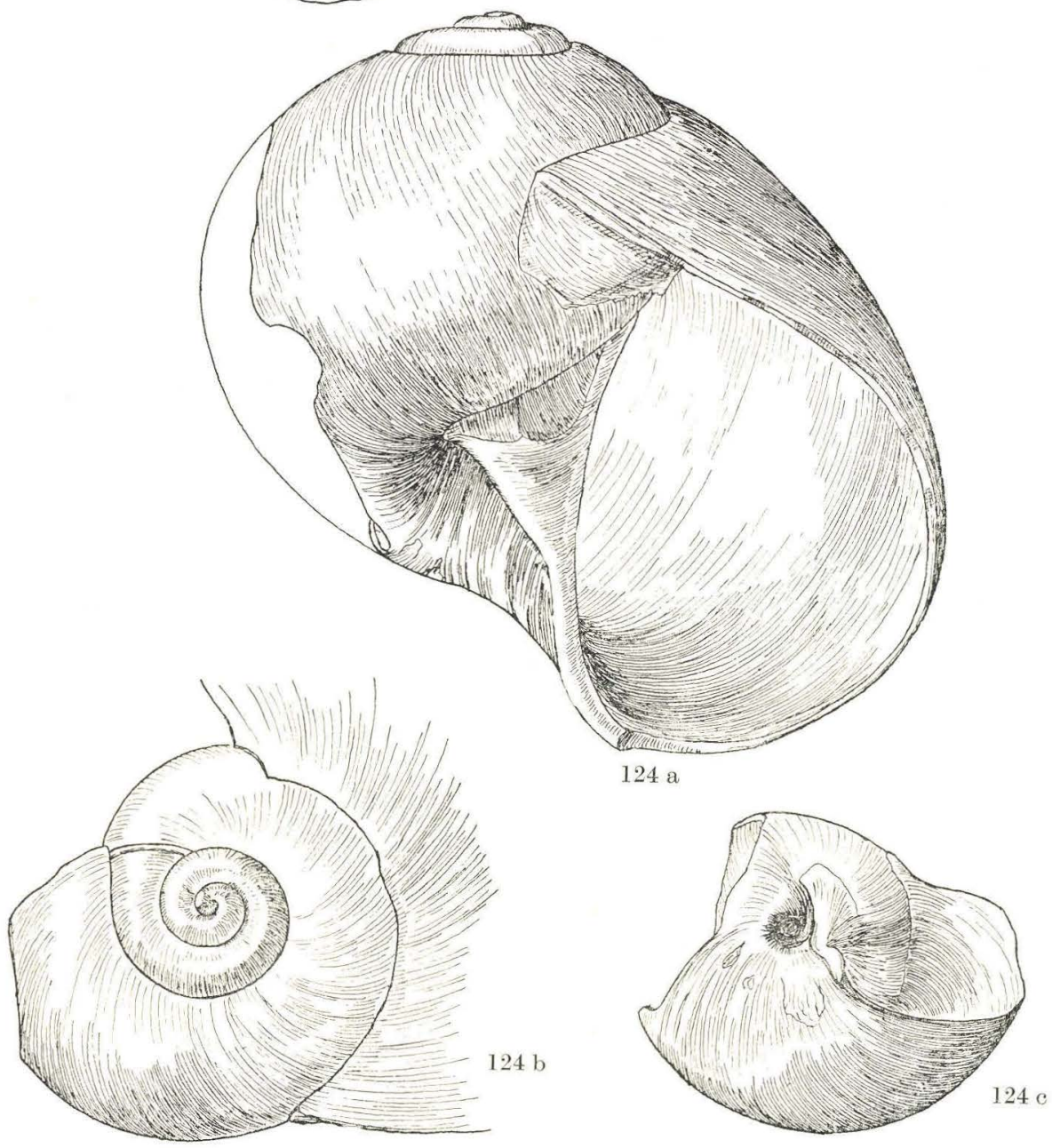

Th. S. del. 


\section{Plate 37.}

Location Depth Diameter Height Page

123a-c. Natica (Naticina) miopusilla KaUt-

SKY. $(\mathrm{a} \times 12.5 ; \mathrm{b}-\mathrm{c} \times 25) . \quad$ Toftlund $\quad 75-100 \mathrm{~m} . \quad 3.66 \quad 3.99 \quad 191$

127. Natica $s p .(\times 40)$.

Toftlund $115-1.0 \quad 195$

128a-c. Globularia sp. $(\times 20)$.

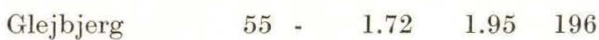

Shell dimensions in millimeters. 
D. G. U. II. Ser. No. 79.

Plate 37

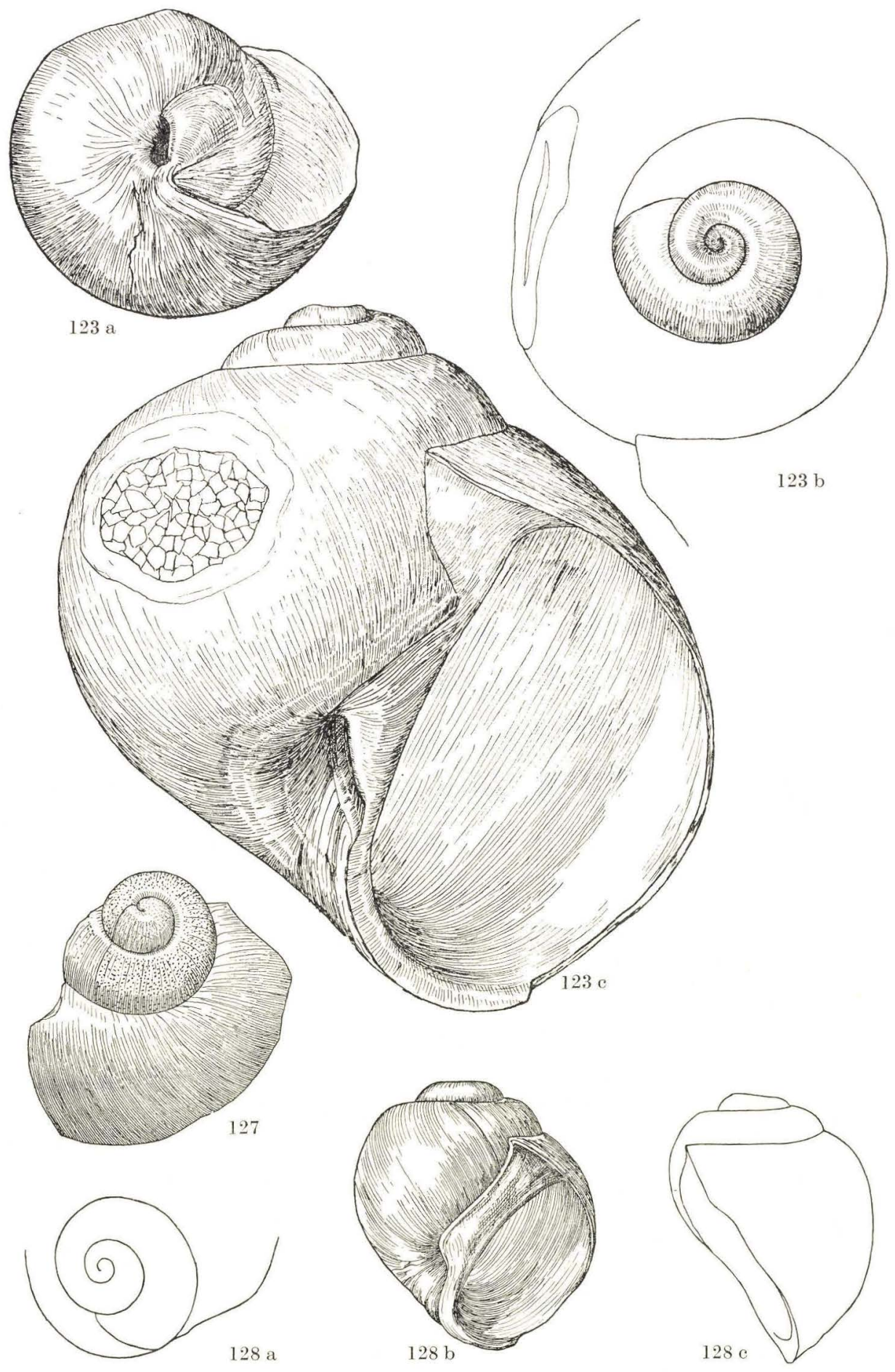

Th. S. del. 


\section{Plate 38.}

Location Depth Diameter Height Page

122a-c. Natica (Naticina) tectula Boner.r.

$\begin{array}{llllll}(\times 20) . & \text { Toftlund } & 75-100 \mathrm{~m} & 2.50 & 2.25 & 190\end{array}$

125a-c. Natica (Polynices) affinis (GME-

LIN). ( $\times 25)$.

Toftlund $\quad 75-100 \quad-\quad 2.33 \quad 2.12 \quad 193$

Shell dimensions in millimeters. 


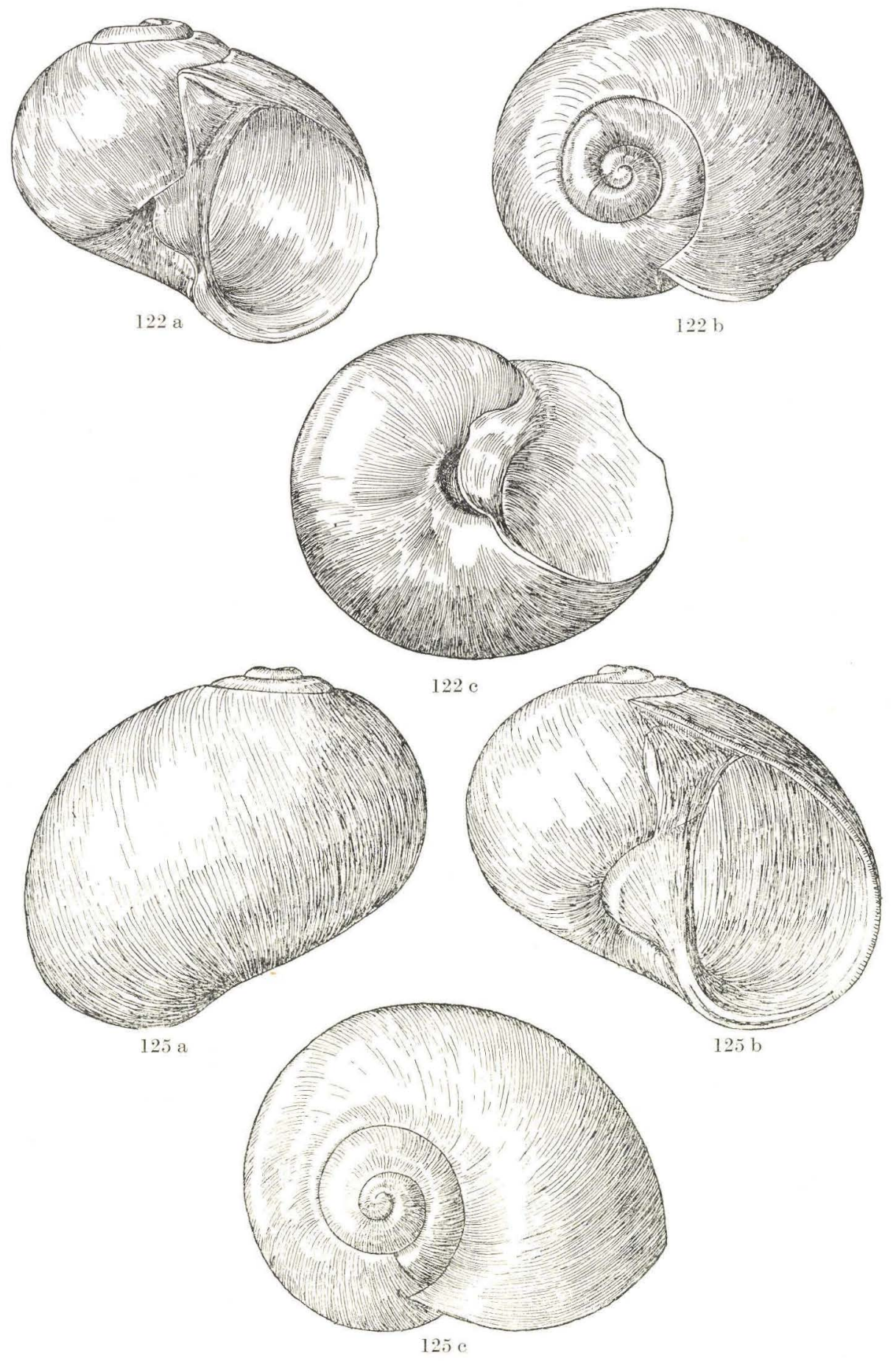

Th. S. del. 
Plate 39.

126a-c. Natica (Neverita) Josephinia

Location Depth Diameter Height Page

(RIsso). (a-b $\times 30: \mathrm{c} \times 15)$.

Toftlund $\quad 75-100 \mathrm{~m} . \quad 3.41 \quad 2.50 \quad 194$

129a-b. Sigaretus sulcatus (Grateloup)

$(\times 22)$.

Toftlund $\quad 75-100 \quad-\quad 2.54 \quad 2.33 \quad 196$

Shell dimensions in millimeters. 

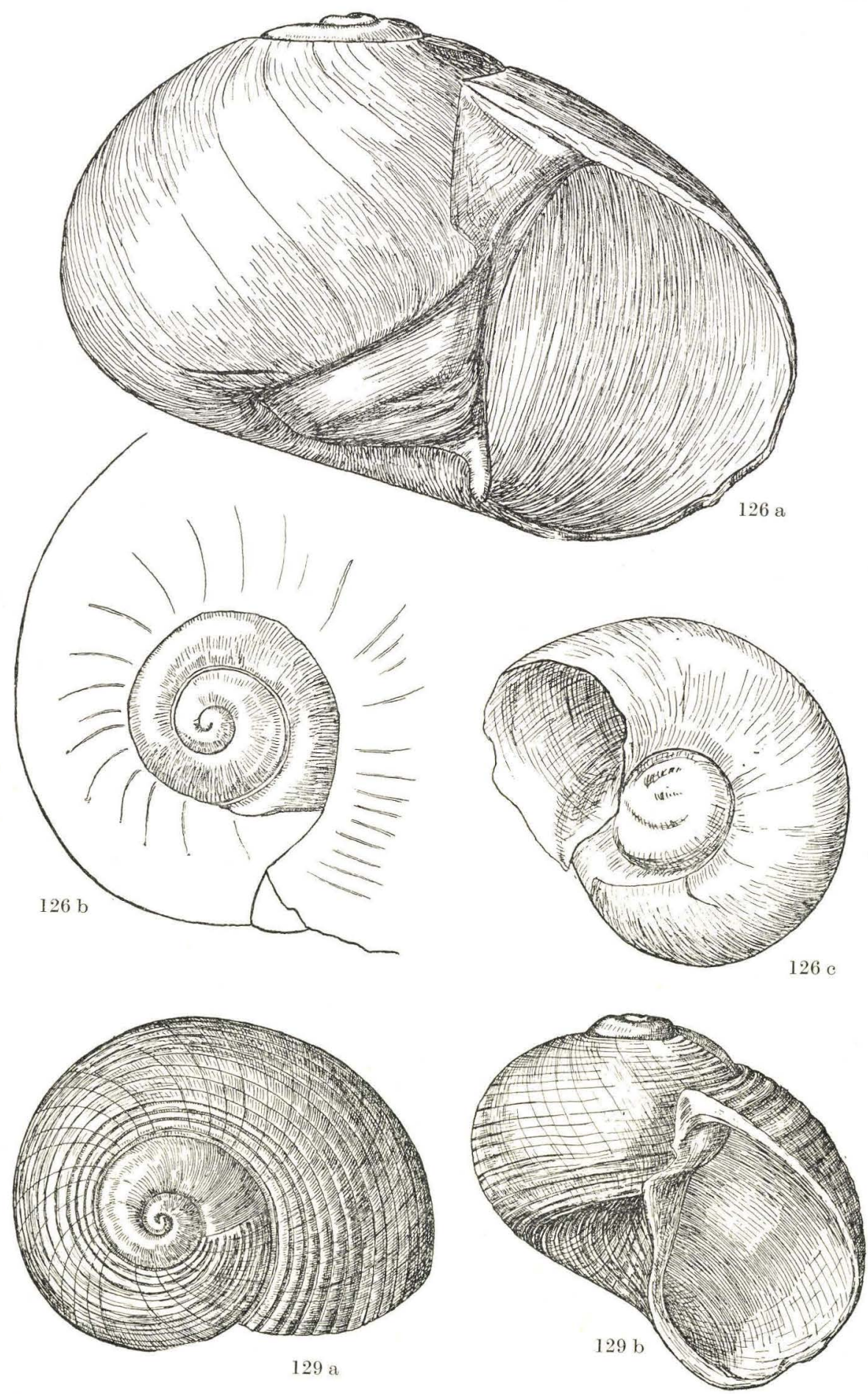

Th. S. del. 
Plate 40.

Location Depth Diameter Height Page

130a-b. Sigaretus of. aquensis RECLUZ. $(\times 30)$.

$\begin{array}{lllll}\text { Toftlund } \quad 75-100 \mathrm{~m} . & 3.65 & 2.41 & 197\end{array}$ Shell dimensions in millimeters. 


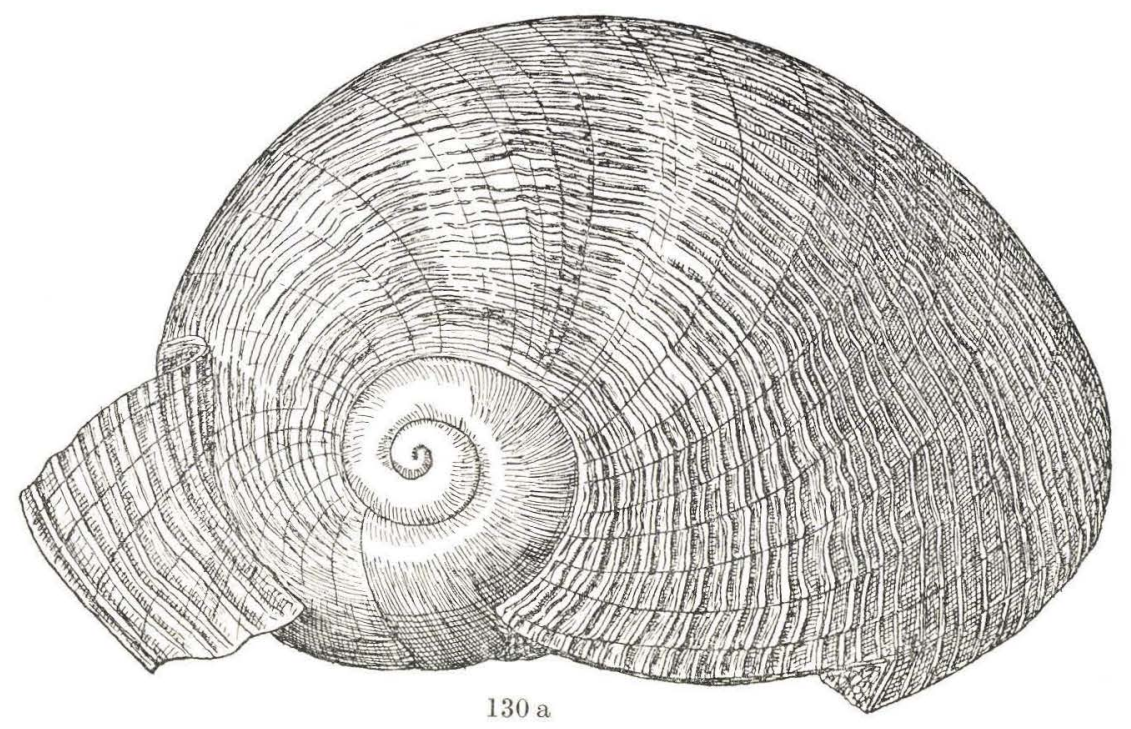

Th. S. del.

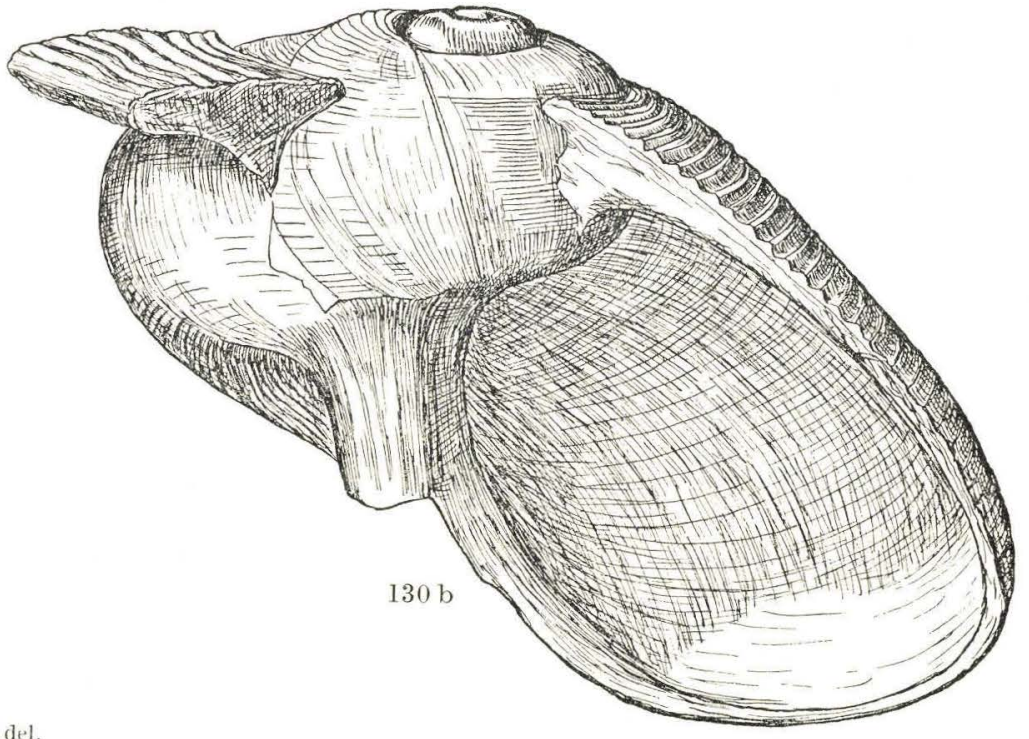


Plate 41.

Location Depth Diameter Height Page

131. Semicassis sp. $(\times 30)$.

Toftlund

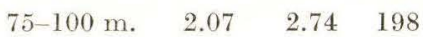

134a-b. Pyrula condita Brongniart. ( × 25). Toftlund

$75-100-3.07 \quad 4.32 \quad 200$

Shell dimensions in millimeters. 
D. G.U. II. Ser. No. 79.

Plate 41

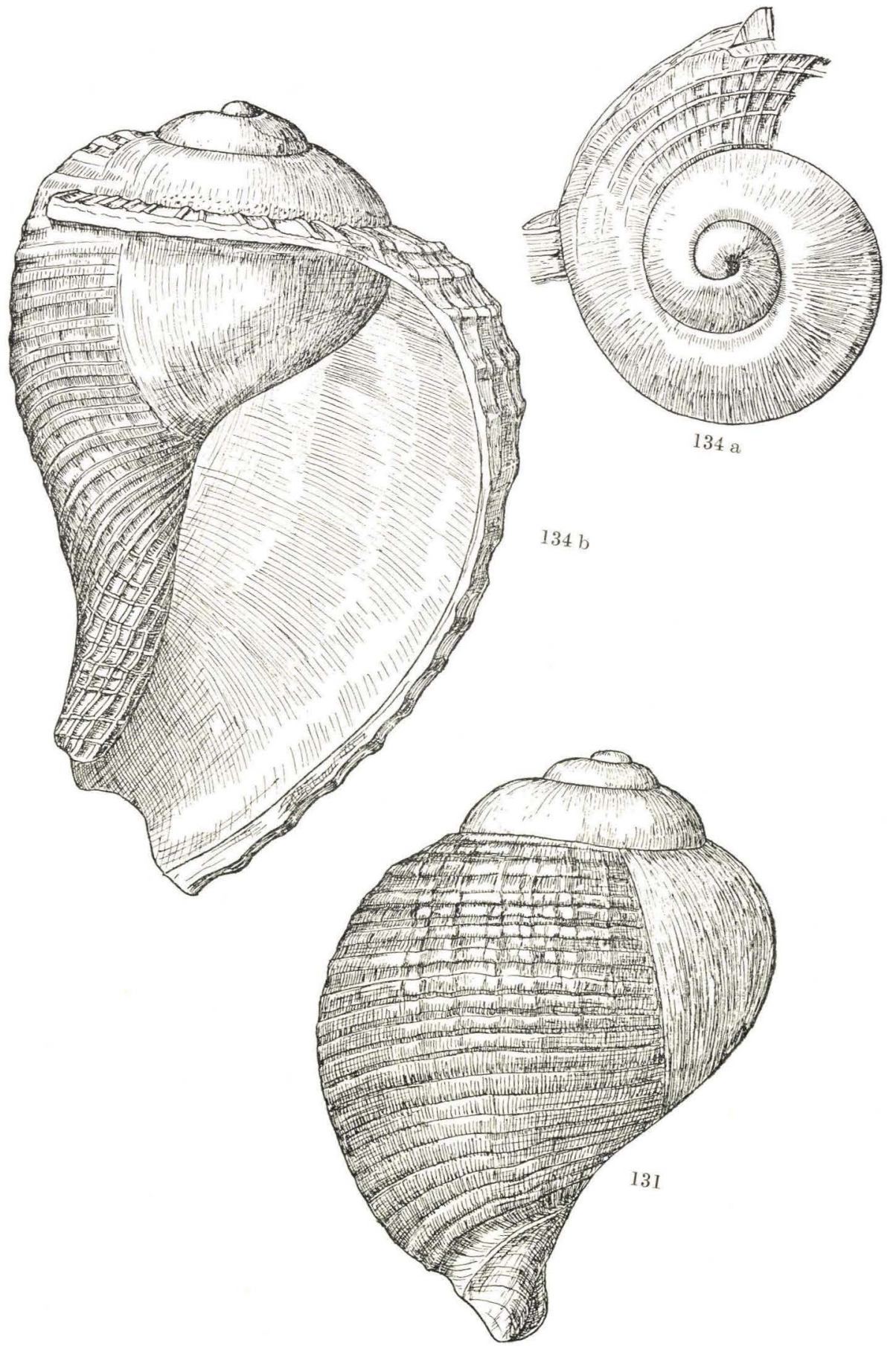


Plate 42.

135a-b. Murex cf. aturensis Cossmann \&

Location Depth Dianeter Height Page PeYrot. $(\times 30)$. Toftlund

$\begin{array}{cccc}75-100 \mathrm{~m} . & 1.83 & 3.41 & 201 \\ 75-100- & 1.79 & 3.79 & 202 \\ 70-80- & 6.0 & 15.3 & 206\end{array}$

$\begin{array}{llllll}\text { 136a-b. Murex inornatis Beyrich. }(\times 30) \text {. Toftlund } & 75-100 & - & 1.79 & 3.79 & 202 \\ 139 \text {. Tritonalia coelata DUJARdin. }(\times 5) \text {. Bramminge } & 70-80 & - & 6.0 & 15.3 & 206\end{array}$

Shell dimensions in millimeters. 
D. G. U. II. Ser. No. 79.

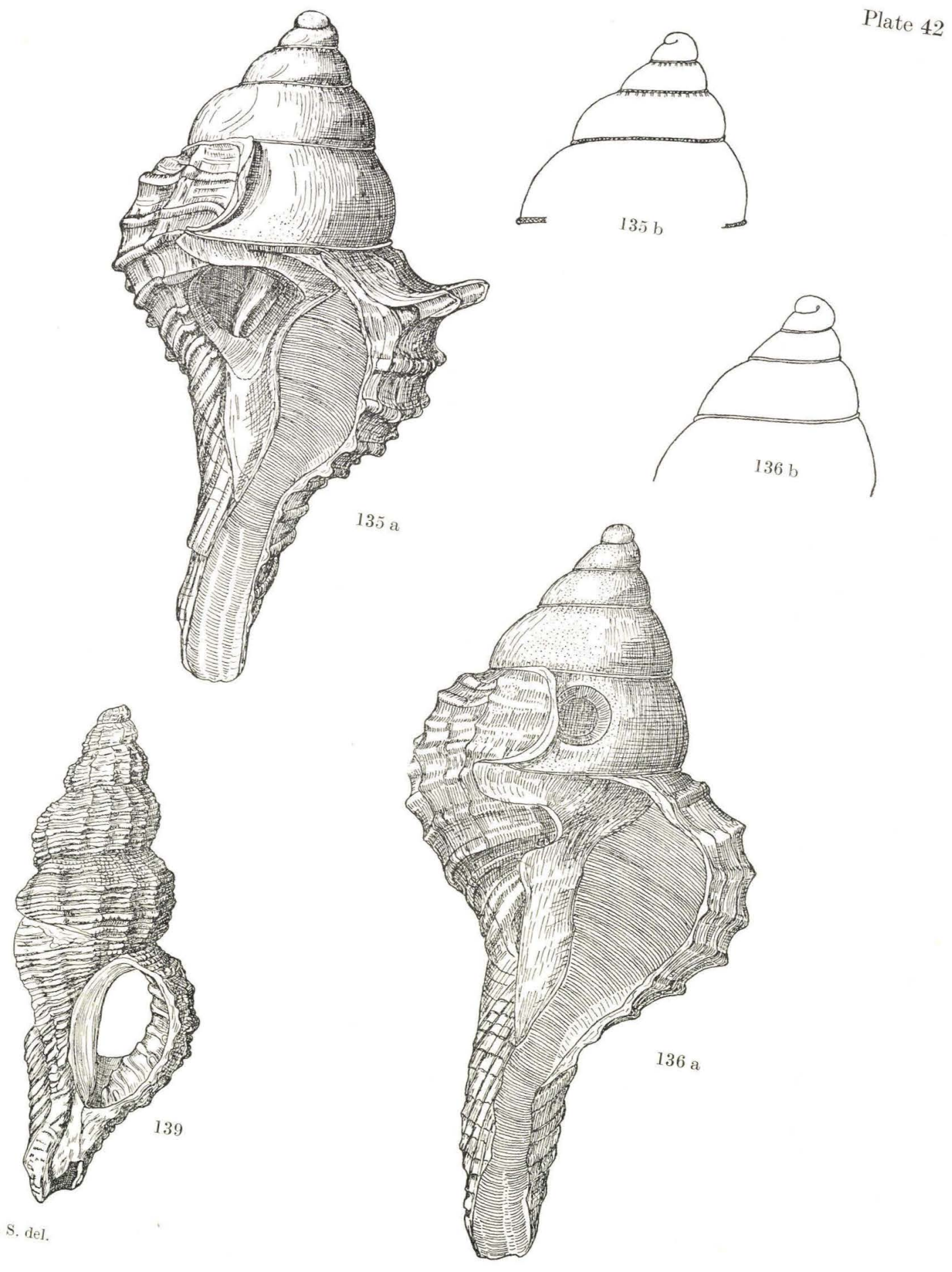




\section{Plate 43.}

Location Depth Diameter Height Page

138. Typhis fistulosus (BROCCHI). ( × 25). Toftlund $\quad 75-100 \mathrm{~m} . \quad 2.90 \quad 5.48 \quad 204$

140. Pyrene (Atilia) nassoides (GrateLOUP $).(\times 25)$.

Toftlund $\quad 75-100-2.3 \quad 5.6 \quad 206$

14la-d. Pyrene (Anachis sp.) 208

$\mathrm{a}-\mathrm{b} .(\times 25)$.

c. $(\times 20)$.

Arnum (25b) 62.7-62.9- $\quad 0.91 \quad 1.73$

Toftlund $105-110-1.7 \quad 2.7$

d. $(\times 20)$.

$\begin{array}{llll}\text { Bramminge } \quad 70-80 & - & 1.8 & 3.9\end{array}$

Shell dimensions in millimeters. 
D. G. U. II. Ser. No. 79.

Plate 43
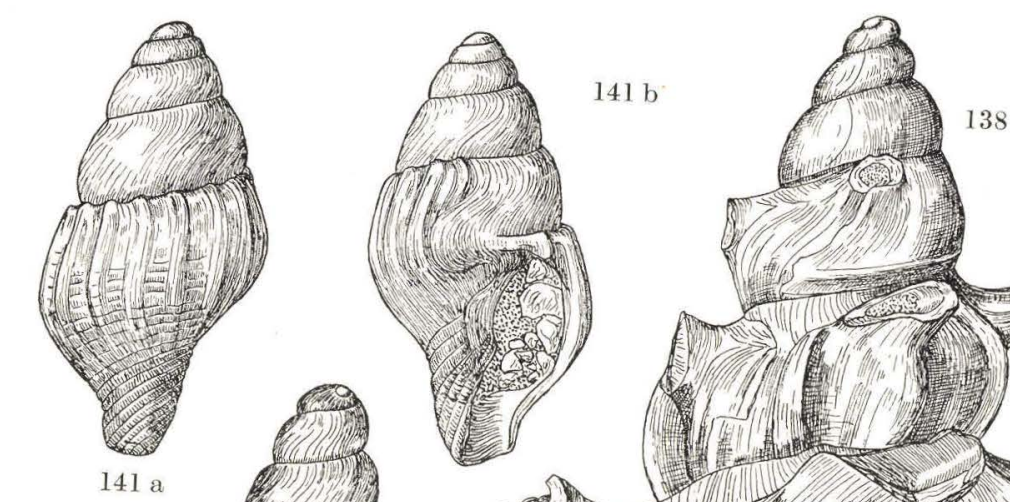

138
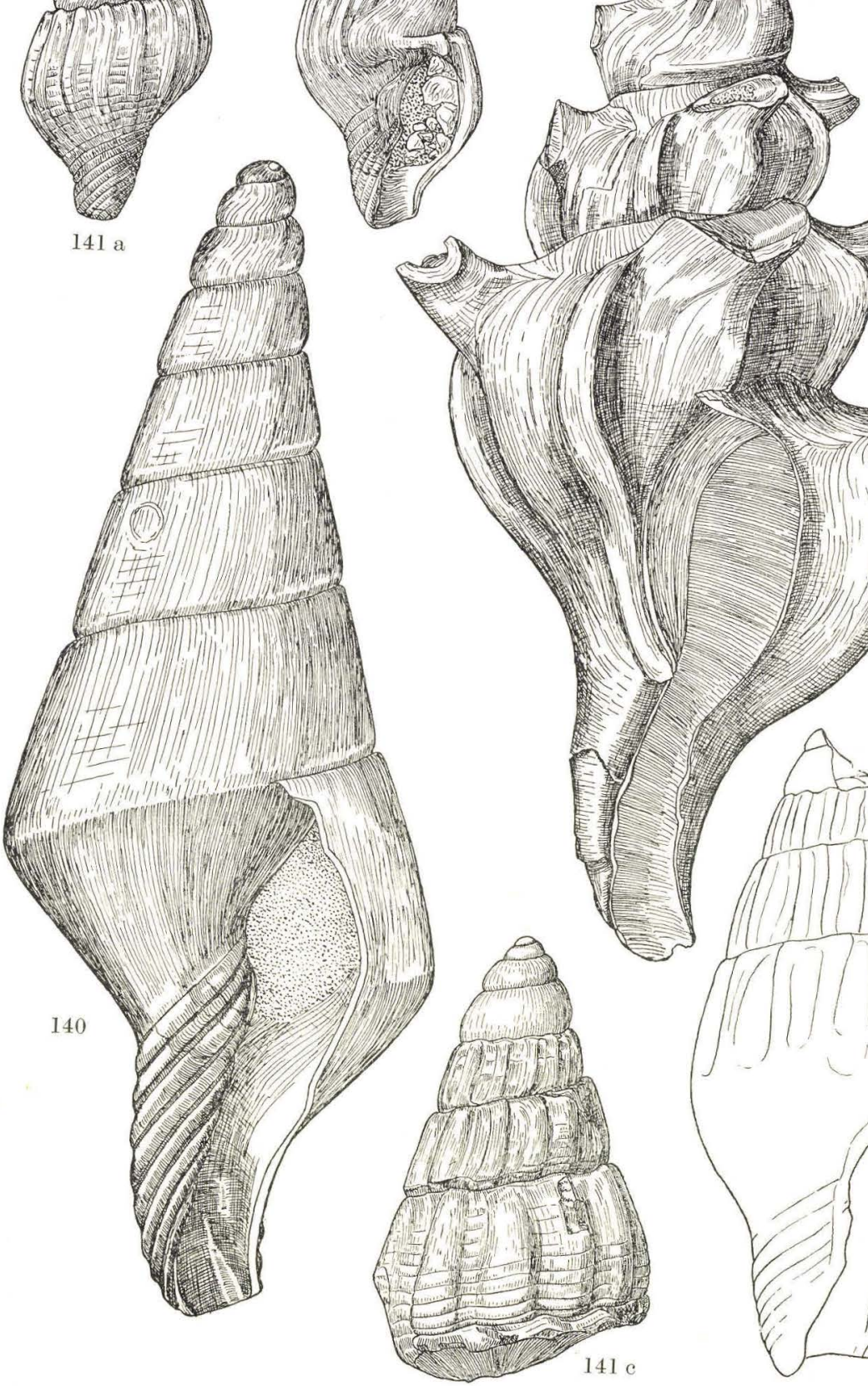


\section{Plate 44.}

Location Depth Diameter Height Page

142. Phos decussatus von Koenen.

$\begin{array}{llllll}(\times 25) . & \text { Toftlund } & 110-115 \mathrm{~m} . & 2.65 & 4.90 & 208\end{array}$

143. Nassa tenuistriata (BEYRICH).

$(\times 25)$ Toftlund $\quad$ T5-100 $\quad$ T $\quad 2.52 \quad 3.99 \quad 210$

147. Nassa Fuchsi von Konnen. $(\times 27)$. Toftlund $\quad 75-100 \quad-\quad 2.02 \quad 3.33 \quad 215$

Shell dimensions in millimeters. 
D. G. U. II. Ser. No. 79.

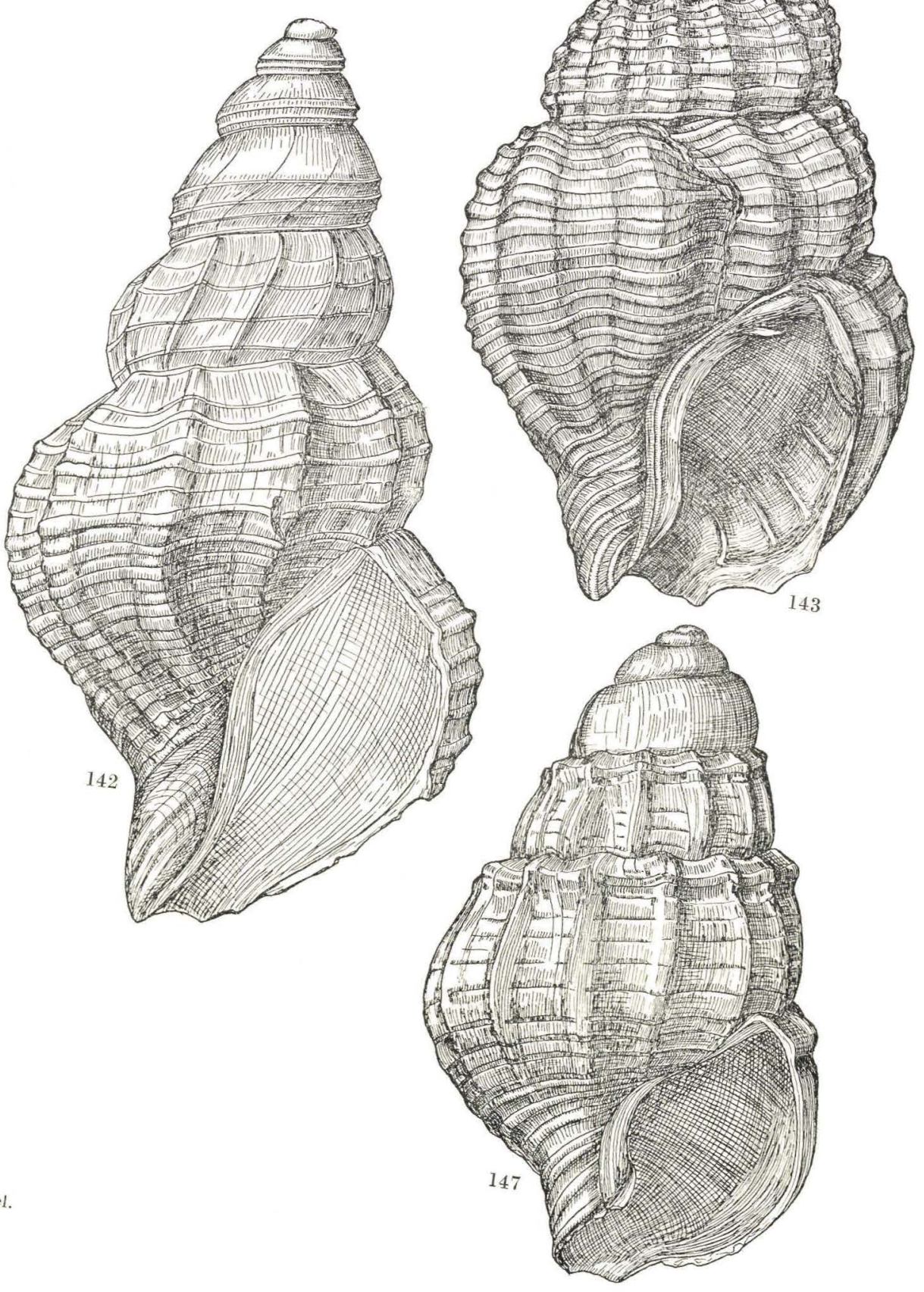




\section{Plate 45.}

Location Depth Diameter Height Page

146. Nassa turbinella (BrocchI). ( $\times 26)$. Toftlund $\quad 75-100$ m. $\quad 2.90 \quad 5.35 \quad 214$

148. Nassa Schlotheimi (BEYRICH).

$\begin{array}{lllllll}(\times 25) . & \text { Toftlund } & 75-100 & - & 2.38 & 3.91 & 216\end{array}$

Shell dimensions in millimeters. 
D. G. U. II. Ser. No. 79.

Plate 45

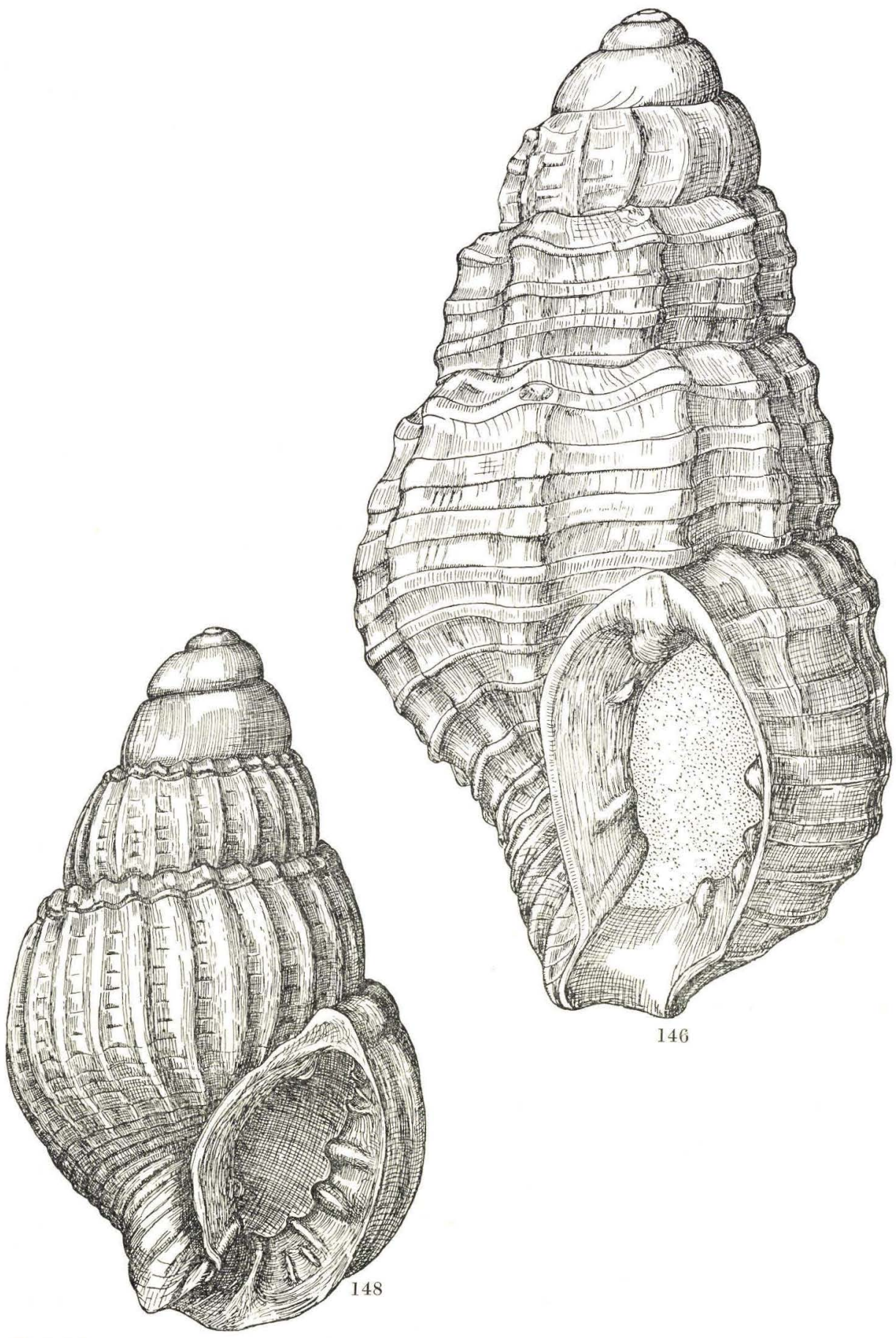

Th. S. del. 


\section{Plate 46.}

Location Depth Diameter Height Page

144. Nassa serraticosta (BRONN). ( $\times 25)$. Toftlund $\quad 75-100 \mathrm{~m} . \quad 3.00 \quad 5.22 \quad 212$

154. Nassa subobesa DEgrange-Tou-

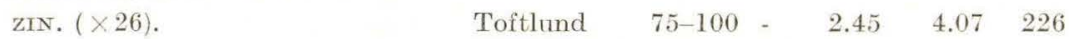

Shell dimensions in millimeters. 
D.G.U. II. Ser. No. 79.

Plate 46

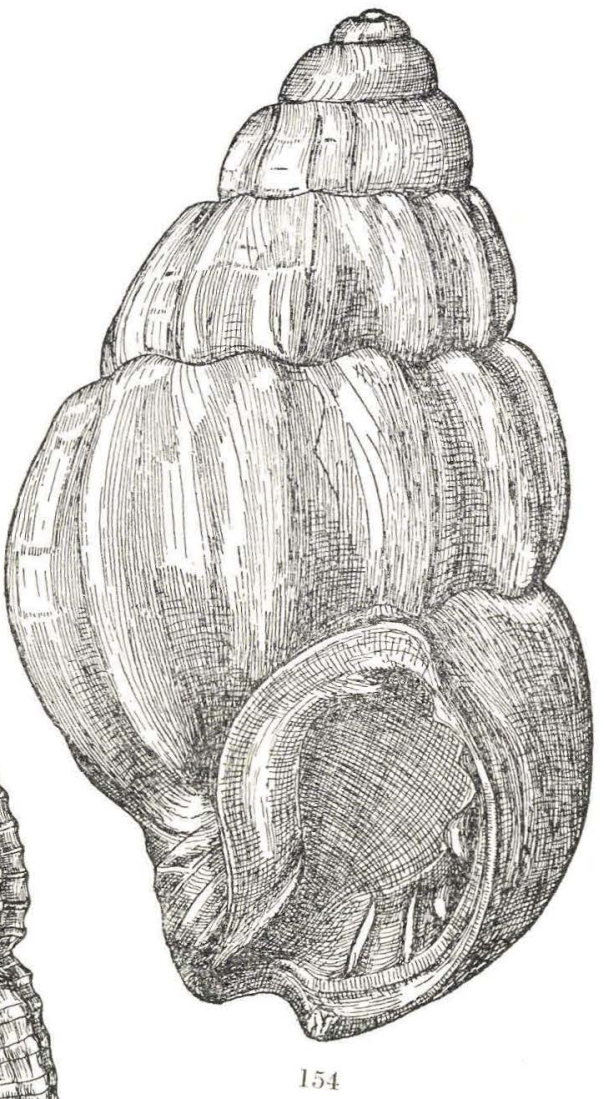

Th. S. del.

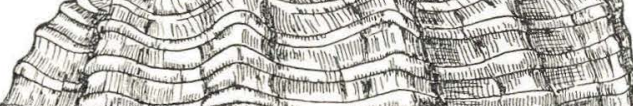

bus of

154
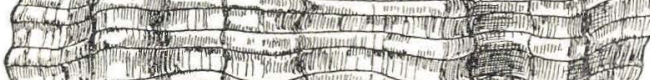

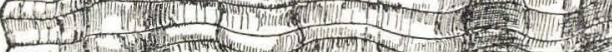

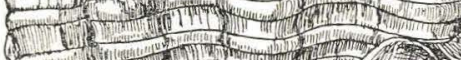
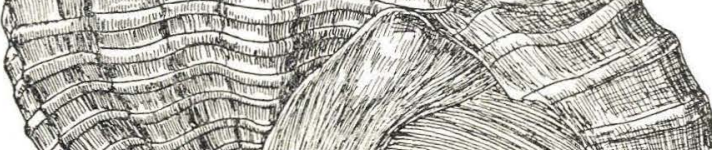

(1)
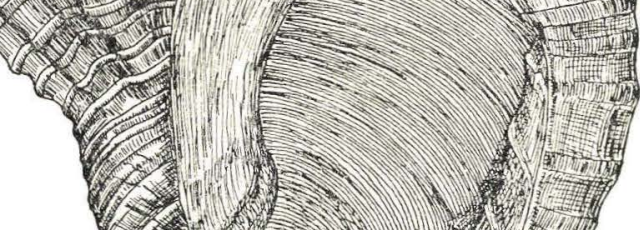

1. $1+t^{2}=$ 
Plate 47.

Location Depth Diameter Height Page

150. Nassa Facki von Koenen. ( $\times 26)$. Toftlund $\quad 75-100$ m. $2.57 \quad 4.40 \quad 220$

155. Nassa cimbrica Ravr. $(\times 26)$. Toftlund $\quad 75-100 \quad-\quad 2.57 \quad 4.40 \quad 228$

Shell dimensions in millimeters. 


\section{G. U. II. Ser. No. 79.}

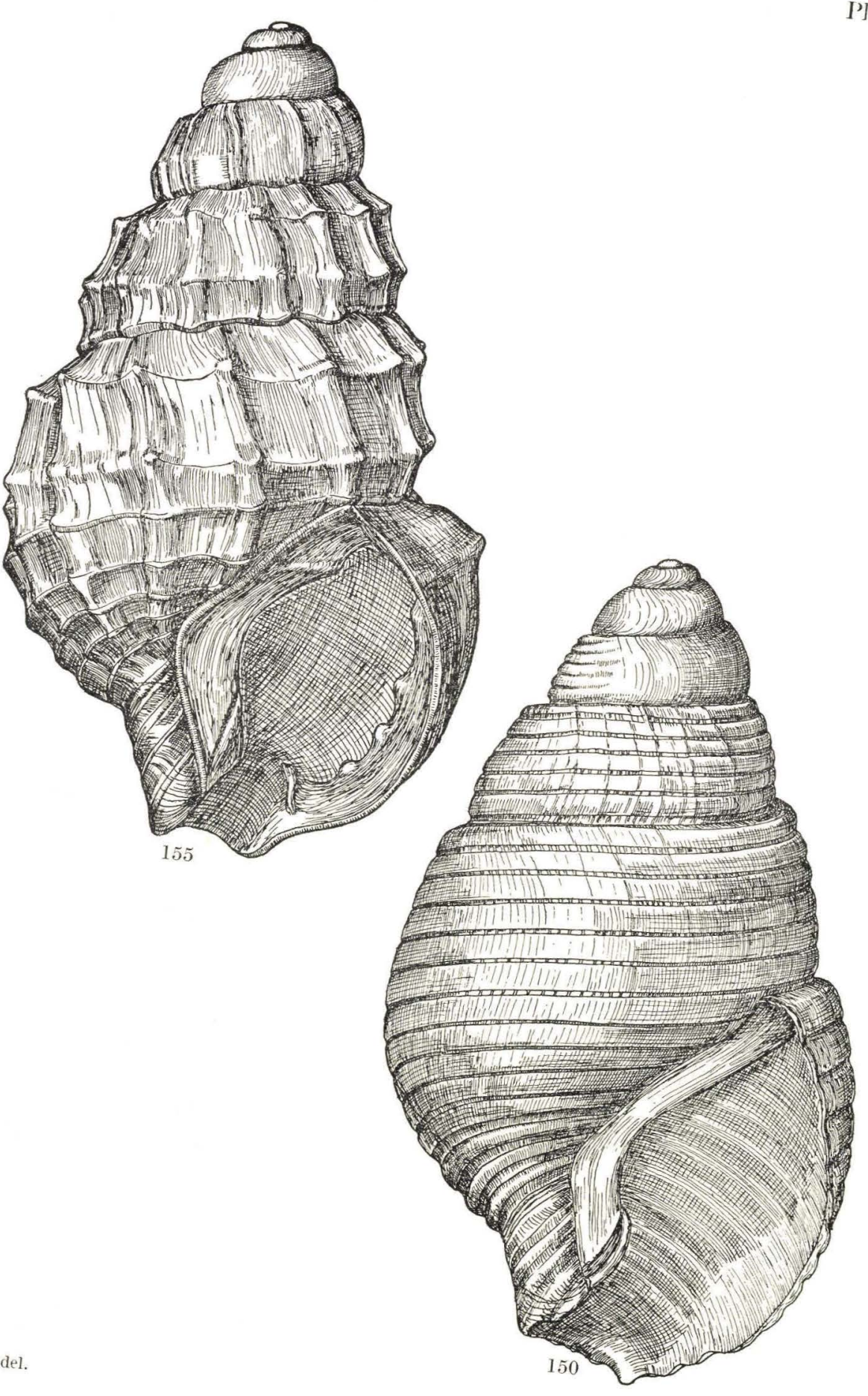

Pate 47 


\section{Plate 48.}

Location Depth Diameter Height Page

149. Nassa holsatica (Bеyrich). $(\times 22.5)$.

15la-c. Nassa laevissima Brusina

a. $(\times 20.5)$.

b. $(\times 20.5)$.

c. $(\times 20.5)$.
Bramminge $\quad 70-80 \mathrm{~m} . \quad 2.62 \quad 4.46 \quad 219$

Toftlund $\quad 75-100$.

$1.89 \quad 3.37$

$1.77 \quad 2.81$

$2.12 \quad 3.70$

156. Nassa pölsense (AUINGER). (×26). Glejbjerg $\quad 53.5 \quad-\quad 2.08 \quad 3.04 \quad 231$

Shell dimensions in millimeters. 
D. G. U. II. Ser. No. 79.

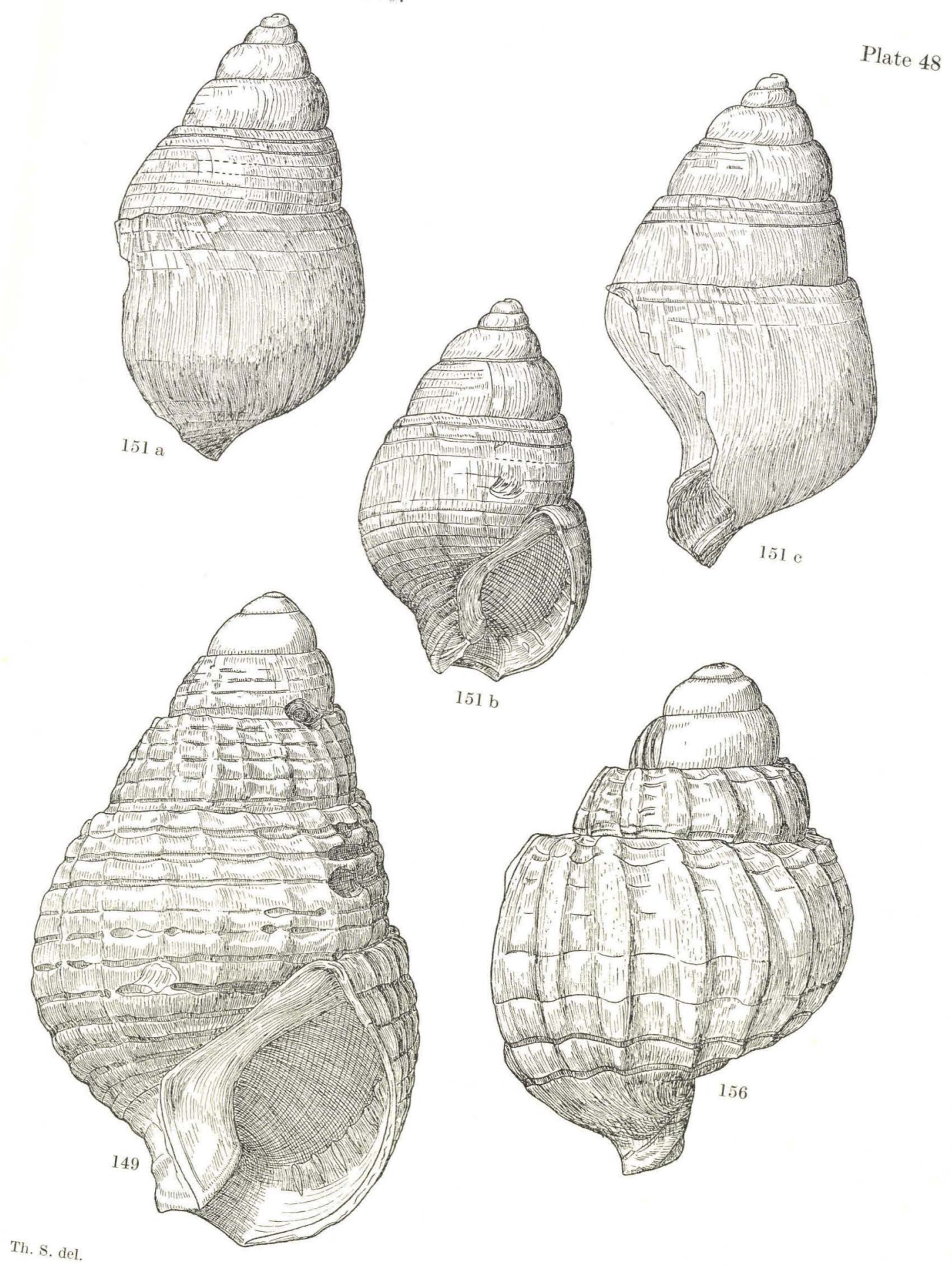




\section{Plate 49.}

\section{Location Depth Diameter Height Page}

153. Nassa Woodwardi Harmer. $(\times 25)$. Toftlund. $110-115$ m. $2.99 \quad 4.57 \quad 225$

160a-c. Ancilla obsoleta (BrocchI). ( $\times 15$ ). Toftlund $\quad 75-100 \quad-\quad 2.00 \quad 4.15 \quad 236$

161a-e. Oliva minutissima (KAUTSKY).

(X15). Toftlund $\quad \begin{array}{rrrrr}75-100 & - & 2.17 & 4.85 & 237\end{array}$

Shell dimensions in millimeters. 

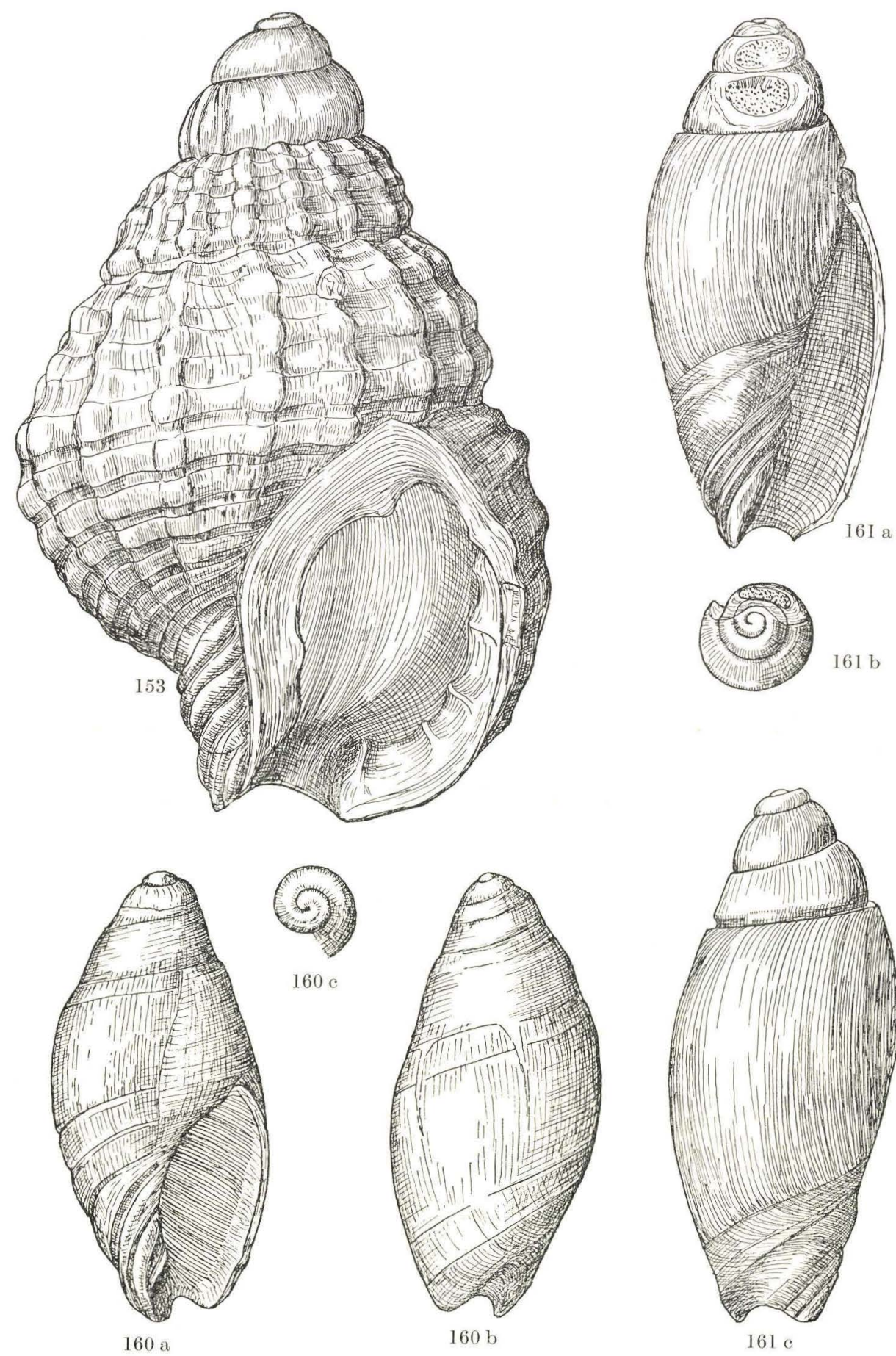

Th. S. del.

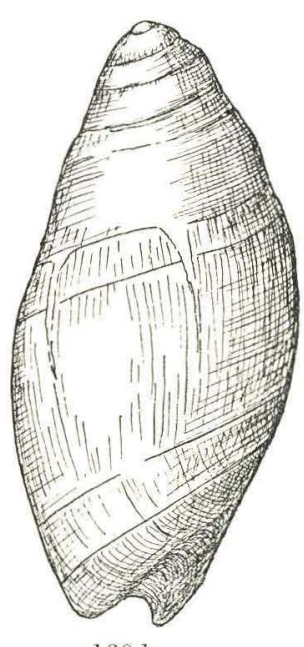

$160 \mathrm{~b}$

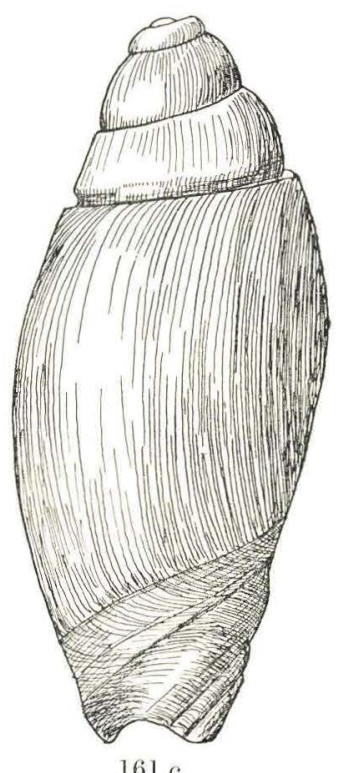


Plate 50.

Location Depth Diameter Height Page

157. Lathyrus (Dolicholatyrus) Rothi

(BетRICH). $(\times 26) . \quad$ Toftlund $\quad 75-100 \mathrm{~m} . \quad 2.20 \quad 4.15 \quad 232$

158. Fusus of. sexcostatus Beyrion. $(\times 29)$.

Toftlund $75-100$ -

$4.25 \quad 233$

159. Fusus (Aquitofusus) Grippi
(KAUTSKY). $(\times 13)$.
Glejbjerg
$53.5-3.35$
$5.75 \quad 235$

164. Cancellaria (Cancellaria) cancellata (LinNé). ( $\times 11)$.

Toftlund

115

$5.15 \quad 7.58 \quad 239$

Shell dimensions in millimeters. 


$$
\text { D. G. U. II. Ser. No. } 79 .
$$

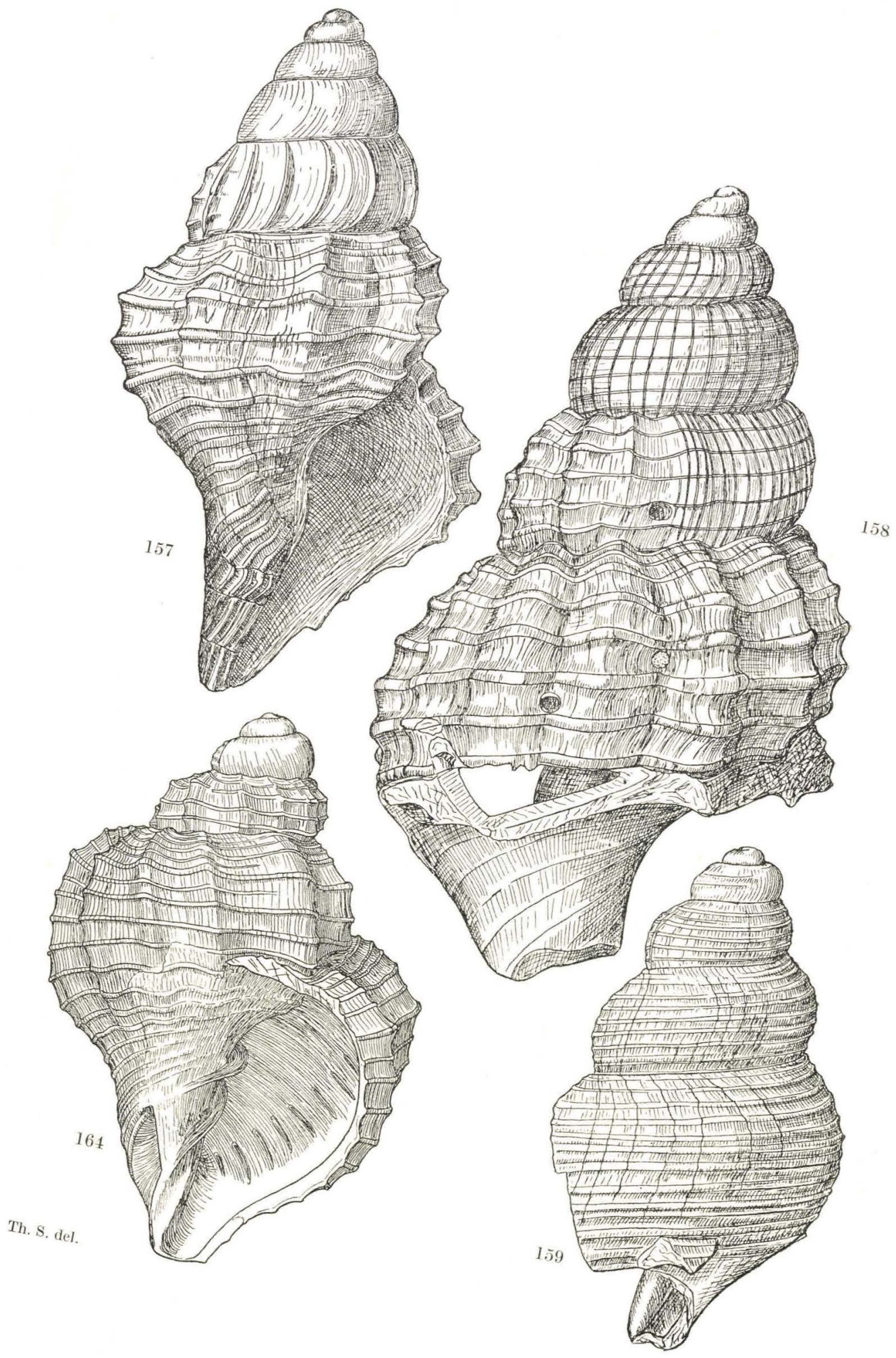




\section{Plate 51.}

Location Depth Diameter Height Page

166. Cancellaria (Trigonostoma) acutangula Faujas de Saint Fond.
( $\times 15)$.
Toftlund $\quad 110-115 \mathrm{~m}$.
3.62
$5.03 \quad 241$

168a-b. Cancellaria (Narona) calcarata (BRocCHI)

Bramminge $\quad 70-80$.

a. $(\times 17)$.

$2.77 \quad 4.07$

b. $(\times 17)$.

$2.28 \quad 3.29$

169a-b. Cancellaria (Narona) varicosa
(ВRоссні). $(\times 25)$.
Toftlund
$75-100$
2.57
$4.15 \quad 244$

170. Admete of. fusiformis (CANTraine). $(\times 15)$.

Toftlund $\quad 75-100-3.65$

$6.75 \quad 246$

Shell dimensions in millimeters. 
D. G. U. II. Ser. No. 79.

Plate 51

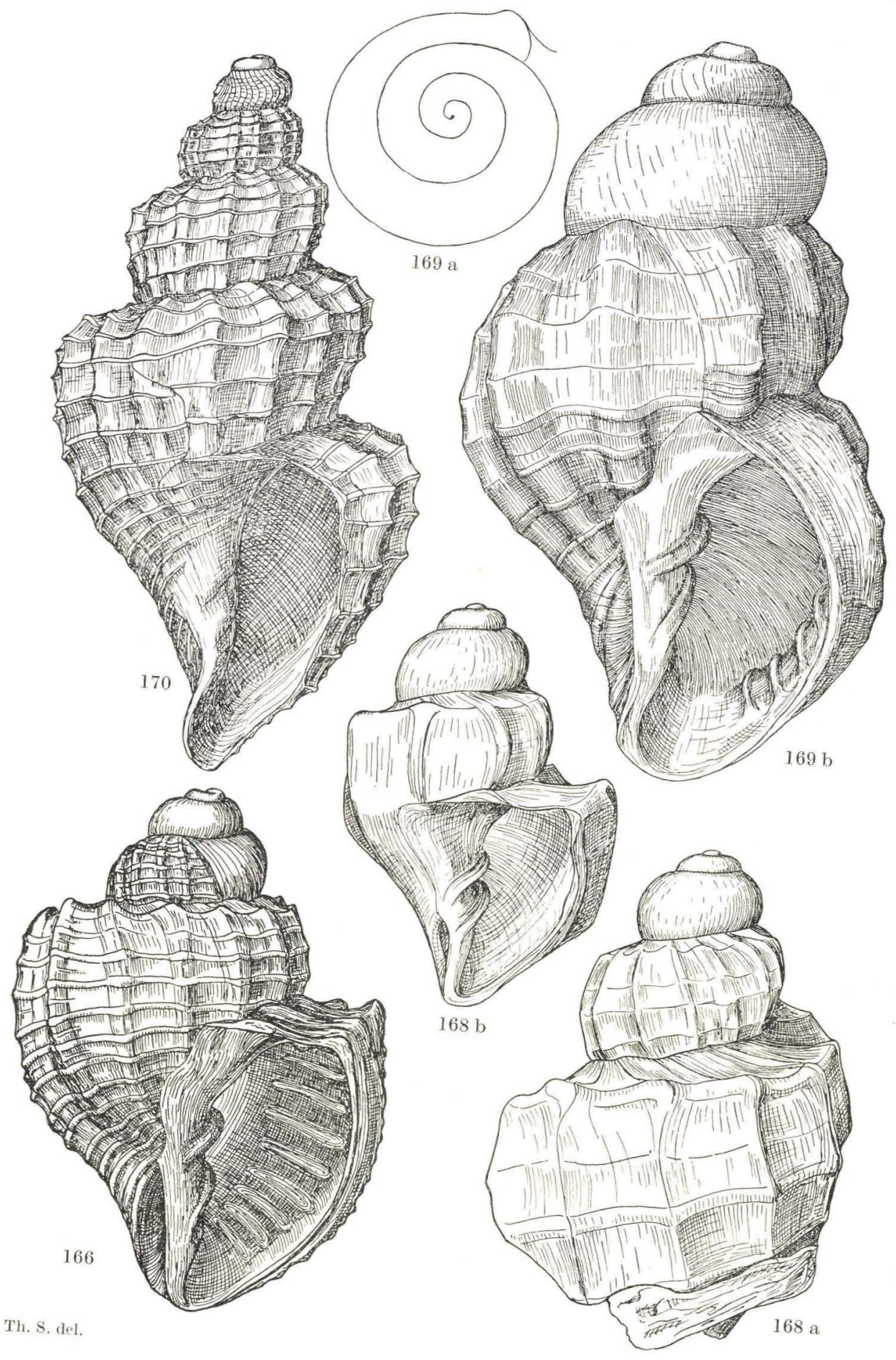


Plate 52.

Location Depth Diameter Height Page

171. Conus Dujardini Deshayes. $(\times 25)$. Bramminge $\quad 70-80 \mathrm{~m} . \quad 1.82 \quad 4.25 \quad 248$

172. Gemmula cf. rotata (BROCCHI).
$(\times 30)$.
Toftlund
75-100
$\begin{array}{lll}1.66 & 3.41 \quad 251\end{array}$

173. Gemmula badensis (HöRNEs).

$(\times 30) . \quad$ Toftlund $\quad 75-100 \quad-\quad 1.83 \quad 3.92 \quad 252$

174a-e. Gemmula boreoturricula (KAUTSKx).

(×21). Toftlund $\quad 105-110 \quad-\quad 1.43 \quad 3.31 \quad 254$

Shell dimensions in millimeters. 


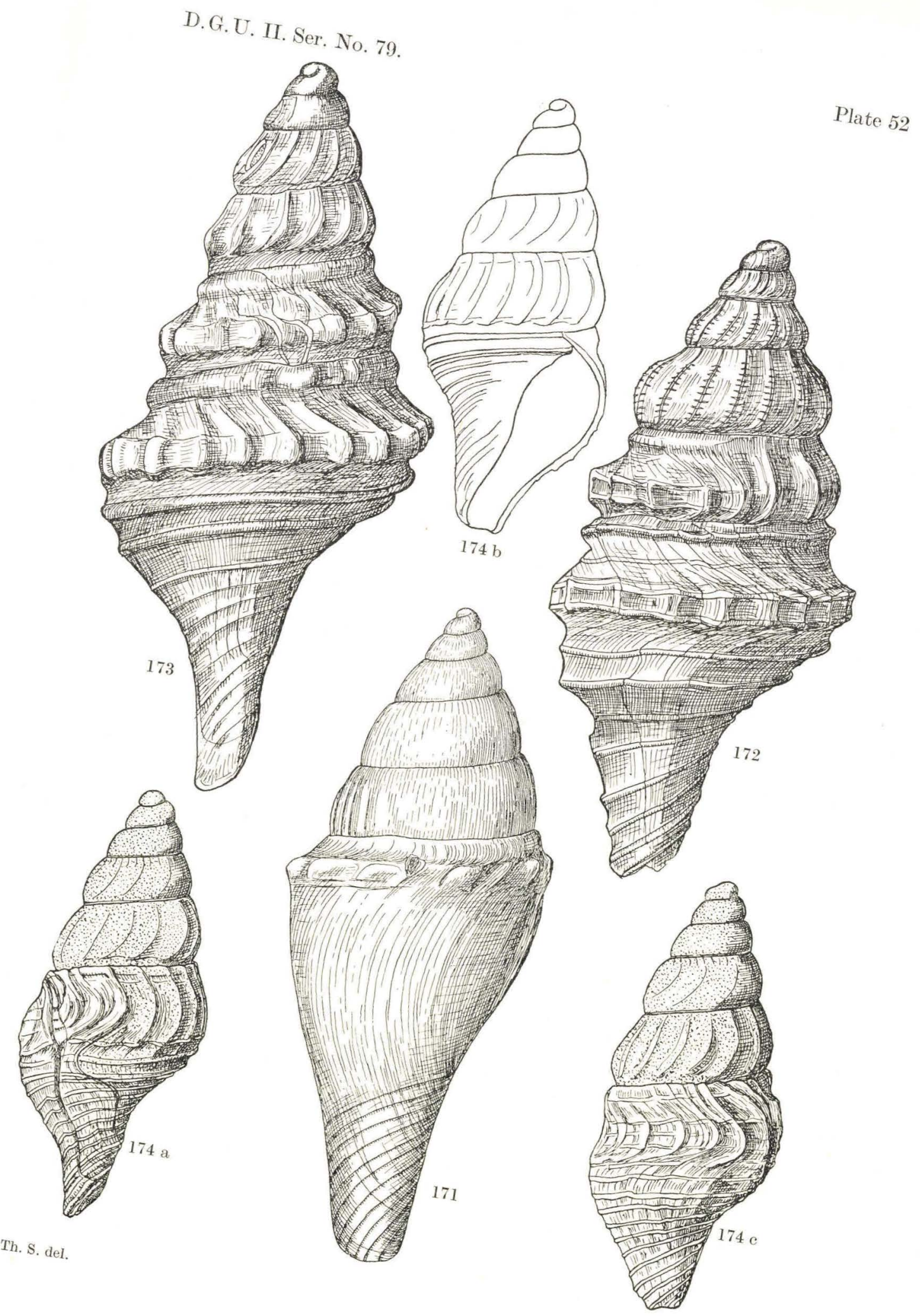




\section{Plate 53.}

174. Gemmula boreoturricula (KAUT-

Location Depth Diameter Height Page SKY). $(\times 31)$.

Toftlund $\quad 75-100 \mathrm{~m} . \quad 1.79 \quad 4.15 \quad 254$

175. Gemmula Stoffelsi (Nyst). (×30). Toftlund $\quad 75-100 \quad-\quad 1.91 \quad 3.99 \quad 256$

176. Gemmula Zimmermanni (PHILIPPI). $(\times 5)$.

Bramminge $\quad 70-80 \quad-\quad 5.2 \quad 12.2 \quad 257$

178. Fusiturris inermis (HöRNES).

$(\times 30) . \quad$ Toftlund $\quad 75-100-\quad 1.54 \quad 3.50 \quad 259$

180a-b. Turricula Steinvorthi (vON

KOENEN). ( $\times 12)$.

Toftlund 110-115 - $\quad 7.2 \quad 262$

Shell dimensions in millimeters. 
D. G. U. II. Ser. No. 79.

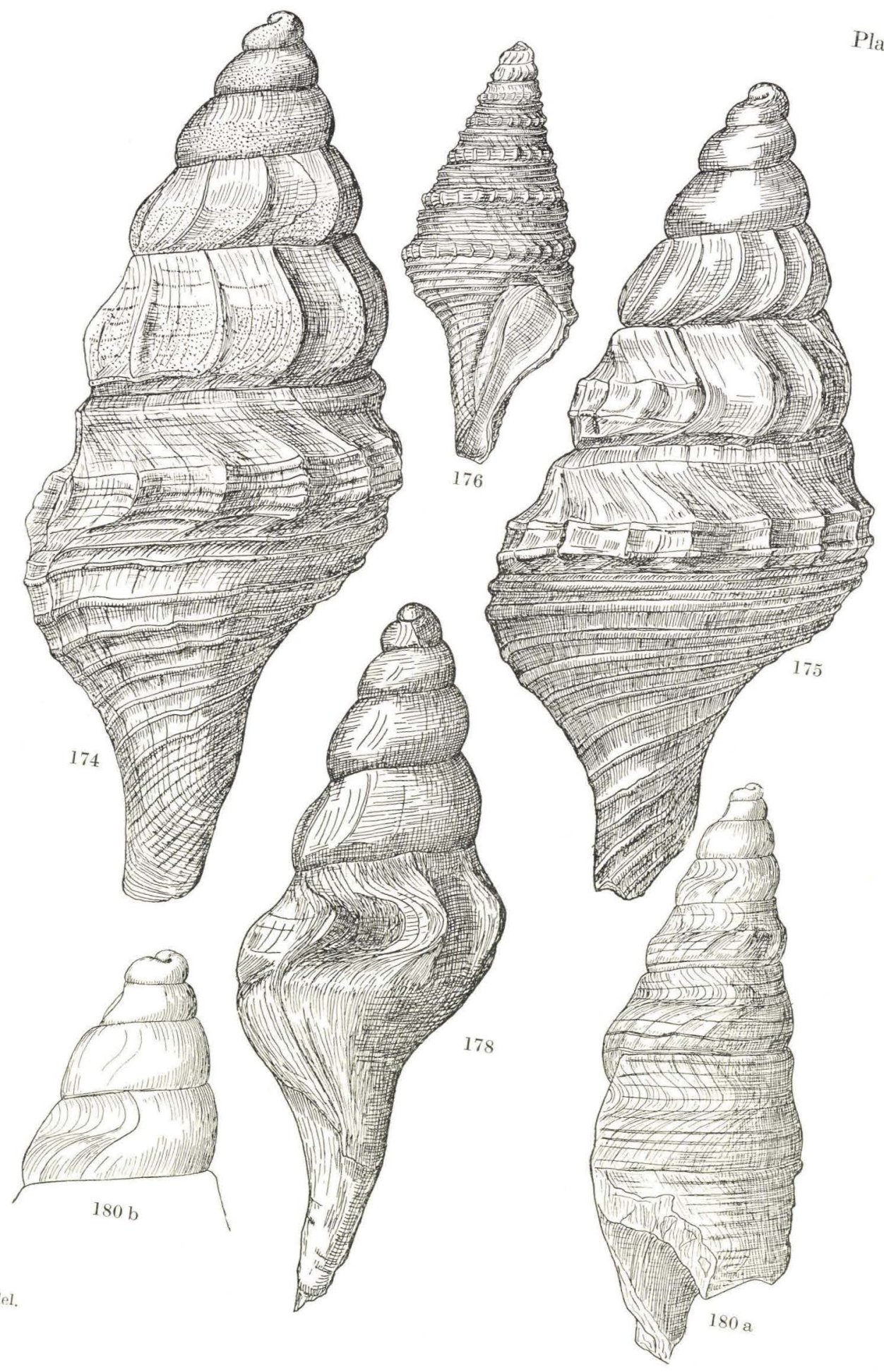




\section{Plate 54.}

Location Depth Diameter Height Page

177. F'usiturris Duchastelii (NYST).
$(\times 31)$.
Toftlund
$75-100 \mathrm{~m}$
1.87
$4.45 \quad 258$

179. Bathytoma cataphracta (BROCCHI),

$\begin{array}{lllllll}(\times 30) . & \text { Toftlund } & 75-100 & - & 1.94 & 3.99 & 260\end{array}$

181a-b. Clinura sp. $(\times 30)$.

$1.62 \quad 2.63 \quad 263$

183a-b. Clavatula boreointerrupta KAUTsky. Juvenile shell. ( $\times 18)$.

Toftlund $105-110-1.55$

$2.35 \quad 264$

Shell dimensions in millimeters. 


\section{G. U. II. Ser. No. 79.}

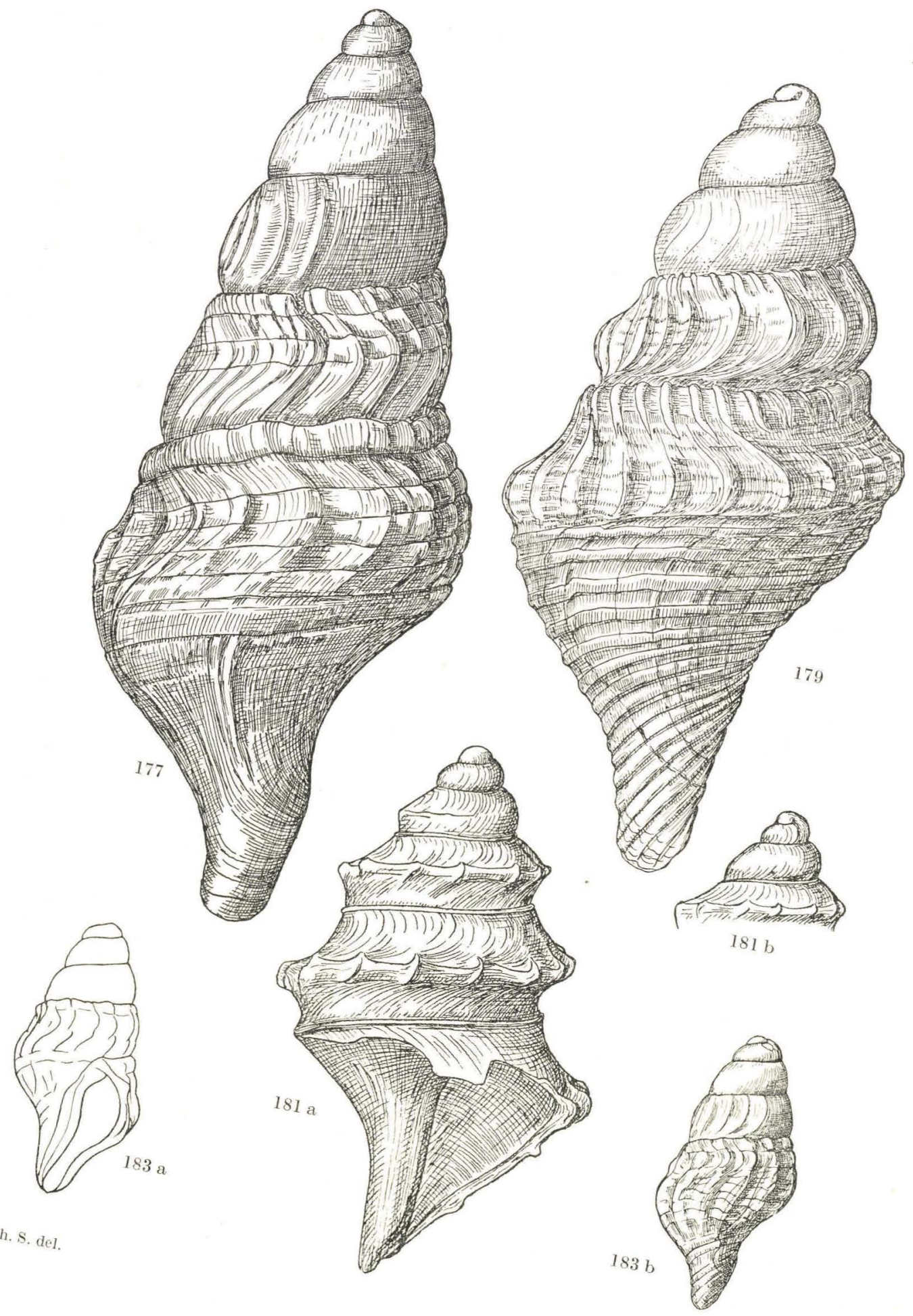

Plate 54 


\section{Plate 55.}

184. Clavatula sp. $(\times 37)$.

186. Genota ramosa (BAsterot)
a. $(\times 25)$
b. $(\times 15)$.

Location Depth Diameter Height Page

Toftlund $\quad 100-105 \mathrm{~m}$. $\quad 1.15 \quad 2.04 \quad 265$

\begin{tabular}{l}
$75-100-2.08-6.07$ \\
\hline
\end{tabular}

Bramminge $\quad 70-80$ - $\quad 3.15 \quad 7.15$

Shell dimensions in millimeters. 
D. G.U. II. Ser. No. 79.

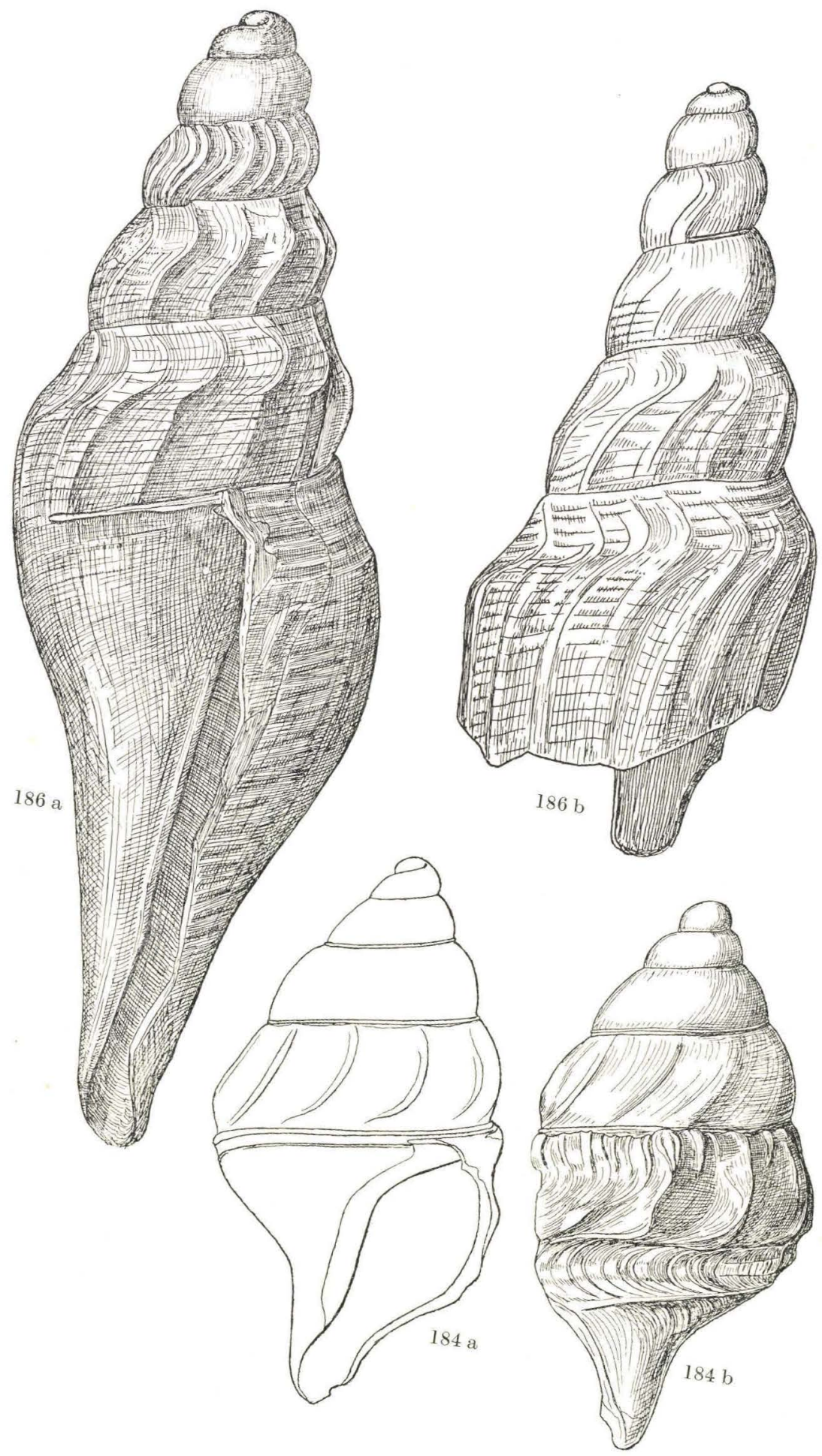

Plate 5.5

Th. S. del. 


\section{Plate 56.}

Location Depth Diameter Height Page

185. Clavatula obliplicatula KAUtsky.

Glejbjerg

$55 \mathrm{~m}$.

4.11

$8.6 \quad 266$

187. Acamptogenotia cf. Escheri (MAYER).

$\begin{array}{llllll}(\times 12) . & \text { Toftlund } & 110-115 \mathrm{~m} . & 4.07 & 8.55 & 267\end{array}$

189. Inquisitor obeliscus (DEs Mou-

LINS). $(\times 25) . \quad$ Toftlund $\quad 75-100 \quad-\quad 1.89 \quad 4.40 \quad 268$

190a-c. Splendrillia Selenkae (von KoE-

NEN). Protoconch $(\times 40)$. Toftlund $105-110 \quad-\quad 0.86 \quad 1.58 \quad 270$

Shell dimensions in millimeters. 
D. G. U. II. Ser. No. 79.

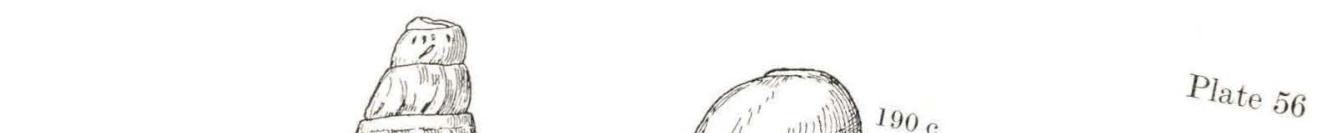




\section{Plate 57.}

Location Depth Diameter Height Page

$191 \mathrm{a}-\mathrm{b}$. Boreodrillia toftlundensis nov. gen.

de nov.sp. $(\times 20) . \quad$ Toftlund $110-115 \mathrm{~m} . \quad 1.85 \quad 3.65 \quad 271$ Holotype.

192. Asthenotoma of. pannus (BASTE-

Rот). $(\times 30) . \quad$ Toftlund $75-100 \quad-\quad 2.00 \quad 4.82 \quad 272$

193. Brachytoma electa nov. sp. $(\times 30)$. Toftlund $\quad 75-100 \quad-\quad 1.74 \quad 4.32 \quad 273$ Holotype.

196a-b. Brachytoma sp. $(\times 10) . \quad$ Glejbjerg $\quad 55-\quad 2.45 \quad 5.85 \quad 277$

Shell dimensions in millimeters. 
D. G. U. II. Ser. No. 79.

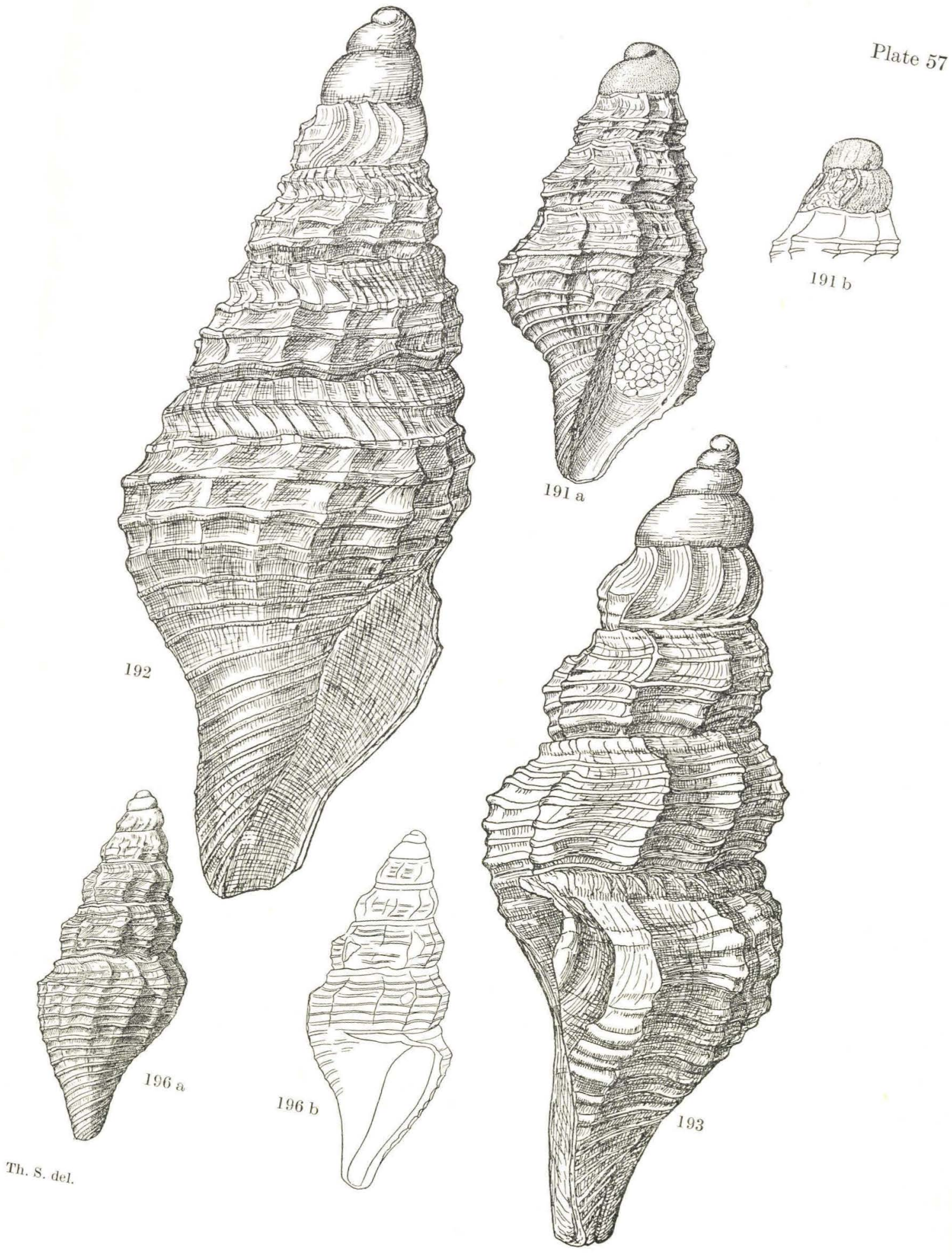




\section{Plate 58.}

Location Depth Diameter Height Page

194a-c. Brachytoma Grateloupi (Реупот) $\quad$ Bramminge $\quad 70-80$ m. $\quad 3.33 \quad 8.80 \quad 274$ (a $\times 15 ; \mathrm{b}-\mathrm{c} \times 30)$.

195. Brachytoma obtusangula (BROcCHI)

$\begin{array}{lllllll}(\times 30) . & \text { Toftlund } \quad 75-100 & - & 2.00 & 4.35 & 275\end{array}$

196. Brachytoma sp. $(\times 10)$. Bramminge $\quad 70-80 \quad-\quad 2.20 \quad 6.70 \quad 277$

Shell dimensions in millimeters. 
D. G. U. II. Ser. No. 70.
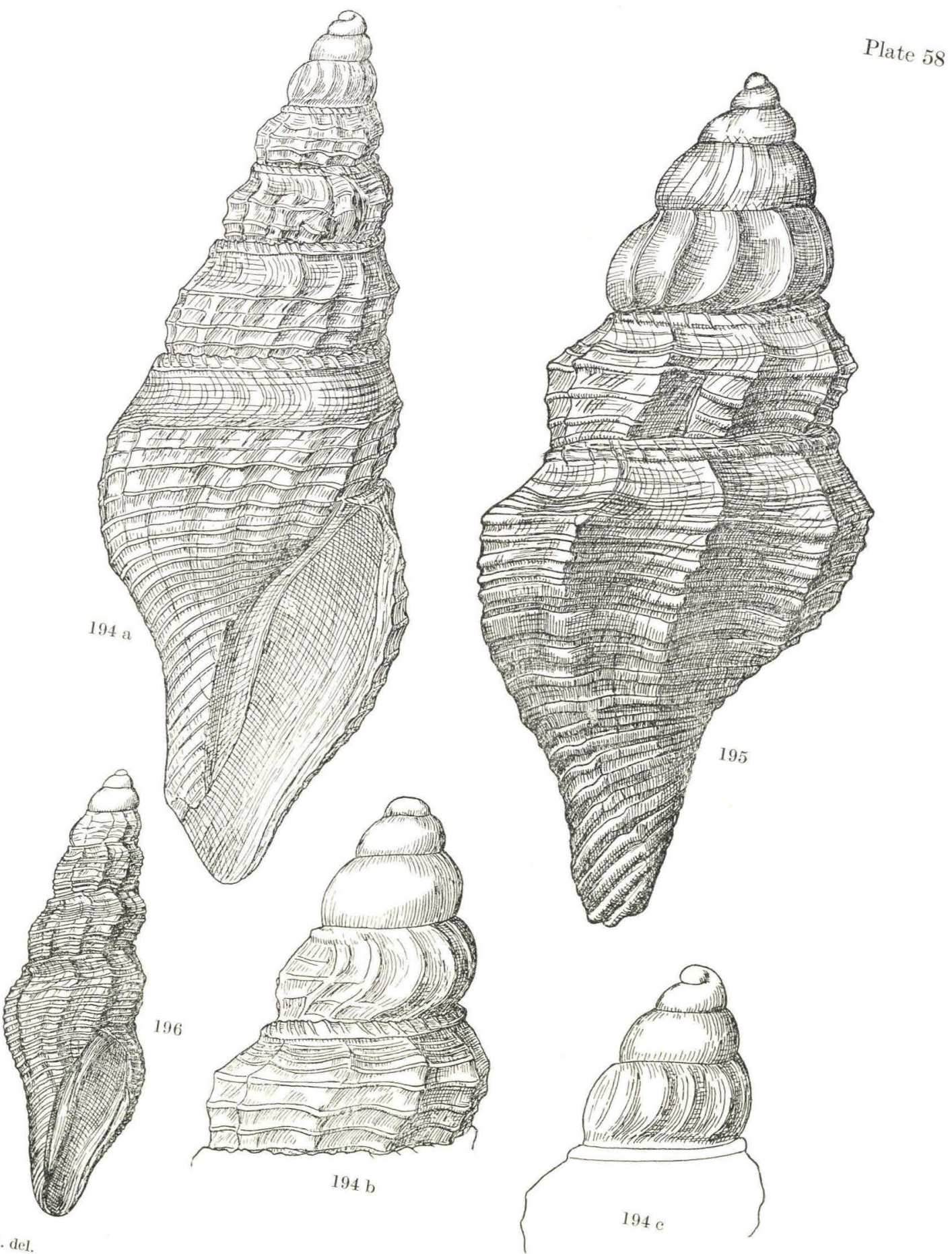


\section{Plate 59.}

Loeation Depth Diameter Height Page

197. Aphanitoma glejbjergensis nov.sp.

$(\times 13)$.

$\begin{array}{lllll}\text { Glejbjerg } & 53 \mathrm{~m} . & 3.4 & 8.4 & 277\end{array}$

Holotype.

198a-c. Neoguraleus calais (KAUtsky.)

$(\times 30)$.

Toftlund $75-100$ -

1.70

$4.15 \quad 278$

199a-b. Neoguraleus tenella (MAYER). $(\times 30)$. Shell with granulated spirals and wide apical angle.

Toftlund $\quad 75-100$

2.10

$4.32 \quad 279$

Shell dimensions in millimeters. 
D. G. U. II. Ser. No. 79.

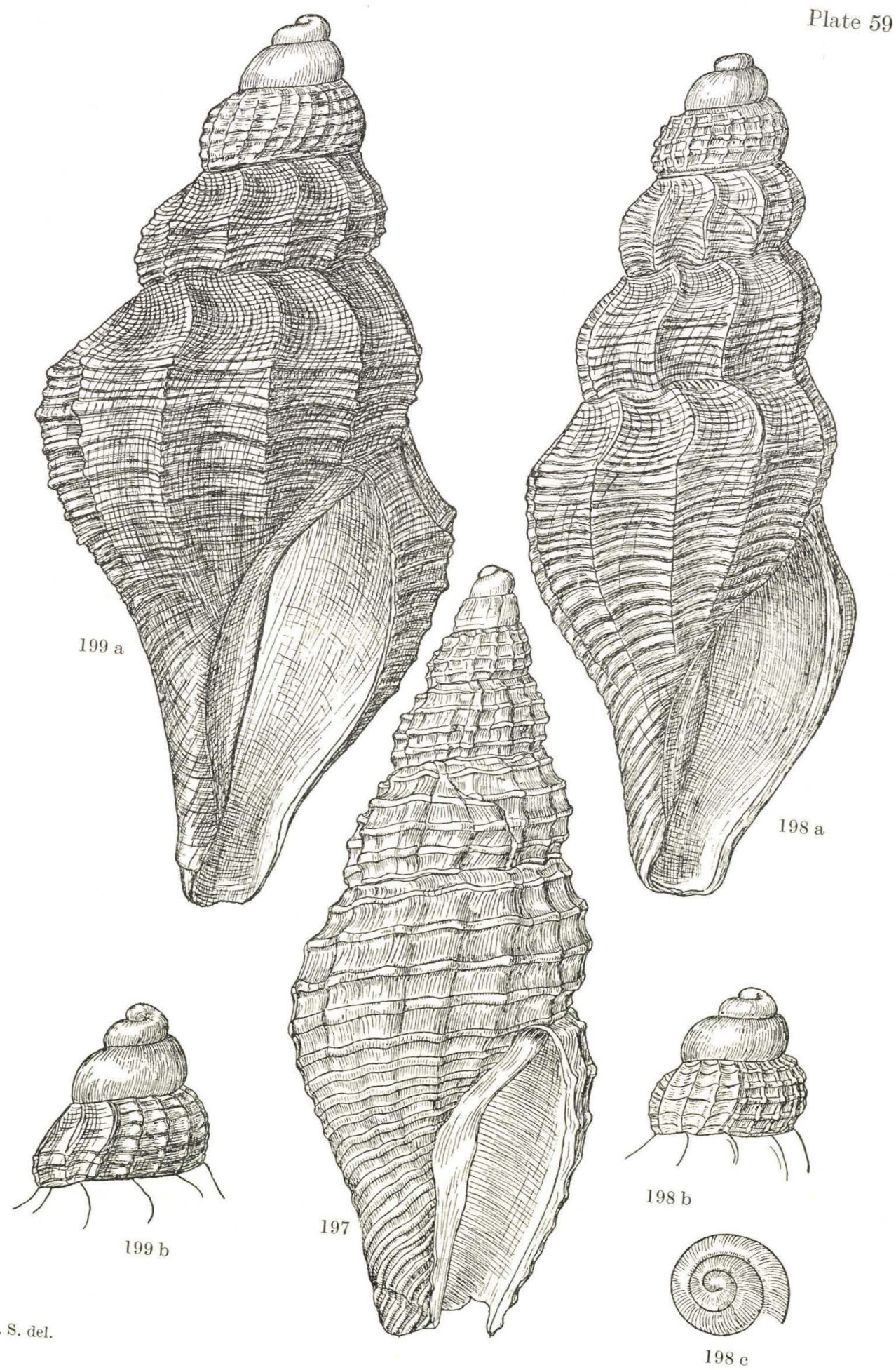




\section{Plate 60.}

Location Depth Diameter Height Page

200a-b. Neoguraleus Gürichi (KAUTskY).

$(\times 25)$.

201. Pleurotomoides Johannae (PEYRОT). $(\times 30)$.

203a-b. Pleurotomoides simplex nov. sp. $(\times 30)$.
Bramminge $\quad 70-80 \mathrm{~m}$. $\quad 1.28 \quad 2.7 \quad 281$

Toftlund $\quad 75-100-\quad 1.58 \quad 3.65 \quad 282$

Toftlund $\quad 75-100 \quad-\quad 1.83 \quad 4.81 \quad 284$

Shell dimensions in millimeters. 
D. G. U. II. Ser. No. 79.

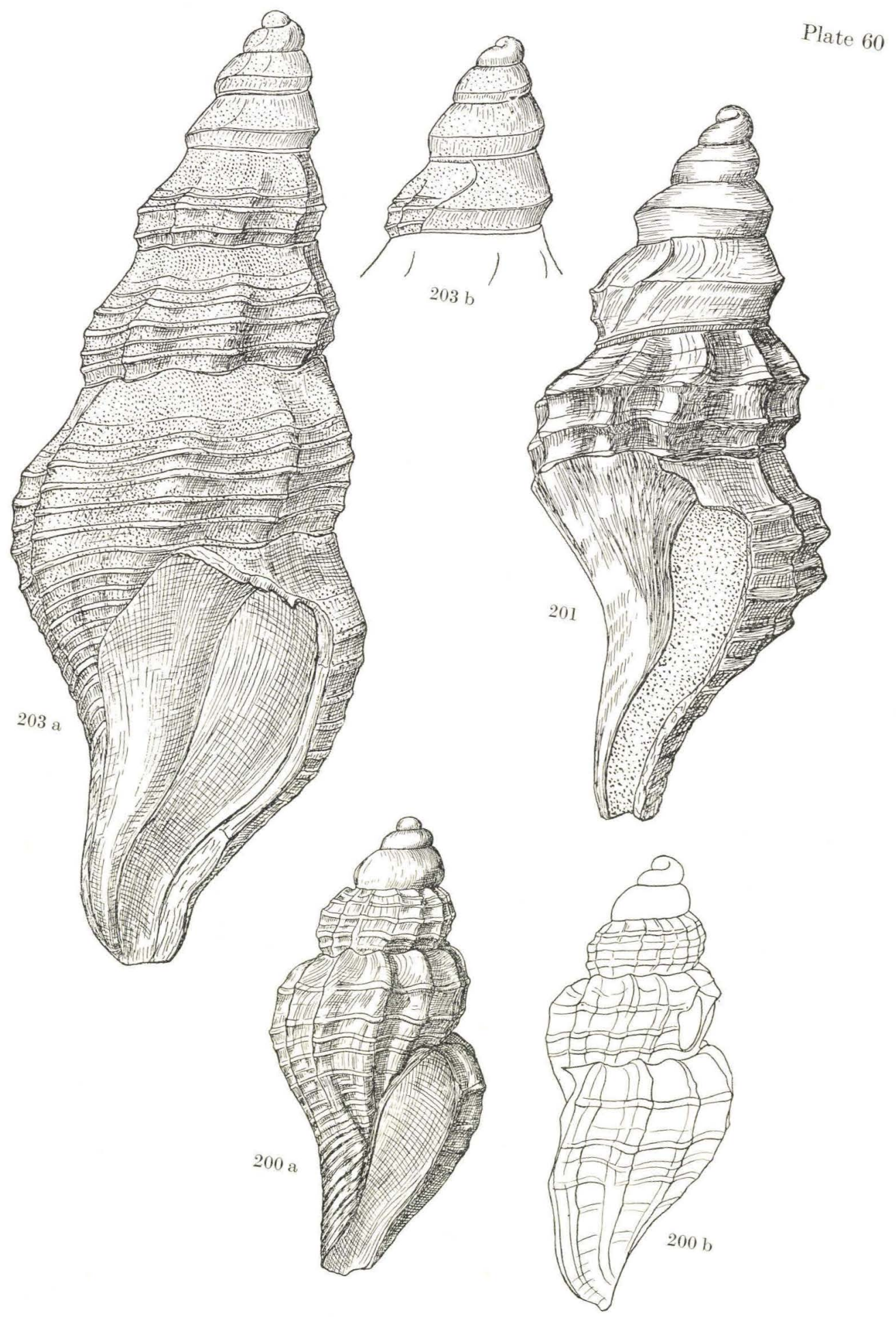




\section{Plate 61.}

Location Depth Diameter Height Page

199. Neoguraleus tenella (MAYER). ( $\times 24)$. Toftlund $\quad 75-100 \mathrm{~m} . \quad 1.77 \quad 4.96 \quad 279$ Normal type.

201. Pleurotomoides Johanna (Реугот).

Toftlund 75-100.

$2.20 \quad 5.7$

282

Shell dimensions in millimeters. 
D. G.U. II. Ser. No. 79

Plate 61
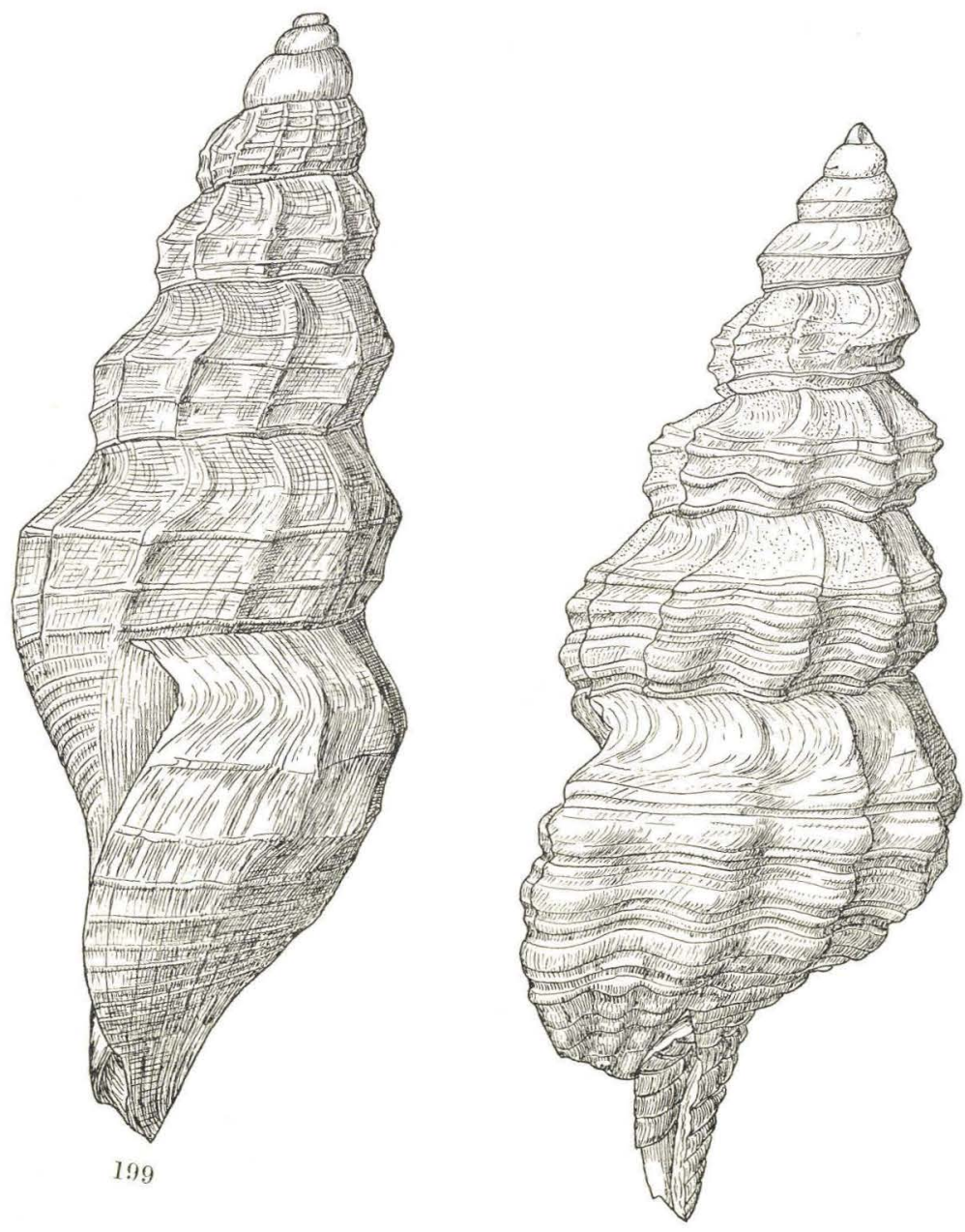

201

Th. S. del. 


\section{Plate 62.}

Location Depth Diameter Height Page

204a-b. Pleurotomoides cf. Luisae (von
Konnen). ( $\times 15)$.
Bramminge $70-80 \mathrm{~m}$
$\begin{array}{lll}2.16 & 4.80 \quad 285\end{array}$

206. Teretia anceps (EICHWALD). $(\times 30)$. Toftlund

$75-100$ -

$\begin{array}{lll}1.33 & 3.50 \quad 287\end{array}$

208

Philbertia scabra (PHILIPPI). ( $\times 30)$. Toftlun

$75-100$

2.50

$4.72 \quad 289$

Shell dimensions in millimeters. 
D. G.U. II. Ser. No. 79.

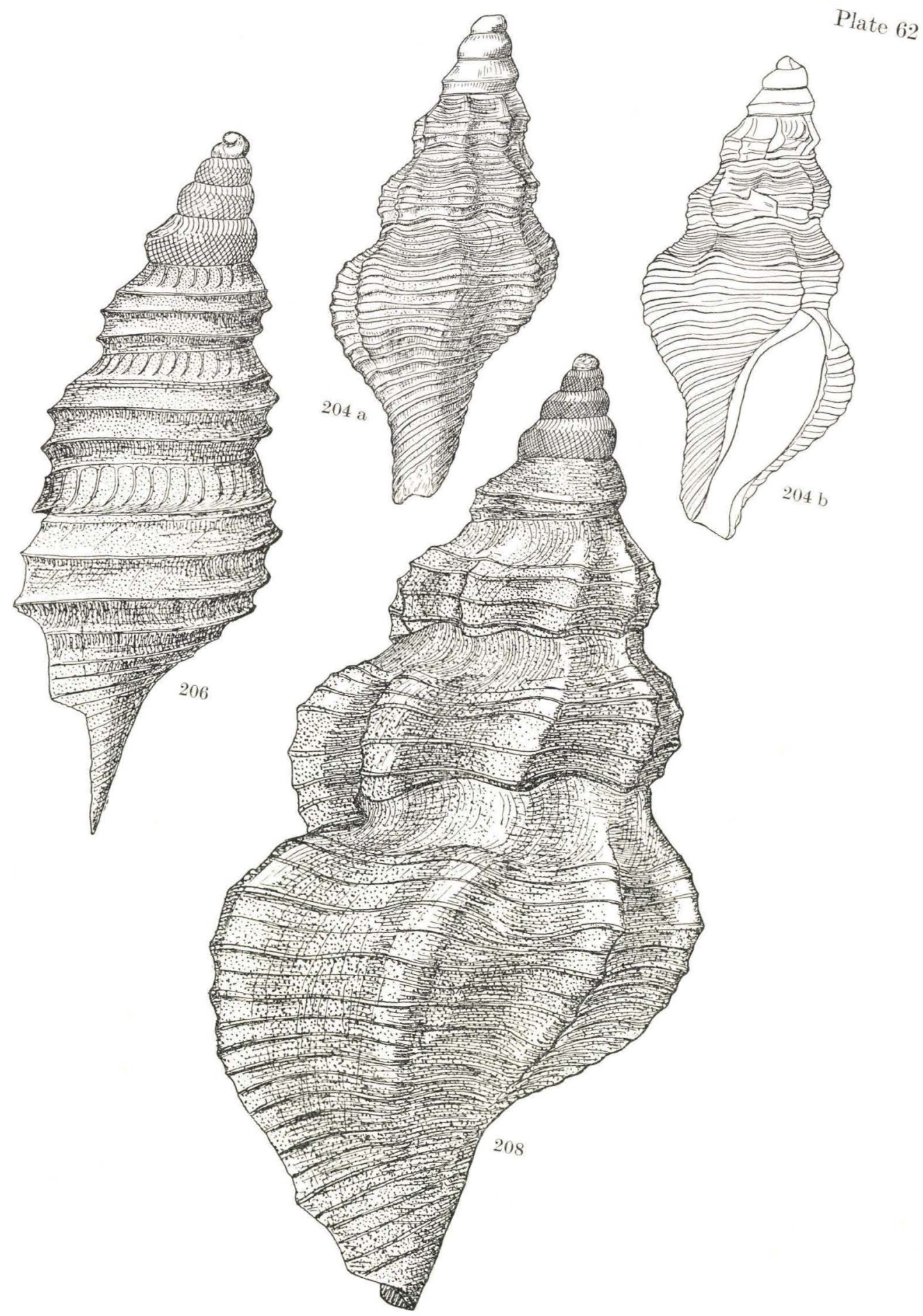




\section{Plate 63.}

Location Depth Diameter Height Page

205. Pleurotomoides campanulata nov.

$\begin{array}{llllll}s p .(\times 30) . & \text { Toftlund } & 75-100 \mathrm{~m} . & 1.87 & 4.74 & 286 \\ \text { Holotype. } & & & & & \end{array}$

209a-c. Philbertia sinuosula nov. sp.

a. $(\times 30)$.

Bramminge 70-80- $\quad 4.08$

b-c. $(\times 39)$.

Toftlund 110-115 - $\quad 1.00 \quad 1.98$

Shell dimensions in millimeters. 
D. G. U. II. Ser. No. 79.

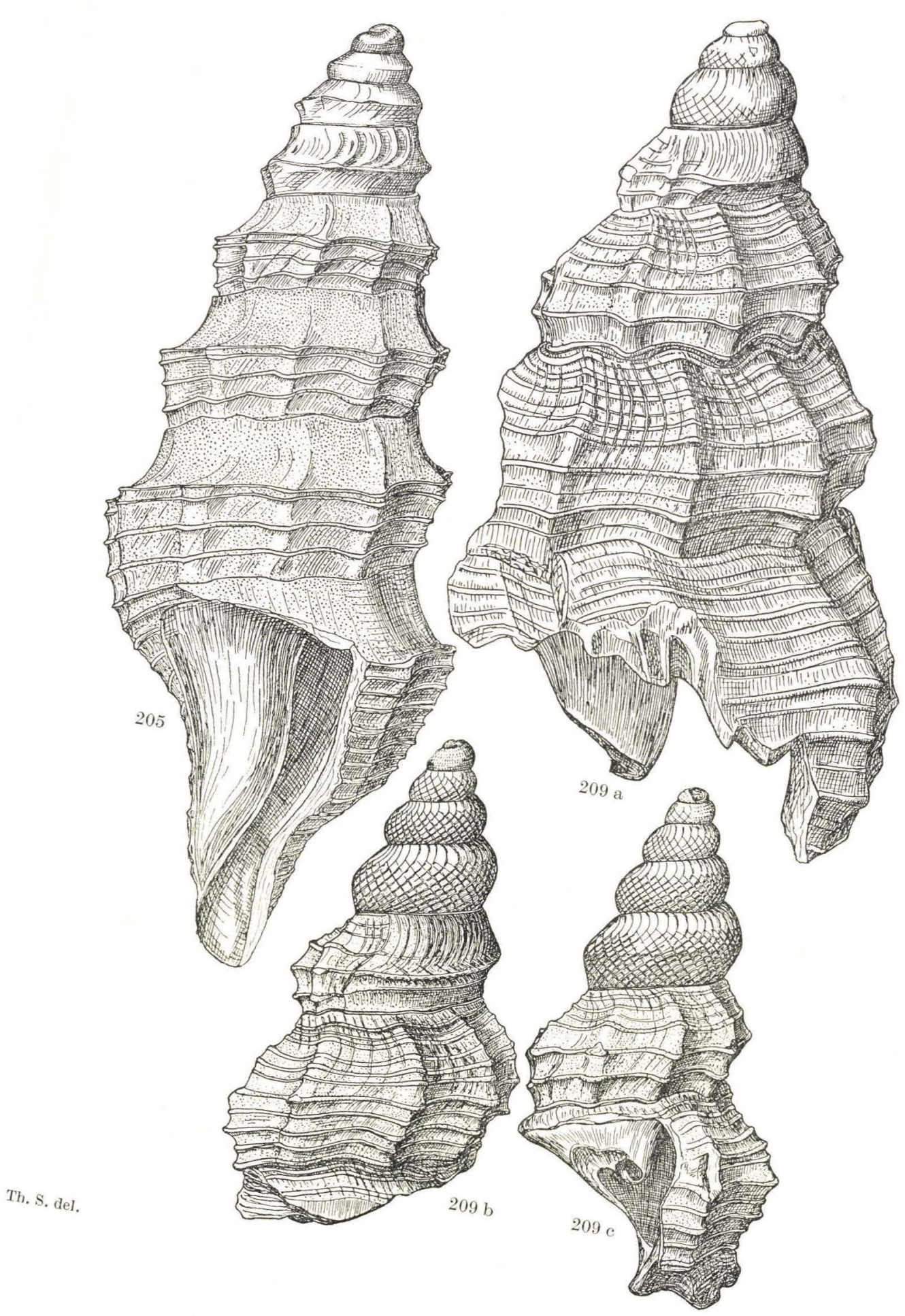




\section{Plate 64.}

Location Depth Diameter Height Page

210a. Eubela trochlearis (HöRnEs). ( $\times 29)$. Bramminge $\quad 70-80 \mathrm{~m} . \quad 1.75 \quad 3.30 \quad 291$ 210b. Eubela trochlearis (HöRNES).

Shell from the Lower Miocene at

Klintinghoved. $(\times 29)$.

212. Metuonella Grippi (KaUtsky).
( $\times 31)$.
Toftlund
$115 \quad-\quad 2.05 \quad 5.1 \quad 293$

213 a-e. Oenopota sp. $(\times 40)$.

Toftlund 110-115 -

$\begin{array}{lll}0.68 & 1.05 \quad 295\end{array}$

Shell dimensions in millimeters. 
D. G. U. II. Ser. No. 79 .

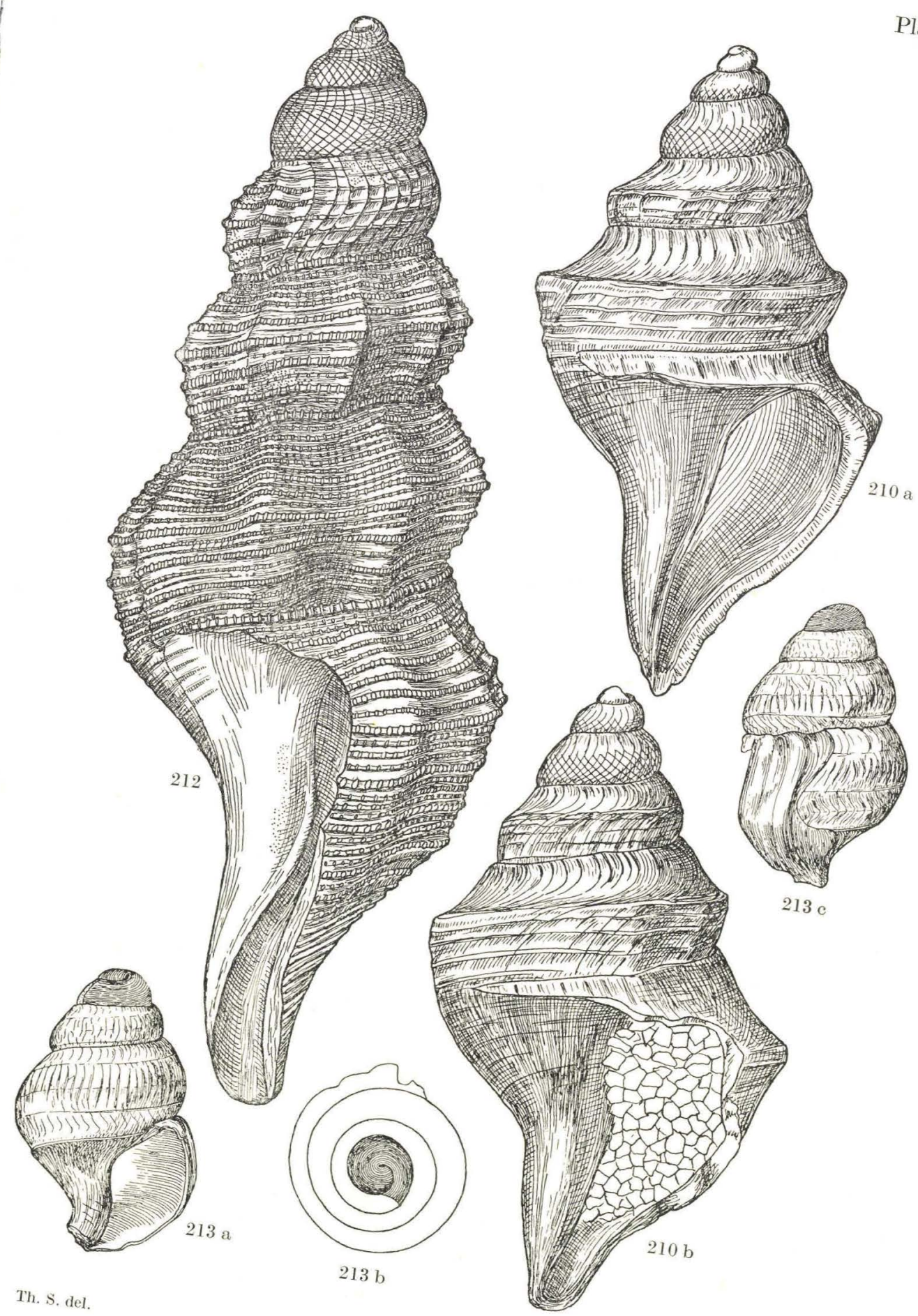




\section{Plate 65.}

\begin{tabular}{|c|c|c|c|c|c|c|}
\hline & & Location & Depth 1 & Diameter & Height & Page \\
\hline 214. & Terebra Hörnesi Вечвісн. ( × 31$)$. & Toftlund & $75-100 \mathrm{~m}$. & 1.72 & 4.97 & 295 \\
\hline 216. & $\begin{array}{l}\text { Acteon semistriatus (BASTEROT). } \\
(\times 30) \text {. }\end{array}$ & Toftlund & $75-100-$ & 1.58 & 2.91 & 298 \\
\hline & $\begin{array}{l}\text { Acteon laevigatus Grateloup. } \\
(\times 30) \text {. }\end{array}$ & Toftlund & $75-100-$ & 1.20 & 2.60 & 300 \\
\hline
\end{tabular}


D. G. U. II. Ser. No. 79.
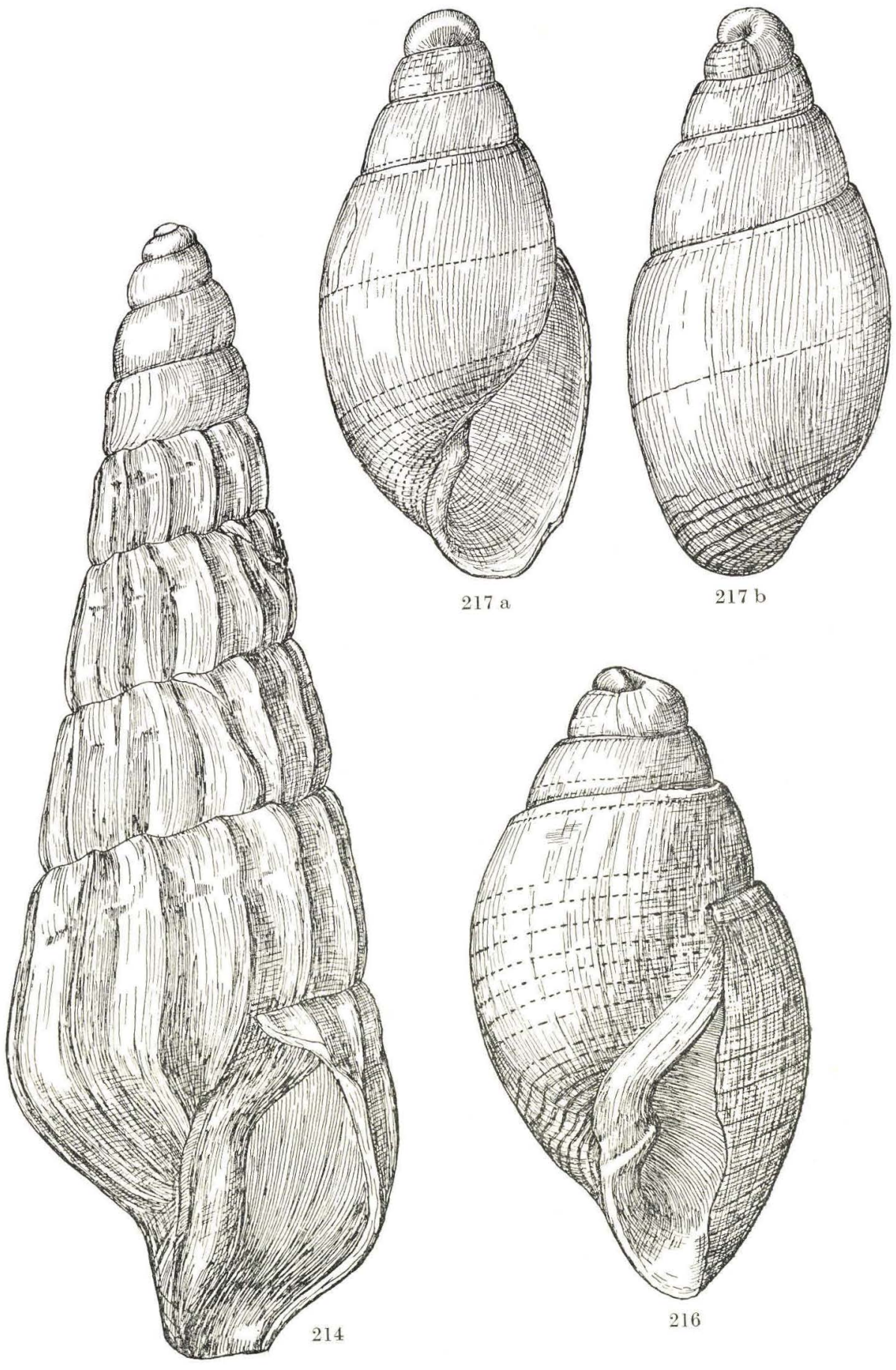

Th. S. del. 


\section{Plate 66.}

Location Depth Diameter Height Page

220a-c. Acteon tornatilis (LrNné). ( $\times 30)$.

Toftlund $\quad 75-100 \mathrm{~m} . \quad 1.75 \quad 2.63 \quad 303$

$221 \mathrm{a}-\mathrm{b}$. Acteon sp. $(\times 15)$.

Toftlund $\quad 75-100-2.58 \quad 3.41 \quad 304$

223a-b. Chrysallida of. cimbrica (KAUTSKY).

$(\times 58)$. Arnum (13) $53-84 \quad-\quad 0.58 \quad 1.25 \quad 305$

224. Chrysallida nodifera nov.sp. $(\times 55)$. Toftlund $\quad 75-100 \quad-\quad 0.66 \quad 1.42 \quad 306$

Shell dimensions in millimeters. 


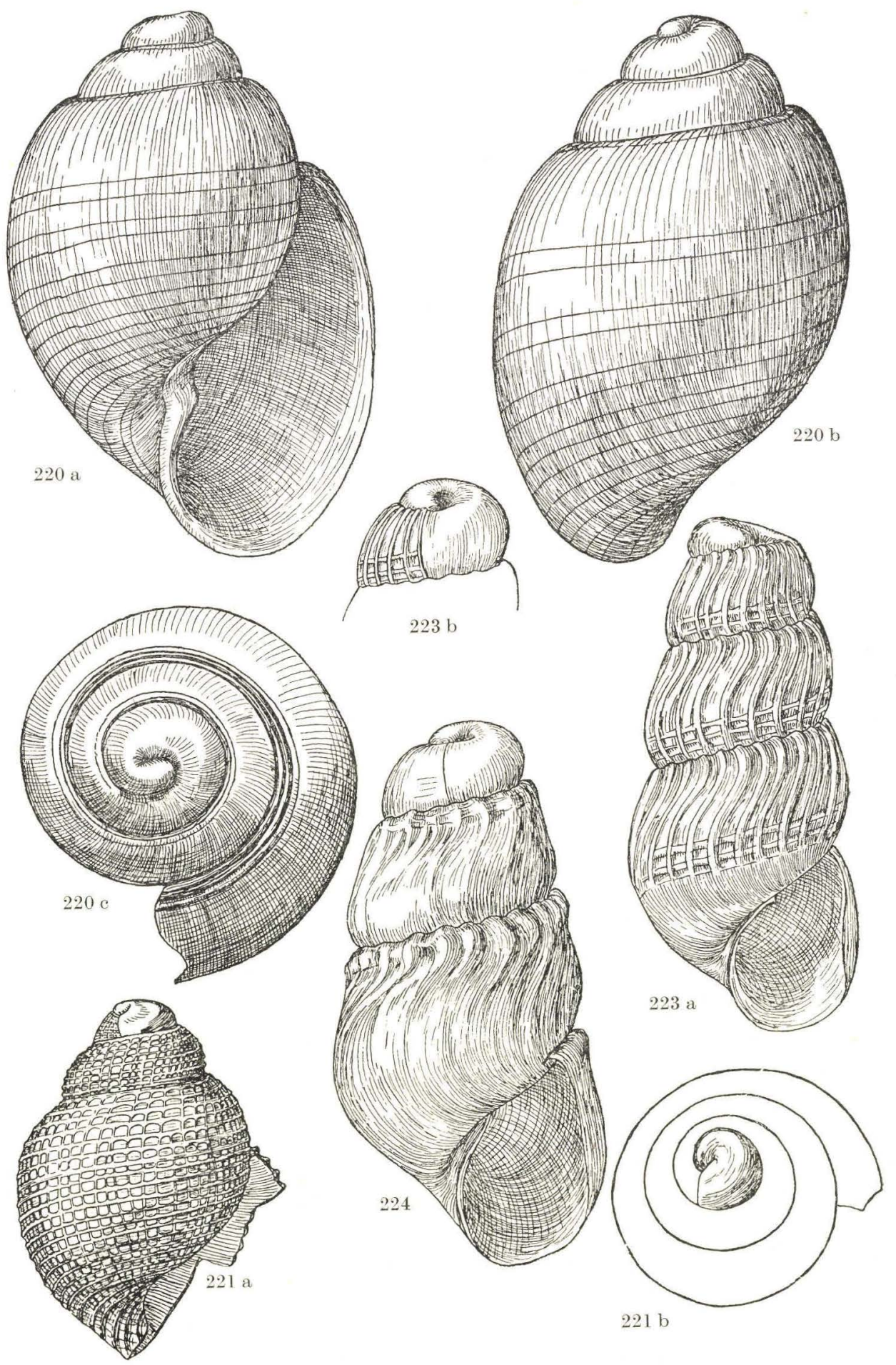

Th. S. del. 


\section{Plate 67.}

Location Depth Diameter Height Page

224. Chrysallida nodifera nov. sp. $(\times 26)$. Toftlund $\quad 75-100 \mathrm{~m} . \quad 0.81 \quad 1.92 \quad 306$ Holotype.

225. Chrysallida toftlundensis nov. sp.

$\begin{array}{lllllll}(\times 42.5) . & \text { Toftlund } & 75-100 & - & 0.55 & 1.24 & 307\end{array}$

Holotype.

226a-b. Chrysallida acuticostata nov. sp. $(\times 42)$.

Holotype.

227a-b. Chrysallida semireticulata nov.sp. $(\times 42)$.

Arnum (25b) 62.7-62.9 - $\quad 0.69 \quad 1.50 \quad 308$

Holotype.

228a-b. Chrysallida modesta nov. sp. (×42). Arnum(25b) 62.7-62.9- $\quad 0.56 \quad 1.47 \quad 309$ Holotype.

Shell dimensions in millimeters. 
D. G. U. II. Ser. No. 79.
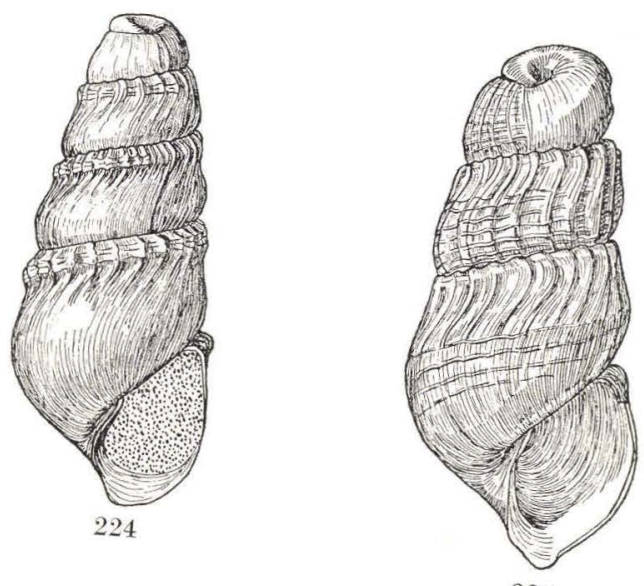

Plate 67
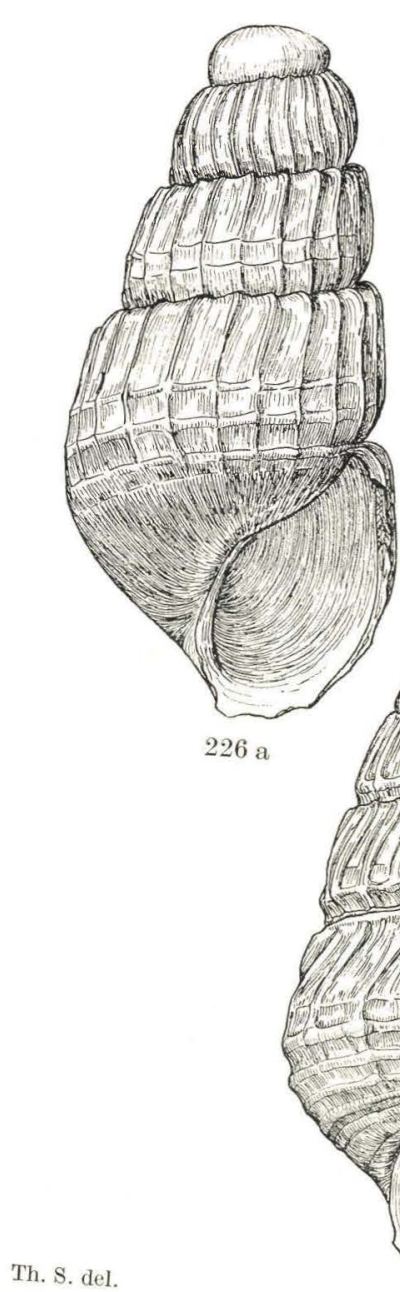

225

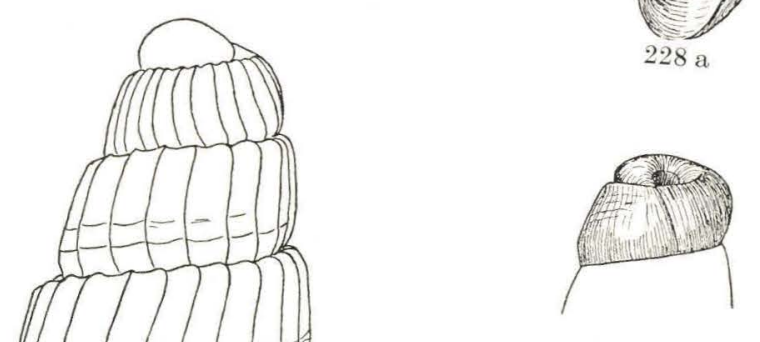

226 a

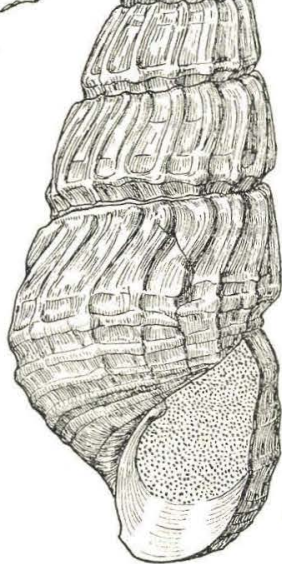

227 a
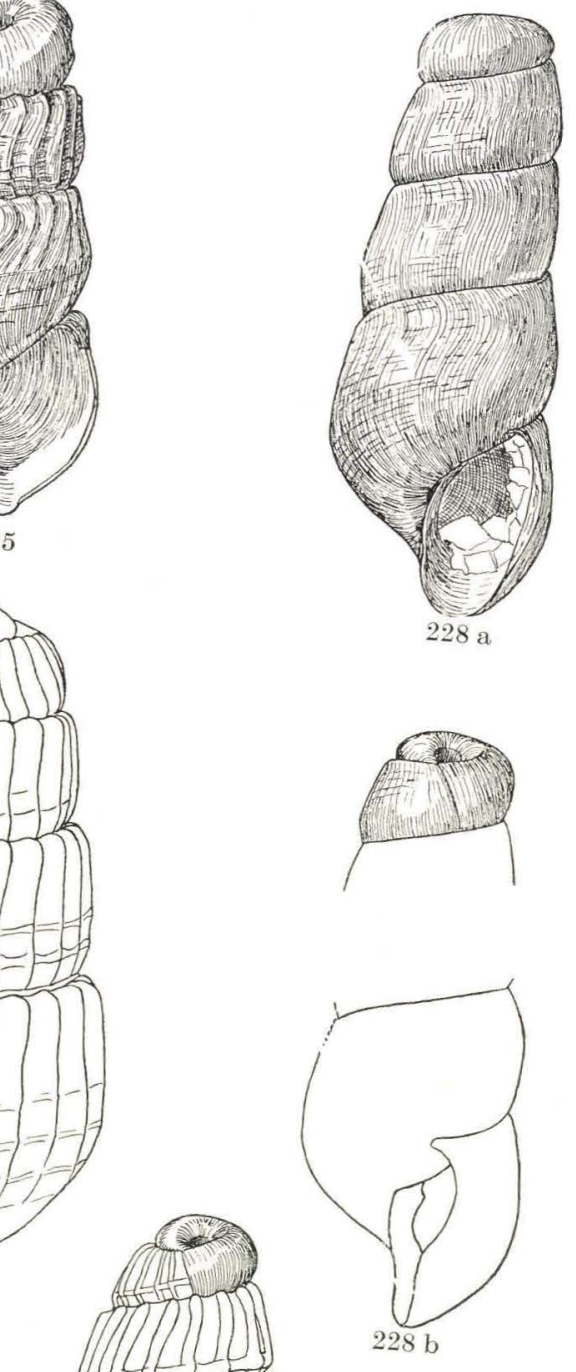

Th. S. deI.

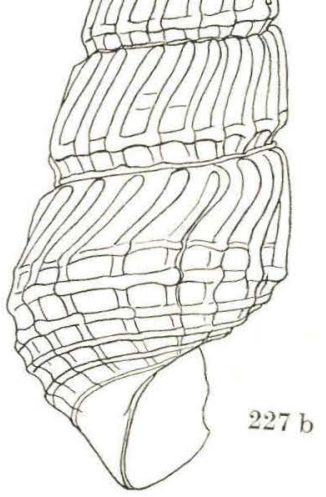




\section{Plate 68.}

Location Depth Diameter Height Page

228. Chrysallida modesta nov.sp. $(\times 60)$. Arnum (13) $\quad 53-83 \mathrm{~m} . \quad 0.42 \quad 0.87 \quad 309$

229. Chrysallida pygmaea (GRATE-

LOUP $(\times 60) . \quad$ Arnum (13) $\quad 53-83 \quad-\quad 0.66 \quad 1.08 \quad 309$

230a-c. Kleinella (Leucotina) Nordmanni nov. sp.

310

a. Holotype. $(\times 30)$ Toftlund $\quad 75-100 \quad-\quad 1.16 \quad 2.54$

b-c. juvenile shell. $(\mathrm{b} \times 17 ; \mathrm{c} \times 45)$. Toftlund $105-110 \quad-\quad 0.92 \quad 1.45$

233a-b. Odostomia sallespissensis (Coss-

MANN \& Peyrot $)(\times 30) . \quad$ Toftlund $\quad 75-100 \quad-\quad 1.08 \quad 2.50 \quad 315$

234a-e. Odostomia pallidaeformis (SACCO)

a-b. $(\times 30)$.

316

c-e. $(\times 30)$.

Toftlund $\quad 75-100-1.04 \quad 2.33$

Arnum (13) $\quad 53-84 \quad-\quad 0.66 \quad 1.45$

Shell dimensions in millimeters. 
D. G. U. II. Ser. NO. 79.
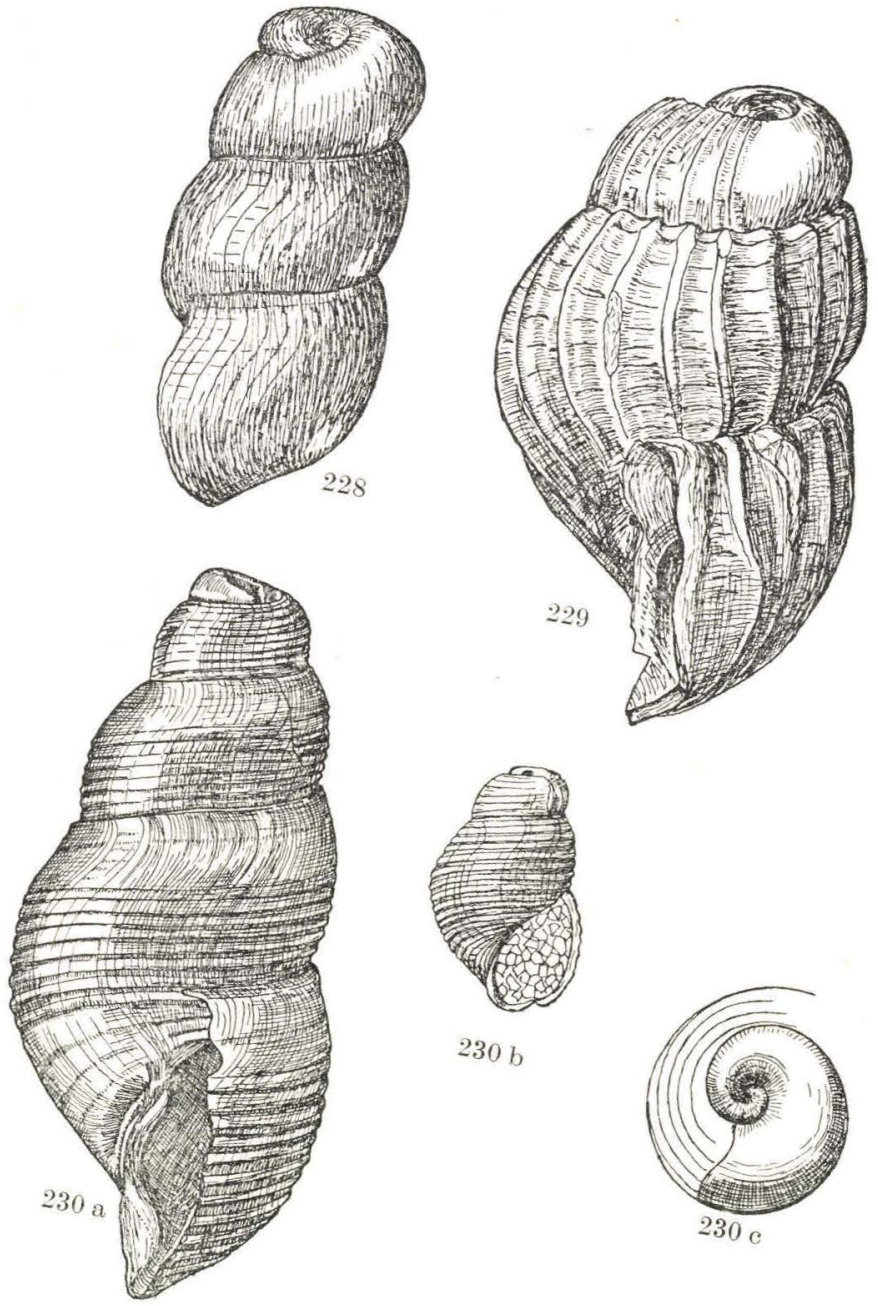

$230 \mathrm{~b}$
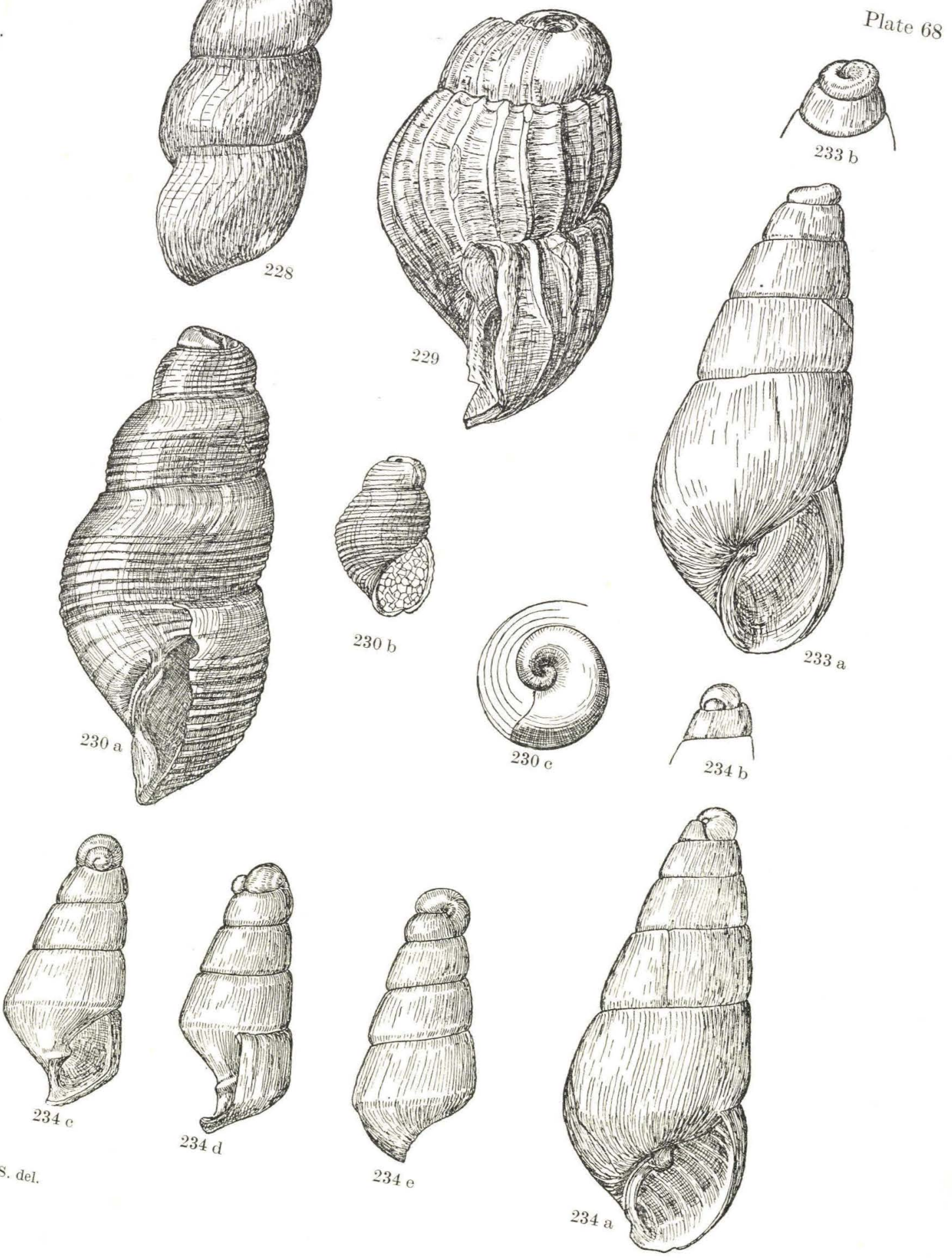


\section{Plate 69.}

$$
\text { Location Depth Diameter Height Page }
$$

235a-b. Odostomia mutinensis (SACCO).

$$
\begin{aligned}
& (\times 30) \text {. } \\
& \text { Normal type with shoulder. }
\end{aligned}
$$$$
\begin{array}{lllll}
\text { Toftlund } & 75-100 \mathrm{~m} . & 1.08 & 2.08 & 317
\end{array}
$$

237. Odostomia (Syrnola) dubia (GRA-

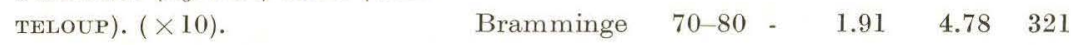

238a-b. Eulimella concinna nov.sp. $(\times 60)$. Arnum (13) $\quad 53-83 \quad-\quad 0.58 \quad 1.69 \quad 321$

239a-c. Eulimella Scillae (SCACCHI) (×18). Toftlund $105-110 \quad-\quad 0.97 \quad 3.2 \quad 322$

241a-b. Eulimella crassitesta nov. sp. $(\times 18)$. Bramminge $\quad 70-80-\quad \begin{array}{llll}1.21 & 3.63 & 325\end{array}$

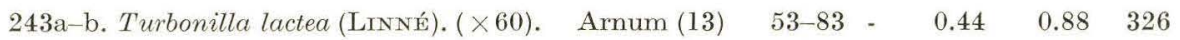

Shell dimensions in millimeters. 
D. G. U. II. Ser. No. 79.

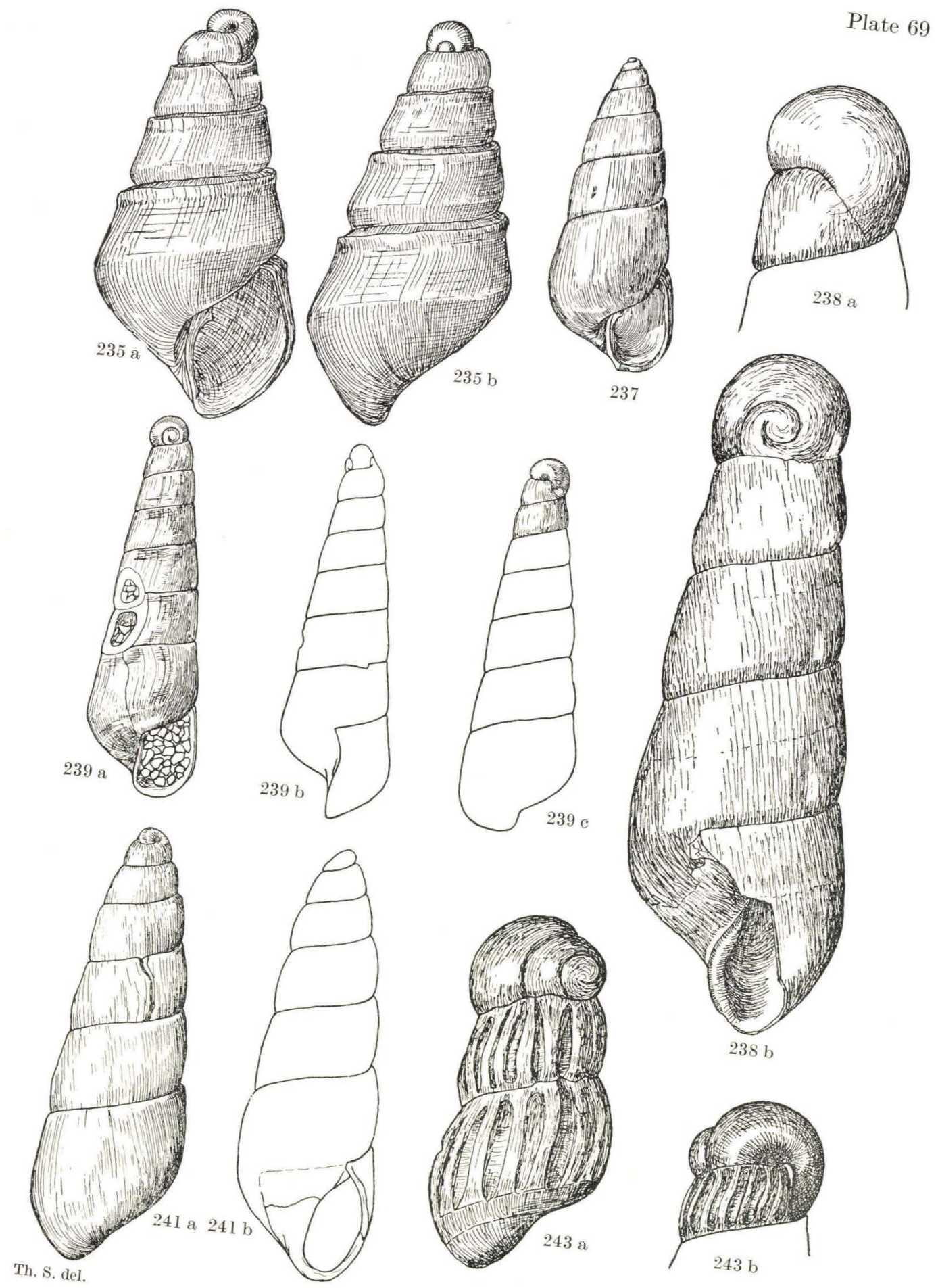




\section{Plate 70.}

Location Depth Diameter Height Page

231a-e. Odostomia conoidea (BrocchI). Toftlund $105-110 \mathrm{~m}$.
a. $(\times 21)$.
$1.14 \quad 2.44$
b. $(\times 21)$.
$1.12 \quad 2.02$
e. $(\times 21)$.
$1.08 \quad 1.93$

232. Odostomia subintermedia (CossMANN \& Peyrot). $(\times 21) . \quad$ Arnum(25b)62.7-62.9 $-\quad 0.77 \quad 1.70 \quad 314$

234. Odostcmia pallidaeformis (SACCO). $(\times 21)$

Toftlund $\quad 105-110 \quad-0.82 \quad 1.84 \quad 316$

235. Odostomia mutinensis (SAcco). Smooth type without shoulder. $(\times 21)$.

Toftlund 105-110 -

1.21

236. Odostomia (Syrnola) subumbilicata

$\begin{array}{lllllll}\text { (Grateloup). }(\times 21) . & \text { Glejbjerg } & 53.5 & - & 1.34 & 4.16 & 320\end{array}$

238. Eulimella concinna nov.sp. $(\times 21,5)$. Toftlund $\quad 105-110-\quad 1.09 \quad 4.45 \quad 321$ Holotype.

241. Eulimella crassitesta nov.sp. $(\times 26)$. Gramby $82.66-83.76-\quad 0.96 \quad 2.46 \quad 325$ Holotype.

242. Turbonilla costellata (GRATELOUP). $(\times 26)$.

Shell dimensions in millimeters. 
D. G. U. II. Ser. No. 79.

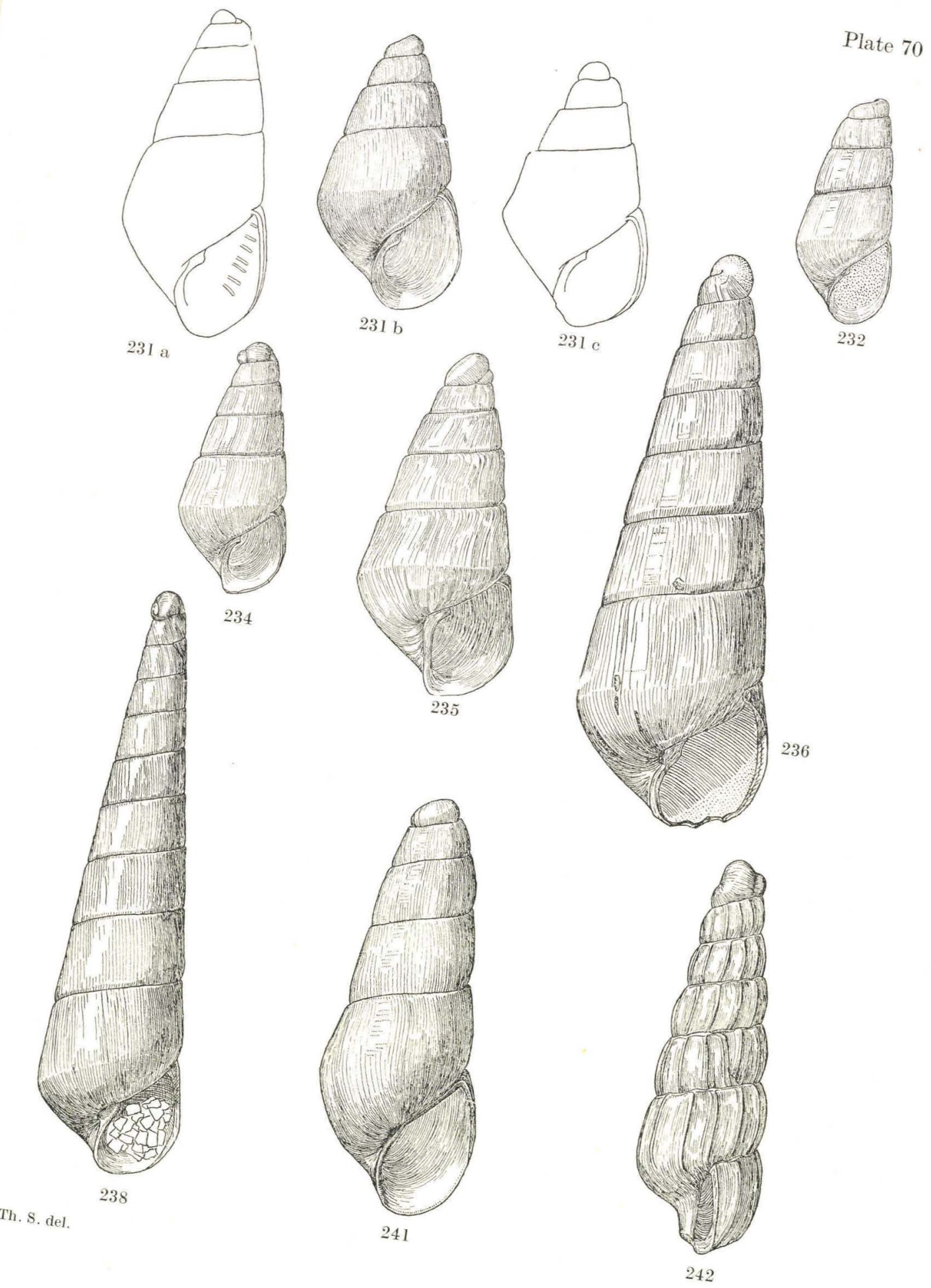


Plate 71.

Location Depth Diameter Height Page 243. Turbonilla lactea (L.). $(\times 26) . \quad$ Arnum(25b) $62.7-62.9 \mathrm{~m} . \quad 0.89 \quad 3.27 \quad 326$

246. Turbonilla sp. $(\times 26)$. Tramby $82.66-83.76-4.41 \quad 4.65 \quad 331$ Shell dimensions in millimeters. 
D. G. U. II. Ser. No. 79.

Plate 71
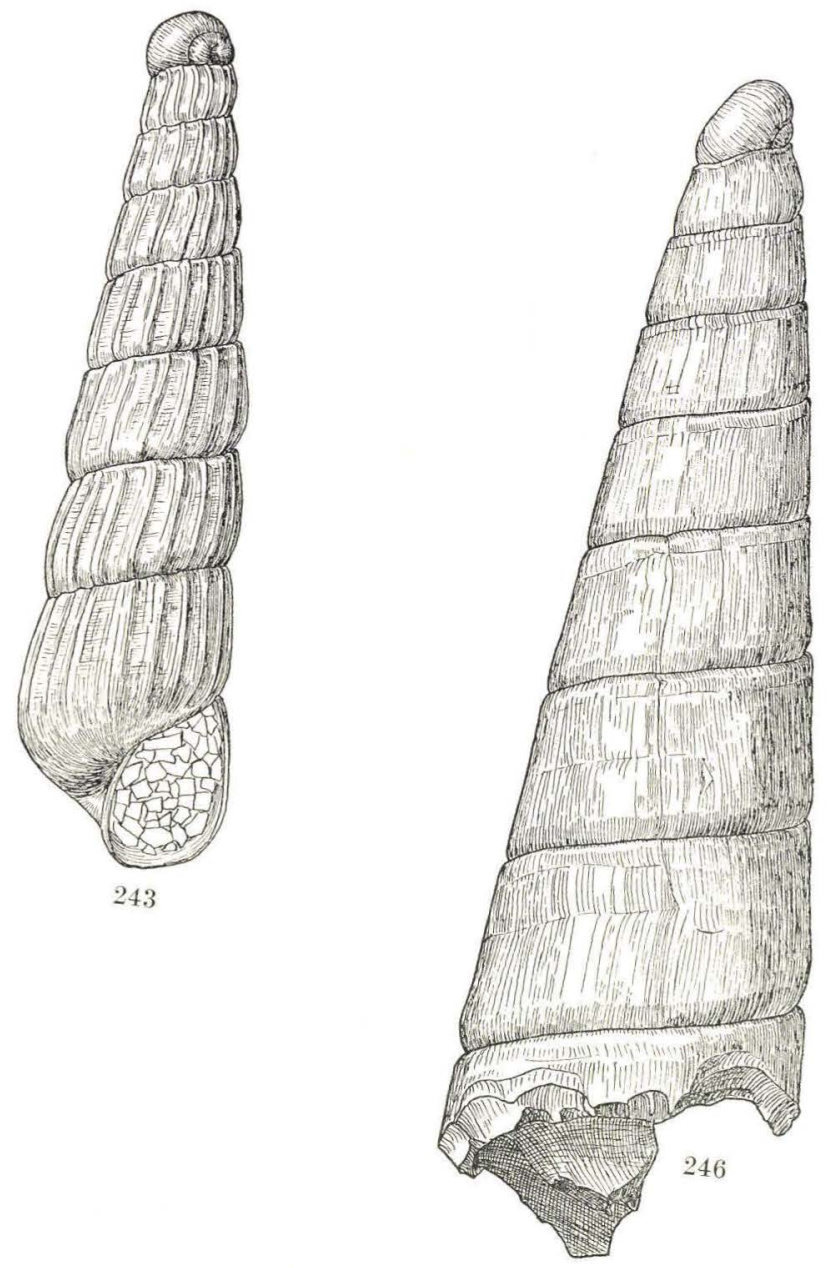

Th. S. del. 
Plate 72.

Location Depth Diameter Height Pagə 244a-c. Turbonilla rufa (PніLгтPI). (×30). Arnum (13) $\quad 53-83$ m. $\quad 0.75 \quad 2.19 \quad 328$ 245a-c. Turbonilla pseudoterebralis (SACCO).

$\begin{array}{lllllll}(\times 36) & \text { Toftlund } & 105-110 \mathrm{~m} . & 0.85 & 1.81 & 329\end{array}$

247. Pyranidella plicosa Bronn. $(\times 24)$. Toftlund $\quad 75-100 \quad-\quad \begin{array}{lllll}7.83 & 5.25 & 332\end{array}$ 248a-b. Ringicula ventricosa (SOWERBY).

$(\times 10)$. Toftlund $\quad 115 \quad-\quad 4.99 \quad 6.65 \quad 333$

Shell dimensions in millinetors. 
D. G. U. II. Ser. No. 79.

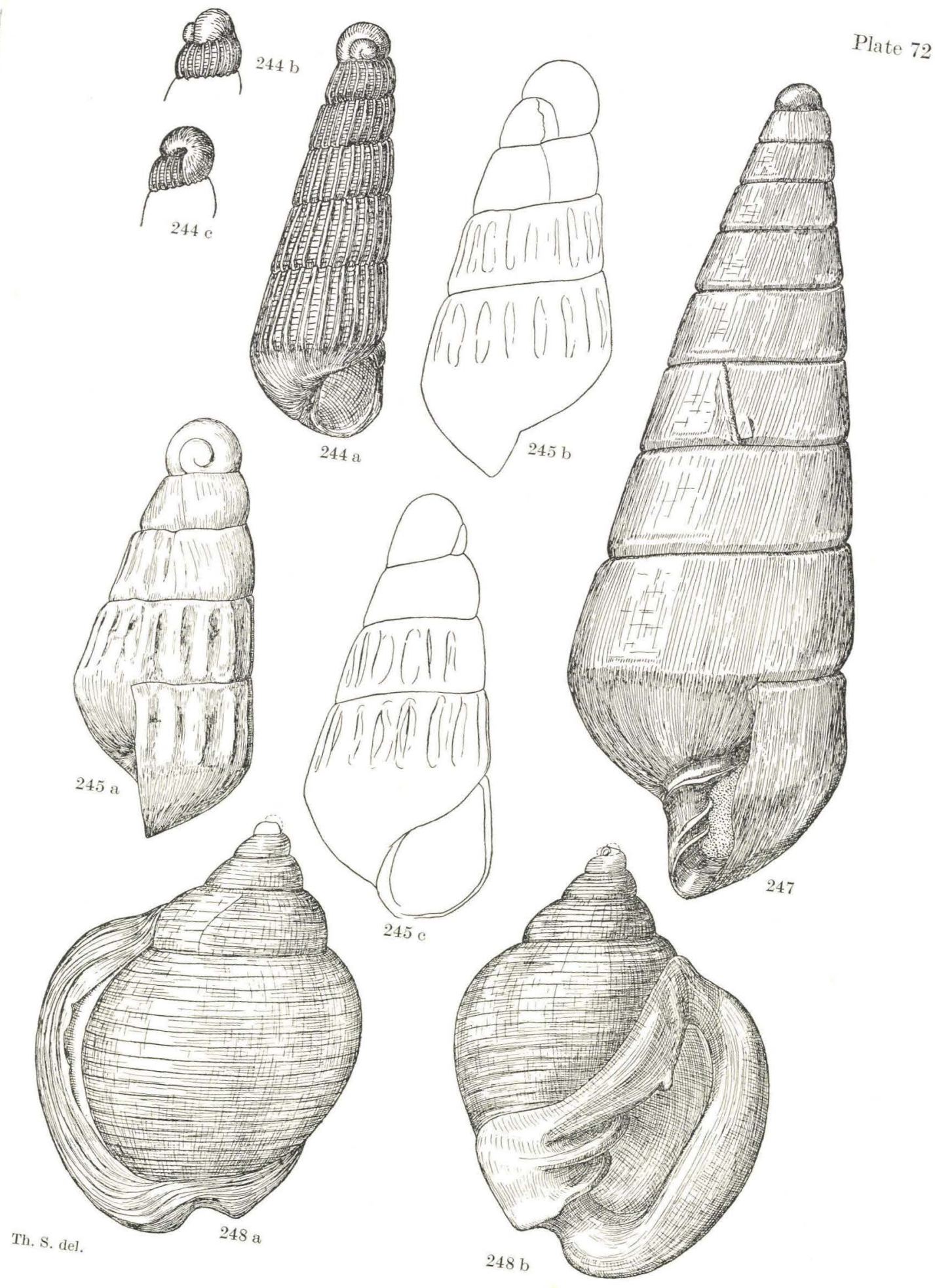




\section{Plate 73}

249a-m. Ringicula buccinea (ВRоссні) a-h. $(\times 10)$.

j. $(\times 10)$.

k-m. ( $\times 15)$.
Location

Toftlund
Depth Diameter Height Page

75-100 m.

334

$2.52 \quad 3.93$

$2.74 \quad 4.07$

$\begin{array}{lll}1.64 & 2.76 \quad 340\end{array}$

Holotype.

Shell dimensions in millimeters. 
D. G. U. II. Ser. No. 79.
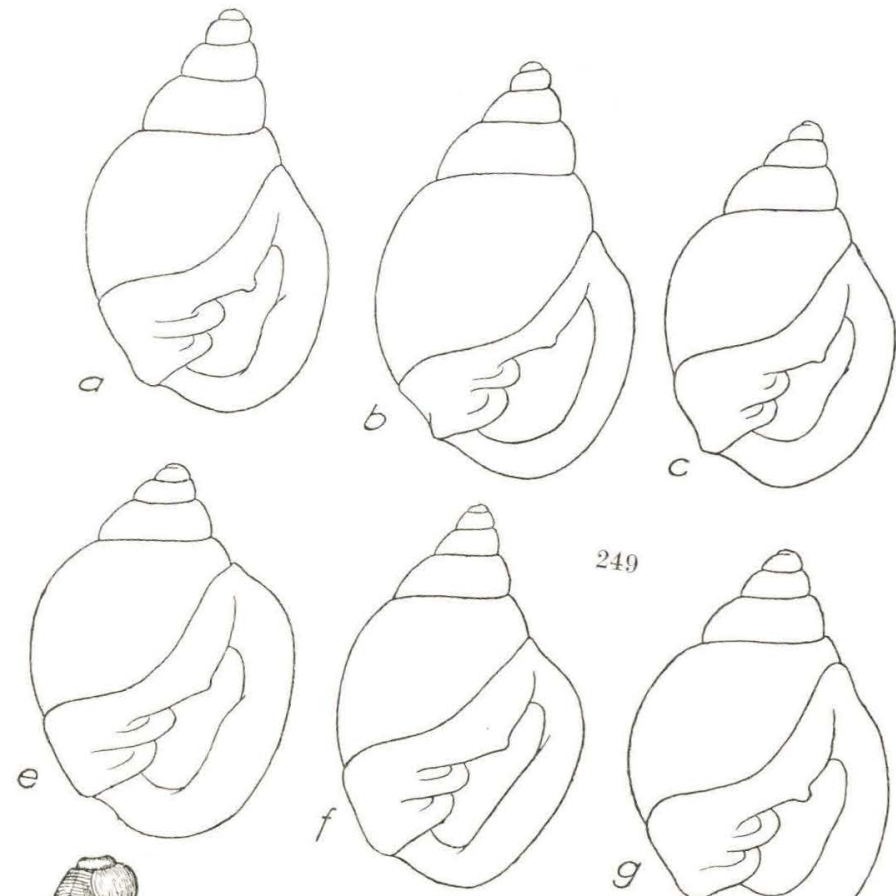

Plate 73
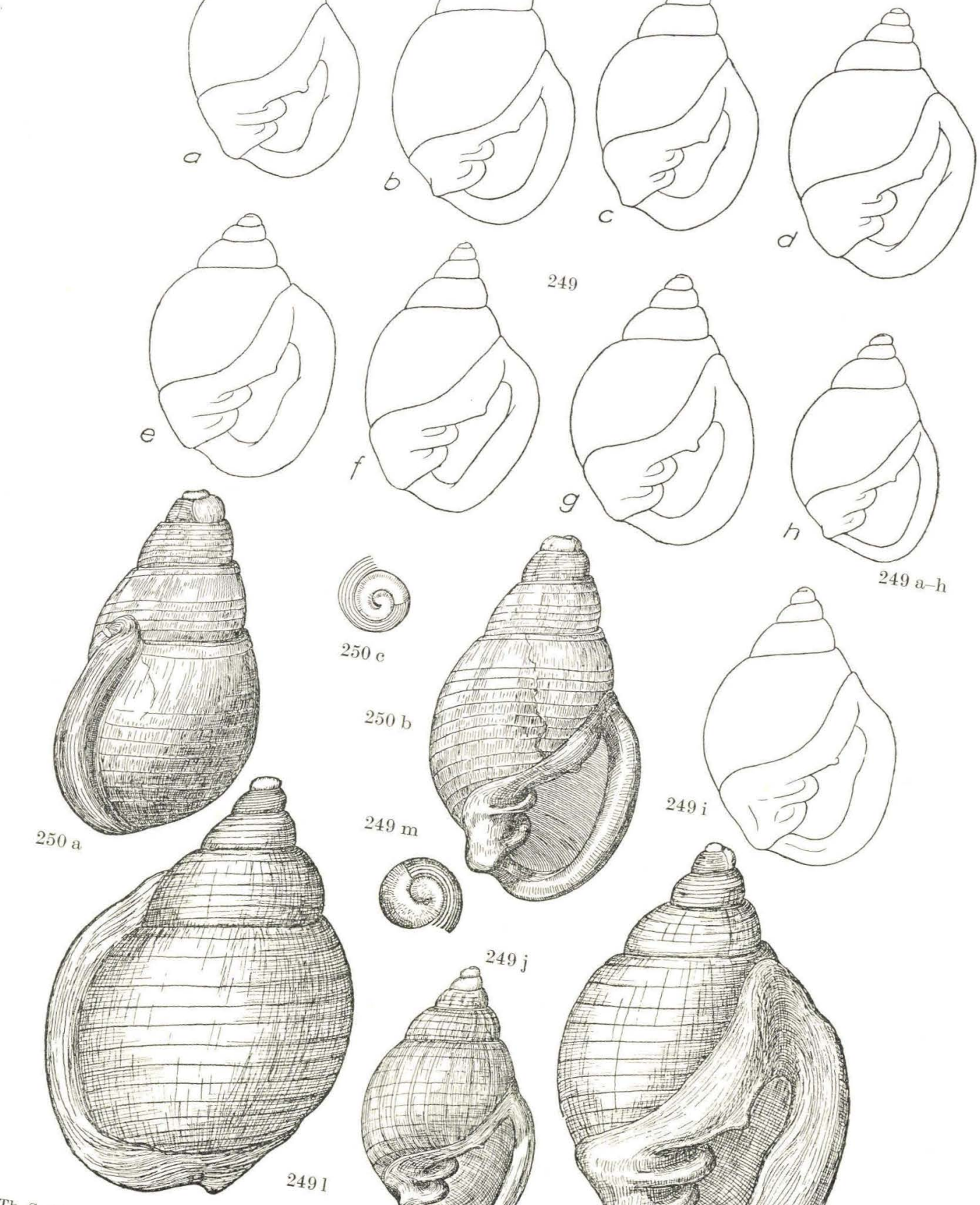

Th. S. del
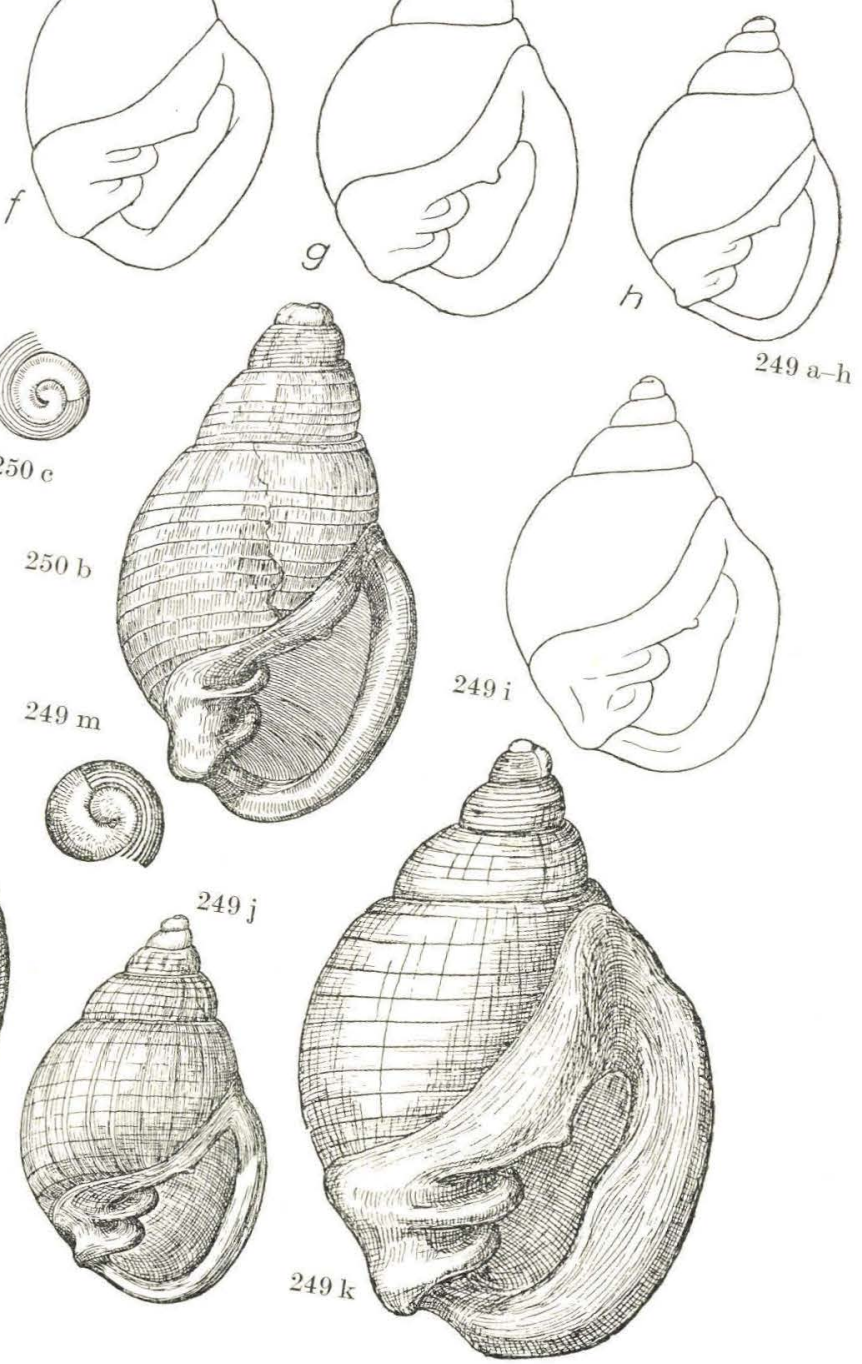


\section{Plate 74.}

\section{Location Depth Diameter Height Page}

25la-c. Cylichna of. cylindracea (PEN-

NANT). $(\times 40)$.

Toftlund $\quad 110-115 \mathrm{~m} . \quad 0.69 \quad 1.37 \quad 342$

253a-c. Rhizorus acuminatus (BRUGUIÈRE).

$(\times 60)$.

Arnum (13) 53-83.

$\begin{array}{lll}0.83 & 2.02 \quad 344\end{array}$

254a-c. Retusa elongata (Erchwald).

$(\times 60)$.

$\begin{array}{lllll}\text { Arnum (13) } \quad 53-83 & - & 0.92 & 1.59 & 345\end{array}$

Shell dimensions in millimeters. 

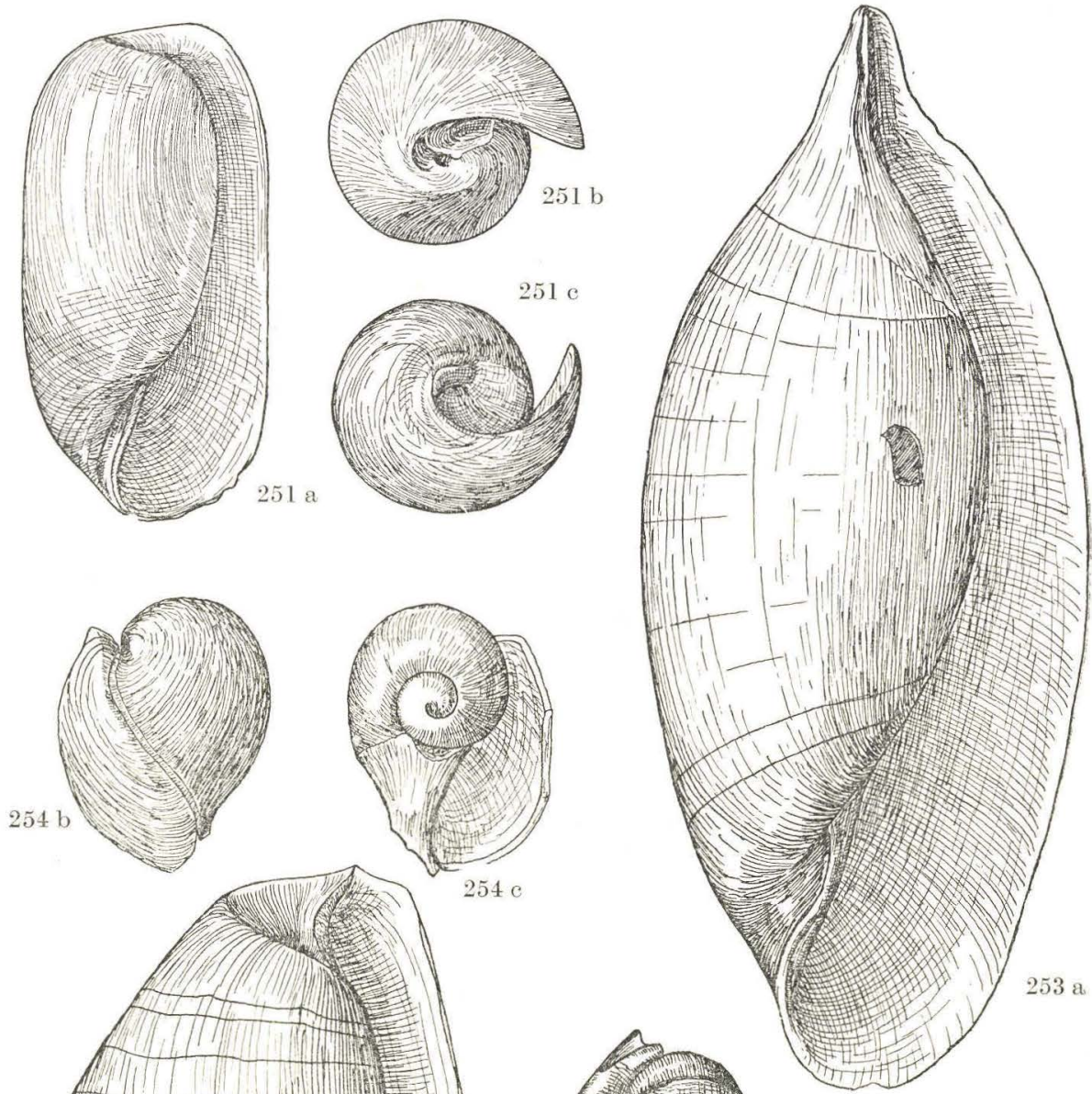

$51 \mathrm{c}$
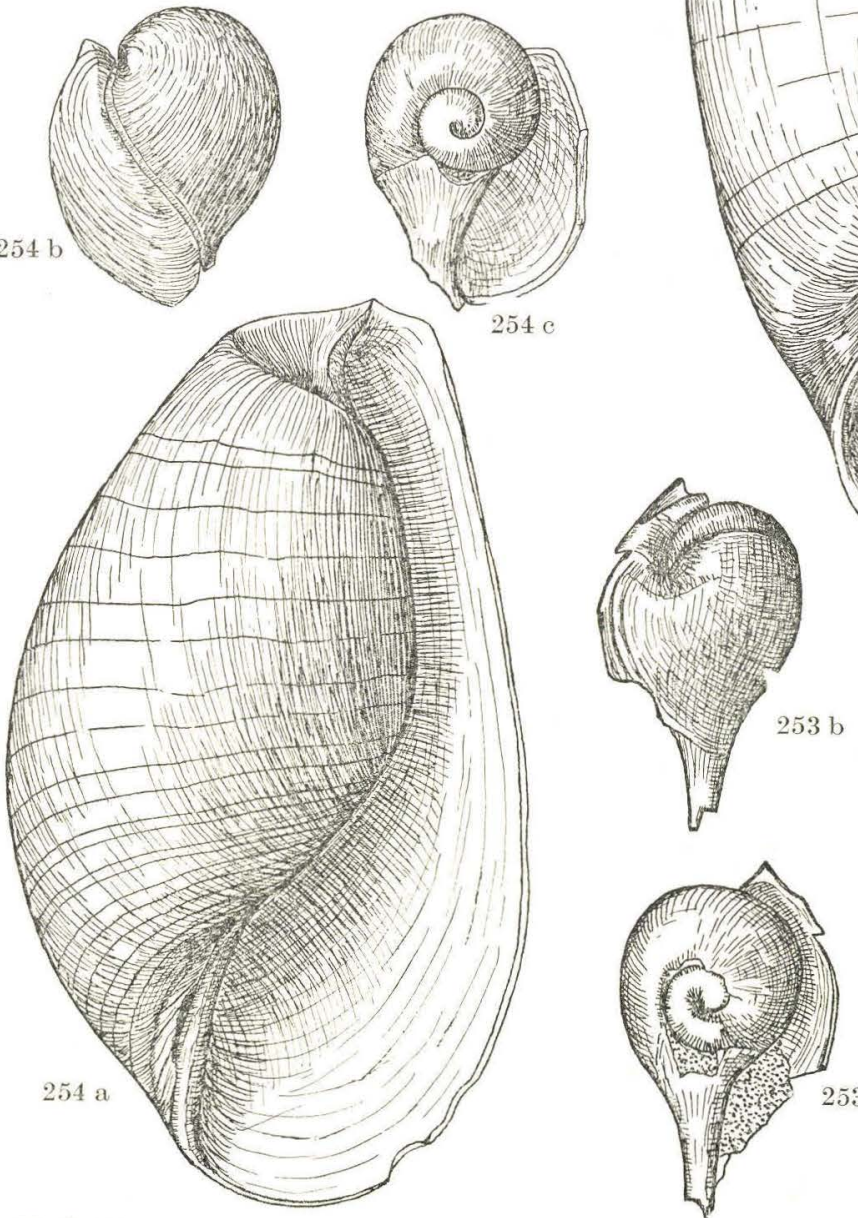

Th. S. del

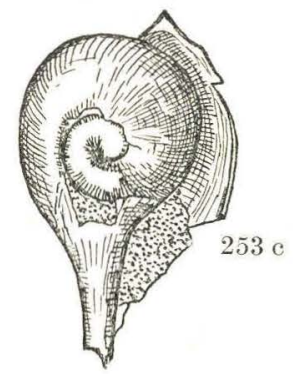




\section{Plate 75}

\section{Location \\ Depth Diameter Height Page}

255a-c. Retusa umbilicata (Montagu)

Arnum (13)

$53-83 \mathrm{~m}$.

346

a. $(\times 50)$.

b. $(\times 60)$.

$0.97 \quad 1.87$

c. Protoconch. $(\times 60)$.

$0.50 \quad 0.83$

255d-e. cf. Retusa umbilicata (Montagu). $(\times 30)$.

Toftlund $\quad 105-110-0.98 \quad 1.96$

258a-c. Acteocira Lajonkaireana (BAsTEROT). $(\times 60)$.

Arnum (13) $\quad 53-83 \quad-\quad 0.71 \quad 1.50 \quad 348$

Shell dimensions in millimeters. 
D. G. U. II. Ser. No. 79.

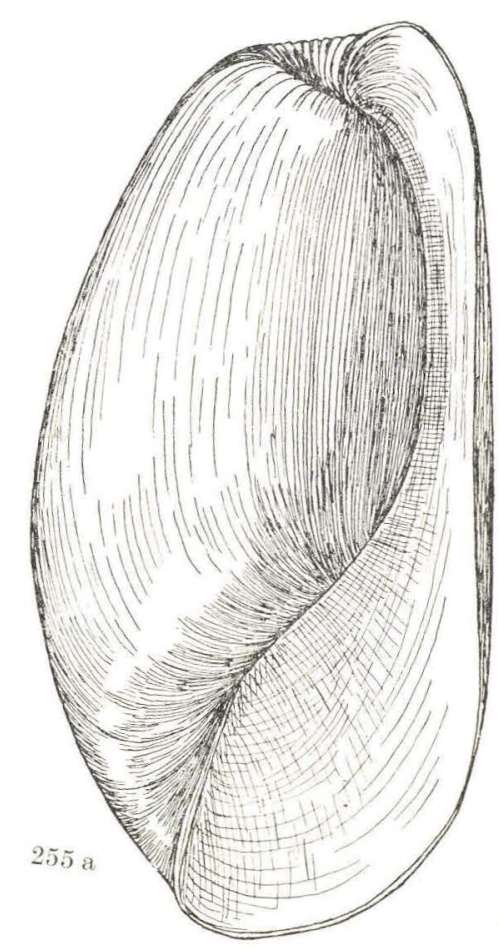

Plate 75
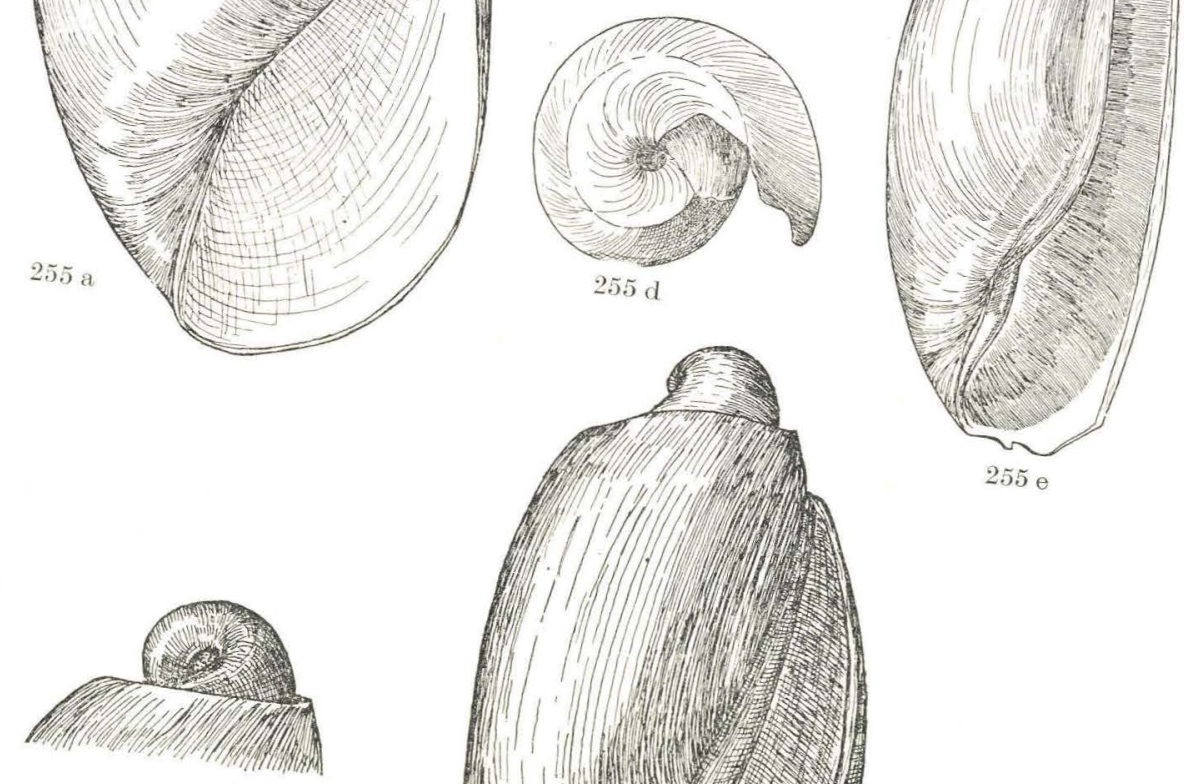

$255 \mathrm{~d}$

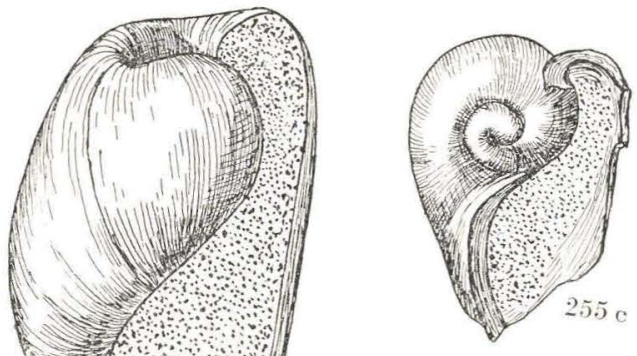

Th. S. deI
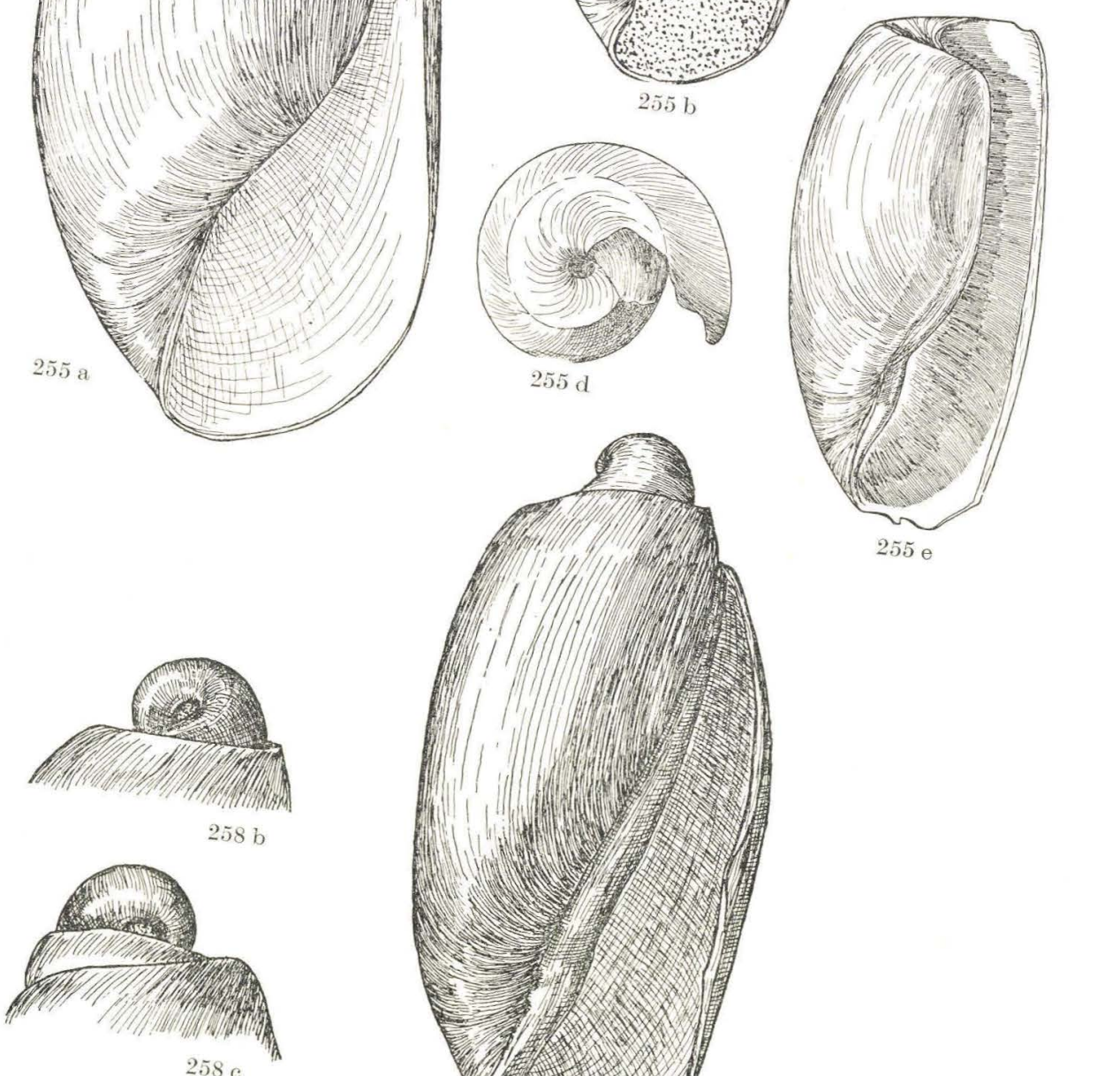
Plate 76.

Location Depth Diameter Height Page

209. Philbertia sinuosula nov. sp. (×23) Holotype $\quad$ Toftlund $\quad 105-110 \mathrm{~m} . \quad 1.74 \quad 3.49 \quad 290$

219. Acteon arnumensis

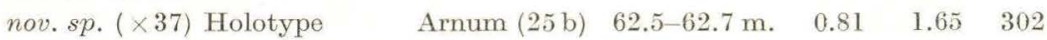
$260 \mathrm{a}-\mathrm{b}$. Roxania utriculus (BROccHI). $(\times 60)$.

Arnum (13)

$53-83 \mathrm{~m} . \quad 1.04$

1.62350

Shell dimensions in millimeters. 
D. G. U. II. Ser. No. 79.
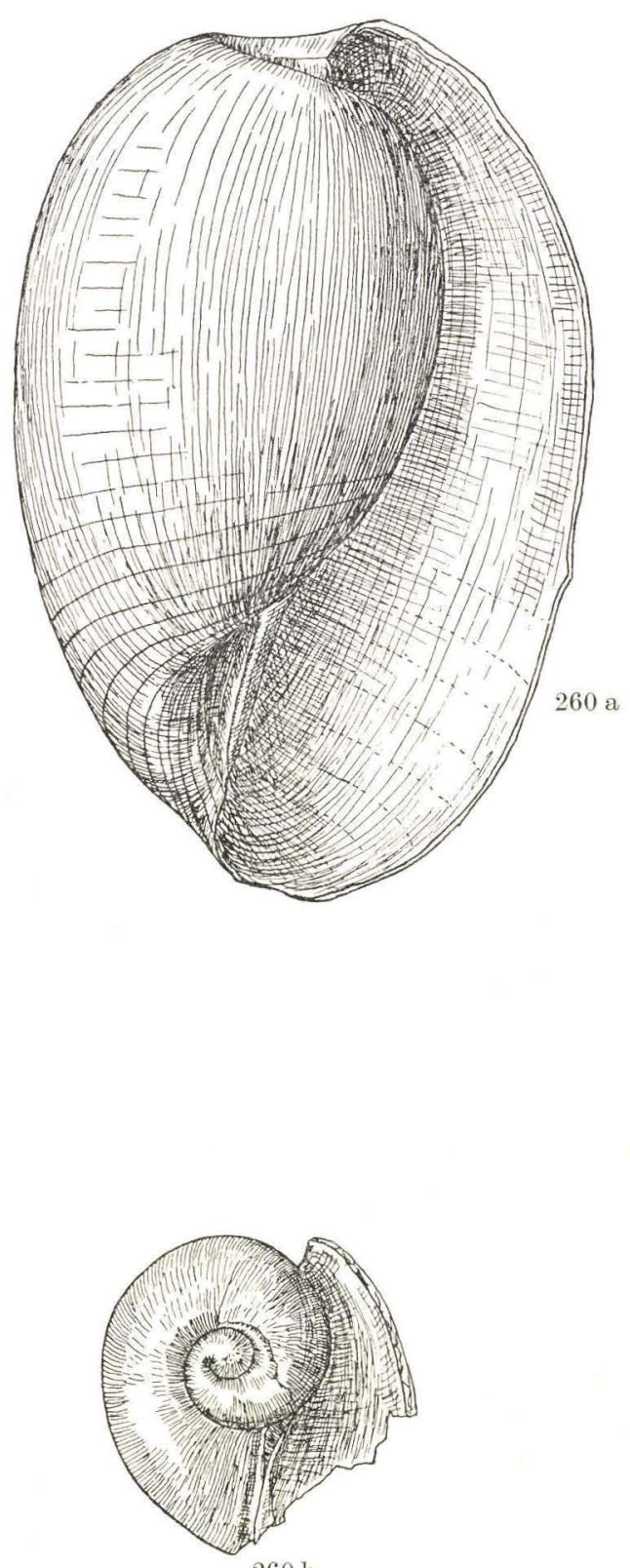

$260 \mathrm{~b}$
Plate 76

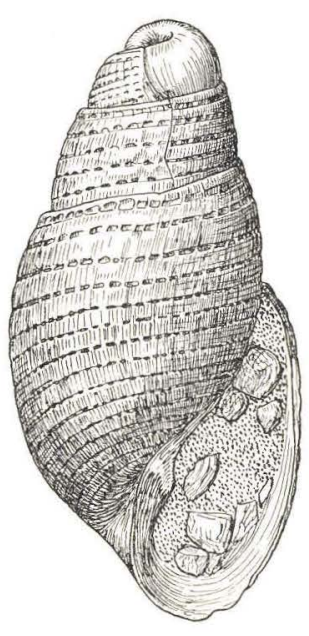

219

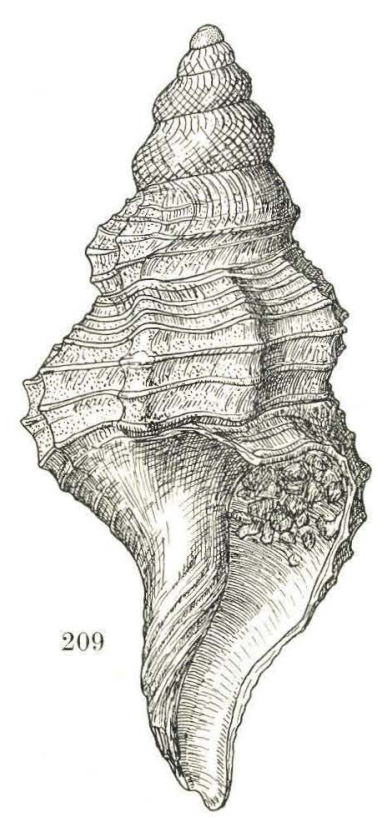

Th. S. del. 
FR. BAGGES KGL. HOFBOGTRYKKERI KøBENHAVN

Pris bd. I-II 70 kr. 